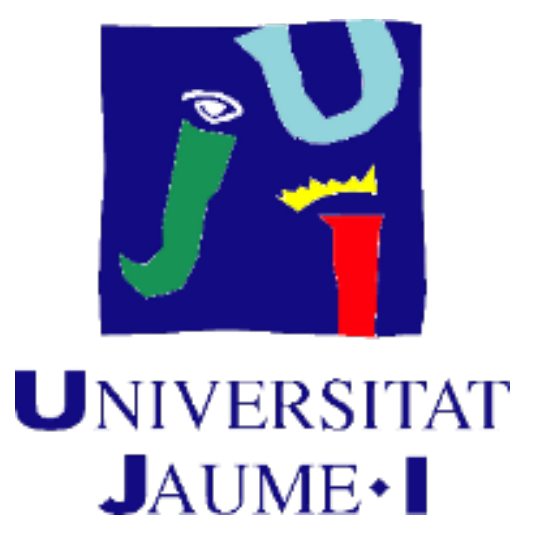

Tesis Doctoral

\title{
La fabricación del taíno. \\ Concepto étnico-cultural y desventajas de una nomenclatura para la historia insular caribeña
}

Randle Sloan Toraño

Director de Tesis:

Dr. José A Piqueras Arenas 


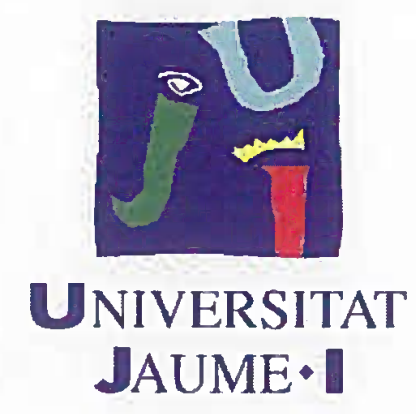

Programa de Doctorado en Historia y Estudios Contemporáneos

Escuela de Doctorado de la Universitat Jaume I

\section{La fabricación del taíno. \\ Concepto étnico-cultural y desventajas de una nomenclatura para la historia insular caribeña}

Memoria presentada por Randle Sloan Toraño para optar al grado de doctor/a por la Universitat Jaume I

Nombre $y$ apellidos del doctorando y FIRMA original

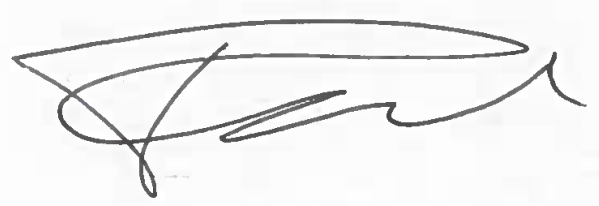

Castelló de la Plana, Junio de 2021
Nombre y apellidos del director de la tesis y FIRMA original

Firmado por JOSE ANTONIO PIQUERAS ARENAS - NIF:20399267S el dia 02/07/2021 con un certificado emitido por ACCVCA-120 


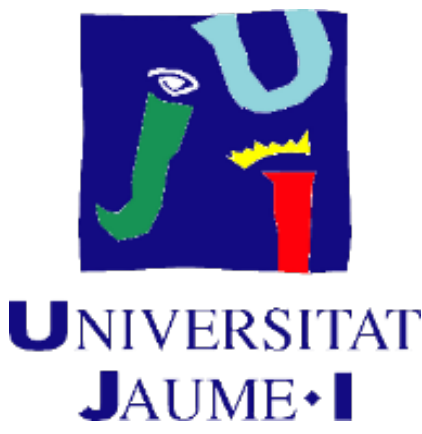

Programa de Doctorado en Historia y Estudios Contemporáneos

Escuela de Doctorado de la Universitat Jaume I

\section{La fabricación del taíno. \\ Concepto étnico-cultural y desventajas de una nomenclatura para la historia insular caribeña}

Memoria presentada por Randle Sloan Toraño para optar al grado de doctor/a por la Universitat Jaume I 
Licencia CC Reconocimiento - Compartir igual (BY-SA).

(c) (1) (2) 


\section{Dedicatoria}

Dedico esta tesis a mi adorado hijo James Lewis Sloan, a mi compañera y esposa Santa Lorenzo y a todas las amistades y familiares que me apoyaron durante estos largos años de investigación, -incluso a los que no me apoyaron.

En adición, dedico esta tesis a todas esas personas y comunidades que se afectan por el contenido de esta tesis, considerando que la intención siempre ha sido proveer historia, identidad y justificación. 
Mi director de tesis, el catedrático José Piqueras Arenas, nunca imaginó el ingente trabajo de dirigir esta tesis. Nuestro compromiso sobrepasó años de investigación, correcciones, viajes, distancias y cirugías enmarcándose su final durante una pandemia que parece no tener fin. El profesor Piqueras ha mantenido una fiel disposición enfocada en una metodología científica y al contenido, mientras el investigador buscaba remover algo artificial y ajeno a la herencia e historia del nativo caribeño. Esa diligencia formativa nunca ausente del catedrático, junto a su experiencia y practica académica es digna de admiración, y por eso quedo infinitamente agradecido por su dedicación.

Le agradezco a la Universidad Jaume I las herramientas y facilidades que me permitieron mantener un continuo ritmo de trabajo bajo pésimas circunstancias naturales en este último año. Igualmente le estoy agradecido al departamento de Historia, muy especialmente a la Dra. Imilcy Balboa Navarro, con quien conté en todo momento.

Le estoy agradecido, en general, a la Universidad de Oviedo por los años que compartí en sus facilidades, y particularmente al profesor Ismael Sarmiento Ramírez.

Esta tesis es la culminación de años de trabajo comenzado en Puerto Rico. En San Juan, entre amistades, compartíamos temas de toda índole que incluían los arqueológicos, antropológicos e históricos de importancia no solo en la isla, pero igualmente en otras islas vecinas. Son muchas las personas a quienes les estoy agradecido sin hacer mención específica.

Por ultimo, por años navegue las islas al este y oeste de Puerto Rico en mi velero y otras embarcaciones, en ocasiones junto a mi hermano James y otros parientes y amistades. Mi padre, James, mi hermano y yo compartimos toda una vida navegando. En ese sentido, 
mi agradecimiento corresponde a todas esas personas que me acompañaron entre viajes y mares y a esas gentes de mar y otros que conocí en esas navegaciones, compartiendo cuentos, costumbres y hazañas siguiendo pistas y pisadas sobre la arena que conducirían al tema de esta tesis. 


\section{ÍNDICE}

Introducción

Capítulo 1: Marco metodológico: el problema de la investigación, el estado actual de la terminología nativa caribeña ante la historia antigua y posibles alternativas

1. Planteamiento de los componentes científicos. El problema y la investigación $\quad 20$

$\begin{array}{ll}1.1 \text { Hipótesis } & 21\end{array}$

1.2 Objetivos $\quad 23$

1.3 Metodología 24

2. Las razas caribeñas y notas sobre Constantino Samuel Rafinesque-Schmaltz 30

2.1 Anotaciones de exploradores. Entre libertad, razas, política esclavista y género 35

2.2 Lenguas y diferencias $\quad 40$

3. Definiciones generales y ordenación $\quad 45$

3.1 Definiciones generales $\quad 48$

A. Términos y aplicaciones $\quad 49$

B. Terminología: trilogía económica tainista 50

C. Etnia taína 53

D. Supervivencia nativa caribeña, uniformidad biológica 56

4. Aplicaciones terminológicas, historia y la Revolución Industrial 57

5. Implicaciones de la utilización y difusión terminológica 63

6. Desviaciones científicas: tribus homogéneas, vivir entre tortugas y sapos 66

7. Una palabra, tendencias superfluas y aplicaciones académicas 74

7.1 Aclaraciones y principios: una relación entre naturaleza y cultura 75

7.2 Interpretaciones socioculturales-históricas basadas en indicios fortuitos 77

7.3 La educación caribeña durante el siglo XX en relación con la cultura nativa precolombina. $\quad 83$

8. La cristianización y el bautismo 86

9. Consideraciones a una reconstrucción histórica primitiva caribeña

desde una perspectiva nativa

Capítulo 2: Las políticas de los primeros contactos de América junto a la perspectiva y vida de los naturales.

1. Espacios geográficos y sus componentes 97

2. La investigación heurística 102

$\begin{array}{ll}\text { 3. Sobre la naturaleza } & 111\end{array}$ 
4. Notas de pie significados y utilización $\quad 114$

$\begin{array}{ll}\text { 5. Patrones culturales y periodización } & 117\end{array}$

6. Los Indios: bautizados por Colón, particularidades y denominaciones $\quad 124$

$\begin{array}{ll}\text { 7. Cronología, geografía y sistematización } & 137\end{array}$

Capítulo 3: Orden histórico y fechas clave, la terminología estandarizada y sus teorías definiendo el desarrollo teórico científico, las opiniones favorables, los opositores, y los reproductores.

1. Métodos históricos aplicados 151

2. Denominaciones prehispánicas 155

2.1 El mercado de la cultura y la ciencia $\quad 161$

2.2 La adquisición de Puerto Rico 162

2.3 Documentos históricos y notas de pie $\quad 166$

2.4 Razas y tribus en Fewkes 169

$\begin{array}{ll}2.5 \mathrm{ADN} & 170\end{array}$

3. EL tainismo 173

3.1 Un término obligado, sin recursos o lexicón $\quad 187$

3.2 Etnónimos y exónimos 193

3.3 Desimanaciones y anotaciones 197

Capítulo 4: Supervivencia nativa, género, familia y el entorno construido

1. Matrimonio, lenguaje y civilización 199

2. Supervivencia nativa $\quad 212$

2.1 Familia y la mujer nativa $\quad 215$

2.2 Mujeres notorias y otros datos $\quad 219$

2.3 Fisionomía de la mujer indígena de América 228

2.4 Variaciones a matrimonios nativos y sus abusos 236

3. Mujeres nativas $\quad 242$

4. El entorno de lo construido 248

$\begin{array}{lr}\text { Conclusiones } & 258\end{array}$

$\begin{array}{ll}\text { Bibliografía } & 266\end{array}$

$\begin{array}{ll}\text { Apéndices } & 286\end{array}$ 
Tablas

$\begin{array}{lr}\text { Tabla \#1 } & 110\end{array}$

Tabla \#2 115

$\begin{array}{lr}\text { Tabla \#3 } & 125\end{array}$

$\begin{array}{ll}\text { Tabla \#4 } & 248 \\ & 254\end{array}$

Table \#5 254

Dibujos

Dibujo \#1 290

Dibujo \#2 290

Dibujo \#3 298

Dibujo \#4 312

Fotografías

Fotos \#1 y 2

Fotos \#3 y $4 \quad 292$

Fotos \#5,5a y $6 \quad 293$

Fotos \#7 y $8 \quad 294$

Fotos \#9 y $10 \quad 295$

Fotos \#11 y $12 \quad 296$

Fotos \#13 y $14 \quad 297$

Fotos \#15 298

Fotos \#16y $17 \quad 299$

Fotos \#18 y $19 \quad 300$

Fotos \#20 y 21

Fotos \#22 y 23

Fotos \#24 y 25

Fotos \#26 y $27 \quad 304$

Fotos \#28 y $29 \quad 305$

Grabados: América de Theodor de Bry edición alemana de $1617 \quad 306$

Memoria de Henando de Escalanate Fontaneda 313

$\begin{array}{ll}\text { Emblema del Instituto de Cultura Puertorriqueña } & 318\end{array}$ 



\section{INTRODUCCIÓN}

Constantino Samuel Rafinesque-Schmaltz concibió el término taíno en $1836 .{ }^{1}$ Con anterioridad a la obra de Rafinesque ningún trabajo académico había identificado al taíno como un pueblo nativo, "tribu" o lengua caribeña. Por tanto, la historia del taíno tiene unos 185 años. Esa historia del taíno -de la terminología y caracterización como un determinado pueblo caribeño- es acogida por la ciencia y es desarrollada ampliamente en los comienzos del siglo XX. Nos preguntamos ¿por qué hacia falta un nuevo término para una historia antigua? La primera respuesta conduce a la necesidad de los investigadores de identificar y estandarizar las culturas nativas antillanas, como se había hecho con los pueblos del continente, muchos de los cuales habían dejado una extensa cultura material. Así comienza un episodio crítico y alarmante en la historia del nativo caribeño, como se analiza a fondo durante el transcurso de esta tesis.

En el periodo de 185 años encontramos tres fases cronológicas en las que se afianza una visión deformada de una realidad histórica, cuya principal consecuencia es la negación de la diversidad nativa y su confusión en un pueblo mítico cuya existencia a cada paso desmienten los testimonios reunidos por los primeros cronistas llegados de Europa. Estas tres fases corresponden con el periodo de incubación de la idea taína, entre 1836 y 1900; la segunda fase, de 1901 a 1955, consistió en su categorización por la ciencia etnológica, antropológica e histórica; la tercera fase, desde $1956,{ }^{2}$ corresponde a su estandarización, divulgación y asimilación por el público. Esta separación en fases

\footnotetext{
${ }^{1}$ A lo largo de esta tesis examinamos los trabajos de Constantino Samuel Rafinesque-Schmaltz por su importancia a nuestro tema / Rafinesque, C. S. 1836. The American Nations or, outlines of their General History, Ancient and Modern Nations of North and South America. Annals. Philadelphia: C. S. Rafinesque. / Rafinesque, C. S. 1836. A Life of Travels and Researches in North America and South Europe: or Outlines or Life, Travels and Researches or C.S. Rafinesque. Philadelphia: C S Rafinesque.

${ }^{2}$ Sloan Toraño, R. 2018. 'Terms and Terminology Conflicts of Social Quandaries Engendered by the Taino Native Fixation a Cultural Crisis Analytical Study in Caribbean Contemporary History', Novelty Journal, pp. 243-256. Ver, la tabla \#1 de esta tesis cual identifica algunos difusores principales que facilitaron la evolución de la terminología estandarizada taína. Notamos que la adquisición de reliquias caribeñas desde el comienzo del siglo $\mathrm{XX}$ se agiliza, documenta $\mathrm{y}$ cataloga eficientemente bajo la eficacia de la fabricación taína.
} 
cronológicas guarda relación directa con la conceptualización del taíno, mientras examinamos y verificamos la estandarización contrapuesta a la diversidad y la conformidad de las culturas nativas caribeñas.

El éxito de Rafinesque en el largo plazo es incuestionable, a través de sus difusores, repetidores y seguidores, y sin embargo ha sido escasamente reconocido por los propios investigadores. A lo largo del siglo XIX, la idea de la existencia de un pueblo taino común a la mayor parte del Caribe insular va abriéndose paso lentamente, logrando su aceptación inicial en Alemania y Francia, proporcionando un crédito a su autor y al concepto que después facilita su aceptación futura en América. A comienzos del siglo $\mathrm{XX}$ se crean las condiciones de una necesidad científico-cultural que devuelve su actualidad a la fabricación cultural de 1836; gracias a ello, se cumplen los objetivos de definición (y apropiación) de una geografía, de un patrimonio arqueológico revalorizado por el presunto hallazgo de una civilización común al área $\mathrm{y}$, también, para fines académicos. Las reliquias de antaño juegan un papel de primer orden en la nueva área de influencia económica y política de los Estados Unidos después de 1898. Por décadas, los científicos se alejaron de estudiar la diversidad nativa caribeña, mientras trabajos significantes de investigadores extranjeros y locales asumían una fabricación terminológica, una nomenclatura que por mas de un siglo dominaría el mundo académico y cultural. Ese acomodamiento terminológico, a su vez, es encontrado en las nuevas ediciones de textos clásicos del siglo XVI, bien en forma de aparato crítico, notas a pie que conducen a una lectura condicionada, en realidad ausente de base científica, si por ello entendemos la conformidad con los testimonios de los propios conquistadores y sus cronistas, bien llegando a modificar el propio texto principal, supuestamente para facilitar su contextualización, cuando lo que hacen es falsearlos.

No obstante el uso que se hace de las crónicas originales de la conquista, el objeto de esta tesis no son las crónicas -la restitución de su originalidad a algunas ediciones-, ni el análisis de su valor como fuente, sus contradicciones, estudio hermenéutico, etc., para lo que se dispone de una extensa bibliografía. Únicamente se acude a la crítica de determinadas ediciones cuando se aprecia una alteración del original -las ediciones acreditadas- por parte de investigadores con el propósito de ajustarlas a sus teorías en torno a la estandarización taína.

Autores reconocidos, de la altura de José Juan Arrom, Ricardo E. Alegría y otros ofrecieron explicaciones convincentes sobre la población nativa caribeña a partir de un 
taíno fabricado que encontraba supuesto respaldo en documentos históricos. Entre los autores clásicos, Cristóbal Colón, Bartolomé de Las Casas, Pedro Mártir de Anglería, Gonzalo Fernández de Oviedo y Valdés y Ramón Pané, entre otros, debían confirmar esas teorías. A partir de los anteriores, numerosos autores contemporáneos integraron mitología, política, folclor, agricultura, dieta y medio ambiente del nativo caribeño bajo la etiqueta del taíno.

En esta tesis nos interrogamos por la facilidad con la que se creó en la época contemporánea la noción de la existencia de un pueblo común caribeño precolombino, el taíno, extendido en la mayor parte de las grandes islas. Nos preguntamos también qué fuerza movilizó a instituciones a financiar por décadas proyectos de investigación en el Caribe, de voluntad clasificadora, que parecen alejarse de quiénes eran y cómo se autodenominaban los naturales precolombinos. Esta situación a lo largo del siglo XX cobra su propia vida mientras los científicos y expertos en el tema de nativos caribeñas entendían haber encontrado el alma cultural de las comunidades y naciones caribeñas que discutimos a lo largo de esta tesis.

Las complicaciones de esa línea de investigación en base a una fabricación son diversas, complejas y llenas de problemas, según se irá exponiendo; la confusión en un único pueblo de una diversidad que se puede constatar ha provocado en el largo plazo un daño casi irreversible en las comunidades caribeñas, que reconstruyen su identidad a partir de una ficción.

En nuestro trabajo mostramos la falta de sensibilidad que a lo largo del siglo XX, continuando en el siglo XXI, ha prescindido de los nativos reales y sus descendientes. Esa nueva historia se proponía identificar ancestros en la prehistoria e implantar un nativo imaginario confinado en ese espacio. En el caso que nos ocupa, como señalan Patricia A. Cochran et al (2008: 22), “El impacto más significativo de la investigación insensible es la perpetuación del mito de que las personas indígenas representan un 'problema' que debe resolverse y que son 'objetos' pasivos que requieren la asistencia de expertos externos". Mientras que Cochran utiliza la idea de investigaciones insensibles en busca de mejorar practicas entre investigadores y nativos vivos, en nuestro caso el significado tiene más alcance, pues, como se analizará en esta tesis, el periodo de tiempo del que nos ocupamos abarca en una primera dimensión desde 1836, mientras un segundo espacio temporal, de alcance mayor, comienza en 1492. La insensibilidad tiene un largo historial en América. Separar la data de documentos originales requiere un examen riguroso debido a las controversias arrastradas por expertos del siglo XX. Adicionalmente, 
presentaremos la filosofía -un marco ideológico específico de comprensión de la realidad -y las condiciones sociales que favorecieron avances clasificatorios estandarizados, según fueron aplicados a comunidades nativas caribeñas.

El método analítico a partir de textos clásicos busca poner a prueba teorías e interpretaciones que se alejaron del conocimiento original según fue documento en circunstancias naturales e incorruptas. Se enfoca esta tesis en quiénes eran esos nativos, su historia documentada y la manera en que los identificaron cronistas y exploradores desde sus primeros contactos. Entrelazamos esa historia nativa caribeña con el estudio de la supervivencia nativa, las nociones de etnia y raza, y su relación con las tendencias actuales vinculadas a la cultura popular, analizando interpretaciones científicas y sus efectos etnohistóricos.

La revisión de la literatura documental de la época de la conquista permite establecer algunas denominaciones originales de los nativos precolombinos hallados en los actuales países de Cuba, República Dominicana, Haití y Puerto Rico. A su vez, esa literatura pone a prueba teorías y prácticas, bien sea en base a investigadores o a instituciones. Examinaremos las interpretaciones que se han realizado de los textos clásicos desde la llegada de los españoles a América, lo que implica extender el periodo de estudio hasta el siglo XV para extraer evidencias y comprobar desvíos, controversias y la mencionada "insensibilidad", así como otras variantes que en su tiempo se apartaron de la idea original de los autores, de la historia documentada o de ambas, como aparece en ocasiones. El hecho de que la historia de los nativos caribeños carezca de profundidad o aportación a esa diversidad cultural durante las primeras décadas del descubrimiento de América se convirtió en un espacio donde los científicos contemporáneos encontrarían un mundo de nuevas oportunidades para exponer teorías no siempre fundamentadas.

La investigación nos condujo a una detallada revisión de lenguas europeas, especialmente el inglés, citando trabajos originales traducidos por el autor, yuxtapuestos en ocasiones a cronistas y autores clásicos fiables, en busca de precisión y justificación histórica. Utilizamos palabras como legitimidad y justificación para intensificar el examen de la veracidad y la fiabilidad de autores que interpretan narraciones de cronistas en aplicaciones contemporáneas que se alejan de las intenciones originales. Como Edward H. Carr ([1961], 2018: 14, 15) señaló: "Nietzsche ya había enunciado el principio: La falsedad de una opinión no es para nosotros ninguna objeción a ella. (...) La pregunta es qué tan lejos preserva-vidas, preserva-especies, o quizás, crea-especies". Carr nos habla de una falsedad que crea-especies, algo inconsistente pero análogo a la 
fabricación de términos para substituir denominaciones nativas caribeñas, que en esta tesis equivalen a una falsedad. A lo largo de esta tesis analizaremos ese espacio aprovechado por científicos de diferentes décadas del siglo xx, lo que se convierte en una condición o variable, la cual retomamos continuamente para establecer las características transmitidas de insensibilidad, aprovechamiento y la explotación de elementos culturales por motivos del continuo crecimiento de una ciencia fabricada, que como bien muchos dicen, encaja a las necesidades de los investigadores.

A partir de 1956, en el Caribe insular comenzó un renacer popular del nativo prehispánico, manifestándose en culturas folclóricas que tomaron sus identidades étnicas de las investigaciones llevadas a cabo por especialistas en la terminología taína, continuamente influenciados por estudiosos extranjeros. El revivir nativo popular caribeño es un subtema inseparable de la supervivencia, que se diferencia y se enfrenta a una serie de problemas etnológicos. No es posible demostrar en el Caribe una genética biológica como se encuentra en México, Perú, Bolivia, Ecuador y otros países latinoamericanos. Las sociedades caribeñas que estudiamos se diferencian del prototipo de los nativos de América por ser comunidades multiétnicas. Por lo tanto, se considera apropiado una ordenación de la evolución biológica natural de las antiguas culturas caribeñas desde el descubrimiento, conciliando las denominaciones originales con la evolución biológica del mestizaje caribeño. En este sentido, nos referimos a estudios de ADN (F. Mendisco, 2015; E. Mendizábal et al, 2008; J. C. Martínez Cruzado, 2005; C. Lalueza Fox, 2001 y 2003; A. Moreno Estrada, 2013; B. Marcheco-Teruel et al, 2014; H. Schroeder et al, 2018) ${ }^{3}$ y a la relación que guardan con la evolución biológica caribeña y la supervivencia nativa en las islas que estudiamos.

En ocasiones, encontramos esos patrones etnográficos en el Circuncaribe y en las Américas. El ADN demuestra porcentajes genéticos nativos en nuestra época, lo que de por sí contradice la versión históricamente aceptada de la extinción del nativo caribeño. Parte integrante de este examen consiste en evidenciar la supervivencia nativa caribeña, evolucionada íntimamente desde un mestizaje colonial, presentando variables críticas que permiten argumentar los porcientos encontrados en el ADN nativo entre habitantes caribeños, supuestamente extintos. La distinción en los resultados de ADN frente a la

\footnotetext{
${ }^{3}$ Schroeder, H. et al 2018. Hace mención a taínos en sus paginas: 2341, 2342, 2343, 2344, 2345. En su agrupación de científicos encontramos a Menno Hoogland y C. L. Hofman quienes hasta esta fecha han publicado numerosos artículos planteando a los taínos en lugar de los respectivos nativos caribeños. Por ejemplo: Hoogland, M.L. \& Hofman, C.L., 1999. Expansion of the Taino cacicazgos towards the Lesser Antilles. Journal de la Société des Américanistes, pp. 93-113.
} 
estandarización taína resulta necesaria, pues en otro caso, la supervivencia genética se está aplicando a una imagen ilusoria.

En esta tesis se pondrá de relieve cómo la definición de la cultura popular revivida responde a un sentir romántico y a un despertar artístico-folclórico, alejado de sus raíces debido al desconocimiento de la historia, después de haberse incorporado términos estandarizados e interpretaciones sospechosas, como las relativas a la terminología taína. Estas ideas están ligadas a un concepto popular que se ha visto influenciado por aportaciones científicas sospechosas, e incluso apócrifas, avaladas por investigadores reconocidos, lo que en la presente tesis se considera inadecuado e injustificable. Siguiendo a Conrad Phillip Kottak (1994: 40), asumimos: "Las razas son grupos étnicos de los que se asume (por parte de los miembros de una cultura particular) que tienen una base biológica, pero en realidad la raza es algo construido socialmente".

La ordenación científica de los grupos étnicos es imprescindible para el intento de rescatar particularidades regionales. Nos serviremos para ello de la toponimia en conexión con los complejos exónimos y etnónimos tribales, junto a las divergencias contemporáneas y sus consecuencias socio-colectivas prehispánicas isleñas. Los problemas de la periodización y la geografía desde la perspectiva de los naturales es un desafió ante la estandarización. Los conflictos raciales, la esclavitud y las políticas coloniales adversas a los naturales durante las primeras décadas no se han ordenado desde una neutralidad y una perspectiva sensible al entendimiento de los naturales. Los exploradores soñadores durante el "Descubrimiento", junto a los apasionados nativos de América, cambiaron el mundo. Por esa potente razón, la historia debería definir ese patrimonio cultural particularizado reconstruyendo los nombres tribales originales, utilizados por los nativos en su momento histórico. Si entendemos el desarrollo terminológico, encontraremos formas de subsanar una parte de los daños ocasionados a esas comunidades en la actualidad por una estandarización científica.

"La historia de la sociedad es historia; es decir, tiene el tiempo cronológico real como una de sus dimensiones. No nos interesan solo las estructuras y sus mecanismos de persistencia y cambio, con las posibilidades y patrones generales de sus transformaciones, sino también con lo que realmente sucedió" (E. J. Hobsbawn, 1999: 29). En este sentido, examinamos documentos en busca de credibilidad y fiabilidad en cuanto a la forma en que científicos durante el siglo XX y XXI avanzaban sus teorías y resultados implementando la estandarización taína. 
En un segundo apartado, nuestra tesis examina la estrecha relación e implementación entre la explotación comercial de los conceptos taínos, los sectores de la educación elemental y de jóvenes universitarios y otros medios de difusión didáctica que se han ocupado del carácter nacional caribeño para resolver desventajas originales. Ese mecanismo comercial e institucional, desde su plataforma de mercado, ha publicado y difundido durante décadas teorías acerca de lo taíno y el taínismo. Esa plataforma taínista dirigiría las excavaciones, los develamientos del pasado, la adquisición de objetos arqueológicos y la formación de colecciones basadas en una estandarización material taína, influenciados erróneamente por una historia local que ha influido indebidamente en el pensamiento popular. Nuestro estudio se ocupa de la popularización, el simbolismo y el develamiento taíno, periodizándolo e interrogándose por qué y dónde surge ese razonamiento. Veremos así que se promovieron investigaciones institucionales sirviéndose de la historia, la antropología, la arqueología y la etnografía hasta dar lugar a la creación de estereotipos étnicos caribeños transnacionales, sirviéndose de una comercialización de términos. Por ejemplo, basándose en la arqueología, se han identificado estilos, artefactos, estructuras y artes, atribuyéndole una uniformidad cronológica teorética, reflejada en los trabajos de autores como Fewkes, Harrington, Rainey, Rouse, Alegría y Arrom, entre otros estudiosos que han hecho del taíno una comunidad que a grandes rasgos representa a las sociedades del archipiélago caribeño. A partir de lo anterior, se promueven conceptos como el taínismo, el taíno clásico, el taíno central, la cultura o sociedad taína y otras interpretaciones reafirmadas a partir de artefactos, mitología, folklor y costumbres apócrifas, difundiéndose esta visión en los sistemas educacionales.

Este estudio analiza rectificaciones o alternativas al término taíno, la sociedad o cultura taína, el tainato, que incluyen lo denominado en inglés tainoness o tainan, lo que significaría el tainismo y la tainización entre otras teorizaciones. En la tercera fase del taíno de Rafinesque se destacan autores como Ricardo E. Alegría (1978) ${ }^{4}$, José Juan Arrom (1967), J. R. Oliver (1992), Roberto Cassá (1974), S. M. Wilson (1990), William

\footnotetext{
${ }^{4}$ Ricardo E. Alegría fue un difusor principal de la cultura y teorías taínas. En el 1956 conformo con el artista Lorenzo Homar el emblema del Instituto de Cultura Puertorriqueña (ICP). El elemento aborigen esta representado por un cacique indigena que en sus brazos sostiene un cemí representativo del arte taíno. Ese emblema se exhibe en el ICP en el 2021. Presentamos esa ilustración junto a su escrito por ser representativo del estado actual de la terminología estandarizada, lo ubicamos en la última página del apéndice documental.
} 
F. Keegan (1996), M.L.P. Hoogland, C.L. Hofman (1999), I. Rouse (1992) y otros. La aplicación de un término singular etnohistórico al extenso plano geográfico caribeño isleño resulta dudoso, frente a la evidencia que mostraremos de las condiciones que facilitaron la implementación de esa errata. Como afirma B. H. Rosenwein, "La mayoría de los historiadores del período moderno están acostumbrados a que la Edad Media sirva como una lámina conveniente para la modernidad, por lo que la gran narrativa es extremadamente fácil de tragar para ellos" (2002: 6). Y prosigue: "La nueva narrativa reconocerá varios estilos emocionales, comunidades emocionales, salidas emocionales y restricciones emocionales en cada período, y considerará cómo y por qué han cambiado con el tiempo" (2002: 16).

Monumentos arqueológicos autóctonos acogen actividades turísticas que son un reflejo comercial de teorías derivadas de estudios tainistas que recrean una vida primitiva prehispánica, que ha sido ordenada bajo una terminología taína, alejada de los fundamentos históricos. Esa realidad de la transformación del taíno, la sociedad taína, cultura taína, el tainismo, convertidos en una raza nativa y un ancestro, es un grave problema que esta tesis señala y analiza como asunto principal, relevante y teórico.

Nuestra pregunta, el problema que a continuación nos planteamos, es la siguiente: ¿Han superado el taíno y su estandarización la prueba del tiempo en su espacio científico, (o), caen ante la supervivencia nativa, el resurgir ancestral y la sociedad caribeña coetánea que valora sangre, sacrificio e historia sobre la insensibilidad de un fenómeno científico, (y), es la diversidad ancestral caribeña hecho o ficción?

Esta tesis señala la decadencia del tainismo en el siglo XXI mientras expone la supervivencia y la evolución biológica nativa, junto a la victimización de comunidades a manos de la educación que por décadas se acogieron a trabajos académicos tainistas.

a. Se presentarán opciones a las variables identificadas, acudiendo a evidencias, autores, documentos y sucesos históricos relacionados con la evolución de la estandarización y la sustitución actual de términos nativos.

b. Se presentarán razones científicas y objeciones durante las tres fases de evolución taína y su terminología, organizando su rastro, su historia y sus seguidores.

c. Se analizarán usuarios, investigadores y necesidades institucionales beneficiadas por las ventajas de la estandarización.

d. Se presentarán las condiciones que desde el siglo XIX promovieron la rápida aceptación de la estandarización taína, desde la Revolución industrial -con su orientación 
sistematizadora- hasta la época actual. Entre estas condiciones analizamos lo surgido desde que los EE UU tomó posesión de Cuba y Puerto Rico.

e. Se razonarán opciones basadas en las objeciones que desde 1871 cayeron ante la estandarización, sus argumentos y los paradójicos estudios académicos.

f. Se identificará la "crisis cultural" como resultado de las profundas huellas dejadas a consecuencias de la "fabricación” del taíno más allá de la idea original de Rafinesque, cuando la estandarización terminológica por supuestos visionarios de los siglos XX y XXI ingresa en salones escolares.

g. Se presenta un argumento sobre la estandarización conceptual que creó nuevos espacios adversos a lo nativo; estas creaciones fueron realizadas por estudiosos extranjeros y locales que dieron lugar a una ficción que dificulta el conocimiento histórico y obstaculiza a investigadores caribeños, acostumbrados a la terminología estandarizada y alejados de la comprensión de su pasado históricao. Esta crítica situación representa uno de los temas relevantes y principales de esta tesis.

Diseño de la tesis:

Se define esta tesis como un estudio analítico, basado en fuentes documentales impresas que se examinan con el propósito de presentar data especializada y especifica. La complejidad del tema surge en base a las tendencias contemporáneas de aplicar a los nativos una terminología estandarizada y no una basada en particularidades específicas de las comunidades nativas durante y después del descubrimiento.

En el contexto de las autodenominaciones ${ }^{5}$, se analizan y presentan todas las opciones disponibles, siguiendo las huellas nativas en páginas de historia e investigaciones. La dimensión del estudio es abarcadora: en el contexto bibliográfico, incluye el arte, el folclor, la poesía y la filosofía social que fue necesaria al formular conceptos fiables extraídos de palabras originales que identificasen denominaciones nativas, el tema, afectados y las razones actuantes que favorecen la estandarización terminológica.

El primer capítulo atiende interrogantes sobre la historia nativa caribeña y la trayectoria exitosa de la terminología estandarizada taína desde 1836, en su propia

\footnotetext{
${ }^{5}$ La tabla \#3 presenta un listado básico para asistir en la reconstrucción de denominaciones nativas junto a las naciones a las que estas aplican.
} 
historia considerada una empresa exitosa según fue diseñada originalmente por C. S. Rafinesque, quien persuadió a otros estudiosos, sumando admiradores ininterrumpidamente en el mundo científico por casi dos siglos. Las fases de evolución de esa terminología estandarizada comenzada desde Rafinesque muestran una trayectoria ligada también a prestigiosos objetores junto a numerosos difusores y promotores cuyas teorías y razonamientos sobrepasaron los límites de la historia. El estudio analítico nos demuestra que finalmente se ha llegado a una etapa de conciliación, al considerarse que la estandarización terminológica taína no tiene un significado fiable que pueda aplicarse a la cultura nativa caribeña. Los ciudadanos de las islas que la estudian se encuentran en una crisis cultural, al vivir un simbolismo terminológico fabricado para propósitos académicos que nunca debió formar parte de las estructuras institucionales, educativas o culturales.

En el siglo XXI existe una tendencia cautelosa que sugiere un cambio académico en su aquiescencia a la terminología y estandarización taína. Científicos especializados en todas las ramas académicas se enfrentan a los resultados de la exitosa comercialización de un símbolo ancestral fabricado en el siglo XIX y difundido en el XX. Esa fabricación comprende no solo una brecha alejada de la historia, sino de la propia comunidad caribeña que estudiamos. Emprender una vigorosa ruptura de esa terminología taína proveerá de nuevos espacios al entendimiento del futuro ancestral, la supervivencia nativa y la reconstrucción psicosociológica de comunidades caribeñas. Ese cambio y ruptura instauraría un nuevo modelo al estudio de nativos caribeños distanciado de una ciencia y filosofía dudosa. La vigente crisis cultural encontraría su primer paso al futuro en base a la historia. La historia examina el pasado y pone a prueba el presente en forma específica para un examen más profundo de teorías, data y evidencias fallidas del pasado.

El segundo capítulo de esta tesis profundiza en lo interpretado durante momentos históricos comúnmente aceptados, poco refutados, procedentes de la epistemología cultural teórica de lenguas europeas, de países que controlan o controlaron económica y políticamente territorios caribeños, y de sus direcciones investigativas. Algunos de estos países son España, Francia, Holanda, Portugal, Italia, Reino Unido y Estados Unidos, entre otros. Se examina la autonomía ontológica nativa en el conjunto de controversias históricas y lingüísticas suscitadas entre grupos de académicos que estudian la espiritualidad, el folclor y los ancestros, correspondientes a conceptos y teorías que han considerado el término "taíno" como autóctono de la región caribeña. Se señala lo controversial de la terminología tainista desde la época de la Revolución Industrial (no 
tanto por lo que es sino por la necesidad de esta de definir y catalogar productos), identificando trabajos académicos en los que se manipula el conocimiento, comercializando ideologías y teorías caribeñas de manera intencionada para llenar espacios designados vacíos, satisfaciéndose así necesidades técnicas y académicas. Se establece en el transcurso del tiempo una cronología documental desde el siglo XIX que facilitó la práctica y desarrollo del término y su explotación institucional. Examinamos la educación caribeña, en especial la educación infantil, que permitió difundir a los niños la estandarización de ancestros precolombinos fabricados. Una de las razones por la cual existen tan serias desviaciones de la historia son precisamente las prácticas académicas y administrativas dirigidas a la educación infantil. El siglo XX acumula la más amplia literatura de los avances de estandarización terminológica del tainismo. Esos supuestos avances académicos se difunden influenciando a los niños a temprana edad, dando lugar a adultos que interpretan esas teorías académicas como realidades históricas. Investigadores prestigiosos caribeños y repetidores de la estandarización por décadas fueron educados en esos sistemas académicos, y a la vez son víctimas del sistema educativo y de la institucionalidad sistémica.

El tercer capítulo abarca la supervivencia nativa en el Caribe, considerando el mestizaje, su relación con el bautismo y el catolicismo, junto a estudios de ADN, particularidades sociales actuales, el entorno construido, hechos históricos, condiciones sociológicas y otros asuntos relacionados a la supervivencia, como el género, herencia patrimonial, educación y la tradición. Estos conjuntos de elementos configuran unas variables en una red imparcial legitimándose y justificando orígenes históricos. Este capítulo recoge problemas y plantea argumentos, facilitando una rectificación al presentar en su análisis el problema y las desventajas comunitarias. El conjunto documental de las fuentes de los principales autores clásicos son la base fundamental; no obstante, en el caso de los taínos, las contribuciones científicas son posteriores a Rafinesque (1836), y mientras carecen de justificación, abren el camino a revalorizar la historia. Esta carencia se considera y designa por ser la causante principal de desventajas en sociedades actuales, cuando la procedencia de los conocimientos populares en comunidades simples es desconocida, mientras el debate de investigaciones académicas vive un pasado, un presente y un futuro afectado bajo un fenómeno fabricado. Esta disyuntiva históricocultural y sus antecedentes sociales y biológicos se unen, demostrando deslices en las fuentes actuales, ilustrando sus graves consecuencias culturales hasta el momento. Ese dilema se conforma en las partes de esta monografía al señalar prejuicios, daños y 
desventajas a sociedades y comunidades victimizadas en busca de remediar distorsiones y la falta de conocimientos. Resaltamos a los descendientes naturales, transformados en víctimas desventajadas al identificarse como descendientes naturales de lo que no sucedió en los términos que han recibido, asumiendo un término aprendido, inservible en el complejo mundo de las hipótesis y las vicisitudes; al tratar de recuperar sus propias huellas culturales, llenan esos espacios con la terminología taína ilegítimamente, pues esta fabricación, como bien citamos de Hoogland y Hofman (1999), solo son etiquetas malversadas.

Entrando en el siglo XXI, comienza el mundo cambiante académico enfrentando la crisis cultural sin un discurso apropiado para identificar el problema. Difusores y repetidores de la estandarización terminológica taína buscan la forma de desligarse de sus propias investigaciones por haberse acogido a una terminología falseada.

El mundo del nativo caribeño era una utopía desconocida por los europeos, quienes pronto controlaron y dividieron vida, tierra y propiedad de estas gentes, basándose en sus propios derechos, religión y superioridad militar. La vida natural y costumbres de los nativos sufrió lo intolerable, pero resistió y vuelve en un renacer que merece lo mejor de la historia y no simplemente una etiqueta o una fabricación comercial.

El cuarto capítulo argumenta la supervivencia desde la perspectiva de la mujer caribeña, la violencia sexual, las costumbres nativas y el ADN. Se entrelaza este cuarto capitulo a esa mujer entre la construcción nativa, los artesanos y el pensamiento de originarios, por estar íntimamente ligados en la naturaleza orgánica de la región. Se interpreta en estas relaciones cómo la construcción y sus ramificaciones otorga una vida nativa evolucionada que sobrevive la colonización en el mestizaje. ${ }^{6}$ La cultura multirracial se apropia del folklore popular, pasando desconocida su diversidad y la historia que arrastran mientras los estudiosos promueven sus trabajos taínos.

\footnotetext{
${ }^{6}$ Wade, P. 2003. Repensando el mestizaje. Revista colombiana de antropología, 39, pp.273-296. "Se abrazó la identidad de ser mixta como persona y nación, a veces con miras explícitas o tácitas hacia otras naciones -como Estados Unidos- donde la mezcla racial era un tabú y el racismo contra las poblaciones negras e indígenas notorias. Celebrar el mestizaje se convertía en una aseveración de la supuesta democracia racial latinoamericana" / Nash, G.B. 1995. The hidden history of mestizo America. The Journal of American History, 82(3), pp.941-964. "El matrimonio de Rolff-Pocahontas podría haberse convertido en el embrión del mestizo en Estados Unidos. Utilizo el término mestizo en el sentido original, refiriéndome a las mezclas raciales de todo tipo. A principios del siglo XVII, las ideas negativas sobre el mestizaje apenas se habían formado: de hecho, la palabra en sí no apareció durante otros dos siglos y medio". / En esta tesis el mestizo o mestizaje considera uniones multi-culturales, multi-raciales y etnias desarrolladas formando parte de una evolución nativa caribeña continuamente encontrando nuevas vías unificadoras y no discriminantes.
} 
En general, la geografía, periodización, diversidad y las políticas nativas se identifican al unirse a la explotación durante el colonialismo, conformando un conjunto de evolución biológica y social poco estudiado desde la perspectiva de los naturales. Como escribió Lucien Febvre (1971: 21):

“«El historiador no debería elegir los hechos. ¿Con qué derecho, en nombre de qué principios, elegirlos? Elegir es la negación de la obra científica...». Sin embargo, toda historia es elección. Lo es porque existe el azar que aquí destruyó y allá salvaguardó los vestigios del pasado. Lo es porque existe el hombre: cuando los documentos abundan, abrevia, simplifica, hace hincapié en esto, relega aquello a segundo término. Y lo es, principalmente, por el hecho de que el historiador crea sus materiales o los recrea, si se quiere: el historiador no va rondando al azar através del pasado, como un trapero en busca de despojos, sino que parte con un proyecto preciso en la mente, un problema que resolver, una hipótesis de trabajo que verificar". 


\section{Capítulo 1: Marco metodológico. El estado actual de la terminología nativa caribeña, la historia y sus posibles alternativas}

\section{PLANTEAMIENTOS DE LOS COMPONENTES CIENTÍFICOS. EL PROBLEMA Y LA INVESTIGACIÓN}

Tratamos en este capítulo la trayectoria del problema académico que invade la etnohistoria de los nativos caribeños en su conjunto de variables, interrogantes y controversias científicas a través de puntos de intersecciones que acentúan conflictos y alejamientos a la historia. Al profundizar en el origen e incógnita de la terminología taína, se establecen parámetros de investigación, se facilita diligenciar la aplicación de secuencias lógicas identificando el problema teórico, al igual que las incoherencias hipotéticas alejadas de documentos anteriores o clásicos. El problema por investigarse se plantea en la siguiente interrogación: ¿Han superado el taíno y su terminología la prueba del tiempo en su espacio científico, (o), caen ante la supervivencia nativa, el resurgir ancestral y la sociedad caribeña coetánea que valora sangre, sacrificio e historia sobre la insensibilidad de un fenómeno científico, (y), es la diversidad ancestral caribeña hecho o ficción?

La denominación taíno o taino y su terminología evolucionó desde 1836 geográficamente desde Norte América a Europa, arriazándose luego en el Caribe y difundiéndose por el mundo académico a modo de un modelo genérico real. Por ende, la vida nativa quedo atrapada y contenida en una bibliografía científica avanzada, construida sobre una base sospechosa y acogida o influenciada mayormente por autores insensibles. La dimensión de ese problema por casi dos siglos abarca una inmensa región de forma estandarizada y exitosa, en la que no faltan premios y galardones entre los que comparten esa visión, mientras alcanza e identificamos una crisis cultural y ancestral. Sin duda esta tesis es controversial requiriendo un largo proceso de análisis para resolver ambigüedades, falsedades y presunciones. Linda Tuhiwai Smith (2013) sostiene la idea de que lo nativo provoca silencio entre las personas investigadas ante investigadores, y en ciertos lugares hasta se les cataloga de terroristas. Ante ese sentido de inflexión y argumentación, accedemos a la idea de sensibilidad en el estudio de nativos caribeños y a su vez levantamos palabras como justificación y legitimidad. Justificación y legitimidad 
son indicadores plenos aplicados en todo su peso de considerarse necesario o básico. Smith (2013: 3) sostiene que "Desde una perspectiva de la comunidad, la recopilación de información por parte del científico fue tan aleatoria, ad hoc y perjudicial como la realizada por aficionados".

Smith nos refiere a la época actual. Pensemos por solo un momento que cantidad y calidad de estudios caribeños padecen ese síntoma. Ese síntoma es reconocible, y al señalar esas coyunturas aplicamos una lógica plena en virtud a la sensibilidad nativa, señalando ese fenómeno con palabras afirmativas. En ese sentido, injustificable o ilegitimo corresponden a la protección ancestral y sensibilidad nativa. Es indispensable tratar cuidadosamente la vida nativa caribeña, una considerada, extinta, subyugada, esclavizada, colonizada, mestiza y cuyos propios nombres ha sido tergiversados.

\section{Hipótesis}

Esta tesis doctoral ordena una investigación analítica en busca de resolver el dilema contemporáneo de términos y terminología taína en base a Rafinesque, lo que se ha convertido en un fenómeno científico de apelativos aplicados en estudios multidisciplinarios, con énfasis directo en el marco espacial de las culturas oriundas del archipiélago caribeño específicas de, Cuba, Puerto Rico, República Dominicana y Haití. Teóricamente se verifica y resuelve el problema expuesto probando resultados:

(a) Al separar hechos básicos de autodenominaciones nativas documentadas durante los primeros contactos con europeos, de las teorías sospechosas de denominaciones contemporáneas, examinando conjuntamente documentos clásicos para separar realidades fiables de invenciones. A esas invenciones les llamamos fabricaciones por haber surgido como un producto a detallarse por vías académicas e institucionales a multitudes indiscriminadamente. La información bibliográfica es extensa: Según dice C. R. Kothari (2004: 13): "Después de una extensa encuesta bibliográfica, el investigador debe establecer en términos claros la hipótesis o hipótesis de trabajo. La hipótesis de trabajo es un supuesto provisional hecho para extraer y probar sus consecuencias lógicas o empíricas. Como tal, la manera en que se desarrollan las hipótesis de investigación es particularmente importante ya que proporcionan el punto focal para la investigación”.

(b) basándonos en el amplio material bibliográfico y las variables que consecuentemente surgen, entramos de lleno a probar un patrón cronológico identificando de qué forma se ha llegado al estado del conocimiento actual de la cultura nativa caribeña. 
Resulta indispensable identificar documentos concluyentes, dividiéndose en base a autores, calidad e importancia del trabajo y la fase cronológica a la que pertenece. ${ }^{7}$ Un documento es de vital importancia cuando de él se desprende una lógica clara que sirve para identificar y probar el problema a resolver. Los detalles históricos y la consecuencia de su uso en el largo plazo implican precisión y, sobre todo, mantener la información original intacta;

(c) su dimensión temporal especifica abarca monografías, documentos y artículos desde 1836, cuando el término taíno se normaliza en los Estados Unidos hasta el presente, ya asumido y proliferado por doquier como parte del tainismo, enmarcando una hipotética sociedad conocida como la cultura o sociedad taina. En esta tesis se analiza el por qué y de donde procede, el taíno ${ }^{8}$ y el tainismo, ${ }^{9}$ ordenando desde su génesis -durante el periodo de la Revolución Industrial-, su imposición cultural y su implementación institucional y académica. Comparamos resultados científicos de la terminología taína con los trabajos clásicos desde 1492, y el de sus opositores en busca de verificación y consenso; ${ }^{10}$ En relación a cronistas, cronicas, y escritores clásicos en Korotkikh (2018: 35); "La formación textual es una noción muy amplia, por ejemplo, lo son la literatura, la historia y el ensayo. El segundo nivel, más restringido, es llamado "tipos discursivos" que representan "un nivel clasificativo interno", decir, son una forma o un género, verbi gratia, una carta o un diario."

(d) en sus 185 años de existencia, el taíno y la terminología tainista ${ }^{11}$ se ha comercializado sobre una base institucional eficiente, innovadora y económicamente viable, en la cual las realidades nativas, ancestros y sus descendientes evolucionados

\footnotetext{
${ }^{7}$ Referirse a la tabla \#1 de esta tesis.

${ }^{8}$ Taíno: un supuesto nativo caribeño, un símbolo fabricado por los seguidores de Constantino Samuel Rafinesque-Schmaltz a partir del siglo XIX, una ciencia ajena a la historia nativa caribeña de origen, -uno que no es representativo de raza, tribu o idioma de nativos caribeños.

${ }^{9}$ Tainismo: designación terminológica sugerida en esta tesis por el autor, acomodada a identificar los procesos y costumbres de investigaciones socioculturales y la utilización del término taíno para la identificación, clasificación e interpretación contraria a los nativos caribeños encontrados por Cristóbal Colón en sus viajes a América.

${ }^{10}$ Korotkikh, N. 2018. Filosofía de la historia de América: los cronistas de Indias en el pensamiento español. / Este diccionario de escritores y cronistas proporciona un listado de interés, igualmente señala la utilidad de cualquier persona que redacte un escrito durante el descubrimiento. / Esta tesis no hace estudio crítico de las crónicas sino que analiza y compara esos escritos textules o verbi gratia del descubrimiento a los producidos en nuestro caso por los científicos tainistas mientras verificamos y analizamos su fiabilidad y credibilidad".

${ }^{11}$ Terminología tainista: la aplicación científica de un término singular a nativos caribeños, a la historia y a la memorística caribeña, en el empeño de desarrollar una formación epistemológica y teórica sobre un símbolo fabricado como el taino. La terminología taína crea una distopia caribeña obligada, entre tainistas y sus víctimas.
} 
orgánicamente aparentan ser de segunda naturaleza. Desde esa perspectiva, se plantean las desventajas sociales y educacionales derivadas de una planificación que difundió una imagen cultural fabricada, que evolucionó desde sus comienzos hasta representar a un ancestro. Esta tesis presenta alternativas al tainismo en busca de fiabilidad y correcciónes históricas. En (a, b, c, d,) la evidencia empírica nos conduce a un dialogo filosófico del cual se desprenden la búsqueda de la idea original de los historiadores, escritores clásicos, verbi gratia y relatos documentando hechos ocurridos y colaborados durante el descubrimiento. Las interpretaciones y las nuevas técnicas de enfocar esos episodios en el presente forman parte de nuestro análisis . En esta tesis, por ende, se analiza la empírica original clásica desde 1 perspectiva del historiador mientras el enfoque contemporáneo se presta para interpretar el cómo se diferenciaban los naturales caribeños los unos de los otros desd sus propios mundos. Y, por qué y de qué manera surge el fenómeno científico de la estandarización terminológica taína caribeña.

\section{Objetivos}

En esta tesis se examinan aportes, disfunciones y contrariedades de la historia caribeña en su conexión a la terminología contemporánea de las denominaciones étnicas y la supervivencia nativa en su aquiescencia a la herencia ancestral. Se trasluce que la herencia ancestral de un pueblo se personifica de forma fiable basada en hechos verificables. Se dice que el nativo caribeño vivía inherente a su tierra y la naturaleza. Esta tesis pretende recoger esa naturaleza orgánica al interpretar el carácter y persona de esa simple gente viviendo en harmonía. Analizamos en el ámbito sociocultural la construcción de términos nativos y sus aplicaciones, verificando espacios históricos descuidados o pasados por alto, junto a interpretaciones apócrifas y sus periodizaciones. Los anteriores y siguientes objetivos generales se ordenan de forma organizada al;

(a) analizar la documentación de cronistas e historiadores clásicos con la intención de verificar la fiabilidad. Con la intención de remover el significado d la terminología contemporánea taína en base a la historia nativa caribeña;

(b) analizar el paradigma de la memoria histórico-cultural según es visualizado por investigadores proponentes del tainismo, determinando veracidad, justificación y legitimidad, junto a sus consecuencias desafortunadas a corto y largo plazo para daños a a las victimas; 
(c) establecer una cronología de intervenciones culturales que implicaron cambios que influenciaron la cultura popular y la llevaron a encontrar y aceptar el tainismo, la sociedad taína, el tainato y tainismos, y planteamos posibles soluciones;

(d) identificar errores en traducciones, interpretaciones lingüísticas, etnohistóricas, antropológicas, arqueológicas e históricas que en su momento promovieron, eliminaron o substituyeron la naturaleza nativa caribeña y sus apelativos originales por unos nuevos ignominiosos;

(e) señalamos opciones dirigidas a restaurar exónimos o etnónimos nativos prehispánicos caribeños, y entrelazamos ese concepto con el renacer nativo del siglo XX y las disfunciones del exónimo contemporáneo;

(f) identificando la mujer nativa, el mestizaje, la religión, él costumbrismo y las circunstancias que circundan esos temas y sus variables.

En fin (a, b, c, d, e, f), en su marco de referencias, encierran un dialogo científico, explorando la estandarización entre los hechos históricos documentados de las sociedades antiguas caribeñas durante los primeros contactos europeos y lo contenido en documentos clásicos. Analizamos las discrepancias de nuevos conocimientos contrapuestos a la transformación de áreas científicas explotadas.

\section{Metodología}

El marco teorético perfila la compleja transformación histórica del Caribe insular y sus problemas desde los siglos XV y XVI, específicamente en Cuba, Puerto Rico, los actuales República Dominicana y Haití, ordenando, teorías, conceptos y patrones de numerosos investigadores contemporáneos, facilitadores y originadores de la terminología tainista moderna aplicada a progenitores nativos. La hipótesis científica de por sí requiere herramientas sociales, filosóficas e históricas al interpretar el pasar de una fase a otra durante la investigación. El presente estudio se inscribe dentro de las investigaciones analíticas que repasan el dilema contemporáneo de la toponimia y fenomenología de apelativos distintivos desarrollado en estudios humanos, con énfasis directo a las culturas primitivas del archipiélago caribeño según señalamientos anteriores que se han alejado de la historia.

Su dimensión especifica abarca monografías, documentos y artículos desde 1836, cuando el término taíno nace en los Estados Unidos difundiéndose extensamente durante el siglo XX y acogido hasta el presente, ya asumido y proliferado por doquier como parte 
del tainismo, enmarcando una hipotética sociedad conocida como la cultura o sociedad taína. En este proceso analítico surge desde el siglo XV documentación valida y antagónica al tainismo, que fue estudiada por algunos autores contemporáneas opositores al tainismo que se discutirán durante el transcurso de la tesis, pero cuyas interpretaciones fueron ignoradas en su día. ${ }^{12}$

Uno de nuestros argumentos centrales señala que el tainismo o la tainización caribeña corresponden a teorías sospechosas. Desde esa perspectiva, y junto a ese dilema, los indicadores actuales estudiados demuestran que los términos aplicados a los nativos $o$ naturales $^{13}$ caribeños solo originan incertidumbres y desventajas socioculturales, al sumarse su falta de validez al personificar ancestros, junto a sus correlaciones a comunidades. Surgen de forma directa antagonismos cuando esas denominaciones teóricas se asumen por la cultura popular de hoy en el día a día. Esas denominaciones contemporáneas se comercializan y propagan sistémicamente, dejando huellas académicas de esa transformación asumida por la cultura popular en base a la educación. La cultura popular en la geografía isleña que estudiamos se refiere a la evolución nativa, transformándose en la sobrevivencia ancestral en el largo plazo influenciada por movimientos nativistas, que se identifican en base a un símbolo fabricado. Esta situación se exterioriza en una crisis cultural. Por tanto, el vivir e identificarse en base a un símbolo fabricado en el largo plazo da lugar a una crisis cultural y ancestral. Una crisis cultural existe cuando una comunidad, nación o naciones interpretan un símbolo, en este caso uno fabricado como un ancestro real. La crisis se amplifica y comercializa al substituirse adscripciones nativas e historia clásica caribeña por teorías académicas difundidas en publicaciones científicas y acogidas por instituciones y sistemas educacionales, llenando espacios con un pragmatismo teórico, eficiente y practico. De acuerdo con David Bidney (1946: 535): "Se puede decir que una determinada sociedad histórica posee una cultura bien integrada en la medida en que sus miembros viven de manera más o menos consistente y compatible de conformidad con las normas ideales de verdad, belleza y bondad que profesan y que han incorporado más o menos perfectamente en su sistema de instituciones".

\footnotetext{
${ }^{12}$ Referirse a a la tabla \#1.

${ }^{13}$ Nativos o naturales: designaciones distintivas aplicadas en esta tesis a los oriundos, originales, autóctonos o primogénitos caribeños encontrados en el ecosistema del caribe insular durante el descubrimiento de América. Se distancian estas designaciones de términos contemporáneos ligados al tainismo y a otras enigmáticas o desacertadas denominaciones, por ejemplo: indios, indígenas, aborígenes, primitivos o taínos, etc.
} 
El argumento de la crisis cultural en esta tesis trata al tainismo como una imposición académica creando una adversidad a la historia caribeña. La terminología taína nunca formó parte de la herencia ancestral, no es una denominación natural, nunca fue seleccionada o representativa de ninguna población, comunidad o nación en la antigüedad. Nunca fue una norma perfeccionada desde la antigüedad representativa de persona alguna. "Desde la perspectiva de las víctimas humanas involucradas, una crisis cultural es un mandato a la decisión o a una acción que puede marcar una separación radical de los caminos o direcciones de la vida" (David Bidney,1946: 535).

La separación radical de la historia del nativo caribeño, en nuestro caso, es una imposición perturbadora que ha victimizado las sociedades caribeñas desde el siglo XIX, mientras que los efectos de esa perturbación aún son desconocidos o ignorados a conveniencia. En este sentido, la crisis cultural y la crisis ancestral son el resultado del desconocimiento del patrimonio histórico de los naturales. Ese desconocimiento, junto a insensibilidades académicas y el arrogarse a ancestros fabricados, ha prolongado y concretado la crisis. La conexión que existe entre la comercialización perfeccionada del tainismo, mientras ciudadanos se educan en sistemas educacionales acogidos a términos y terminologías sospechosas, se discutirá a lo largo de esta tesis.

Nuestra investigación es un estudio de larga duración, por la extensión del tiempo histórico, los marcos geográficos anexos y las realidades biológicas inseparables; también como un estudio diacrónico y sincrónico: lo primero, porque analiza el empleo de una demarcación a lo largo de diversas fases, geografía y periodizaciones históricas, reflexionando el desarrollo pasado y la sucesión cronológica de los hechos relevantes en que se implica a lo largo del tiempo; lo segundo, porque a su vez permite observar el empleo de esta circunscripción y sus causantes más directos en un momento dado significante, en este caso, en su presente más inmediato.

De forma específica, esta investigación tiene un fin mayormente analíticosintético al intentar armonizar determinados postulados teórico-metodológicos con aspectos de la supervivencia de estos primogénitos nativos del Caribe insular y sus descendientes, definiendo una mejor conformación y utilidad entre las minúsculas comunidades existentes en la actualidad y el público en general, dentro de sus raíces étnicas culturales colectivas y particularizadas.

Se analiza la integridad e interpretan particularidades geopolíticas, sociales, morfología lingüística y etnohistóricas con relación a etnónimos, exónimos, periodización y las desventajas a comunidades y colectividades afectadas por los 
desperfectos fusionados entre pleonasmos contemporáneos, a gente simple que desconoce sus raíces, asumidas por su cultura popular. Nos adentramos en lo que es la moral, los valores sociales y la responsabilidad del historiador de interpretar una historia legitima. Por tanto, se articula un reto en el cual la fiabilidad, legitimización y justificación de términos y la supervivencia nativa caribeña isleña resisten, entrelazados e inmóviles, los intentos de resolver lo que son desventajas para comunidades marginadas, al convertirse esos términos científicos en supuestas realidades populares. Aquí nuevamente señalamos una crisis cultural.

Analizamos la epistemología del término taíno acuñado por Constantino Samuel Rafinesque-Schmaltz en $1836,{ }^{14}$ sus efectos, aportaciones y fiabilidad científica al carácter cultural e histórico del archipiélago caribeño, y sus consecuencias coetáneas contrapuestas a las considerables fuentes originales de cronistas y autores clásicos fidedignos. Se interpretan textos, artículos y documentos de estudiosos internacionales contemporáneos que han influenciado la historia nativa caribeña y su cultura popular desde el siglo XX, que razonaron la terminología orientada a la estandarización o galvanización taína. ${ }^{15}$

Esa orientación y tendencia es analizada extensamente, acoplada a la proliferación taína y el tainismo en el conjunto de conceptos manejados por investigadores tainistas en sus propias ambigüedades. Por tanto, son considerados los diversos periodos coloniales críticos desde el siglo $\mathrm{XV}$, al prestarse esas primeras décadas a nuevas incursiones teoréticas, dando paso a un proceso sistemático, adaptándose cada vez más a tendencias sintetizadoras en una innovadora terminología. En este sentido, esas teorías sintetizadoras o estandarizadas plantean el archipiélago isleño como dos geografías étnicas poscolombinas, la cultura caribe y la taína, o sea, aun siendo islas de amplia extensión territorial se proponen una unificación étnica, dividiendo lo oriental y lo occidental,

\footnotetext{
${ }^{14}$ Rafinesque, C. S. 1836. The American Nations or, outlines of their General History, Ancient and Modern Nations of North and South America. Annals. Philadelphia: C S Rafinesque. I Rafinesque, C. S. 1836. A Life of Travels and Researches in North America and South Europe: or Outlines or Life, Travels and Researches or C.S. Rafinesque. Philadelphia: C. S. Rafinesque.

${ }^{15}$ Estandarización o galvanización taína: se considera su principal marco temporal y evolutivo el siglo XX, durante el cual el término erróneamente es utilizado para denominar una raza, tribus y sociedades nativas en el Caribe insular es extensamente implementado y desarrollado. La tabla \#1 proporciona un orden cronológico abarcados en agrupaciones de décadas y fechas especificas por un numero de razones. Un numero limitado de autores fueron influenciados directamente por Rafinesque, otros por investigadores en sus idiomas, nacionalidades o su filiación académica. Un claro ejemplo es que Rafinesque no era arqueólogo o antropólogo; sin embargo, los arqueólogos y antropólogos se apropiaron de esa terminología. Son pocos los autores del siglo XX que hacían referencia a Rafinesque con anterioridad al siglo XXI.
} 
abarcando más de una isla Rouse (1992). Este concepto étnico geográfico significaría la imposibilidad de la coexistencia de grupos tribales homogéneos o viviendo en sus diversidades. La teoría de Rouse esta contrapuesta a tratados de cronistas, al considerar solo el occidente de Cuba y a os guanahatabeys como los únicos nativos en las Antillas Mayores durante el descubrimiento, en adición a los taínos. En nuestra tesis encontramos similitudes con la preocupación anteriormente señalada por Smith (2013: 22): "Para las personas del Pacífico, el patrón histórico de recopilación de datos, creación de conocimiento y teorización ha sido establecido por investigadores externos que recopilan historias de personas del Pacífico. Luego, tratan de dar sentido a las historias, y las vuelven a contar, desde su propia perspectiva haciendo posturas".

Desde comienzos del siglo XX, la arqueología, antropología y la etnografía presentan monografías y estudios avanzados que se apartan de las denominaciones étnicas reconocidas hasta el siglo XIX por los autores caribeños. Da comienzo, así, en el siglo $\mathrm{XX}$ a brechas académicas patrocinadas por prestigiosas instituciones y academias estadounidenses y extranjeras. Estas teorías visualizan una perspectiva de nativo $y$ colonizador, o colonizado y colonizador, alejándose del ethos local al descartar la cohabitación en una solo isla de múltiples grupos tribales siendo, o, no rivales entre ellos. Para otra región, Timote M Vaioleti (2006: 32) ha señalado algo que es de aplicación en el Caribe: "Las comunidades del Pacífico están compuestas de diferentes culturas, lenguas y valores y que un investigador tiene que entender whakapapa (la familia) y fakahohoko (la conexión ancestral) para relacionarse y actuar adecuadamente".

Se examinan en los próximos capítulos monografías y artículos científicos acordes a las afirmaciones de Vaioleti (2006) y Smith (2013).

La existencia étnica del archipiélago caribeño es limitada y sintetizada sobre una base geográfica definida a modo de taíno clásico, taíno del este o taíno del oeste en Irving Rouse (1992), José Juan Arrom (1999), William Keegan (1996), Roberto Cassá et al (2013), entre otros acogidos al tainismo. Esa práctica de sintetizar culturas caribeñas geográficamente no considera las uniformidades encontradas en el norte de Sudamérica, donde en una extensión territorial equivalente cohabitarían decenas de tribus ${ }^{16}$ o sectas

\footnotetext{
${ }^{16}$ Tribu(s): en esta tesis se refiere a pueblo(s), nación o naciones basados en sus demografías, ancestros, mitología, costumbres, políticas territoriales y configuración. Debido al tiempo histórico analizado y las diversas colectividades geográficas visitadas, asumimos que parentelas, grupos, clanes, poblaciones y aldeas son análogas a tribus pequeñas. A su vez, una demografía en crecimiento de tribu(s) asentadas en un área geográfica ordenada bajo sus propias leyes patrimoniales pueden constituir una nación. O sea, una tribu de la nación o un territorio de una
} 
particularizadas y reconocidas como independientes las unas de las otras. Regresamos a Vaioleti (2006) y Smith (2013) con el propósito de analizar regiones. Una minúscula muestra lo serían las tribus venezolanas: achantis, achariguas, araucas, bares, caribes, chiricoas, maipure, onotos, teques, etc., Ese número de tribus, pueblos o comunidades de nativos venezolanos conocidas superan las 40 hoy día. Analizar desde el punto de vista del nativo caribeño en su propia naturaleza representa reintegrar clasificaciones antiguas que hoy están fundamentadas bajo el tainismo caribeño. En este sentido, desaparece el nativo caribeño bajo el concepto de fulminación de la raza, la sustitución de sus autodenominaciones y nombres tribales bajo la nueva estandarización terminológica taína difundida científicamente en un sistema de periodización y geografía que excluye las denominaciones y culturas nativas originarias. Esa periodización y geografía nativa la estaremos analizando a lo largo de esta tesis para identificar adscripciones originales. En palabras de Michel Foucault (1978: 154, 155):

"La historia 'efectiva', sin embargo, trata los eventos en términos de sus características más singulares, sus manifestaciones más agudas. (...) ¿Las fuerzas que operan en la historia no están controladas por el destino o los mecanismos regulativos, sino que responden conflictos al azar? (...) El mundo que conocemos no es una configuración simple en última instancia donde los eventos se reducen para acentuar sus rasgos esenciales, su significado final o su valor inicial y final. Por el contrario, es una profusión de eventos enredados".

En esta tesis buscamos aclarar el ambiente académico que definió al nativo caribeño en un término estandarizado, examinando la sensibilidad de esa postura científica y su fiabilidad desde la historia. Por ende, entramos en continuos diálogos de verdades y falsedades ubicados en una periodización y geografía que requieren examinar orígenes nativos en consideración a sus propias perspectivas:

"Una nación es un alma, un principio espiritual. Estas dos cosas en verdad son solo una, que constituyen el alma y el principio espiritual. Una habita en el pasado, la otra en el presente. Una es la posesión en común de un rico legado de recuerdos; la otra consiente lo actual, el deseo de vivir juntos, la voluntad de perpetuar el valor del patrimonio que uno ha recibido en forma indivisa" (Renan, 1998: 7).

tribu principal (en crecimiento) pueden ser intercambiables. A su vez tribus de una nación acogidas en sus propias políticas geomorfológicas facultan a cabecillas o caciques con ciertos derechos sobre sus originarios. Un concepto de leyes nativas lo es, admapu (Delrio 2014): Costumbre de la tierra, normas consuetudinarias de indole moral y jurídica, reglas para el conjunto de las relaciones entre las personas, fuerzas de la naturaleza y los antepasados. I (Albornoz 2005): Esto no es otra cosa que un conjunto de leyes y tradiciones rituales religiosas heredadas de los antepasados. Examinamos características del concepto admapu basado en ley, territorio, política y ancestros. Esa ligadura al suelo, la naturaleza y la raza de sus antepasados existió en el Caribe. 
Esta noción de alma y espíritu que habitan en el pasado y en el presente la identificamos desde los conjuntos de familias hasta las naciones al analizar congregaciones de nativos. Esa alma y ese espíritu recogen de su entorno natural la diversidad nativa que les identifica por sus características únicas, manifestando en ese conjunto sus propias leyes y políticas internas que determinaron sus vidas y su historia. La sustitución de esa alma y ese espíritu es el comienzo de una crisis cultural y ancestral.

\section{LAS RAZAS CARIBEÑAS Y UNA NOTA SOBRE CONSTANTINO SAMUEL RAFINESQUE-SCHMALTZ}

Los planteamientos científicos relacionados con la raza y la etnicidad en nuestra área de estudio aportan un mejor entendimiento del nativo caribeño. Sin embargo, hay que indicar que raza y etnicidad facilitan aplicaciones comunes y no enteramente científicas. Según Gloria Ladson-Billings (2014: 38): “Biólogos, genetistas, antropólogos y sociólogos están de acuerdo en que la raza no es una realidad científica. A pesar de lo que percibimos como diferencias fenotípicas, el examen de un microscopio o la secuenciación de genes no revela diferencias perceptibles entre lo que llamamos razas".

Raza es un concepto amplio. Su acomodamiento interno representa una propia identidad basadas en sus propios criterios raciales. Grupos o naciones externas interpretan esa identidad racial de acuerdo con otros criterios. En esta tesis se entiende que raza es un principio interno de comunidades, no discriminante en teoría, no revela diferencias en las funciones de sus integrantes. La variada problemática postcolonial nativa esta relacionada con un largo proceso de promiscuidad y de supervivencia en el marco de la cultura popular, lo que constituye solo dos aspectos de lo multirracial caribeño. Las dificultades de etnia y etnicidad agravan aún más las condiciones relacionadas a la cultura nativa en evolución.

Dice Bill Ashcroft (1998: 146): "Por otro lado, la naturaleza multicultural de la mayoría de las sociedades poscoloniales hace que la cuestión de lo que constituye la cultura "nativa" precolonial sea obviamente problemática, especialmente cuando el estado-nación postcolonial actual se define en términos que favorecen un grupo cultural dominante". 
Este comentario de la enigmática condición de la naturaleza multicultural poscolonial es una variable a la cultura nativa, que a su vez está ligada a variaciones de la promiscuidad multirracial caribeña cuyos antecedentes históricos, en el largo plazo, no están completamente entendidos. La promiscuidad multirracial caribeña identifica una vía elemental de supervivencia nativa que ha dejado su rastro de ADN y sus rasgos primitivos, encontramos en pleno siglo XXI en comunidades caribeñas. Tratar esta temática de promiscuidad multirracial caribeña desde una perspectiva terminológica taína para explicar una etnia nativa evolucionada representativa de un estado-nación constituye un grave error. La estandarización taina y su terminología análoga son una discontinuidad etnohistórica de los primeros contactos y de la evolución racial histórica. El periodo de tiempo entre 1492 y 1836 abarca hechos humanos de la historia nativa caribeña referidos por cronistas, y experiencias personales de exploradores, colonos, clérigo y de los propios naturales encontrados a bordo desde ese primer viaje a Europa en 1493. Los nativos llegaron a la corte de los Reyes Católicos en el primer viaje de regreso a Europa, y esos nativos eran lucayos. Saturar ese espacio histórico de tribus y naciones compuestos de factores y leyes ancestrales con una ilusión terminológica post industrialización, representativa de esos estados-naciones caribeños, constituye un error histórico.

Cronológicamente, 1836 representa un punto de partida desde el cual una nueva historia surge. En esa métrica, y en ese año, se le adjudica a Constantino Samuel Rafinesque-Schmaltz grabar el comienzo del término taíno. Peter Hume (1986), C.L. Hofman y M. L. O. Hoogland (1999), Neil Whitehead (2002). En la primera década del siglo XX, a medida que el término ganaba aceptación institucional e internacional, se aceleró la caída de la diversidad nativa caribeña tradicional Sloan (2018). En consecuencia, tenemos hechos históricos antagónicos a los avances de nuevas -y sospechosas- investigaciones científicas. Por ende, Rafinesque no solo acuña un término, sino que da comienzo a una ficción histórica que cada vez se aparta más de la vida y naturaleza del nativo caribeño.

Constantino Samuel Rafinesque-Schmaltz es una figura enigmática que en su época unió ciencia y ficción, fabricando al taíno y llenando páginas de historia que dieron vida a una terminología científica. Nació en Constantinopla (llamada Estambul desde 1923 ) en 1783, en una familia franco-alemana: su padre era francés, su madre de familia alemana nacida en Grecia. Se ha argumentado que la lengua materna de Rafinesque era el griego, sin embargo, se piensa que debió serlo el francés por haberse criado en Francia. 
La etnicidad de Rafinesque bien pudiese ser tema de estudio. Antes de emigrar a América del Norte, en 1802 había vivido en Turquía, Francia, Italia y otros países, adquiriendo una competencia lingüística que guiaría o complementarían con existo sus intereses académicos. Rafinesque, citado por T.J. Fitzpatrick (1911: 13), dice de sí mismo: “nunca estuve en un colegio regular, ni perdí mi tiempo en lenguas muertas (...). Me he comprometido a aprender latín y griego, así como hebreo, sánscrito, chino y otras cincuenta lenguas".

La vida de Rafinesque no es debatida por tainistas, simplemente citan su nombre, por la complejidad histórica y su desconocida vida. Según Fitzpatrick (1911: 50), Rafinesque recibió de la Sociedad Geográfica de París en 1841 una medalla de oro y un diploma de mérito por un estudio científico sometido, siendo ese galardón la primera instancia en que tal honor fuera otorgado a un ciudadano estadounidense. Rafinesque era un hombre de ciencia, cuyo trabajo se publicó ampliamente en más de 220 publicaciones, que incluyen no menos de treinta y cinco monografías y extensos artículos escritos en varios idiomas. Fue profesor durante siete años en la Universidad de Transilvania, en Lexington, Kentucky; sin embargo, no había obtenido credenciales de educación superior en su juventud. Era autodidacta y los medios y recursos de los que dispuso fueron un tanto limitados, pero fue hombre de mérito y de gran éxito.

Mientras esta tesis se opone al término y terminología del taino propuesto por Rafinesque, igualmente le reconoce como una figura de importancia en la historia del taino. El reconocimiento a las investigaciones de Rafinesque por los seguidores de esa terminología subsiste en pocas páginas de la historia tainista. En 1924 los restos de Rafinesque fueron desenterrados y se trasladaron de Filadelfia a la Universidad de Transilvania, donde los estudiantes de "Transy" celebran la vida, legado y un curso de fábulas culminando anualmente en "Raf week" [la semana Raf], Spurlock (2014: 4).

Rafinesque fue un botánico, lingüista, profesor y un hombre de logros poco comunes. Se dice que murió en la pobreza. Con Rafinesque asimismo murió un especialista étnico consumado, cuyo ilusorio taíno ha perfeccionado una vida propia. ${ }^{17} \mathrm{Si}$ el taíno caribeño sobrevive al tiempo, el escrudiño y la historia es por la ingeniosidad y dedicación de ese científico. En los próximos capítulos se identifican secciones de la obra

\footnotetext{
${ }^{17}$ Sloan Toraño, R. 2018. Terms and Terminology Conflicts of Social Quandaries Engendered by the Taino Native Fixation a Cultural Crisis Analytical Study in Caribbean Contemporary History. / Sloan Toraño, R. 2019. Caribbean History and Heritage Crisis Resulting from Generic Standardization and Substitution of the Native Borinqueños, Boriquans or Boricuas of Puerto Rico Subsequent to Suspicious Taino Research
} 
de Rafinesque cuya especialidad en culturas nativas de América prestan validez a su inclinación científica.

Este estudio demuestra cómo un hombre de ingenio científico y articulación académica transformó una palabra común en un lenguaje y en una raza, articulando en un razonamiento científico exitoso la fundación de naciones civilizadas taínas. Ese hecho fundamental, seguido por estudios perfeccionados en ciencias y comercializados por instituciones de importancia, dejan rastros históricos que analizamos para liberar al hombre natural caribeño y su diversificación del yugo de la estandarización terminológica taína.

Esta tesis se opone no al indiscutible éxito del ingenioso Rafinesque, sino a su teoría terminológica estandarizada opuesta a la diversidad cultural del hombre original caribeño. Simplemente se honra el éxito y se impugna el resultado. Tomamos nota que ese resultado hoy es muy diferente a lo propuesto originalmente por Rafinesque en su terminología original; los investigadores y la ciencia a la que se acogen han logrado nutrir al azar esa imagen, concepción e historia.

Dentro de una evolución nativa autentica y diversificada se reconocen un sinnúmero de elementos fundamentales, por ejemplo, el color de la piel es un factor limitante a la herencia nativa pero no determinante; los factores multirraciales son distinguidos en porcentajes biológicos heredados y no visuales. Ese tema, íntimamente relacionado a la promiscuidad, el género y la violencia y política que los abarcan, los examinaremos en los próximos capítulos. Desde la perspectiva multirracial, una persona considerada negra puede tener un factor nativo, asiático o blanco, lo que no eliminaría ninguno de los tres grupos de su composición biológica o su etnicidad.

En este sentido, personas multirraciales pueden retener algún nivel biológico nativo indiferentemente al color de la piel. El porcentaje biológico evolucionado viabiliza el que un mayor segmento de la población pueda acogerse dentro de la cultura nativa popular. Por ejemplo, los Yemassee del sureste norteamericano son de apariencia física africana, los Garifunas son negros descendientes de caribes isleños y otros nativos caribeños habitantes de las Antillas Menores desde el siglo XVI. ${ }^{18}$ Estos últimos fueron

\footnotetext{
${ }^{18}$ Los negros en el marco racial de los nativos americanos comienzan sus estirpes desde las primeras décadas del siglo XVI en colonias de españoles y portugueses, los Garifundas proceden las Antillas Menores mientras que otros tales como los Miskitos/Mosquiros o Mostique proceden de Nicaragua y Honduras. Los Yemassee o Yamassee de Carolina del Sur, EE UU a lo largo del siglo XVIII se desplazaban a la Florida española huyendo de los británicos, mientras negros esclavos se refugiaban en la Florida huyendo de británicos y colonos, dándose lugar a unos
} 
desterrados por británicos y franceses a Belize y Honduras. Sin embargo, la proporción racial no presenta una irreconciliable problemática, según Ashcroft, en su grupo dominante en nuestra área geográfica solo identifica tendencias prejuiciadas, desconsideraciones sociales y falta de conocimiento. Los argumentos de ese discurso racial han sido levantados post descubrimiento, por ejemplo, en las palabras de John Quincy Adams escribió en su diario el 29 de abril de 1829: "La esclavitud negra fue una criatura del artilugio-humano de Las Casas al mitigar las condiciones de los indios americanos" (Cit. por Stimpson, 1950: 28).

Kluchholme y Murray (1953), citados por Honigmann (1954: 195), trabajando el tema de la personalidad, señala cinco elementos en los que se combinan aspectos antropológicos y psicológicos:

(1) los factores constitucionales del lugar de nacimiento

(2) el grupo al que la persona pertenece

(3) el rol en el que la persona opera, padre, jefe, esposo

(4) los accidentes en los que se encuentra, y

(5) la geografía que encierra.

Honigmann trata relaciones indirectas usando de ejemplo a los Attawapiskat, una banda de las más de 135 que componen los Cree. Los Cree pasaban hambre a consecuencias del medio ambiente en el que vivían. Los Cree es una tribu principal o primera nación, y Attawapiskat (nombre de un río) es una banda, usando ese nombre, ubicada entre el río Kapiskau, la bahía de Hudson y la isla Akimiski, en el este del lago Mississa, en Ontorio. En Canadá y Estados Unidos la población Cree o de ancestros Cree sobrepasan 300.000 habitantes. En nuestro caso, los factores constitucionales los discutiremos, pero se conoce que en la época del descubrimiento y dependiendo del territorio, estos ofrecían algo de seguridad y protección. De la servidumbre a la esclavitud, viviendo una vida accidentada en inimaginables formas, habitando una geografía en la que los autóctonos se convierten en sirvientes. Por ende, si estos cinco factores

amasijos entre estos dos grupos, fundamentándose algunas de las características raciales encontradas hoy día. Otros grupos de nativos y africanos con ancestros comunes incluyen a los Cherokee, Pequot y Lumbee, entre otros. Ver, Garroutte, E. M. 2001. "The racial formation of American Indians: Negotiating legitimate identities within tribal and federal law", The American Indian Quarterly, 25(2), pp. 224-239. Katz W. L. 1986. Black Indians a hidden heritage. Ethrac Publication. / Ruether, R.R. ed., 2002. Gender, ethnicity, and religion: Views from the other side. Fortress Press. 
promueven la personalidad, el nativo caribeño estaba destinado a pasar del autoabastecimiento y la persona autóctona de raíces y naturaleza propia, al hambre. Mientras las relaciones indirectas, según los estudiosos, encierran magnitud y discreción, su articulación respecto al nativo caribe del siglo XV posee un alto nivel especulativo; en consecuencia, analizaremos la palabra escrita, y de entre sus faltas y errores reunimos detalles de la idea original.

El proceso legal y social, junto a la clasificación de los nativos bajo las nuevas leyes generadas en 1542, se prestan al argumento de la supervivencia nativa, dentro y fuera de la perspectiva multirracial. Dentro de la composición biológica nativa de esa era, junto a las garantías delegadas a la liberación de nativos de la América hispana, existió una vía a la supervivencia nativa en el mestizaje multirracial. Este tema, de suma importancia, se refleja a lo largo de esta tesis.

\subsection{Anotaciones de exploradores. Entre libertad, razas, política esclavista y género.}

Reconociendo que los nativos de la América hispana en general fueron de alguna manera protegidos desde 1542, se presentan un sin número de situaciones. Las Leyes Nuevas de 1542 han merecido, entre otros, el estudio de José María Ots Capdequí (1941), R. Konetzke (1960) y Esteban Mira Caballos (1996). ${ }^{19}$ Ots Capdequí afirma: “(...) jugó este derecho castellano un papel preponderante en lo que se refiere a la legislación jurídica de la familia y al derecho de sucesión" (1941: 15). En esta tesis, los derechos de familia y de sucesión se incorporan al examinar el género y su aportación a la evolución biológica y costumbres nativas. Sigue el historiador jurídico: "En cuanto a la influencia positiva que lograron ejercer en la vida de las instituciones jurídicas coloniales las primitivas costumbres de los indios aborígenes que no estuvieran en contradicción con los principios básicos del Estado español, es esta cuestión que no ha sido todavía suficientemente estudiada". Esta tesis se dirige precisamente a investigar esa cuestión desconocida por Ots, al investigar la política territorial y ancestral practicadas por los nativos caribeños

\footnotetext{
${ }^{19}$ Ots Capdequí, José María. 1941. El Estado español en las Indias. / Konetzke, R. 1960. Los mestizos en la legislación colonial. Revista de estudios políticos, (112), pp.113-148. / Caballos, E. M. 1996. 'El sistema laboral indígena en las Antillas"' (1492-1542)', Encomiendas, Indios y Españoles, pp. 13-31. Ver: Mira Caballos, E. 2009. 'De esclavos a siervos: amerindios en España tras las Leyes Nuevas de 1542', Revista de Historia de América, pp. 95-109. / Archivo General de Indias (AGI).
} 
desde sus propias perspectivas. Se propone el concepto de admapu, citado por Delrio (2014) y Albornoz (2005), como un preámbulo a esas costumbres territoriales y jurídicas practicadas por los nativos caribeños durante esas primeras cinco décadas. En el transcurso de esta tesis nos acercamos a temas jurídicos y ancestrales en todos los capítulos en busca de identificar y analizar la acción y la práctica nativa por cuyo acceso encontraron la supervivencia.

Hasta que comenzaron las revueltas de la Florida debido a las invasiones inglesas, las razones de interés comercial se interponían ante la ley (Mira Caballos, 1996). En San Agustín, tras su derrota, los ingleses comenzaron una lucha de guerrillas, capturando y vendiendo nativos entre 1670 y 1715 , cuando se dio comienzo a la expansión en Norte América y a la gran comercialización esclavista de negros y nativos. En definitiva, existen marcadas diferencias en el comportamiento anglosajón y el ibérico en su trato de negros y nativos.

Alvar Núñez Cabeza de Vaca, en su obra Naufragio, originalmente publicada en 1555 [la edición utilizada es de 1749 (cap. XVI), hace mención a Eftevanico el Negro, y en otros capítulos lo nombra en el desempeño de sus tareas. William L. Katz (1986: 9094) cita la existencia del marroquí negro nacido en Azamore (Azamor) alrededor del 1500 , capturado por cristianos posiblemente en el 1513 y luego reapareciendo como esclavo de Andrés Dorantes, viajando a La Española y posteriormente a la Florida en 1528; este se llamaba Estevanico o Estebancito, y su final no es ciertamente conocido, si sobrevivió a la expedición de Narváez junto a tres otros, entre ellos Dorantes y Cabeza de Vaca, y luego se unió a la expedición de Coronado. Marroquí implica nacionalidad, musulmán de religión, o converso, en este caso también negro, esclavo, y ladino por haber sido capturado de niño y criado entre cristianos en España.

En Naufragios, Cabeza de Vaca (1982: 66-67, cap. xv) escribe en esa ocasión: "como eran de otra lengua y de otra parentela...", y continua su relato hablando de una isla (Mal-Hado) cercana a la costa:

"Las mozas se cubren con unos cueros de venado. Es gente muy partida de lo que tienen unos con otros. No hay entre ellos señor. Todos los que son de un linaje andan juntos. Habitan en ella dos maneras de lenguas; á los unos llaman de Capoques y a los otros de Han: tienen de costumbres cuando se conoscen y de tiempo á tiempo se ven, primero que se hablen estar media hora llorando: y acabado esto, aquel que es visitado se levanta primero y da al otro todo cuanto posee, y el otro lo recibe, y de ahí á un poco se va con ello, y aun algunas veces después de rescebido se van sin que hablen palabra". 
Cabeza de Vaca presenta cómo una isla es habitada por dos grupos nativos de diferente habla, que a su vez comparten un hábitat circundado por agua, cuya denominación identifica separadamente a cada grupo por su parentela; la diversidad entre bandas se identifica en el lenguaje y algunas costumbres que comparten. Cabeza de Vaca partió de España el 17 de junio de 1527 y comparte su conocimiento de autodenominaciones nativas de esas primeras décadas. Así, se refiere a un indio tuerto que acompañaba a Dorantes, el amo de Estebanico, a su vez con su mujer, un hijo y otro indio, todos tuertos. "Estos se llamaban mariames y Castillo estaba con otros sus vecinos, llamados iguaces" (Cabeza de Vaca, 1982: 77). La expedición del explorador recogió detalles autóctonos de denominaciones originales en una narrativa simple cuyo significado estriba en el ordenamiento de qué es la diversidad, naturaleza y geografía nativa compartida en sus propias políticas. En el caso de Cabeza de Vaca, las parentelas asumen vida propia, por lo vivido. Durante ocho años, el castellano, en compañía de Castillo, Dorantes y Estevanico, fue náufrago, viajando de tribu en tribu en calidad de mercaderes y curanderos, atravesando desde la Florida hasta llegar a México, presentándose ante el capitán Diego de Alcaraz, a quien solicitó constancia de su llegada al campamento español, que estaba a treinta leguas de San Miguel, en la provincia de Nueva Galicia.

Las aventuras de Cabeza de Vaca y sus compañeros náufragos son de importancia a esta tesis por sus experiencias vividas, pues recogió e identifico en su publicación datos irremplazables de costumbres nativas. En los próximos capítulos citaremos a Cabeza de Vaca en esos momentos en los que resulte necesario revalidar datos históricos rescatados en vida propia, constituyéndose no solo una verdadera hazaña. Esos episodios nos los presentan como exploradores adaptados, fuera de sus automatismos, interpretando la vida nativa y su relato ofrece alternativas a lo que se entiende por tribu, ancestros, territorio y las leyes de las naturales aplicadas a su diario vivir. En este sentido, el explorador subsiste integrándose a la vida nativa, apartado de ser el colonizador en busca de riquezas o el rutinario colono.

El tema de raza, descendencia y mestizaje es abarcado durante el transcurso de esta monografía ordenando aportaciones e interpretaciones anfibológicas o axiomáticas. ${ }^{20}$ En las proezas de los exploradores encontramos espacios interpretativos que amplían las

\footnotetext{
${ }^{20}$ El mestizaje nativo-europeo es anterior en Iberoamérica al mestizaje entre negros, nativos y/o europeos por al menos hasta la segunda década. Sin embargo, en esta tesis la supervivencia biológica nativa es una multirracial.
} 
dimensiones del conocimiento. Siguiendo ese factor humano, esta investigación atiende problemas de identidad y cultura fundamentándose en narraciones históricas, al enfocar problemas sociales de mestizaje, servidumbre forzada o clasificaciones y estructuras internas primitivas durante las primeras décadas del descubrimiento. En este sentido, y bajo estas condiciones, es justificable señalar las experiencias vividas y legadas en su momento por exploradores. Colón, en su Diario de a bordo, durante sus primeras semanas del descubrimiento hace anotaciones que son esenciales para entender la mentalidad de los exploradores. Así, manda tomar nativos el domingo 14 de octubre 1492; Colón habla de cautivos, pero la decisión de tomar gentes contaba con un precedente. F. A. Kirkpatrick (1940: 11) describe las actividades de Colón en 1477: "En un viaje a la Guinea portuguesa, donde entró en contacto con los negros habitantes de extrañas tierras, realizado provechosas transacciones comerciales por trueque y un lucrativo tráfico de esclavos".

En este sentido, aun cuando la referencia es a africanos, Colón resulta experimentado en la subyugación y el tráfico de seres humanos libres, reducidos a esclavos, con anterioridad a sus viajes a América. Luis Arranz (1991: 17) comparte lo citado por Kirkpatrick desde otra perspectiva: "En suma, una actividad corsaria -como la que se puede atribuir en esos años a Colón -es una forma licita de guerra, legalizada por patentes de corso, es decir, autorización de una ciudad o de un estado".

Entre la política del Mediterráneo de la época y las previas experiencias de Colón queda claro que las palabras de Colón en su diario deben examinarse cuidadosamente, al momento de interpretarlas en lo relacionado a esos primeros encuentros. Las experiencias de Colón forman parte intima de su vida y, en específico, de sus futuras decisiones.

En lo concerniente a las hermosas mujeres nativas descritas por Colón, unas desnudas y accesibles a los exploradores, nos resulta realmente difícil pasar por alto o negar las actividades sexuales inmediatas durante tres meses de esos 90 hombres. Encontrados esos hombres en un entorno caribeño acogedor a sus cortejos y acosos, pensar que no engendrarían al menos un niño, o el razonar que pudieron ser docenas de niños los engendrados, resulta innegable al sentido común. En relación con los engendrados, primero examinaremos el número original de tripulantes en ese primer viaje y sus nuevas costumbres. Washington Irving ${ }^{21}$ (1882: 34) plantea que el número de

\footnotetext{
${ }^{21}$ Irving, W. 1882. The life and voyages of Christopher Columbus. New York: Pollard \& Moss. Se conoce que entre la tripulación se encontraban un árabe musulmán y un judío, pero no se ha encontrado al momento negros identificados racialmente.
} 
tripulantes era de 90 hombres, sin embargo, Colón, los hermanos Pinzón, los pilotos Sancho Ruiz, Pedro Alonzo Niño y Bartolomeo Roldan, junto a Rodrigo Sánchez, Diego de Arana y Rodrigo de Escobar, un médico, un cirujano y unos aventureros privados y sirvientes pudiesen superar los 90. En las listas definitivas de Alice B. Gould ([1940] 1984), el número total de viajeros es de 87 , John Thatcher (1903) mantiene 87 con ciertas repeticiones, y otros, como R. Fuson (1987), considera un total de 109. Entre estos autores existen ciertas diferencias, pero en definitiva se puede aceptar noventa como el total de personas a bordo de las carabelas durante ese primer viaje como un número razonable. ${ }^{22}$ Al analizar las dimensiones de las carabelas, sus capacidades espaciales articulan números de tripulaciones, pasajeros y desahogos en viajes cortos o largos. Por ej., La Santa María (la Gallega) de Juan de la Cosa era de 19-21 metros, con capacidad a 40 viajeros, la Niña (Santa Clara) de Juan Niño de unos 15-16 metros con capacidad de unos 25 viajeros, y la Pinta de Cristóbal Quintero, de 17-18 metros con capacidad de unos 26 viajeros. Las incomodidades espaciales de superarse estos números de viajeros, las logísticas de requisitos mecánicos y alimentación de a bordo en un viaje de exploración no superarían 91 viajeros. En este sentido se establece un preludio a la teoría de la supervivencia nativa desde las primeras semanas del descubrimiento, pudiéndose añadir que, por razón de decoro o penuria, los reyes, el papa y los cronistas cristianos prudentemente menguarían ese tema. Igualmente, esa dejación es inseparable del origen poblacional de la sociedad caribeña que estudiamos.

No obstante, las comunes y tempranas prácticas sexuales durante el descubrimiento solo inferían inmoralidad, resultando inmaterial sus resultados biológicos desde quizás el primer día del descubrimiento. Es menester señalar que ese primer viaje enmarco un entorno donde se procreó el primer mestizo de América y en la eventualidad del colonialismo se convirtió en una práctica común, social y política. Se puede señalar que ese primer hibrido nació en 1493 y fue de una madre nativa, lucaya, cubana, quisqueyana, macorix, haitiana o ciguaya, sin contar tribus o clanes contactados formados en parentelas de los que se desconocen sus denominaciones. Por meses las prácticas

\footnotetext{
${ }^{22}$ Se puntualizan estas diferencias numéricas que abarcan tanto tripulaciones, razas, autoridades y condiciones o destrezas puesto que aun cuando estas parezcan de poco significado científico por su matemática a través de cinco siglos pueden por definición influenciar directa o indirecta durante la evolución caribeña a la supervivencia nativa. En medidas numéricas sean de ADN, el ambiente construido, el género y sus herencias distribuidas en variables se encuentra una fórmula matemática que descifra espacios negados, como lo es la extinción, una que implica la fulminación en base a un cien por cien.
} 
sexuales de los tripulantes dejados en el fuerte de la Navidad, o bien el Fuerte de la Natividad, son inexplicables. ${ }^{23}$ Se presta a interpretaciones las posibles acciones de los conquistadores dejados en La Española en la cita de Richard H Major ([1847], 1870: 53): “uno tenía tres mugeres, otro cuatro”. En este sentido la posibilidad de ese primer hibrido nacido en 1493 se amplía matemáticamente por fárrago y promiscuidad.

Las palabras entre Hernán Colón y Guacamari (Guanacanagari) implican que Caonabo y Mayreni fueron los responsables de las muertes, y estas por causas de abusos, dice Hernán Colón, por celos. Colón y Cabeza de Vaca recogieron denominaciones por parentelas, aunque ambos coincidieron en las semejanzas físicas uniformes. El principio básico por el cual hombres expuestos a campañas esclavistas legales y comerciales bajo protección de algún estado o ciudad tomaran o subyugaran mujeres nativas sexualmente es una teoría viable.

\subsection{Lenguas y diferencias.}

Emerge desde la primera década una identidad nativa caribeña cuyos componentes de auto protección pasan inadvertidos ante los ojos ciegos de la historia, reapareciendo en el siglo XX bajo las peores interpretaciones. De la obra de Ramón Pané, original de 1498 (1988:10 $)^{24}$ surge un claro ejemplo. José Juan Arrom, basándose en una coincidencia entre Pedro Henríquez Ureña y Fernando Ortiz, dice que Ramón Pané nunca habló el taíno. Es hecho claro que en Haití y Quisqueya se hablaban más de una lengua en esa diversidad étnica histórica, pero nadie hablaba el taíno: "Marolis tenia (sic) 25 diversas lenguas que las otras, y que no la entendian en toda la tierra" (H. Colón, 1892: 13). Las lenguas y parentelas reconocidas entre nativos no se identifican particularizadas, simplemente se amontonan basándose en una diversidad de lenguas. Esa exégesis de

\footnotetext{
${ }^{23}$ El Fuerte de la Navidad representa un concepto de promiscuidad, treinta y nueve hombres quedaron en la Haití-Quisqueya (La Española) por unos diez meses, en su matemática figura insostenible, tanto por lo conocido, como lo desconocido que esa primera criatura no nació. Fuson (1987: 226-227) contabiliza hasta 42 dejados en la Navidad e incluye sus nombres como el número de hombres dejados en la Navidad.

${ }^{24}$ Pané, R. 1988. Relación acerca de las antigüedades de los indios: el primer tratado escrito en América. 3ra ed. Editado por J. J. Arrom., Siglo XXI. Ramón Pané escribió lo que debe ser considerado el primero libro acerca de nativos caribeños y de América, escrito en la primera década del descubrimiento por un español.

${ }^{25}$ Debe considerarse que las citas con errores no se identificarán por ser numerosas. De ser necesario se interpretarán en el texto.
} 
Arrom implica que los tainos existieron, mientras que lo único demostrable es que Arrom, Ureña y Ortiz coincidían entre ellos al afirmarlo. Arrom, Ureña y Ortiz concurrían en que en La Española se hablaban tres idiomas, que ellos conocieran, y según Arrom, "porque ninguno, clérigo, ni fraile, ni seglar, supo ninguna perfectamente de ellas si no fue un marinero de Palos o de Moguer, que se llamó Cristóbal Rodríguez” (1988: 10).

El reconocer una diversidad de idiomas, y luego asumir que entre esas lenguas surge el taíno, o que todas se basaban en la lengua taína, o que exista una relación lingüística, resulta irónico. El marinero Cristóbal Rodríguez, en dos o tres años se convierte en el traductor peninsular más reconocido, logrado para 1496. ¿Cómo logra Rodríguez superar las habilidades lingüísticas expresadas por Pané? ¿En qué consistía su íntimo enlace con nativos? ¿Tenía familia o hijos? ¿Convivía en una colectividad o bando, o mantenía una cohabitación nativa natural según normas tribales y rituales aceptables entre ellos?

Desde los primeros momentos de la llegada de los españoles tienen lugar uniones de nativos y colonos. Mark Harrington (1921: 247) identifica al Sr. Mosquera, un viejo español casado con una mujer india, vivían juntos en una pequeña villa donde sus hijos e hijas vivían en bohíos cobijados de palmas. Esta vida nativa natural de Mosquera muy bien pudo haber sido la vivida por Cristóbal Rodríguez ene 1496. En este sentido, el nativo buscó alternativas en su propia naturaleza, logrando salvar el futuro de su comunidad o parentelas por vía de la mujer. Ciertas ramificaciones de la supervivencia se establecen, por una parte, en la figura la mujer casada o sometida y forzada sexualmente, que engendra niños de colonos, conformando familias con o sin padres; segundo, se someten comunidades enteras a trabajos forzados y violaciones en el marco de las encomiendas; tercero, el huir a lugares remotos dentro y fuera de La Española; y cuarto, la cohabitación anómala junto a ladinos y otros nativos salvaguardados. En este marco de uniones existe un claro vinculo biológico en la supervivencia nativa, sin olvidar que en ese montaje pudo existir un verdadero amor entre iberos y nativos, o cristianos y nativos por más ínfimo fuese.

La terminología contemporánea aplica nuevas visiones y logra científicamente separar tanto las culturas nativas genuinas y las contribuciones antiguas, y da a lugar a adversidades mientras en su periferia nace la cultura popular sin las facultades necesarias para resguardarse de fallos históricos. Las culturas nativas regionalizadas y las aportaciones investigativas locales, junto a las extranjeras, son un hecho de importancia. En este sentido, examinaremos diversas temáticas y aportaciones con miras de acercarnos 
cada vez más a las identidades étnicas genuinas. Harrington (1921) usó los siguientes términos, muy representativos de los tainistas de la primera mitad del siglo XX: "tainan, tainan culture, sub-taino, typically tainan, taino village, y taino skulls", etc. Estos términos, en inglés, representan lo taíno, cultura taína, sub-taíno, típicamente taíno, villa taína, cráneos taínos; el conjunto de expresiones facilito a Harrington la identificación de artefactos y restos desenterrados, por ejemplo, figuras \#66 y \#70 y otras. Harrington usó el término taino entre corchetes, asistiendo a la simplificación e identificación de su obra.

Examinemos algunos argumentos publicados en la segunda mitad del siglo XX: "Debido a que la mayoría de las reconstrucciones de los cacicazgos Taíno se han basado en los relatos de los invasores españoles, la presente revisión se centra en la arqueología y la etnohistoria de la Edad Antigua (finales del siglo XV al comienzo del siglo XVI)" Keegan (1996: 266). La revisión arqueológica y etnohistórica de William Keegan (1996) aparenta alejarse o considera repudiables los trabajos escritos de invasores españoles, en cuya historia de cacicazgos y señoríos nunca existieron taínos, pues en la historia de esos invasores españoles antiguos esa terminología era desconocida. Keegan plantea un alejamiento de los cronistas y autores clásicos, quienes fueron los responsables de documentar los primeros encuentros entre los hombres primitivos de América y los europeos; simplemente, puede ser porque ninguno de esos autores escribió página alguna de taínos como tribu, raza o lengua nativa en el Caribe o América. Si partimos de la premisa de Keegan, entramos en un inmenso campo especulativo con el solo propósito de encontrar un espacio en el cual depositar la estandarización y terminología taina de finales del siglo XX. Según Keegan, la arqueología y la etnohistoria recoge información de autores de la Edad Media, y en algunos de esos casos esa documentación facilita la interpretación de artefactos y monumentos en una forma particularizada para formalizar estandarizaciones y terminologías actuales. En resumidas cuentas, si removemos invasores españoles y luego seleccionamos autores, no invasores, o quizás, no españoles, del siglo XV y XVI para estudiar el Caribe y el descubrimiento, mientras mejoramos nuestro conocimiento, nos topamos con algo que pudiese catalogarse de preocupante. Esa teoría de Keegan la recordaremos en su debido tiempo para identificar sus méritos, junto a autores que investigan esa línea de estandarización terminológica taína tal vez enfocada en invasores españoles.

Notamos una rotura, una separación entre la historia caribeña y la historia del taino. Esta tesis analiza dilemas específicos de la historia y su estrecha relación a la crisis cultural caribeña: "una crisis cultural puede considerarse como un estado de transición, 
como una condición inestable o pasajera" (Bidney, 1946: 538). Desde esta perspectiva de rotura e inestabilidad, analizamos prácticas vigentes e interpretaciones, y nos enfocamos en el más mínimo detalle. Añadimos en beneficio a Keegan que F. A. Kirkpatrick (1940), al comienzo del capítulo V de su libro, citando a Pedro Mártir [“la caída de la civilización azteca ante los invasores españoles"], presentó este pasaje original de Prescott y continuó diciendo: "el aniquilamiento de un gran imperio por un puñado de aventureros, considerado en todas sus exóticas y pintorescas manifestaciones, más parece novela que sería historia". Kirkpatrick y Prescott consideran la cita de invasores españoles de Pedro Mártir merecedora de halago: "el narrador se siente desde el principio sobrecogido de asombro" (Kirkpatrick, 1940: 53). Las palabras, invasores españoles formulan diferencias académicas entre las opiniones de estudiosos de diferentes épocas que visualizan la hispanidad, en unos casos fiables, en otros no.

Peter E. Siegel (1999: 216) coincide con Keegan en el uso de la terminología taína y determina qué, los "caciques taínos usaban técnicas chamanísticas para interpretar mitos". Siegel, en ese mismo párrafo, estipula que Pané documentó rituales en donde los caciques inducían substancias alucinogenitas para comunicarse con el mundo espiritual. Tanto Keegan como Siegel dependen del taíno para identificar sus trabajos, utilizando ese fenómeno terminológico, y al igual que Arrom, implementan la teoría y denominación de Rafinesque acogida científicamente por Fewkes, Harrington, Rouse y otros autores; estos científicos taínistas acostumbran a adaptar a autores clásicos o antiguos a sus anfibologías. Esa inestabilidad científica acogida a la estandarización terminológica taína identifica la crisis cultural caribeña. Keegan (1996: 276) señala dos opciones:

“(...) se han planteado cuestiones de identidad cultural con respecto a los tainos. Cuando anteriormente se suponía que todo el norte del Caribe estaba habitado por una cultura única y en gran parte homogénea, estudios etnohistóricos recientes han desafiado esta conclusión. Granberry (1993, p. 58) se burla de esa perspectiva para crear una imagen que él llama 'Taino genérico', y Whitehead (1995, p.92) sostiene que el uso del término ‘taino' como una atribución étnica debe ser discontinuado por completo”.

Keegan presenta dos teorías independientes relativas a la inestabilidad cultural: primero, el Taino genérico de Julian Granberry, y segundo, Whitehead, quien propone la descontinuación del taino como una atribución étnica. Keegan sintetiza la teoría de Neil Whitehead de la descontinuación del término; la descontinuación es adecuada y correcta, 
una inclinación apoyada desde Daniel Garrison Brinton $(1871)^{26}$ con anterioridad a la popularización y comercialización del etnónimo taíno, una tendencia de descontinuación también encontrada en Hulme (1986). Esa tendencia, señalada por Whitehead, se sostiene sobre una base histórica de autores caribeños pasados por alto: Cayetano Coll y Tosté (1897), Agustín Stahl (1889), Alejandro Tapia y Rivera (1854), Alfredo Zayas y Alfonzo (1914), entre otros, cuyos trabajos no fueron considerados por Fewkes (1907), Olsen y Bourne (1906), Harrington (1921), Ricardo E. Alegría (1978), Rouse (1992), Keegan (1996) y Granberry (1993), entre otros tainistas. Señalamos que la cultura individual o la cultura social no pueden sostenerse en el largo plazo sobre una base académica que difunde un símbolo ancestral fabricado. En este dialogo, analizamos espacios en controversias donde se encuentra la fragilidad de la inconsistencia teórica que argumenta desde interpretaciones sospechosas e inestables.

La teoría de Whitehead utiliza unidades sociales basadas en títulos de caciques. En este estudio, esas unidades sociales de Whitehead son denominadas particularidades, produciéndose en comunidades o regiones que pudieron haberse basado en títulos de caciques, títulos de cacicas, jerarquía, militarismo nativo, la demografía o geografía de una comunidad y sus necesidades, u otro elemento mitológico, social, especifico de una colectividad nativa desconocida al momento o pasadas por alto. O, según estableció anteriormente Cabeza de Vaca, en las llamadas parentelas, lo que constituye una realidad histórica que a su vez contiene un auténtico nivel de sensibilidad. Surgen lagunas y espacios históricos olvidados o en descuido, propicios a conjeturas contemporáneas por dejadez, discordia teórica $\mathrm{y}$, en ocasiones por falta de sensibilidad. Esa dejadez o utilización residual, que identifica un material histórico fruto de invasores españoles, presenta varios problemas pues el tema de América es uno e internacional. En este sentido, existe una animadversión en contra de lo español, y más ampliamente de lo hispano, dando lugar a interpretaciones alegóricas. Ese aparente resentimiento en contra de la hispanidad de América representa un obstáculo a investigadores que no puedan sobrepasar esa condición puesto que resulta inseparable de la historia de América.

Numerosos investigadores contemporáneos extranjeros y locales caribeños, expertos fiables, han idealizado dramáticas teorías aprovechando oportunidades

\footnotetext{
${ }^{26}$ Daniel Garrison Brinton, graduado de Yale, fue cirujano durante la guerra civil norteamericana (1862-1865) era arqueólogo, antropólogo y lingüista profesor en la "Academy of Natural Science (Drexel University) una institución investigadora importante en (1812), Brinton fué el primer opositor del término taíno.
} 
sistémicas, fomentando trabajos originales, asignándole distintivos a los nativos caribeños, particularmente en Cuba, República Dominicana y Puerto Rico, basados en el razonamiento que se ha presentado hasta el momento.

Esta línea de investigación taína es debatida hoy en día, representándose en ella estudios basados en lingüística, etnología, antropología, arqueología o aplicaciones multidisciplinarias en busca de ampliar el conocimiento de artefactos, monumentos y etnias, en ocasiones alejados de la historia. Alejados de la historia, puede desprenderse del pensamiento, repudiando invasores españoles. Arrom (1967: 380): "El saber algo más de cómo imaginaron los tainos el mundo y poetizaron las fuerzas de la naturaleza tal vez nos ayudaría a calar más hondo en nuestras propias creencias y a entender mejor algunas de las actitudes vitales que se reflejan en nuestras costumbres y en nuestras letras".

Arrom busca en los autores clásicos o antiguos, o bien pistas principales para alcanzar resoluciones a lo que en esta tesis se considera, las raíces al suelo, o raíces a la tierra, indagando un mejor conocimiento de contextos nativos. Esa búsqueda en relación con la tierra se basa en la evolución de la vida y el pensamiento primitivo, y sí pueden deshilarse pistas en los autores clásicos estudiados por Arrom y descritos por Keegan como invasores españoles. Las interpretaciones de Keegan y Arrom estriban en la conformidad y perfeccionamiento de la terminología taína, ajustando a esa línea de estudio científicos sus articulaciones y resultados.

Esta primera sección nos identifica términos y terminología contemporánea, promotores y problemas a discutirse en el trascurso de esta tesis doctoral. La variedad de lenguas caribeñas, colectividades geográficas independientes y patrones particularizados dentro de una uniformidad biológica nativa, son indispensables en el estudio que realizamos en base a la historia verificable, por minúscula sea. Durante la fase de incubación del taíno de Rafinesque, solo Antonio Bachiller y Morales (1883), entre los autores caribeños, escribió acogiéndose ampliamente en favor del valor científico del taíno.

\section{DEFINICIONES GENERALES Y ORDENACIÓN}

Se precisa en este estudio analizar autores internacionales y sus interpretaciones lingüísticas y etnográficas al identificarse raíces históricas ligadas al tema de pobladores 
nativos isleños. Ese interés global agrupa un amplio conjunto lingüístico contemporáneo, con énfasis en la lengua inglesa por su acogida académica, sin embargo, se originan resultandos indispensables en lecturas de diversas lenguas. Por ejemplo, Luis A. Curet (2010: XI) se refiere a Sven Loven como un autor clásico y a su obra como una joya académica, y dice: "El origen de la cultura taína, de las Indias occidentales es uno de estos libros". Curet considera una joya el libro de Loven El origen de la cultura taina, publicado en Alemania en 1924 y traducido al inglés en 1935. Esto representa un claro ejemplo, primero de los valores lingüísticos añadidos, y segundo, de su utilización, hoy en día, para promover y comercializar al taíno desde una perspectiva coetánea. En el caso de culturas primitivas, topónimos y denominaciones étnicas caribeñas nos referimos nuevamente a la lengua inglesa por ser la más utilizada al promover y comercializar al taíno desde el comienzo del siglo XX, siendo la base documental dominante al momento.

Fundamentándonos en nuestra muestra de estudiosos extranjeros, cronistas, autores clásicos e investigadores del tema de los nativos, reconocidos del siglo XIX y $\mathrm{XX}$, se ha podido diferenciar el estado del problema de la terminología. Señalamos un grupo influyente de extranjeros en ese tema; Franz Boas (alemán), Julius Emil Olsen (noruego), Sven Loven (sueco), Alejandro de Humboldt (alemán), Jean Baptist Thibault de Chanvalon (Martiniqués, francés), Carl Friedrich Philipp Martius (alemán), Juan de Barros (portugués), Lucien Levy-Bruhl (francés), Claude Levi-Strauss (francés), Pietro Martire d'Anghiera (italiano) y Girolomo Benzoni (italiano). En este sentido, tenemos tanto fuentes contemporáneas como fuentes antiguas cuyos trabajos constan en latín, castellano y dialectos ibéricos, portugués, italiano, francés etc., algunos escritos han sido traducidos al inglés o al español moderno de Iberoamérica. La complexidad lingüística de los nativos caribeños, sumada a la de los autores multinacionales considerados clásicos, junto al mercadeo de términos étnicos, crea un ambiente verdaderamente competitivo, amplio, significante y propenso a la confusión, dando lugar a teorías necesarias a la investigación. Señalamos argumentos de cultura dominante y multirraciales en Ashcroft, un tanto alejado de la identificación de Keegan de invasores españoles. En esa complexidad y amplias variables vive el conocimiento nativo, el cual, analizando muestras en un enfoque natural y neutral, removiendo seguidamente ambigüedades e interpretaciones restrictivas, se encuentran resultados axiomáticos. En este sentido, se trata de promover una ruta fiable y abarcadora. A. E. Figueredo (2005: 5) proporciona otra variable: 
“Rafinesque (1836) identificó al taíno como un lenguaje 'aruaco.' Brinton (1871) hizo un estudio más científico, considerándolo 'similar al lenguaje Arawack.' Las muchas formas y, en este caso, la sílaba extra se puede atribuir a los misioneros alemanes. Los aruacos de los españoles, en la ortografía alemana, se convirtieron en Aruwack, y mediante más confusión, Arawack, y ahora, Arawak. El desarrollo posterior (y pasando del lenguaje a la cultura) de 'similar a los Arawak' a completamente 'Arawak' es una lección en chismes literarios. Ni los taínos ni los igneri son verdaderamente aruacos en cuanto a su cultura, aunque ambos hablan lenguas aruacas del ramo de Maipuré".

Las investigaciones lingüísticas son normativas e indicativas de rastros culturales. Estos pueden ser válidos, al igual que debatibles, y en continuo perfeccionamiento. Muchas de esas personalizaciones en el Caribe insular son el resultado de estudios realizados por misioneros que redactaron historias en sus diversas lenguas europeas mientras dispersaban doctrinas a comunidades particularizadas. Primero, Brinton (1871) consideró el trabajo lingüístico de Rafinesque era inútil en relación con el lenguaje de Haití. Segundo, las contribuciones de autores internacionales aportan variables lingüísticas importantes, pues no solo se trata de un chisme literario, según Figueredo. Tercero, el taíno nunca existió étnicamente: ¿qué valor histórico puede adjudicársele legítimamente? Por tanto, las implicaciones lingüísticas que se acogen a las prácticas culturales estandarizadas se limitan, en su alcance, a investigadores en el marco académico y/o económico, en las que estos trabajan sujetos a directrices institucionales. El asunto principal es atender lo verdaderamente verificable en el conjunto de lo fiable o no fiable, o sospechoso en base a la ciencia. Asimismo, interpretamos corrupciones lingüísticas a las que Figueredo llama chismes literarios, a manera del resultado de traducciones, del o al, idioma utilizado por el investigador durante el curso de su estudio. Las traducciones a otros idiomas de estudios lingüísticos no son una deficiencia, al contrario, el resultado bien puede estar en acorde o abrir una nueva vía investigativa a la lengua primitiva estudiada. Alfredo Jahn, durante sus años de investigación en Venezuela, 1910 a 1912, y durante otros viajes, de 1914 a 1917 y de 1921 a 1922 , auspiciado por el Gobierno nacional, reunió datos que publicó en 1927 (1973: 8), y dice:

“El nombre 'Arhuaco' que al principio usaban los indios como apodo despectivo, puede que a los de Santa Marta se lo impusieran los españoles a causa de su índole pacífica para distinguirlos de las tribus guerreras ('indios caribes flecheros') y si así fuere, realmente existiría alguna relación, aunque indirecta y no de orden etnológico, de este grupo con los Arowak de Guayana". 
Empezamos señalando que los nombres Arhuaco y Arowak son dos variaciones adicionales a los presentados en Figueredo con una historia de origen. Elizabeth Knowlton (1944: 265) explica:

"Gustaf Bolinger habla de los arhuacos como aparentemente una tribu mixta, que muestra elementos culturales de varias regiones. Esto también es sugerido por su leyenda de la inundación. Después del diluvio solo quedaba una mujer. Luego aparecieron ocho mujeres más y se unieron a ella. Después de un largo tiempo, cuatro hombres vinieron a ellas, llegando desde los cuatro puntos diferentes de la brújula, y sus descendientes son los Arhuacos".

A esos nativos, en esta tesis los tratamos de arahuacos o araucos, y bien puede decirse por una corrupción idiomática, que a su vez es inteligible entre las otras variaciones, incluyendo las de Figueredo y otras que presentaremos en otros capítulos. Para Jahn (1973), Bolinger (1925) y Knowlton (1944) existe una conexión entre arhuacos o arahuacos y su procedencia, lo que es significativo en el momento de reconocer una raza uniforme viviendo en una diversidad idiomática entre sus autodenominaciones.

\subsection{Definiciones generales}

Nuestro trabajo implica atender necesidades científicas precisas al formular interpretaciones paleográficas, siguiendo pistas fiables dirigidas a mantener una consistencia rigurosa con sucesos humanos antiguos. Las definiciones presentadas identifican las aportaciones de autores sostenidas en el transcurso de la historia y las de autores científicos que nunca estimaron el costo cultural en el largo plazo de una fabricación terminológica. Las consideraciones señaladas identificaron el escudriño y la sensibilidad para alcanzar resultados imparciales. Las anotaciones señaladas trazan líneas de investigaciones considerando citas especificas dentro de amplios conceptos en busca de una consistencia verificable y coincidencias en lo minucioso. El punto de partida, por tanto, se logra al estudiar sucesos humanos estableciendo hechos históricos básicos y claros conceptos definitivos. Alejándonos de prejuicios y definiendo resultados a variables en base a una lógica científica lúcida e innovadora. David Bidney (1946: 549) afirma: “Así, los pueblos nativos, aunque disfrutan de una considerable estabilidad cultural cuando se los deja solos, viven en un estado de crisis perpetua debido a su creencia en la malevolencia de las fuerzas naturales de su entorno y su temor a otras sociedades que no reconocen lo humano. Derechos de extraños extranjeros". La 
estabilidad cultural nativa caribeña requiere en las articulaciones que los definen no solo un alto grado de sensibilidad, sino una base histórica fiable para identificar la crisis actual.

A. Términos y aplivcaciones: el vivir en una simbología o fenomenología cultural fabricada.

En esta sección identificaremos razones y aplicaciones que fueron y han sido utilizadas en el desarrollo continuo del término taíno. Peter Wade (2017: 4) precisa: "La raza y la etnicidad no son términos que se refieran de manera neutral a una realidad transparente (...) sino que son términos incluidos en discursos académicos, populares y políticos". Wade resume en esta cita dos de los discursos básicos presentes en esta tesis, que se acoplan íntegramente a la aceptación y practica de términos como el taíno. En lo primero, la raza y la etnicidad consideradas inseparables entre sí y del tema de la terminología que discutimos; segundo, la relación existente entre los discursos académicos, populares y políticos, igualmente inseparables en esta investigación, cuando estas actúan sobre bases diferentes y motivos heterogéneos.

Estas separaciones en el marco histórico y humano realzan su complejidad al analizar las desventajas asociadas a la cultura popular, añadiendo temas como el mestizaje, el género y la persona cultural, según señalamos en esta tesis, y a lo que se define como el vivir en una simbología o fenomenología cultural fabricada ${ }^{27}$. Esta tesis considera lo siguiente: si el término taino es aplicado y no es histórico, es fabricado y a su vez representa un símbolo inexistente, lo que se conforma en una fenomenología donde ciudadanos son mal identificados a unos niveles injustificables.

Wade identifica la empresa del conocimiento y la señala dentro de una relación de poder -dice en diálogo con Michel Foucault- "en la que los países occidentales han tenido la ventaja. En este sentido, los discursos académicos y políticos desde el siglo XIX, según hemos señalado, se conforman al presentar las desventajas sociales a las que se ha

${ }^{27}$ Con el propósito de avanzar estudios académicos organizadores tainistas desde plataformas académicas e institucionales se capitalizan al proteger la cultura material caribeña estandarizada. La persona cultural, por ende, vive una identidad inexistente en un símbolo fabricado aplicado a su sociedad calculadamente por esos investigadores. La forma de vida e identidad conformada bajo la terminología taína conduce a: el vivir en una simbología o fenomenología cultural. 
sometido la cultura nativa caribeña bajo la metodología investigativa académica y política que promueven o promovieron el termino taíno y la terminología del tainismo.

La palabra "término" "designa un concepto de forma univoca en un campo temático particular" (Oficina de la Lengua Francesa de Quebec). Por tanto, el "termino" es especializado y contiene referencias específicas para designar aplicaciones individualizadas y particularizadas. En esta simple definición está llamada a promover su uso correcto. Uno de los argumentos en esta tesis es que el término taíno es injustificable, pues no provee un uso correcto y se aparta de ser una legítima adscripción de raza, etnicidad, tribus, clanes, lenguas o dialectos caribeños. En ese sentido, toda aplicación de esa unidad terminológica en estudios académicos o político-sociales, junto a la terminología e ideología que los rige, carece de justificación y legitimidad histórica.

En esta tesis el etnónimo taíno es un término simple, sea masculino o femenino, singular o plural, junto a sus derivados no compuestos, por ejemplo, taíno, taini, taína, tainato, tainista o tainismo, etc., se acogen a estas especificaciones. El término complejo igualmente formulado está compuesto de dos o más palabras, por ej., sociedad taína, taíno clásico, mitología taína, etc., y sus derivados compuestos se cogen a estas especificaciones, en este sentido, lo estandarizado que ya habíamos definido como un símbolo fabricada asume vida propia. Esa vida propia adquirida por vía de ciencia e ingenio es asumida por la sociedad desinformada y da lugar a una crisis cultural.

\section{B. Terminología: la trilogía económica tainista.}

Por "terminología" se entiende el "Estudio de la designación de conceptos particulares a uno o más de los dominios de la actividad humana, a través de la investigación y el análisis de términos en su contexto, con el fin de documentar y de promover su uso correcto" (Oficina de la Lengua Francesa de Quebec). En este sentido, tanto términos como la ciencia que los estudia, la terminología, antes de la Revolución industrial era limitada, pero en coincidencia con la explosión de aplicaciones contemporáneas que abarcaron todas las ciencias, y coinciden e incluso influenciaron a C.S. Rafinesque, esto varía. Esta explosión e influencia es consistente en nuestro tema del nativo caribeño al sintetizarse las denominaciones étnicas asumidas en palabras simples o compuestas, la práctica especializada, académica y política que utiliza o adapta o adopta y la conforma en una cultura que es transmitida por vía de la educación, 
institucionalmente o socialmente aprobadas por políticas de gobierno por medios de comunicación con intenciones específicas de promover, en este caso, el tainismo como símbolo de una cultura nacional.

Si contestásemos las partes terminológicas según definidas, encontraríamos que en la etnografía caribeña predominan términos simples y compuestos taínos promocionados y mercadeados a nivel global desde grandes instituciones, por ej., museos, universidades, junto a agencias gubernamentales de turismo y cultura, y fundaciones privadas. Al definirse esta terminología en un supuesto orden histórico resaltan su inutilidad para representar las denominaciones étnicas caribeñas, pero aún más las actividades comerciales y académicas que habitan conjuntamente en esa explotación debido a lo que Ashcroft llama "términos que favorecen a un grupo dominante".

Son significantes, desde ese punto de vista, las desventajas asumidas por la cultura popular influenciadas, bajo ese proceso investigativo especializado teorético, por la difusión terminológica cultural surgidas tras la Revolución industrial. Esa terminología facilitó la relación entre investigadores y centros de investigaciones vinculados al Caribe, sirviendo de herramienta unificadora en el logro de repatriación de grandes colecciones de artefactos que a su paso dejan huellas de una supuesta herencia cultural.

Esto implica separar por clasificaciones tanto los trabajos como los investigadores. Esta tesis alude a la demografía y paleografía dentro de la historia para rescatar en lo más correcto las denominaciones étnicas caribeñas consideradas genuinas e históricamente verificables. En este sentido, existen dos marcadas diferencias, una entre grandes instituciones extranjeras, sus abarcadores estudios y la adquisición de importantes colecciones arqueológicas caribeñas precolombinas, que se adscriben a un simbolismo estandarizado al ser catalogado. Por otra parte, las denominaciones étnicas, geográficas y particularizadas verificables con anterioridad al siglo XIX. Esa diferencia en el largo plazo ha legado una herencia cultural simbólica y artificial, puesto que el tainismo se fundamenta en una base hipotética terminológica planteada para obtener y diseñar una estructura académica, comercial y política especializada basada en la singularidad de un término dominante.

Se mercadea dicha estructura empresarial en una trilogía perfeccionada del siglo XX, concertándose una secuencia económica entre la herencia material repatriada, la comunicación académica clasificadora especializada y la actividad de colección, catalogación y almacenaje, formando un eficaz sistema de difusión cultural y turística 
legando a su paso el ilusorio mundo taíno. Bien puede denominarse ese espejismo comercial y cultural perfeccionado la trilogía económica tainista.

C. Etnia taína. ${ }^{28}$

Para B.P. Kottak (1994: 39), "La raza, al igual que la etnicidad en general, es una realidad cultural más que una biológica". La etnia o raza taína nunca existieron en la historia del descubrimiento. Son una afirmación académica contemporánea basada en necesidades. En general, Rouse (1992: 5) y otros fundamentalistas tainistas concuerdan en siguiente estandarización:

"Colón encontró tainos en la mayoría de las Indias Occidentales. Estos habitaron las Bahamas y la mayor parte de las Grandes Antillas, excepto el oeste de Cuba, donde fueron separados de América media por un grupo étnico periférico, los Guanahatabeys. Los cronistas no indican claramente quién ocupó la parte norte de las Antillas Menores, pero las investigaciones arqueológicas recientes han demostrado que su población era, también, taína. Un segundo grupo periférico, los Caribes Isleños, vivieron en Guadalupe y las hacia el sur, separando el taino de Suramérica".

Este párrafo es incorrecto en los siguientes conceptos. Primero, Colón nunca conoció a los tainos en su primer viaje, esa teoría es una estandarización mal ubicada entre la uniformidad y conformidad cultural nativa caribeña. Segundo, dónde habitaron los tainos es hipotético, especialmente aplicando una terminología específica a un área diversa, entre parajes remotos internos y extensas autonomías isleñas deslindadas por cuerpos de agua sean el Atlántico o el Caribe. Que la arqueología ha demostrado que el taino también vivió en la parte norte de las Antillas Menores, significa que el comercio, viajes marinos, matrimonios y política entre tribus nativas fue extenso y no limitado. Tercero, que un segundo grupo periférico vivió en Guadalupe y hacia el sur, denominados caribes, facilita el acomodamiento de un tainismo caribeño en un área geográfica que estaba claramente definida y ocupada por numerosas tribus durante el descubrimiento. Los lucayos que acompañaban a Colón en su primer regreso a España identificaron

\footnotetext{
${ }^{28}$ Kottak, C.P. 1994. Antropología cultural. McGRAW-Hill, 357. / Raza y etnias eran conceptos desconocidos durante el descubrimiento. En esta tesis razas y etnicidad son intercambiables, no científicas, y generalmente injustas. Se utilizan en la argumentación de faltas, raza y etnicidad son inseparables del racismo. / Delgado, R. \& Stefancic, J. 2017. Critical race theory: An introduction (Vol. 20). NYU Press.
} 
caribes incluso en Puerto Rico. Las tres teorías de Rouse son desacertadas, basado en la premisa que los tainos eran una raza para tratarse genéricamente y aplicarla geográficamente a fronteras establecidas en el siglo XX. Rouse dice que los cronistas no identificaron correctamente quién ocupó la parte norte de las Antillas menores. Ahora, indica Rouse que los cronistas sí identificaron quién vivía en las Antillas Mayores, y estos eran los taínos. Rouse y sus expresiones de los taínos nos recuerdan a Figueredo (2005: 5) y sus chismes literarios. En este caso, es claro que Rouse establece la utilización de cronistas para aplicar o acomodar una terminología contemporánea puramente científica, por ej., lo ocurrido con Ramón Pané (1988) según editado por José Juan Arrom. Editar trabajos clásicos remplazando la intención original de sus autores es injustificable.

Rouse entiende que la etnia taina se puede organizar según definiciones basadas en la raza uniforme de esos nativos, y no por las particularidades de comunidades nativas habitando en sus propios entornos naturales con anterioridad al descubrimiento. La independencia de naciones o nación primitiva(s) caribeñas en áreas geográficas especificas exteriorizan fronteras y limitaciones bajo el concepto de cacicazgos, y el de tribus homogéneas. Cacicazgos y tribus homogéneas se definen con fronteras y en grupos de la misma afinidad cultural o parentelas en sus propios territorios y denominaciones. Irving Rouse (1948: 521, n9): “Como nombre, el término taíno no es aborigen, pero fue probablemente introducido por Rafinesque (1836), para distinguir el dialecto arawak característicos de las Antillas Mayores de los igneri, el termino desde entonces se ha usado en muchas maneras".

Irving Rouse reconoce que taíno no es un nombre nativo, sin embargo, él difunde la estandarización taína y sus aplicaciones científicas. En consecuencia, educó e influyó a muchos estudiantes y seguidores, invitándoles a que difundieran al taíno como una adscripción de origen. ¿Qué motivó a este científico a difundir tal concepto? Rouse encontró un sin número de repetidores y algunos colegas difusores de importancia en la tercera fase de la terminología de Rafinesque. Por ejemplo, Ricardo Alegría y José Juan Arrom. Irving Rouse admite que taíno no es un nombre aborigen en 1948, y en el 1992 escribe que fueron los tainos quienes recibieron a Colón.

Resumiendo lo examinado al momento, el taino es una incongruencia etnológica y arqueológica donde algunos arqueólogos reconocidos contemporáneos, por ejemplo, Daniel Torres Etayo (2008), José Oliver (2009), Menno Hoogland y Corinne Hofman (1999) y L.A. Curet (2014), entre otros estudiosos del siglo XXI, tienen dudas de una etnia taína pero no asumen una posición de autoridad. Se hacen referencias al estorbo e 
inutilidad del término, sin recordar que hay miles de "víctimas" que aprendieron de ellos a ser taínos. Por ejemplo, fueron pasadas por alto las objeciones encontradas por Carl Ortwin Sauer (1966), Peter Hulme (1986), Neil Whitehead (1995), Daniel G. Brinton (1871), Cayetano Coll y Tosté (1897), Alfredo Zayas y Alfonso (1914) y otros. Dentro de esas dudas, comienzan los repetidores en el siglo XXI a notar la inutilidad del taíno en un intento de revestir incluso sus propias décadas de tainismo.

La geografía caribeña, sumando la extensión territorial de Cuba, Puerto Rico, Haití y la Republica Dominicana, abarca unas 75.400 millas cuadradas $(121.344 \mathrm{~km}$ cuadrados, sin incluir los mares entre islas). Hoy día, existen tribus registradas de nativos americanos en estados y naciones de cuya geografía e historia se configura una data, entre extensión territorial y nativos, que arroja luz sobre recreaciones geográficas nativas. Estas dimensiones territoriales de naciones caribeñas de 75.400 millas las podemos comparar con las millas cuadradas de los estados norteamericanos de Delaware, New Jersey, Massachussets, Maryland y Vermont, con un total de 43.271 millas cuadradas y unas 20 tribus nativas registradas, Oklahoma con 69.960 millas cuadradas y unas 35 naciones nativas registradas. La Guyana, con 133.576 millas cuadradas, tiene nueve naciones registradas, incluyendo Arawaks y Caribs conviviendo entre sus fronteras. Surinam, con 101.451 millas cuadradas, tiene siete tribus registradas, incluyendo arawaks y caribs conviviendo entre sus fronteras. En Venezuela habitan más de 40 naciones entre sus fronteras. ${ }^{29}$ Esto implica que las millas cuadradas y las condiciones de islas promueven la teoría de haber sido habitado por múltiples etnias durante el descubrimiento y décadas, luego consistiendo en más de las dos o tres designadas por Rouse, y sin considerar que estas son islas independientes.

Cabeza de Vaca (1982: 67) nos narra de su experiencia vivida en una isla habitada por dos bandas de habla diferente, unos los Capoques y otros los Han. Sus experiencias en vida durante las primeras décadas del descubrimiento contradicen lo estereotipado de la estandarización geográfica taína en una época ajena a las fronteras culturales del siglo XX. Si consideramos que existen numerosos etnólogos, antropólogos, arqueólogos, e historiadores americanistas contemporáneos que favorecen la estandarización terminológica, podemos visualizar la extensión del problema. Pensar en una figura cultural dominante que ocupa singularmente tres grandes islas resulta una enigmática hipótesis cuya aceptación es dudosa. Matemáticamente, las regiones y sus tribus

\footnotetext{
${ }^{29}$ Ver. Native languages of the Americas website.
} 
registradas demuestran que las tribus por milla cuadrada y su diversidad es considerable al compararse a nuestra área de estudio, lo que resulta irrazonable. Basándonos en cálculos matemáticos simples aplicados a la geografía caribeña estudiada, resalta lo inconsistente de estandarizar la región bajo una denominación terminológica.

A largo plazo, esta etnia taína ha penetrado la cultura popular apartándose de las naciones auténticas particularizadas de todas las comunidades nativas isleñas identificadas históricamente. Ese proceso terminológico de teorías étnicas dudosas fundamentó una identidad, un carácter propio popular y una comunicación académica y política aceptada por las autoridades aun cuando esa sea injustificable. ${ }^{30}$

La cultura popular es afectada por estudiosos que utilizan la trilogía taína victimizando simples comunidades expuestas institucionalmente a principios y prácticas educacionales dudosas. Esta dinámica de mercado y prácticas educacionales se continuarán presentando a lo largo de esta tesis para descifrar diferencias étnicas y ordenar irregularidades históricas. Considerando las etnias taínas también se pueden señalar condiciones de raza y herencia. Señala Jesús Guanche (1993: 205):

"En relación con una hipotética 'minoría étnica', especulativamente sólo pudiera considerarse a los muy lejanos descendientes de aborígenes agroalfareros que habitan en la parte más oriental de la Isla, pero de hecho y por varias generaciones ellos son cubanos muy mezclados ya con la población local, aunque conservan diversos rasgos físicos de sus ascendientes aruacos; pues como bien se ha señalado, los rasgos raciales no deciden la especificidad del etnos, en relación con los rasgos lingüístico-culturales, psico-sociales y territoriales".

El color de la piel, el mestizaje, raza y etnicidad en la geografía estudiada son relativos a las tres islas estudiadas; por sus relaciones sociales y políticas tribales, congruentes entre sí, en conflictos y naturaleza desde el descubrimiento. El contenido biológico nativo precolombino era uniforme al evolucionar dentro de un mestizaje mayormente entre blancos y negros, esa diferencia se establece en variables de color de la piel donde puede hacerse más reconocible si la influencia racial es mayor de una u otra parte. En esa forma, queda la herencia ancestral distribuida en porcientos biológicos de los habitantes.

En cuanto al pasaje citado de Guanche, este identificó correctamente a los ascendientes Arauco. Sin embargo, en Guanche (2015:71) identifica a los taínos como

${ }^{30}$ Sloan, R. 2018. Terms and Terminology / Sloan, R. 2019. Caribbean History and Heritage Crisis Resulting from Generic Standardization 
los habitantes de Puerto Rico, Cuba y La Española a la llegada de los conquistadores, lo que es consistente y acorde con Rouse (1992) y con académicos que coinciden que los taínos recibieron a Colón. En este ejemplo notamos la influencia académica en un área cultural donde investigadores de Cuba y Estados Unidos colaboran en un tema crítico actual. Añadamos que tanto Cuba o Coiba era una de las adscripciones identificadas por cronistas y exploradores, por tanto, en términos generales nativos cubanos constituye una denominación en el marco de historia verificable.

D. Supervivencia nativa, uniformidad biológica.

El diccionario de la Real Academia define sobrevivir: "Dicho de una persona: Vivir después de la muerte de otra o después de un determinado suceso". Vivir después de un determinado suceso identifica eficientemente la definición usada en esta tesis al diferenciar la denominada, "extinción nativa caribeña" contrapuesta a la supervivencia nativa según interpretada en esta tesis. En esta tesis, supervivencia y sobrevivencia son palabras intercambiables. Se acogen bajo este principio la conformidad nativa de Rudolf Virchow (1886), donde existe una uniformidad biológica dentro de las diversidades tribales particularizadas y ordenadas independientemente de las fronteras, incluso en islas distantes o compartidas, esa conformidad biológica identifica rasgos comunes encontrados en el Caribe insular; utilizamos esa conformidad al designar periodizaciones en los márgenes de trabajo. El identificar diversidad nativa, biologías evolucionadas y culturas materiales bajo el tainismo, remueve características tribales independientes precolombinas; por tanto, la agrupación de estas características socioculturales bajo una denominación étnica se pierde en el texto escolar y resulta impropio, pues solo trata de simplificar la independencia de esas culturas y su evolución y no aporta al estudio de nativos caribeños de origen. La uniformidad nativa se ha manipulado para razonar que siendo biológicamente compatibles se pueden identificar como una solo raza sin diversidades tribales y desde esa teoría conformar una ciencia dentro de la religión, el mestizaje y la extinción.

Utilizando esa disociación al interpretar documentos dentro de un planteamiento empírico se evidenciarán extracciones bibliográficas beneficiosas ligadas a la sobrevivencia. Las premisas examinadas en ese concepto de sobrevivencia analizan, por tanto, la analogía entre extinción, denominaciones étnicas y la terminología contemporánea aplicada a las islas caribeñas que estudiamos encaminadas a conclusiones 
ajenas al tainismo. En este sentido, examinamos asuntos socioculturales minúsculos al identificar particularidades étnicas, por ejemplo, exónimos, cuando las comunidades se refieren a un lugar determinado en una lengua ajena a la suya propia, esta actividad se refleja en las mujeres araucas viviendo entre caribes luego de haber sido obtenidas por secuestro, botín de guerra o negociadas por acuerdo. Y lo endónimo, la forma utilizada por habitantes locales para referirse a sí mismos en su lenguaje o costumbre. En el caso de exónimos y endóminos, estos son significativo por el valor añadido lingüístico cultural que prestan a la etnodemografía caribeña estudiada en esta tesis para examinar sobrevivencia, particularidades y denominaciones étnicas. Existen ejemplos de investigadores cautelosos como José Abreu Cardet (2013: 71) al registrar la siguiente documentación: "El treinta de junio de 1849, 'D. Miguel Antonio García Ibarra cura de la iglesia auxiliar de esta ciudad de Holguín bauticé a María Luisa hija legitima de Diego Macho y María Bramas, indios del caney" ".

José Abreu Cardet (2013) cuida de separar términos y terminologías dudosos de la sobrevivencia nativa cubana, irrumpiendo en lo mínimo necesario en sus exámenes con Puerto Rico y La Española. Elimina Abreu Cardet sistémicamente el uso del taíno e identifica la sobrevivencia nativa cubana sin entrar en el desafortunado conflicto de la extinción o la argumentación del término taíno. Cautelosamente, Abreu Cardet interpreta la relación de elementos chicoides y aspectos iconográficos encontrados en la complejidad socio cultural y arqueológica de Cuba, Puerto Rico y La Española, que en su momento encauzó a Rouse a integrar a Cuba a su denominación étnica conocida por el término complejo de taínos del oeste, western taino. En este sentido, Rouse genera un término complejo llenando un espacio compartido, independiente donde se fragmentan áreas geográficas separadas por agua y específicas de la Cuba oriental y del Puerto Rico occidental, donde La Española representa el área central geográfica del taíno clásico.

\section{APLICACIONES TERMINOLÓGICAS, HISTORIA E INDUSTRIALIZACIÓN}

La terminología taína se populariza durante la tercera fase de la Revolución industrial. ${ }^{31}$ Esta consta de cuatro fases entre 1750 y 1870 en el Reino Unido, Europa y

\footnotetext{
${ }^{31}$ La Revolución Industrial, tiene su comienzo en el Reino Unido en el ámbito tecnológico, económico y sociocultural, implica que la revolución industrial adjudicaría nombres al, control y desarrollo de mercados, las operaciones científicas o mecánicas de la fuerza laboral, un factor
} 
los Estados Unidos. ${ }^{32}$ A partir de su tercera fase examinamos la dicotomía académica y la correspondiente adaptación popular de términos que invadieron los marcados campos históricos caribeños desde principios del siglo XX, recogidos y habituados en el siglo XXI.

Las fechas de la Revolución Industrial varían entre países e industrias. Edward Hallett Carr [1961] (2018: 48), recuerda su legado: "Examinemos la historia de la industrialización de Gran Bretaña entre, por ejemplo, alrededor de 1780 y 1870. Prácticamente todos los historiadores tratarán la revolución industrial, probablemente sin discusión, como un gran logro progresivo. También describirá la expulsión de los campesinos de la tierra, el pastoreo de trabajadores en fábricas y viviendas insalubres, la explotación del trabajo infantil”.

Las expulsiones, las fábricas y la insalubridad de las condiciones de la población son de interés, pues son representativos de las vividas por trabajadores en los países en pleno desarrollo. Desde esta perspectiva histórica, evaluamos a simple vistas el estado general de la población tanto en Europa como en Norteamérica durante la explosión científica de la terminología. Los objetivos y aplicaciones tecnológicas principales de la terminología, originalmente, eran promover y atender necesidades de la economía, la empresa y los mercados emergentes. A su vez, mecanización, bajos salarios y demanda de productos y artículos crean una gran migración a ciudades que requiere nuevos términos, mientras imprevistamente esa movilización terminológica se incorpora a las ciencias sociales. Ese movimiento de explotación comercial e innovación científica promueve una rápida expansión terminológica, utilizada para satisfacer necesidades logísticas al agrupar y simplificar procesos de identificación, etiquetación, comercialización y mercadeo de productos.

La gran demanda operacional de términos causa un distanciamiento a la crítica analítica y científica perteneciente a la Historia. Desde esa perspectiva, la Historia de cronistas es percibida común o limitada hasta cierto punto, según lo señalado por Keegan (1996), como una historia de invasores españoles. El ingenioso Rafinesque abrió un camino a nuevas interpretaciones de las regiones caribeñas, eventualmente facilitando un razonamiento y una ciencia que aplicaría la estandarización terminológica simple o

indispensable. Se da comienzo a etiquetar productos, maquinaria, fabricaciones, habilidades, nombres, etc., sin normas o regulaciones abarcadoras en esas fechas. Usaremos el término de industrialización para cubrir ese espacio conflictivo.

${ }^{32}$ Clark, G., O'Rourke, K.H. \& Taylor, A.M. 2008. Made in America? The new world, the old, and the industrial revolution. American Economic Review, 98(2), pp.523-28. 
compuesta para sintetizar y consolidar etnias nativas caribeñas. Esta supuesta homogeneidad del hombre original caribeño facilita la organización de teorías y trabajos científicos dirigidos a una identidad común aceptada por estudiosos.

Examinamos algunas ideas que conducen al entendimiento o razón por la cual ciertos términos tuvieron tanto éxito desde el siglo XX:

\begin{abstract}
"Durante la primera mitad del siglo XX, ni los lingüistas ni los científicos sociales prestaron especial atención a la terminología. La terminología, tal como la entendemos hoy, empezó a tomar forma en los años 1930s. El nombre más prominente asociado con el estudio de la terminología es el de Eugen Wüster. El trabajo de Wüster, un lingüista austriaco considerado un padre de la terminología, fue muy importante para el desarrollo de la terminología moderna. En su tesis doctoral de 1930, presentó argumentos para sistematizar los métodos de trabajo en terminología, estableció una serie de principios para trabajar con términos y esbozó los puntos principales de una metodología para el procesamiento de datos terminológicos" (Protopopescu, 2010:2).
\end{abstract}

Los usos y aplicaciones de términos en general son nombres o palabras que definen o identifican lo nuevo, lo antiguo o lo futuro, en ciencias, medio ambiente, ingeniería, tecnología, etc. Por ejemplo, en programas tecnológicos, fabricas, materiales, piezas, diseños, arquitectura, etc., que facilitaban operaciones empresariales, mercados y la comunicación entre profesionales o académicos, sirviendo ese propósito de sintetizar a la transferencia de conocimiento. En nuestro caso de estandarización terminológica, las ciencias sociales a mediados del siglo XIX y aun en el siglo XX se encontraban en plena implementación de lo que en esta tesis tratamos como una fenomenología sistémica. La sociedad moderna estaba completamente inmersa en la nueva economía en la que se acumulaban grandes riquezas en manos de pocos.

En este sentido, podemos enmarcar el logró eficaz de Rafinesque (1836), expandiéndose hasta mediado del siglo XX en el tainismo, con pocas objeciones, y no es hasta finales del siglo XX y el comienzo del siglo XXI que algunos investigadores internacionales señalan dudas ante una posible problemática terminológica por el uso de la estandarización taína. El debate del nativo caribeño de finales del siglo XIX y comienzos del siglo XX desestima a los estudiosos caribeños de esa época que manejaban diversas denominaciones regionales sin oponerse a Rafinesque, puesto que muchos lo desconocían quedando esos estudios en el olvido.

El marco histórico caribeño a principios del siglo XX era propenso a intervenciones extranjeras, desde la invasión norteamericana de las últimas dos colonias españolas, Cuba y Puerto Rico. Primero, con anterioridad al siglo XX, se consideraba que 
los nativos eran extintos, y segundo, no existía interés popular en atender la diversidad nativa caribeña y sus particularidades originales y naturales. Ambas condiciones se propagaron originalmente a través de la religión, que buscaba cristianizar a herejes y el mestizaje, ambos temas le fueron negados a la historia originalmente, siendo reestructurados en la cultura popular e históricamente avanzados bajo la terminología del siglo $\mathrm{XX}$, sintetizando una vasta región caribeña en lo que se consideraba un nuevo horizonte. Consecuentemente, la educación caribeña se acoge a un modelo conservador y religioso alejado de lo nativo o primitivo original, entendiéndose desde esta perspectiva lo escrito por Lohania Aruca Alonso (2012: 4): "El bajo nivel de las culturas aborígenes caribeñas en comparación con el de las grandes culturas de Mesoamérica y sur América hacen que sus aportes a la cultura cubana sean de poca o ninguna trascendencia, y por ello no se difunden, ni estudian en los programas educacionales. No existe la raíz aborigen (aruaca) en la cultura cubana".

Las realidades, según presentadas por Aruca Alonso, encierran una contrariedad, pues sí existió una cultura natural y sí existe hoy en día una descendencia de esa cultura Arauca o arahuacas, e incluso caribe en Cuba y el Caribe, la cual es difundida como tainismo. Se ha identificado en modelos de ADN, estudios de dientes de pala, la lingüística y el no menos entorno construido, la agricultura, herramientas y costumbres originales, la diversidad de la vida primitiva reflejada en análisis de artefactos y monumentos representa una diversidad cultural. En comparación a las grandes culturas de Mesoamérica y sur América, es como decir que el neandertal no merece estudios pues no legaron monumentos sino solo unas piedras de pedernal, unos cráneos y algunos huesos entre desperdicios. Ese pensamiento generalizado inicialmente facilita la estandarización caribeña acogiéndose a una terminología considerada avanzada.

El antropólogo Neil Whitehead (2015: 72) nos presenta esa trascendencia en la siguiente cita tomada de Hill (1996a): “(...) quinientos años de conquista colonial han dañado gravemente nuestra capacidad de reconstruir las interacciones históricas y culturales de muchas personas, y cultural". Este diálogo sugiere los problemas de la reconstrucción histórica de la conciencia y cultura nativa pasados quinientos años. Whitehead y Hill concuerdan en la dificultad de la reconstrucción histórica. Aruca Alonso plantea una diminuta aportación nativa a Cuba. En este sentido, una reconstrucción es compleja y se dificulta aún más al aplicarse la terminología del tainismo geográfico según examinado en Rouse (1992). Por ejemplo, el taíno del este, taíno del oeste, taíno clásico, etc. produciendo un profundo alejamiento con particularidades independientes e 
históricas. Ese alejamiento, por ejemplo, de borinqueños, boricuas, cubanos, quisqueyanos, haitianos, etc., en su relación a otras lenguas, culturas y colectividades geográficas nativas independientes identificadas por la historia, se distancian si se consideran minúsculas. En el futuro parece posible que el alejamiento del tainismo provoque lo señalado por Aruca Alonso, resultando más fácil un alejamiento total que acoger correcciones e identificar lo que ya dan por extinto. ${ }^{33}$ Cualquier movimiento nativista moderno se beneficiaria al acogerse a hechos históricos, documentando herencia e identidad cultural en las propias denominaciones originales alejados de la estandarización moderna y sus intersecciones interpretativas. Por ejemplo, acogerse a las obras de Bartolomé de Las Casas, Pedro Mártir de Anglería, Gonzalo Fernández de Oviedo y Valdés, Ramón Pané, Cristóbal Colón, Hernán Colón y otros que vivieron y escribieron sobre nativos caribeños. Igualmente, en los escritos de Juan de Castellanos (1589), Alejandro Tapia y Ribera (1854), Cayetano Coll y Tosté (1897), Agustín Stahl 1888), Fray Iñígo Abbad y Lasierra ([1782] 1866), Salvador Brau y Asencio (1894), Alfredo Zayas y Alonzo (1914), y otros que aportaron a la historia nativa caribeña.

Aun cuando las aplicaciones terminológicas de muchos autores se encontraban erradas, los resultados de sus investigaciones aportan información científica valida, por ejemplo, en arqueología, antropología y etnología. Es esta base científica la que ha dado crédito a la parte no científica de las mismas investigaciones, la que consagraba la terminología tainista, en la que tuvo un papel destacado la política de mercado cultural.

Regresamos a Protopepescu (2010:5):

"Según Wüster (citado en Cabré, 1995), cuatro eruditos pueden ser identificados como los padres intelectuales de la teoría terminológica: 'Alfred Schlomann de Alemania, el primero en considerar la naturaleza sistemática de términos especiales; el lingüista suizo Ferdinand de Saussure, el primero en haber llamado la atención sobre la naturaleza sistemática del lenguaje; E. Dresen, un ruso, pionero en subrayar la importancia de la estandarización; y J. E. Holmstrom, académico inglés de la UNESCO, que contribuyó a difundir las terminologías a escala internacional" ".

Wüster y Cabré sirven para periodizar la terminología como punto de partida, razón por la que el tainismo se difunde fácilmente en el mundo académico. Destaca el hecho de que el término taíno implementado por Fewkes (1907), décadas con anterioridad a los tratados de terminología, ha logrado pasar desapercibido en el escrutinio de

\footnotetext{
33 Ver, tabla \#3, lista limitada de denominaciones de los nativos caribeños. La restauración histórica de lo auténtico nativo se organiza recogiendo fragmentos fiables de documentos y configurado una ilación lógica de su significado.
} 
lingüistas e investigadores. Según señalamos, Daniel Garrison Brinton, en 1871, publicó su argumento en contra del uso del término taíno por considerarlo inadecuado, siendo pocos los que prestaron atención a su llamamiento, incluso estudiosos del siglo XX rara vez hacen mención a Brinton en relación a esta temática. De haberse reconocido y excluido según los argumentos lingüísticos y antropológicos aportados por Brinton, posiblemente no hubiesen sido difundidas ni invadido el conocimiento popular. Brinton había designado al arahuco isleño (Island Arawak) y el Caribe isleño (Island Carib) como troncos o grupos existentes durante el descubrimiento, en los cuales se acogían tribus particularizadas que estaban documentadas históricamente.

Indiscutiblemente, los estudios multidisciplinarios avanzan información especializada, de cuyo examen se pueden extraer conclusiones fiables, razón por la cual citamos a Peter Siegel (2010: 306):

"La colonización de las islas caribeñas por gentes arcaicas y neolíticas han sido el centro de la investigación arqueológica durante décadas (Chanlatte Baik, 1981, Chanlatte Baik, 1991, Keegan, 1995, Rainey, 1940, Rouse, 1958, Rouse, 1986, Rouse, 1992, Siegel, 1991a, Wilson, 2007 y Wilson et al., 1998). Gran parte de esta investigación ha sido descriptiva y vista de manera monolítica, con poca o ninguna preocupación por procesos subyacentes o circunstancias históricas".

Nuestra investigación se conforma con esa síntesis de Siegel cuando cita la manera monolítica a investigadores especializados, junto a la falta de preocupación por la historia: "con poca o ninguna preocupación por procesos subyacentes o circunstancias históricas". La cita de Siegel aparenta imparcialidad y es notable su preocupación personal por esa falta de conocimiento histórico al incluir su propio trabajo. Procedemos a interpretar esa falta de verificación y fiabilidad científica por su alejamiento de la historia, específicamente cuando el tema de estandarización y terminología nativa caribeña es estudiado y aplicado por la arqueología designándose indiscriminadamente a la sociedad caribeña fuera de un contexto histórico fiable. No obstante, los principales nombres en esa lista serían: Rainey (1940) y Rouse (1958, 1986, 1992), pues los restantes se limitan a reproducir a los primeros. Se han calificado de tainistas a investigadores que promovieron la imagen estandarizada del taino. Una de las razones por la cual se procedió a aceptar la base clasificatoria de Rafinesque fue precisamente buscar la separación de los principales difusores y los científicos que trabajan en instituciones económicamente competitivas, cuyo énfasis neutralizó la historia caribeña desde los comienzos del siglo XX. Esa neutralización de la historia caribeña se expandió de manera científica 
inmutable, y ha pasado un siglo desde que comenzaron las objeciones sin que hubiera reparo alguno. Los investigadores que cruzaron esa línea invisible asumieron una dimensión científica un tanto reprensible. Esa exitosa empresa ha llevado a la cultura popular a desconocer los verdaderos hechos históricos y las denominaciones nativas originales, siendo victimas comunidades enteras al acogerse a una etnia fabricada por expertos. En este sentido, la arqueología, simplemente al adaptar un etnónimo fuera del contexto histórico, no solo crea una continuidad académica aislada del contexto histórico, sino encausa un proceso instituyendo desventajas educacionales, sociales y culturales. Lo que en esta tesis se identifica como el vivir en una simbología o fenomenología cultural fabricada. Entender esa disyuntiva implica conocer íntimamente las comunidades afectadas, los estudios causantes y sus efectos junto a reflexiones antropológicas para aislar el problema.

\section{IMPLICACIONES DE LA UTILIZACIÓN Y DIFUSIÓN TERMINOLÓGICA}

A las oposiciones de Brinton (1871) y Whitehead (1995), señalamos otras voces que reflejan el interés. Peter Hulme (1986: 60) es una de estas:

\footnotetext{
"El primer nombre dado a la lengua de las Antillas Mayores fue 'Taino', de Cornelius Rafinesque en 1836. 'Taino' puede haber la cultura principal de estas islas, y a sus habitantes. Así, el término se deslizó imperceptiblemente, sin que nadie tomara una decisión consciente ni mostrara ninguna conciencia de las posibles consecuencias, desde significado 'noble' o 'persona de importancia' en la lengua hablada en la española. Este nombre fue adoptado entonces por Harrington (en 1921) y Loven (en 1935) para referirse a el nivel de la lingüística, hasta el de la cultura, hasta el de la etnicidad. Mientras tanto, Brinton había sugerido en 1871 que el idioma taino de Rafinesgue había estado estrechamente relacionado con el Arawak de la Guayana. El idioma taino fue así colocado dentro de la familia de las lenguas Araucas. Así que ni Araucos ni Taino fueron, hasta donde sabemos, las auto-adscripciones. Debemos tener claro lo que esto implica. No significa que los nativos del norte del Caribe (o los nativos de una isla en particular) no tuvieran una auto-descripción o, incluso, sin auto atribución, no se consideraran una comunidad de alguna clase: es justamente que no tenemos una cosa (un nombre usado por ellos) que contaría como evidencia concluyente".
}

Hulme identifica correctamente, dentro de sus limitaciones, el problema: “Así, el término se deslizó imperceptiblemente". Se debe entender que estas aclaraciones representan y validan estudios de angloparlantes. Anotamos que a Harrington le antecedían en EE UU las importantes obras de Fewkes (1907) y Olsen y Bourne (1906), fundamentales en el desarrollo del tainismo. Originalmente, el trabajo de Sven Loven fue 
publicado en alemán en 1924, contando con antecedentes en ese país en las obras de Karl Friedrich Philipp von Martius (1867), Jegor von Sivers (1861) y Oscar Peschel (1876), entre otros autores europeos (Sloan, 2018). Con relación al taíno, Hulme clarifica que la aplicación del lenguaje de Haití proviene de Rafinesque y el hecho que ni taíno ni arauco son adscripciones usadas por los nativos. Tal y como se ha señalado anteriormente, existen denominaciones geográficas y humanas desprendidas de la historia, aun cuando estas sean desconocidas. Algunos de esos autores les habíamos citado previamente: Juan de Castellanos (1589), Alejandro Tapia y Ribera (1854), Cayetano Coll y Tosté (1897), Agustín Stahl (1888), Fray Iñígo Abbad y Lasierra (1866), Salvador Brau y Asencio (1894) y Alfredo Zayas y Alonzo (1914). Algunos de estos autores publicaron con anterioridad a Rafinesque, y habían recogido autoatribuciones, lo que no había hecho Hulme. Los grupos primitivos primarios, e incluso bandas, se identificaban los unos a los otros; ese reconocimiento era espiritual, tribal, parental o en parte basado en la geografía o el entorno natural inmediato. La geografía nos dirige a esta realidad básica, al señalar que ciudadanos de Francia son franceses, de Alemania son alemanes, de España son españoles, y así sucesivamente.

En una sección anterior se presentó la existencia de varias lenguas en La Española. Lo señalaron los trabajos de Arrom, Ureña y Ortiz, por ejemplo. La variación lingüística sugiere una diferenciación tribal, que a su vez identifica diversificaciones étnicas y denominaciones propias. ${ }^{34}$ Lo que sí es cierto es que los Arauco y los Caribe son raíces o ramas de los nativos de las cuales se desprenderían particularidades regionales, tribales, clanes o colectividades, que se reconocían entre ellos. Existen algunas denominaciones nativas legadas por cronistas, exploradores y viajeros durante el descubrimiento, por ejemplo, ciguayos, haitianos, mayorixes, borincanos, cubanos, siboneyes, xamaiquinos, guanahatabeys, etc. Adicionalmente, la secuencia de uso y practica señalada por Hulme proviene de autores contemporáneos: Rafinesque (1836), Brinton (1871), Harrington (1921), Loven (1935) y otros, comunicándose en inglés durante el periodo más significativo de la segunda fase científica de la terminología de Rafinesque, cuando la terminología científica de mercado -en coincidencia con la Revolución industrial- es acogida y promovida. Lo que resulta incomprensible es que, ante tantas reclamaciones e intervenciones, la terminología tainista continúo aplicándose, y aun prospera, creándose

\footnotetext{
${ }^{34}$ Sloan, R. 2018. Terms and Terminology / Sloan, R. 2019. Caribbean History and Heritage Crisis Resulting from Generic Standardization
} 
una naturaleza nativa apócrifa y una casta taina que ha alcanzado la aceptación popular desde mediados del siglo XX.

Cayetano Coll y Tosté (1897) tomó cartas en ese asunto, sin que su trabajo haya sido evaluado Sloan (2019). En este sentido, retomamos la insensibilidad de investigadores extranjeros que desconsideraron o desconocían a los autores citados junto a Coll y Tosté. Ante esta creciente dinámica, algunos investigadores reconocidos y sus colaboradores comienzan a publicar cautelosamente a partir de la primera década del siglo XXI, en un intento de apartarse de la estandarización terminológica taína, excusándose por la utilización del término por no tener otra opción, como sucede con Curet (2014, 2015), Oliver, (1999, 2009) y Torres-Etayo (2008), entre otros señalados anteriormente. Lo sorprendente a estas alturas es la falta de estudios críticos refutando científicamente esta utilización terminológica, especialmente las formulaciones de arqueólogos y etnólogos. Volvemos a señalar a Hulme, quien examina y comenta sobre la tipología de Julian Haynes Steward ([1948] 1963), autor que asumió incorrectamente premisas de los procesos históricos. Dice Hulme (1986: 53):

“(...) sólo son estas premisas, en lugar de un examen de cualquier evidencia histórica, que establecieron las cuatro categorías que permitieron a editores Caribes y Araucos el especular sobre los procesos históricos que dieron lugar a su configuración a principios del siglo XVI. La evidencia arqueológica ahora contradice estas especulaciones, pero siempre se fundaron en premisas teóricas inválidas”.

Este enfoque de Hulme comparte con Siegel (2010) las teorías arqueológicas invalidas, algo irrefutable de la época. Apoyándose en Keegan (1996: 276), cita también a Whitehead (1995: 92) cuando el antropólogo británico, categóricamente, dice: “El término 'taino' como atribución étnica debe ser cancelada por completo".

Una de las consideraciones a tener en cuenta es que el citado término se acogía en el siglo XX a obligaciones político-económicas ligadas a fondos multinacionales como la Smithsonian Institution, el Bureau of American Ethnology (BAE), el Instituto de Cultura Puertorriqueña, Harvard y Yale, entre una larga lista de museos e instituciones que intervenían directamente en el Caribe. La tipología y tendencias originadas desde estas instituciones logran obras significantes en Olsen \& Bourne (1906), Fewkes (1907), Harrington (1921), Rouse (1992), Alegria (1978) y otros, apartándose de los procesos históricos según lo señalado por Hulme (1986) y Siegel (2010), llevando a la conclusión correcta de Whitehead (1995). La financiación de proyectos de investigaciones 
socioculturales continuó usando los criterios de denominaciones étnicas estandarizadas, adjudicadas y obligadas en base a mercados económicos.

En definitiva, no se encuentran citas directas de cronistas o autores clásicos que vinculen a los nativos caribeños con el tainismo, la sociedad taína o un taíno dominante, solo existen avances contemporáneos desprendidos de una terminología científica en la literatura clásica, mayormente en notas de pie, editoriales, apéndices añadidos y teorías anexadas a variedad de documentos antiguos, creando una nube académica. Esta ordenación documental se ha planteado y se discutirá a fondo durante el transcurso de esta tesis. Esta sección señala la vía económica, académica e institucional desarrollada por los tainistas, cuyos resultados han llevado la cultura del hombre primitivo caribeño al caos cultural.

\section{DESVIACIONES CIENTÍFICAS: TRIBUS HOMOGÉNEAS, VIVIR ENTRE TORTUGAS Y SAPOS}

Las anomalías toponímicas y la tipología arqueológica y etnológicas contemporáneas descuidadas por décadas exceden los limites teóricos hasta extremos insostenibles, una de las razones por la cual editores como Curet $(2014,2015)$ tratan de definir la paradójica tainista o el tainismo. Curet entiende que la denominación taína encierra dudas académicas. Para Keegan (1996: 266), "La transformación de las Indias Occidentales del remanso académico al campo de batalla posmoderno es evidente en las caras cambiantes de los mismos arqueólogos". Estos cambios han sido notables si consideramos los recursos científicos y los equipos disponibles para datar artefactos y examinar topografías complejas o inaccesibles. Por tanto, se debe reconocer ese tema posmoderno y esa batalla fundamentados en historia verificable. La carencia de conocimiento históricos elementales en la adjudicación fiable de denominaciones a grupos primitivos caribeños no solo es fundamental al datar artefactos, sino que son necesarios en el conjunto ancestral heredado por comunidades contemporáneas, sin pasar por alto las teorías arqueológicas invalidas señaladas por Hulme el alejamiento de la historia de Siegel o las caras cambiantes de Keegan.

De esta encrucijada surgen varias perspectivas para la histórica, la arqueológica, la antropológica y la etnográfica, todas con fuertes influencias lingüísticas, buscando interpretar el factor humano. Desde esa variable, en base a la historia se han presentado 
y se continuara haciéndolo los criterios utilizados por investigadores y la lógica que se distancia de realidades étnicas identificadas históricamente por cronistas, exploradores y autores clásicos, y las crudas realidades heredadas por comunidades en base a estudios contemporáneos. El desarrollado terminológico de principios del siglo XIX avanza en los siglos XX y XXI por la aceptación popular, viviendo una terminología dudosa. En este sentido, tenemos la Historia enfrentada a teorías arqueológicas como las de Fewkes (1907), Harrington (1921), Loven (1935), Alegría (1955-1978), Rouse (1948-1992), Keegan (1996), entre otros y repetidores para los que los taínos se convierten en una raza.

El asunto histórico implica conocer nombres reales por los cuales los nativos caribeños se identifican dentro de su uniformidad biológica. Citamos a Kalervo Oberg (1955: 477-478):

"Tribus Homogéneas. Son pequeñas unidades tribales en las que todas las relaciones son en términos de parentesco, siendo la tribu el único grupo gremial nombrado. (...) En otras palabras, un grupo tribal homogéneo es un grupo sociopolítico, internamente, que se autoperpetúa, identificado por un nombre y un mito de origen que define la verdadera pertenencia bilateralmente a través de ambos, padre y madre, regresando a los antepasados míticos. La mayoría de los cazadores del sur y muchas tribus en el bosque tropical y en el área circumcaribeña pertenecen a este tipo estructural. Buenas muestras son las tribus Yahgan, Nambicuara y Xingu superior".

Para Oberg, el grupo sociopolítico perteneciente al tipo estructural de una tribu homogénea se distribuye situando a padres y ancestros en territorios definidos. Esos territorios fijos o temporales son defendidos y a su vez pueden ser reducidos por razones naturales -muertes, enfermedades y desastres- o aumentados -nacimientos, matrimonios, producción, eficiencias y acuerdos. Oberg y Stewart concuerdan en esa clasificación de tribus homogéneas, exceptuando una diferencia en el tema de marginalidad, se entiende que en general la idea es llegar al consenso de los mecanismos internos y externos que implican diversidad observada y nombrada por los integrantes de un grupo y sabido por otros grupos. La definición grupo homogéneo del diccionario de La Real Academia es la siguiente: "Perteneciente o relativo a un mismo género, poseedor de iguales caracteres; Dicho de una sustancia o de una mezcla de varias: de composición y estructura uniformes. Dicho de un conjunto: formado por elementos iguales".

Tribus homogéneas que contienen un orden atado a una geografía, definidas por el tamaño o número de habitantes que la componen y sus parentelas. En el ambiente natural de esa región tribal, existe un pueblo cuyos linajes los une en un núcleo común reconociéndose entre sí en su propia denominación, definido en el testimonio de Cabeza 
de Vaca y los estudios de Oberg y Steward. Esa estructura aplica a una pequeña isla tal como Guadalupe, pudiendo ser habitada por una sola tribu homogénea aun cuando sus habitantes estén íntimamente relacionados con habitantes de otras diminutas islas circundantes. Esta tipología de homogeneidad es utilizada a grandes rasgos para sistematizar raza y tribus en una estructura genérica, removiendo particularidades en busca de simplificación. En islas mayores, por ejemplo, Borinquén, Cuba, HaitíQuisqueya y Jamaica, el número de tribus homogéneas, o bien parentelas poblando una misma isla, se definen generalmente por un cacicazgo dentro de los lindes topográficos que esa colectividad ocupa. A su vez, esa unidad cacical mantiene su propia identidad como señalamos anteriormente y señalaremos en adelante. Bien vale tener en mente las experiencias vividas por ocho años caminando desde Florida hasta México, de 1528 a 1535, de Cabeza de Vaca (1982: 67): "No hay entre ellos señor. Todos los que son de un linaje andan juntos”. Esta cita se refiere a casos específicos de pequeñas bandas cuyos números son desconocidos. Esas pequeñas bandas acogidas a la terminología taína es un error, siendo ese error perpetuado. En otros capítulos discutiremos algunas bandas pequeñas pasadas por alto y grupos parentales. Oberg claramente menciona tribus, por ejemplo, Yahgan, Nambicuara y Xingu superior, con el propósito de satisfacer una necesidad científica que a su vez aplica directamente al área circum-Caribe.

Resulta propio y lógico pensar que tribus homogéneas se autodefinen dentro de su ambiente natural, entre familia, amigos, enemigos y las circunstancias geográficas que les rodea. Por ejemplo, Colón, el 13 de diciembre, anota en su diario haber encontrado 1.000 casas con 3.000 habitantes; anteriormente, el 5 de diciembre encontraron 50 casas con 1.000 personas. Estas cifras y su significado en relación con la construcción nativa implican diferencias matemáticas que se discutirá a fondo en el cuarto capítulo. A simple vista, la cantidad de casas y de personas no guardan proporcionalidad.

La observación relevante en este capítulo se dirige a la tipología citada en Oberg y Steward en consideración a los habitantes, sus estructuras políticas, la producción alimenticia y la metodología administrativa requerida en la ordenación sociopolítica de mil casas y sus habitantes. La distancia entre estas tribus o poblados implica la posibilidad de tener cierta independencia entre ellas, y el número de casas con relación a la población bien puede ser indicativo de una casta pobre o una privilegiada, o más avanzada en política, especialidad agrícola, alfarería o pesca, o ligada al entorno natural inmediato desconocido. El interés estriba en la infraestructura ocupacional y su ordenación en la cadena alimenticia, no solo atada a estructuras físicas o sociales, sino también a la 
administrativa del producto común o público y la política de las comunidades en un mercado de autoabastecimiento. Mil casas y sus habitantes representan unas necesidades más avanzadas a las sugeridas comúnmente, en este caso puede ser una comunidad administrada por varias entidades, y no la única administrada por un cacique dentro de una población homogénea mayor.

La ecuación poblacional de esos números interconectados de residencia-residente encierra incógnitas. Oberg (1955: 482) establece la siguiente teoría: "Tal y tal es mi hermano porque él es una tortuga como yo. Este mismo principio de crear divisiones en la unidad original sociopolítica, después de alcanzar cierto tamaño, da lugar a asociaciones para juegos, rituales y ceremoniales". La sencillez de Oberg logra su objetivo al profundizar en el pensamiento primitivo. Partiendo de esa perspectiva, las denominaciones étnicas basadas en el tamaño poblacional, topografía y especialidades dan lugar a rituales y ceremonias comprendidas en su medio ambiente, complementándose con costumbres particularizadas o generales de bandas o tribus en un escenario natural que promovería autodenominaciones. Ese proceso de desarrollo bien pudo llevar siglos de duración antes de la llegada de los europeos al territorio caribeño. Por tanto, en la escala de desarrollo los grupos tribales homogéneos especializados que alcanzaron un alto nivel de especialidad, comercio, política administrativa y organización social, posiblemente basados en sus capacidades y la eficiencia, se reconocían entre sí y respecto a otros grupos. Siguiendo el planteamiento "Es mi hermano porque él es una tortuga como yo", Oberg no se detiene en este simple pensamiento y lleva el razonamiento a: "es mi hermano porque somos tortugas, y a bien, los sapos son nuestros amigos”. Así, Cabeza de Vaca $(1749,1982)$ menciona dos parentelas, de habla diferente, compartiendo amistad. Siguiendo la línea de pensamiento de Oberg (1955), las tortugas y los sapos pueden ser amigos incluso hablando leguas diferentes. En este sentido, los Capoques y Han de (Cabeza de Vaca) corresponden a los Yahgan, Nambicuara y Xingu superior (Oberg), entre las muchas denominaciones escritas por estos dos autores

No obstante, como hemos señalado no se trata únicamente de simples comunidades, una comunidad numerosa es por si compleja y requiere tratarse más allá de juegos, baile y ceremonias. El natural caribeño se apoyaba en la naturaleza y por tanto razonar la idea de él es una tortuga como yo es válida, pudiendo esa representación asumir cualquier forma lógica encontrada en el ambiente, la geografía, oficio o la vida diaria de una comunidad definida por sus castas o linaje. En adición, el pensamiento y el juicio colectivos, a su vez, aportan directrices organizadas y aplicadas a la selección de vida 
comunitaria, en cuyo trabajo se representaría la influencia de esas decisiones del nativo caribeño relacionadas con una vida estructurada en la que existían sus autodenominaciones. Ramon Pané, habiendo vivido entre los nativos de La Española por años, escribe desde el 1494 sobre idiomas, costumbres, juegos, sin entrar en detalles que se puedan relacionar con el reconocimiento de tribus homogéneas y sus denominaciones específicas. José Juan Arrom (1967) interpreta los trabajos de Ramon Pané y los de Bartolomé de Las Casas intercalando a los tainos en sus notas a pie y en narrativas destinadas a acomodar la terminología estandarizada del tainismo, o sea, remueve ese espacio en el que una tortuga o un sapo son significativos. Los trabajos de Arrom durante tres décadas recogen enlazan con la tercera fase de la saga de Rafinesque en la diseminación del tainismo. Lo que aquí se discute de Rafinesque y Arrom es el uso del término taíno que crea un pueblo inexistente.

La vía lingüística ha abierto posibilidades interpretativas para reconocer los nativos de América. Alain Fabre (2005:1) señaló que el tronco arawak (maipure) se divide en cinco ramas: maipure septentrional, maipure oriental, maipure meridional, maipure pre-andino y wapishana, y entre ellas tienen una base lingüística de al menos 36 lenguas. Arawak es sinónimo de arahuaco o Arauco, la lengua de los lucayos, ciguayos, borincanos, aytianos (haitianos), quisqueyanos, cubanos y siboneyes, entre otros autodenominados caribeños de las islas que estudiamos. Esas ramas arawak-maipure procedentes de sur y centro América son habladas por decenas de clanes, tribus y bandas en las áreas descritas consistentemente. Tom Durand (2018:1) explica que el arahuaco es hoy hablado por 500.000 personas en unas 40 lenguas. Durand incluye lenguas habladas por pequeñas bandas de unas diez personas.

Coll y Tosté (1907: 62) señala a Martius -refiriéndose a Karl F P von Martius (1867)-, el amigo de Rafinesque, como el autor que divide a los guaraníes en ocho grupos: el indo-antillano, al cual Martius clasifica como nativo taini (taino), lo que influyó, al igual que lo hizo Rafinesque, en la obra de Antonio Bachiller y Morales Cuba Primitiva. En 1925 Jahn (1973) concuerda parcialmente con Coll y Tosté en su cita de von Martius (1867: 6): “Tupi-Caribe y otros, como el sabio Martius, llegaron a clasificar los dialectos caribes en diversas familias, negando así la existencia autónoma de la familia caribe”. Las lenguas nativas y su parentesco no se limitan a solo una en el Caribe, y un territorio caribeño puede tener más de una lengua. En este sentido, podemos razonar el pensamiento basado en Oberg sobre la lógica primitiva: "El sapo habla diferente a nosotros las tortugas, pero somos buenos amigos". Ese pensamiento puede evolucionar en los 
conceptos naturales de la amistad y los enemigos comunes: "Tenemos de enemigo a las jutías, esos se comen nuestros huevos y a los renacuajos o (sapillos)". El viernes 12 de octubre Colón pisa tierra en una isleta de los lucayos que se llamaba en lengua de indios Guanahani, y luego vieron los exploradores gente desnuda. El primer día se identifica a los lucayos y el 14 da a la vela Colón trayendo hombres y mujeres, quienes le dijeron por señas de islas "Que eran tantas y tantas que no había número y nombraron por sus nombres más de ciento". Esta ecuación numérica-geográfica y étnica presentada por Colón se discutirá a fondo en el tercer capítulo. Sin duda alguna, en las páginas de la historia los lucayos serían los primeros nativos caribeños encontrados por el almirante en América y no los tainos citados por Rafinesque, Fewkes, Harrington, Loven, Arrom, Alegría, Rouse y sus seguidores. El alejamiento de esa primera denominación nativa identificada por Colón en la historia de América es un grave error. Antonio de Herreras, en su mapa del 1601 identifica las Bahamas, $Y$, de los Lucayos, a las más de 25 islas plasmadas en el mapa. Esa agrupación de islas eran territorios de los lucayos. Juan de la Cosa, en su mapa de 1500, a esa misma agrupación la denomina Habacoa, y a la isla Caicos (en Herrera) le llamo Jucayo. Sin embargo, durante la tercera fase de la saga de Rafinesque, tainistas reconocidos continúan teorizando que los tainos recibieron a Colón, idea que solo tiene importancia en el mercadeo institucional, dentro del conjunto científico de investigaciones ligadas a colecciones y artefactos.

Las mil casas encontradas por Colón el 13 de diciembre 1492 presentan un interesante dilema numérico enmarcando una dinámica de ingeniería, y a su vez señalan datos socioculturales. En ese día anota Colón varios asuntos de interés los cuales citaremos en esta corta serie de tres frases:

"La población era de mil casas y de más de tres mil hombres". - El indio que llevaban los cristianos corrió tras ellos dando voces, diciendo que no hubiera miedo, que los cristianos no eran de Caniba ${ }^{35}$, más antes eran del cielo, y que daban muchas cosas hermosas a todos los que hallaban. - y que son blancos más que otros, y que entre otros vieron dos mozas tan blancas como podían ser en España".

La pregunta es, el porqué: que los cristianos no eran de Caniba; y quién instruye a los lucayos recién recogidos en Guanahani por Colón a identificar a los exploradores que no eran de Caniba, más antes eran del cielo. Keegan (1996) y su referencia a los

\footnotetext{
${ }^{35}$ Caniba o canima, los habitantes de territorios o tierras de los Caribes los cuales desde muy temprano fueron reconocidos por su audacia, ferocidad y eran considerados antropófagos.
} 
invasores españoles ofrece una respuesta fácil, pero no es tan fácil de resolver la cuestión. Es indudable que los lucayos recibieron a Colón; en la política de los exploradores, estos se pensaban superiores; por tanto, entendían que esos seres inferiores los veían con buenos ojos. ¿Qué les ofrecieron a esos hombres primitivos, que les motivara de inmediato a favorecerles con sus cortesías? Quizás se debió al asombro y la sorpresa lo que los llevo a pensar que esos seres barbudos y vestidos en fortalezas sobre el mar eran caciques de otras tierras. La edición de a bordo de Colón preparada por Luis Arranz Márquez (1991: 63), basada en el trabajo del historiador Carlos Sanz, afirma: "Todo lo que sorprendería, que era mucho (fauna, flora, población indígena, etc.) ha quedado reflejado magistralmente en las imperecederas páginas del Diario de a bordo”. Se habían reproducido varias copias del Diario de a bordo, una de ellas posiblemente utilizada por Bartolomé de Las Casas y otra, o la misma, por Hernán Colón. La copia original parece haber desaparecido. Bartolomé de Las Casas editó el texto original del Diario al igual que Hernán Colón utilizó una copia en la preparación de su Historia del primer viaje. Por el amigo evangelizador y defensor de la América nativa y el hijo historiador dedicado a su padre conocemos la obra de D. Cristóbal. En ese sentido, dos celebradas figuras estrechamente vinculadas a Colón, que en vida compartieron experiencias en América y España, proveen obras evidenciando la faena, diario y carácter del "descubridor" desde los primeros días.

Volviendo al diario, la segunda frase del 13 de diciembre contiene la denominación étnica y geográfica Caniba referida al etnónimo Caribe y antropófagos, por tanto, se identifica a un grupo o raza de nativos diferente a las de ellos ${ }^{36}$. Se desprende del tamaño poblacional (mil casas) la organización necesaria de las tierras requeridas en la agricultura, de donde surge el llamado pan de niamas, ${ }^{37}$ de sabor como de castañas, y adicionalmente sus necesidades básicas de materiales prácticos y una producción o línea alimenticia. Estas condiciones son las características básicas que tendrían un pueblo o comunidad para administrarse, alimentarse, autodenominarse y diferenciarse de otras comunidades en esa geografía, un hecho que pasó desapercibido. No se pasa por alto que Colón mostraba más interés en las nuevas mujeres lucayas que hiso atrapar o el algodón

\footnotetext{
${ }^{36}$ Sin embargo, figuran estos canibas en ocasiones como fabulas: Armas, J.I. de, 1884. La fábula de los Caribes (Vol. 1). El Fénix de Francisco S. Ibáñez. / Cardín, A., 1990. Colón y los Caribes. Los Cuadernos del Norte: Revista cultural de la Caja de Ahorros de Asturias, 11(57), pp.110-116.

${ }^{37}$ Niamas, la yuca y muy cierto que su sabor es parecido al de las castañas a su vez conocido en España como el pan del campesino.
} 
almacenado en las casas que los nombres de las comunidades o su denominación étnica. Sin embargo, estos nativos son considerados por arqueólogos e investigadores (Rouse, Arrom, Alegría) como taínos clásicos, lo que se separa del contexto histórico caribeño. Hasta el 13 de diciembre se identifican dos ramas lingüísticas, la arawak-maipure y la caribe; en cuestión de semanas, y simultáneamente, se multiplican las denominaciones étnicas originales y se aprecia la necesidad de efectuar correcciones terminológicas.

En el esfuerzo de definir el alcance del tainismo, citaremos a Menno Hoogland y Corinne Hofman (1999: 95): "La palabra Taino se introduce en la investigación histórica y lingüística en el curso del siglo XIX. En 1836 Rafinesque usó el término Taino por primera vez para indicar el dialecto de la población nativa de las Antillas Mayores, en contraste con el Igneri de las Antillas menores, ya a finales del siglo XIX, Von Martius (1876) usó el término para indicar los habitantes de las Antillas Mayores". ${ }^{38}$

Hoogland y Hofman señalan lo sucedido con el término taíno en el contexto de la primera fase de implementación de la terminología taína, cuando antes había pasado desapercibido, para oponerlo a los igneri. ${ }^{39}$ Esta cuestión es básica para entender los próximos capítulos. Es evidente que taíno es un artificio y no un lenguaje, y mucho menos una raza o etnia. Hoogñand y Hofman atribuyen a Rafinesque, en 1836, el primer uso relativo a las Antillas Mayores, y proporcionan una larga lista de autores tainistas de la segunda y tercera fase posteriores a Rafinesque, llegándose a la estandarización terminológica. Los autores citados por Hoogland y Hofman son una mínima muestra de difusores y repetidores que promueven el tainismo en arqueología, antropología, historia y lingüística: Fewkes (1907, 1922), Harrington (1921), Loven (1935): Bullen and Bullen (1970), Alleire (1977, 1980, 1984, 1987), Boomert (1986), Chalantte (1983), Rodríguez (1991), Rouse (1992), Oliver (1999), Hofman and Hoogland (1999) y Walters and Petersen (1999). Los autores identifican a los tainos en las Antillas Mayores y desarrollan una diacronía que lleva a reconocer el genio de Rafinesque y no a los autores locales. Hoogland y Hofman (1999: 95), basándose en algunas citas de Jane (1988), concluyen que nitaínos o mitaines no son denominaciones utilizadas por naturales, sino que son esterificaciones políticas. Es aparente que aun reconociendo la estandarización teórica del taino de Rafinesque, Hoogland y Hofman no proponen el cese del término o la

\footnotetext{
${ }^{38}$ No obstante, según señalado en nuestra: p. 10 la estandarización aun tiene utilidad al utilizarse en la restauración y validación de denominaciones de origen.

${ }^{39}$ Martius, K. F. P. von 1867. Etnographie un Sprachenkunde Amerika's zumal Brasiliens. Leipsig: Friedrich Fleicher.
} 
terminología y se limitan a reinterpretan su diacronía en el uso. En una sección anexa se ofrece la lista de los experimentados investigadores, ordenados en Hoogland y Hofman (1999), cuyos estudios principales se acoplan científicamente en la estandarización terminológica taína.

\section{UNA PALABRA, TENDENCIAS SUPERFLUAS Y APLICACIONES ACADÉMICAS}

Taíno se identifica desde las primeras décadas del descubrimiento como una palabra que significa bueno o buenos. Su primera utilización la realiza Pedro Mártir de Anglería ${ }^{40}$ al señalar a un grupo de guerreros nativos, quienes se refirieron a sí mismos de buenos o sea taínos y no caníbales, para evitar un enfrentamiento militar con exploradores. La segunda vez que se utiliza la palabra taíno fue en 1825, cuando Manuel Fernández de Navarrete ${ }^{41}$ rescata de entre archivos históricos a su alcance una carta escrita en Guadalupe (Caruqueria) por el Dr. Diego Álvarez Chaca, ${ }^{42}$ médico cirujano de los Reyes Católicos asignado al segundo viaje de Colón, dirigida al Cabildo de Sevilla, posiblemente a Juan de Fonseca. ${ }^{43}$ La tercera vez que se utiliza corresponde al término grabado por Samuel Constantino Rafinesque en su libro publicado en Pennsylvania en $1836 .{ }^{44}$

La palabra taino, sin tilde en inglés, es aplicada representando la lengua de Ayti, Haity (Haiti), que de acuerdo con Rafinesque (1836: 215-216) la había rescatado tras filtrarse entre las páginas de la historia. Otros habitantes anteriores a los haitianos, según Rafinesque (1836: 206), son los camaguas o camayaguas, descendientes de Lybia

\footnotetext{
${ }^{40}$ Mártir de Anglería, P. 1944. Décadas del Nuevo Mundo. Buenos Aires: Editorial Bajel.

${ }^{41}$ Fernández de Navarrete, M. 1946. Primer viaje de Colón, Los indígenas. España: Calpe. Fernández de Navarrete, M. 1941. Viajes de Américo Vespucio. España: Espasa Calpe.

${ }^{42}$ Gamazo, A. S. (no fechado) 'Digo Álvarez Chanca Primer espía de América', Universidad de Burgos, pp. 20-40. / Gamazo, A. S. 1995. 'El protagonismo de Juan Rodríguez de Fonseca, gestor indiano, en la diplomacia y política castellana desde su sede episcopal de Burgos.', Boletín de la Institución Fernán González, pp. 273-317. / Diego Álvarez Chanca fue una figura controversial argumentan algunos historiadores que fue el primer espía de América vinculado a Juan de Fonseca ${ }^{43}$ Gamazo, A. S. 2005. 'Juan de Fonseca y el memorial de 1503: la creación de la Casa de la Contratación.', Universidad de Valladolid, pp. 11-139. Juan de Fonseca el Obispo de Burgos fue una importante figura en la Casa de Contratación de Sevilla y de la monarquía, en la administración de los viajes y licencias de América. Fue encargado de los asuntos del Nuevo Mundo desde 1493 hasta su muerte en 1524.

${ }^{44}$ Rafinesque, C.S. 1836. The American nations; or: Outlines of their general history, ancient and modern: including the whole history of the earth and mankind in the western hemisphere. $\mathrm{C}$. S. Rafinesque.
} 
(Libia). La aplicación de Rafinesque, en definitiva, fue la que movilizó la curiosidad y despertó el interés de los investigadores desde el siglo XIX. Estos relatos de Rafinesque guardan cierta lógica de poderse obviar la relación a Lybia.

Rafinesque nunca menciona al Dr. Álvarez Chanca en su bibliografía, lo que nos lleva a pensar que su rescate se basa en la referencia de Pedro Mártir de Anglería. La opinión de Rafinesque (1836: 262) constituyó un rescate lingüístico de Haity, según señala el autor, y una aplicación étnica científica, identificando a una tribu o raza caribeña, según es citado por los autores tainistas examinados hasta el momento.

Rafinesque teorizó lengua, tribu y raza mediante un proceso de "mercadeo" científico que alcanzó honores en su tiempo. La importancia de ese éxito no puede desligarse de la ideología del tainismo contemporáneo, que tiene un hito a comienzos del siglo XX en los Estdaos Unidos, donde Olsen \& Bourne (1906) citan en notas a pie a los tainos, sin tildé. El trabajo arqueológico y etnológico de Fewkes (1907) favoreció el remplazo del término antillano por taino. A partir de la primera década del siglo XX el término cobra una identidad étnica, sustituyendo cuatro siglos de historia. Cierto es que en esos cuatro siglos las justificaciones y distinciones de los nativos examinadas escaseaban, pero existían suficientes estudios, como los mencionados anteriormente de Coll y Tosté ([1897] 1907).

Resta reconstruir y analizar críticamente la cronología sistémica y las aplicaciones científicas e idiomáticas que han desarrollado en la avanzada dicotomía y terminología taína hoy día, para concluir que solo es un adjetivo contemporáneo.

En el sentido lingüístico, queda por señalar que el deletreado de nombres y palabras nativas americanas fueron escritas por autores, cronistas o historiadores en latín o sus diversas lenguas maternas basándose en su propia fonética y características nacionales. Este dilema surge no solo en lingüística sino en otros estudios científicos, sean arqueológicos, antropológicos o etnohistóricos por la nacionalidad de los autores, al interpretar la diferencia entre aplicaciones contemporáneas y las realidades históricas. Sobre esta base, y en este sentido, se examinarán tanto autores como trabajos traducidos donde una palabra se escribe y varía lingüísticamente.

\subsection{Aclaraciones y principios: una relación entre naturaleza y cultura.}

Resulta práctico interpretar la naturaleza y cultura nativa desde su propia perspectiva. Para ello es inevitable examinar y establecer en qué consistía su pensamiento. 
Claude Levy-Strauss (1970: 67) señala la diferencia entre naturaleza y cultura: "En un caso, el principio de la diferenciación surge de la naturaleza; en el otro de la cultura".

Levy-Strauss clasifica en este pensamiento dos principios de diferenciación: los grupos totémicos y los grupos de castas. En nuestro caso, el uso de la terminología comprende ambos grupos en su entorno natural y el social, identificando a los nativos singularmente bajo una estandarización nativa caribeña predominante, sin abarcar la variedad de grupos independientes y su diferenciación. Levy-Strauss nos conduce a la naturaleza de la tierra, aplicada a la geografía caribeña en la que se desarrollan las condiciones de sociedad necesarias para alcanzar las autodenominaciones.

El hombre original isleño vivía como parte integrada y principal a la naturaleza y no a modo de un mero observador. Eduardo Viveiros de Castro (1998: 469) nos recuerda las dificultades de ese hombre originario y citamos: "En particular, como muchos antropólogos ya han concluido (aunque por otras razones), la distinción clásica entre Naturaleza y Cultura no puede ser usada para describir dominios internos a las cosmologías no occidentales sin primero someterse a una crítica etnográfica rigurosa". El estudio de Viveiros es conmovedor. Viveros y Levy-Strauss coinciden en la valoración de naturaleza y cultura, añadiendo Viveiros (1998: 470): “(...) el etnocentrismo no sería el privilegio de Occidente sino una actitud ideológica natural, inherente a la vida colectiva humana. Levi-Strauss ilustra la reciprocidad universal de esta actitud con una anécdota”. Y cita de Levy-Strauss: "En las Antillas Mayores, algunos años después del descubrimiento de América, mientras que los españoles estaban despachando comisiones inquisitoriales para investigar si los nativos tenían un alma o no, estos mismos nativos estaban ocupados ahogando a los blancos que habían capturado para descubrir, después de larga observación, independientemente de si los cadáveres estaban o no sometidos a putrefacción (1973: 384)".

Dos antropólogos se envuelven en un dialogo de interés a este estudio, pues estas perspectivas señaladas aportan un orden de credibilidad a la esencia del hombre primitivo, su espiritualidad y su comprensión en su entorno natural y cultura. Levy-Strauss y Viveiros reconocen claramente las habilidades humanas y las dimensiones mitológicas de estos nativos para gobernarse, autodenominarse según sus costumbres, creencias y culturas. En este sentido, la terminología estandarizada invade esos espacios de orden histórico, sociocultural y orgánico al alejarse científicamente del razonamiento primitivo vivido dentro de su propia naturaleza en una diversificación étnica y geográfica con distintivos diferenciados entre ellos. La esencia de este dialogo entre Viveiros y Levy- 
Strauss la habíamos encontramos en Vaioleti (2006) y Smith (2013) en referencia a la sensibilidad. El lente examinador en esta tesis concuerda con la teoría de Levy-Strauss de que los nativos presenciaban la putrefacción de los cuerpos de los españoles, y, sugerimos que esos mismos que observaban, pensaban que esos cuerpos de españoles asemejaban las jutías que habíamos sintetizado anteriormente en la ensambladura natural que existía entre jutias, tortugas y sapos. No obstante, considerados tenebrosos los españoles, los nativos evalúan esa descomposición desde una perspectiva natural.

Estos primogénitos caribeños vivían en agrupaciones organizadas geográficamente singularizando castas e identidades, rituales, particularidades tribales y lingüísticas, cohabitando en ordenaciones compartidas socioculturales preexistiendo el descubrimiento. El mismo Colón describe en su diario entre el 13 de octubre y el 3 de diciembre $^{45}$ las condiciones nativas que prestan autoridad el diálogo de Levy-Strauss y Viveiros.

Consecuentemente, las terminologías aplicadas al orden histórico vivido se apartan al evolucionar y adaptar un nuevo carácter teorético, planteando límites y perjudicando la herencia sociocultural de comunidades que en numerosos casos carecen del conocimiento de la historia. En adelante, abordaremos la vida natural del originario isleño que vivía y compartían con otras tribus y naciones en sus geografías, y de igual manera conocían de otras naciones, como el mismo Cristóbal Colón anotó en su diario en esos primeros días. ${ }^{46}$ Es imperativo entender el pensamiento nativo encontrado durante el descubrimiento al investigar la vida nativa encaminada a la supervivencia en su nueva identidad y evolución biología.

7.2 Interpretaciones socioculturales-históricas basadas en indicios fortuitos.

El proceso histórico se fortalece al interpretar y analizarse la documentación regional junto a fondos de intersecciones comunes de otras áreas del mundo y de América, por ejemplo, el norte del Orinoco, las costas caribeñas entre Venezuela, el Yucatán, la

${ }^{45} 13$ de octubre: $Y$, después junto con la dicha isleta están huertas de árboles las más hermosas que yo vi, y tan verdes y con sus hojas como las de Castilla en el mes de abril y de mayo, y mucha agua. 3 de diciembre: Subió una montaña arriba y después hallóla toda llana y sembrada de muchas cosas de la tierra y calabazas, que era gloria verla; y en medio de ella estaba una gran población.

${ }^{46} 14$ de octubre: Todas son muy llanas, sin montañas y muy fértiles y todas pobladas, y se hacen la guerra la una a la otra (...). El texto identifica tanto poblados como guerra y agricultura lo que significa tener espacios de paz y comercio en ese medio ambiente. 
Amazonia pre-andina, la Florida, Iberia y Europa. La región caribeña carece de estructuras físicas de las magnitudes arqueológicas encontradas en Bolivia, México, Perú, Ecuador, o Norteamérica y otros parajes americanos. Consecuentemente, resulta obligatorio no solo razonar y analizar críticamente hipótesis y prácticas actuales basadas en términos contemporáneos, sino examinar a fondo etnónimos históricos representativos de particularidades que pueden ser el último y más íntimo de los atributos regionales. La falta de monumentos o estructuras físicas sustanciales afecta originalmente a un espacio donde existían limitaciones culturales que fueron aprovechadas en las intervenciones arqueológicas durante la clasificación de las estructuras nativas y los artefactos descubiertos en el siglo XX.

Mientras que la base histórica del tainismo ha sido argumentada desde un fondo internacional, la influencia sustancial proviene de instituciones norteamericanas de principios del siglo XX, compartiendo teorías con estudiosos europeos hasta mediados del siglo XX, cuando autores e investigadores caribeños comenzaron sus aportes a gran escala. Antonio Bachiller y Morales (1883) es una rareza caribeña al haberse incorporado a la saga de Rafinesque durante el periodo de incubación de la corriente, convirtiéndose en el padre del tainismo cubano.

La secuencia científica señala rupturas o interpretaciones analíticas tainistas que difundieron teorías homogéneas caribeñas, basadas en un solo término para llenar espacios considerados vacíos, creando un genotipo especializado. Esta brecha arqueológica comenzó a fomentar el citado fenotipo institucionalizado desde Olsen \& Bourne (1906), Fewkes (1907), Harrington (1921, 1935) y Loven (1935) seguidos por el cúmulo sobresaliente de investigadores. Encontramos en esta reconstrucción nativa los cimientos y desarrollo científico del término, sonoro y aceptable. ¿Qué es aceptable? ¿Y, en qué condiciones presentamos o debemos responder al analizar el problema creado? Este problema sería enteramente caribeño si el fenómeno fuese local, pero es internacional ya que intervienen otras naciones y culturas. En adición, el problema se ha convertido en una empresa comercial dentro de un mercado educacional, cultural y social. No se trata singularmente de términos y terminología, su dimensión empresarial se equipará a una marca. Esa marca brand tiene historia, abundante financiación y acogida popular, ya que los Estados caribeños acogidos a una terminología. Así, afirma Steward (1948: 1): "Ya fueran insulares o en tierra firme, eran fácilmente accesibles desde la costa y fueron rápidamente alcanzados por los conquistadores españoles. La gran mayoría de ellos se han extinguido culturalmente, si no racialmente". 
Julian Steward (1948) fue un experimentado editor. En su Manual del Indio Sur Americano, publicado por el Bureau of American Ethnology, de la Smithsonian Institution, recoge información de importancia. Steward refleja el interés material junto a la falta de conocimiento histórico sobre el nativo caribeño, su cultura y otras culturas en relación con lo que se supo de los nativos del continente en el siglo XX. Asignar nombres libremente, sin una severa crítica, constituyó algo necesario empresarialmente, y erróneo desde el punto de vista histórico. De todo ello se desprenden desventajas que afectan a las comunidades del Caribe y a su historia. En adición esa situación facilita la adquisición de colecciones arqueológicas sin conocer la cultura de los portadores simplemente basado en la belleza de artefactos acogidos en una terminología.

El artículo de Ulises M. González Herrera es significativo por su fecha (2010), lugar de publicación (Cuba), tema y selección de autor. Se presta el articulo al análisis crítico, pues su contenido e intención se basan en la historia y etnohistoria. El criterio de González Herrera es que Mark Raymond Harrington carece de referencias a los cronistas, un problema básico encontrado en Olsen \& Bourne (1906) y Fewkes (1907) décadas antes, autores que trabajaban en comunicación desde la oficina del Bureau of American Ethnology. Tenemos entonces varios autores en la misma oficina de etnología y arqueología de Estados Unidos, quienes durante tres décadas difunden el término y la terminología taína. Steward también trabajaba en 1948 en esa Oficina y es quien comenta la falta de conocimiento cultural por casi seis décadas. La fecha es significante pues guarda relación con la fundación del Instituto de Cultura Puertorriqueño, de donde proceden decenas de estudios tainistas.

Afirma González Herrera (2010: 12):

"Antonio Bachiller y Morales fue el primer autor cubano en darle cierta connotación étnica al término taíno al exponer en su obra Cuba Primitiva lo siguiente: "debía buscar por el mediodía la procedencia de los indios del tipo caribe de raza pacífica o noble; como ellos mismos se apellidaban: los tainos. (...) Cuarenta y un años después de escritas mis presunciones y conjeturas, negadas por los contemporáneos, en 1882 he leído en la apreciable obra del sabio alemán Peschel (The Races of Man, 1876) la siguiente confirmación: Las pequeñas y las grandes Antillas como Las Bahamas, fueron habitadas antes de 1492 por una raza en extremo pacífica, que Von Martins ha llamado Taini” (Bachiller, 1883:115-116)".

Antonio Bachiller y Morales se adelantó a buscar fuentes de autoridad y encontró a von Martins (Martius). El botánico alemán Friedrich Philipp von Martius fue un amigo personal del botánico Constantine Samuel Rafinesque-Schmaltz. Daniel Garrison Brinton 
(1871: 9) habla de su amigo von Martius, con quien comparte ciertos criterios lingüísticos. Sin embargo (1871: 13), en referencia a Rafinesque y amigos, dice que carece de autoridad para el término taíno, e incluye a von Martius en esa falta relacionada con la utilización de prefijos. A Jegor von Sivors y Rafinesque, Brinton (1871:10) les considera peor que inútiles.

El botánico Rafinesque y sus amigos Jegor von Sivors y von Martius publicaron libros de lingüística tanto en inglés y alemán como en francés, y alcanzaron por medio de esas lenguas a difundir esa toponimia, que alcanzo a Cuba desde muy temprano. Ese desarrollo "empresarial" temprano de Rafinesque fue genial, pues esos primeros años del periodo de incubación de las nuevas tesis lograron difusión internacional, aunque no produjo resultados académicos y económicos hasta el siglo XX en los Estados Unidos, de donde se difunde exitosamente por el Caribe.

Antonio Bachiller y Morales encontró a Peschel citando a von Martin (von Martius) en 1882, y pensó haber encontrado un importante descubrimiento en el término taíno. Luego encontró que esa teoría procedía de Filadelfia. Von Sivors, von Martius, y Peschel publicaron en alemán originalmente, mientras que Rafinesque público en inglés, francés y alemán en el siglo XIX, durante el periodo de incubación del taíno - taini. Brinton, al contrario, había encontrado a Esteban Pichardo (Richardo) y su Diccionario Provincial casi-razonado de Voces Cubanas (1849), a quien identifica como un académico cuidadoso.

Bachiller y Morales y Brinton se cruzan en sus estudios de nativos caribeños, siendo Bachiller y Morales el que resulta atrapado en la terminología tainista. Si Bachiller y Morales, en el transcurso de su investigación, hubiese encontrado a Daniel Garrison Brinton (1871) en lugar de von Martius (1867) la historia de los nativos cubanos en el siglo XX supondría diferencias a lo reconocido hoy. A pesar de que en Cuba Alfredo Zayas y Alfonso (1914) estaba en completo desacuerdo con Harrington y nunca aceptó la designación taína.

Oscar Peschel (1876: 206) sostuvo que los caribes eran una raza extraordinariamente dotada, física y mentalmente, y continúa diciendo que no se les debe juzgar con severidad por sus desnudeces, su inclinación a la piratería, sus deseos por la carne humana o por sus flechas envenenadas. Afirma que ocupaban la parte este de Porto Rico (Puerto Rico). Habla de aventureros que habían establecido monarquías en Haití (La Española), en el este de la isla. Bien puede ser una de las tres lenguas anteriormente identificadas. Describe las pirogues (piraguas) caribes, de capacidad de hasta 50 
marineros y capacitadas con velas de algodón, moviéndose a un tiempo establecido por el cantante. Peschel era conocedor de las embarcaciones de vela y hace sus referencias, primero, a Bernal Días del Castillo como testigo en Yucatán, y segundo, a Colón, que encontró en Honduras una embarcación comercial de vela de Yucatán. ${ }^{47}$ Peschel (1876:205) menciona a von Martius y su designación y uso del taini.

Juan Antonio Cosculluelas (1952:10) concuerda con Rafinesque y cita en su investigación autores tales como Osgood, Rouse, Rayney [Rainey] y Harrington, acercando a Cuba aún más a la terminología tainista. "Rafinesque, en sus ingeniosos Anales de Haiti, dice que los naborías (ciboneyes) eran una tribu de Haiti sojusgados por los tainos, y efectivamente es así" (Cosculluelas, 1952: 32).

En los investigadores recae la responsabilidad de reencontrar el lenguaje que identifique a los naturales caribeños y fortalezca el conocimiento comunitario $\mathrm{Y}$ lo encontramos en la línea menos esperada. Así, hallamos los extremos del sentir caribeño tratando de encontrar un consenso. Afirma G.B. Handley (2000: 5): "La naturaleza seguirá siendo un mito, despojada de su historia humana, siempre que el lenguaje sea 'sobre' la naturaleza, y no producido como resultado de nuestra interacción con ella". En sus observaciones literarias, este autor reconoce el debate del ser humano con su historia como complementarios a la naturaleza, reconociéndolo en la obra de Derek Walcott, quien busca en el océano, la tierra o el cielo caribeño la historia sin el ser humano, cuando se ha perdido la historia común y solo resta contemplar mar y tierra. La presente tesis examina la historia humana en el entorno que le rodea para el bienestar de sus descendientes, busca consolidar el pasado y el presente sin negar la naturaleza, el ser humano, su entorno natural y sus logros y fracasos recogidos como su historia. En este sentido, se sitúa en las páginas de la historia, sin la negación de cielo, mar o tierra.

"La historia, enseñada como moralidad, es religión. La historia, enseñada como acción, es arte. Esos son los únicos usos que nosotros, burlados como personas sin historia, podemos expresar. (...) el hombre despojado y desnudo, sin importar cuán maltratado, sin importar cuán desilusionado de viejas creencias, instintivamente, incluso desesperadamente comienza de nuevo como artesano" (Walcott, 1974).

La visión de Walcott es un tanto preocupante, más bien se lee un sufrir sin futuro, en la línea del tema abordado anteriormente por Levy-Strauss (1970), Viveiros (1998), Vaioleti (2006), Smith (2013) e incluso, de cierta manera, por Oberg (1955). Continua

47 Estas observaciones de navegantes y la construcción de embarcaciones y estructuras las estaremos discutiendo a fondo en el cuarto capítulo. 
Walcott: "No creamos nada, solo el pasar de lo absurdo antropológico a la basura pseudofilosófica, para discutir la realidad de la nada". Walcott presenta el maligno resultado del colonialismo y sus desventajas sociales, diferentes a las estudiadas en esta monografía, mientras en el marco geográfico e histórico se comparten siglos. En este sentido, el tratado de Peschel forma parte de la historia y rinde beneficios, unos beneficios no encontrados en Walcott, acogido a la persona sin historia. Dice Handley que el poeta necesita un sitio para ser poeta, para conmemorar o estar de luto. Sin embargo, el poeta Alejandro Tapia y Rivera (1852) recoge en esa misma tierra, sobre ese mismo mar y bajo ese mismo cielo la historia en sus versos. Aruca Alonso visualizó ese vacío de historia en la Cuba indígena irrelevante.

W. Harris (1970) identifica el archipiélago americano desde la perspectiva de los artistas y las artes para sanar heridas de una historia brutal, y dice:

"Es en las artes de la región que aquellos arquetipos sanadores se pueden encontrar que ayudarían a los pueblos del llamado Nuevo Mundo en trascender los traumas de la esclavitud y las migraciones forzadas y, por lo tanto, la auto-división psíquica y la alienación consecuente a la historia brutal de la región, tan acertadamente descrita por Fanon".

Harris piensa que en el mundo artístico se encuentra la sanación, una idea muy válida especialmente considerando que la música sobrevivió en la geografía del nuevo mundo que estudiamos. Walcott razona el artesano como el comienzo de un ser sin historia. En el variado folclor caribeño encontramos muestras típicas nativas de sus instrumentos, por ejemplo, maracas, güiros y mayohuacanes, mientras pocas son sus líricas. La melodía de esos sentires es real, no metafórica; el artista se conmueve por su historia, igual sea Walcott, Hall, Fanon, por el drama absurdo y social de la historia.

Frantz Omar Fanon nació en Martinica. Dice Fanon (1968:325): "Sólo tengo una solución: elevarme por encima de este drama absurdo que otros han puesto a mi alrededor, rechazar los dos términos que son igualmente inaceptables y, a través de un ser humano, alcanzar lo universal". En nuestro caso, repudiar la terminología taína y reencontrar las raíces nativas caribeñas en la historia es un nuevo renacer de la imposición, sea cual sea su curso. En este sentido, la causa y el problema son compartidos en la cultura de Cuba, Puerto Rico y la República Dominicana. Si la cultura nativa de nuestra área de estudio se interpreta y asume sus aspectos de raza y costumbres en la historia, el legado ancestral lograría una base sobre la cual construir y facilitar beneficios a comunidades y Estado. Al reformar el estado de la terminología nativa caribeña se logra dentro de su diversidad 
recuperar la herencia ancestral independientemente del color de la piel. En este sentido, convivían en el Caribe tortugas y sapos entre jutías. Sincretizar sobrevivencia, etnia e historia en su propia naturaleza es nuestro objetivo principal, donde multitudinarias herramientas humanas son evaluadas y propuestas.

7.3 La educación caribeña durante el siglo XX y su relación a la cultura popular.

¿Qué es cultura popular, y cuál puede ser su alcance social y cultural? Empecemos por definir cultura de la mano de Roger Chartier (1994: 44):

"A riesgo de simplificar en exceso, podemos remitir las innumerables definiciones de la cultura popular a dos grandes modelos de descripción y de interpretación. El primero, deseoso de abolir cualquier forma de etnocentrismo cultural, concebía la cultura popular como un sistema simbólico coherente y autónomo, que funcionaba según una lógica absolutamente extraña e irreductible a la de la cultura literaria. El segundo, ávido de remarcar la existencia de las relaciones de dominación que organizan el mundo social, percibía la cultura popular en sus dependencias y sus carencias en relación con la cultura de las clases dominantes. Tenemos, por un lado, así, una cultura popular que constituye un mundo aparte, cerrado en sí mismo, independiente. Por el otro, una cultura popular enteramente definida por la distancia a una legitimidad cultural de la que estaba privada".

Sin entrar en detalle, la cultura popular, desde el punto de vista etnocentrista incluiría arte, folclor, poesía, literatura, música e innumerables actividades comunitarias expresadas por un pueblo orgulloso de su identidad. Naturalmente esas condiciones se aplican a cada comunidad independientemente, incluso dentro de una misma nación cuando en sus provincias identifican y actúan en sus propias tradiciones. Desde esta perspectiva, la sanación de Harris, el rechazo de Fanon y el mundo aparte de Chantier se topan por sus propiedades acogedoras positivamente, al promover la cultura popular en el marco artístico. Pensar en un mundo cultural independiente y otro privado conforma vivir en la discontinuidad de no integrarse a lo común que une.

El principio de la comunidad dominante de mediados del siglo XX es contraproducente. En este caso, son las autoridades y los académicos los que privan y educan mientras encaminan estratégicamente la cultura popular y a las comunidades escolares a vivir una identidad de la historia nativa inservible desde principios del siglo XX. En este sentido, el mundo independiente y el privado caribeño de Chartier se ajusta a lo que anteriormente llamamos el vivir en una simbología o fenomenología cultural fabricada. 
En este estudio, la cultura popular corresponde directamente con la propia identidad de comunidades desde el punto de vista de sus propios habitantes. Por tanto, los países que examinamos poseen culturas populares independientes a nivel nacional y regional caribeño, mientras a su vez comparten algunos valores culturales de naturaleza precolombina e hispánica centrados en un mestizaje racial-cultural, un folclor sanador y una artesanía representativa de sus herencias individuales y compartidas. Uno de esos conceptos de valores culturales compartidos incluye la denominación étnica acogida bajo el tainismo del siglo XX, que proliferada por doquier. Un ejemplo lo hallamos en Jorge Baracutei Estévez (2013:14):

"Las palabras "taíno" y "nitaíno" provienen de la lengua taina. Por todo lo anterior, la aplicación del nombre Taíno y su uso actual para identificar a los pueblos indígenas del Caribe y sus lenguas estrechamente relacionadas es la mejor palabra que tenemos para describir a los pueblos Taínos clásicos y sus descendientes. Y lo más importante, el término sí encaja".

Estévez es uno de muchos renacentistas o activistas nativos que piensan que su identidad nativa prehispánica es indiscutible, y que la supervivencia cultural, lingüística y biológica merece ser reconocida por lo aprendido académicamente, acogiéndose al tainismo. En esta encrucijada existen varios problemas básicos. Primero: la aceptación de la denominación terminológica taína es vivir en un fenómeno científico fabricado, no una cultura legada. Y segundo: la supervivencia y herencia cultural caribeña no se puede definir singularmente bajo un término que acapara una geografía compartidas por naciones, removiendo la tipología étnica histórica de la región. Por más romántica que parezca la opción, la idea, que encaja, es ilegítima e injustificable. Estévez vive y protege lo que tiene, aun cuando no sea lo mejor. Esto muy bien pudo ser lo que Walcott llamó lo absurdo antropológico.

El Caribe posee vida e historia, sueños y soñadores que pueden abrir un camino donde otros piensan que no hay salida. En este sentido, es justificable salvaguardar hasta la última letra de la historia visualizando lo que es un comienzo de la unidad necesaria conducente a la protección cultural, donde esa persona desnuda encuentra su historia.

Las intervenciones e interacciones comerciales y de mercadeo norteamericano en el Caribe a partir de mediados del siglo XX se centran en Puerto Rico, Cuba y la República Dominicana. Estas intervenciones fomentaron una progresión cada vez más acaparadora en todos los sectores, incluyendo la cultura nativa, guardando una estrecha relación con artefactos y monumentos que dependían íntimamente de una fenomenología 
simbólica y de su terminología. Steward ([1948] 1963) presento el problema existente de las maravillosas piezas almacenadas en museos e instituciones en los Estados Unidos y Europa. Las denominaciones étnicas establecidas a partir de Rafinesque un siglo antes, y sus lazos europeos, fomentaron y facilitaron ese fenómeno cultural.

Refiriéndose a ese fenómeno, escuchamos decir a Hoogland y Hofman (1999: 96): "Los nombres étnicos derivados de estas fuentes son hoy en día asignados por los arqueólogos como etiquetas a los grupos culturales importantes como Tainos, Caribes isleños e Igneris". El uso de etiquetas arqueológicas es aplicable a ese periodo desde Rafinesque, sin embargo, Hoogland y Hofman se refieren a la era más reciente y el formulismo popular contemporáneos, cada vez más dependiente de una terminología fabricada. Lo cierto es que antes del siglo XX pocos en el Caribe reclamaban su legado nativo, y de acuerdo con las interpretaciones contemporáneas ese legado dejó de existir a raíz del colonialismo a causa de una extinción nativa.

En Puerto Rico, la educación pública, privada, universitaria, junto a agencias gubernamentales y la cultura popular son intervenidas científicamente. El revivir nativo caribeño a la altura de 1960 se adueña de lo primero que encontró académicamente para vitalizar su causa cultural, encontrándose con el taíno. Puerto Rico se convirtió en un centro de actividades de las influyentes investigaciones norteamericanas debido a su estructura política, idioma y centros arqueológicos. El plan económico y cultural en Puerto Rico encontró un símbolo de mercado en el taíno, seguido de estudios multidisciplinarios provistos por grandes agencias e instituciones que recogería a los artistas de la época para vender y clasificar su producto cultural. En el sentido comercial, las etiquetas arqueológicas se han convertido en unidades de una marca reconocible mercadeada desde su organizada plataforma terminológica, alejándose cada vez más de realidades etnohistóricas.

Investigadores cubanos, puertorriqueños y dominicanos difundieron la noción de la cultura taína en el Caribe, bien porque es solo una etiqueta, como afirman Hoogland y Hofman o porque encaja en el modelo construido, como para Estévez. 


\section{LA CRISTIANIZACIÓN Y EL BAUTISMO.}

José Juan Arrom escribe: “Fray Ramón puntualiza que ‘el primero que recibió el santo bautismo en la isla Española fue Juan Mateo, el cual se bautizó el día del evangelista San Mateo, año de 1496'. Como San Mateo cae el 21 de septiembre" (1988: 7). ${ }^{48}$ La obra de Ramón Pané [1498] menciona el primer bautismo católico en América. Estas referencias nos abren un camino al entendimiento y difusión de denominaciones relacionadas al primer libro de América y a los secretos que en él se ocultan. Para Arron, "Fernando Ortiz ha objetado que nuestro fraile [Pané], 'según Las Casas, sólo entendía una de las tres lenguas de los indios de Quisqueya, la de los macorixes, que no era la general de la isla'. Y Pedro Henríquez Ureña, coincidiendo con Ortiz, declara que 'la lengua que habló Pané no fue el taíno, general de la isla, sino la del Macorix de abajo: véase Las Casas, Apologética historia de las Indias, cap. 1.40'."

En el contexto general, la discusión abarca las tres lenguas habladas por los indios de Quisqueya, mientras Arrom, en su afán de la estandarización terminológica considera que el taíno era la lengua general de la isla. Arrom menciona a los indios de Quisqueya y a los macorixes en su presentación de las objeciones de Fernando Ortiz y Pedro Henríquez Ureña. En primera instancia, Ramón Pané nunca utilizo el taíno en forma alguna. De estas citas surgen denominaciones, argumentos, objeciones en base a una fabricación terminológica que pretende apoderarse de un episodio y literatura histórica. Manuel Serrano y Sanz, en 1932, realizo una de las primeras traducciones de la obra de Ramón Pané y en ella no figura el taíno en manera alguna. Arrom (1988: 10), por el contrario, escribe: "fray Ramón vivió varios años entre los taínos y tuvo tiempo, sobre todo con la adhesión y ayuda de Guaicabanú...". Serrano es preciso en su traducción acogiéndose a normas y reglas científicas. Arrom interpreta y añade fuera de contexto eventos que nunca sucedieron. El porqué de estas actuaciones las examinaremos en los próximos capítulos. En esta sección nos detendremos en detalles del significado de la cristianización y el bautismo.

Se convierte al nativo caribeño en esas primeras décadas del descubrimiento en una nueva sociedad. Primero, cuando se cristianizan y bautizan sus gentes dentro de unas

\footnotetext{
${ }^{48}$ Pané, R. 1988. Relación acerca de las antigüedades de los indios: el primer tratado escrito en América (Vol. 5). Siglo XXI. / Arrom, José Juan. 1974. Relación acerca de las antigüedades de las Indias de fray Ramón Pané. (México D. F: Ed. Siglo XXI). / Serrano y Sanz, M.1932. La Relación, tomo II editada por la Librería General de Victoriano Suárez.
} 
reglas, viviendo conflictos entre el acoplamiento a la cristiandad, la doctrina y la supervivencia nativa. Segundo, en las complejidades del matrimonio español y nativo en el que ocurre el mestizaje y nace una diversidad autóctona. Ese proceso de cristianización fue muy debatido, pues para muchos, estos "salvajes" ni siquiera tenían alma. Fernando Colón (1892: 15) señala que Juan Mateo fue el primer nativo de La Española en ser cristianizado, en 1496, por vía del bautismo, seguido de siete miembros de su familia. Colón se dirigía a conocer a un cacique principal llamado Mavitúe en compañía de fray Ramon Pané el hermita, fray Juan Borgoñón y Juan Mateo (Guaticaba). Esto nos inclina a pensar que entre 1493 y 1496 se habían bautizados numerosos naturales. En este sentido, las mujeres jóvenes de la familia de Juan Mateo se convierten en las primeras mujeres nativas que eventualmente contraerían un posible matrimonio dentro de la religión católica en lo que es hoy República Dominicana y Haití. Sin embargo, mencionamos que de los nativos lucayos y otros transbordados a España en 1493, incluyendo a los diez que fueron presentados en Barcelona a los Reyes Católicos, y por órdenes de estos habían sido apadrinados y bautizado, entre ellos dos hijos de Goacanagarí, junto a otros varios que nunca regresaron a sus tierras pues murieron en España por causa de viruelas (Mira Caballos, 2001: 9). ${ }^{49}$

Las mujeres nativas a partir del 1493 parían los primeros mestizos de América. Esos primeros llantos de hijos de europeos limitadamente se transfieren a las páginas de la historia. Este tema se discute ampliamente en el cuarto capítulo. Resuena ese grito infantil en el oído del colonizador, lo que sí es indiscutible es que numerosas mujeres nativas fueron madres y reconocieron en sus hijos sus propias naturalezas desconocidas: que esos hijos de dioses encontrados entre sus brazos lloraban y se amamantaban igual que sus otros niños nativos. Esa unión propia y desconocida de esas madres nativas constituiría una sustancial incógnita del descubrimiento conteniendo el primer elemento de la sobrevivencia nativa. Esa experiencia maternal convierte a la mujer nativa en testimonio, en un hilo humano entre europeos y el primitivo caribeño. En América esas parentelas vivían una nueva humanidad contemplando el crecer de esos niños, mientras en Europa la realidad y el futuro de esos niños era otra. Lo trivial de ese nacimiento entre leyes y colonos encontraría en su momento ciertas virtudes.

${ }^{49}$ Caballos, E. M. 2001. 'Caciques guatiaos en los inicios de la colonización: el caso del indio Diego Colón.', Iberoamericana, pp. 7-16. Caballos, E. M. 2000. Las Antillas Mayores, $1492-$ 1550: ensayos y documentos. Vervuet - Iberoamericana. Caballos E. M. 1999. La educación de indios y mestizos antillanos en la primera mitad del siglo XVI. Revista complutense de historia de América, 25, pp.51-66. 
En relación con esta temática de razonamiento y razas, encontramos ingeniosos métodos formulados desde el Estado para la conquista y la dominación de América que tuvieron su práctica en la primera década de la colonización de La Española. Como indica F.L. Alencar y R. Ruiz-González (2010: 41), “Quizás en Portugal el tema de la noracialización sea más evidente que en España. Pensemos, por ejemplo, en la política portuguesa de hacer que los oficiales de la Corona casaran con las hijas de los jefes de las tierras descubiertas". Esa política portuguesa simboliza lo ocurrido en América desde el descubrimiento, donde los exploradores buscaron satisfacer sus apetitos sexuales y a su vez cumplir con los controles del Estado. Pensar que en 1492 noventa hombres a la mar por meses encontrándose repentinamente en fabulosas islas. Estos tripulantes poblarían colonias y engendrarían generaciones junto a las mujeres nativas, originándose la supervivencia biológica nativa dentro y fuera de la conversión cristiana y el bautismo en una nueva y diversificada sociedad. Singularmente en la primera década del descubrimiento en La Española desembarcan sobre 2.000 hombres y la pregunta es cuántos niños engendraron, pues las relaciones sexuales fueron denunciadas con anterioridad a Montesinos. Este primer mestizaje eventualmente se convierte en las raíces que en un futuro se utilizarían por autores como Ricardo Alegría $(1955)^{50}$ para definir las descendencias raciales de la herencia caribeña.

Ricardo Alegría fundamenta un linaje en el que forman parte la sociedad taina entre blancos y negros, lo que identifica erróneamente como las particularidades del nativo caribeño. Alegría y el Instituto de Cultura de Puerto Rico utilizaron ese símbolo taíno incesantemente, y tan reciente como en el 2011 se publicó el libro La rebelión taina. Lógicamente, si los tainos de Alegría nunca existieron, ¿cuál era el propósito de esa ciencia?

La historia nos orienta a entender la cristianización y los bautizos de los primeros nativos caribeños generado una filosofía de la tercera cultura primitiva. Esos nuevos mestizos bautizados dejan de ser exclusivamente nativos naturales y al vestirse aprenden a proteger sus vidas y las de sus familias, constituyéndose nuevas raíces nativas caribeñas dentro de un nuevo idioma y una nueva biología. A partir de esas primeras décadas comienza la integración de los negros esclavos y libres en el mestizaje caribeño. En las primeras décadas de la colonización la integración social era recóndita. Podemos

\footnotetext{
${ }^{50}$ Alegria, R. E., H. B. Nicholson, \& G. R. Willey 1955. The Archaic Tradition of Puerto Rico. American Antiquity 21: 113-121.
} 
preguntarnos qué lenguaje identificaba a terceras y cuartas generaciones de "razas mezcladas", que pasaron a llamarse tercerones o cuarterones.

Los hijos e hijas de uniones o violaciones de mujeres nativas constituirán una ruta a la supervivencia pues al pasar del tiempo sus cambios raciales y rastros fisionómicos se integrarían eventualmente en una demografía multirracial abarcadora de futuras uniones matrimoniales legitimas o no. Por ende, la cristianización abre un camino de sabiduría en el que las mujeres encuentran un refugio en el único ambiente que les permitía un limitado grado de seguridad y sobrevivencia a la herencia nativa. Señalamos una posible vía de las consecuencias de la cristianización en la cita teosófica de H. P. Blavatsky (1879: 7): "Por lo general, los seres ridiculizados y motejados como 'infieles' de una generación, se convierten en los sabios y los santos de la siguiente". De infieles-sabios-santos es un camino mitológico nativo-colono en el que incursionaremos ocasionalmente por sus valores añadidos unos que son adoptados, popularizados y sincretizados a futuras generaciones dando lugar a la cultura popular y el cristianismo. En su diario, escribe Colón el viernes 12: "Y creo que ligeramente se harían cristianos, que me pareció que ninguna secta tenían". Esta línea guarda una cercana relación a lo establecido anteriormente. Cristóbal Colón conoció rápidamente que estos nativos eran cordiales y por poca cosa daban todo lo que tenían.

Existe una generosidad nativa que se presta a muchas interpretaciones, considerando la amistad señalada anteriormente de lo vivido por el hombre primitivo en su medio ambiente, pensando; o sea, la odisea de, yo, la tortuga y el sapo viviendo entre jutías.

En su segundo día en América, Colón tenía clara la visión del cristianismo como fuente evangelizadora. Los principios de conversión forzada no eran enteramente nuevos a Castilla y Aragón durante la expulsión de los judíos y la conquista de Granada. En 1492 Francisco Jiménez de Cisneros se convirtió en confesor de la Reina Isabel y luego es nombrado arzobispo de Toledo, cargo vacante por el nombramiento a primer arzobispo de Granada de Hernando de Talavera, quien fuera el confesor de la reina desde 1474. Hernando de Talavera se opuso a la Santa Inquisición mientras que el Cardenal Cisneros era un afanado reformista, lo que causaría problemas entre estos dos hombres religiosos en Castilla durante la primera década del descubrimiento. El cardenal Cisneros fue regente de España en dos ocasiones, hasta su muerte en 1517. Estos dos confesores de Isabel I de Castilla influenciaron a la reina hasta su muerte en 1504. Desde la primera década del descubrimiento se refleja la postura de estos dos religiosos, Talavera puede 
decirse afín con los principios de Bartolomé de las Casas, mientras que la mano dura de Cisneros no favorecería a los nativos de América. Gonzalo Fernández de Oviedo, en 1507, se convierte en notario público y secretario del consejo de la Santa Inquisición, y en 1513 viaja a América ([1535] 1851).

La maternidad de mujeres nativas añade unas nuevas dimensiones. Primero, la nueva generación de mestizos es físicamente distinguible, constituyéndose un concepto criollo aceptable y explotado por los europeos, que continuaría expandiéndose por siglos. Segundo, esa nueva generación de nativos mestizos bautizados aprendería a sobrevivir en esta dualidad cultural, tomando ventajas de su fisionomía y de su pertenencia a la Iglesia. Esta estructura de supervivencia ya existía en la región, integrada a la cultura caribeña precolombina entre arahuacos y caribes y sus descendientes, quienes habían establecido un concepto cultural análogo al capturar mujeres de raíces arahuacas, lucayas, haitianas, ciguayas, cubanas, siboneyes, macorixes, quisqueyanas, borincanas y otras de la región durante la época precolombina, con el propósito de la procreación, donde sus descendientes, viviendo en tierras caribes, se convertirían en caribes, aun considerando que sus madres eran de otras naciones. Este proceso de abducción, procreación y conversión primitiva formaba parte de una integración cultural completa, convirtiéndose en una vía natural, orgánica y reconocible que los nativos hubiesen aceptado por su habituación de uso y costumbre. Por tanto, este proceso se puede distinguir y asumir como uno nativo establecido y adaptable a cualquier raza; los europeos, desde la perspectiva nativa, actuaban en el sentido de la procreación y dominación igual a los caribes. En este sentido, la mujer primitiva actuaba bajo esa dominación dentro de su propia naturaleza para salvar a su familia. La cita de Jalil Sued Badillo (2007: 41) avala esta visión:

"Si hubo borincanos en Guadalupe, ¿qué hacían allí? Las relaciones de parentesco, los matrimonios exógamos, el rapto de mujeres, y aun los conflictos entre caciques, podrían explicarlo. Nunca sabremos con certeza. Lo que sí es cierto, no obstante, es que todas estas opciones fueron prácticas comunes y frecuentes que no deben descartarse".

La carta del Dr. Diego Álvarez Chanca encontrada en 1825 según se ha señalado anteriormente, narra que los borincanos en Guadalupe eran cautivos de los caribes llevados a la fuerza. Este complejo concepto cultural se puede definir desde la naturaleza del género, las costumbres nativas, la explotación sexual-económica por colonos y los evangelizadores. Entendemos que no se debe descartar por su significado, como bien habíamos señalado a modo de las raíces de familias heterogéneas y originales caribeña. 
Se trata específicamente de la relación que existía entre la mujer nativa y su condición de madre. Los caribes de Guadalupe sobreviven hasta el siglo XXI, donde el ADN de caribes y otros oriundos aún vive, e igualmente esa genética se encuentra en el Caribe en general.

Entre, mestizos, mulatos, etnias y culturas nace la Raza cósmica, de José Vasconcelos, donde encontramos una visión del mundo que depende de conflictos.

\begin{abstract}
"Sólo un salto del espíritu, nutrido de datos, podrá darnos una visión que nos levante por encima de la microideologia del especialista. Sondeamos entonces en el conjunto de los sucesos para descubrir en ellos una dirección, un ritmo y un propósito. Y justamente allí donde nada descubre el analista, el sintetizador y el creador se iluminan" (Vasconcelos, [1925] 1948: 6).
\end{abstract}

La historia es un proceso científico que recoge información del ser humano y su medio ambiente y lo presenta para el beneficio común. Como escribe Edward Hallett Carr: "El pasado es inteligible para nosotros solo a la luz del presente; y podemos entender completamente el presente solo a la luz del pasado. La función dual de la historia es permitir que el hombre entienda la sociedad del pasado y aumente su dominio sobre la sociedad del presente" ([1961] 2018: 32). El pasado lo entendemos y lo aceptamos según los discursos que afectan el diario vivir y la habilidad de separar lo bueno de lo malo. En este sentido, analizamos actividades y documentos disponibles para llegar a interpretaciones que faciliten el entendimiento del pasado.

La victima original sometida y subyugada por siglos, negada de su propia historia, se convierte en el conejillo de indias en el laboratorio científico de la terminología caribeña, convertido en el hombre desnudo de Walcott. Y, aquí la ironía toma forma en Franz Fanon (1963), Harris (1970), Chantier (1994) y Stuart Hall (1996), que buscan en el arte encontrar un camino a la reconstrucción nativa, o al alejamiento y sanación de la esclavitud; después, encontramos el sepelio del nativo caribeño y su extinción, lo que resulta necesario para comercializar la simbólica imagen fabricada taína sobre un difunto original. 


\section{CONSIDERACIONES A UNA RECONSTRUCCIÓN HISTÓRICA ANCESTRAL CARIBEÑA DESDE UNA PERSPECTIVA NATIVA.}

El concepto de restauración perfeccionada examina y se basa en análisis e interpretaciones documentales como consideración especial. Esta restauración perfeccionada integra la tercera cultura primitiva caribeña, cuya base científica y filosófica se amplía en consideración del mestizaje y la sociedad multicultural homogénea de Caribe. Se enfatizan ciertas condiciones consideradas de importancia en la interpretación y propuesta de la tercera cultura nativa caribeña. Hall (1996a: 170), citando a Frantz Fanon (1963: 223, 224) afirma: "La colonización no se satisface simplemente manteniendo a su gente en su agarre, vaciando el cerebro nativo de toda forma y contenido. Y por una especie de lógica pervertida, se vuelve al pasado de las personas oprimidas, y distorsionan, desfiguran y lo destruyen".

Fanon (1963) y Hall (1996a) presentan un realismo profundo de lo que fue el colonialismo al señalar lógica y efecto. El mecanismo de esta lógica pervertida no se limita a la dominación y explotación humana, trasciende la deshumanización nativa desde las primeras décadas del descubrimiento neutralizando comunidades y removiendo culturas. El renacer nativo caribeño desde una perspectiva nativa situada en la segunda mitad del siglo XX debate el concepto de volver a la madre, de volver a un origen nativo perdido en busca de habitar, reencontrar y reconstruir la herencia prehispánica neutralizada y distorsionada. Este reencuentro está integrado al renacer popular y cultural nativo en busca de su propia naturaleza, vida y pensamiento original, requiriendo sanar las heridas dejadas por esa lógica pervertida, escondida profundamente en el arte de la vida. En este sentido, la restauración perfeccionada de la cultura primitiva caribeña busca a su madre y su origen regional particularizado, buscando materializar la humanidad arrebatada y encontrar nuevamente esas raíces de la antigüedad clásica prehispánica, distanciándose de las consecuencias destructivas del colonialismo, tratadas $\mathrm{y}$ mercadeadas aún hoy bajo las aplicaciones terminológicas del siglo XIX. Por tanto, el alejamiento de las disconformidades del colonialismo y de la terminología aplicada a la historia crea una barrera favoreciendo ese reencuentro y renacer nativo, aportando nuevas direcciones investigativas para extraer del material documental existente beneficios, al reinterpretarse lo sustituido, lo pasado por alto o desconocido, facilitando ese reencuentro con la madre naturaleza nativa en su propia historia considerando en pensamiento y conocimiento nativo. 
Se agrava esa perspectiva si analizamos variaciones de autores y sus pensamientos. Al respecto, presentamos la siguiente cita de Walcott por su significado filosófico (1974: 10):

"Pero los que ven sólo el desorden, la futilidad y el caos deben buscar los patrones que estos producen, y encontrarán en esos patrones contradicciones y tensiones que a menudo no debieron adaptarse, mucho más para sobrevivir. Hubo quienes no sobrevivieron, no por la debilidad, sino por un proceso de la defoliación que desató el desafío; Y este proceso, el genocidio, es lo que destruyó al nativo, destruyó a los aztecas y a los indios americanos y al indio caribeño. Muy bien, digamos qué estos no eran una cultura, ni una civilización, sino un modo de vida, entonces, una manera con sus propios dioses y lengua y vida doméstica o costumbres maritales. El punto es que los rompieron, que fueron maleable por un tiempo, pero los rompieron. Estos han desaparecido. Quedaron pocas ruinas, ya que el ego era tribal, no individualista, pagano si quieren, no cristiano. Podemos alabarlos por no imitar, pero hasta la imitación los diezmó, o los ha humillado como al aborigen y al indio americano. Lo que nos han estado ofreciendo aquí como una alternativa, solo el suicidio. No sé si los simios cometen suicidio su imitación no es tan avanzada-pero los hombres lo hacen, y parece también, ciertas culturas".

Volvemos al tema de la sensibilidad o falta de sensibilidad, según es presentada en Vaioleti (2006), Cochran (2008) y Smith (2013), vinculadas a estudios arcaicos, con la idea de hilar condiciones existentes substraídas del pasado. En este sentido, bien se puede visualizar el resultado poetizado de la colonización. Walcott (1974) interpreta una cruda visión, que en su conjunto engloba fragmentos de lo expresado en Hall (1996a) y Fanon (1963). Estas opiniones o sentimientos las proponemos en el marco teorético como parte del análisis realizado de conceptos y expresiones, aceptadas o ligadas a culturas caribeñas, que carecen de poder conformarse en la historia o en las raíces nativas caribeñas. Naturalmente, resulta insólito examinar posibles semejanzas entre suicidios de simios, suicidios de humanos y suicidios culturales, y comparar esos resultados e interpretaciones a un genocidio caribeño. Añadimos que desde la perspectiva científicafilosófica el contexto aporta muy poco al análisis de una cultura.

En este análisis en base a ciencia y filosofía encontrados con lo insólito cultural, regresamos a la historia citando de nuevo a Carr (2018: 82): "La historia es la larga lucha del hombre, en el ejercicio de su razón, para comprender su entorno y actuar en consecuencia. Pero el período moderno ha ampliado la lucha de manera revolucionaria. El hombre ahora busca entender y actuar, no solo en su entorno, sino también en sí mismo; y esto ha agregado, por así decirlo, una nueva dimensión a la razón, y una nueva dimensión a la historia". Esa nueva dimensión de la historia guarda relevancia con el desarrollo de nuestro tema. En ese sentido, lo que aparenta ser lo insólito cultural se 
analiza dentro del carácter de la persona, tratando de entender y razonar su propio entorno y su historia. Esa dimensión del pensamiento es la que conduce a nuevas interpretaciones históricas conformes a lo original ancestral y no a lo fabricado. En relación con interpretaciones de textos y teorías que conllevan a un intenso análisis, es útil la reflexión de Whitehead (2002: 10):

"los textos lingüísticos y etnológicos coloniales no estaban compuestos de argumentos sin fisuras y de conjuntos de datos perfectos, sino que a menudo eran simples acumulaciones de observaciones sin clasificar y testimonios secundarios. Como resultado, estos textos también contienen muchas indicaciones para otros tipos de interpretaciones del Caribe nativo y, cuando se combinan con fuentes posteriores y los datos de la arqueología, pueden utilizarse para proporcionar una interpretación más adecuada y más completa de la situación encontrada por Colón, Y en particular el significado de los términos carib / caniba, y aruaca / guatiao".

En el encadenamiento de argumentos imparciales e interpretaciones de Whitehead se definen marcadas diferencias con los sentimientos de Walcott. Whitehead plantea una premisa ineludible al refinar talantes antropológicos o históricos, considerados espacios dudosos, esencialmente si la literatura disponible carece de una estructura clara según indican algunos investigadores. En este sentido, la imparcialidad aplicada al análisis y el estudio de la etnología caribeña desde el descubrimiento es esencial al interpretar textos y circunstancias imprecisas de las culturas nativas particularizadas originarias desde sus propias perspectivas. Whitehead entiende la delicadeza de los archivos y propone examinar el significado de términos y el entendimiento de documentos antiguos, de hecho, el estudio de archivos originales del siglo XV y XVI requiere el conocimiento del castellano antiguo, la interpretación de la caligrafía utilizada y un enfoque filosófico del pensamiento y lenguaje de esa época.

Ante Walcott, la supervivencia nativa y de la cultura popular serían inexplicables; su razonamiento de la destrucción nativa de la América prehispánica es total. Acertadamente, identifica Whitehead las imperfecciones de los textos coloniales y la necesidad de expandir el conocimiento en busca de lo realmente precolombino, y hasta cierto punto viabiliza y neutraliza el concepto de invasores españoles de Keegan (1996). Sin embargo, muchas de estas fuentes contemporáneas, como bien señala Fanon, responden a una lógica pervertida. Esta lógica pervertida surge de raíces coloniales que devastaron el archipiélago y el continente, donde floreció la naturaleza homogénea legada desde el vientre de una madre nativa sacrificada en unión a su naturaleza y al suelo donde sobreviven inseparables, la una de los todos, en el escenario caribeño. 
Numerosos investigadores internacionales a principios del siglo XX promueven conceptualizaciones y teorizaciones originales estimulando futuros cambios sociales y desventajas a comunidades caribeñas basándose en estandarizaciones. Esa dimensión científica del siglo XX documentó variaciones etnológicas, lingüísticas y patrimonios culturales en las regiones históricas de naciones precolombinas del archipiélago caribeño. En este primer capítulo se analizaron conceptualizaciones etnográficas que en su tiempo histórico, y en base a la naturaleza nativa, fueron contrapuestas a las culturas europeas a partir de 1492, señalando ciertas divergencias que desde el siglo XIX componen los comienzos a una ruptura a la historia. En este sentido, centrándonos en la economía contemporánea, citamos nuevamente a Hall (1996a): “A través del mercadeo, el diseño y el estilo, de una 'imagen' proporciona el modo de representación y narrativización ficticia del cuerpo del que depende gran parte el consumo moderno".

Una imagen para el consumo moderno es precisamente lo que logra la estandarización terminológica taina. Se crea un simbolismo que separado de la historia encuentra su propia ciencia y se difunde en la cultura popular. Mientras pensamos que esta terminología taína es académica exclusivamente, su institucionalidad es económica y lo ha sido desde la Revolución Industrial, en la cual la imagen taína de Rafinesque fue comercializada desde Norte América a Francia, Alemania y luego a Europa en general por su autor, llegando a Alemania con von Sivers (1861), von Martius (1867), Peschel (1876), y luego a Cuba, por vía de Bachiller y Morales (1883) citando a von Martius (1867), Peschel (1876) y Rafinesque (1836), haciendo el taíno su entrada en Cuba.

Se analizaron variables tainistas substanciando los estudios principales y el debate correspondiente a las trayectorias académicas en la comercialización, investigación y la educación taína. Al tratarse de un símbolo cultural fabricado crea un conflicto que obstaculiza el ordenamiento cultural nativo caribeño y encontramos a nativistas y tainistas en una ciencia alejándose cautelosamente de su propia creación.

De la pasión y violencia de las primeras décadas emergen tendencias prejuiciadas e impugnables a lo largo de cuatro siglos, dejándose sin documentar a fondo durante el transcurso de esos tiempos la humanidad, la colectividad y la conciencia nativa. Este espacio ha generado y constituye un punto de partida utilizado por algunos autores contemporáneos para fundamentar sus teorías del taínismo. En las primeras décadas, la intolerancia era tal que entre los mismos conquistadores la conspiración, traición y rebeldía cobraban vida y fortuna. América comenzaba a elaborar un nuevo orden ajeno a la voluntad de los Reyes Católicos en un continuo enfrentamiento entre conquistadores y 
sus afiliaciones, donde opresores en busca de riquezas se enfrentaban incesantes a defensores de los naturales en busca de legitimidad.

En el siglo XIX, teorías científicas comenzaron a producir nuevas definiciones etnográficas y arqueológicas aplicadas a conceptos materiales, culturales y espirituales, enfocándose en el Caribe insular y sintetizando raza, cultura, geografía y costumbres apartadas de la historia. Identificar, examinar y analizar esas conceptualizaciones teoréticas científicas es primordial en la ruta de rectificar faltas o fallas culturales, en base a mediar y viabilizar el conocimiento de la historia. 


\section{Capítulo 2: Políticas de los primeros contactos de América y la perspectiva de los naturales.}

\section{ESPACIOS GEOGRÁFICOS Y SUS COMPONENTES}

Gerardo Reichel-Dalmatoff (1960: 162), en su discusión del grupo Yuko-Chaké y sus subdivisiones (noroiente de Colombia y noroccidente de Venezuela), nos habla de: “(...) las diferencias dialectales, tecnológicas, y somáticas debidas probablemente en parte por el aislamiento geográfico y a una marcada tendencia a uniones consanguíneas, en parte a razones históricas". El aislamiento es de interés, puesto que en un espacio geográfico especifico se desarrollan las diferencias somáticas que evaluamos en el Caribe. Reichel-Dolmatoff identifica el número de los componentes de esos grupos, en la que señala siete subdivisiones del grupo Yuko-Chaké, cuyas poblaciones fluctúan entre $30 \mathrm{y}$ 200 habitantes en cada uno de esos grupos. En su ejemplo, los denomina según pudo identificar: (1) Manaure 50, (2) Susa 120, (3) Tukushmo 30, (4) Iroka 200, (5) Sokarpa 30, (6) Maraka 100, (7) Sokomba 100, (8) Curumaní; “pequeños grupos más bien migratorios". La importancia del trabajo de Reichel-Dolmatoff es que identifica en sus propias denominaciones quienes son y donde se ubican las tribus que estudia. Mientras que el número de individuos es reducido. En adición, Reichel-Dolmatoff hace una anotación de interés y dice: "En su mayor parte los nombres de los subgrupos son nombres de regiones, ríos y cabeceras, de manera que al trasladarse los habitantes a otro paraje cambia eventualmente su designación".

Gerardo Reichel-Dolmatoff levanta dos puntos de interés en el tema de los nativos, los subgrupos y sus eventuales cambios de nombre basados en la migración y en las características geográficas y el medio ambiente. Ese cambio de nombre basado en la migración se identifica en conexión al suelo. En el caso presentado, una de las razones fue la expansión poblacional hacia la selva. Esa misma movilización ocurrió en el Caribe durante la colonización por razones similares, escapar de abusos y la esclavitud, considerando la geografía de cada isla. En el caso del Caribe, las consecuencias coloniales de las primeras tres o cuatro décadas encierran variables geográficas en base a la movilización o asuntos político-sociales como el matrimonio multiracial,etc. 
La topografía de La Española facilitaba la posibilidad de esconderse por años, Enriquillo y su poblacion es uno de esos casos. Un análisis de geografía, medio ambiente y población nativa de La Española considerando la evolución biológica nativa junto a resultados de ADN demostraría que el caso de Enriquillo no fue único.

Reichel-Dalmatoff estudia una pequeña tribu y sus subdivisiones, cuyos habitantes totales son unos 800 habitantes, y logra identificar propiamente ocho de sus denominaciones. Sin embargo, en las cuatro amplias islas que estudiamos, con fronteras nacionales independientes, se pretende estandarizar raza, tribus, lenguaje y costumbres bajo una terminología. A simple vista, esto es ilógico. A esas naciones bien puede sumarse las Bahamas, agravando el problema numéricamente.

Volvemos a retomar la dirección analítica de la literatura caribeña para examinar el razonamiento que facilitó la estrategia de Rafinesque.

Cristóbal Colón (1991: 92) contribuye a la mitología de algunos pueblos de las Antillas y de la tierra firme en su cita del Diario de a bordo del domingo 14 de octubre, cuando un viejo nativo, en conversación con Colón y otros, llamó a grandes voces: “(...) venid a ver los hombres que llegaron del cielo, traedles de comer y beber". Arranz añade a Diario de a bordo la palabra taínos entre paréntesis (1991: 93, n52). Esa es la única vez que dicha adscripción es citada en esta edición del diario, utilizada para identificar nativos en las Antillas, como en el continente se habla de aztecas y mayas. Esa nota de pie falsea una realidad formada por decenas de pueblos y denominaciones de nativos caribeños, como hay muchas más denominaciones en México que los aztecas y mayas. Aun cunado en esta edición, en su analogía de los nativos de América Arranz (1991: 187), cita a los Ciguayos, diciendo "aclara Las Casas al margen", la aclaración no la provee Las Casas en lo correspondiente al taíno. Esa implicación improcedente es el problema básico de la terminología taína. Primero, un editor o un autor desconoce la historia nativa, y segundo, presenta una aplicación o alternativa contemporánea de otros autores con el mismo padecimiento, cuando era más prudente no escribir anotación alguna.

Examinemos el contraste entre Arranz y un concepto de terminología aplicada en Granberry (2012 :7): "Igual que los ciguayos, los pueblos macorijes habían sido empujados hacia la costa norte de La Española y hacia el mar por la migración posterior taína. Su conquista por los taínos y su conversión a modos de vida aruacos todavía estaban en progreso cuando los españoles llegaron en 1492”. Granberry sitúa ciguayos, macorijes (macorixes) y araucos en La Española identificados por cronistas y exploradores discutidos anteriormente en sus narrativas del descubrimiento junto a taínos del siglo XIX 
ligados en una conquista repobladora basado en teorías tainistas académicas y no en historia. ${ }^{51}$ La primera impresión es la magnitud de variables y distancia filosófica entre Arranz, el historiador, y Granberry, el lingüista, postulando marcadas diferencias. Arranz (1991: 92) inserta una nota de pie (\#52) al Diario de a bordo de Colón y aplica el término taíno para describir a los nativos antillanos. La primera impresión resulta inofensiva pero no lo es, y está fuera de lugar; de hecho, los lectores pueden confundir el significado del diario. Primero, porque los taínos nunca existieron, y segundo, por creer que Colón conoció tainos, algo que nunca sucedió; finalmente la confusión llega a manos de lectores quienes interpretan notas editoriales en un contexto erróneo. El asunto se complica si incluimos a Keegan (1996) y sus invasores españoles. El Diario de a bordo de Colón fue editado por Bartolomé de las Casas y puesto a prueba por su hijo Hernán Colón. La cita del domingo 14 de octubre en el diario se asemeja a un evangelio: "que llegaron del cielo, traedles de comer y beber", cuando la realidad de Colón era la conquista y el oro. Y se puede asumir que los nativos en ese primer encuentro con europeos estarían temerosos y confundidos ante tales seres vestidos.

Las presunciones de Granberry expresan el resultado de acogerse a la terminología taína. En Puerto Rico buscamos catorce décadas antes de Granberry, en el siglo XIX, y encontramos que Oscar Peschel (1876) afirma que aventureros, refiriéndose a los caribes, habían conquistado las Antillas Menores, la porción este de Porto Rico (Puerto Rico) y hacían incursiones en Hayti: “(...) aventureros habían fundado monarquías y los antiguos que llegaron habían tomado posesión de la costa este". Incluso se puede añadir que J. W. Fewkes (1907) y Peschel concuerdan en que los caribes durante el descubrimiento estaban establecidos en la costa este de Puerto Rico. Para entender el alcance de la cita previa examinamos otra de Granberry (2012): “Ciertamente desde el 1 d.C. hasta por lo menos el 500 d.C., taíno fue el idioma del conjunto y la lingua franca que se entendía y se usaba por todos en ambas las Antillas Mayores y Menores, a pesar, de su lengua nativa". Esta línea de Granberry, en su conjunto, es completamente contraria a los trabajos del antropólogo y lingüista D. G. Brinton (1871), de Fewkes (1907) o de Peschel (1876), y lo discutiremos a fondo en este capítulo. Recordemos que Brinton se opuso en su momento a Rafinesque. Estas marcadas disconformidades entre historia, lenguaje y arqueología se abarcan a lo largo de esta monografía, donde analizaremos

\footnotetext{
${ }^{51}$ Ver; tabla \#1 denominaciones de nativos caribeños.
} 
desde lo interpretado, propuesto y presentado en la terminología tainista, a diferencia de la historia, y esas marcadas diferencias que son interpretadas entre tainistas.

Si se utiliza de base al taíno, y este no existió en la historia, ¿qué evidencia lingüística existe para determinar lo que representa un periodo lingüístico pre-taíno de 500 años d.C., donde indiscutiblemente existen según Granberry otros siglos de expansión taínas previas al descubrimiento? En ordenaciones cronológicas las investigaciones teóricas requieren una base científica fiable y sujeta a verificación. Bien notamos en Gerardo Reichel-Dalmatoff su fiel identificación de subdivisiones de tribus poco numerosas. Reichel-Dalmatoff describe científicamente la evolución tribal prestando atención a las denominaciones de grupos pequeños reconociéndose entre sí dentro de su propio grupo principal. En el caso descrito por Granberry, considerando los censos desde 1492, fluctuando entre cientos de miles a millones de habitantes, la teoría de la expansión y alcance taíno resulta dudosa.

Las definiciones de Reichel-Dalmatoff se basan en documentación de expediciones previas que permiten comparar tribus y sus movilizaciones en el conjunto de carácter y condiciones actuantes. Los Yuko-Chaké, dice Reichel-Dalmatoff (1960: 165), reconocen diferencias entre sus propios subgrupos y se identifican entre sí: a los bravos le llaman Yuko, a los mansos le llaman Yukpa o Yapa, para designar su propio subgrupo añaden tok o tayo a su nombre. Entre los muchos ejemplos están los Irok, designándose a sí mismo como los Iroka-tayo, y los Macoa, designándose de Makoshitok. Al examinarse esa dinámica lingüística íntimamente ligada a la geografía, hábitat y las auto denominaciones en el Caribe encontraríamos enormes faltas. Estas estructuras de denominaciones en la antigüedad se basaban en la necesidad de integrarse a sus condiciones y particularidades.

Podemos razonar que la recuperación de artefactos en una excavación, un rio o algo originalmente perdido o abandonado en algún lugar debería describir no solo la localización, estilo y una fecha aproximada de su producción, sino al artesano y a su comunidad. En el caso del Caribe, la norma actual consiste en la estandarización para simplificar la catalogación. Esa falla, identificada por Steward ([1948] 1963), facilita una fácil comercialización de la estandarización terminológica taína, pues simplifica los procesos mientras se aleja del identificar al artesano y a la comunidad a la que este pertenecía. Marvin Harris lo ha expresado bien (1996: 326): 
"Steward (1955, p. 82) ha comentado las consecuencias que tendría el confiar demasiado en la tipología de áreas culturales con respecto a tres problemas concretos: 1) el centro y los límites del área cambian con el paso del tiempo: 2) la cultura dentro del área puede cambiar de tal forma que se asemeje a otras culturas en diferentes áreas y en diferentes momentos; 3) porciones de una misma área pueden contener culturas radicalmente diferentes pese a compartir muchos rasgos. Todos estos problemas están perfectamente ilustrados en el ejemplo de la que Kroeber llama gran área del sudoeste".

Esta cita identifica la tipología de áreas culturales y sus ejemplos son claros en el sudoeste americano, un área continental que sobrevivió los primeros tres siglos del descubrimiento aislados. En el Caribe, los tres problemas concretos de Stewart son los significantes. El paso del tiempo, los cambios de cultura en una misma geografía y la separación de la conformidad típica caribeña y las cultura nativas particularizadas y desarrolladas en geografías específicas que a su vez poseen movilidad y tecnología.

Las razones que conllevan a la generalización terminológica continúan señalándose para diferenciar aplicaciones dudosas de áreas de interés. Por tanto, se prestará atención a mínimos detalles, a las notas de pie y a comentarios añadidos, a datos históricos al igual que a las sustituciones o investigaciones sospechosas al razonar las estandarizaciones. Reichel-Dalmatoff (1960) amplía el concepto de denominaciones al incluir el nombre que un subgrupo aplicado a otro en sus interrelaciones personales. En este sentido, conociendo la diversidad nativa que existió en base a su hábitat buscamos encontrar lo mínimo documentado para identificar opciones a la estandarización. Esa búsqueda se dirige a encontrar la palabra singular que identifica a grupos en sus propias peculiaridades, y de igual manera palabras compuestas que representan interactuaciones entre naciones, tribus y clanes.

Las palabras se encuentran en los lugares menos esperados. Existen momentos históricos que interactúan con lo fundamental de las palabras o denominaciones que buscamos. Veamos al obispo Bartolomé de las Casas en la edición de las palabras escritas por Colón. Ese alejamiento se puede identificar en las anotaciones del obispo o en el hecho de que sus palabras no están lejos del pensamiento original. Esa actividad entre un autor y su editor, especialmente si el editor es amigo del autor y su familia presta cierta fiabilidad, son de gran utilidad. Las Casas o Colón, independiente de sus propias articulaciones, anotaron un nombre o denominación ajustada a un territorio específico. 


\section{LA INVESTIGACIÓN HEURÍSTICA}

La investigación heurística analiza componentes y elementos tanto generales como particulares expandiendo su hermenéutica desde el descubrimiento, identificando de forma científica la evidencia correspondiente presentando resultados fiables de forma clara y definitiva.

La cronología de trabajos comparativos nos dirige a analizar las consecuencias de lo planteado, demostrado en una serie de problemas verificables a determinar, por ejemplo, (1) la fiabilidad de la ciencia terminológica; (2) su vulnerabilidad y defectos; (3) justificación y legitimidad.

Los objetivos, por tanto, consisten en: (1) Presentar y analizar el dilema de la terminología aplicada a los nativos caribeños incluyendo notas de pie y extracciones sospechosas; (2) aclarar usos y aplicaciones folclóricas populares deficientes; (3) encontrar áreas comunes a la rectificación terminológica; (4) señalar desventajas sociales por desconocimiento, intervenciones o indiscreciones por investigadores modernos; (5) y señalar lo factible de la tendencia científica estandarizada y su historia apartada de la historia clásica del nativo caribeño.

Con motivo de expandir el conocimiento de la historia nativa caribeña y su rectificación, dirijámonos a examinar otras articulaciones de investigadores preocupados, según da la impresión, ante el dilema terminológico taíno, que planteamos profundizar en este capítulo. Por ejemplo, evaluemos detalles citados por Daniel Torres Etayo (2008: 13): "La cultura taína no dependerá de la negación o afirmación de su existencia de acuerdo con un criterio de autoridad personal o apropiación institucional, sino a partir de las formulaciones científicas que seamos capaces de poner a prueba, cosa que hasta el momento actual no se ha realizado explícitamente". Torres Etayo está en lo correcto. ¿Qué fuerza se enfrentó a esas objeciones? ¿Y porque razón perdura ese éxito rotundo de la estandarización y su ciencia? Esa preocupación se encuentra en la historia aplicando el concepto de sensibilidad y entendimiento al comportamiento nativo, su hábitat y la naturaleza que les rodeaba.

Las afirmaciones las hemos recogidos en un crecido número de autores hasta el momento [Fewkes (1907), Olsen y Bourne (1906), von Martius (1867), Bachiller y Morales (1883), Alegría (1978), Rouse (1948, 1992)], junto a otros estudiosos discutidos

y las objeciones pasadas por alto de Coll y Tosté (1897, 1907), Sauer (1966), Hulme (1986) y Whitehead (1995, 2002). 
Torres y Granberry son investigadores experimentados que nos demuestran el problema de la terminología aplicada en la arqueología y la lingüística, la cual continuaremos señalando con la idea de aclarar las discordancias que estas aplicaciones producen. Se justifica por esta vía analítica la síntesis en esta tesis, al presentar repuestas al problema señalado por Torres (2008), entre otros que seguirán.

Las objeciones a la terminología taína no han cesado desde Brinton (1871) y ha sido reafirmada por Sauer (1966), Hulme (1986) y Whitehead (1995, 2002). Ampliando la base señalada en el primer capítulo, nos enfocamos en instituciones y figuras notables internacionales al presentar trabajos influyentes de principios del siglo XX que establecieron normas investigativas favoreciendo la terminología.

Jesse Walter Fewkes (1907: XII) entregó al Museo Smithsonian, por vía del Bureau of American Ethnology (BAE), una gran colección de artefactos de piedra, huesos, conchas, madera y barro adquiridos durante sus tres inviernos de investigación en las Antillas, logrando una reconocida hazaña arqueológica. El problema presentado hasta el momento identifica a Fewkes por ser un notable investigador que presentó al taíno en sustitución del antillano como algo natural. Fewkes se convierte en una de las más importantes figuras en la arqueología caribeña desde principios del siglo XX, y pasarían cien años antes que desde Cuba se hiciera la pregunta que formuló Torres (2008), seguido por los señalamientos de Oliver (2009) o Curet (2014, 2015).

Se ha formulado una cronología en una base histórica verificable contestando esas y otras preguntas, examinando la data existente y presentando argumentos y aclaraciones que faciliten un ordenamiento de esa documentación. La base histórica presentada en este caso se ha fundamentado hasta el momento desde Cristóbal Colón, en forma limitada, pero se presentarán argumentos históricos basados en lo recogido y fiable de cronistas e historiadores de diversas épocas. Adicionalmente, debemos recordar y mantener en mente la internacionalidad del tema y las lenguas de los autores para diferenciar argumentos y reconocer las influencias educativas en los años de formación de los investigadores nativos caribeños.

En la introducción a la monografía de Fewkes (1907), originalmente presentada en 1903-1904, leemos del director de BAE, W.H. Holmes la opinión que le merece la colección de artefactos llevada de Puerto Rico y el Caribe: "Sin lugar a duda la más completa hasta ahora reunida para representar lo precolombino de la gente Caribe y Arawak, que fueron prácticamente exterminados por los invasores españoles". Lo primero que advertimos es la referencia del casi genocidio a manos de los invasores 
españoles. Surge nuevamente el concepto de culpabilidad en el momento de catalogar la más completa obra reunida. Si recordamos a Stewart (1963) en su relato de los artefactos, en los museos poco se sabe de sus creadores cuatro décadas después de Fewkes. El problema es que saber o pensar que fueron los españoles invasores quienes infligieron daño sobre los nativos no responde a la pregunta sobre quiénes eran los nativos. Los artefactos y colecciones obtenidas por Fewkes junto a su monografía fueron de suma importancia en su momento histórico para fundamentar el continuo crecimiento de la terminología taína. Lo que sí es actual hoy es la necesidad de repatriar esas colecciones e identificarlas debidamente.

Keegan se refiere a los castellanos como los invasores españoles, al igual que Holmes, con nueve décadas entre ambos. Bien podemos entender que la historia se repite mientras los artefactos están faltos de definición y sin satisfacer necesidades históricas o culturales. Desde esa perspectiva, quiénes eran y el modo de identificar en sus propias adscripciones a esos nativos es lo importante. En este sentido, visualizamos la historia del tainismo enfrentada a la historia del nativo caribeño. Surge de tal manera la historia del tainismo que se refiere a Rafinesque y sus seguidores en su base científica, que busca la acreditación de la estandarización terminológica caribeña.

La monografía de Fewkes (1907), presentada por el director del BAE W.H. Holmes el 29 de enero de 1906, se convierte en una fuente y una autorizada obra de arqueología en la investigación institucional, fundamental en la sistematización de la terminología caribeña aplicada, exhibiendo un alto grado de profesionalismo y difusión de la prehistoria de las Indias occidentales. Esta obra fundamenta el comienzo y comercialización del tainismo, aun cuando otros autores, citados en el primer capítulo, habían preparado la base aprovechada por Fewkes.

Holmes indica que, de acuerdo con el acta del Congreso de EE UU para el estudio de los indios americanos a cargo del Smithonian Institution, se había llevado a cabo la operación según planificado, o sea, la formación de la colección y la exitosa monografía de Fewkes. La segunda parte de esta tesis entra en detalles y análisis de las consecuencias en el largo plazo, no planificadas en su momento, las llamadas desventajas sociales.

Utiliza Fewkes (1907:19) tres métodos investigativos en la elaboración de su monografía: el histórico, el etnológico y el arqueológico, reconociendo que el material histórico del nativo de Puerto Rico era limitado y resultaba, por tanto, legítimo utilizar material investigativo de las islas adyacentes del cual había más información, por ser razas relacionadas. Fewkes cita a los autores de los que ampliamente recoge escritos: Las 
Casas, Ramon Pané, Benzoni, Oviedo y Peter Martyr. Naturalmente si la interpretación de Fewkes se derivara de estos escritores, se reflejarían en su monografía. Sin embargo, la inconsistencia radica en el uso del término taíno, que procede de Rafinesque (1836), Olsen \& Bourne (1906), von Martius (1867) y otros que discutimos anteriormente. En las notas a pie, cita también a Fray Iñigo Abbad y Lasierra (1866) (Fewkes, 1907: 20). Si examinamos la referencia de Fray Iñigo, cuya primera edición se publicó en 1830 en Puerto Rico, aun cuando la obra fue escrita en 1780, notamos lo siguiente: Abbad y Lasierra (1866: 62), en referencia a los indios que recibieron ayuda de los caribes, dice:

"Supo el gobernador por sus espías que los indios, desconfiados por sus fuerzas para vencerles, habían buscado ayuda de los Caribes, y estos iban llegando y juntándose con los gandules de la isla en la parte de Aymaco, en donde habia ya un cuerpo de más de once mil indios. y (continúa redactando Fray Iñigo (1866:65): (...) después de la derrota que los indígenas de Borinquen sufrieron en el Coayuco, acordaron llamar en su socorro a los caribes".

Abbad y Lasierra hace referencia a Herrera y Oviedo, y continúa citando: “Así consta que los Borincanos reclamaron y obtuvieron el auxilio y cooperación de los Caribes desde el momento que pusieron por obra su alzamiento". Esta discusión se profundizará citando a Diego Colón posteriormente. No obstante, queda claro que aun cuando limitada esta cita, establece que los indios de Puerto Rico eran los Borincanos, según lo señalado y compartido por dos cronistas, Oviedo y Herrera, y un autor clásico, fray Iñigo Abbad y Lasierra.

Si Fewkes hubiese reconocido lo escrito por fray Abbad y Lasierra entendería que llamar taínos a los borincanos era un gran error. Más trace, Fewkes (1922: 54) sostiene que la raza prehistórica que vivía en las Antillas Menores no eran caribes pero estaban relacionados con estos: "Esa cultura aquí la llamamos -Ierian- como a esa de Porto Rico se conoce como taína (Tainan)". ${ }^{52}$ Entre 1907 y 1922 existe solo un cambio, el geográfico en relación al tainismo. Rouse (1948: 521) mencionará que Fewkes había utilizado el término taíno en referencia a las Antillas en 1907 y en 1922 se retracta, para limitarlo solo a las Antillas Mayores. Rouse estaba en lo correcto. Lo significante es la facilidad con la cual difusores científicos ajustaban denominaciones a nativos en extensas áreas geográficas según sus necesidades.

${ }^{52}$ Fewkes, J.W., 1922. A prehistoric island culture area of America (No. 1). US Government Printing Office. 
A continuación, presentaremos otros autores clásicos que narraron sobre los borincanos. En adición se encuentran otras muestras de otras denominaciones. Señalamos que por diminuta sea la cita de gandules, refiriéndose a nativos de Aymaco, indicamos que gandules es una peculiaridad nativa puertorriqueña y consta como una referencia escrita en Puerto Rico. Buscando otras posibles explicaciones de uso, encontramos que gandules además de ser una especie de frijol, parece provenir de Marruecos y aparenta haber significado soldado o militar. Oviedo (1851: 67, L iii, cap v) comienza narrando de un lago en las altas sierras localizadas, a unas quince o dieciséis leguas de Santo Domingo, a la que viajaron Pedro de Lumbreras y subió a este lago: “(...) é con el otro hidalgo, llamado Mexia, é con ellos hasta seys indios gandules e bien dispuestos; pero cuando fueron cerca de la altura quedaron el Mexia e los indios, assi como comenzaron á oyr el ruido que en lo alto sonaba”. En su cita, Oviedo se refiere a un hecho de La Española y se detiene, pues dice que existen muchas novedades en cuanto al lago. No obstante, hace otros comentarios en la misma página que son de interés y citamos:

"Vengamos á los caribes flecheros. Estos viven en las islas comarcadas, y la principal desta gente fué la isla de Boriquen, que ogara se llama Sanct Juan, é las otras cercanas della, assi como Guadalupe, la Dominica, Martino y Cubuqueyra, que agora se dice Sancta Cruz, é las de aquel paraje.

Oviedo ha encontrado a los gandules y ubica a Puerto Rico como la isla principal de los flecheros caribes, ambas cosas son de suma importancia. Sin embargo, Oviedo no termina de asombrarnos en este capítulo; en la siguiente página citamos:

“(...) é lo banco de los ojos algo turbio. Esta manera de frente se hace artificialmente; porque al tiempo que nacen los niños, les aprietan las cabezas de tal manera en la frente y el colodrillo, que como son las criaturas tiernas, las hacen quedar de aquel talle, anchas las cabezas delante é detras, é quedan de mala gracia".

Oviedo nos acerca a tres puntos que analizamos: las denominaciones, la ubicación geográfica de tribus nativas y unas costumbres típicas y a su vez una práctica común las islas, centro y Sudamérica como lo es la deformación craneal.

Entre las citas de Oviedo volvemos al tema de los nombres geográficos, como boriquen o borinquen, y su relación a los borincanos, los denominados nativos de Puerto Rico a la llegada de fray Iñigo a Puerto Rico en 1775. Entre Oviedo y fray Iñigo el asunto de los caribes en su hermandad caribeña borincana ante un imponente enemigo asume mayor importancia. Fray Iñigo no recurre a la denominación indios y opta por otras 
opciones. Primero, la de una historia oral específica; segundo, en su interrelación de teólogo e historiador en su poblado aprende de la comunidad; y tercero, favorecido con su experiencia de investigador teniendo acceso a los archivos eclesiásticos de esa época en Puerto Rico, identifica y publica sus resultados. Cinco décadas antes de Rafinesque, Abbad y Lasierra identificó los nativos de Puerto Rico en el siglo XVIII. Esa identificación representa una desviación por difusores, repetidores y seguidores de Rafinesque, pues Rafinesque solo pretendió dar nombre a nativos y al lenguaje en Haití. Por otro lado, fray Iñigo, como historiador clásico, cita a cronistas clásicos, y en ese enfoque investigativo incorpora data de su era histórica, acogiéndose a un argumento étnico de ciudadanos, aplicando su interpretación y criterio exclusivamente a su propia obra, basándose en su propia investigación. En esta línea investigativa vinculamos los datos de fray Iñigo Abbad y Lasierra a los de Alejandro Tapia y Rivera, organizando un conocimiento nativo genuino del que se puede extraer de entre la formación de estos importantes autores que en su momento compartieron experiencias tanto en Puerto Rico como en España. En teoría, fray Iñigo y Tapia y Rivera desconocían el argumento de la estandarización taína.

Alejandro Tapia y Rivera nace y muere en Puerto Rico (12 de noviembre de 1826 -19 de junio de 1882). Era poeta y dramaturgo y durante sus años en el destierro (11 de septiembre de 1849 hasta el 1862) vivió en España, donde se desempeña en la investigación de archivos y documentos históricos relacionados a Puerto Rico. Escribió siete obras antes de regresar a la isla. Entre ellas La palma del cacique, citada a continuación, ${ }^{53}$ y otras diecinueve obras en Puerto Rico. Ahora recurrimos al puertorriqueño Tapia y Rivera cuando la cultura se fundamenta en manos del arte (1852: 2, cap. IX):

\begin{abstract}
"El cacique Mayagoex estaba ausente, y su defecto Guarionex, reunió la escolta que había traído de sus estados, y que se componía de más de cien gandules, escogidos entre los más valientes y robustos de sus vasallos, -Arengoles, manifestándoles el peligro en que se hallaba, pesto que los voraces enemigos de Borinquen, violando los pactos rompían las hostilidades, para lanzarse sobre el país y destruirlo. - Es necesario, añadió, que los vasallos de Guarionex, prueben que las flechas enemigas no les arredran, y que ellos solos, bastan para vencer a sus contrarios cualquiera que sea su número".
\end{abstract}

Tapia y Rivera documenta la escolta de más de cien gandules, y gandules se refiere a los guerreros de Guarionex, los que prestarían batalla en contra de los enemigos

${ }^{53}$ Tapia y Rivera, A. 1852. La Palma del Cacique. S. Martínez Ael, Madrid. 
de Borinquen. Los enemigos eran los caribes y los gandules, eran los vasallos nativos de Guarionex. Estos gandules eran escogidos de entre los más valientes, una información indicativa de una conformación intima de un grupo, o bien integrado a una tribu o un clan. Tapia y Rivera usa esa referencia aplicada o un grupo específico una sola vez. Gandules en referencia a guerreros en Puerto Rico igualmente refleja una autodenominación documentada por fray Iñigo Abbad y Lasierra desde su primera publicación en España en (1788), obra que fray Iñigo había completado para la imprenta en 1782. Fray Iñigo Abbad y Lasierra y Alejandro Tapia y Rivera coinciden en que los gandules eran guerreros, estos dos hombres nunca se conocieron; antes de nacer Tapia y Rivera, fray Iñigo había muerto en España. Pedro Tomas de Cardona (1831: 32) “acude Salazar a enfrentar 300 gandules o indios guerreros". Tomas de Cardona entra en la conversación de fray Iñigo y Tapia y Rivera en una fecha significante desde Puerto Rico y aporta verificación de uso y significado. En las páginas escritas por fray Iñigo la palabra gandules se utiliza solo una vez, al igual que Tapia y Rivera. Lo más notable de ese uso es que Guarionex se refiere a sus vasallos como gandules y gandú, gandul o guandú puede derivarse de la lengua nativa del cacicazgo de Mayogoex en borinquen. Definimos un uso singular por cada autor Abbad y Lasierra y Tapia y Rivera. Curiosamente, el Dr. Diego Álvarez Chanca usó la palabra tayno (no taíno o taino) una solo vez, al igual que Pedro Mártir de Anglería, (tayno). Se ha señalado la búsqueda de la palabra singular significante. En ese sentido la estandarización surge de una palabra en la cual se basa la investigación científica del taíno. Notamos la importancia de la periodización, pues fray Iñigo y Tomas Carona son anteriores al 1836 .

En el diccionario de la Real Academia, guandú, significa: 1. adj. coloq. Tunante, holgazán. U. t. c. s. - 2. m. Individuo de cierta milicia antigua de los moros de África y Granada. - 3. m. Individuo de ciertos pueblos de indios salvajes. - Usos en (1. Col., C. Rica, Cuba, Hond., Nic. y P. Rico. guandú. - 2. m. Cuba y P. Rico. Semilla del gandul). En relación con el uso isleño buscamos en Pichardo (1836) ${ }^{54}$ gandú, guandú y gandules, y para nuestra sorpresa no se identificaban en su diccionario ninguna de estas palabras. La tercera definición de la Real Academia es muy específica: Individuo de ciertos pueblos de indios salvajes; es una definición adecuada y consistente para identificar al nativo guerrero borincano. Ese tema se discutirá más a fondo en el tercer capítulo en la sección

\footnotetext{
${ }^{54}$ Pichardo, E., 1836. Diccionario provincial de voces cubanas Imprenta de la Real Marina., Cuba.
} 
correspondiente a Hernán Colón y la relación que mantiene a fray Iñigo Abadd y Lasierra, a Alejandro Tapia y Rivera y a Tomas de Cardona.

Lo significativo hasta el momento de las descripciones de Abbad y Tapia es la simpleza y naturaleza de la aplicación y su uso limitado alejado de una terminología predominante. Tapia adentra en el pensamiento que los vasallos gandules de Guarionex, “(...) y que ellos solos, bastan para vencer a sus contrarios cualquiera que sea su número". Recordamos que Tapia se refiere a los feroces caribes con los que habían previamente hecho acuerdos. La separación de la historia del nativo caribeño se independiza en esta tesis de la historia de la estandarización humana y geográfica caribeña desde Rafinesque y sus seguidores. En este sentido, se busca presentar opciones al nativo caribeño acogidas al pensamiento local e identificándose en una base orgánica anterior a la culminación de a primera fase de incubación de Rafinesque. Una base acoplada a lo representativo de Reichel-Dolmatoff, encontrando resultados científicos en pequeñas muestras representativas de tribus heterogéneas pequeñas, migrantes o permanentes cuyos nombres se ajustaban a la naturaleza. Pedro Tomas de Cardona (1831: 39) escribe lo siguiente: “(...) caribes juntándose con los gandules de la isla”. Entendemos que fray Iñigo [1788] y Tomas de Cardona (1831) fueron dos autores publicados en Puerto Rico en 1830 y 1831 que coinciden en una denominación puertorriqueña desconocida hoy día. Tapia y Rivera (1852) y Oviedo ([1555] 1851) igualmente usan la denominación gandules. La periodización y el uso limitadísimo de esa denominación implica su uso en dos islas. Si bien se recogió de Oviedo la razón para aplicarse en Puerto Rico desde 1788. Tomas de Cardona (1831) es muy específico al decir caribes juntándose con gandules. Fray Iñigo [1788] Tomas de Cardona (1831) y Oviedo [1555] son anteriores a Rafinesque (1836) y en sus búsquedas de la palabra singular no encontraron taíno alguno, si coincidieron con gandules. Solo nos queda pensar que desde los Estados Unidos el trabajo de Rafinesque logró mayor difusión en América y Europa por un origen del escrito, en inglés, difundido también en francés y alemán. La palabra singular comercializada en inglés en una época de crecimiento económico y científico encontró amplía difusión y repetidores comunicándose en inglés. El crecimiento de esa población de difusores nórdicos, junto a repetidores caribeños de la segunda mitad del siglo $\mathrm{XX}$, comercializaron efectivamente una ficción cultural. 
Tabla 1.

Las tres fases del desarrollo de la estandarización terminológica taína de C. S. Rafinesque

\begin{tabular}{|c|c|c|}
\hline $\begin{array}{l}\text { Fechas de incubación 1836- } \\
1899\end{array}$ & Segunda fase $1900-1955$ & Tercera fase 1956- hoy \\
\hline Autores difusores e Instituciones & Difusores e Instituciones & Difusores e Instituciones \\
\hline $\begin{array}{l}\text { Société de Géographie France } \\
\text { C. S. Rafinesque-Schmaltz } \\
\text { Jeogor von Sievers } \\
\text { Frederick von Martius } \\
\text { Oscar Peschel } \\
\text { Antonio Bachiller y Morales }\end{array}$ & $\begin{array}{l}\text { Smithsonian Institution } \\
\text { Bureau of American } \\
\text { Ethnology } \\
\text { Yale University } \\
\text { Harvard University } \\
\text { Julius R Olsen } \\
\text { Edward Gaylor Bourne } \\
\text { Jesse Walter Fewkes } \\
\text { Mark R Harrington } \\
\text { Douglas Taylor } \\
\text { Irving Rouse } \\
\text { HM Holmes } \\
\text { John Willey } \\
\text { Sven Loven } \\
\text { Froelich Rainey }\end{array}$ & $\begin{array}{l}\text { American Journeys } \\
\text { Collection (AJC) } \\
\text { Wisconsin Historical } \\
\text { Society (WHS) } \\
\text { Instituto de Cultura de PR } \\
\text { Archivo General de RD } \\
\text { Irving Rouse } \\
\text { Ricardo Alegría } \\
\text { José Juan Arrom } \\
\text { Roberto Cassá } \\
\text { Marcel Veloz Maggiolo } \\
\text { Ernesto Tabio } \\
\text { Estrella Rey } \\
\text { William Keegan }\end{array}$ \\
\hline Opositores & Difusores & Opositores \\
\hline Daniel Garrison Brinton & $\begin{array}{l}\text { Adolfo de Hostos } \\
\text { Fernando Ortiz } \\
\text { Cornelius Osgood } \\
\text { Juan A Cosculluelas }\end{array}$ & $\begin{array}{l}\text { Neil Whitehead } \\
\text { Peter Hulme } \\
\text { C O Sauer } \\
\text { E. Tejera Penson } \\
\text { E. Tejera Bonetti }\end{array}$ \\
\hline
\end{tabular}




\begin{tabular}{|l|l|l|}
\hline Otros principales & Principales y opositores* & Otros Principales \\
\hline Richard Henry Major & Cayetano Coll y Tosté* & \\
Manuel Ubeda y Delgado & Alfredo Zayas y Alfonso* & \\
Pedro Tomas de Cardona & Félix M Pérez Sánchez* & \\
Fray Iñigo Abbad y LaSierra & Pablo Morales Otero* & \\
Alejandro Tapia y Rivera & Julian Stewart & \\
José Julián de Acosta y Calbo & J Alden Mason & \\
Esteban Pichardo & Franz Boas & \\
Manuel A Alonso & Herbert W Krieger & \\
Agustín Stahl & & \\
Joaquín Pérez & & \\
\end{tabular}

Nota: Los autores e instituciones listados representan un mínimo número de los examinados. Los numerosos autores repetidores que comercializaron sus teorías sospechosas vinculadas a la estandarización terminológica taína no forman parte de estas listas. Los numerosos repetidores que publicaron a partir de la segunda fase en la tercera fase del tainismo niegan sus propios aportes.

\section{SOBRE LA NATURALEZA}

C. Geertz (1987), citando un estudio de Talcott Parsons y otros, señala: "En la naturaleza de los sistemas sociales, en la naturaleza biológica y psicológica de los individuos que los componen, en las situaciones externas en las que éstos viven y obran, en la necesidad de coordinación de los sistemas sociales. En [la cultura] (...) estos focos de la estructura nunca se ignoran. De alguna manera deben 'adaptarse' o 'tenerse en cuenta'".

En ese sentido, buscamos un proceso fiable que abarque el pensamiento y naturaleza nativa en su relación a los términos que son incorporados a las zonas geográficas estudiadas. En el pasado se buscó simpleza en le estandarización terminológica; en el futuro el conocimiento se basará en resultados de estudios perfeccionados analizando lo mínimo de su contenido cultural. En este sentido podemos pensar que los arqueólogos excavan y extraen artefactos que se ubicaran en museos y luego rellenan esas excavaciones con la tierra que excavaron. Este estudio presta atención 
a quien depositó o descartó lo excavado o lo encontrado por arqueólogos desde la perspectiva de la tierra, o sea, esa misma tierra encontrada tras esos naturales que vivieron sobre esos suelos. El remover artefactos sin reconocer al artesano, su cultura, y su afinidad ancestral es adquirir un objeto ciego a la historia. El clasificar artefactos a nivel de etiquetas culturales y fabricaciones terminológicas es una inconsistencia histórica en las islas que estudiamos.

Recapitulemos y comparemos los pasos seguidos hasta el momento en esta sección, donde el autor y el poeta se encuentran. Los fuertes relatos antropológicos, junto a interpretaciones históricas y valores, se unen sistemáticamente y enfocan tanto el problema de una práctica común de la terminología y el fenómeno taíno y la historia contenida en una fiabilidad requerida en el momento actual. En fray Iñigo (1866), Tapia y Rivera (1852), Pedro Tomas de Cardona (1831) y Reichel-Dalmatoff (1960) encontramos cuatro estudiosos que concuerdan en la naturaleza nativa. En este sentido, Vaioleti (2006), Smith (2013); Viveiros (1996) y Levy-Strauss (1970) se unen a estos autores en lo que representa sensibilidad, conocimiento y estudio de la mente primitiva. Queda señalar que Reichel-Dalmatoff ha dejado claro que el nombre primitivo no es aplicable, pues a las personas a quienes se le impone habían creado grandes civilizaciones.

Resulta claro que enfocarnos en todos los elementos discontinuos resultaría en una tarea inacabable, pues las intersecciones de investigadores y estudiosos ante el folclor popular resultan de igual forma intensas y laboriosa. Examinemos el proceso mediante el cual la terminología entra de lleno en la cultura popular, primero señalando que los gandules de fray Iñigo, Tapia y Rivera y Tomas de Cardona son justificables y legítimos representantes de guerreros boricuas, o puertorriqueños verificables, y que el taíno no puede representar a esa persona cultural, meramente por ser una marca comercial fabricada. No existe ningún documento histórico en el Caribe que identifique a tribus, nación o lengua taína antes de Rafinesque. Examinemos algunas circunstancias que pudieron influenciar al éxito del tainismo. Gordon E. Lewis (1963: 14) cita al gobernador Arthur Yager, testificando "Cuando declaró ante el comité de Asuntos Insulares de la Cámara de Representantes en 1916, indicando que los puertorriqueños eran un pueblo 'tropical' carente de 'fibra' e 'iniciativa' para adaptarse a las condiciones de la vida americana”. Arthur Yager fue gobernador de Puerto Rico entre 1913 y 1921, y basa sus referencias en sus experiencias propias, adquiridas mientras vivió y trabajó en la isla. Frankie-Rivera (2013: 7) añade: “El Departamento de Guerra de EE. UU. consideró que 
la estabilidad en la isla era esencial para asegurar la hegemonía de EE. UU. en el CircunCaribe. Poderosos grupos de presión en la metrópoli argumentaron que la ciudadanía apagaría disturbios en la isla y llevaría a la estabilidad sociopolítica”.

El 2 de marzo de 1917 el presidente Woodrow Wilson firma el Acta Jones dando la ciudadanía a Puerto Rico. Unos 18.000 soldados puertorriqueños fueron enlistados durante la Primera Guerra Mundial, incluyendo entre muchos el reconocido Rafael Hernández. En el marco teorético de las primeras dos décadas del siglo XX implica nuevas reglas y ordenaciones académicas ligadas al futuro caribeño, en el que Puerto Rico asume un rol principal, y estas se basaban en realidades políticas alejadas de las narraciones de fray Iñigo, Tomas de Cardona y Tapia y Rivera.

Las citas de Lewis y Frankie-Rivera contienen un material prejuiciado al que no podemos prestar gran atención, pues es un tema que se aparta del tema y objetivos de esta tesis, no obstante, queda establecida una razón discriminante experimentada en el Caribe por siglos. Gordon E. Lewis (1969: 12), con relación a los puertorriqueños, comenta: "Se les imputa que nunca llegarán a americanizarse completamente debido a su diferente fondo cultural, a su lengua, sus tendencias a congregarse en distritos restringidos (ghettos)". El exgobernador de Puerto Rico Arthur Yager y el historiador Gordon E Lewis describen tiempos pasados y los perjuicios de épocas distantes en el criterio norteamericano. Sin embargo, comentan de los puertorriqueños que por sus hábitos tropicales son diferentes y considerados inferiores. El argumento principal de Lewis está basado en una perspectiva desde el 1898, al examinar y comparar esa segunda mitad del siglo XX a la primera y al colonialismo pre-1898 entendemos que son dos temas completamente aislados. La política norteamericana y la española son polos aparte, por tanto, la imagen grabada del puertorriqueño desde la primera década del siglo XX, considerando los prejuicios de los norteamericanos en relación con el Caribe, Puerto Rico y sus posesiones, no era muy halagador.

Según lo citado en Lewis y Geertz, resulta prudente examinar el material investigativo de la primera y segunda mitad del siglo XX por separado, evaluando extractos generales y las consecuencias de esos prejuicios en relación con la terminología. Lewis era director en el BAE de la Oficina de asuntos de indios sudamericanos.

Peschel (1876: 206) mostró su simpatía por los caribes, a quien no se les debía culpar por sus actos de violencia que incluían los antropófagos. Peschel actúa en comprensión de los caribes inmersos en una vida primitiva y natural. Mientras que Lewis 
nos hace recordar que los museos y las instituciones poseedores de artefactos hermosos desconocen los artesanos que exponen.

El proceso que incorpora extracciones e interpretaciones académicas al lenguaje y folclor popular representan más que un limitado uso, y no se confinan en un estudio o un periodo limitado. En este sentido, continuamente recordamos que el contenido mínimo de un término estandarizado representa en nuestra tesis unas teorías y un uso no se puede contener en una utilización simple o básica, sino que consiste en su eliminación total. Debemos señalar que el gobernador Yager, Holmes, Fewkes y los presentes en las vistas del War Department eran todos empleados o financiados por fondos del Estado, esto indicaría la existencia de normas y procesos a seguir. En el gran marco de la cultura norteamericana se menciona que pasada la Guerra civil norteamericana el concepto de "ni una gota" en su desprecio a razas consideraría el mestizaje y lo multirracial de gentes inferiores.

\section{NOTAS DE PIE Y LA EVOLUCIÓN DEL TÉRMINO TAÍNO.}

José Juan Arrom (1999: XI, XII) cita en sus notas a pie como difusores a Ricardo E. Alegría (1981) y Irving Rouse (1992) en relación con la evolución del término taíno. Esa evolución requiere un abarcador análisis deductivo, organizado en una cronología, estableciendo los puntos clave de partida. Estos dos hombres son de suma importancia en la difusión del taíno en el Caribe, y la articulación de ambos en sus periodos históricos influenciaron a muchos estudiantes desde la segunda mitad del siglo XX. 
Tabla 2.

Cronistas y Autores Clásicos

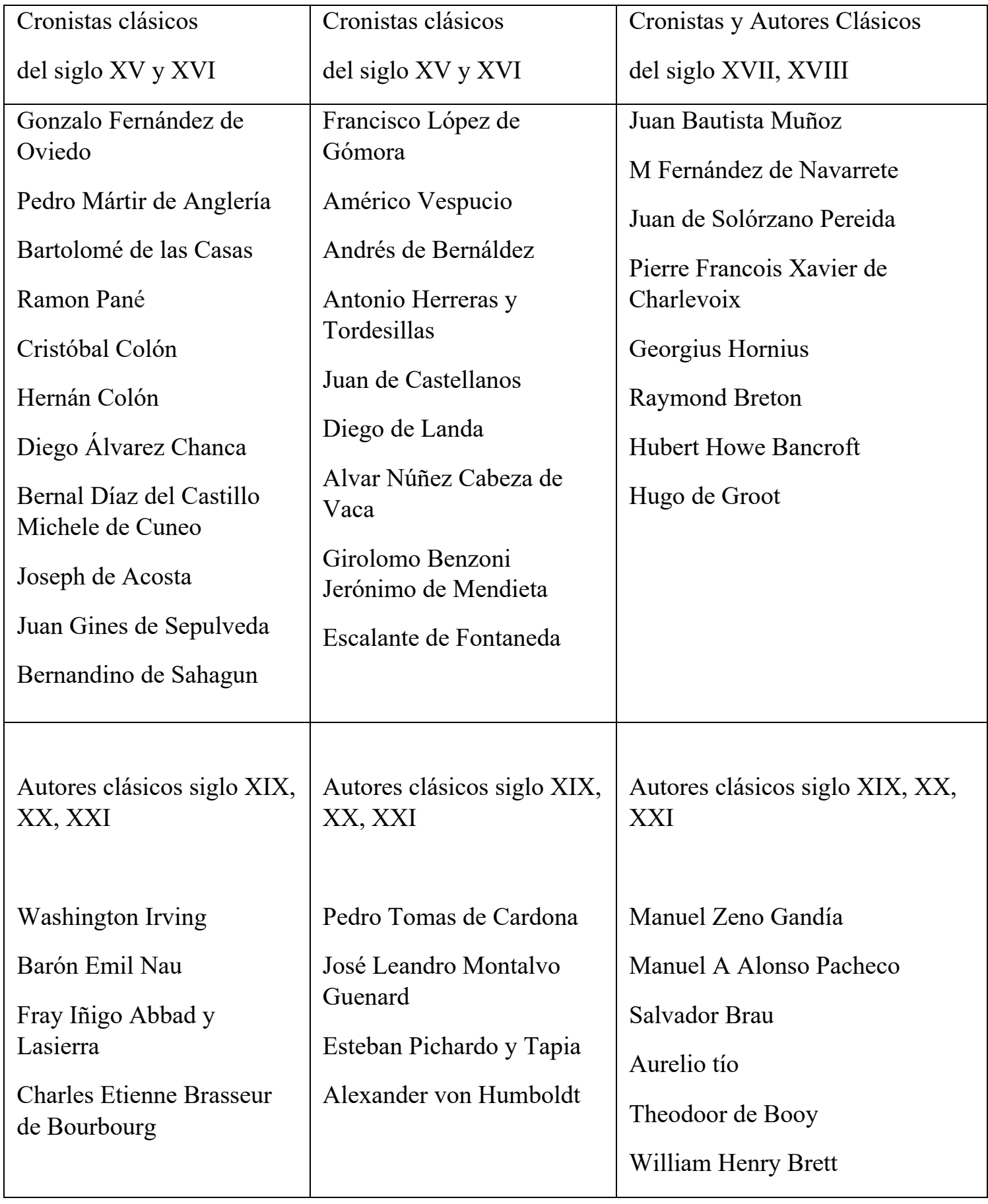

Nota: Los estudiosos en estas listas documentaron denominaciones, lenguajes y ubicaciones geográficas de origen. Los estudios y referencias de estos autores simplifican la periodización y las ideologías de sus épocas. Muchas de estas teorías facilitaron interpretaciones audaces desde el siglo XX que facilitaron la difusión de la estandarización terminológica taína.

Al momento se han señalado elementos que identifican tanto el problema terminológico como el uso de notas de pie y editoriales alejados de la historia, y un sinnúmero de trabajos y citas carentes de sensibilidad afiliados a la estandarización. 
En el primer capítulo se presentaron textos de José Juan Arrom en los que el investigador proponía en su terminología taína diálogos de autores representativos de raza, tribu y colectivos geográficos usados por Cristóbal Colón, Alfredo Zayas y Alfonso o Felipe Pichardo Moya. Esas interpretaciones son exclusivas de Arrom o de Alegría y Rouse. Este problema de implicar autores clásicos durante la segunda parte del siglo XX facilitó a jóvenes investigadores un modelo científico.

Se presenta una evolución cronológica dividida en fases que se acoplan a las fases de evolución de las terminologías taínas desde Rafinesque, por tanto, la fase histórica desde el descubrimiento 1492 hasta el día de hoy. Y lo representativo histórico del taíno desde 1836, desde la primera fase de incubación de [1836 hasta el 1900], la segunda fase; desde el [1901 hasta el 1955], y la tercera fase final; desde [1956 hasta el presente]. La tabla \#1 inicia la identificación de los promotores principales en las diferentes etapas. Algunos autores promotores principales interactuaron en más de una fase, por ejemplo, Irving Rouse, Ricardo Alegría y William Keegan, y algunos repetidores que influenciaron y continúan menudeando esa terminología en la actualidad.

Enfocados en Geertz, Taylor, Parsons, Kluckholn y Benedict, y comparando esa perspectiva al trabajo de Lewis, resulta posible razonar que los sistemas sociales de la época en Norteamérica desde 1898 considerarían las diferencias caribeñas lagunas obscuras por desconocimiento. La expansión terminológica taína abre camino en el ciclo hipotético de la cultura caribeña para catalogar espacios, tiempos y artefactos nativos, y aun con la mejor de las intenciones la pretensión es injustificable. Nos alejamos del tema de sensibilidad si visualizamos igualdad en un proceso científico que establece la estandarización nativa caribeña.

Ruth Benedict ofrece una idea de interés para descifrar el asunto que estudiamos: "Mi convicción es simplemente que hoy las tradiciones científicas y humanistas no son opuestas ni mutuamente excluyentes. Son complementarias, y la antropología moderna pone en tela de juicio el método y la percepción, al descuidar el trabajo de los grandes humanistas" (1948: 587). En el transcurso de la evolución de la terminología taína se ha olvidado o desestimado la ciencia a la cual Benedict se refiere. Lo importante es atender el significado de la persona cultural y la comunidad. No se trata de crear a tientas, en la oscuridad, como Rafinesque; se trata de presentar adscripciones usadas por los naturales que se pueden verificar por más de una fuente a nombres históricos adjudicados en áreas geográficas específicas. 
El alejamiento de nombres históricos se produce por Olsen \& Bourne (1906), Fewkes (1907), Harrington (1921), Loven (1935), y otros que se apartaron en esas primeras décadas del siglo XX de particularidades culturales históricas y prefirieron una universalidad caribeña identificando esos espacios, tiempos y artefactos, prestando máximo interés a la clasificación de la cultura material, minimizando en un término la propia diversidad de gente caribeña.

Examinemos un asunto numérico geográfico para identificar posibilidades tribales caribeñas. La superficie geográfica compuesta por Cuba, Haití, República Dominicana y Puerto Rico y sus islas es de aproximadamente 1.213.00 kilómetros o 754.00 millas cuadradas, donde, según investigadores contemporáneos, vivieron los taínos, quienes recibieron a Colón, junto a residuos de guanahatabeys. A estas extensiones de terreno, de incluirse las Bahamas y Jamaica, que en general son incluidos en el mapa taíno, las dimensiones aumentarían significantemente haciendo el problema aún mayor. Hoy día, en la Guyana Francesa, con la mitad de la superficie, viven reconocidas al menos nueve tribus. Resulta, por tanto, inconsistente razonar que tres grandes islas separadas las unas de las otras geográficamente fuesen en el pasado habitadas por menos tribus particularizadas que un territorio continuo.

\section{PATRONES CULTURALES Y PERIODIZACIÓN. FILOSOFÍA Y VIDA HUMANA.}

El nativo insular caribeño vivía patrones geomorfológicos en su propia naturaleza, dentro de una ecología geográfica ampliada por la navegación y su conocimiento especifico, en una evolución primitiva conectada intensamente al suelo, agua y al ambiente orgánico. Fundaban en esos espacios geográficos independientes sus identidades tribales particularizadas, que eran conocidas e identificadas entre ellos y sus vecinos. Estos patrones tribales y sus características culturales fueron identificados por cronistas originarios como Bartolomé de Las Casas, Ramón Pané y Hernán Colón, que anotaban nombres de colectividades nativas, sus distintivos, peculiaridades y rituales primitivos, que por descuido, intervenciones y agendas privadas acabaron siendo olvidados.

Uno de los objetivos de este estudio es rescatar los nombres reemplazados, identificando réplicas, descuidos, aportaciones y/o intervenciones de autores, 
contrastando lo que en sus respectivos momentos históricos se aportó al conocimiento y que ahora resulta incongruente.

La periodización resulta fundamental para remover obstáculos a través del tiempo. La periodización de los naturales, en sus propias culturas y desarrollo, es diferente a la periodización contemporánea. Nuevamente nos cruzamos con la sensibilidad o falta de ella en este tema. Se atiende la periodización, identificación y organización de los intereses e historia de los exploradores y se limita lo conocido de los naturales durante las primeras décadas. Se deduce que en su momento el conocimiento, intención y razón original de los autores clásicos incitaría a debates y apotegmas, generando nuevos órdenes hipotéticos. La idea de invasores españoles representa uno de estos conceptos. En este sentido, existe una verdad en lo positivo y una verdad en lo negativo, puede decirse que existe una especie de contrariedad.

Cuando reagrupamos y organizamos esas fuentes originales junto a las aportaciones contemporáneas ordenadas y argumentadas se armoniza una objetividad de distintivos y las peculiaridades tribales aparecen alineadas a una posible rectificación histórica de la terminología contemporánea del natural caribeño. La historia nos narra lo que en su momento existió (o se conoció) y las consecuencias hermenéuticas del ayer, mostrándonos cenizas, remanentes y huellas que hoy rastreamos, revelándose una naturaleza innegable de una prehistoria particular caribeña y la raíz natural de la supervivencia nativa. Jerry H Bentley (1996: 749) nos recuerda que "Los historiadores se han dado cuenta durante mucho tiempo de que los esquemas de periodización basados en las experiencias de Occidente o de cualquier otra civilización particular hacen un mal trabajo al explicar las trayectorias de otras sociedades".

Si consideramos que la periodización de los asuntos de los naturales del Caribe e desde 1492 carece de un orden eficiente a la hora de registrar eventos, y que la importancia concedida a los hechos era unilateral, empezamos a descifrar el porqué de muchos problemas. Siguiendo a L. E. Grinin (2007: 150):

"Sin duda, la periodización es un método muy efectivo para analizar y ordenar material. Sin embargo, se trata de fenómenos excepcionalmente complejos de tipos de proceso, desarrollo y de tiempo, e inevitablemente áspera y simplifica la realidad histórica. Por lo tanto, cualquier periodización es unilateral y difiere de la realidad. Sin embargo, estas simplificaciones pueden servir como flechas que apuntan a cosas importantes".

Al evaluar la naturaleza del ayer, identificando esas huellas del hoy, sin remover el más ínfimo legado, se lograría una rectificación moral y social, justificada al restaurarse 
nombres tribales junto a la existencia biológica de sus descendientes. De esta forma presentamos la trágica evolución del término taino como injustificable históricamente, dando comienzo a una reordenación de términos tribales originales. En este sentido, fray Iñigo y el poeta Tapia y Rivera nos recuerdan que lo mínimo representa un brote y un futuro. Un brote sobre las huellas del pasado significa un ancestro viable, un símbolo fabricado sobre esas mismas huellas significa obstrucción.

En la época contemporánea se exteriorizan en las tierras caribeñas las estampadas huellas de una sangrienta historia, naciendo un nuevo mundo enredado y prejuiciado entre sus raíces, y luego junto a exploradores y conquistadores.

Los naturales se encuentran unidos a hombres de acción motivados por lo desconocido en busca de fortunas. Se origina lo llamado por fray Antonio de Montesinos crueldades e injusticias. En unos años, Bartolomé de Las Casas asumiría la defensa y protección de los indios. En solo dos décadas, la integración de esclavos y la extracción de riquezas cambiarían el mundo. En adelante examinaremos como esas acciones de los exploradores obligan a nuevas políticas nativas, que en su mayoría son recogidas en guerras y revueltas. Citamos de nuevo a Ruth Benedict (1948: 588-589):

"La historia, como arte humanitario, dejó al lado los análisis económicos y políticos vitales, pero trató de mostrar los hechos y objetivos de los hombres en un período determinado y cuáles fueron las consecuencias de estos; puede representar los hechos de los hombres como caprichos o destructivos, pero los vincula con consecuencias; Responsabiliza al hombre de sus éxitos y sus fracasos".

Los patrones culturales de los naturales durante los primeros contactos fueron fracturados ante la política de los exploradores.

La historiadora española Mercedes Gaibrois de Ballesteros escribió: "Seguramente antes de 1875, año en el que se celebró el primer congreso internacional de americanistas, la palabra precolombino no toma carta de naturaleza para designar a un grupo importante de culturas y de siglos de la vida humana de un continente" (1978: 6). En ese año quedan así conocidos los americanistas y lo precolombino, según Ballesteros, dos nombres genéricos y válidos.

En la discusión de la filosofía y vida natural buscamos palabras clave. Andrés Bello (1848: 1), citando a Jean-Jacques Rousseau, afirmó: "No hay peor guía en la historia que aquella filosofía sistémica que no ve las cosas como son, sino como concuerdan con su sistema". 
Las narraciones de cronistas y autores pueden validarse, pero no sin riesgo, por otros autores en sus respectivas épocas. Numerosos relatos han sido considerados representativos de la estandarización que estudiamos. En los próximos párrafos examinaremos variables que se apartan de la historia y cubren grandes periodos de tiempo, cruzándose en la metafísica.

En los contactos iniciales con nativos y durante esas primeras décadas posteriores a 1492, los conquistadores recogieron nombres y particularidades que no se pueden dejar al olvido o remplazarse para satisfacer necesidades sistémicas institucionales. Los nombres atribuidos y verificables en los periodos históricos con respecto a las razas, tribus o naciones de América se analizan desde una perspectiva de riesgo. Estos nombres nativos documentados desde la colonización cobraron un nuevo interés investigativo en el siglo XX.

Los usos o costumbres naturales del archipiélago se basaban en su geografía, bajo el control patrimonial de los caciques, dándose desde esa jerarquía nombres a los caciques $^{55}$, cacicazgos ${ }^{56}$ y a cada colectividad singularmente junto a nombres personales. Ese orden constituiría una forma de derecho consuetudinario ejercido por cada comunidad, identificando su identidad en todos sus derechos.

La primera década fue de una de gran violencia que impactaría para siempre a los nativos. Lo describe Bartolomé de Las Casas (2009: 81): “Tomaban las criaturas de las tetas de las madres y por las piernas, y daban de cabeza con ellas en las peñas". La perspectiva nativa habitando junto a unos colonizadores violentos, según es descrito por las Casas no deja duda de que estos nativos emprenderían inacostumbradas prácticas para romper cadenas, muy de acorde con lo señalado anteriormente de Levy-Strauss.

El relato de Las Casas presenta algunas dudas. Las Casas se refiere a La Española y a un lugar específico, quizá a un hecho específico, no se sabe si habitual o de venganza porque el relator parece proteger la figura magnánima de su amigo el almirante, pero no hace lo mismo cuando se refiere a hechos de españoles o de los negros.

Eugenio María de Hostos (1863: 53) ofrece su valoración de otro episodio:

"Guacanagari fue desgraciado: por admiración al genio que advino en Colón, lo amó y amó a los que les acompañaban, ausente este defendió contra sus compatriotas a los que

\footnotetext{
${ }^{55}$ Caciques o cacica nombres aplicados a jefes tribales caribeños, calachioni en Mexico. Cacica mujer de autoridad.

${ }^{56}$ Cacicazgos territorios en los que caciques ejercen la máxima autoridad. Estas clasificaciones incluyen grandes o pequeños grupos, tribus o naciones.
} 
defendieron su patria, y a pesar de las sospechas que le hicieron blanco, con lo que el mismo Colón lo ultrajo, llego un día en que puso su fuerza y su poder de parte de la injusticia, i lucho contra los indios del Cibao, contra los hermanos del héroe de la isla, contra los súbditos de Caonabo, al lado de colón y de los suyos, mal hijo de su patria: es indigno de lastima."

En esa ordenación de Hosto, que destaca el patriotismo y heroísmo de Caonabo, no se desvaloriza lo razonable del argumento y vida de los naturales. Pero en su preocupación literaria, añade en el dialogo a los negros:

"Una raza que prueba que el hombre no tiene color en el espíritu; que hay una chispa igual en todos, de que todo los hace capaces, los negros han fundado un imperio en este sitio. (...) Misteriosa justicia! Tu estas en todas partes. Al infeliz africano arrancado de sus selvas, y hecho esclavo por la fuerza, le das fuerzas, rompe con ellas sus cadenas; el hierro les da armas, las armas, un imperio".

Alex Bukhari et al (2017: 2) ofrecen una visión contemporánea:

"El impacto de la colonización europea fue tan profundo que, 50 años después, solo unos 500 taínos permanecieron en las Antillas Mayores (Rouse y Allaire, 1978). La causa de este declive masivo de la población se ha atribuido a varios factores que incluyen enfermedades infecciosas como la viruela y el sarampión, la guerra (con europeos y caribes rivales) y las duras condiciones de trabajo como esclavos (Rouse, 1992)".

Valiéndose de un estudio de ADN, cuya base histórica corresponde directamente al siglo XX, se añade:

"Una encuesta oficial estimó que para 1514, apenas dos décadas después del primer contacto, alrededor del $40 \%$ de los colonos españoles se habían casado con mujeres taínas (Rouse, 1992). Los números reales de familias mixtas españolas-tainas fueron sin duda mayores. En comparación con otros europeos, los españoles tendían a tener una actitud más relajada para establecer familias con mujeres tainas (Rouse, 1992)".

Y continua:

"Otro hecho intrigante revelado por el estudio actual son las sorprendentes diferencias en las proporciones de ADNmt de Taino en Cuba (33.1\%), República Dominicana (22.0\%) y Puerto Rico (61.3\%). Dado que la República Dominicana era el centro del dominio Taino en las Antillas Mayores en el momento del descubrimiento con el mayor número de nativos, uno esperaría frecuencias más altas de ADNmt de Taino allí hoy”.

Las sucesivas citas muestran la intervención de la estandarización taína en el siglo XXI y las fallas históricas que ese estudio tiene. La supervivencia nativa caribeña queda 
clara, en cualquier caso. Luego discutiremos las implicaciones de esa supervivencia nativa y la herencia africana.

Ahora examinemos lo que parece estar fuera del contexto histórico pero recogido en un estudio académico basado en una intervención cara a cara. En Sherida FelicianoSantos (2017: 20) encontraremos argumentos filosóficos acogidos a la estandarización taína, alejándose de las realidades históricas:

"Partiendo de mis propias experiencias como un académico puertorriqueño que ha leído la Profecía de Aura Surey y mi investigación sobre la interacción cara a cara entre los taínos, demuestro las narrativas de los taínos que intervienen en la forma en que el Taíno responde y enmarque la importancia de los eventos y cómo esto afecta la construcción y el activismo de la comunidad taína en Puerto Rico. En términos más generales, este artículo aboga por una consideración de las narrativas proféticas como sitios para congregar identificaciones y pertenencias, entendimientos históricos, interpretación y acción social futura”.

Este estudio de 2017 se basa en una terminología cuyo resultado representa la propia crisis cultural y la crisis ancestral caribeña, y asume tendencias antropológicas fuera de contexto. Esa configuración ideológica se amplía en la siguiente articulación (p. 22):

"Les pregunté a los ancianos, a los que tenían la capacidad de comunicarse con los Espíritus Ancestrales, ya los que estaban a cargo, si estaban seguros de que el rol social que me atribuyeron era correcto. Bajo el peso de tales expectativas necesitaba ser honesto. Les dije que nunca me había identificado como una persona taina, y que continué considerándome a mí mismo como no particularmente taíno. Me pregunté por qué estaban tan convencidos de que tenía una tarea particular que cumplir para el Taíno. Me dijeron que mi trabajo me revelaba y que, tal como estaba profetizado, este era mi Camino, al igual que otros tenían su Camino".

En esta estructuración científica, el investigador se convierte en testigo de su propia observación en el año 2006. La proposición se ampara en un mundo taíno en el que existen espiritualistas capaces de interpretar alma y necesidades taínas. Primero, un anciano en el 2006 constituiría una persona nacida alrededor del 1926, un periodo de tiempo en el que había una supervivencia nativa desconocida, pero nunca era taína. En esa fecha, los trabajos de estandarización de Fewkes o Harrington eran básicamente desconocidos y el sistema educacional de Puerto Rico no había integrado la enseñanza del taino, lo que sucedió después de los 60. La periodización de la supervivencia nativa caribeña y la diseminación de la estandarización desde la segunda fase del taíno de 
Rafinesque chocan en el 2017, y sirve de evidencia de la crisis cultural a la que nos referimos.

La vida espiritual, según Feliciano-Santos, pierde toda fiabilidad científica al aplicarse su legitimidad en el tainismo. La supervivencia nativa caribeña y el tainismo no son históricamente compatibles. La supervivencia es real, la terminología taína es fabricada.

En busca de recuperar argumentos sobre la supervivencia de los caribeños, debemos citar un estudio significante para Cuba, presentado en Beatriz Marcheco-Teruel et al (2014: 1):

"Las proporciones más altas de ascendencia africana se observaron en las provincias del sudeste de Santiago de Cuba y Guantánamo, y las proporciones más altas se encontraron en las provincias orientales de Granma, Holguín y Las Tunas. Los Guanahatabey eran cazadores-recolectores que vivían en el oeste de Cuba. Comprendían aproximadamente el $10 \%$ de la población indígena cubana, hablaban un idioma que no era arawak y se los considera descendientes de los primeros pobladores de la isla. Los taínos eran agricultores de habla arawak que habitaban en el resto de la isla y comprendían el $90 \%$ de la población indígena".

Primero, nos alejaremos de la estandarización taína y de las fallas histórica y examinaremos las partes significantes, que lo son los naturales caribeños y los negros. Hostos nos propuso una integración humana significante, y a su modo patriótica, sin sobrepasar ciertos límites Marcheco-Teruel et al. Ofrece otros resultados de interés:

"Con respecto a las contribuciones de los nativos americanos, también está presente un patrón claro, con contribuciones promedio más altas en las provincias orientales, en particular Granma (15\%), Las Tunas (12\%) y Holguín (12\%) que en las provincias occidentales. (...) El promedio de la ascendencia europea, africana y nativa americana en aquellos que se reportan a sí mismos como "blanco" fue de $86 \%, 6.7 \%$ y $7.8 \%$, en aquellos que se reportan como "mestizo" $63.8 \%, 25.5 \%$ y $10.7 \%$, y en esos autoinformes para ser "negro" $29 \%, 65.5 \%, 5.5 \%$ ".

En el 2014 los porcentajes de población multirracial en Cuba son claros. Algunas situaciones son de sentido común y deben periodizarse a lo largo de los siglos para entender los resultados de ADN actuales. El puertorriqueño Manuel A. Alonso (1849: 58) añade algunos detalles que son útiles al respecto:

"En Puerto-Rico hay dos clases de bailes: unos de sociedad, que no son otra cosa que el eco repetido allí de los de Europa; y otros los llamados garabatos, que son propios del país, aunque dimanan á mi entender de los nacionales españoles mezclados con los primitivos habitantes; conocensé además algunos de los de África, introducidos por los 
negros de aquellas regiones, pero que nunca se han generalizados, llamándoseles bailes de bomba, por el instrumento que sirve en ellos de música”.

Manuel Alonso hace evidente que la gente conocía la supervivencia biológica nativa, aun cuando se entendía como una mezcla.

\section{LOS INDIOS BAUTIZADOS POR COLÓN, PARTICULARIDADES Y DENOMINACIONES.}

En las últimas décadas las principales líneas de investigaciones que estudian a los nativos caribeños hablan de los tainos como el oriundo natural, intercalando con los testimonios de los cronistas antiguos las nociones difundidas por Olsen y Bourne (1906), Arrom (1966) y Rouse (1992), entre otros. La terminología sistémica favorece al investigador contemporáneo, al singularizar y sintetizar las unidades geográficas tribales bajo un solo nombre. Esta singularización guarda una estrecha relación con la interpretación de documentos históricos originales aplicados a los nativos, extrayendo resultados impropios. Colón fue el primero en llamar erróneamente indios a los habitantes nativos del Caribe, por pensar que había llegado a Asia. Ese término se expandió a todas las colonias de la Corona española por décadas y luego en su momento a norte América. Los indios bautizados por Colón remplazo nombres históricos en el Caribe, como borincanos, borinqueños o boricuas, ciguayos, lucayos, macorix, mayorixes, marolis o quisquianos, quisqueyanos, ciboneys, siboney, guanahatabeys etc. Ese proceso comenzó a extenderse desde el primer viaje de Colón, ganando popularidad desde el siglo XV, lo que promueve la idea de la estandarización desde el siglo XIX, según hemos señalado en varias ocasiones.

La siguiente tabla de nombres y adscripciones documentadas desde el siglo XV representan alternativas para investigar y catalogar espacios caribeños alejados de la estandarización taína. 
Tabla \#3 denominaciones: derivadas de diversos idiomas nativos y regionales.

\begin{tabular}{|c|c|c|c|c|c|}
\hline $\begin{array}{l}\text { Nativos caribeños, naciones, tribus, } \\
\text { clanes y parentelas }\end{array}$ & Cuba & Bahamas & RD/Haití & PR & $\begin{array}{l}\text { Antillas } \\
\text { menores }\end{array}$ \\
\hline $\begin{array}{l}\text { Aruac, araguas, aroakos, arruwak, } \\
\text { arawak, arhuaco, arawack, aruwack, } \\
\text { araucos, arahuacos, arawaac, } \\
\text { aruwaac, arouages }\end{array}$ & $\mathrm{X}$ & $\mathrm{X}$ & $\mathrm{X}$ & $\mathrm{X}$ & $\mathrm{X}$ \\
\hline Aunabeys, maisi & $X$ & & & & \\
\hline $\begin{array}{l}\text { Borincanos, boricuas, boriquans, } \\
\text { boriquenos, borinqueños, boriqui, } \\
\text { buruchena, buriquen, burichena, } \\
\text { buriquem burriquem }\end{array}$ & & & & $\mathrm{X}$ & \\
\hline Ciguayos, ciguaios, siguayos, & & & $\mathrm{X}$ & & \\
\hline Cabres, guaccaierima & & & $\mathrm{X}$ & $\mathrm{X}$ & $\mathrm{X} X$ \\
\hline $\begin{array}{l}\text { Caribes, caribs, canima, caraiba, } \\
\text { caribales, galibi, karina, kariñas, } \\
\text { kalinago }\end{array}$ & & & $\mathrm{X}$ & $\mathrm{X}$ & $\mathrm{X}$ \\
\hline Camagüeyanos & $\mathrm{X}$ & & & & \\
\hline Caquetío, carinepagoto, guaiquerí & & & & & $\mathrm{X}$ \\
\hline Ciboney, siboney, sibunei & $\mathrm{X}$ & & $\mathrm{X}$ & & \\
\hline Eyeri, igneri, igñeri, Ieri, Ierian & & & $\mathrm{X}$ & $\mathrm{X}$ & $\mathrm{X}$ \\
\hline Gandules & & & & $\mathrm{X}$ & \\
\hline $\begin{array}{l}\text { Guanahatabey, guanajatabeyes, } \\
\text { guanahatabeyes, guanahatabibes }\end{array}$ & $\mathrm{X}$ & & $\mathrm{X}$ & & \\
\hline Guaymaros, guanajos & $\mathrm{X}$ & & & & \\
\hline Huhuici & & & $\mathrm{X}$ & & \\
\hline Jamaiquinos, xaniaquinos & & & (Jamaica) & & \\
\hline Lucayos, lucayans, jucayos, yucayos & & $\mathrm{X}$ & $\mathrm{X}$ & & \\
\hline $\begin{array}{l}\text { Macorixes, macorijes, macoris, } \\
\text { macorix, marolis }\end{array}$ & $X$ & & $\mathrm{X}$ & & \\
\hline Quisqueya, quisquella, quisqueia & & & $\mathrm{X}$ & & \\
\hline Taino, taíno, taína, tayno & Nunca & Nunca & Nunca & Nunca & Nunca \\
\hline Juava Variu o Guava Variu & & & $\mathrm{X}$ & & \\
\hline
\end{tabular}

Notas: Algunos deletreados en los encasillados están basados en el idioma del investigador. 
En el ordenamiento de denominaciones verificables, señalamos que Boriken procede del hijo del Almirante, Hernando Colón. Borriquen fue un etnónimo publicado por Antonio de Herreras ([1625] 1730: 10). Aiti y Quisqueia, significando aspereza y tierra grande, procede de Antonio de Herreras (1730: 6). Ciguayos y Macorixes proceden de Bartolomé de las Casas. Sin embargo, indios es un término inaplicable en América, es erróneo, no fiable y su uso correcto identifica a personas oriundas de la India. Los autónimos borinqueños, boricua, quisquiano, quisquellano, aitianos, Haitíanos, junto a ciguayos y macorixes son adecuados para identificar etnias, tribus o clanes, al igual que deletreados, que identifican usos fonéticos similares a estas denominaciones y a otras verificables.

En las formulaciones de adscripciones basadas en geografía, hábitat y ancestros, la base general puede ser comparada a otras áreas de América. Las denominaciones de la tabla se discuten a lo largo de la tesis y fueron propuestas, examinadas o analizadas por investigadores con anterioridad.

Daniel Valdeblánquez (1979) narra la procedencia de un nombre investigado por Reichel-Dolmatoff en su extenso trabajo de los arhuacos compuesta de varios grupos: Kogi, Sanká y Kankuamá, y con otros nombres genéticos: Kágabe, Koggaba, Cágaba, Aouraques (Reichel), Bintukua, Busin (Vilanesa), Kasikiva, clasificados lingüísticamente en la lengua Chibcha. Esta mención se utiliza para ubicar el trabajo de Reichel-Dolmatoff y el nombre de Alauhuiku, un héroe que llego del este y pobló la región alta del Rio Ancho y San Miguel, por la cual dicha región toma el nombre de “Tierra de Aluaká” o Aruacá. Y bien puede ser de donde surgen los arahuacos o arawaks. Notamos de Alau-hui-ku es un conjunto que nos dirige a los huhuicis o hu-hui-cis, tema que discutiremos en adelante.

Irving Rouse (1951: 194-195) discutió la teoría Circuncaribeña (CircumCaribean), en referencia a las Antillas mayores: "Debido a su aislamiento, la cultura original del Circum-Caribe debió sobrevivir en forma relativamente pura, y por tanto nosotros podemos usar las características históricas de la cultura del Circum-Caribe en las Antillas Mayores para determinar lo ocurrido por esa cultura en la prehistoria". La narrativa arqueológica debe poseer sentido común como base de interpretación de la historia. En su interpretación de la prehistoria caribeña, Rouse sostiene:

\footnotetext{
"Afortunadamente, los indios históricos de las Antillas Mayores usaban una gran variedad de estructuras y parafernalia en conexión a sus ceremonias; estas tenían significancias políticas y religiosas; y un gran e inusual número de estos ha sobrevivido
} 
arqueológicamente; en parte porque era acostumbrado a guardarles en capillas en cuevas, donde se protegieron del clima (Lovén, 1935, pp. 125-34)”.

Lovén (1935) y Rouse (1951) se inclinan por la uniformidad caribeña originada en tierra firme durante siglos o milenios. Rouse los denomina indios históricos. En los nombres tribales que hemos señalado encontramos semejanzas y diferencias marcadas, aun cuando la tribu es de la misma rama. El aislamiento de las Antillas Mayores referido por Rouse es justamente el espacio tribal en el cual generación tras generación desarrollan sus identidades y sus culturas particularizadas. Lovén y Rouse identifican objetos como sillas, representativos de símbolos de clase, plazas de baile, plazas de juego de bola, espátulas de vomito, tubos para inhalar, piedras talladas y una amplia variedad de huesos, conchas, madera e ídolos de algodón o zemis. En fin, los tratados arqueológicos de estos objetos son examinados y datados con los últimos avances tecnológicos. No obstante, el aislamiento señalado por Rouse provee ese espacio de larga duración donde las culturas $\mathrm{y}$ adscripciones originales son uso y costumbre de sus habitantes. O sea, se plantea a través del objeto actividades y costumbres en la cual esa actividad, según era practicada y vivida por las personas eran identificadas en relación con la política y la religión de las comunidades. Esta tesis se nutre de esa universalidad nativa de nuestra área de estudio durante el descubrimiento. A esa universalidad caribeña le hemos llamado uniformidad típica biológica y culturalmente, distinguiéndose entre sí las homogeneidades tribales en sus propias denominaciones y fronteras geográficas.

La interpretación de la historia cambiante que hemos examinado se acoge a la necesidad de cambios generados desde 1836, convirtiéndose en la ruta por la cual se desplazó la estandarización taína. En ese sentido, y considerando todas las adscripciones nativas, el enfoque no es exclusivamente histórico, es a su vez antropológico, arqueológico y etnológico, perteneciendo a sucesos pasados cuyos valores y actividades deben ser reinterpretados. Por tanto, en el espacio ocupado antes por los taínos ahora surge una diversidad cultural y nuevos debates, que a su vez benefician a las comunidades ubicadas dentro de fronteras nacionales, racionalizadas bajo el concepto de islas separadas. Se viabilizan ancestros fisiológicamente uniformes que vivieron vidas e historia diferentes, no tan solo en sus lenguas o aislamiento geográfico, sino en sus hábitos y costumbres. Esas diferencias dentro de esa uniformidad dan paso a reinterpretar el pasado. Fewkes (1914: 671) ofrece algunas opiniones certeras: 
“(...) puede suponerse con razón que las formas de estos objetos prehistóricos de Puerto Rico se desarrollaron de manera bastante independiente de las de otras islas; y como estos objetos característicos no existen en América del Norte o del Sur, es probable que se originen en las islas donde se encuentran".

La independencia organizada entre islas y sus políticas es a lo que llamamos particularidades culturales, desarrolladas en la asimilación de la naturaleza en sus geografías especifica. Las unidades más pequeñas las hemos definido anteriormente como parentelas. Cabeza de Vaca (1749) ofrece sus características de los gentilitates, contenidas en el plano menor de clanes por estar sus circunstancias heterogéneas y homogéneas en una misma geografía. E. Sánchez Moreno (1996: 116) ofrece al respecto la siguiente precisión:

"Además, a la hora de adaptar esta terminología histórica (gentes, gentilitates) a una realidad sociológica más tangible se ofrecieron distintas respuestas, como la identificación respectiva de: Gentilitates $=$ (clanes, grupos emparentados menores); gentes $=($ grupos emparentados mayores $)$; populi $=($ confederación tribal "formada por varias gentes")".

Nuestra definición de parentelas, o lo llamado gentilitates por Sánchez Moreno, parten de la identificación de los grupos menores. Al examinar y evidenciar históricamente la aplicación de términos originales, ordenaciones y la dimensión humana de los naturales caribeños se intenta acogerse a las denominaciones de la región. Esta tesis no se propone teorizar la prehistoria, es obvio, se plantea reinterpretar denominaciones de habitantes de las que se han deducido etnias.

En el pasado se ha pretendido negar ciertos nombres, por ejemplo, el quisqueia de Herreras, destacando que es un derivado de otras lenguas y representa una adscripción infundada. A lo largo de la historia del descubrimiento se recogen en la historia oral fragmentos que aportan la identificación de primogénitos y sus etnónimos, unos relevantes y propios a culturas, aun cuando se constituya tal rescate basándose en una solo palabra. C.S. Rafinesque fue el maestro por excelencia de esto, pues con una sola palabra generó una terminología convertida en ciencia que ahora tiene su propia historia. Desde esa perspectiva resulta indispensable examinar el contexto de cada denominación, pues no se trata de chismes literarios según los llama Figueredo (2009).

La comunicación entre culturas caribeñas incluye ramas lingüísticas comunes y dialectos inteligibles entre habitantes de diferentes islas, al igual que dialectos no inteligibles en territorios colindantes, este es tema recurrente. Por tanto, el etnónimo 
quiequeiano, quisquellano o quisqueyano, es aceptable y consistente con la conformidad lingüística y biológica del circum-Caribe y las influencias de otras lenguas nativas de América. Si Quisqueyano era una adscripción reconocible entre algunas o una comunidad precolombina se desconoce al momento; que fue una referencia geográfica especifica en la hoy Republica Dominicana y Haití, no hay duda. Que se utilicé la denominación quisqueyana para identificar habitantes de la República Dominicana es correcto.

De la misma generación que Ramon Pané, y sirviéndose de la misma información, Fernando Colón (1892: 12) ofrece una interpretación distinta:

"la provincia de Magdalena la cual se llamaba antes Marolis, (...) y el señor de ella Guavavoconel, que quiere decir el hijo de Guavaenechin. (...) en esta casa viven sus criados, o servidores o favorecidos, que por sobre nombre tienen, el de Juava Variu, y entre todos eran diez y seis personas. (...) señor, ¿como quiere V. S. que yo valla a estar con Guarionex, no sabiendo otra lengua que la de Marolis? deme V. S. licencia para que venga conmigo alguno de los Huhuici, que después fueron cristianos, y sabían ambas lenguas, lo cual me concedió".

En su estudio preliminar a esta crónica, en nota a pie, Arrom (1966: 5) escribe:

"De la entrevista que tuvo con Colón en aquella ocasión, y del subsiguiente viaje que emprendió, fray Ramón relata lo siguiente: 'Señor, ¿cómo quiere Vuestra Señoría que yo vaya a vivir con Guarionex no sabiendo otra lengua que la de Macorix? Deme licencia Vuestra Señoría para que vaya conmigo alguno de los de Nuhuirey, que después fueron cristianos, y sabían ambas lenguas' ".

Hernán Colón nos deja claro que habitaba cerca de Marolis una parentela o clan, los denominados Huhuici (Un-hui-rey de Arrom), que eran bilingües, un dato importante relacionado a los dialectos de Haití o Quisqueya. Los huhuici son poco identificados en la actualidad pero fueron una comunidad nativa. La conexión entre el Huhuici (Hu-hui$c i$ de Hernán Colón), el Alauhuiku (Alau-hui-ku de Reichel-Domatoff) y el Unhuirey (Unhui-rey de Arrom), asume significado enmarcada en el conjunto de denominaciones que examinaremos.

En la cita de Hernán Colón el autor nos presenta a Guavavoconel, Gua-va-vocoel, que quiere decir el hijo de Guavaenechin, Gua-va-ene-chin; y sus favorecidos o sirvientes que por sobrenombre tienen el de Juava Variu, jua-va Va-riu. Juava Variu es el etnónimo del colectivo identificado por H. Colón, semejante a una parentela de las identificadas por Cabeza de Vaca (1749). En esa secuencia se observa el nombre original y heredado por un hijo, y el nombre del clan conteniendo en el prefijo Gua-va, convertido en Jua-va para designar el exónimo del clan. Menciona H. Colón que esta era una de las 
casas principales de Marolis, pero no se refiere o dice tratarse de un cacique. En este detalle se identifica una jerarquía y toponimia entre gente y un lugar reconocible y verificable.

Reichel-Dolmatoff ofrece el nombre de Alauhuiku, héroe de los Arhuacos, de donde proviene posiblemente no solo Arhuacos, sino Arawaks (Valdeblánquez, 1979). Nombres nativos relativos entre sí los presentamos en nombres genéticos, por ejemplo, Kágabe, Koggaba, Cágaba. En ese sentido, incluso en el Nu-hui-rey de Arrom encontramos afinidades de nombres genéricos. En Ká-ga-be, Ko-gga-ba, Cá-ga-ba encontramos mínimas variaciones entre sufijos, prefijos en cuerpo ga parece inmutable al igual hui al que Arrom añade en español rey, lo que en cierta manera corresponde con la leyenda del héroe Alauhuiku. Si de ese relato surgió un héroe conocido, entonces los arahuacos asumen aun más significancia. Hernán Colón recoge la historia oral de la propia gente y de los exploradores; Reichel-Dolmatoff pasa cinco décadas en Colombia estudiando los nativos selváticos y costeros.

Hernán Colón usa estos nombres autóctonos al identificar provincia y personas: Marolis, Maviatúe y Caonao. Arrom escribe e interpreta en su trabajo: Macorix, Mabiatué y Caonabó. A simple vista se puede entender lo representativo de cada una de las referencias utilizadas para identificar provincia y personas. Por tanto, la conexión genérica de nombres es real y evolutiva, siendo recogida según la fonética o una interpretación de palabras corruptas dentro de ese desarrollo genérico lingüístico. Se ha listado como nombres propios de nativos esa conexión genérica. ${ }^{57}$ Se ha encontrado información de importancia en los estudios de Arrom.

Hernán Colón, el historiador y heredero de la conciencia y los documentos de su padre, mientras recopilaba libros para su Biblioteca Fernandina, conocida como Biblioteca Colombina, custodiada en la Catedral de Sevilla, tuvo conocimiento del trabajo de Ramon Pané, vivió en La Española junto a su padre, a raíz del cuarto viaje, retornando a La Española por segunda vez en 1509 cuando su hermano Diego se convirtió en gobernador. Conoció a personas sobre las que escribió, y estuvo muy cercano a hechos que relató. Como historiador, fue cauteloso al documentar los acontecimientos próximos a su padre. Hernán Colón dejo muestras de denominaciones nativas de valor histórico. La cultura taina y el taino no aparecen en sus escritos. Rouse (1992), por el contrario, habla de taínos occidentales, taínos orientales o taínos clásicos para identificar espacios

\footnotetext{
${ }^{57}$ Ver; Tabla \#3
} 
precolombinos habitados por borincanos, ciguayos, quisqueyanos, haitianos o cubanos, etc. Cranberry (2012:1) cita a siete comunidades de hablas nativas durante la intervención española, e identifica a dos de interés taino: Ciboney taíno, Macoris, Ciguayo, Guanahatabey, Taino clásico, Kaliphuna y Caribe Karina.

Haciéndose eco de las opiniones de Norman McQuown sobre la América en general, J. Alcina Franch (1978: 142) recuerda: "Esta región no puede ser comparada a ninguna otra del mundo por su multiplicidad y diversidad. Se han estudiado alrededor de dos mil idiomas y dialectos divididos en diecisiete grandes familias y treinta y ocho pequeñas, con cientos de lenguajes sin clasificar". Entre las diecisiete grandes familias citadas por J. Alcina Franch (1978) dos son de interés principal a nuestra investigación: el Macro-Arawak y Macro-Caribe; restaría analizar las treinta y ocho pequeñas familias y formalizar estudios para verificar cuales otras fueron influyentes en el Caribe.

En el marco geográfico del estudio de Cranberry, el autor aporta dos lenguas de dos de las grandes familias en el ciboney, macorix, ciguayo, que forman parte de la Macro-Arawak, y Kaliphuna y Caribe Karina, que forman parte de la Macro-Caribe. Las relaciones son razonables habiendo los caribes habitado el este de Puerto Rico, partes de la Republica Dominicana, Haití y posiblemente las Bahamas durante ese periodo de intervención española. Así, Oscar Peschel (1876: 206), hablando de los caribes, escribe: “(...) extendían sus incursiones de secuestro en Hayti, donde algunos de sus aventureros habían fundado monarquías, y los antiguos llegados habían tomado posesión del país en la costa este".

No obstante, las lenguas durante ese periodo y geografía no se pueden agrupar tan fácilmente, dada la diversidad tribal y las particularidades regionales y las tribus aisladas que se han examinado al momento. Es posible que dos grandes familias lingüísticas ocupando la totalidad de las islas caribeñas que estudiamos, los caribes y los araucas, puedan ser aceptadas con alguna excepción conocida, por ejemplo, los guanahatabeyes o grupos expedicionarios establecidos. Entre esas familias lingüísticas se desarrollarían culturas nativas y tribales particularizadas de raíces uniformes y de lenguas o dialectos diferentes, o evolucionados en aislamiento. No se puede descartar lo vivido por Cabeza de Vaca en una isla con dos parentelas de diferente habla que convivían en amistad. Y tampoco se puede descartar la intriga idiomática de las interpretaciones de nombres genéricos nativos de denominaciones adaptadas y recogidas por lenguas europeas.

Sin embargo, cuando resulta posible que siete lenguas fueran las habladas en nuestra área geográfica, el Ciboney Taíno y el Taíno Clásico (Granberry) nunca pudieron 
ser posibles, pues el taino nunca existió. En teoría, en este caso Ciboney, al igual que el Macoris o el Guanahatabey de Granberry pudieran por si solos representar esa lingüística nativa y ser autosuficientes en esa toponimia.

Se difunden entre los escolares las teorías tainistas. Alegría $(1969,1971,1992)$ y Figueras (2000), entre otros, lo han hecho. E igualmente se propaga entre los adultos en programas académicos desde la segunda mitad del siglo XX. Como escribe Alegría (1999: 231), “Al momento del descubrimiento de América, los taínos vivían en Puerto Rico, gran parte de la Española (República Dominicana y Haití) y el este de Cuba”. Ese pensamiento fue originalmente propuesto por Rouse y tiene sus profundas raíces en el siglo XIX, pero destaca durante la segunda mitad del siglo XX. El área geográfica citada por Alegría representa sobre las 754.00 millas cuadradas. Mientras Keegan, Hulme y Whitehead rechazaban esta denominación, Alegría escribía cuentos a los niños sobre sus ancestros taínos.

La trayectoria tainistas abunda en la estandarización. Jalil Sued Badillo (1989: 91) escribe: "Descripciones de la geopolítica taína a la llegada de los españoles se encuentran en todos los principales cronistas de Indias: Pedro Mártir de Anglería-Décadas del Nuevo Mundo, Buenos Aires, 1944-, aunque Mártir nunca visito América, y numerosos de sus relatos han sido cuestionados en este tema, tuvo acceso privilegiado a los trabajos de Andrés Morales, cosmógrafo al servicio de Nicolás de Ovando, quien le encomendó trazar el primer mapa de la isla Española".

Primero, la palabra taína nunca fue utilizada por Mártir para identificar etnias nativas. Mártir utilizó la palabra tayno (con ese deletreado), significando bueno, en su carta dirigida a Ascanio Sforza, en el segundo libro, página trece de la primera década, y en ninguna otra ocasión. Segundo, ningún cronista principal designó nativos con ese etnónimo o un área geopolítica taína. El cosmógrafo Andrés Morales no es conocido por ningún documento de términos o autodenominaciones nativas.

Se amplía el tema si incluimos el Códice Dominicano. Roberto Cassá et al (2016) identifica que fueron los taínos los aborígenes que recibieron a Colón, e interpreta la sociedad taína. El Códice Dominicano retoma aquí las teorías de Rouse (1951), basadas en Fewkes (1907) y Harrington (1921), igualmente acogidas por Alegría (1978, 1999), Arrom (1966) y Badillo (1989), entre otros, a pesar de que la terminología adoptada se aleja de las realidades étnicas de la República Dominicana. Esos conceptos pasan de lleno a los salones de clase difundiendo teorías ajenas a la historia. Este vestigio de mediados del siglo XX lo encontramos en postgraduados de sistemas escolares secundarios y/o 
universitarios en Puerto Rico post 1955, posiblemente Badillo, Curet, Oliver, Rodríguez y otros a quienes se les dificulta desconectarse completamente del taíno. Aun cuando autores contemporáneos reconocen la inutilidad del término, estos no han logrado separar la problemática histórico-social y cultural para dar comienzo a una reconstrucción del ordenamiento de términos tribales originales.

Examinamos algunos autores contemporáneos que han contribuido a la difusión de los taínos definiendo a nativos caribeños y sus descendientes y a su vez reteniendo conceptos indefinidos que cada vez están más alejados de verificaciones justificables. Curet presenta en una de sus publicaciones esa dinámica conflictiva: "Yo uso el término taíno en contra de mi mejor juicio para simplificar la discusión y prevenir confusión" (2015: 205). Curet sabe que el término es inservible, sin embargo, en el 2015, para evitar la confusión, acuerda seguir con su uso. Estos titubeos filosóficos son comunes en las últimas décadas en numerosos investigadores. Robert Poole es representativo de la dimensión y alcance del fenómeno: "Los taínos impresionaron a Colón con su generosidad lo cual pudo haber contribuido a su desaparición" (2011: 2). Poole es un investigador experimentado del Smithsonian Institute. En una entrevista con Ricardo Alegría notamos dos asuntos: la terminología taína y la extinción del nativo caribeño, enmarcados en un mismo pensamiento. Estas perspectivas se dirigían a llenar grandes espacios en unas investigaciones estructuradas a la transferencia de conocimientos estandarizados dentro de un mercadeo ideológico y comercial de productos académicos e institucionales. Poole nota que la enfermedad pudo haber contribuido la desaparición del taíno, y eso en parte es correcto pues las condiciones a una desaparición o extinción requieren mucho más que una teoría simplista. En la entrevista mencionada, dice:

"Alegría había revisado los archivos españoles para rastrear el eclipse del Taíno. Su cultura fue interrumpida por la enfermedad, el matrimonio con españoles y africanos, etc., pero la principal razón por la que los indios fueron exterminados como grupo fue la enfermedad", me dijo. Repasó las cifras de su isla nativa: "En 1519, un tercio de la población aborigen había muerto a causa de la viruela".

Sostener que un tercio de la población aborigen desaparece en 1519 no está documentado históricamente. La intervención cultural basada en matrimonios con españoles y africanos es una vía a la supervivencia. Ese comienzo multicultural inicial, sumado al comienzo de lo multirracial puertorriqueño y caribeño acogido al pensar nativo es el posible comienzo del jibaro puertorriqueño, el campesino dominicano y el guajiro cubano. Harrington (1921) ya presentó el caso del viejo español, Mosquera, viviendo 
junto a su esposa nativa, y sus descendientes siendo eso un claro ejemplo de la supervivencia nativa. Harrington se convierte en testigo de la supervivencia nativa en Cuba y nos deja ese claro ejemplo en el cual él mismo documenta y entrevista a la familia. Entre las páginas escritas de importantes investigadores tainistas encontramos la evidencia de nativos sobrevivientes, familias multirraciales o mestizos cohabitando en el Caribe en este caso Cuba en 1921. En este sentido, tanto Harrington como Arrom han contribuido a la investigación de la supervivencia nativa.

Los autores que usaron o usan "taíno" como un símbolo sistémico institucional en conjunto junto a la extinción nativa caribeña, han sido contestados por otros historiadores. Torres Etayo (2008: 2) dice: “(...) ha sido entendido largamente en la literatura histórica, que la palabra taíno es equivalente a denominación étnica. Para nosotros es verdaderamente sospechoso la ausencia del pretendido etnónimo en el resto de los documentos de la conquista". Aclararemos, para evitar dudas, sospechas y confusión, que la palabra taíno simbolizando etnia, tribu o cultura nativa nunca existió. Numerosos investigadores desconocen o ignoran las raíces de esta estandarización por ser conveniente, tiene historia y evita confusión aun tratándose de una fabricación.

Un estudioso, semejante en formación -o superior- a muchos de los citados del siglo XIX, fue el de Washington Irving. En su libro sobre Colón escribió lo siguiente: “(...) por todas partes echando los fundamentos de la verdad que hasta ahora ha sido tan adulterada par los escritores parciales o sistemáticos" (1882: 4). Irving escribió a partir de consultar la Biblioteca Real de Madrid, invitado en 1825 por Manuel Fernández de Navarrete a examinar los nuevos documentos sobre los viajes de Almirante Colón. Entre estos se incluía la carta del Dr. Diego Álvarez Chanca, encontrada en ese año. La controvertida carta del Dr. Chanca la discutiremos en adelante. Señalamos que antes que Rafinesque, ni Fermández de Navarrete ni Irving identificaron lenguaje, tribus o ningún nativo dominante denominado taíno se referían a los caníbales caribes o a los borincanos viviendo cautivos en Guadalupe en ese llamado canibalismo.

Curet (2015: 214) propone denominar Neo-taínos a grupos que avalan la supervivencia nativa en el siglo XXI como taínos. Curet se apoya en Haslip-Viera (2001), Borrero (2004), Castañeda (2011) y Feliciano-Santos (2011), entre otros. La imagen taína de los autores citados por Curet se adapta a las investigaciones de difusores principales (Fewkes, Harrington, Rouse, Alegria, Arrom) y repetidores del siglo XX de la terminologia estandarizada taína. 
Este fenómeno educacional y cultural comenzó en el Caribe a partir de 1955, durante la tercera fase de la evolución taína de Rafinesque, cuando la juventud caribeña, mayormente la puertorriqueña, es víctima del nuevo Instituto de Cultura Puertorriqueño. Ese fenómeno educacional influenció a la República Dominicana y luego a Cuba, que aun teniendo el tainismo raíces propias en la estandarización llevada a cabo por Antonio Bachiller y Morales, encontraron nuevas fuentes. Transcurren sesenta años antes que autores caribeños como Curet, Oliver, Torres y Rodríguez comensaran a dudar de la fiabilidad de la terminología taína. Entre tanto, estos autores aportaron significantes obras al tainismo. Sin duda, los requisitos académicos tainistas, oscurecidos por la llamada brecha arqueológica del siglo XX les cautivo y solo origina un titubeo filosófico. Examinemos ese titubeó filosófico y el fenómeno tainista perfeccionado.

Tenemos que preguntarnos si Neo-taíno es apropiado, y si una vez más los términos están por resaltar en el futuro como inútiles. J. Leerssen (2007: 19) se apoya en Wellek (1941) y Spiering (1999) para señalar que el aumento de la escritura de la historia en su propio lenguaje forma la identidad nacional: "No hace falta decir, que la noción relativa a la esencia o carácter nacional están totalmente determinadas por los estereotipos arraigados y ampliamente corrientes en imágenes étnicas”. En otras palabras, la literatura citada por autores sugiriendo la denominación de taínos (tainos), taínas (tainas) o (Neotaínos) forma parte de una nueva cultura literaria fundamentada en la educación recibida, inseparable de los nativistas. ${ }^{58}$

En las muestras examinadas se aprecia el prejuicio en contra de los puertorriqueños desde la primera década del siglo XX. A propósito, merece la pena recordar lo que escribe Stuart Hall (1996b: 445-446): "Pensamos en la identificación, generalmente, como un proceso simple, estructurado en torno a nosotros mismos, que somos o no somos (...) lo que Gayatri Spivak llama la 'violencia epistémica' (...) de los colonizados". Hall nos presenta el simple proceso de aceptación y remite a la idea de Spivak de la violencia epistémica de los colonizados. Hemos discutido antes temas como la lógica pervertida que regresa a destruir lo que sobrevivió. En ambas situaciones el yo soy queda afectado en Puerto Rico y el Caribe en el proceso de la colonización, familiaesclavitud-mestizaje, y en la política-territorio-ciudadanos. En el Caribe, la violencia

\footnotetext{
${ }^{58}$ Nativistas, una posible designación a grupos o personas atraídas por la cultura oriunda o natural en nuestro caso en Caribe. Nativista, uso singular designando a una persona cautivada por la cultura de nativos naturales. Naturales son los nativos en un marco geográfico definido, el oriundo o primogénito regional particularizado por su propia identidad.
} 
epistémica la habíamos visitado desde otras perspectivas. En la primera situación, el yo soy es afectado al identificarse con un símbolo-dominante-artificial que representa a esa persona-cultura en un espacio inexistente. En ese sentido, en Puerto Rico se dice culturalmente yo soy boricua pa' que tú lo sepas, lo que consideraríamos correcto en la tierra borincana del nativo puertorriqueño. La otra cara de la moneda lee: yo soy taíno; en este sentido, esa contrariedad de identidad no es simple, según Hall es compleja, y es la mayor desventaja de la personalidad cultural, o lo que Spivak identifica como violencia epistémica. El yo soy taíno representa lo atribuido científicamente, no lo heredado. Por tanto, el que asume esa atribución, a su vez, asume sus defectos epistemológicos, convirtiéndose en victima sistémica de una ciencia avanzada, a su vez alejada de la cultura y la historia.

En este sentido, se aclara la diferencia entre la violencia epistémica y lo que Curet llama una creación académica. A ese hecho de violencia epistémica no se le considera en esta tesis una creación sino una desventaja social, creada y atribuida institucional y comercialmente a la personalidad cultural y al yo caribeño arbitrariamente en su relación de colonizado-colonizador. En ese marco académico surge un problema sociológico, al desarrollarse una crisis cultural que evoluciona desde una práctica científica. Por tanto, la persona o comunidad cultural vive en una simbología o fenomenología cultural fabricada.

El atribuirse el yo vivo y quien soy le corresponde sin intervenciones a la persona o comunidad cultural. En el Caribe, estas opciones culturales están articuladas por expertos intercalando imposiciones injustificadas, o sea, ensalzando desventajas personales o comunitarias. Esa práctica es una perpetuación del concepto colonizadocolonizador. Sin embargo, existen quienes viven en el tainismo porque, como bien dijo Estévez (2013), “encaja”, y resulta accesorio si es o no justificable. Esa dinámica se ha convertido en una situación crítica, en la cual la terminología taína caribeña propaga audazmente su lógica pervertida en el siglo XXI. A las víctimas de este sentir y actividad cultural, Walcott (1974) se refiere como el hombre despojado y desnudo. Ese hombre desnudo de Walcott converge con la reivindicación de los caribes de Peschel (1876), pero fundamentalmente apreciamos la letra y el sentir de Colón al ver esa gente desnuda como dios los trajo al mundo viviendo en su propia naturaleza. Ese nativo desnudo asume otro rostro en el futuro, uno fabricado por científicos. 


\section{CRONOLOGÍA, GEOGRAFÍA Y SISTEMATIZACIÓN.}

Una evaluación cronológica metódica de la literatura caribeña presentada coincide en que la sistematización y singularización geográfica del término taino había encontrado resistencia desde el siglo XIX aun cuando era limitada. ${ }^{59}$ Michel Rolph Truillot (2011: 81) ha llamado la atención sobre la influencia exterior en los análisis históricos caribeños. "Los universales noratlánticos son particulares que han adquirido un grado de universalidad, son pedazos de la historia de la humanidad convertidos en estándares históricos". En primer lugar, debemos establecer el concepto noratlántico, pues lo consideramos un orden geográfico, sistémico y filosófico. Trouillot lo interpreta en el marco caribeño y de sus estructuras originales (2011: 93):

"[la existencia de] El golpeador [especialista en la cocción del azúcar] es, entonces, el hecho que hace que la historia del Caribe, como la conocemos, comience con una ruptura abrupta entre pasado y presente: para los europeos, para los nativos americanos y para los africanos esclavizados. Las imposiciones de la modernización, impartidas por la colonización, de ninguna manera pudieron haber sido percibidas por alguno de estos actores como la simple continuación de un pasado inmediato. Así lo vivieron en el Nuevo Mundo todos los involucrados, incluidos aquellos que habían estado en él antes de convertirse en unos «nuevos» para otros".

Para Trouillot, el [artesano] "golpeador" fue el esclavo negro eficiente que logra, en el desarrollo de su trabajo, cobrar según su producción. En nuestra visión del concepto noratlántico entendemos al golpeador en el comienzo de la modernidad, pero nos centramos en el nativo golpeado. Continuamos con Trouillot para encontrarnos con la geografía y sus sistemas en los primeros contactos: "Si tener conocimiento de una diferencia sociocultural, y la necesidad de negociar entre esas diferencias, es parte de lo que llamamos modernidad, entonces el Caribe fue moderno desde al menos el siglo XVI: desde el primer día de la modernidad noratlántica. De ser así, la primacía cronológica noratlántica titubea". Tener conocimientos socioculturales, y negociar diferencias en esos temas y políticas durante los primeros contactos por los nativos, es la ruta por la cual se hace posible la supervivencia nativa en el Caribe. En ese primer contacto, el golpeado es abusado por los que buscan la riqueza y el placer sexual, y en ese momento crucial

${ }^{59}$ Las fases de la tabla \#1 promueven un concepto cronológico adaptable al problema de la estandarización taína desde 1836. Por ejemplo, esta tesis se fundamenta en lo acontecido desde 1836 y su significado en lo relacionado a la fabricación taína del siglo XX mientras científicos de la segunda y tercera fase de la estandarización taína en escasas ocasiones se refieren al siglo XIX y buscan teorizar sus investigaciones en base a escritos del siglo XV y XVI. 
extraen, esclavizan, negocian y procrean un nuevo modernismo que no fue planificado. Trouillot discute una lógica sensible a la naturaleza nativa y consistente con este estudio, y nos recuerda: "La historia del Caribe, como yo la leo, es menos una invitación a buscar la modernidad en diferentes tiempos y lugares, lo que sería una empresa útil pero secundaria, que un llamado a cambiar los términos del debate" (2011: 94).

Cambiar los términos del debate, en este caso, tiene su comienzo con la sustitución o remoción total de la estandarización terminológica taína en toda la cronología, geografía, o institucionalidad relacionada al nativo caribeño y su historia. En la selección de trabajos se limita el número de autores para limitar la cronología en relación con la difusión de la estandarización. El trabajo del investigador es atender conflictos causados por los conceptos universales del noratlántico. Las actividades de investigadores promotores de la estandarización tienen consecuencias, y a esas nos dirigimos para corregir daños a la persona o cultura colectiva. Opositores al concepto, como Brinton (1871), Coll y Tosté (1897), Agustín Stahl (1889), Zayas (1914), Sauer (1966); Hulme (1986) y Whitehead $(1995,2002)$ señalaron la inutilidad del término taíno aunque reconocían las cualidades del nativo caribeño. Alejándonos de esa tendencia, verifiquemos algunas incógnitas. ¿Cómo y por qué se propaga ese término, y a qué se debió su razonamiento y aplicación? ¿Cuál fue la motivación institucional de acogerlo en el siglo XX? ¿De dónde surgen fondos para esta comercialización? ¿Por qué comenzó el Bureau de Etnología Americano, e instituciones académicas como Harvard y Yale, a comercializar ese término, justo después de la adquisición de Puerto Rico por los Estados Unidos? ¿Cuál era la política económica, institucional y educacional seguida entonces? Esa serie de preguntas se contestan con evidencias a cada una de ellas.

Oscar Jara Holliday (2006: 3-9), a propósito de la sistematización, dice: "El sentido con que nosotros asumimos el concepto de sistematización de experiencias, ha sido creado históricamente en América Latina. Varios trabajos han abordado esta perspectiva histórica”. Y añade:

"El colombiano Orlando Fals Borda, es el pionero de esta nueva búsqueda, cuando con su texto fundacional: "Causa Popular, Ciencia Popular- una metodología del conocimiento científico a través de la acción" y otros documentos sucesivos dio base desde la realidad latinoamericana al surgimiento de una nueva corriente en la investigación social: la Investigación-Acción-Participativa, entendida como un enfoque investigativo que busca la plena participación de las personas de los sectores populares en el análisis de su propia realidad, con el objeto de promover la transformación social a favor de éstas personas: oprimidas, marginadas y explotadas". 
Señalamos las imperfecciones institucionales desde 1836, de donde surgieron interpretaciones sistémicas de mercado y opciones comerciales sin considerar las resistencias y advertencias de experimentados autores. La Investigación-AcciónParticipativa, de la que habla Holliday, nos muestra a investigadores dedicados a difundir y educar al público o a los estudiantes, y esta actividad directa implica la estandarización terminológica. La sistematización desde las instituciones desconocía la magnitud de un problema potencial en al largo plazo. El visionario Daniel Garrison Brinton (1871) estaba en lo cierto en sus comentarios lingüísticos y advertencias. Brinton reconoció rápidamente una futura crisis cultural caribeña ocasionada desde Norteamérica. En ese sentido, el concepto de lo noratlántico y la modernización actuaron como una vía para la comercialización de la terminología taina. Cayetano Coll y Tosté (1907) fue el primero en objetarlo desde Puerto Rico. Antonio Bachiller y Morales (1883) favoreció esa aplicación científica. En este sentido, examinaremos el campo investigativo internacional y sus avances junto a autores caribeños a favor o en contra de la estandarización. En este marco cronológico se define el titubeo académico como parte de una crisis cultural, y la estandarización como una ciencia dudosa que no se puede aplicar a persona o comunidad cultural contemporánea.

Los naturales caribeños y sus descendientes del siglo XXI han sido negados y separados de su historia, y como resultado de ello, su naturaleza cultural heredada está afectada y en su lugar existe una filosofía sistémica convertida en una doctrina educacional tainista, cuyo futuro es operado institucionalmente como una marca comercial. Si las personas o los autores victimas de esas desventajas aprendidas desarrollan una literatura en esa cultura estandarizada, identificándose como neo-tainos, el problema se agrava. Reinhart Koselleck (1993: 269) nos advierte:

"Tan pronto como el historiador se vio precisado a construir su historia fundamentándola artística, moral y racionalmente, se remitió también a los medios de la ficción. Pero con esto se hizo tanto más urgente la pregunta de cómo se podría reconocer científicamente la realidad histórica a la que había de referirse. La pregunta retórica por el arte de la representación fue sobrepasada en el siglo XVIII por la teoría del conocimiento".

El asunto de la moralidad y la racionalidad en esa perspectiva artística se ha señalado en lo representativo del modo en que las culturas populares caribeñas han interpretado la estandarización de sus ancestros por décadas. La cultura taína crea también un mercado seductor, organizándose en base a una racionalidad heredada y difundida en su propia historia. Las barreras políticas de la época se adaptaron rápidamente al 
razonamiento formulado por esta nueva cultura y sociedad taína, asumiendo al pasar del tiempo campos culturales populares y artísticos. Primero, educamos niños a que reconozcan una imagen ancestral fabricada y luego los responsabilizamos por creer que la ficción puede convertirse en un ancestro. Esta sistematización se convierte en un trágico dilema, requiriendo no solo un gran esfuerzo, sino un costo económico sustancial que no remedia la penosa situación.

La cultura taína se comercializa y es acogida por economías científicas sin fronteras, al extremo de que un académico nacionalista puertorriqueño como Badillo (1989:29) habla del pueblo taíno (en la línea de Rafinesque, Fewkes y Harrington) y no del borinqueño de Coll y Tosté (1907), Stahl (1889) y Tapia y Rivera (1852). La comercialización se acoge al concepto de modernización que habíamos examinados en su relación al concepto noratlántico. Badillo describe cómo una nueva brecha de investigación aborigen generada por la etnohistoria y la arqueología abren nuevos caminos. De estas llamadas brechas surgen las teorías más inesperadas y los resultados más devastadores para las comunidades del Caribe. Esas nuevas brechas académicas se convierten en una especie de herramienta empresarial para la distribución comercial de un continuo producto cultural, educacional e investigativo. La teoría evolucionaria de esas investigaciones acogidas a la estandarización falla cuando se difunden esa practicas a comunidades nativistas. Lo vemos en Figueredo (2009: 3):

"La geografía se ha aplicado al estudio de los aborígenes de las Antillas por muy largo tiempo (Fewkes 1914; de Hostos 1924). La idea de un Área Cultural Antillana (Fewkes 1922) tiene sus raíces en ambas la geografía y su hija, la biogeografía insular (cf. Koopman 1959, 1968; Hedges 2006). En este trabajo, nos concentramos en el área taína, que incluye las Grandes Antillas y las islas de las Bahamas".

Figueredo señala a Fewkes como el investigador principal que ha comercializado institucionalmente al taíno en las Antillas como una fuente viable de la geografía nativa. La designada área taína de Figueredo carece de verificación histórica o de un orden geográfico. Fewkes propone al taíno para simplificar la arqueología caribeña en relación con los oriundos caribeños en la ordenación de espacios tribales bajo la estandarización, por desconocimiento de nombres históricos. En otras obras de Fewkes (1914a-1914b) no hace mención del taino; en Fewkes (1922), repasa su geografía y aplica el taíno solo a las Antillas Mayores. Estas desviaciones arqueológicas no constituyen nuevas brechas, simplemente una orientación filosófica del concepto "noratlántico", encontrado por ejemplo en Olsen y Bourne, Fewkes, Harrington, Loven y Rouse, entre otros. En el 
intento de ubicar conceptos, rescatar intenciones y tendencias, citamos a José Jiménez y Lizandra Jiménez (2008: 13):

"El más desafortunado de los nombres lo introdujo Irvin Rouse en 1942 para nombrar a las comunidades del Período Tardío, que no llegaban al nivel más elevado de desarrollo de los grupos tardíos, a los cuales nombró subtaínos. Imagine usted que alguien se refiera a los cubanos que vivieron el siglo XIX como subcubanos, sólo porque vivieron en un período histórico más temprano, y su desarrollo tecnológico y económico no era como el del siglo XX".

Estudiamos tendencias terminológicas para ubicar en la geografía caribeña examinando lo transcurrido entre la relación de términos y aplicaciones y sus consecuencias a la historia. Desde el descubrimiento, como bien señala Jiménez, estos nuevos nombres se aplican a la prehistoria con una gran facilidad por investigadores tales como Figueredo (2009), Badillo (1989), Alegría (1999), Rouse (1992), Veloz (2013) y Cassá (2016), entre otros. En ellos se pretende una conexión entre geografía, historia y prehistoria adaptando existencia teórica al taíno.

Esa dinámica empresarial implica una administración de fondos públicos $\mathrm{y} / \mathrm{o}$ privados dirigidos a difundir la etnicidad nativa caribeña. Los institutos de cultura promueven la etnia taína a nivel nacional y se responsabilizan al publicar y financiar obras asociando la terminología taína a comunidades simplemente porque la gente lo acepta. En este sentido, los jóvenes estudiosos producen con la intención de acogerse a esa economía estudios, cuyos resultados concuerdan con la práctica institucional y la actividad administrativa, pero no con la historia.

Roberto Cassá et al (En Veloz, 2013: 228): ha escrito: “Aunque muchos autores engloban las sociedades antillanas bajo el concepto de taino, nosotros hemos planteado una posición que siguen algunos investigadores, y que se refiere al 'tainato' o la sociedad taina a una relación con el alto desarrollo con la cultura ligada a la alfarería de estilo 'Boca Chica'". Este caso nos plantea otra variante de los periodos tardíos de la actual República Dominicana, desprendidos del concepto terminológico del tainismo, ligando a un estilo de alfarería nativa. Luis Antonio Curet (2015: 20) describe esta posición como una invención académica. Si existe un estilo vernáculo, el "Boca Chica" netamente dominicano, se compromete su significado con una terminología problemática. Así sucede también cuando Alegría (1999: 199) afirma: "Una de las teorías sobre la llegada de los indios taínos a la isla de puerto Rico (que ellos llamaron Boriquén) la sitúa entre los años 500 -1000D.C. Badillo (1989:15) El Borikén taíno, rebautizado como isla de San 
Juan de las Indias, fue el segundo territorio conquistado y colonizado por Castilla en su expansión hacia el Nuevo Mundo".

Alegría y Badillo muestran que ambos estudiosos son consientes de la herencia de Boriquén o Borikén, tierra del nativo de Puerto Rico. Sin embargo, optan por denominarlos taínos. $\mathrm{Y}$ es que la segunda mitad del siglo XX fortalece una nueva identidad cultural compartida en el Caribe, conformándose con una iconografía intervenida. Ese proceso de estandarización científica se apropia de la identidad nacional de Puerto Rico y en esa encrucijada académica social se encuentran Cuba y la República Dominicana.

Desde 1492 las particularidades étnicas originales de la toponimia fueron recogidas por los cronistas. Durante los primeros cuatro siglos numerosos autores caribeños y extranjeros recogieron ese conocimiento y costumbres de la historia oral y la cultura popular. Sabemos que los naturales en el Caribe convivían en unidades de parentelas o grupos, formando tribus y naciones geográficamente aisladas, convirtiéndose esas diversidades geográficas eventualmente en campos incorrectamente identificados. Esa deficiencia ocurre por sinnúmero de razones, por ejemplo, los naturales fueron extintos, o los textos originales en castellano o portugués arcaico y sus semasiologías falseaban, o el latín clásico y otras lenguas europeas antiguas dificultaban las interpretaciones. ¿Cuántos investigadores pensaban como Figueredo que ciertas corrupciones idiomáticas eran chismes literarios? De los investigadores del siglo XIX y XX en el mundo académico, ¿cuántos leían estos textos y archivos de españoles invasores en sus textos originales?

La inexistencia de estudios de ADN en el siglo XIX facilitó la idea de la total inexistencia o extinción de los naturales caribeños. Esa articulación del nativo caribeño americano aún prevalece debido a la falta de razonamiento de la política de supervivencia nativa investida en la evolución multirracial. No obstante, las raíces tempranas de exploradores peninsulares y sus parejas nativas bautizadas, que comenzaron sus familias en las primeras décadas del descubrimiento, son innegables. En el marco académico multidisciplinario se han navegado esas articulaciones poniendo en duda teorías científicas ante la preocupación de la estandarización y terminología taína. Al pasar del tiempo, esas generaciones de mestizos nativos convertidos en cristianos bautizados se acogen a la vida colonial, "disolviendo" la sangre nativa que aún corría por sus venas en busca de seguridad y protección a sus nuevas parentelas criollas. Ese disolver biológico dejó espacios obscuros, no obstante en su transcurso deja un rastro anónimo que en un 
futuro atraerá a investigadores del mundo a seguir las huellas de las políticas nativas de la supervivencia. El descifrar e interpretar a esas gentes caribeñas originales, encontrando residuos biológicos contemporáneos, ofrece una alternativa física que simbolizará un resultado autenticó a la supervivencia nativa. Como bien sabemos, un símbolo desconocido fue "la salvación por vía de la religión de sus adversarios", que le había sido ofrecida a Hatuey, y este prefirió ser quemado. No todos los presentados con esa alternativa prefirieron la muerte.

Las influencias de estudios angloparlantes del siglo XX y de otras lenguas con la intención de simplificar nombres particulares autóctonos, considerados complejos, desarrolló senderos por los cuales los estudiosos caribeños eventualmente incorporan sus propias intervenciones. La encrucijada entre la religión católica, la educación y la terminología estandarizada se enriquecen presentando ideas acogedoras al pensar contemporáneo. Esta dinámica religiosa y política puso rostro a través del tiempo, y así, Alegría (1999: 157) sostiene: "La iglesia católica se ocupaba, en términos generales, de la educación elemental. Los primeros esfuerzos por establecer educaciones educativas fueron realizados por la iglesia”. Instruir a los niños en la fe católica era para la iglesia un deber, ese deber y doctrina durante las primeras tres generaciones de la integración se convierte en una de las razones por la cual se mal interpreta extintos en lugar de asimilados, vestidos y recortados. La extinción física formaría parte de un genocidio, mientras que el bautismo comprende la extinción pagana por vía de la fe cristiana. Esa extinción pagana no es una extinción física o biológica, pero sí se refiere a un profundo cambio. Uno no aceptado por muchos naturales que continuaron en rebelión por décadas.

En cuanto a Alegría, este nos dirige a razonar sus prácticas educativas a través del Instituto de Cultura Puertorriqueño, un interesante tema que continuaremos examinando. En la plaza de Utuado se sitúa una estatua del indio taíno levantando un crucifijo. El simbolismo es claro, el indio converso y la educación eclesiástica es una realidad mientras que la etnohistoria falsea. Entre la salvación de bautismo y religión entrelazamos otros asuntos para lograr una dimensión extendida viabilizando el identificar la diversidad. Reichel-Dalmatoff (1977: 7) adelantó una idea que bien puede dirigirse a fundamentar estereotipos del pensamiento colonial: "Esta actitud de considerar al indígena como inferior y "pobre", con menos capacidad de pensamiento abstracto o inteligente que un blanco, se expresa entonces en la enseñanza formal que se da en muchas escuelas de los misioneros". Se ha señalado ese pensamiento discriminante a lo tropical y a lo nativo en intervalos de siglos. José Juan Arrom (1967) nos dice que: "Pocos pueblos han tenido un 
destino tan cruel como el de los sonrientes tainos que recibieron a Colón en 1492 en las acogedoras playas caribeñas". Como se ha señalado en el transcurso de la tesis, el tainismo académico sigue ciertas reglas básicas en sus investigaciones. La imagen favorable de un indio pacífico y propenso a una fácil conversión religiosa, según Colón anota en su diario en su primera semana en América, es una característica esencial necesaria para implantar una nueva imagen fabricada que cumpla con ese pensamiento original. En este sentido, los sometidos salvajes mueren, surgiendo de las aguas bautismales los salvados por la cruz vestidos y viviendo entre colonos.

Examinemos alternativas entre estas tendencias: "Anacaona contribuyo a aliviar las penalidades de los cristianos y a alegrar la vida de D. Bartolomé, convirtiéndose pasajeramente en su amante" (Casas et, al, Gil y Varela, 2013: 279). Anacaona representaba una sociedad matriarcal, era una mujer líder esposa de Caonabo que pagó con su vida por su política. Si de hecho fue o no amante de Bartolomé, el hermano de Cristóbal Colón, no es lo que se analiza aquí sino su género y su obligación a hacia sus súbditos. Intercalamos conceptos investigados por sus detalles comunes que semejan lo comúnmente leído en la literatura caribeña. Por ejemplo, Carlos Alberto Uribe (1987: 125) dice lo siguiente: "Se intercambiaba el pescado y la sal por mantas de algodón y oro. Unos grupos eran 'donadores' de mujeres en matrimonio a otros grupos con los que tenían establecidas sus alianzas, para cumplir así con los dictados de la exogamia que obliga a encontrar esposas por fuera del propio grupo". Anacaona y Caonabo se acogen al concepto de exogamia por la descendencia de Caonabo. Estas alianzas son de interés, pues se prestan al pensamiento nativo y dan fundamento a una razón por la cual las mujeres nativas fueron receptivas a hombres de otras culturas. En este sentido, desde la perspectiva nativa surge una vía por la cual las obligaciones matrimoniales con colonos fueran acogidas. Volvemos al asunto racial y como se percibe la gente.

Con Gordon E. Lewis hemos recorrido el camino de la raza y su significado en Puerto Rico y en Norteamérica: “(...) aquel que en su isla se considera 'blanco’ descubre rápidamente con horror (...) una identificación étnica le clasifica como negro" (1970: 13). Sabemos que esa clasificación peyorativa norteamericana es común al día de hoy. Igualmente, la raza blanca predomina más en Puerto Rico que en la República Dominicana, en la que existen alineaciones ofensivas. Es adecuado señalar que en el análisis del concepto de supervivencia nativa caribeña la raza no es una condición determinante. La analogía que existe entre el género, la exogamia, la raza y el 
colonialismo caribeño genera un cierto nivel de lógica, favoreciendo la supervivencia nativa en los contenidos biológicos de sus habitantes.

Daniel Torres (2008) señala correctamente: “(...) en el profuso mundo de las investigaciones realizadas descubrimos que "lo taíno" se refiere a fenómenos distintos, dependiendo del autor, las evidencias manejadas y el país". Así, señala correctamente los fenómenos distintos desde Cuba en un artículo que contiene algunas de las realidades de la terminología taína y sus aplicaciones en Cuba. Ahí se refiere a que tal vez la semántica Arauca del término taino remita a "su acepción de bueno no belicoso". Sería de aplicación lo que afirma Marvin Harris (1996: 8): "Y como todavía está por descubrir la manera de separar en todo el repertorio de la conducta de una población humana dada (o incluso de una infrahumana) los elementos heredados de los elementos adquiridos, difícilmente se puede esperar delimitar de un modo operacionalmente válido un campo cultural de estudio utilizando esos términos teóricos".

La carta del Dr. Diego Álvarez Chanca no puede servir de base a la estandarización terminológica. Esa carta de Chanca, enmarcada en su estadía en Guadalupe, un territorio caribe, o el escrito por Pedro Mártir de Anglería desde España, ubicado en La Española, no generan en forma alguna transmisión de herencia ancestral. En La Española, un territorio ciguayo y de etnias diversas, nunca se manifestaron sobre sus lenguas, raza o adscripción alguna. En Cuba escribió Alfredo Zayas y Alfonso que taíno bien parece haber significado bueno (1914). Lo histórico acertado ubica en ese espacio geográfico caribeño a Chanca y Mártir, en dos regiones interpretando lenguas y dialectos distintos, en donde se encuentra la verdad nativa de una palabra, y esa indiscutiblemente, nunca se habló en taíno.

Se ha subrayado que el taíno es una figura fabricada, una anomalía, que no tiene identidad de individuo, grupo o tribu, no es una raza, ni un idioma o dialecto, es una hipótesis académica aplicada científicamente a necesidades técnicas y económicas de naturaleza comercial, y, por tanto, nunca debió simbolizar gente o gentes. Se ha presentado una secuencia o cadena de investigaciones enfocadas en popularizar el tainismo infundiendo en el Caribe tanto a jóvenes como a comunidades a pensar que los tainos fueron sus ancestros. Volviendo a Marvin Harris (1996: 494): "Una premisa fundamental del análisis lingüístico es la de que ni el sistema fonémico ni las reglas gramaticales tienen por qué corresponder al análisis que el propio parlante nativo es habitualmente capaz de realizar". 
Las muestras examinadas en este capítulo amplían la base histórica y presenta al estado del conocimiento en la problemática terminológica que estudiamos. Se han presentado investigadores que favorecieron la estandarización taína. Señalamos hasta ahora la necesidad de sensibilidad en los trabajos relacionados a la cultura nativa caribeña. Para Marvin Harris (1996: 323):

\begin{abstract}
"El concepto de área cultural tuvo su origen en las exigencias prácticas de la investigación etnográfica americana, que lo elaboró como un instrumento heurístico para clasificar y para representar cartográficamente los grupos tribales de Norteamérica y Sudamérica. El desarrollo de las colecciones etnográficas del American Museum of Natural History y el Chicago Field Museum, coincidiendo con la tendencia contra las tipologías evolucionistas, propició la aparición de categorías geográficas usadas como unidades de exposición para la ordenación de los materiales en secciones o en salas".
\end{abstract}

Se utilizó el concepto de área cultural para explicar, diferenciar e identificar semejanzas en norte América. En Puerto Rico y el Caribe se utilizó para avanzar en la estandarización terminológica taína. El detalle de categorías geográficas en la ordenación de materiales de exposición en la República Dominicana, Puerto Rico y Cuba se representa por taína en el área geográfica del Caribe Insular. Así Ricardo Alegría (1996: 257) explica:

"En 1987, la valiosa Colección Latimer, reunida a lo largo de los años por el Sr. George Latimer, Cónsul de los Estados Unidos en Puerto Rico, fue donada al Instituto Smithsonian en Washington, DC. El Smithsonian aún conserva una parte importante de esta colección, aunque muchas de sus piezas más notables, incluidas algunas correas monolíticas llamadas "collares de piedra", se intercambiaron a otros museos en los Estados Unidos y Europa".

Las valiosas colecciones desaparecen de Puerto Rico. Que protección se utilizo para garantizar que esa y otras regresarían eventualmente a Puerto Rico. Nos podemos preguntar qué beneficio cultural presta a la cultura puertorriqueña que sus reliquias de antaño y sus grandes colecciones privadas sean exportadas, catalogadas y engavetadas. Hablamos del 1987 qué leyes existían en Puerto Rico para la protección de la cultura material. Este tema señala que el Smithsonian por ocho décadas recibe, compra y cataloga reliquias del area geográfica que estudiamos.

Gerardo Reichel-Dolmatoff (1960) claramente identifica la importancia de nombres tribales de lo que son grupos aislados de una misma familia, exhibiendo notable diferencias. Igualmente señala fronteras dentro de una geografía selvática. En su 
discusión, Reichel-Dolmatoff señala que los indios se identificaban entre sí con nombres diferentes a los utilizados comúnmente. Así, identificó al grupo occidental en Venezuela Dobokubi y al oriental Mapé. De ambos nombres, uno recogidos de fray Francisco de Cartarroja dice lo siguiente: "Tampoco parece cierto que Dobokubi (sea o era) un nombre tribal; tal vez simplemente signifique "amigo", "bueno", "vecino". Tampoco está comprobado que Mapé sea el nombre de una tribu propiamente dicha" (1960: 184). Mientras el difusionismo es la práctica de investigadores tainistas, teorizando aplicaciones a la difusión de la estandarización terminológica. Al respecto, leamos de nuevo a Marvin Harris (1996: 326-327):

\footnotetext{
"Estas objeciones al concepto de área cultural sacan a la luz la básica esterilidad de cualquier intento de explicar las diferencias y las semejanzas culturales apelando al antípríncípío de la difusión. Aunque sea verdad que, como Driver (1966) ha demostrado, la proximidad geográfica e histórica resulta con frecuencia más útil para predecir rasgos culturales que la causalidad psicofuncional, en ningún caso puede esa proximidad geográfico-histórica constituir una explicación válida de las semejanzas y de las diferencias culturales. Primero que nada: la difusión es manifiestamente incapaz de dar cuenta del origen de ningún rasgo cultural, salvo «pasando el muerto» en una regresión infinita: A f- B e- e é- ...? Tan pronto como admitimos, como la arqueología del Nuevo Mundo nos obliga a hacerlo hoy, que la invención independiente se ha producido en una escala masiva, la difusión es por definición más que superflua: es la encarnación misma de la anticiencia".
}

Durante la segunda fase de la expansión terminológica de Rafinesque, la base hipotética de la estandarización se desarrolló por dos factores de importancia: el área cultural propuesta por Fewkes (1907) y la difusión sistémica e institucional de Harrington (1921), Loven (1935), Rouse \& Taylor (1948) y Alegría y Nichelson (1955), presentando a sus repetidores una ciencia especializada que a su vez no debía representar a persona alguna. La secuencia documental en este capítulo nos deja claro el plano científíco seguido por los especialistas, culminando en una crisis cultural.

Hasta el momento, los fundamentos ordenados de la historia nativa caribeña que estudiamos cumplen con el requisito de fiabilidad y la sensibilidad requerida para formalizar resultados relacionados a la vida humana. La vida humana y su historia se interpretan basándonos en la evidencia documentada en busca de resultados fiables, beneficiosos a comunidades en el entendimiento de sus ancestros junto a las denominaciones usadas por los naturales y el porqué.

Cerramos este capítulo con las palabras de Elizabeth Benedict (1948: 593): "Mi punto es que, una vez que los antropólogos incluyen la mente del hombre en su materia, los métodos de la ciencia y los métodos de las humanidades se complementan entre sí”. 
En la metodología de esta tesis se busca la palabra singular en la dialéctica nativa, recogiendo el significado original de sus denominaciones dentro de sus propias corrupciones, junto a las corrupciones de los investigadores, derivando resultados de entre ambas correcciones. En este sentido, el poeta y el artesano visualizan la mente del ancestro natural mientras viven sobre esas huellas en sus propias geografías, facilitando que verifiquemos verdades y emociones. Examinamos la historia del nativo caribeño en las páginas de autores clásicos cuyos trabajos presentan alternativas a la crisis cultural y académica del siglo XXI. En adición, se discutió la diferencia entre la historia clásica del nativo caribeño y la historia de la evolución de la estandarización terminológica del nativo caribeña basada en el taíno de Rafinesque. Se debe mantener claro que los clásicos representan alternativas mientras la estandarización representa un alejamiento a la historia y una crisis cultural. Se señalo el género y la exogamia como conceptos unificadores, para bien o mal, en el desarrollo de la población caribeña. Este tema unificador lo seguimos intercalando la intención de definir nuevos conceptos complejos junto a resultados conocidos de actividades de los nativos caribeños viviendo en sus hábitats acogidos a sus culturas y pensamientos. Considerando la inexistencia de estudios de ADN en el siglo XIX, se consideró fulminado al nativo caribeño lo que consiste en un error. En Marvin Harris (1996: 33-34) visitaremos el razonar hipotéticamente la evolución biológica contrastado a la cultura y un resultado específico de ADN:

"A esta primera fase de la evolución cultural se la llamaba «estado de naturaleza». Aunque las caracterizaciones concretas de este estado primitivo divergían considerablemente (Hobbes hablaba de la «guerra de todos contra todos»; Rousseau, del «buen salvaje»\}. la explicación del modo en que los hombres salieron del estado de naturaleza y llegaron a las instituciones y a las costumbres que hoy tienen era bastante uniforme. (Harris 1996: 123) Aunque la mayor parte de esos informes provenían de viajeros y de misioneros escasamente cualificados, también hubo una cierta acumulación de datos por obra de observadores preparados y hábiles, entre los que las figuras más ilustres son Henry Schoolcraft, Alexander van Humboldt, Johann van Spix y Karl von Martius, Lewís y Clark. Para una exacta comprensión del desarrollo de la teoría antropológica parece esencial no colocar en ningún punto entre 1750 y el presente una brusca ruptura en la calidad y cantidad de los conocimientos etnográficos".

En esta coyuntura, nuestro primer apunte consiste en lo representativo de una brusca ruptura, y en esta tesis se ha probado esa ruptura por la estandarización terminológica. La pregunta es: ¿sobrevive bilógicamente la exogamia de distintas culturas en tiempos de conflicto? En esta tesis pensamos que es posible. En el estudio de ADN de A Moreno-Estrada et al (2013: 21-22) prestamos atención a un detalle íntimamente 
integrando mestizaje y la evolución biológica de Cuba, Puerto Rico, República Dominicana-Haití:

"En contraste con las muestras de población del continente, el modelo que mejor se adapta a las cuatro poblaciones de las islas del Caribe involucra estimaciones más antiguas del contacto inicial entre los nativos americanos y los europeos. Es decir, hace 17 generaciones para los cubanos y 16 generaciones para los puertorriqueños, dominicanos y haitianos. Los registros históricos indican que las primeras colonias europeas en las Antillas se establecieron poco después del contacto inicial en 1492; es decir, hace unos 500 años o 16.6 generaciones (considerando 30 años por generación), en excelente acuerdo con nuestras estimaciones de tiempo. Otra distinción importante entre las poblaciones continental y caribeña es que el mejor modelo para cada una de estas últimas incluye un segundo pulso de ascendencia africana, que ocurrió hace siete a cinco generaciones, con tasas de migración más altas en haitianos y dominicanos, seguido por cubanos y puertorriqueños".

El promedio de 17 y 16,5 generaciones es calculado a 30 años por generación, de ser menos los años de una generación se cambiaría el número total de generaciones. Por ejemplo, si se calcularan las generaciones a 25 años, el cálculo cambiaría a 20 generaciones en 500 años, lo que es muy posible solo al considerarse las jóvenes embarazadas de entre 12 y 16 años. En la práctica caribeña un bajo promedio de todas las generaciones antiguas ha evolucionado de matrimonios canónicos, la procreación caribeña desde sus comienzos sobrepasó la legitimidad canónica dejando a los niños encaminados a otras clasificaciones. Es de interés que las generaciones de la ascendencia africana en el estudio de ADN de Moreno-Estrada se constituye entre 6 y 7 generaciones, a menos del cincuenta por ciento de lo que serían las generaciones con nativos. Robert Schomburgk (1854: 116-117):

"Pero un cuidadoso observador de las razas mestizas, que en gran medida forman la población de la República Dominicana, ocasionalmente rastreará entre ellos los rasgos característicos de los aborígenes. Algunas poblaciones de la raza humana conservan sus características mucho más tenazmente que otras, las peculiaridades de unos se pierde en unas pocas generaciones y las de otra se transmiten a través de varias. Nunca he visto esa tenacidad más manifiesta que entre las razas mestizas, que hasta el día de hoy se llaman "Indios" en Santo Domingo, y en las que las peculiaridades de los indios puros se han conservado durante más de dos siglos".

En su estadía sirviendo de cónsul británico en la República Dominicana, Robert Schomburgk, experimentado en asuntos de nativos tras ocho años en las selvas de Guayana, dejo claro que no encontró un indio puro, pero si evidencias de lo que llamamos la evolución biológica nativa. El historiador dominicano Luis Joseph Peguero (1763: 378) hace una definición que pudiese ser lo identificado por Schomburgk: 
"Mesclavanse los españoles con mestizos y producían una especie de gente que se llama indios cuarterones, (...) Si el español se mezcla con cuarteronas de algunas de las especies dichas sus producidos se llaman Puchuela, o semi blancos = y si el negro se mezcla con grifa sus producidos son saltatrases. O semi negros. $=\mathrm{y}$ si el indio con grifa sus producidos se llaman cabras".

La lista de mesclas de L. J. Peguero es extensa y en sus propias palabras decía que de todas estas mezclas se componía la isla Española, y añade: "En nuestros tiempos, por la infinita misericordia de dios, no se encuentran sino dos especies, que son blancos y negros". Entendemos que Schombourk observó lo inicialmente dicho por Peguero. Es aparente que Schombourgk difiere con lo que Peguero llama "la infinita misericordia de dios", o el resultado multirracial. Sin embargo, la perspectiva de evolución narrada por Peguero es indicativa de la supervivencia y evolución nativa caribeña en la República Dominicana. 


\section{Capítulo 3: Orden histórico, terminología estandarizada y teorías}

\section{MÉTODOS HISTÓRICOS APLICADOS}

Entre las figuras destacadas del siglo XX cuyas exploraciones y monografías difundieron el futuro del nativo caribeño se encuentra Jesse Walter Fewkes, al que nos venimos refiriendo en esta tesis. El autor nos relata que utilizó tres métodos de investigación en la producción de su manuscrito, presentado al BAE, y estos son: el histórico, el etnológico y el arqueológico: "De los tres métodos de tratar el tema, el arqueológico que se sigue es el principal de este informe, también ofrece una buena oportunidad para el trabajo original; Sino que se extraen de fuentes históricas y etnográficas para dar a las memorias un carácter más comprensible, y se introducen cuando es necesario para interpretar el significado de objetos arqueológicos" (Fewkes, 1907: 21).

El trabajo original desarrollado por Fewkes coincide con la preservación de las antigüedades americanas ${ }^{60}$. Este interpretó la arqueología caribeña a esos fines, y su trabajo se sitúa en una nueva disciplina que examina la historia y las fuentes históricas clásicas. La oportunidad de un trabajo original era un campo abierto. Desde esa fecha se distinguen ciertos trabajos originales de autores de la segunda y tercera fase de Rafinesque acogidos a una nueva terminología estandarizada taína. El contenido arqueológico de la monografía de Fewkes no se analiza en esta tesis, solo se examina el contenido y desviación histórica y sociocultural en su relación a la terminología aplicada a la persona cultural nativa, mientras se repasa el historial del BAE, institución en la que Fewkes trabajo. Y la influencia que el BAE desarrolla en el Caribe.

El Comité de Tierras Publicas sometió el reporte \#2224 en 1906, al que asistieron 39 hombres y mujeres de las instituciones y agencias más importantes de los EE. UU con la intención de aprobar la propuesta para la preservación de las antigüedades americanas (H.R. 11016, 1906). En la representación de esta histórica propuesta encontramos a J.W. Fewkes y a H.M. Holmes del Instituto Smithsonian, a F. W. Putman de Harvard, Seymore

${ }^{60}$ Preservation of American Antiquities 1906. 59th Congress, House of Representatives. 1st Session Report No. 2224. Washington: US Congress, Marsh 12, 1906. pp. 1-8, (p. 2). 
de Yale, Franz Boas de NY Society, Mrs. W.S. Peabody y F.W. Putman del Peabody Museum, y otros como G.W. Bates, S.Y. Stevenson, H. Mason Baum y F.W. Kelsey. Estas instituciones y esos nombres son familiares y contribuyeron a la implementación y desarrollo de las antigüedades norteamericanas, de la cual se deriva la monografía de Fewkes (1907). Por tanto, se da comienzo a la investigación en el Caribe, particularmente en Puerto Rico. El reporte 2224 acompaña la propuesta H.R. 11016 y representan un poderoso mecanismo sobre una base institucional, que en la primera década del siglo XX financiaría centros arqueológicos e investigaciones. Como indica las últimas líneas del reporte: “(...) y yo creo que puede convertirse en una base económica y un eficiente método para llevar a cabo servicios públicos" (H.R. 11016: 8).

Los territorios señalados de los Estados Unidos, a excepción de Utah, que no se habían convertido en estados de la Unión a la fecha de este reporte, se citan en el informe: (...) preparó y presentó a su comité un memorando muy interesante sobre las ruinas en Arizona, Nuevo México, Colorado y Utah, que se incorpora aquí como parte de este informe". Se nota que Alaska y Hawaii no se convierten en estados hasta 1959 y los señalados por Hewett a partir de 1907, a excepción de Colorado. A principios del siglo XX los Estados Unidos entraba de lleno en sus nuevos territorios encontrándose en negociaciones pacificas desde 1867 con Dinamarca para efectuar la compra de las Indias Occidentales danesas. En 1917 pasaron a llamarse las Islas Vírgenes americanas en 1917, tras efectuarse la compra. El novelista Anthony Trollope (1859: 139), desde Cuba, nos cita: "El motivo bajo el cual el señor Buchanan se propone pelear con España, es si ella no quiere vender lo que Estados Unidos desea comprar. Ese es el motivo bajo el cual Ahab se peleó con Naboth. Un hombre queda, individualmente, disgustado cuando un presidente de los Estados Unidos hace tal declaración”. Continua Trollope narrando en un sentido más amplio los beneficios que Cuba recibiría. Cuatro décadas más tarde esa misma acción resulta en una invasión y retención de Puerto Rico. Esa primera década del siglo XX fue critica en la anexión de territorios y la administración política de una cadena de islas bajo la bandera norteamericana que incluía a Puerto Rico, donde existía una hispanidad, un mestizaje y una cultura de cuatro siglos básicamente desconocida en Estados Unidos, mientras que el ordenamiento y rescate de la arqueología, etnografía, antropología e historia caribeña se organizaba desde Washington.

Estos acontecimientos fortalecen la influencia norteamericana en el Caribe en asuntos políticos, económicos y administrativos en todos sus niveles sociales. Esa estructura económica favorece el desarrollo de una metodología moderna relacionada con 
la investigación científica de la cultura del Caribe por angloparlantes, y se acoge al programa de protección de antigüedades de las autoridades de tierras norteamericanas. Las primeras décadas del siglo XX introducen una nueva visión comercial en un conjunto de avances tecnológicos que no dejaron espacios sin explorar. En los procesos científicos, la metodología es ampliada formalmente en inglés y esas intersecciones las hemos señalado para identificar el éxito de la terminología taína de Rafinesque.

Desde las primeras décadas del siglo XX se da comienzo a una historia paralela a la iniciada en 1836. La semilla cultural había germinado desde Filadelfia y sus raíces durante la fase de incubación se habían fortalecido. La búsqueda de atributos afines entre diferentes grupos humanos tendió a homogenizar culturas y etnias caribeñas.

Del estado de esa ciencia en la época, afirma Marvin Harris (1996: 221): "Boas era una auténtica fortaleza de sobriedad científica si se le compara con la mayoría de sus contemporáneos. Aunque su cautela ante las generalizaciones retrospectivamente parece exagerada y derrotista, no hay duda de que los criterios de sus contemporáneos eran absolutamente indefendibles. Sin un fundamento firme en las universidades, los temas antropológicos eran presa fácil para todo tipo de aficionados imaginativos". Los criterios de sus contemporáneos eran absolutamente indefendibles. Esa realidad, en el caso de estandarización terminológica taína, desde Rafinesque es innegable. En este capítulo examinamos los resultados de esa nueva ciencia. En este amplio territorio caribeño se han agrupado bajo esa terminología razas precolombinas, culturas nativas, particularidades tribales, parentelas y clanes en geografías separadas aun cuando el taíno carece de realidades históricas. Caracterizar esos ámbitos socioculturales y las particularidades internas y externas de comunidades caribeñas de origen siempre fue un gran error antropológico. El rotundo éxito comercial de las expediciones arqueológicas y las importantes colecciones desde comienzos del siglo XX favorecieron a los aficionados imaginativos sobre un campo fértil.

Este enfoque agrupador lo emplean gran parte de investigadores contemporáneos modificando una tendencia unificadora basada en una fabricación que aprovechó la economía y política para homogenizar particularidades culturales autóctonas, singularizando y neutralizando el Caribe insular. La recompensa sería un siglo de estudios avanzados desligados de la literatura de cuatro siglos de historia caribeña, por considerarse una nueva brecha, o bien ser, una rotura cultural que continuamos presentando y analizando. Resulta infructuoso atestar espacios inéditos, menospreciando culturas apartadas de las marcadas tendencias humanas y verificables que aportaron los 
autores clásicos. Estos espacios se manifiestan infinitos y abarcan innumerables teorías en la historia y prehistoria caribeña. Se han examinado tendencias de mercado aplicadas a un símbolo singular representativo de la eficiencia y tendencias comerciales desde capitales extranjeras con anterioridad al siglo XX al Caribe, adquiriendo esos recursos intelectuales y económicos en el siglo XX un mayor alcance.

Volvemos a encaminarnos a los textos de investigadores en línea con el ordenamiento de lo que cada vez da la impresión de ser consecuencias de una política en base a una adquisición y captura no solo de la cultura material, o la persona cultural, sino abriéndose el camino a una nueva formación científica y comercial.

Este tema tiene dimensiones difíciles y complejas, dando lugar a investigaciones profundas que pueden ser alarmantes. Y citamos a J. Jiménez-Santander y L. JiménezOrtega (2008: 13):

"Como para complicar mucho más una madeja que ya se había tornado compleja, Fernando Ortiz también decidió poner nombres nuevos y muy diferentes a los grupos aborígenes que poblaron Cuba: al Guayabo Blanco, lo denominó Aunabey, al Cayo Redondo, lo nombró Guanajatabey; al Ciboney, Baní y a los tainos, Pueblo Viejo. Por suerte, estos nombres no fueron reutilizados por los investigadores, ni mucho menos llegaron al conocimiento general de la población".

Ese enfoque de madeja de Jiménez continua en Rodríguez-Ramos (2008):

"Hasta hoy día somos testigos de una marcada inconsistencia aplicada de términos culturales para hacer referencia a las personas que habitaban las islas antes de la migración(es) Arauca. Mientras algunos académicos todavía utilizan Ciboney para referirse a culturas que son "reliquias" de los primeros habitantes de las islas (Gonzalez 1995; Lalueza Fox et al. 2003; Osgood 1942) otros usan ese término para referirse a los sub-grupos taíno en Cuba (ej., Alegría 1981), para identificar las últimas manifestaciones de esta cultura (ej., manifestaciones Cayo Redondo; La Roza 2003), o como un concepto genérico refiriéndose a todos los indígenas de Cuba (ej., Coll y Toste 1897)".

Los cambios presentados en estas citas bien pueden ser los que Harris llamó aficionados imaginativos, que comenzaron desde mediados del siglo XIX a identificar esas culturas reliquias de los primeros contactos. Coll y Tosté (1897) es el único cuya asociación con los investigadores listados parece estar fuera de lugar en discusiones de sub-tainos. Coll y Tosté es el único que descartó la terminología taína y es el único autor publicado en el siglo XIX y citado.

En general, las obras de Olsen \& Bourne (1906), Fewkes (1907), Harrington (1921), Loven (1935), Rainy (1940), Rouse (1992) y Alegría (1978) fueron financiados 
por instituciones en un proceso de comercialización e investigación. Esos medios económicos les proveían a sus investigadores ordenación, distribución y clasificación de la cultura material, prefiriendo acogerse a la normalización y estandarización en procesos y actividades para simplificar y comunicar resultados científicos replicables.

En las referencias señaladas, los estudios críticos contemporáneos dan cuenta de grupos geográficos nativos en el Caribe insular cuyas dimensiones no deben restringirse al término taíno o expandirse en esa terminología. Estas bifurcaciones penetradas por el tainismo barajan campos socioculturales intercambiando teorías e interpretaciones o, según dice Rodríguez-Ramos, "somos testigos de una marcada inconsistencia aplicada de términos culturales". Interponer teorías a lo desconocido e implantar un orden nativo fuera de los márgenes históricos pone en riesgo la imagen cultural de comunidades, y la herencia cultura, creado daños a comunidades y a la persona cultural.

\section{DENOMINACIONES PREHISPÁNICAS Y TEORIAS QUE ENCIERRAN PROYECTOS}

Nombres comunes de comunidades nativas precolombinas de mayor reconocimiento son: borincano, boricua, borinqueño, quisqueyano, quiesquellano (quiqueianos), siguayos, ciguayos, macorije, marolis, (macorixes), haitianos, aytianos, cubanos, lucayos, jucayos y demás de raíces arahuacas/araucas, junto a caribes sus dependencias uniformes y otras tribus y uniones. ${ }^{61}$ Las analogías significantes de la composición de nombres no han sido estudiadas en su profundidad. Las conformidades biológicas nativas según Virchow (1886) se asumieron con el propósito de generalizar, nunca con el propósito de entender el propósito original de adscripciones. Estas características de uniformidades particularizadas se expanden en geografías y toponimias ligadas a la naturaleza del medio ambiente dentro de colectividades en su propia evolución. Sin embargo, esa evolución pasó desapercibida, al igual que el significado de las denominaciones nativas.

Otro problema de las investigaciones actuales acogidas al tainismo es que se apartan de realidades patológicas, psicológicas y socioculturales del primogénito caribeño que vivió en su entorno natural particular, junto a sus características dentro de su historia. Si olvidamos que expandir el conocimiento requiere entender esa evolución

\footnotetext{
${ }^{61}$ Ver tabla \#3
} 
de antepasados fuera de la terminología taína al intentar llenar esos llamados espacios oscuros o lagunas en su relación a las comunidades auténticas, especialmente en Cuba, Puerto Rico y la República Dominicana, constituimos una incongruencia.

Levy-Bruhl (1923) señaló que las representaciones colectivas se desarrollan en el pensamiento aborigen colectivo y siempre parecen estar presente en su entorno natural inconscientemente. Carl Jung (1967: 99), refiriéndose a Levy-Bruhl, dice que existe un segundo sistema psíquico: el colectivo, universal e impersonal y natural, que es idéntico en todos los individuos y es heredado. Esta naturaleza orgánica del pensamiento inconsciente nativo, contenido en sus costumbres, entorno material y el suelo de los naturales, está contrapuesta a una estandarización terminológica donde se implantarían desventajas a estos naturales y sus descendientes. Al remplazar la herencia cultural colectiva de sus ancestros con una imagen ilusoria, sea el taíno u otra fabricación académica, se crea una disconformidad cuyas consecuencias son desconocidas a largo plazo; mientras negando una herencia auténtica de antepasados reales, interviene con lo colectivo natural.

Esas representaciones colectivas en el plano universal de Levy-Bruhl (1923) y Jung (1967) que heredan los individuos de su medio ambiente se representa en una amplia diversidad lingüística en comunidades tribales isleñas, viviendo integrados dentro de la naturaleza geográfica que los rodea, de las que surgen peculiaridades autóctonas diferenciadas. Esas diferencias autóctonas deben ordenarse singularmente en sus propios exónimos, etnónimo y toponimias alejados de un fenómeno fabricado. En este sentido, la mente colectiva primitiva caribeña, en sus operaciones naturales, según bien dice LevyBruhl, se limita a lo que ve y conoce, que son conceptos de lo reconocido. Lo reconocido es su naturaleza y lo que ven es inseparable entre sí, por tanto, estos nativos caribeños se distinguirían unos de otros en sus propios ambientes y se autodenominarían en su propio método de pensamiento para protegerse de sus adversarios, sean humanos, espíritus o encontrados en la naturaleza física del entorno.

Hemos examinado denominaciones de pequeños grupos que se identificaban por amistad, matrimonio, comercio a enemistad dentro de su ambiente orgánico. Uno de los lugares donde encontramos el quien soy primitivo lo provee Levy-Bruhl (1923: 59): “(...) los primitivos viven, sienten, piensan, se mueven y actúan en un mundo que en grandes y muchas maneras no coinciden con el nuestro". El primitivo caribeño ve, conoce y se mueve entre sus propias realidades y dentro de su colectividad, su tribu, clan, parentelas o agrupación definida por sus rutinas separadas las unas de las otras en su propio hábitat 
dando lugar a identidades auténticas propias. Levy-Bruhl señala que no coinciden con el nuestro, lo que habíamos discutido. ${ }^{62}$ Esta sección señala lo auténtico del primitivo caribeño dirigido en su análisis al entendimiento y racionalización de la base investigativa de Fewkes al plantear sus tres formas analíticas de investigación sin abarcar la propia naturaleza orgánica nativa. La vida colectiva natural es un elemento fundamental en trabajos socioculturales al identificar factores humanos, así sea en objetos arqueológicos o en la vida y manos auténticas de la gente que los elaboraron justificando esa naturaleza orgánica.

Las páginas de la monografía de Fewkes contienen muy poco, a juzgar por el volumen del trabajo relacionadas al taíno, sin embargo, esas pocas páginas son las más citadas y atractivas para los investigadores.

Cuando centramos la discusión en el término taíno con el propósito de reconstruir el lenguaje nativo de Haití, nos topamos con inmensas impropiedades, una y otra vez. Julius R. Olsen y Edward Gaylord Bourne (1906) y Jesse Walter Fewkes (1907) despertaron el interés de los estudiosos cuando promovieron una terminología para sintetizar una raza, tribu o ingenio caribeño. Se apoyan estos científicos en la traducción que realizo el británico Sir Richard Henry Major (1847) de la carta del doctor Diego Álvarez Chanca, médico cirujano en el segundo viaje de Cristóbal Colón en 1493. Sin embargo, es a partir de 1907 cuando el término taíno se populariza, desde el momento en que Jesse Walter Fewkes presentó los resultados finales de sus investigaciones arqueológicas en el Caribe al Smithsonian Institution en su monografía titulada The aborigenes of Porto Rico and neighboring islands. Fewkes substituye antillano por taíno, e incluso el nombre de Puerto Rico por Porto Rico basándose este último en las interpretaciones del Congreso norteamericano del 12 de abril 1900. Esa nueva teoría taína agrupará a los nativos caribeños por más de un siglo, donde los límites naturales de comunidades nativas caribeñas asumen nuevas particularidades.

Las teorías de Fewkes y Olsen y Bourne fueron aprovechadas por otros destacados especialistas, creando modelos que servirán de base a nuevas generaciones de repetidores arqueólogos, etnólogos e historiadores caribeños especializados en la reconstrucción nativa. La primera década del siglo XXI marca unas tendencias reconstructivas de las

\footnotetext{
${ }^{62}$ Ver, cap. 1, Levy-Strauss y Viveiros y (Smith 2013; Vaioleti 2006). En relación con la vida natural nativa, y: la distinción clásica entre Naturaleza y Cultura no puede ser usada para describir dominios internos a las cosmologías no occidentales sin primero someterse a una crítica etnográfica rigurosa.
} 
representaciones ligadas a la terminología taína junto a su alejamiento. En este sentido, investigadores experimentados y otros se encuentran en encrucijadas cambiantes.

Veamos una hipótesis de requisitos propuestos como referentes principales en el caso de los tipos de las tribus Crow y Omaha. Floyd G Lounsbury (1965: 149):

\begin{abstract}
"Suponemos que el principal referente de cualquier término de parentesco es el tipo de parentesco genealógico más cercano de la clase de los cubiertos por el término en cuestión. Especificamos esto como el "miembro focal" de la clase, del cual todos los demás deben derivarse por medio de los principios de extensión que se deben postular para el sistema. Si dos o más tipos de parentesco son los genealógicos más cercanos en una clase y están igualmente cerca, especificamos ambos como miembros focales. Cuando dos parecen estar igualmente cerca (en la notación en la que están escritos), pero uno es lineal y el otro es de tipo colateral, el tipo lineal siempre se considera más cercano".
\end{abstract}

Lounsbury supone un término de parentesco del cual se derivan otros principales considerados miembros focales otros serian colaterales. Usamos esta comparación para analizar el significado de sociedad taína. Taíno pretende ser un miembro focal, pero carece de familia. No puede constituir un término de parentesco, pero pretende representar una tribu principal y colateralmente una etnia homogénea geográficamente ocupando una genealogía compleja en un archipiélago de islas. A la altura de las primeras dos décadas del siglo XXI encontramos marcadas diferencias en la definición de la estandarización terminológica taína. La institucionalidad de esa estandarización terminológica no aporta repuestas fiables al complicado universo del lenguaje, parentescos originales y un significado idiomático en base a la geografía y cultura nativa caribeña. La perspectiva nativa caribeña y el concepto noratlántico están ligados por las incongruencias y simplismos de investigadores durante un siglo de malas interpretaciones. Floyd G Lounsbury (1965: 160) vuelve a recordarnos:

"Regla de fusión y colaterales: En el artículo anterior sobre sistemas de tipo Crow y Omaha (1964a) se señaló que los casos más simples de estos tipos requieren solo tres reglas de equivalencia fundamentales: (1) una regla de "sesgo" de Crow o Omaha de una de las subvariedades indicadas; (2) una regla de "fusión"; y (3) una regla de "medio hermano". Para el sistema Trobriand, acabamos de exponer nuestra hipótesis sobre la forma apropiada de la regla de Crow. Ahora debemos dejar al lado lo que pensamos que son las formas apropiadas de las reglas de fusión y medio hermano, también como cualquier otro que parezca necesario. Luego podemos probar nuestras hipótesis para ver si son capaces de explicar los datos empíricos proporcionados por Malinowski”.

Los estudiosos contemporáneos de estudios caribeños no coinciden entre sus propias tendencias al identificar fundamentos de lingüística y origen nativo alejados de la terminología taína. Lounsbury se acoge a reglas y diminutos signos apropiados para el 
examen de tribus o naciones de nativos americanos. Desde la segunda mitad del siglo XX los investigadores reflejan la citada normalización y su cuestionamiento genera inquietud entre investigadores institucionales, directores de museos y editores comerciales especializados. Las teorías taínas, según fueron advertidas por el antropólogo Daniel Garrison Briton (1871), se convertirían en unas teorías descabelladas. Autores caribeños, entre los que se encuentran A. Zayas y Alfonso (1914), A. Stahl (1889), C. Coll y Tosté (1907) y E. Tejera Penson (1978), se opusieron a denominar a los nativos regionales con el término y terminología taína.

La base documental taína continuó ampliándose cuando investigadores tainistas, buscando raíces agrupadoras clásicas, implicaron en su intento justificativo a figuras de la talla de fray Ramón Pané, escribano del primer documento de costumbres nativas de América, cuando Ramón Pané nunca utilizó el término taino. Un claro ejemplo lo es Arrom (1967). Del mismo modo se atribuyen a otros autores clásicos del siglo XVI de la talla de Bartolomé de las Casas, Gonzalo Fernández de Oviedo, Michele de Cuneo, Pedro Martir de Anglería, Francisco López de Gomera, Antonio Herreras y Tordesillas, Amerigo Vespucci y Andrés Bernáldez, entre otros autores una relación a la terminología taína, aplicada a raza o tribus y sus tendencias. Las numerosas ediciones de estos autores hasta el siglo XX permanecieron libres de estas suposiciones terminológicas, hasta adentrada la comercialización caribeña de colecciones de reliquias y artefactos nativos a partir del 1900.

Al interpretar agrupaciones nativas apoyados en relatos construidos en el periodo moderno, algunos investigadores del siglo XXI teorizan un taíno real a comunidades caribeñas. Tras cien años de comercialización terminológica examinando e interpretando escritos clásicos y su relación a nativos, es imperativo entender la toponimia desde la organización nativa y no la interpretativa institucional. Siguiendo el grupo de autores señalados en Rodríguez Ramos et al, encontramos una nueva muestra en José Oliver (2009: 6), quien señala: “Esta sección es también difícil de escribir pues si 'taino' es en esencia un término inoperativo que se refiere a nada de substancia real, entonces qué término deberán usar los arqueólogos". Oliver se detiene a identificar un problema y asume la postura de Arrom, quien difundió sus ideas en las notas a la edición del primer libro de América de Ramon Pané, unas teorías que luego los arqueólogos contemporáneos y otros especialistas afines usan de modelo, teorizando un universo taíno y/o cultura taína, alejándose de las realidades caribeñas naturales. Oliver presenta un espacio: entonces que término deberán usar los arqueólogos. La historia provee un importante 
listado de denominaciones. ${ }^{63}$ Esa pregunta o ese espacio lo contesto Harris con relación a Boas. La ciencia o el estado de la arqueología caribeña, según Oliver, supone una imperfección. Volvemos a las palabras de Elizabeth Benedict (1948: 593), que a su vez responden a la interrogante de Oliver: "Mi punto es que, una vez que los antropólogos incluyen la mente del hombre en su materia, los métodos de la ciencia y los métodos de las humanidades se complementan entre sí”. La repuesta al problema señalado por Oliver a una aplicación arqueológica terminológica se encuentra en esa mínima palabra representativa de las denominaciones usadas por nativos caribeños en sus propios entornos. Encontrar y aplicar esa palabra es el asunto correspondiente para acreditar el artesano en su medio ambiente uno que ahora es desconocido.

Ruth Benedict se refiere a las humanidades como una herramienta de recursos al perfeccionamiento de un estudio científico. Esa actitud multidisciplinaria representa una alternativa en la reconstrucción del obstáculo señalado por Oliver. La estandarización taína y su terminología científica no pueden sobrepasar la obstaculización creada por su propia imperfección. Su base científica desde sus comienzos desestimó la historia que es un requisito en estos momentos de crisis cultural. La solución epistemológica requiere identificar el artesano y su ámbito cultural estableciendo un orden lógico entre artesano, artefacto, cultura y ancestro. La incidencia levantada por Oliver no es únicamente, pues si 'taino' es en esencia un término inoperativo, y tampoco exclusivamente, el hecho es que esa falla científica pasó desapercibida durante las tres fases del taino de Rafinesque y en ninguna de esas fases se prestó atención a las objeciones. El establecer geográficamente quien, y cuando, basado en la perspectiva nativa de la persona cultural en el medio ambiente tribal se ha convertido en una urgencia.

La crisis cultural se identifica cuando: (1) un número indeterminado de personas piensan ser herederos legítimos de una gente que nunca existió; (2) cuando personas nacidas y educadas asumen la herencia taína, a su vez considerándose indios entre ellos y sus familias; (3) cuando, nativistas como Estévez, piensan que asumir el término y terminología taína es adecuado simplemente porque encaja (la aceptación de el vivir en una simbología o fenomenología cultural fabricada; (4) el estado promueve la estandarización terminológica taína.

${ }^{63}$ Ver; tabla \#3 


\subsection{El mercado de la cultura y la ciencia}

La terminología del nativo caribeño junto a su mercantilización son una cuestión operacional clave. Basándonos en esa dinámica empresarial y su relación a las humanidades, algunas preguntas son esenciales para interpretar y aplicar reglas metodológicas: ¿Es legítimo el término? ¿Causará desventajas a comunidades? ¿Es justificable la política de su implementación? ¿Cumple con objetivos sociales? ¿Cómo se prueban factores humanos y comunitarios a corto y largo plazo? ¿Contesta el término taino esas preguntas, es apropiado su uso en la demografía caribeña y son sus diferencias socioculturales? ¿Son legítimos y justificables los intereses comerciales en torno al taino?

El reporte de la Cámara de Representantes de (H.R. 11016, 1906) era claro en sus intenciones: proteger la cultura material en forma eficiente y económica fundamentándose esa práctica en un elemento básico aplicado al Caribe con la intención de proteger, exhibir y archivar. El éxito de esa práctica fue contundente y la protección física de objetos y artefactos y los estudios que le acompañan son de una alta calidad, sin embargo, las ventajas a la persona y comunidad cultural brillan por su ausencia. Se formaron colecciones mientras los archivos y la documentación no ha cesado de aumentar desde comienzos del siglo XX, proporcionando beneficios a museos e instituciones como resultado directo de una excelente producción científica comercial.

Con el concepto de la industrialización, los científicos nombraron por miles objetos, artefactos, productos, tecnologías, personas, razas y eventos, componiendo categorías y nombres operacionales técnicos que hasta entonces no habían sido identificados según su uso. El fin era avanzar en el conocimiento, en un formato mecánico de economía de mercados uniformes. Avanzar en la simplificación y homogenización de los términos significaba mayor comunicación entre especialistas diversos, originando un proceso de conocimientos mejorando los beneficios mientras satisfacían a sus consumidores. Este proceso se convirtió en una práctica común, prolongada por décadas, que se alejaba de la estructura tradicional de la investigación científica. Wuster (1930), un lingüista austriaco, desarrolló la primera metodología para el procesamiento de datos de terminología y el análisis de términos ordenadamente. Porque, como bien nos recuerda Protopopescu (2010: 2): “antes de la primera mitad del siglo XX ni lingüistas ni científicos sociales prestaron atención a la terminología”.

Debido a esa falta de atención de lingüistas y demás humanistas, la nueva terminología, el término taíno, poco destacado, pasó casi desapercibido del mundo 
académico mientras satisfacía al interés comercial angloparlante y europeo. El término taíno comienza a promoverse a inicios del siglo XX, tras la adquisición de Puerto Rico en 1898. Consecuentemente, este nuevo vocablo evoluciona entre intervenciones políticas y manipulaciones económicas interesadas en colecciones, adquisiciones y controles escolares. En ese sentido, desde mediados hasta el final del siglo XX no se habían identificado falla alguna, la economía era excelente y los consumidores eran los funcionarios y los operativos institucionales continuaban evaluando el interés de alumnos que desconocían que la raza y cultura taína era una fabricación.

El uso cuestionado de añadir notas editoriales y de pie a documentos históricos, apartándose de la intención o idea original, era común y descansa parcialmente en el dictum de la ley del menor esfuerzo propuesto por Hill (1900:712-713), cuando el lenguaje se convierte en un impedimento. Quehacer que facilitó inicialmente la diseminación del término taino. A este proceso de ordenación económica lo habíamos identificado como la trilogía fenomenológica económica tainista.

A Rafinesque le pueden agradecer sus seguidores el éxito y marketing del término taíno, siendo numerosas las investigaciones científicas beneficiadas. El empleo de la expresión taíno se priorizó con interés comercial en las últimas dos colonias españolas, Cuba y Puerto Rico, definiéndose con un mayor potencial en el Caribe. En esta forma, el taíno se convierte en una herramienta académica, económica y social para el establecimiento de controles identificativos de nativos caribeños.

\subsection{La adquisición de Puerto Rico}

El termino se consagró en un proceso administrativo desde una plataforma académica y económica. En palabras del director del Bureau of American Ethnology (BAE) W.H. Holmes: "La adquisición de la isla de Puerto Rico en la clausura de la guerra con España aumenta considerablemente el interés popular y científico en la arqueología antillana y la etnología en los Estados Unidos" (Fewkes 1907: XXVI). El BAE, como rama investigadora del prestigioso Instituto Smithsonian fundado en el 1879, representa prestigio e institucionalidad. En 1901 le asignaron al arqueólogo Jesse Walter Fewkes la tarea de investigar las Antillas y al concluir afirmó la locución taína, y él nos relata el porque del taíno: "Como es significante y sonoro, se puede adoptar como un conveniente 
substituto para el adjetivo 'Antillano' para designar un (fenotipo) tipo cultural”' (Fewkes 1907: 26).

Surgen de Fewkes dos palabras de importancia, significante y sonoro, utilizadas para una sustitución de antillano, extendiéndose en un continuo crecimiento del término y terminología taína. Basándonos en la simpleza de la cita es difícil comprender el increíble éxito académico y comercial obtenido, y el hecho que las objeciones del momento fueron totalmente ignoradas. Habíamos señalado los proyectos de conservación de las antigüedades, el Bureau of American Ethnology, y el Manual del Indio Sur Americano de J. H. Stewart $(1963)^{64}$. Luego de haber identificado esas dos palabras como justificables, citamos nuevamente a Fewkes (1907: 6): “otros autores lo utilizaron con anterioridad (...) como un nombre característico de la raza antillana”.

Con solo dos palabras y unas oraciones se implementa y validan una serie de objetivos arqueológicos y etnológicos que directamente afectará a comunidades en el Caribe por décadas. El éxito fue tan significante que ha debido transcurrir un siglo para comenzar a dudar de su validez, y se ha entrado en la segunda década del siglo XXI en un periodo de normalización revisora. ${ }^{65}$ Debe entenderse que esas mínimas palabras tuvieron un impacto impresionante

El adjetivo "antillano", a su vez, es otro término limitado que se refiere a la raza arahuaca, caribe o a la uniformidad biológica de sus descendientes habitando el archipiélago caribeño precolombino y post-columbino. De manera especializada, Fewkes alude a las teorías y aplicaciones internacionales de Rafinesque (1836) y de sus amigos Jegor von Sivers (1861) y von Martius (1876), quienes en Alemania investigaban asuntos caribeños identificados por Olsen \& Bourne (1906). En este proceso de sustitución de razas, Fewkes tendría que justificar la legitimidad de dicha sustitución.

Según Ogola Onyango (2005), adaptar un término a sociedades, razas y seres humanos ya diferenciados entre sí históricamente no cumple con objetivos legítimos. No existe razón alguna por la cual los niños en comunidades caribeñas deban aprender en sus escuelas desde la infancia a usar un término que sustituye su propia raza y herencia cultural. Luciano Gallino (2005), en su diccionario de sociología define la tendencia investigadora de Fewkes en su relación a términos y terminología de la siguiente forma:

${ }^{64}$ En adición Stewart publicaba en sobre Puerto Rico: Stewart, J.H., 1956. The People of Puerto Rico, A Study in social Anthropology.

${ }^{65}$ Normalización revisora, en este estudio constituye una revision y un periodo de tiempo desde 1836 que aun en el presente es dudosa en relación a la terminología taína. Esa normalización hoy día no se ha logrado. 
“esta acción es común de antropólogos culturales, en especial cuando el término es utilizado en plural".

Resulta indispensable examinar una variable específica y preocupante que comenzó en el colonialismo e incluye a Rafinesque e investigadores de principios del siglo XX. Olsen y Bourne (1906: 443) conduce una discusión bajo el tema de Las funciones mentales de las sociedades inferiores. Como se observa en su título, el autor considera a los nativos inferiores en el siglo XX, siendo esa adjudicación peyorativa solo el comienzo. Este tema lo hemos examinado ligeramente puesto que es malinterpretado y es controvertido, muy relacionado a lo noratlántico. Este sentimiento de discriminación es muy difícil de reprimir en las tendencias del mundo anglosajón y europeo, y aparenta haber sido conscientemente utilizado durante el desarrollo de criterios aplicados a las comunidades caribeñas de la época facilitando la implementación del término taíno.

Este nivel de supresión se presenta al mundo a través de la obra de Fewkes como el de la nueva raza caribeña en una forma directa y efectiva. Desde el 1901 la decisión de adaptar una nueva denominación en una enorme área de millones de habitantes fue posible. Pensar que eso pueda lograrse o perpetuarse en el pleno del siglo XXI es totalmente contrario a las realidades de esta época.

El término taíno fue adaptado como si fuese una pieza mecánica, instituyéndose la imagen de una marca plurilingüe utilizada comercialmente en un formato académico público para mercadear, etiquetar y fabricar simbolismos y conceptos en el Caribe institucionalmente.

A esa teoría de seres inferiores se le deben sumar las nuevas desventajas que, aun sin conocerse a largo plazo sus consecuencias, están íntimamente relacionadas al término Taíno en su analogía a la persona cultural caribeña. Estas desventajas son el resultado directo de las aplicaciones técnicas y operacionales de especialistas que acompañan el vocablo e interpretan a su vez la mente y la inferioridad nativa.

Ahora bien, ¿cuál es el dilema? La historia verificable y real en este sentido fue distanciada o silenciada por fuerzas externas para crear una base científica, moderna y flexible que se conceptualizara e intercalara en un espacio considerado oscuro o vacío para facilitar las nuevas investigaciones. La idea era materializar nuevos conceptos y teorías de una raza diferente en la imagen predominante del taíno en las Antillas, evitando expandir el tema de la autodenominación nativa especifica.

En esta sección se presenta una serie de argumentos axiomáticos que proyectan innegables condiciones sociológicas y políticas que se pudieran interpretar prejuiciadas y 
comunes, según nos presenta Premdas (1996: 23): “A menudo, a los caribeños se les dice que no pertenecen y son tratados como ciudadanos de segunda clase".

El ciudadano de segunda clase relacionado a las últimas dos colonias de España en América es algo que en su momento histórico fue significante por las fechas y los prejuicios de esa época: en 1898 se firma el tratado de Paris, en 1902 la independencia de Cuba, en 1901 se encarga a Fewkes la responsabilidad de estudiar a Porto Rico y las islas colindantes. Hoy en día la resonancia de ese ciudadano de segunda clase forma parte de factores que eventualmente se ordenan enfilando desventajas. Entre 1902 y 1907 se discute y se presenta en Washington los pormenores de la región, estudiando, protegiendo artefactos, colecciones y cultura e historia a cambio de un símbolo. Este acomodamiento es reminiscente de los cascabeles que los conquistadores intercambiaban por oro a los que consideraban salvajes. El simbolismo de la terminología taína presentaba un camino a la convalidación humana de la vida caribeña desde sus primeras notas históricas. Premdas (1996: 15) se refiere al residuo aborigen del Caribe que no reclama o reclamó su propia patria, que ahora pertenece a nuevos ciudadanos, y añade: "La patria caribeña, no son de todas maneras lugares de antaño donde la gente del Caribe y sus ancestros han vivido siempre". "Los desendientes de los imigrantes post-indígenas son ahora los legítimos herederos del Caribe. (...) todo esto parecería haber dejado el Caribe como un lugar donde la propiedad de la patria es indiscutible e incuestionable".

Esta reflexión señala un pensamiento común y aprovechable para entender cómo y porque el término taíno cobra vida en la simpleza caribeña de la época. El poder sustituir un término e implantar la creación de una raza fabricada por falta de oposición nativa o considérense la patria, de nuevos habitantes, convierte esa patria en terra nullius. El territorio debe ser reinventado y poblado con una nueva memoria. Tanto es así que en 1996 se desconocían los porcentajes de genética nativa encontrados en Puerto Rico, Cuba y en la República Dominicana.

En esta sección nos acercaremos al pensamiento local de los que viven el día a día caribeño y desde Puerto Rico. Jalil Sued Badillo llegó a expresar "que los puertorriqueños no tenemos sangre indígena en nuestras venas"; y habría añadido: "Como investigador del tema indígena puedo asegurar que la herencia biológica de los aborígenes en Puerto Rico es totalmente inexistente" (Delgado, en Robiou et al, 2011: 91). Esa opinión Delgado no la comparte, como han confirmado los estudios de genética llevados a cabo por Martínez (2003), Luna (2006) y Mendizabal et al (2008), entre otros. 
Cuenta A. Tío (1966: 275) que Ricardo Alegría realizó un estudio en la Universidad de Puerto Rico (UPR) basado en el diente de pala, recogiéndose que un $30 \%$ de los estudiantes tenían características o sangre del indio-americano. Alegría completó su estudio proponiendo la terminología taína a la comprobación por su propio estudio que había una supervivencia nativa. El resultado del diente de pala y el porcentaje recogido arroja un numero compatible con estudios de ADN cinco décadas más tarde.

\subsection{Documentos históricos y notas a pie de página}

El Dr. Diego Álvarez Chanca era un médico cirujano de Sevilla asignado por los Reyes Católicos a acompañar al almirante Colón en su segundo viaje a las Indias en (1493). La carta que escribió Álvarez Chanca al Cabildo de Sevilla, a Juan Rodríguez de Fonseca, organizador del segundo viaje, ha llevado a identificarlo como el primer espía de América (Segarra, 2009: 1) ${ }^{66}$ Durante su estadía de ocho días en Guadalupe o Turuqueira o Cibuqueira, según conocida por los nativos, Álvarez Chanca uso la palabra tayno, cuyo significado es aceptado, significando paz o bueno. Esta es una palabra que siglos más tarde servirá de instrumento para crear la nueva estructura social y de raza antillana o caribeña, según las intenciones originales -Olsen y Bourne, 1906, seguidas por Fewkes, 1907- para interpretar razas, rasgos, y estilo de artefactos bajo una terminología análoga al término taíno. "En Guadalupe había, entonces, evidencia de asentamientos muy parecidos a los de las Antillas taínas, incluyendo su distintivo espacio formal para el juego", escribe en nuestros días Badillo (2007: 66). De ahí la pertinencia de las palabras de Catherine Hall (2018: 48): “La pregunta ‘¿Qué es un antillano?’ Nunca se resolvió finalmente, como quizás ahora podamos esperar. En parte, al menos, estos asuntos, activan la dinámica de la identidad, permaneciendo abiertas para siempre". Si nos preguntamos quién se considera antillano en el Caribe hispano, la repuesta común es muy pocos, la mayoría de las personas preguntadas contestarían inseguras.

\footnotetext{
${ }^{66}$ Segarra Gamazo, A. 2009. 'Diego Álvarez Chanca, Primer Espía de América', Revista de estudios colombinos, (5), pp. 19-40 / Tío, A. 1966. Diego Álvarez Chanca, printed in Barcelona, Spain: Publicaciones de la Asociación Médica de Puerto Rico. / Badillo, J.S. 2007. Guadalupe: ¿Caribe o taína? La isla de Guadalupe y su cuestionable identidad caribe en la época precolombina: Una revisión etnohistórica y arqueológica preliminar. Caribbean Studies, pp.3785.
} 
La carta del Dr. Álvarez Chanca fue traducida al inglés en 1847 por el británico Sir Richard Henry Major, un distinguido geógrafo de la Royal Geographical Society, bibliotecario del British Museum y miembro del primer consejo de la Sociedad Hakluyt británica, junto a Charles Darwin y otras personalidades distinguidas. La traducción de Major fue publicada mucho después en una monografía, editando el texto con unas notas de pie añadidas por Olsen y Bourne (1906: 288, 309, 310) bajo la supervisión de J. Franklin Jameson, un investigador del Carnegie Institution. La copia de la carta del Dr. Chanca, editada y publicada en Olsen y Bourne, ese reproducida en el documento de la American Journeys Collection ${ }^{67}$, y hoy se encuentra difundida por internet, bibliotecas, archivos y otros medios de divulgación. Como se ha dicho, esa carta fue encontrada y publicada originalmente por Manuel Fernández de Navarrete en 1825, hasta entonces un documento inédito en posesión de la Real Academia de la Historia de España. El documento había sido transcrito por fray Antonio de Aspa en el siglo XVI (Jane 1930: CXLIV). No obstante, Andrés Bernáldez, en 1513 escribió El descubrimiento del nuevo mundo, y comenta la carta del Dr. Diego Álvarez Chanca.

Después de comparar las copias de la carta original y la presentada en la obra de Olsen y Bourne (1906: $288\left(n^{\circ} 2\right), 309\left(n^{\circ} 1\right)$, y $310\left(n^{\circ} 1\right)$ atribuidas a Major, se infiere que las notas fueron añadidas por los editores, pues no constan en el original. Dichas notas implican a Pedro Mártir de Anglería y constan como una tendencia desde la segunda fase de Rafinesque. Examinemos una de esas notas añadidas por Olsen y Bourne (1906: 288), por ej., en la nota al pie número 2 se lee: "Taino era el nombre tribal de esta gente, quienes se diferenciaban así mismos de los Caribes”.

Naturalmente se sabe que los taínos no pudieron haberse diferenciados en ese modo. Las notas al pie de las páginas publicadas por Olsen y Bourne no constan en la traducción de Major, medio siglo antes, ni en el documento original del Dr. Chaca. El aditamento de notas está dirigido exprofeso en estos casos a difundir el nuevo término taino con el propósito de justificar una ciencia. En el análisis que realiza Jane (1930) de la traducción de Mayor y de la carta del Dr. Chanca no se utiliza la palabra tayno como raza o tribu, lo que es editorialmente correcto.

\footnotetext{
${ }^{67}$ American Journeys Collection (AJC) provee información geográfica, cultural, y cronológica de Norte América y ha recibido fondos de organizaciones como, Wisconsin Historical Society (WHS), National History Day (NHD) y el Institute of Museum and Library services. La carta del Dr. Diego Álvarez Chanca se publica en acorde a: 'Letter of Dr. Chanca on the second voyage of Columbus: Document No. AJ-065. 2003. Wisconsin Historical Society (WHS).
} 
La palabra good (bueno) en el texto de la publicación de AJC y WHS según Olsen \& Bourne (1906: 288) aparece dos veces, o sea el documento también ha sido manipulado en la traducción de Major y en la carta del Dr. Chanca good o bueno aparece una sola vez. En el documento del Dr. Chanca y en Olsen y Bourne (1906: n.1) esa nota añadida hace referencia a Karl Friedrich Philipp von Martius, un botánico y lingüista asociado y amigo personal del botánico Constantino Samuel Rafinesque, poniéndose de manifiesto la conexión entre ambos. Rafinesque, von Sivers y von Martius eran amigos y compartían en común estudios caribeños. La publicación de von Martius (1867: 307-319) incluía un diccionario taíno (taino) seguida de una sección del taíno de Boriquen, lo que bien puede ser el primer diccionario publicado denominado taino.

El uso de taino (taino taino), y no tayno junto a las notas de pie, y las referencias de las amistades de Rafinesque desde Alemania son un conjunto de factores planificados con alguna intención especifica desconocida pero que encaminan la estandarización terminológica taína a su rotundo éxito por más de un siglo. El AJC y WHS al día de hoy continúan distribuyendo la interpretación de Olsen y Bourne de la carta del Dr. Diego Álvarez Chanca y continua siendo una referencia de apariencia científica en los estudios arqueológicos e históricos. ${ }^{68}$

Tras la muerte en 1492 de Hernando del Pulgar, cronista de los Reyes Católicos, Andrés Bernáldez, el conocido cura de los palacios, se destaca como cronista. Andrés Bernáldez fue amigo de Cristóbal Colón y de esa amistad, bien nos dice Medeiros (1945), surgen relatos históricos que "le presta un sello de verdad y exactitud muy digno". Bernálde escribió la Historia de los Reyes Católicos y el Descubrimiento del Nuevo Mundo. Bernáldez llega a utilizar la palabra taínon asociándolo al significado de bueno, lo que nunca se consideró para prestar significado a una palabra, tal vez por la siguiente razón: su obra desapareció y no fue hasta 1870 que reaparece en manos del bibliófilo D. Francisco Flores, quien facilita su manuscrito para publicarse en Sevilla. La publicación de esa obra de Bernáldez, su amistad con Colón y su posible contacto personal con el Dr. Álvarez Chanca son algunos hechos que ocurrieron en la ciudad de Sevilla. Por tanto, para Bernáldez taíno, tayno o taínon sólo puede significar bueno. No obstante, debemos considerar que Bernáldez murió en 1513 y su trabajo no fue encontrado y publicado hasta 1870, no pudo ser leído por Rafinesque en 1836 y tal vez nunca fue leído por Fewkes o

\footnotetext{
${ }^{68}$ Olsen, Julius E, \& Edward Gaylord Bourne. 1906. The Northmen, Columbus, and Cabot, 985 -
} 1503 US: Charles Scribner sons. 
por Olsen y Bourne, pues no consta en sus bibliografías. A excepción de Rafinesque, es la tercera vez que dicha palabra fue utilizada, significando bueno desde España. Todas las referencias de España son especificas en cuanto a la traducción de tayno o tainon, significando bueno. Las obras de los alemanes von Sievers (1861), von Martius (1867) y Peschel (1876), por sus fechas de publicación, evidencian su desconocimiento de la obra de Bernáldez y el significado de bueno de tainon.

\subsection{Razas y tribus en Fewkes}

El uso de la palabra taino (taíno) por Fewkes (1907: 26) como significado de raza o tribu carece veracidad histórica, es una teoría sin mayor fundamentación extraída de notas al pie de página en publicaciones que se desviaron del significado de un documento histórico original para introducir el taino (taíno) de Rafinesque. Fewkes asume implementar el taíno de Rafinesque y cita sin nombrar a otros autores, anteriores usuarios del término que ahora conocemos. Este enlace internacional tenía fuertes raíces en Francia y Alemania por el reconocimiento a Rafinesque. En la carta original del Dr. Diego Álvarez Chanca, o en el capítulo V del libro II de Pedro Mártir de Anglería, nunca se hizo mención del término taino (taíno) vinculado a raza o tribu. En la lectura del documento del Dr. Álvarez Chanca se ha prestado más credibilidad a las notas editoriales añadidas por angloparlantes y europeos comunicándose entre sí, que a la traducción original de Major o al documento original.

El prestigioso antropólogo y etnólogo norteamericano Daniel Garrison Brinton (1871) ya nos había advertido sobre teorías descabelladas. Brinton nunca se hubiese imaginado que manipulaciones editoriales conducirían al rotundo éxito de C.S. Rafinesque, acogido por académicos internacionales. No puede pretextarse un uso de época: "Hasta las primeras sistematizaciones de la crítica textual, sobre todo la edición de Lucrecio (1850) de Karl Lachmann, esta distancia entre un trabajo dado y su creador permitía a los estudiosos sentir que podían intervenir drásticamente en los textos que tenían la intención de restaurar. Los editores, en otras palabras, percibieron ellos mismos como "autorizados" para intervenir con el texto a voluntad, por lo tanto, posiblemente reemplazando la voluntad del autor con la suya propia. Esta forma de tratar las obras antiguas se extendió con frecuencia" (C.M. Bajetta, 2006: 308-309).

El presidente norteamericano William McKinley firma el 12 de abril de 1900 el Acta Foraker, aprobada por el Congreso un día antes. En esa acta la denominación oficial 
de Puerto Rico queda resuelto oficialmente como Porto Rico, según consta en el Acta para la formación del gobierno de la isla y en el Tratado de Paris de 1898. El norteamericano no juzga importante el nombre de Puerto Rico pero las opiniones son públicas y en sus palabras Hill (1900: 712) se expresa y dice: "Puerto Rico is a thing of the past, and like all the unpronounceable foreign words, it has sacrifice its live to the 'dictum of the law of least effort'." ["Puerto Rico es una cosa del pasado, y como todas esas impronunciables palabras extranjeras a sacrificado su vida al 'dictum de la ley del menor esfuerzo" "].

Si en la palabra Puerto la supresión de dos vocales ue causan tal revuelo, al punto de sacrificar su vida y ser sustituidas por una $o$, por ser mejor pronunciable en inglés, siendo Puerto Rico un nombre histórico que identifica un país, qué se puede esperarse de ese dictum de la ley del menor esfuerzo en relación con los arahuacos o caribes y de otros autónimos acogidos en particularidades históricas en el archipiélago caribeño conocidas y vinculadas entre sí. Olsen y Bourne (1906) como Fewkes (1907) presentan en sus monografías lo que ahora podemos identificar como bien sugiere Hill (1900: 712) el: "dictum of the law of least effort. - dictum de la ley del menor esfuerzo". Ese mismo dictum del menor esfuerzo es exactamente lo que aprovecharon estudiosos y editores contemporáneos durante sus investigaciones, amparándose en los mercados accesibles, sus instituciones y el tainismo para desarrollar trabajos originales, o sea, el resultado de la ironía o es el erudito engreído.

El 17 de mayo de 1932 el Congreso de los Estados Unidos restaura por ley el nombre original de Puerto Rico. Si se tardó treinta años en restaurarse dos vocales, ¿cuándo se hará efectivo el rechazo de una raza fabricada utilizada con premeditaciones y cuánto tiempo puede pasar hasta aceptarse y volver a restituirse el vocablo original que distingue a los nativos caribeños?

\section{$2.5 \mathrm{ADN}$.}

El ácido desoxirribonucleico (ADN) proporciona la información genética de un individuo, es una evidencia científica.

En el Departamento de Salud y Servicios Humanos de los Estados Unidos encontramos esta definición: 
"La información en el ADN se almacena como un código compuesto por cuatro bases químicas: adenina (A), guanina $(\mathrm{G})$, citosina $(\mathrm{C})$ y timina (T). El ADN humano consta de unos 3 mil millones de bases, y más del 99 por ciento de esas bases son las mismas en todas las personas. El orden, o secuencia, de estas bases determina la información disponible para construir y mantener un organismo, similar a la forma en que aparecen las letras del alfabeto en un cierto orden para formar palabras y oraciones".

Los recientes estudios de Martínez (2003), Mendizábal (2008), Schroeder (2018) y Moreno-Estrada (2013), entre otros investigadores que identifican la supervivencia nativa en el Caribe, han realizado aportes incuestionables para conocer la supervivencia de la vida nativa.

Las alegaciones de origen lingüístico presentadas por (Hill 1900) en su dictum de la ley del menor esfuerzo no son correctas por muchas razones, pues las denominaciones California, Arizona, Colorado e incluso Montana provienen del español. Al igual que se usan palabras del alemán como hamburger, pretzel, iceberg o waltz, e incluso nombres de razas como Schnauzer, Dachshund, Doberman y Poodle de entre muchos otros términos, según Hill son palabras extranjeras e impronunciables. Numerosas palabras fueron retenidas de los propios nativos americanos en Norte América, por ej.: Caribou, moccasin, husky, pecan, racoon, squaw, tomahawk, entre otras de diversas extracciones lingüísticas. Puédase considerar que esa diferencia estriba de nombres provienen de una descendencia europea y nativa norteamericana alejadas del Caribe o la hispanidad, lo cual representa una variante aplicada a la población caribeña como se ha discutido en secciones anteriores.

El antropólogo Daniel G. Brinton (1871) denunció el término taíno por considerar su empleo truncado del nitaíno y los estudios lingüísticos que le apoyaban inadecuados. $\mathrm{Su}$ crítica se dirigió a von Sievers y von Martius. Por su parte, investigadores contemporáneos, haciendo uso del término taíno, teorizan un nativo predominante y pacifico partiendo de la necesidad que Rafinesque llama tientas en la oscuridad, representando a un indio noble, educado, inteligente y religioso para poblar espacios oscuros o vacíos según ellos afirman. Un estereotipo indio educado y religioso cumple con los requisitos de conversión caribeña colonial y a su vez se acoge a la mente del investigador académico cristiano.

El término taíno prescribe raza y una imagen adaptándose ligeramente a ideales religiosos de escritores antiguos pero basado plenamente en grupos de investigadores contemporáneos. Esa terminología carece de rigor y de legitimación científica, representa una historia humana de gente a quienes hoy día es conocido como un pueblo plurilingüe, 
multicultural y asimilador, considerados en ocasiones ciudadanos de segunda clase y, para más, se les altera la patria nativa al fabricar, implementar y ampliar una raza taína ajustada a un mercado, simplemente por considerarse sonoro, en palabras de Fewkes. En este sentido, siguiendo esta línea de investigación examinaremos razones modernas por las cuales la utilización del tainismo resulta aún más preocupante y fuera de contexto en su relación con la herencia de la persona cultural.

En relación con gente simple citamos una serie de argumentos con las palabras del Dr. Delgado (en Robiou et al, 2011: 93):

"En la década de 1970, algunos ancianos estaban conscientes de que su apellido era «de los indios», y de que ese era su apellido original. En Ciales entrevistamos una anciana que nos narró la historia de cómo un cura de ese pueblo le había cambiado el apellido a su familia. De acuerdo a la historia oral de familia, ellos eran 'Los Mamio', naturales de Utuado, pero el cura los obligó a cambiar su identificación jurídica 'porque el apellido no era cristiano" ".

Delgado recuerda haber hablado en Caguanas con ancianos nacidos en el siglo XIX en Utuado, poco modificados por el sistema escolar. Esos campesinos claramente recordaban su familia y se consideraban indios cuando el término y la terminología taína eran inexistente en la estructura social o en el sistema escolar. De hecho, estos campesinos eran presa fácil para académicos experimentados en busca de implementar sus nuevos conceptos en un terreno fértil. Sin embargo, hoy día existen descendientes de esos ancianos muy confundidos, especialmente los más jóvenes.

El concepto obligado de la religión es válido, complejo y significante con relación a la supervivencia nativa. La Iglesia católica, en el caso de Delgado, actúa posiblemente con la idea de proteger indios, lo que para el 1970 parecería algo irregular. Esta tendencia evangelizadora existió en Cuba y la República Dominicana, y hemos señalado un matrimonio entre indios en Cuba un siglo antes de Harrington (1921), utilizando sus nombres nativos.

Un estudio científico de personas mayores de ochenta años viviendo en campos aislados es posible incluso hoy día en Puerto Rico y Cuba, pues aun estos pueden recordar su educación primaria con anterioridad a los años de 1955. La creación del Instituto de Cultura Puertorriqueño promovió la terminología taína a unos extremos incomprensibles. 


\section{EL TAINISMO.}

Constantino Samuel Rafinesque advierte de las consecuencias lingüísticas de la elaboración del nuevo concepto del término, taino, un complicado acertijo en su momento exitoso que luego resultó contar con piezas falsas y yuxtapuestas: "Por falta de vocabularios antiguos frecuentes, regularmente andamos a tientas en la oscuridad; pero no me desespero de poder restaurar muchos idiomas, por fragmentos escapado de la ruina común, Ya he tenido éxito con los tainos de Haití" (Rafinesque, 1836: 31). Las palabras de Rafinesque son una expresión del estado de las investigaciones en su época. Rafinesque ubica a los tainos en Haiti, luego desplegándose al Caribe. Mosquin (2004: 1) dirá sobre Rafinesque: "surge un hombre de un ingenio fallido, cuya incapacidad para trabajar dentro de los límites de la convención científica necesariamente llevaron a bajar el reconocimiento que de otro modo hubiera merecido".

Daniel Garrison Brinton (1871:10) fue de los primeros en expresar que los trabajos de Rafinesque y Jegor von Sievors eran peor que inútiles. Hemos visto que Pedro Mártir de Anglería (1989: 109), Diego Álvarez Chanca (1493: 5) y Richard Henry Major (1847: 28) utilizaron la palabra tayno, y que a partir de la impresión por Manuel Fernández Navarrete en 1825 de la carta original del doctor Diego Álvarez Chanca ese nombre fue acogido por otros autores. Olsen y Bourne (1906: 288) usó la palabra tayno. J. W. Fewkes (1907: 26) recurre al nombre taino (taíno) desprendido del trabajo de Rafinesque. Briton (1871: 10) descarta el empleo del término aludiendo que este no cumplía con rigor lingüístico necesario. Andrés Bernáldez y Pedro Mártir de Anglería son los únicos que pudieron haber conocido personalmente al Dr. Álvarez Chanca, y en la edición de 1945 se utiliza el término tainon, con el significado de bueno. K.F.P. von Martius uso la palabra taini. La analogía entre autores comienza en el siglo XX a partir de Fewkes (1907), al concretarse sus definiciones culturales. Según hemos señalado, autores como E. Pichardo (1875) y C. Coll y Tosté (1897) no usaron el término taino. ${ }^{69}$

Los arahuacos y caribes son las razas matrices de los nativos caribeños. A estos grupos pertenecen los que más murieron y sufrieron en las islas caribeñas durante las primeras décadas. Haitianos y cubanos llenan ciertos espacios nativos a partir de endónimos reconocidos. Cuba o Coiba son señalados desde 1492 como nombres nativos

\footnotetext{
${ }^{69}$ E. Pichardo no utilizo deletreado alguno derivado del taíno en ninguna de sus cuatro ediciones
} del Diccionario de Voces Cubanas. 
que identifican a Cuba. Haití, ayti y otros endónimos derivados representan igualmente a los nativos junto a otros exónimos encontrados en cronistas que en su tiempo se recogieron por la vía oral. Llamarles nativos cubanos o nativos haitianos es correcto aun en su simpleza, notando que en cada uno de estos países existen numerosas otras tribus señaladas en la tabla \#3.

El prestigioso tainista Irvin Rouse (1992) sostiene la identidad nativa taina, incluso en el título de su obra: The Tainos: Rise and Decline of the People who Greeted Columbus (Los Taínos: auge y decadencia de las gentes que recibieron a Colón). Los escritores clásicos, los exploradores y colonos más familiarizados con el vivir del nativo caribeño, de haber leído el título de la publicación de Rouse considerarían su significado algo desconocido, o como bien dijo Brinton (1871:10) al comentar la obra de Rafinesque quizás la considerasen peor que inútil. Rouse (1992: 69) no tardó en entonar el mea máxima culpa individual y colectivo en que estuvieron los investigadores tainistas: "Mi generación de arqueólogos fue entrenada para proceder únicamente en términos de artefactos y las culturas a las que pertenecían". Sin embargo, además del anacrónico título de su obra, afirmaba haber avanzado en el estudio de la edad lítica a la arcaica en un intento por reconstruir la población antillana taína. Si el concepto de poblamiento caribeño comenzó en Rouse (1941, 1948), fue continuado por Taylor y Rouse (1955). Rouse culminó su obra en 1992: es verdaderamente asombroso que en cuatro décadas de investigaciones no hubiera prestado atención a las objeciones de Brinton (1871), Stahl (1889), Coll y Tosté (1897), Zayas y Alfonzo (1914), Sauer (1967), Hulme (1986) y Whitehead (1995). Rouse continuó asumiendo, siguiendo a Arrom y Alegría, que los clásicos conocieron a los indios taínos.

En Cuba, las tendencias arqueológicas de la segunda mitad del siglo XX se acogían a las tendencias contemporáneas difundidas por Harrington (1921) en relación con el sub-taíno y el taíno: "Este punto de vista lo aceptamos nosotros y lo venimos aplicando desde 1962 en nuestras labores investigativas" (Tabio y Rey, 1965: 118). Desde 1962 son aceptados estos puntos de vista a gran escala no solo en Cuba sino en Puerto Rico y la República Dominicana, compartiendo criterios e investigaciones homologas en la región. Queda claro que la tendencia de autores caribeños desde la segunda mitad del siglo XX era interpretar y suplementar los trabajos institucionales y académicos que se fundamentaron en la primera mitad del siglo XX, avanzando hacia una acrecentada inclusión de notas contextualizadoras en las nuevas ediciones de autores clásicos. 
En la Republica Dominicana, la edición de la obra póstuma de Emiliano Tejera Penson (1935), un compendio de unas 1.383 páginas de indigenismos, llevada a cabo en dos volúmenes por su hijo Emilio Tejera Bonetti (1977), comienza por la definición de Taíno con la referencia del profesor Félix M. Pérez Sánchez (1948), quien expuso que: "Es el mayor error etnológico llamar Tainos a los Arauco", ante lo que Tejera hijo aseguró: "ningún antiguo escritor habría utilizado dicho término". En su extensa obra, Tejera Penson nunca incluyó el término taíno. Tejera Bonetti explica cómo un error etnológico se ha vuelto tan generalizado, y pone como ejemplo lo sucedido con otras palabras, el caso de Antillas, Indias e indios, impuestas y aceptadas con el tiempo. Con estos ejemplos, Tejera Penson y Tejera Bonetti muestran su oposición al término taíno.

Fewkes (1907: 26) demostró en pocas palabras el fácil proceso de ruptura con los términos antillanos y raza antillana, para ser sustituidos por el término taíno y raza taína. Hall (2018) señaló que el antillano, como bien dijo Tejera Bonetti, era noción impuesta.

El prestigioso arqueólogo puertorriqueño Ricardo Alegría, en 1955, unos 120 años después de Rafinesque, fue designado por el Gobernador de Puerto Rico Luis Muñoz Marín para dirigir la formación del Instituto de Cultura Puertorriqueña. Alegría, un hombre joven educado en el sistema universitario de los Estados Unidos, en las universidades de Chicago y de Harvard, se vio influenciado por las obras de Fewkes, Boas, Harrington, Krieger, Loven, Rainy, Rouse, y por las obras desarrolladas en la BAE. Después de sus colaboraciones con el profesor John Willey, de Harvard, y I. Rouse, encontró una comunidad permanente de notables estudiosos, a la cual se añade Arrom.

Esta comunidad de prestigiosos estudiosos del saber humanístico, junto a diversos tainistas, difundieron y comercializaron el término taíno, popularizándolo en las últimas cinco décadas del siglo XX desde Puerto Rico. El éxito fue rotundo, pues la gente creyó y todavía cree que el taíno existió. Las intervenciones de tainistas en reuniones científicas durante las décadas post 1950 procuró la difusión del término, acogido por prestigiosas instituciones académicas y culturales, de las que sus autores recibían ayudas económicas. El Instituto de Cultura Puertorriqueña, en conformidad ideológica con esa comunidad de estudiosos, organizó el $5^{\circ}$ Centenario de la Rebelión Taina (Robiou et al, 2011).

Fue otro puertorriqueño, Pablo Morales Otero (1945: 7), quien poco antes observó diferencias y diversidad: “Antes del descubrimiento habitaban la isla de Puerto Rico los aborígenes. La isla no estaba toda en poder de los araucos, pues los caribes ocupaban la parte oriental y es probable que la población de Borinquen fuera una mezcla de ambas familias, que vivían agrupadas en tribus y guiabanse por un casique”. Morales Otero 
presenta el porqué de la población de Borinquén, cohabitando los arauco y caribes en Puerto Rico.

El borincano, boricua o borinqueño es uno de los hijos naturales de la isla de Borinquen o Burichena, lo que es Puerto Rico. En esta sección evitaremos la repetición de endónimos y exónimos, a fin de mostrar la incoherencia del taíno en Puerto Rico. Pedro Mártir de Anglería llamó burichena (Bajael,1944: 19) a la isla que Alejandro Tapia y Rivera y fray Iñigo Abbad y Lasierra llamaron Borinquen, tierra de borincanos. Tapia y Rivera (1852) presenta al borincano y comienza con el ídolo de borinquen sobre el pedestal de piedra, la macana borincana (cap., X p.,1) y hace referencias al borincano o borinquen en al menos diez páginas. ${ }^{70}$ Estos tres autores coinciden en que borinquen, boriquen o burichina es lo que hoy día llamamos Puerto Rico.

Hernán Colón (1947: 147), al narrar el segundo viaje del almirante a Guadalupe, en 1493, dice: "un mozo que se había escapado de los caribes, teniendo por cosa más segura entregarse a gente que nunca había visto y tan diferentes de su nación que permanecer con aquellos". Hernán Colón obtuvo de su padre, de su tío Bartolomé y de su hermano Diego documentos y testimonios orales que añade a sus propios viajes y experiencias. Entre los acuerdos, documentos y descubrimientos de Cristóbal Colón compila una narrativa de América muy exclusiva. Hernán Colón era historiador y pensador de su época que dedicó su vida a coleccionar libros para su investigación, alcanzando más de 15.000 volúmenes, en los que recogió las interpretaciones del Nuevo Mundo de los autores europeos. En la catedral de Sevilla se mantiene una parte de esa colección, hoy en día conocida como la Biblioteca Colombina. Del segundo viaje de su padre, Hernán Colón recoge publica la palabra nación atribuida a boriquen, o sea, la nación de boriquen, lo que es hoy día Puerto Rico; así consta en la edición del 1947, donde la palabra nación es subrayada.

La Nación de Boriquén tras estas expresiones de Hernán Colón queda adecuadamente identificada en toponimia y geografía. A las narraciones de H. Colón, P. Mártir, fray Iñigo y Tapia y Rivera faltaría complementar la casuística que unía a esos pueblos en sus propios dialectos para justificar y legitimar la historia de la persona cultural nativa de origen.

\footnotetext{
${ }^{70}$ Tapia y Ribera, A. 1852. La Palma del Cacique
} 
El Almirante Colón llega a Borinquen en compañía de nativos borinqueños, y en las palabras de Washington Irving (1882: 83) ${ }^{71}$ : "I se llamaba por los nativos Boriquem, pero él le llamo San Juan Bautista: Es la misma que desde entonces se llama Porto Rico". Esta referencia de Washington Irving tiene varios significados, uno es la identificación de Boriquén, a la identifica como Boriquem y utiliza el nombre de Porto Rico según utilizado en su época. Irving, antes que el Congreso de EE UU implementara el uso de Porto Rico. Porto Rico y el Caribe hispano eran un centro de corrupciones gramaticales fácilmente manipuladas durante el siglo XX.

Pero Washington Irving en 1825 se había reunido con M. Fernández de Navarrete para examinar los hallazgos de este, que incluían la carta del cirujano Diego Álvarez Chanca. Irving y Navarrete se encontraron en Madrid, mientras Irving residía bajo el techo del cónsul americana, O. Rich, uno de los más infatigables biógrafos de Europa (Irving, 1882: 3). Ninguno de estos dos experimentados estudiosos propuso la idea y existencia que desde Turuqueira hasta Boriquem habitaba un nativo predominante denominado taino.

La resistencia a cambios en la historia de Cuba en las primeras décadas del siglo XX era notable, aun cuando Bachiller y Morales había encontrado a Peschel (1876) y von Martius (1867), otros como Zayas y Alfonso se resistían. Uno de los más importantes momentos de esas confrontaciones académicas la anota Harrington (1921:131) y citamos: "A lo largo de la obra, sin embargo, es evidente que el uso de la palabra "Taino" como un término general para la clase predominante de nativos de las Antillas Mayores, cuyo idioma Zayas presenta, es estudiadamente evitado". En esta controversia se sostiene el dialogo de la oposición taino: o Zayas (1914) o Harrington (1921) no han comprendido. Harrington no acepta que el experimentado etnólogo, lingüísta y presidente de Cuba, Alfredo Zayas y Alfonzo, evite usar el término taíno. Para Zayas su uso es inaceptable. Harrington promueve la expresión tainos y en concepto de Antillas. Por el contrario, Zayas (1914), en su diccionario había manifestado que el término tayno solo parece haber significado bueno, en la línea de los expresado por H. Colón, fray Iñigo y Tapia y Rivera. Cuatro décadas más tarde, queda clara la influencia de Harrington en Cuba en la segunda mitad del siglo XX (Rey, 1962: 118).

\footnotetext{
${ }^{71}$ Washington, Irving. 1882. The life and voyages of Christopher Columbus. New York: Pollard \& Moss.
} 
Emilio Tejera Bonetti (1977) comentó que “el Dr. Cayetano Coll y Tosté se negó a utilizar el término taíno en el 1900 y correctamente utiliza Araucos en Puerto Rico". En la República Dominicana, el trabajo de Tejera nunca fue considerado. El Dr. A. Stahl (1889) titula su monografía Indios Borinqueños, y se refiere al pueblo indo-borincano y luego a la raza borincana en sus referencias a los aborígenes de Puerto Rico (Stahl, 1889: 47-50). Stahl está en lo correcto. En esta tesis se difiere en que el indio era inferior en el contexto de su vida a expensas de la naturaleza. Citamos un comentario compartido y dice el Dr. Agustín Stahl (1889: 49): "los pueblos primitivos se hallan ligados íntimamente al suelo". Lo que Brinton (1871) llama la naturaleza orgánica, en lo que se basa el proceso de particularidades, movilización y evolución sociocultural a lo largo de las Antillas. En estas expresiones no se observan discrepancias entre estos autores antiguos sobresalientes sobre una base histórica real en la cual el término taíno es innecesario. Esa naturaleza orgánica es la que Levy Bruhl (1923) y Carl Jung (1967), definen como la inconsciencia colectiva y las representaciones colectivas de la mentalidad primitiva, la forma mística de identificarse con aves, animales y el entorno natural en general como parte integral de ese ambiente natural y no como meros espectadores. El nativo caribeño vivía integrado a la naturaleza en su geografía que le rodeaba; ese vivir los diferenciaba entre ellos, en el sentido que un ave se diferencia de un reptil o una montaña de una ribera.

El Dr. Stahl nunca utilizó el término taíno y fue testigo de que en el diario vivir puertorriqueño ese término nunca existió. En su obra, el término indo-borincano, o borinqueños de boriquen, tiene su raíz histórica en la crónica de Pedro Mártir de Anglería [1530] (1944: 19), cuando se refiere a Borinquén como burichena. Andrés Bernáldez ([1594] 1945: 219, 221) utiliza el término Boriqui y Boriquen en su narración del segundo viaje. En Cuba, Alfredo Zayas y Alfonso (1914: 102) contribuye a esa idea: "Hemos visto en un documento de 1517 escrito Burinquén”. Se identificá entre Mártir de Anglería y Zayas un enlace lingüístico razonable entre burichena y burinquen donde la fonética y la lingüística tienen una obvia correspondencia con Borinquén. Hernán Colón ([1571] 1947: 150) usó el término Boriquén a lo que hoy se conoce como Puerto Rico. ${ }^{72}$ Estas variaciones corresponden a unos términos verificables de la propia cultura indicada antiguamente por Andrés Bernáldez, Hernán Colón, Pedro Mártir de Anglería, y Alfredo

72 Sloan-Toraño, R. 2019. 'Caribbean History and Heritage Crisis Resulting from Generic Standardization and Substitution of the Native Borinqueños, Boriquans or Boricuas of Puerto Rico Subsequent to Suspicious Taino Research', p. 15. 
Zayas. Estos términos son representativos de una comunidad geográfica particularizada basada en la naturaleza orgánica del suelo según entendido por sus habitantes.

Stahl (1889: 39) recuerda que el Profesor Rudolf Virchow de Berlín (fundador del primer Instituto Patológico en Alemania), anunció en noviembre de 1886 que su estudio craneal de Aroakos y Guajiros sobre el norte de la América meridional que existía una completa uniformidad típica. Aroakos es análogo a Arauco teniendo una implicación directa a la base craneal común en el Caribe. Esto implica una genética común significante reconocida con anterioridad a Fewkes (1907). Virchow reconoce en la patología que una perturbación del organismo parental se puede producir al igual que por el ambiente en relación a especies. Esta creación de especies patológicas implica un largo proceso genético-evolutivo único y compartido, en nuestro caso por los nativos caribeños en su relación al suelo. La patología, las costumbres sociales nativas, la conexión al entorno orgánico del suelo entre comunidades aisladas y la historia validan razones por lo cual el término taíno no debió nunca aplicarse a los arahuacos o antillanos y mucho menos usarlo como sinónimo de raza. Estas realidades son intimas y legítimas, basadas en factores colectivos que se apartan de las realidades económicas y tecnologías contenidas en la terminología estandarizada taína. ${ }^{73}$

El término taíno desde una perspectiva histórica es una ruptura de los pensamientos clásicos de escritores antiguos y de escaza credibilidad comparado a las realidades consanguíneas, colectivas, y naturales de la propia gente en sus comunidades. Mientras el objeto humano perdía su identidad, Julian Haynes Stewart (1949: 12) escribe:

"El uso de la difusión para evitar enfrentarse a problemas de causa y efecto no solo no proporciona un enfoque coherente a la historia de la cultura, sino que brinda una explicación de los orígenes culturales que realmente no explica nada. La difusión se convierte en una causa mecánica e ininteligible, aunque universal, y se emplea, como en contraste con otros tipos de causas, para dar cuenta de aproximadamente el noventa por ciento de la cultura mundial".

Stewart entiende el problema de la difusión incoherente en unos porcentajes mundiales de alta proporción y cónsonos con las estrategias epistémicas que favorecieron la difusión de la estandarización taina:

"Una oportunidad es nuevamente encontrada en las Antillas Menores, que habían sidoCircum-Caribe se encuentra nuevamente entre los Arawak (Arahuacos) de las

\footnotetext{
${ }^{73}$ Ver; Sloan 2019. Assessment of Cultural Crisis
} 
Antillas Mayores, y se extendía tan lejos como Cuba y Haití, donde el primitivo cazador y recolector Ciboney todavía sobrevivió (Stewart, 1948: 11):

Steward es cauteloso en su exposición del tema de nativos caribeños y se abstiene de utilizar la terminología taína. Irving Rouse difunde la estandarización taína en un texto publicado por Stewart (1948). Sin embargo, existe una separación ideológica respecto al nativo caribeño entre editor y autor.

La especialidad de Fewkes es la arqueología y la etnología. Su base metodológica se apartó de la historia. Mientras los intereses arqueológicos y etnológicos se concentraban en colecciones y sus clasificaciones, la estandarización terminológica permitía una rápida catalogación de artefactos y narrativas. Sin embargo, su investigación reconocía insuficiencias y contradicciones: "las diversas cuentas que tenemos de las tribus de los antillanos indican que los indígenas de Borinquen eran una raza compuesta de mezcla de araucas y caribes" (Fewkes, 1907: 219). Este relato precolombino de Fewkes de una raza compuesta para extraer un taíno es poco consecuente con el trasladado desde otras islas del Caribe, América del Sur o Centroamérica a Cuba, Puerto Rico o la República Dominicana de nativos que ocasionaron un desequilibrio genético permanente. De hecho, la selectividad genética de mujeres arahuacas debido a las redadas caribes y otras desconocidas era una continua evolución natural. Rudolf Virchow (1886) nos recuerda que existía una completa uniformidad típica. En adición y esa evolución natural en la conformidad nativa y sus conexiones tribales forman parte de la mente primitiva que protegería a infantes nacidos de europeos, que a su vez conllevarían a la evolución biológica y la supervivencia. Nativos nómadas se asentaron en diversas islas caribeñas durante siglos, siendo designados como cazadores, colectores, pescadores o agricultores desde la prehistoria, particularizándose al pasar del tiempo en base a sociedades matrices uniformes: "En el momento del contacto con Europa, el centro y el litoral de los cubanos estaban ocupados por los grupos tainos agricultores, mientras que el oeste estaba habitado principalmente por Ciboneys, cazadores-recolectores que tradicionalmente se han considerado una población reliquia que desciende de la colonización inicial del Caribe" (Laluesa-Fox et al, 2003: 97). Se cita a Laluesa-Fox et el (2003: 102) en busca de identificar una confirmación de lo que identificamos como la conformidad típica nativa: "Las secuencias taínas no se agrupan en ninguna rama exclusiva de América del Norte; no obstante, están ubicadas en sucursales compartidas principalmente con otros países y poblaciones de Centro o Sudamérica”. Esta secuela nos 
identifica lo común encontrado mayormente en Centro o Sudamérica, la razón por la cual el balance genético de ciertas geografías no cambiaría en relación con movimientos de población. Concluye el estudio identificando que la migración mayormente subía por la cadena de islas desde Sudamérica. En este sentido, la conformidad típica nativa caribeña, en sus propiedades biológicas durante el descubrimiento se mantenía natural desde la perspectiva nativa. Los cambios biológicos acentuados son el resultado del mestizaje, según lo hemos señalado a lo largo de esta tesis.

Pero en el proceso de la patología de mezclas genéticas uniformes se subestima lo ocurrido durante esa evolución natural y orgánica. En el largo plazo llenar ese espacio patológico y cultural caribeño por un símbolo fabricado solo constituye un elemento de la crisis ancestral. La evolución continúa uniforme es contraria a la difusión de un orden terminológico estandarizado o una sociedad particularizada e histórica. En este sentido, simplificamos que los cambios genéticos por el movimiento forzado de gente no son fácilmente validados, sobre todo, teniendo en cuenta que la región ya había interactuado en gran medida durante milenios. Los estudios de ADN no arrojan luz sobre ese punto específico. Schroeder (2018) indica que el Caribe era habitado por gente altamente móvil. Habíamos citado anteriormente la aplicación del taíno que se concluye por la vía académica institucional alejada de la historia y señalamos: "encontramos que el componente nativo en los genomas actuales de Puerto Rico está estrechamente relacionado con el antiguo Taino". Los estudios de ADN son indicativos de una biología compartida y la supervivencia biológica nativa. Los naturales tenían entre ellos términos para identificarse e identificar sus territorios, grupos, clanes, tribus y naciones lo que es históricamente verificable. Hemos validado en Puerto Rico a buruchena, en sus filiaciones con caribes y otros nativos, por ejemplo, los arahuaco-borincanos e igualmente espacios en Cuba y sus filiaciones a los arahuaco-cubanos en espacios geográficos compartidos con siboneyes o guanahatabeyes. Los lucayos de las Bahamas y sus espacios en La Española. En el conjunto de haitianos, quisqueyanos, ciguayos, macorijes, entre otros, y en otras islas caribeñas pobladas donde sus gentes se identificaban con nombres tribales particularizados de raíces arahuacas, caribes u otras tribus. Adicionalmente, estos nativos dejaron rastros en sus monumentos $\mathrm{y}$ artefactos para distinguir sus particularidades lo que sí es identificable por la arqueología.

No se sabe con indiscutible precisión la cantidad de veces anterior a Colón que una reubicación masiva forzada o natural ocurriera en la evolución del desarrollo natural del poblamiento de caribes y arahuacos y otros en sus espacios genéticos y geográficos 
cambiantes, desplazándose los unos a los otros de sus asentamientos aislados y comercios durante siglos. La arqueología que pretende establecer esa precisión usa una base histórica inadecuada. La alteración de la identidad regional de los arahuacos o sus homólogos del sur moviendo un mayor número de ellos en islas particulares donde se desarrolla un nuevo nativo el taíno es una teoría sin base histórica. Que los taínos existieron antes y después de Colón solo demuestra desconocimiento histórico y solo se puede utilizar para identificar las fallas académicas de la historia específicas del taino liderado por Rafinesque. En este sentido, el término taíno interfiere con el equilibrio natural de arahuacos y caribe como razas o etnias matriz dentro de la región caribeña y su evolución en colectividades naturales cambiantes y compartidas desde su prehistoria. El término taino es reducido a un adjetivo sustituto o un error gramatical basado en el dictum del menor esfuerzo para el beneficio económico y la comercialización del conocimiento humano, algo peor que trágico. Continuando en esta línea de análisis, encontramos una aportación de Samuel M. Wilson (2007: 27) y su afirmación en el siguiente pensamiento: "En la ausencia de pistas cronológicas en cuanto a la dirección migratoria, la búsqueda de origen de los primeros emigrantes al Caribe se basa en comparaciones de estilos y tecnología de artefactos de piedras en yacimientos del Caribe contrapuestos a ensamblajes contemporáneos sobre terreno firme".

En esta línea de pensamiento se puede entender por qué el rescate arqueológico particularizado precolombino es complejo donde el origen de las ideas procede de un campo especulativo formulando conceptos para cubrir espacios de cientos de años sin ciencia cierta. En ese amplio marco especulativo existe un área de investigación alejada de una base histórica verificable. En ese espacio surgen términos académicos de especialistas difusores alejados de la herencia natural y orgánica de los nativos caribeños. George Peter Murdock (1949: 115) dirá: "En todos estos casos, la mayoría de las semejanzas interculturales deben atribuirse necesariamente a la difusión. Además, dado que tales fenómenos son en gran medida únicos y distribuidos regionalmente, los problemas derivados de su influencia en otros aspectos de la cultura deben ser atacados localmente y por métodos históricos". Murdock identifica el problema de la difusión y las pistas de Wilson. Se ha probado la inexistencia de la terminología estandarizada taína y en el proceso se ha presentado lo que en causa y efecto son las consecuencias.

Partiendo de fundamentos teórico-metodológicos continuamos sometiendo a examen posturas y diversidad. Así, José Abreu Cardet (2013: 38) advierte como "Wilson rechaza la unidad del taino y lo ve como una conjunción de diversos grupos étnicos, 
incluso con ancestros diferentes". Definitivamente no existe una unidad taína. Los diferentes grupos étnicos interactuando entre sí en áreas geográficas independientes con ancestros diferentes en sus límites territoriales compartían una conformidad uniforme evolucionada por siglos. Samuel H Wilson (1990: 5) lo expresa de la siguiente forma: “Otra dimensión se añade a la literatura de la etnohistoria y la arqueología por estudios más resientes trabajos etnográficos de grupos indígenas Sudamericanos que están lingüística e históricamente relacionados al taíno (Alegría 1978; Arrom 1967; Sanoja Obediente 1983; Siegel 1988) ${ }^{74}$ ". Para Wilson, usar estas fuentes históricas era una forma de atacar los problemas encontrados al analizar el taíno. El problema de Wilson en su análisis narrativo es que seguía difusores académicos en lugar de dirigirse directamente a los cronistas. Identifica a caciques y naborias en documentos de Rodríguez Demorizi (1971) y la versión usada en su libro se basa en Olsen y Bourne (1906) y Pané (1974). Olsen y Bourne (1906) es una obra principal de difusión la terminológica estandarizada y Ramon Pané (1974) es la obra clásica para el tema en la edición anotada de José Juan Arrom. Abreu (2013: 39) en referencia a Reniel Rodríguez, dice lo siguiente: "No habría un pueblo taíno, sino múltiples esencias taínas (un espectro de «tainidades») generadas en el contexto de esta interacción y, a su vez, facilitadoras del vínculo y la comunicación en un ambiente multiétnico". En el 2013 la teoría de Reniel Rodriguez de esencias tainas $o$ tainidades forman parte de la estandarización terminológica taína organizada a sabiendas que esa interacción es fabricada y adjudicada y no es histórica. Esa identificación en esta tesis se la identificado de tribus homogéneas coexistiendo en sus culturas particularizadas. A esos efectos nos referimos nuevamente a Abreu (2013: 73):

"De cualquier modo, como lo demostró el doctor Rivero de la Calle, existían y existen grupos de descendientes de indígenas localizados en zonas apartadas geográficamente de los pueblos y ciudades, como es el caso de Yateras. Individuos con estos rasgos aún aparecen en Jiguaní y, con menor fuerza, en los poblados de Fray Benito, en el municipio Rafael Freyre, y en el de Barajagua, municipio Cueto, en la provincia de Holguín".

Esos indígenas citados por Rivero de la Calle son evidencia de una supervivencia nativa cubana. En el contexto de denominaciones los naturales se nombraban y reconocían entre ellos con nombres que no incluían una tainidad. Finaliza Abreu narrando

\footnotetext{
${ }^{74}$ Pasada una década (Siegel, 1988) en (Siegel, 1999: 209), se continua integrando los taínos a autores clásicos. Siegel, P.E., 1999. Contested places and places of contest: The evolution of social power and ceremonial space in prehistoric Puerto Rico. Latin American Antiquity, pp.209238.
} 
de la región de Nipe ídolos y leyendas. José Abreu Cardet (2013: 39) cautelosamente elude el termino taíno y correctamente identifica asuntos arqueológicos sin valerse de la estandarización terminológica taína al identificar los nativos de Cuba.

Hooland y Hofman (1993: 177) ofrecen la idea de una expansión hacia el sureste, mientras mantienen que existió una tendencia de movimientos taínos hacia las Antillas Menores: "la migración de un pequeño grupo de colonos tainos a Saba". Nos interesa la referencia al movimiento en sí, sin entrar aquí en la denominación. Continúan Hoogland y Hofman (1999: 109) años más tarde con la misma idea: "hay una expansión del territorio taíno hacia las Antillas Menores". El citado movimiento lo relacionamos con la evolución continua que existía en el Caribe insular, consistente en relaciones comerciales, disputas tribales y la evolución uniforme compartida. A continuación, alejándonos del amplio significado de la migración, examinamos la terminología aplicada. Contrario a Abreu (2013), Hoogland y Hofman (1999) deciden denominar a sus grupos migratorios como taínos. Después de 1492, según hemos señalado anteriormente, los borincanos se unieron a sus enemigos caribes para combatir a los exploradores. En este sentido, se encuentran grupos de guerreros nativos unidos en un plan de combate que antecede en una década al de La Española. Estos tratados movilizaban a sus gentes por vías marítimas comunes relacionadas a la conformidad uniforme evolucionada. Esas migraciones de antaño para comercio, saqueo o amistad, en sus nuevas estrategias del siglo XVI ante un enemigo común y sanguinario, sirven para refugiarse. La movilización marítima facilita la reubicación a áreas remotas nuevas con el propósito de la supervivencia. En adición, los tratados de grupos independientes incluían arreglos matrimoniales y políticos, lo que integraría conceptos compartidos por el lenguaje, el arte, la construcción y sus rituales, y otras variaciones tribales ligadas a los temas de migraciones y supervivencia. La diferenciación étnica en el Caribe es una particularidad sociocultural pero dentro de una conformidad biológica uniforme, que a su vez no está basada en una sociedad taína, o movilización taína, considerando que los taínos no tienen ancestros o existencia física o material.

En los relatos de Reichel-Dolmatoff $(1960,1977)$ encontramos pequeños subgrupos de una tribu principal en la que todos se conocen por sus propias denominaciones y a su vez hablan dialectos diferentes y cambian de nombre mediante migraciones. Abreu (2013) se expresa de este modo: "En algunos casos la crónica indica que son ancianos y se sugiere el reconocimiento de su sabiduría y experiencia; esto apunta a un mandato tal vez a mecanismos de acceso al poder en los que resultarían claves las 
cualidades personales y el prestigio". Abreu hace referencia a Alegría mientras discute cacicazgos, y es muy cierto que algunos grupos o parentelas no respondían a caciques. En Navarrete (1923: 31), presentando el libro de América en Vespucio, leemos lo siguiente:

"No tienen jefes ni capitanes ninguno de guerra, antes bien caminan sin guardar orden, como dueño cada una de sí mismo. No pelean por deseo de reinar, o de extender su dominio, ni por otra pasión desordenada, sino por la antigua enemistad, grabadas de muy atrás en sus corazones; y habiéndole preguntado la causa de esta enemistad, no han dado otra que la de vengar la muerte de sus ascendientes. Esta gente vive en su libertad, no obedece a nadie, ni tiene ley ni señor".

Fernández de Navarrete, en su nota 1 al texto, comenta: "Esto parece inverosímil y está en contradicción con las relaciones del almirante y demás exploradores". La nota 2 igualmente cita: "(...) carece de todo fundamento".

En Vespucio y Navarrete tenemos un problema clásico. Navarrete compara el escrito de Vespucio del viaje en 1497 con Ojeda al del Almirante, del diario desde 1492, y de otros cronistas. Primero, el área geográfica de Vespucio y la del Almirante son diversas. En este sentido, podemos comparar otras regiones para obtener una mejor idea de la amplia diversidad. Por ejemplo, Abreu (2013) señala a los ancianos como una especie de líderes en Cuba; Reichel-Dolmatoff (1960) en ocasiones los señala de hechiceros en Colombia, a los que Uribe (1977) llama los mamas. En pequeñas comunidades y parentelas caribeña puede darse el caso de Vespucio, no exclusivo de la Guyana, donde se encontraba al redactar sus observaciones.

En el interior de La Española y Puerto Rico bien pudieron existir bandas y parentelas sin caciques, mientras la pauta general de la política nativa se acogía a un cacique como figura de control. En los vocablos y denominaciones de pueblos aislados o nómadas pudieron existir viviendo según relata Vespucio, libres, sin leyes o señores. Estos experimentados exploradores proveen muestras de lo vivido en las regiones recorridas, unas que son comparables entre sí basándonos en la conformidad típica mientras destacamos la diversidad nativa, denominaciones, idiosincrasias y estructuras sociopolíticas. La contradicción inverosímil contrastada por Fernández de Navarrete no consideró la ubicación de Colón y la de Vespucio, unas 1.200 millas la una de la otra, el hecho que una era isla y la otra tierra firme o la diversidad nativa de origen.

Es lógico asumir que dentro del concepto de la conformidad biológica uniforme existía una gran diversidad cultural y sociopolítica A mediados del siglo XIX, Elias 
Régnault (1846: 5) nos dice: "Las Antillas no tienen historia que les sea propia: sus anales se hallan confundidos con las empresas de guerras con los europeos. Solo Haití, que goza de cuarenta años de independencia, puede ofrecer durante este periodo una verdadera historia nacional".

Entre Régnault y Fernández de Navarrete existe un abismo. Régnault desconoce la historia de los nativos caribeños y su teorización colonizadora solo nos recuerda a una lógica pervertida. Al contrario, Fernández de Navarrete argumenta dentro de realidades nativas costumbres y políticas sin razonar copiosamente las condiciones geográficas y costumbres tribales especificadas por Vespucio o el concepto de la diversidad tribal dentro de una conformidad biológica uniforme. Régnault desconocía la historia nativa caribeña mientras Rafinesque es galardonado en Francia por sus méritos al llenar ese espacio desconocido por Régnault y otros europeos. Se perfecciona otra de las razones del inmenso éxito de Rafinesque en Europa al denominar los nativos de Haití desde Francia. El estado de la historia nativa caribeña era desconocida por los expertos: Rafinesque era un visionario, un creador de identidad acomodaticio a gentes sin historia, según Régnault. Ese pensamiento de gente sin historia lo hemos discutido desde Premdas (1996) y otros. Por una parte, tenemos autores desconocedores, autores engreídos, difusores y seguidores neófitos. Examinamos a lo largo de esta tesis quienes favorecieron la visión de Rafinesque en la estandarización terminológica y los que presentaron su oposición junto a los que documentaron esa aventura académica. La invención académica no surge de la nada tenía un propósito y una necesidad científica. Esa insuficiencia o desconocimiento se acoge al pensamiento de gente sin historia específicamente en las Antillas Mayores, como interpretan Régnault y otros. A esa laguna antillana, como bien dijo Fewkes (1907), el sonoro taíno era una buena sustitución. En la fase de incubación de la terminología taina de Rafinesque se cimenta una ideología académica exitosa que pasa desapercibida internacionalmente.

En la tercera fase del desarrollo de la estandarización terminológica taína se identifican asuntos problemáticos, como se desprende de la cita de J. C. Harrington (1955: 1123):

"Me doy cuenta de que el interés de los antropólogos en los resultados de las excavaciones en sitios de indios radica en la contribución que tales proyectos pueden hacer en estudios de antropología y cultura, a los que me referí brevemente en relación con el trabajo de DiPeso. Sin embargo, nuestro interés en ellos aquí está en su contribución al enfoque más convencional de la historia de América. Por supuesto, la aculturación funciona en ambos sentidos, ya que los efectos de las culturas indias en los 
europeos son, o deberían ser, considerados en cualquier estudio histórico en el que estén involucrados tales contactos".

El enfoque más convencional y la contribución a la historia nativa caribeña durante el siglo XX perteneció a la estandarización taína. Continúa Harrington (1955): "Por lo que sé, sin embargo, no se ha intentado utilizar los datos de estos proyectos en la investigación de este tipo, ya sea con respecto a la cultura blanca involucrada o la de las tribus indias adyacentes". Los estudiosos en el siglo XXI que arrastran su bagaje del siglo XX debaten ilimitadamente la terminología estandarizada mientras buscan encontrar explicaciones a sus conceptos de tainidades, tainatos y taínos que nunca existieron fundamentando, política, cultura, raza, lengua, etc.

\subsection{Un término obligado, sin recursos o lexicón}

La palabra taíno, significando lenguaje, tribu, o raza de un nativo, predominante oriundo del Caribe, no consta en ningún diccionario con anterioridad a la Segunda Guerra Mundial del lexicón Arahuaca, Caribe o Antillano. Solo figura en las obras de Rafinesque (1836) y sus amigos, von Sivers (1861) y von Martius (1867), entre otros difusores y seguidores. En esa época, la palabra no tenía el significado adjudicado por Rafinesque, quien admite que él no tenía ningún problema restaurando lenguajes perdidos basados en sus tientas en la oscuridad. Rafinesque, Olsen y Bourne (1906) y Fewkes (1907) tenían en común extraer términos a tientas en la oscuridad o utilizar el dictum de la ley del menor esfuerzo para lograr objetivos técnicos y científicos. Taíno como palabra singular no existe en la lexicografía de la lengua Caribe y se puede comprobar en Courtz (2008), en su amplio diccionario de unas 6.500 palabras y tampoco se encuentra en la lexicografía arahuaca o arawak de Brinton (1871). Brinton (1871: 435) señala correctamente a los arahuacos isleños (Island arawack) pero dice que en Cuba y las Bahamas se hablaba el mismo idioma y continúa diciendo que Gómara, por haber escrito cincuenta años más tarde, no reconoció que los nativos habían sido relocalizados. Gómara estaba correcto, y citamos a Pedro Mártir de Anglería en la edición de O Gorman (1989: 139): "ni el propio Diego, que a la entrada de Cuba había entendido la lengua de los indígenas, comprendía la de estos".

El lucayo Diego Colón, ese niño nativo que Cristóbal Colón aunara en las Bahamas, regresaba al Caribe en el segundo viaje de Colón en calidad de intérprete, 
habiéndose educado en España durante su estadía. Las habilidades de Diego fueron puestas a práctica en Dominica, Guadalupe, Puerto Rico, Cuba y otras islas, concluyendo en La Española. Diego reconoció una lengua diferente en Cuba en relación a la suya. Es decir, Diego, a quien Colón recogiera en Guanahani (San Salvador, Watling Bahamas) en su primer viaje, el 11 de octubre de 1492, según el diario de Colón y Mártir de Anglería, en este sentido Diego es el primer traductor nativo de América. Y no solo es el primer traductor sino también el primer espía nativo, trabajando para Colón transmitiendo información de las gentes con las cuales convenía. Las diferencias idiomáticas isleñas en su tiempo fueron representativas de áreas geográficas específicas, por ej, influyendo en acentos, pronunciaciones y variaciones en dialectos. En la ordenación de este tema citamos a Navarrete, quien escribió sobre los acontecimientos de Vespucio: “(...) hay entre ellos muchas variedades de idiomas. (...) que de cien en cien leguas ya no se entienden los unos con los otros" (1941: 33).

Este clásico ejemplo nos presenta las dificultades que hay al interpretase términos lingüísticos donde la historia es usada fuera de su contexto para identificar factores humanos. La legitimidad de un término con relación a personas depende de la exactitud y verificación de sus aplicaciones. Tribus homogéneas de diferentes lenguas no se pueden conformar singularmente; sus denominaciones y descendencia implican diversidad, y conllevan la utilización de sus propios nombres.

Dice Whitehead (2002: 25) que Brinton decidió usar el término Isleños arahuacos (Island Arawaks) y no el de taíno por considerarlo inadecuado. Esta tesis considera a Whitehead y Brinton como visionarios ejemplares en la investigación del arahuaco y sus descendencias, contrapuestos al tainismo. Afirma Whitehead (2002) que Brinton no trató de agrupar la lexicografía karipuna y lokono en el lenguaje arahuaco. La decisión de Brinton (1871) estuvo bien fundada, facilitando espacios independientes a ambos léxicos mientras señalaba la inutilidad del término taino (taíno). Whitehead escribe que Brinton Movió la lengua Arauca a un nuevo nivel.

Las amplias lexicografías hoy en día son evidencia de una extensa investigación del Caribe. Examinando sólo a Brinton (1871), Zayas (1914), Tejera Penson (1935, 1951), Tejera Bonetti (1977) y Courtz (2008) $)^{75}$ se aprecia la evolución investigativa de

\footnotetext{
${ }^{75}$ El trabajo de Courtz identifica, incluye y separa los siguientes estudios: (Boyer 1640, Pretpratt, 1653-1654; Biet 1664; Adams 1893; Goeje 1909; Ahlbrinck 1914-1916-1931; Salle de L' Estaing siglo XVIII diccionario al francés; Taylor, Hogg y otros.)
} 
ambas lenguas y sus culturas como trabajos fundamentales recogidos en estas lexicografías. Unos trabajos donde no existe el taíno como raza, tribu o nativo.

Ocupémonos ahora de los diccionarios. Las definiciones en ellos son básicas y efectivas al presentar de forma neutra. El Diccionario Provincial de voces cubanas, de Esteban Pichardo (1836), no contiene las palabras siguientes: aborigen, arahuaco, o arauco, taíno, nitaíno, nativo, pero sí, indio, y dice: "En ninguna parte de la isla se le hace aplicación de esta voz a ninguna persona; excepto algunas veces a los naturales de los pueblos de Cauy, Tiguabos y Jiguani, en la parte oriental, solamente por su origen y los privilegios que gozan". El cuidado de Pichardo es admirable por su gentil acercamiento de lo que constituye un indio, en este caso el indio no es un ciudadano de segunda clase y goza por su origen de privilegios; ese goce es lo que una nueva terminología niega a los descendientes cubanos de Cauy, Tiguabos y Jiguani. Adicionalmente, Pichardo identifica nativos vivos por la cual los nativos no deben considerarse extintos, como bien señalamos anteriormente. Desde este punto de vista podemos entender por qué Zayas rehusó la utilización del término taíno. Zayas había corroborado lo definido en Pichardo y entendía la razón y equivocación de Harrington (1921).

En el diccionario etnográfico de Jesús Guanche se citan las etnias extintas: arawak, ciboney, ciguayo y taíno, y en peligro de extinción los caribes; en esta evolución étnica e idiomática las particularidades tribales originarias no asumen un marco histórico, pero se recogen en razas definitivas. En palabras de Gauche (2015: 48): "Los componentes étnicos Arauco desempeñaron un papel fundamental en las primeras relaciones sociocultural establecidas con los inmigrantes hispánicos y africanos durante el proceso temprano de transmisión de acciones y valores adquiridos a través de una permanencia prolongada en el medio cubano". Las restricciones fundamentales en el proceso temprano son señaladas de la siguiente manera:

\footnotetext{
"Se hablaban entonces en las Antillas Mayores, variedades del sub-grupo taíno (o nitaíno). El taíno propiamente dicho se hablaba en Cuba y La Española (Santo Domingo y Haití); el borinquén en Puerto Rico; el yamaye en Jamaica, y en las Bahamas, se hablaba el lucaya. En las Antillas menores se hablaban el eyeri (o allouage), el nepuya, el naparina y el caliponau (usado por las mujeres de las tribus Caribe)" (Guanche, 2015: 6).
}

La identificación idiomática es problemática al aludir a una terminología estandarizada en representación de las personas. Primero, porque sus habitantes han sido aislados de sus denominaciones culturales. Segundo, el conjunto natural y la multiplicidad de sus propias lenguas está comprometido por la terminología. Por ejemplo, 
Gauche considera que en las Antillas Mayores se hablaron variedades del sub-taíno o nitaínos, encontrándonos que al circunscribirnos a esa estandarización desatendemos el borincano puertorriqueño, el yamaye jamaiquino o el lucayo bahameño. El sub-taíno o nitaínos como lengua nunca existió, el taíno nunca se habló ya que no era una lengua nativa. Pasando a las aplicaciones modernas, cruzamos espacios cuyos fundamentos imperfectos engendran el vivir en una simbología o fenomenología cultural fabricada. Al examinar esa problemática impuesta, analizamos ideas y resultandos faltos de sensibilidad. Un ejemplo lo encontralos en Franz Boas (1938: 4):

"Uno de los problemas metodológicos importantes de la antropología es investigar hasta qué punto la distribución geográfica de los fenómenos culturales puede usarse para la reconstrucción histórica. [...] Tampoco es posible estar seguro de sí una fase particular de la cultura no es más bien el desarrollo local de un rasgo antiguo ampliamente difundido que ha florecido más que la fuente de la cual surgió el rasgo más generalizado. [...] Cuando el mismo tipo de cuerpo ocurre entre los habitantes de los países vecinos, hay pocas dudas sobre su origen común. Cuando se encuentran pequeñas similitudes en regiones muy alejadas, es posible que esto se deba a un origen común o al desarrollo biológico paralelo".

Boas reconoce los posibles errores antropológicos basados en principios deducidos de los términos de la biología, origen común y rasgos antiguos conducentes a la generalización terminológica.

Bartolomé de las Casas (2009: 83) nos habla de los cinco cacicazgos de La Española y especifica: "Algunos señores de algunas apartadas provincias no reconocían superior dellos algunos". La referencia a "algunas apartadas provincias" parece un indicador de tribus ajenas, exteriores, convertido en un indicador de jerarquías políticas independientes. Pero hablar de cacicazgos solo alude a una estructura específica y a sus habitantes, no supone estructuras o tribus independientes. Uno de esos grupos fue recogido por Hernán Colón (1892: 12), los llamados Juava Variu. Las relaciones políticas entre tribus $\mathrm{y}$ pequeños grupos o parentelas no corresponden exclusivamente a cacicazgos, existían grupos fuera de esas estructuras. El ambiente externo de naturaleza geográfica y política es donde el enemigo de mi enemigo es mi amigo. En esa relación, la diversidad de nativos que ya vivían en una conformidad natural ahora identifica un enemigo poderoso, que los unió. ${ }^{76}$

\footnotetext{
${ }^{76}$ Los gandules, el feroz ejército de Guarionex, primero pelean en contra de los Caribes y luego se anexan a ellos. Tapia y Rivera (1852).
} 
El Diccionario y Gramática de Caribes de Hendrik Courtz (2008) incluye las siguientes palabras y sus significados: t(y)-ainakùme, manos redondeadas, tainaposine, manos dulces, tainasare, manos abiertas: y tainamorane, gesticulaciones de mano(s). Todas estas palabras contienen un prefijo taina y están relacionadas a movimientos o condiciones de manos. No existe la palabra taíno en singular y las señaladas aparentan significar un modo de saludo. En Guadalupe pudo ser lo observado en la playa cuando los nativos agrupados se manifestaban curiosos. Esa posibilidad puede considerarse remota ya que los nativos huyeron de los castellanos tan pronto como la barca de estos se acercó a tierra. Alfredo Zayas y Alfonso (1914) nos dice de los españoles: “(...) estos le gritaban desde las barcas Tayno a los aborígenes". Ambas interpretaciones concuerdan en el significado correcto que Tayno significa, paz o bueno. Se une a estas narrativas Andrés Bernáldez, cronista de los Reyes Católicos, quien escribiera sobre esas manifestaciones en las playas de Guadalupe (1943: 211); en acuerdo con Zayas, que los españoles gritaban taíno, taíno o más bien, según Bernáldez, taínon, taínon a los nativos. Bernáldez vivió en Sevilla y pudo haber conocido o leído la carta del doctor Álvarez Chanca en esa época, pues su relato es muy parecido, con la excepción del deletreado de taínon y no tayno, pero ambos autores concuerdan en el significado de bueno o noble. Bernáldez, a su vez, tenía acceso a algunos relatos recogidos de marineros, viajantes y exploradores, y entre esos igualmente a Colón. Fewkes (1907) lo traduce como: Paz, paz, y somos amigos, y continúa: "Entre las primeras palabras que oyeron los camaradas de Colón cuando arribaron en Guadalupe fueron “taíno! taíno!”.

Esta oración en inglés tiene un claro impacto y constituye una base sobre la cual arqueólogos deducen la estandarización. En realidad, fueron los españoles quienes le gritaban a los nativos tayno, tayno. Fewkes, en su traducción, se equivocó, y puede decirse que se basó en esa equivocación para sustituir el antillano y arahuacos isleños por el taíno. El deletreado de Fewkes taíno solo coincide con el de Rafinesque y no con el del Dr. Álvarez Chanca, Mártir de Angelaría, R. H. Major, Bernáldez, Coll y Tosté, o incluso Olsen y Bourne, quienes usaron tayno o taínon. Fueron los castellanos quienes gritaban a los nativos. Obviamente, de haber sido los nativos, estos no hubiesen corrido o algunos esperarían a conocer las intenciones de los castellanos. La monografía de Fewkes se materializa en base a un error técnico, constituyéndose sobre un siglo de incongruencias desde Rafinesque. Las mínimas líneas dedicadas por Fewkes al taíno están entre sus más citadas por otros investigadores para significar raza, tribu, y lenguaje. Autores 
pertenecientes a la tercera época repiten una y otra vez sus teorías estandarizadas. Por ejemplo, Kathleen Degan (2006: 622):

"Desde una perspectiva arqueológica, la continuidad cultural de Taino y la transformación cultural española en la Hispaniola del siglo XVI sugiere que el cambio cultural inducido por contacto en la práctica doméstica del hogar era en gran parte unidireccional, desde Taino hasta español”.

Esa perspectiva arqueológica es compartida por replicadores del tainismo como William F Keegan y Morgan D Maclachan (1986: 614):

"En los 800 A.C. Los colonos taínos de La Española comenzaron a asentarse en el archipiélago de las Bahamas. Durante los siguientes 700 años, la población de Lucaya en las Bahamas creció a una tasa exponencial y se expandió para colonizar todas las islas y cayos más grandes (Keegan 1985; Sears y Sullivan 1978). El patrón terminal (posterior a A.D. 1400) de resolución de liquidación muestra una distribución de la población en estado estable en relación con el área de la isla. El examen de las distribuciones de la población terminal ha indicado que este patrón se generó principalmente por esfuerzos para maximizar el acceso a los recursos productivos durante la fase inicial de Expansión (Keegan 1985)", ${ }^{77}$

Las coincidencias de estos autores tainistas recrean una disciplina científica para establecer sociedades taínas en el Caribe y debatir poblados nativos de la prehistoria. Tanto la periodización, la geografía y la etnología en estas citas son anómalas. Se puede considerar una especie de confrontación entre pensamientos en base a diferencias nativas y legados enmarcados en el nivel de abuso en periodos específicos. Jacqueline Clarac de Briceño et al (2016: 154):

“(...) y a partir de hechos de conquista que parecen más bien una historia de locos... La herencia de todo esto ha creado ese imaginario colectivo negativo, culpable de graves problemas identitarios, colectivos e individuales, que ha dado a sus habitantes la

${ }^{77}$ Torres, J.M., 2012. The social construction of community, polity, and place in ancient Puerto Rico (AD 600-AD 1200). University of Florida. Esta tesis fue dirigida por Michael J. Heckenberger y codirigida por William F. Keegan. La prehistoria en esta tesis doctoral refleja una influencia tainista al señalar las comunidades de Puerto Rico de tainos en adición a las autoridades citadas. Por ejemplo, p. 25, "redes sociopolíticas de los pueblos indígenas taínos", p. 131, "En su investigación en el archipiélago de las Bahamas, Los autores sugieren que los asentamientos tainos evolucionaron con el tiempo en tres fases" (Keegan y Mclachalan 1989: 613, 624-626). P. 134, "entidades políticas pretainas". p. 144, "Asociaciones territoriales y Los derechos a la tierra eran probablemente una dimensión central del histórico taíno y es lógico asumir que esta condición tiene sus raices en un proceso anterior de asentamiento y Interacción". p. 352, "Los cronistas del siglo XVI describen las canchas de pelota y el juego, ambos llamados batey, como características centrales arquitectónicas y sociales de los asentamientos taínos". Esta ultima cita proviene de acuerdo a Torres de: (Oviedo y Valdez 1975; Las Casas 1951). 
impresión de vivir en un país desconocido, rodeado de gente peligrosa y bárbara... El hecho que hasta recientemente se cazara en las sabanas da Apure a los indígenas como si fuesen animales, es muestra que hemos vivido en un país que no se ha conocido a sí mismo".

Clarac de Briceño se refiere a Venezuela, pero bien pudiese haberse dicho en cualquiera de los países que estudiamos de poder validarse su periodización. Los problemas individuales de identidad, historia y herencia, junto al problema colectivo natural, se acogen fundamentalmente al pensamiento de la lógica pervertida, según hemos discutido.

\subsection{Etnónimos y exónimos}

Hernán Colón (1947: 147) presenta nombres de islas recorridas y nombradas por los aborígenes, rara vez escuchadas después: Yaramaqui, Cairoaco, Huino, Buriari y Arubeira. Continúa diciendo: Pero la tierra firme que decían ser muy grande, tanto ellos como en La Española la llamaban Zuania. Según Brinton, en el vocabulario caribeño la z no existía y era una corrupción idiomática del español remplazando quizás la c. Los arahuacos y caribe se referían a tierra firme o Sudamérica igualmente por su etnónimo Zuania. Esta era una palabra común con un significado compartido por las dos razas matrices predominantes del Caribe, que rara vez escuchamos o leemos. Ese uso debería darnos una idea de la colectividad típica nativa de lenguaje y geografía a lo largo del archipiélago para identificar entre ellos algunas peculiaridades geográficas, ligústicas y tribales. Esa diversidad es mucho más abarcadora que lo reconocido en nuestros tiempos. A su vez, provee una vía para la difusión de denominaciones que habíamos discutido anteriormente. Por esa vía la conexión entre el Huhuici (Hu-hui-ci) de Hernán Colón, el Alauhuiku Alau-hui-ku de Reichel-Domatoff y el Unhuirey Un-hui-rey de Arrom pueden haber tenido un significado compartido. El Huino (hui-no) citado por Hernán Colón como una isla ahora presenta una coincidencia al Huhuici (hu-hui ci), que identifico como un grupo nativo en La Española.

Se buscaron semejanzas a estos nombres en el diccionario Caribe de Hendrik Courtz (2008) sin lograr comparaciones de tipo alguno. Boas (1938) señala tres grandes problemas de la antropología: (1) la reconstrucción de la historia; (2) el fenómeno de los tipos históricos y sus secuencias; (3) la dinámica de los cambios. En adición a los tres 
importantes señalamientos se propagó una ciencia interpretativa cuya base persistía prejuiciada y corrupta. Esa base no se contentó con estandarizar naciones caribeñas, sino que se justificó adentrándose en sus intervenciones al coartar la historia.

En el diccionario de la lengua arahuaca (Arawak) de Guiana de Brinton (1871: 3), hui es un pronombre que significa tu o usted, pero Huiho (hui-ho) designa un alto nivel. El profesor von Martius hablaba de la riqueza de la lengua Arauca (Brinton, 1871: 8), de la que tomaremos algunos ejemplos idiomáticos sobre la el sistema de composición de a lengua. Examinemos algunos derivados: haikan (hai-kan), pasar adelante; haikanku (hai$k a n-k u)$, muerte o pasar a la muerte; aiikaku (aii-ka-ku), matrimonio, o la muerte de la mujer al separarse de sus padres; kassan (ka-ssan), embarazada; kassaku (ka-ssa-ku), el firmamento, grande como todas las cosas son; y, kassahu behu, la casa del firmamento, el cielo, el día; ukku el corazón; ukkurahu (ukku-ra-hu), la familia, la tribu, los de una sangre, cuyo corazón late en uno; ukuahu (uku-a-hu), una persona; ukkurahu pus, la extraña analogía que en otras lenguas nativas significa masculinidad, de donde sale el germen de la vida. Alauhuiku (Alau-hui-ku), según Reichel-Dolmatoff, es el nombre de un gran heroe, Huhuici (Hu-hui-ci), de Hernán Colón, es un grupo o tribu en La Española, el Unhuirey (Un-hui-rey) de Arrom, quien solo lo uso en una nota y no identificó su significado. Estos tres estudiosos coinciden en que hui significa un alto nivel (tu o usted), ku el firmamento, ukku el corazón, la familia una sangre. Alauhuiku (Alau-hui-ku), el héroe hui, un alto nivel, ku o ukku, el corazón de la tribu, nuestra familia, como bien pudo decir Arrom, un rey en castellano relativo a un alto nivel, o sea, Un-hui-rey.

Brinton y von Martius concuerdan en ciertas cuestiones relativas a la composición de las palabras. Arawanilli, en Brinton (1871: 18), camina por las aguas del Pomeroon, sufriendo por los males e ignorancia de su nación. Súbitamente se levanta de las olas el espíritu de una mujer, Orehu, y le habla. Orehu le manifiesta los secretos de semeci, la hechicería que complace y controla a Yauhahu, y le presenta a maraka, una calabaza llena de piedrecillas blancas que repiquetean durante el exorcismo, el sonido convoca a los espíritus del más allá. Arawanilli íntegramente instruyó a su pueblo en lo que Orehu le encomendó, y así salvó a todos de sus malicias. Cuando tras una vida de sabiduría y buenas obras llegó la hora de su despedida, él no murió, pero subió. Orehu acompañó a los arawaks a moverse y se dice que aún está en el Pomerron. Brinton argumenta que Arawanilli (Ara-wa-ni-lli) pudo ser considerado el nombre que dió origen a la raza arawak. Es muy posible que la etnia de los araucos (arawaks, arahuacos, arhuacos) y su denominación no se encuentre lejos de Alauhuiku o el Arawanilli. En este sentido, el 
aporte de Hernán Colón, Brinton, Reichel y Arrom prestan fiabilidad a los huhuici de La Española; si incorporamos a semeci (se-me-ci) la hechicería, y nuevamente tratamos a huhui-ci interpretándose un más amplio sentido, seme, zeme, cemis, son unas corrupciones lingüísticas de significado mitológicos. Sumándose a la íntima relación mitológica en el sentido incorporado desde Zuania Zua-nia, se puede estudiar una posibilidad del origen de una palabra que implica una etnia en una trayectoria nativa aceptable.

Brinton (1871: 18 n 49) considera que el autor más confiable de la conquista es Las Casas: "Tres lenguas había en esta isla distintas que la una a la otra no se entendían". Sin lugar a duda, la idea original de Las Casas y de Bretts, recogidos por Brinton, es la identificación de áreas geográficas aisladas, distintas y distantes entre sí, que guardaban una estrecha comunalidad entre diversidades culturas unidas por su conformidad típica. En un corto segmento encontramos una profundidad científica que se acoge a la mitología, familia y descendencia del origen de una raza. Ese origen de etnia o nación da a lugar al pensamiento nativo compartido, esparcido por una vasta área geográfica desde tierra firme hasta el archipiélago caribeño, apuntando al Yucatán. En esa conformidad típica, con un pensamiento nativo compartido, conviven sus habitantes comunicándose en diferentes lenguas aun en la misma isla a causa de sus propias identidades tribales. En este sentido, la diversidad nativa evoluciona en su propia naturaleza tribal regionalizada, sirviendo a modos propios y diversificados en su formación de denominaciones mientras retenían un ancestro común. Mártir de Angelaría (1989: 139) ya lo reconoció: “(...) ni el propio Diego, que a la entrada de Cuba había entendido la lengua de los indígenas, comprendía la de estos”. Bartolomé de las Casas discutió las tres lenguas de Haití (La Española) y las variaciones de la lengua universal. Mártir de Angelaría y Las Casas proveen datos lingüísticos que implican el reconocimiento de diversidades. Brinton (1871) presenta en su estudio de la lengua Arauca la vida tribal en una amplia geografía, donde se comparten ideas universales. Oscar Peschel (1876: 206) concuerda en este modo de Hayti: “(...) aventureros habían fundado monarquías y los antiguos que llegaron habían tomado posesión de la costa este".

Las citas de Hernán Colón -en la edición de Iglesias- (1947: 146) sostienen: “(...) los habitantes de esta isla de Guadalupe eran Caribe (...)". Se identifica la etnia Caribe por cautivos de boriquén y se identifica la localización de boriquén atribuido al actual Puerto Rico y continúa describiendo la isla como su nación al referirse al joven mozo borincano. Se extraé de boriquén términos correctos como boricuas, borinqueños o 
boriquenos, siendo esto una etnia particularizada que añade ventajas sociales a la comunidad puertorriqueña históricamente.

Vidal Morales, Cosculluelas, Zayas, de la Torre y otros a finales del siglo XIX y principios del XX son investigadores que no utilizan el término taíno en arqueología, historia, etnografía o lexicografía, por considerarlo erróneo, sin fundamento. En Cuba, la mayoría de los estudiosos hasta 1914 utilizaban términos como Siboneyes o ciboneyes, arahuacos o arauco, boriquenos o boricuas, ciguayos, quiquellanos, macorijes, jucayos o lucayos, guanahatabeyes y caribes, al igual que la designación de arahuacos isleños o arahuacos insulares para la denominación regional de los nativos, junto con caribes isleños o caribes insulares, pero no el taíno. En el siglo XIX la única excepción encontrada fue Bachiller y Morales (1883).

Constantino Samuel Rafinesque es un personaje intrigante que miró apoteósicamente a los norteamericanos. No obstante, promovió avances relacionados con la botánica en los Estados Unidos y Europa. Por más de cien años sus tesis tuvieron un relativo éxito, hasta caer su obra en desuso y su figura en desgracia a causa de nuevas investigaciones. De las más de 6.700 especies nombradas en su vida, sólo alrededor de 300 permanecen en uso, o sea, un 4,5\% aproximadamente, lo que es una buena medida de su éxito. Respecto a la etnología, partiendo de que sus bases científicas son consideradas poco éticas y dudosas desde fecha temprana (Brinton, 1871) los términos que introdujo igualmente fueron exitosos. Es innegable el eco que Rafinesque ha tenido con la idea de los taínos. En Europa, especialmente en Francia, donde creció, goza de buena reputación al contar con más de 30 títulos publicados. Seguramente, queda claro que la figura más importante en la historia del taíno es C.S. Rafinesque. El propio Rafinesque (1836: 116) explica el por qué de su éxito:

"Los Estados Unidos que deberían dar el ejemplo más sabio, de justicia y clemencia, sobre las tribus sometidas, reducidas a visos en lugar de virtuosos, están haciendo lo contrario. Se niegan a amalgamar a las tribus nativas, a admitirlas en igualdad de derechos, como en los nuevos estados españoles; pero obligarlos a cumplir con las leyes no entendidas, en un lenguaje no enseñado, o descalificarlos para los testigos. Los obligan a remover, emigrar, dispersar, vender sus tierras y hogares, a una décima parte del valor, ¡y a esto se llama trato justo!”.

Rafinesque entendía la precaria vida del nativo norteamericano y en su astucia buscó y pensó haber encontrado satisfacer necesidades académicas en la construcción del 
taino. Su sentir sobre el nativo de América era correcto, su remedio ha dado origen a una crisis cultural él nunca pudo imaginar.

En esta sección hemos presentado la conformidad típica desde una perspectiva de colectividad enmarcada por sus dialectos y lenguas universales en grandes áreas geográficas, reteniendo un pensamiento nativo compartido en el que cada tribu o parentela actúa independientemente. Se argumentó la posible descendencia de la etnia arahuaca dando así fiabilidad a denominaciones nativas enclaustradas en la geografía Caribe. Ninguna estandarización genérica fabricada con la mejor intención puede asumirse correcta y anhelarse así llenar en el largo plazo las necesidades culturas de las naciones. La diversidad nativa dentro de su conformidad típica es innegable y la condición actual en el Caribe es remediable.

\subsection{Diseminación y anotaciones}

Posterior a la Segunda Guerra Mundial, en Puerto Rico el uso del término Taíno fue explotado a partir de las tendencias creadas por Olsen y Bourne (1906), Fewkes (1907), Harrington (1921), Loven (1935), Rouse (1948) y otros, hasta socavar la idea de una descendencia arahuaca y caribe. El taíno en Puerto Rico se convirtió en el nativo predominante como por arte de magia y se esparció por todo el Caribe. Pese al poco reconocimiento otorgado a Rafinesque, aseguró su legado a través de los autores citados. Asumida la adquisición de Puerto Rico por los Estados Unidos, se logra un símbolo patriótico-cultural en los taínos, que muchos seguidores y repicadores académicos desde 1956 aceptaron. El taíno de muchos investigadores contemporáneos es una clase noble e inteligente, un indio religioso, un verdadero ladino. En la plaza de Utuado se levanta en bronce un taíno desnudo aguantando la santa cruz en su mano como un triunfo cristiano.

El tema de nativos americanos padece un problema en conexión a prejuicios que ilustramos anteriormente, y que revisitamos con otros autores. Joseph de Acosta (1987: 123) en sus referencias a los nativos, había escrito: "pero de viciosos naturales, inclinados al mal, enemigos de todo bien". Acosta, en una extensa cita argumenta el bien y el mal de los indios, y dice: “(...) los más instruidos y educados por haberse criado entre nosotros los llamamos ladinos" (1987: 25). Los términos ladinos y taínos representan ortográfica y moralmente una configuración cercana, pudiéndose truncar el uno del otro. Simbólicamente estos dos términos, ladinos y taínos, guardan algo en común por ser ambos nobles, educados y acogidos por académicos. Sin embargo, lo contenido entre 
ladinos y arahuacos, o, taínos y arahuacos es una cuestión muy diferente y llena de controversia. Los arahuacos, caribes y descendientes homólogos no tienen en su carácter original de hombre libre nada en común con ladinos o taínos.

Estos primeros tres capítulos presentaron las razones por la cual la terminología taína es ilegítima e injustificable, sobre esa base el taíno obliga a ser completamente relegado al olvido junto a su estandarización y terminología. 


\section{Capítulo 4: Supervivencia nativa, género, familia y el entorno construido}

\section{MATRIMONIO, LENGUAJE Y CIVILIZACIÓN.}

Este capítulo reflexiona sobre el pensamiento nativo. Ese futuro tergiversado concurrió en lo biológico, psicológico, social y político, quedando atrapado en ese conjunto la nueva familia nativa en un colonialismo desconocido y cruel. La naturaleza del tema por sí nos llena de inquietud al analizar la actitud insípida de autores reconocidos. El tema es tan obscuro y la ascendencia nativa tan comprometida que se escriben libros y artículos de indios caribeños sin identificar denominaciones. En este capítulo analizaremos el significado de la poesía y su aporte a la historia que tratamos. En los comienzos de las civilizaciones modernas encontramos unas intersecciones con el tema de la sensibilidad que hemos analizado a lo largo de esta tesis. Suzanne Said (2007: 81) dice: "Al igual que los poetas, tenían la intención de 'traer al conocimiento común cualquier registro o tradición que se encontrara entre los nativos (...) y entregarlos tal como los recibieron, sin agregarlos ni restar de ellos, rechazando ni las leyendas', que se había creído durante muchas generaciones, ni las repentinas inversiones de la acción que son características de la etapa, y que los hombres de la actualidad parecen tener una gran cantidad de tonterías". De Peter Burke (1993: 290) rescatamos la siguiente idea: "Por un lado, los historiadores estructurales han mostrado que el relato tradicional pasa por alto aspectos importantes del pasado de los que es incapaz de dar razón, desde el marco económico y social hasta la experiencia y modos de pensar de la gente corriente. En otras palabras, la narración no es en historiografía más inocente de lo que lo es en la ficción".

El ubicar un pueblo, tribu o nación diferenciada, regionalizada y específica, no generalizada en Puerto Rico, Cuba y República Dominicana es poco habitual y preferiblemente es evitado. Sin embargo, desde el siglo XVIII y XIX existe una segunda base étnica e histórica en la cual se puede basar la evolución nativa caribeña. Bridget Wooding y Richard Moseley-Williams (2004: 26), en un artículo relativo a igualdad e inmigración de haitianos en la República Dominicana, resumen una data histórica: "Tras 
la colonización europea del siglo XVI y el exterminio casi total de los pueblos arawak y caribe, la región fue poblada con esclavos africanos comprados por hacendados provenientes de España, Portugal, Holanda, Gran Bretaña y Francia”. Wooding y Moseley-Williams no tratan el tema de los nativos caribeños, se acogen al concepto del casi exterminio de las razas matrices y a los hacendados europeos compradores de esclavos africanos. Sin embargo, durante la segunda mitad del siglo XVI había hacendados nacidos criollos en el Caribe compradores de esclavos; en segundo lugar, el reemplazo y repoblación caribeña constituyó un extenso proceso aun debatido: el elemento multirracial de la población dominicana es evidente e inseparable de su identidad nacional. Rescatar en el análisis documental el surgir de la supervivencia evolucionada conlleva a examinar la más mínima palabra, pues las terminologías académicas de las últimas dieciocho décadas se basan en pocas palabras saturadas de simbolismo.

Al concentrarnos en el nativo caribeño estudiamos a otros nativos de América con la idea de ampliar el marco de conocimiento y contrastar rasgos comunes dentro de sus variaciones rituales, costumbres y diversidades.

La terminología estandarizada taína se implanta y establece sobre los restos de la fulminación del nativo caribeño por falta de conocimiento. En esta ocasión señalamos la obra del barón Emile Nau (1894: 62) en referencia a las culturas antiguas de Haití:

\footnotetext{
"Sus diferentes modismos idiomáticos tenían analogías obvias y pertenecían a una misma población. De hecho, han sido reconocidos estos signos y otros tan ciertos como la conformación física, la moral y el carácter de los aborígenes de las grandes y pequeñas Antillas, precedentes de un origen común de la misma raza. (...) la afirmación de comunidad de origen, son lo suficientemente notables como para plantear al menos una duda en el observador más desatento. Por lo tanto, en el momento del descubrimiento, parecía que razas de un semblante muy distintas compusieron a los aborígenes de Haití".
}

El barón Emile Nau nació en Puerto Príncipe en 1812 y publicó su obra original en 1855, siendo influyente en la historia y literatura tanto de Haití como de la Republica Dominicana. En la obra de Nau encontramos razas de un semblante muy distinto, estableciendo en 1855 la noción de la diversidad de razas nativas en Haití. José Joaquín Pérez (1877), en sus Fantasías indígenas, recreó la historia de Quisqueya y, consecuentemente, influyó en la historia dominicana. En el prólogo a la obra de Pérez, Apolinar Tejera Penson deja escrito: "Demás que algún merito han de tener, siquiera sea por su carácter eminentemente nacional, pues forman un ramillete de flores quisqueyanas hermosísimo, fragante y sí que en el haya nada de exótico" (1877: 16). Nau, Pérez y 
Apolinar Tejera mencionan las diferencias de naturaleza nativa en el marco de la diversidad de razas, en el lenguaje de la época, etnias. En 1763 Luis Joseph Peguero escribió el primer libro de historia dominicana. ${ }^{78}$ Peguero se denominó dominicano y se refirió a los mestizos como el resultado de los primeros diez años de la conquista, a falta de mujeres españolas; al igual que fray Iñigo y Tapia y Rivera, Peguero usó el termino gandules para referirse a los guerreros nativos de Enriquillo.

Volveremos a interactuar en el tema Haití-Quisqueya mientras examinamos lo sucedido en la época del descubrimiento en comparación a lo sucedido en años posteriores en Norte América. Una de las razones por la cual interactuamos con lo sucedido en Norte América es por ser un lugar de procedencia de muchas de las obras que han influenciado a la historia nativa caribeña desde el siglo XIX, según hemos señalado a lo largo de los primeros tres capítulos de esta tesis. Otra de las razones lo son las conformidades entre naciones de la Florida y territorios norteños y junto a las culturas y naciones caribeñas.

Una de las verdades más inocultables es la violencia y la crueldad de los castellanos sobre los nativos desde el siglo XV. Esas crueldades la vivieron las culturas nativas de Norte América a manos de anglosajones siglos más tarde. En este sentido, examinamos el trato de nativos durante el descubrimiento y lo sucedido posteriormente desde el siglo XIX, que sirvió de base a nuevas interpretaciones de los actos y conocimiento de los castellanos. Elias Johnson (1881: 17) narra una conmovedora historia de las guerras coloniales norteamericanas, relativa al jefe tribal que es conocido por varios nombres: Yutana Nire, o Lone Pine Tree, un Árbol de Pino y Tawennaki, Dos Cosas de Igual Valor, de los Tuscarora: ${ }^{79}$

"Una parienta de ellos, una princesa en sus propios derechos, Wetamore Pocasset, fue perseguida y acosada hasta que cayó exhausta en un bosque muriendo de frío y de hambre. Allí fue encontrada por hombres profesando sentirse impactados por la barbarie de los indios, le cortaron la cabeza y separada de su cuerpo sangrando la ensartaron en un poste, en las carreteras públicas del país, gobernadas por hombres honrados como santos y mártires".

Elias Johnson habla de otra princesa india y su hijo quienes fueron vendidos junto a unos ochocientos miembros de su tribu como esclavos en las Indias Occidentales. Es

\footnotetext{
${ }^{78}$ Peguero, L.J. 1763. Historia de la conquista de la Isla española de Santo Domingo y un compendio de toda la América: v. I, II.

${ }^{79}$ Tuscarora una de las Seis Naciones de los Iroqouis, junto a los Mohawk, Oneida, Onondaga, Cayuga, y Seneca.
} 
decir, fueron desterrados de las frescas brisas de Mount Hope, en la libertad de los bosques de Nueva Inglaterra, al látigo tropical bajo un sol ardiente. Ciertamente estas guerras coloniales ocurren siglos después del descubrimiento y bajo condiciones muy diferentes, pero no fueron menos violentas. Hemos señalado anteriormente el trato de españoles y portugueses, dentro del concubinato nativo, del cual surge el mestizaje, la nueva familia criolla y una cultura heterogénea que da paso a la supervivencia. Johnson (1881:27) se refiere a los pueblos nativos del Norte: "Cada clan también tenía su nombre peculiar, de modo que cuando se mencionaba el nombre de una persona, se sabía de inmediato a qué clan pertenecía".

La tribu es, por tanto, el denominador común compartido por un sinnúmero de clanes, pero identifican parentelas y jerarquías individuales. El denominador común era la tribu seguido del nombre del clan y el de la persona. Clan, persona, nación bien pueden ser partes intercambiables y sensibles; por ejemplo, parentelas, tribus, nación, o nación, pueblos, sectas o cualquier otra formación específica en la que se consideran, la familia, ancestros, naturaleza y geografía. Esta estructuración de denominaciones comunes en las islas Caribe estudiadas carecen totalmente de un semblante distinto de razas según Nau. Dentro de ese semblante distinto, todos eran dueños de sus entornos, ancestros y costumbres, y en base a ese conocimiento y tradición se autodenominaban y reconocían unos y otros, entre tribus y naciones.

Lewis Henry Morgan (1877: 454) narra un ejemplo característico de ese sentir al referirse a los Iroquois y a otras tribus nativas, algo que como examinaremos nuevamente era común en el Caribe: "Los hombres no buscan esposas como lo hacen en la sociedad civilizada, por afecto, por la pasión del amor, que requiere un desarrollo más alto del que habían alcanzado, era algo desconocido para ellos. Por lo tanto, el matrimonio no se fundó sobre el sentimiento sino sobre la convicción y la necesidad”. Morgan sostiene la idea del amor y romance es una actividad de sociedades civilizadas que los nativos no poseían y continúa narrando: "Se dejó en manos de las madres, en efecto, organizar el matrimonio de sus hijos y, en general, se negociaron sin el conocimiento de las partes para casarse y sin pedirles su consentimiento".

Este filosofar no deja espacio para identificar la cultura nativa caribeña naturalmente. Lo narrado por Morgan es solo una imposición. Al examinar a Morgan entendemos que los matrimonios nativos no actúan como sociedades civilizadas sino son otra característica de lo llamado el "bajo estado del barbarismo". Sin embargo dinastías europeas, asiáticas y musulmanas practicaban matrimonios arreglados. 
Brinton (1883: 11) acentúa y corrige el tema mientras identificamos asuntos americanos comunes: "Es un error singular, debido en su totalidad a la ignorancia del tema, a la idea de que las lenguas americanas están abarrotadas en sus vocabularios, o que su sintaxis no les permite definir una relación más delicada de las ideas". Brinton atiende dentro de la sensibilidad el asunto de lenguas americanas desarrollando generalizaciones provechosas, levantando fuertes defensas mientras abarca lenguas nativas del norte, centro y sur de América pues existe una cierta relevancia en esa conexión. Desde esa perspectiva, el lenguaje permite ideas delicadas, unas necesarias en temas de amor, mientras el barbarismo está más relacionado a la violencia o la guerra. Las controversias entre, amor, barbarismo y el pensamiento primitivo surgen en base a quien formula el juicio. Tratemos de entender el problema examinando pensamientos antropológicos ubicados en la segunda fase de la terminología de Rafinesque. Así, Alfred Louis Kroeber (1948: 337), dice:

\begin{abstract}
"Sabemos biológicamente que las razas hereditarias son constantes en la medida en que si nacen mil imbéciles y un genio por millón, en esta generación es improbable que la proporción sea diferente en la próxima generación, o por varias generaciones siguientes. (...) Atenas durante mil años no tuvo grandes hombres. Tuvo un número asombroso de genios clasificados de primera altura en el siglo quinto y cuarto, (...) luego se volvieron estériles y han permanecido así hasta ahora”.
\end{abstract}

Naturalmente, ha pasado mucho desde 1948, sin embargo, Kroeber desarrolla su argumento cuatro décadas después de Fewkes y más de un siglo después de Rafinesque. Este pensamiento se acoge a la antropología norteamericana como algo común. Kroeber (1948: 772) añade: "Hay varias razones por las cuales esta ruptura en nuestro conocimiento ha persistido por más tiempo, en relación con América que en el Hemisferio Este. Después de todo, la historia documental es mucho más corta. Es toda post 1492, a excepción de las áreas que fueron recopiladas por los españoles y la autenticidad de muchos de los cuales no es demasiado clara". Kroeber parece referirse al concepto de invasores españoles, en el contexto de la prehistoria de América, el primer contacto y el avance post 1492. Su entendimiento de este asunto cultural pudo ser limitado pero su influencia es incalculable. En cuestión de matemáticas, pudiésemos examinar cuál es la relación numérica en una variante de mil años (x), en un millón de población (a) generando 1.000 morones (b) y un genio (z) en Atenas, Grecia (n), pudiéndose empezar con; $\mathrm{n}=(\mathrm{a} \div \mathrm{b} \div \mathrm{z})-\mathrm{x}$, la constante $(\mathrm{n})$ de ser substituida por nativos caribeños pudiera ser ( $\tilde{\mathrm{n}})$ solo resta formular la diferenciación entre Atenas y el Caribe Insular, de acuerdo 
a Kroeber, por ej., $\mathrm{n}=100 \%, \tilde{\mathrm{n}}=-100 \%$. La ecuación es muy simple y su resultado corresponde con la tercera fase de la terminologia de Rafinesque y la lógica pervertida en la que se ampara toda una ciencia.

Brinton (1883: 12) supera en su estudio el prejuicio levantando observaciones científicas apropiadas al entendimiento y armonía de la mente nativa capaz de definir ideas dentro de una legitimidad apreciable: "La extraordinariamente rica sinonimia de algunas lenguas americanas, en particular el algonquino, el azteca y el quechua, atestiguan cuán seductores han sido cultivados sus recursos". Debemos mantenernos cercanos a la idea que el lenguaje y las costumbres nativas pertenecen y dependen la una de la otra, pues cada una aclara la otra, y esa diferenciación y comunalidad la estaremos visitando en este capítulo y la hemos discutido en capítulos anteriores. Los Mayas tenían su propios diccionarios y conocimientos organizados, y en esos y otros documentos se registra la prehistoria americana. Brinton menciona un diccionario Maya con unas treinta mil palabras, de las cuales escasamente cien eran extranjeras, y por lo común entendían y hablaban cuatro o cinco de ellas. Las habilidades lingüísticas de los nativos, junto a los recursos idiomáticos que se desprenden de su cultivo, son evidencias del desarrollo de la cultura nativa. En este sentido, la lingüística sirve un propósito sensible para evaluar en qué consiste una civilización nativa antigua.

La estandarización terminológica de los capítulos anteriores presumía esas cualidades, pero ciertamente resulta inconsistente al compararse con la de los algonquinos, aztecas, quechuas o mayas, cuyas culturas provienen de una base histórica verificable. Las lenguas arahuacas y caribes y sus dialectos concuerdan con lo señalado por Brinton, Pérez y Nau. En esa perspectiva de jóvenes nativos hábiles con conocimientos lingüísticos y culturales surge Diego Colón, el joven nativo de Guanahani, quien logra ser el primer traductor nativo americano educado en Europa en 1493. Sabemos que Diego era lucayo y entendía uno o los tres dialectos hablados en La Española y se comunicaba de forma práctica con nativos de otras tierras a lo largo de sus viajes con el Almirante. Diego fue educado en castellano y latín y sabemos que intercedía con nativos favorecidos por Colón como espía y traductor. Diego, formado en Barcelona en la corte de los Reyes Católicos, vivió entre las diversas culturas idiomáticas de la época en su medio ambiente, entre la realeza y los estudiosos.

Un punto de interés señalado por Brinton lo conocemos por Walum Olum, un archivo en pinturas pictográfica, una breve historia de la tribu Delaware. La obra fue adquirida por el Dr. Ward, de Indiana, de un integrante de las Seis Naciones en 1822 
como pago de unos servicios médicos. Las Seis Naciones son conocidas por Iroquois o Aka-no-shu-ne (Johnson 1881:46, 51) y en otras fuentes se les conoce de Haudenosaunee. El Dr. Ward cedió el tratado original a Constantino Samuel Rafinesque, quien tradujo el documento en la copia que posteriormente fue publicada por Ephraim George Squier en 1849. ${ }^{80}$ Rafinesque murió en 1840 y su trabajo de traducción, según Brinton (1883: 21), nunca concluyó. La copia del trabajo original en papel contiene 183 pictografías que originalmente habían sido talladas en unas tabletas de madera, mientras que Squier no concede el crédito de la traducción a Rafinesque, como hizo Briton.

El tratado de la tribu Linápi de Wapahani o Rio Blanco, tribu Delaware, se conoce como el Wallam Olum. En este caso, encontramos a Rafinesque laborando de traductor e intérprete de unas pictografías originales de nativos norteamericanos que fueron preservadas únicamente en las publicaciones de su obra. Estas pictografías estaban basadas en articulaciones orales, según Rafinesque, y eso lo comprobaron -según Brintonel coronel Garrick Mallery, el Dr. W.H. Hoffman, y el capitán W.P. Clark, posteriormente. Según las palabras de Rafinesque, responden a "signos gráficos correspondientes a signos manuales". Rafinesque alcanzó un alto nivel de investigación y su logro en ese trabajo es digno de reconocimiento. El documento traducido por Rafinesque tenía supuestamente unos seiscientos años cuando entró en su poder, algo no verificable. Rafinesque era un estudioso de los signos manuales y su relación lingüística nos conduce a lo considerado en Courtz (2008) al analizar la gramática caribe desde el siglo XVII, en la cual el prefijo taina se acogía a los principios de signos manuales. Esta vía gramatical y sus interlocuciones con signos manuales y sus prefijos pudo ser un tercer encuentro determinante para el "rescate" de la lengua de Haití por Rafinesque.

La obra originalmente publicada en 1824 de James Everett Seaver (1787-1828) fue revisada y publicada en 1856. En ella se narra la historia de Mary Jemison, Dehhewamis, su nombre Seneca, quien fuera conferida a los Senecas, una de esas tribus que formaban parte de ese acuerdo pactado alrededor del año 1200. Mary Jemison fue secuestrada a los trece años y el autor basó su relato en entrevistas con ella. La narración de Seavert (1856) parte desde el tratado de paz de 1783 entre EE UU y Gran Bretaña, sirviendo de base al tratado entre Estados Unidos y los jefes de las Seis Naciones firmado en el Fuerte Stanwix en Rome, NY, en 1784. Mary Jemison nace en altamar entre Irlanda

\footnotetext{
${ }^{80}$ Publicado en el American Whig Review NY Feb 1849. Republicado en The Indian Miscellany editado por W. W. Beach, Albany 1877.
} 
y Estados Unidos hacia 1742-43. Sus padres, escoceses e irlandeses, llegan a la parte oeste de Pennsylvania en 1758. Mary fue capturada por soldados franceses y Shawnee y llevada al fuerte Du Quesne (hoy sitio de Pittsburgh), donde fue entregada a dos mujeres Senecas que habían perdido sus familias. Mary Jemison vivió con los Senecas durante la Guerra de Sucesión mientras las Seis Naciones comprometían sus guerreros en uno u otro bando en busca de sus independencias. Mary Jemison pudo liberarse a comunidades de blancos en varias ocasiones, pero prefirió quedarse entre los Sénecas. ${ }^{81}$ Pasarían cuarenta y dos años antes que se relacionara socialmente con gente blanca; para esa fecha había tenido ocho hijos con dos jefes nativos, con un total de treinta y nueve nietos. Recibió una herencia por parte de los Sénecas por sus dos matrimonios con jefes de esa tribu tras la independencia de Estados Unidos.

Entre las historias de Seaver (1856: 66) aparece otra joven mujer blanca llamada Priscilla Ramsey, que estuvo casada con un nativo tío del capitán Little Billy, y al morir este se casó con un hombre blanco de apellido Nettles, con quien vivió en Grand Rapids, Canadá. Mary Jemison dijo que, aunque inesperado, llegó amar a su esposo, llamado Sheninjee, con quien tuvo una hija cuando ella apenas tenía quince años. Seaver (1856: 87) narra que los nombres nativos son de personas o lugares, o son el significado de una supuesta cualidad, apariencia o situación local. Señalamos una serie de condiciones, pues estas pueden tener ciertas conformidades con las costumbres de nativos caribeños o de otras regiones de América. Las mujeres que describimos, por lo general son nativas, en este caso una mujer blanca irlandesa integrada a la vida nativa y en sus propias palabras explica las experiencias de su vida y su gran familia nativa. La nación Séneca consistía en ocho tribus: lobo, oso, castor, siervo, tortuga, pájaros lavanderas, garza y halcón. Las denominaciones de las tribus, aves y animales de su entorno es lo que se anexaba al registro de persona, clan, nación. A ningún hombre se la permitía casarse dentro de su propia tribu y la herencia era matriarcal. Esta es una de las razones por la cual Mary Jemison hereda de la tribu lo que serían más de 17.927 acres segregados de la reserva Gardeau en 1797. La vida de Mary Jemison es una vida de intrigas de una mujer integrada a la vida tribal Séneca, y sus descendientes acaban casados igual con nativos o blancos, que en cierta forma se integra a la interpretación del mestizaje que se comparte en esta tesis, sobre las relaciones de europeos y nativos incluso en Estados Unidos.

${ }^{81}$ Seaver, James Everett. 1856. Life of Mary Jemison: Deh-he-wā-mis. Miller, Orton \& Mulligan, 
En la política de expansión europea vemos el interés por controlar las riquezas naturales de América a costa de sus habitantes, que son esclavizados para explotar esos bienes. Lewis Henry Morgan nos recuerda una idea básica apreciable por simple lógica, pero a su vez puede interpretarse de muchas formas. Morgan aplica a las familias nativas en América del norte o sur y costas la siguiente consideración: “Algunas tribus y familias se han quedado en aislamiento geográfico para resolver los problemas del progreso mediante un esfuerzo mental original; consecuentemente, han conservado sus artes e instituciones puras y homogéneas, mientras que otras tribus y naciones han sido adulteradas a través de influencias externas" (1877: 16). Es indiscutible la idea de tribus y familias que en aislamiento den comienzo a ideas originales. En las grandes islas del Caribe que estudiamos este pensamiento original pudo desarrollarse y ser significante en la creación de artes y representaciones folclóricas únicas, como bien describe Pérez (1877) en su concepto de tribus aisladas. Incluso se desarrolla por necesidades. Peguero (1763, I: 289-299) describe la villa de Enriquillo a treinta leguas de caminos monstruosos alejados de áreas accesibles; indica, adicionalmente, que la villa se componía de cien casas en las que se alojaban ancianos, mujeres y niños y los gandules guerreros de los seis capitanes de Enriquillo, cada uno comandando a setenta. Bartolomé de Las Casas documentó que Enriquillo se encontraba en compañía de varios miles de nativos. Como sostiene Morgan (1877): "Se ha encontrado que el progreso es sustancialmente el mismo en tribus y naciones que habitan continentes diferentes e incluso desconectados. (...) ese argumento cuando extendido tiende a establecer el origen de la humanidad".

Una de las preocupaciones de esta tesis es el debate entre la conformidad nativa caribeña, la evolución biológica y la estandarización terminológica. Se busca interpretar y encontrar denominaciones tribales en base a una conformidad evolucionada enmarcada en una diversidad lingüística, geográfica y social: “Cada tribu estaba individualizada por un nombre, por un dialecto separado, por un gobierno supremo y por la posesión de un territorio que ocupaba y defendía como propio" (Morgan 1877: 112). Estas características presentadas son compartidas por Seaver (1854), y son de sentido común. Sin embargo, esas aseveraciones de orden común, lógicas, en la literatura norteamericana de estudios nativos americanos no fueron acatadas en el estudio caribeño. Morgan (1877: 103) explica conceptos básicos: "Tribus indias, por lo tanto, son un crecimiento natural a través de la separación de las mismas personas en el área de su ocupación, seguida por divergencias en el lenguaje, la segmentación y la independencia”. Como señalamos en 
capítulos anteriores, el interés en el Caribe comenzó a partir del 1898. En cambio, Morgan sí escribió sobre Grecia, Roma y las grandes culturas asiáticas.

Para Morgan, los nativos americanos de EE UU carecían de atributos mentales y experiencia ancestral, cuando estos habían escrito unos cinco siglos antes un documento político-territorial de importancia histórica, vinculado a una unificación de las Seis Naciones. Ese documento histórico vinculante es significante en lo concerniente a la civilización. Al contrario, Brinton (1883) establece la igualdad documental de excelencia entre libros mayas del Yucatán y de Centroamérica y libros europeos. El argumento entre Kroeber, Morgan y Brinton es filosófico: Morgan y Kroeber buscan en Grecia y Roma sus argumentos del estado de la civilización y Brinton examina estudiosamente los Mayas, Aztecas, Incas y Arahuacos, y destaca el valor de los escritos en pergamino de los Aztecas de Nicaragua, y los quipus peruanos que consistían de cuerdas de varios colores anudados para recordar la memoria, y basándose en el Hombre Americano de Alcide D'Orbigny (1839) narra de tablas hechas de madera y líneas trazadas en escritos utilizados en Bolivia y Colombia.

Esta sección provee un espacio para identificar la vida nativa desde una perspectiva de territorialización, controles y migraciones. En este sentido desarrolla puntos de encuentros comunes con el propósito de visitar nuevas ideas acerca de las tribus. Señala como clan, persona, y tribu dentro de un lenguaje y geografía constituyen por sí mismos los elementos básicos para denominarse. El continuo examen del significado y precedencia documental anterior en un nuevo número de autores identificados con las variadas geografías. El tema científico de verificación y fiabilidad histórica abarca espacios antropológicos al buscar diversidad y claridad. En este caso, examinamos lo perteneciente a la interacción y actividad humana en la vida tribal americana en general. En los capítulos anteriores analizamos las fáciles intervenciones culturales encabezadas desde Europa y los Estados Unidos. Mientras que en los mismos Estados Unidos en pleno siglo XIX y XX los abusos en contra de sus propios nativos aun continuaban y la historia no es completamente conocida.

Hernando Escalante de Fontaneda $[1566]^{82}$ es autor de un relato de la Florida en el cual Escalante a los trece años es un náufrago capturado por el hijo de Senquene, el rey

${ }^{82}$ Fecha derivada basado en el nacimiento y edad al día de su rescate. Archivos Españoles, Archivo General de Indias, Patronato Real 18, Numero 5, http://pares.mcu.es / Smith, B. 1854. Letter of Hernando de Soto and Memoir of Hernando de Escalante Fontaneda. / Juan Bautista Muñoz (col. LXXXIX) Memoria de las cosas y costa y indios de la Florida, que ninguno de cuantos la han costeado, no lo han sabido declarar. 
Carlos Zertepe. El memoir y la memoranda de Escalante de Fontaneda fueron transcritos por Juan Bautista Muñoz en el siglo XVIII; el documento original se encuentra en el AGI. Carlos, dice Escalante de Fontaneda en nuestra lengua, es señor de cincuenta pueblos y a ese conjunto lo refiere Escalante como una provincia. Escalante pasa diecisiete años en la Florida hasta ser rescatado por Pedro Menéndez de Avilés, primer gobernador de la Florida y fundador de San Agustín. Durante esos años se acumula una importante información de las travesías de los nativos en el continente y en el Caribe. Las consecuencias de la experiencia de Escalante son tan diversas y acaparan tantos asuntos, que la examinaremos desde las conexiones interculturales, las travesías y la lingüística. En ese sentido, aclaramos que se han leído varias traducciones y representaciones de estos documentos, de los que hemos señalado dos de unos posibles cinco. Charles Colcock Jones (1873: 51) se refiere al jefe Carlos de Escalante como Coabá y narra la relación entre Avilés, San Agustín y la Florida, y se expande sobre las minas españolas en las montañas Apalaches. En este caso no vamos a implementar la periodización, pues implica un largo proceso enmarcado entre 1560 y 1690. Sin embargo, para avanzar temas anteriores utilizaremos a Juan Bautista Muñoz (1793) y Buckingham Smith (1857) como las dos fuentes primarias en lo relacionado directamente a Escalante.

La leyenda de la fuente de la juventud la recoge Juan Ponce de León en Cuba de los cubeños y, en ocasiones, de los hayties. Dice Escalante de la provincia de Carlos: "En la provincia de Carlos, antiguamente, aportaron muchos indios de Cuba, en busca deste río; y el padre del rey Carlos, que se llamaba Senquene, los tomó y hizo un pueblo de ellos, que hasta hoy día está la generación, y por las mismas causas que ellos, partieron otros de sus tierras, que venían a buscar el río Jordán”. Esta cita da constancia de la leyenda del rio Jordán, pero más importante, da constancia de las travesías comunes entre Cuba y Florida, siendo la migración desde esa perspectiva innegable.

Juan Ponce de León navega en la Florida en 1513 y entre sus asuntos constaba encontrar el rio Jordán. Escalante náufraga en la Florida alrededor de 1549, su carta se publica por primera vez en 1575. Durante esos treinta y seis años las expediciones a la Florida por cubeños y otros nativos de Cuba continuaron. Dice Escalante haber nadado en muchos ríos sin haber escuchado que ninguno de ellos fuese la fuente de la juventud, o haber sentido sus efectos, pero sí habló del mito cubeño. Sin embargo, se establece a los cubeños y otros nativos caribeños viajando entre Cuba y la Florida y viceversa durante la prehistoria. Escalante identificó al menos un pueblo de los de Cuba ubicados en la Florida y es testigo de esos viajes prehistóricos. En este sentido, las experiencias de 
Cabeza de Vaca y Escalante nos permiten asociar la conformidad nativa caribeña con algunos territorios de la Florida, donde algunas tribus de su época son poco conocidas. Por ejemplo: Ais, Apalachee, Calusa, Guale, Guacata, Jaega, Mayaca, Mayaimi, Mayajuaca, etc., Nos concentraremos en las listadas por Escalante para examinar algunos de sus prefijos. Estamos interesados en las denominaciones tribales, gua-le, gua-cata, guale, y las estaremos comparando con otros nombres tribales en el Caribe. En esta situación consideramos que las corrupciones del castellano puedan haber recogido sonidos como jua y deletrearse gua, pues habíamos recogido los Juava Variu de Hernán Colón, que pudo ser Gua-va-va-riu, o Gua-va-riu. Lo indiscutible es que atribuye a una denominación de un grupo de nativos.

Buckingham Smith (1857: 42) presenta una declaración jurada ante magistrados de Vasco Porcallo de Figueroa, dictada en el 1522, usando a Comaguey y Guamohaya en mayúsculas y guaymaros en minúscula, refiriéndose este último a un nombre tribal durante su interrogatorio. En esta sección analizamos las palabras usadas en adelante, examinaremos aspectos de la vida de Porcallo. La audiencia de Porcallo de Figueroa tenía relación con el abuso de los nativos esclavizados que buscaban matarse comiendo arena y el recurso de Porcallo para evitarlo.

El articulo gua se incorpora en la lingüística nativa común de las islas que estudiamos, encontrándose otras denominaciones nativas así configuradas. Recogemos todas estas articulaciones nativas por su inmediatez a la construcción de denominaciones bajo los conceptos señalados. Estas denominaciones y nombres se acogen a un origen común de lenguajes, dialectos y geografía de los naturales. A su vez, algunos de ellos se acogen al género, mitologia y lo construido. Por ejemplo, gua-ti-aos somos hermanos $o$ amigos, gua-i-maros, gua-na-jos, gua-le, gua-ca-ta, gua-le, grupos o tribus de naturales, Gua-ya-ma pueblo, gua-ura-vo rio, Gua-cana-gari un cacique, Gua-rio-nex un cacique, Gua-mi-qui-na un exónimo, asignado a Cristóbal Colón, Gua-y-qui-ries tribu del Orinoco. Gua-ru-gun-ve, que quiere decir en romance «pueblo de llanto», Gua-va-caesgui, que quiere decir «río de cañas». Existen muchas otras utilizaciones gramaticales de gua, por ejemplo, Ma-gua-na, el cacicazgo de Caonabo y Anacaona, I-gua-na-mo-ta hija de Anacoana, ni-gua un rio, gua-na-ga isla cerca de la costa de Honduras, Moquetauri Gua-ya-ba primer señor de Coaibai lugar donde vagan los muertos, o una fruta. Gua-mo-re-te hombre principal dueño del cemi Corocote, Gua-ta-ba-nex dueño de Corocote tras la muerte de Guamorete y cacique de ja-ca-gua. Ve-ra-gua costa de 
grandes riquezas navegadas por Colón, Ci-gua-re el gran reino hacia el oeste rico en oro. Regresaremos a Corocote en la sección de lo construido.

Antonio Bachiller y Morales (1883: 231) señala que Camagüey tenía una población de españoles en 1538 de 19-20, y continúa: "Cual fue el porvenir de los camagüeyanos, no es el objeto de este libro". Bachiller y Morales debió tener algunas dudas. Pensó que camagüeyanos era una denominación nativa quizás cónsona con la declaración de Vasco Porcallo de Figueroa. En adición, escribió: "Los últimos esclavos indios en Cuba se llamaron indios guanajos" (1883: 281). Esteban Pichardo (1836: 50) define el camagüeyano como: "La persona o cosa natural perteneciente a la antigua provincia india de Camagüey donde hoy está situada la ciudad de Puerto Príncipe”. Entre Procallo de Figueroa, Bachiller y Morales y Pichardo encontramos coincidencias de denominaciones en Cuba. A su vez, en el examen del artículo gua, entre guanajos y guaymaros de Cuba encontramos denominaciones parecidas en la Florida, La Española y Puerto Rico. El lenguaje tenía usos comunes, de clanes y tribus y esa conexión se desarrolla por viajes entre ellos no siempre basados en conflictos. Antonio de Herreras (1730: 12) narra el viaje de Colón al Golfo de Paria, navegando a Cubagua, Tortuga cerca de la punta de Araya y comenta: “(...) fue despues á descubrir, i hallo las islas de los Guanajos, y desde antes de Veragua, hasta pasado Nombre de Dios". Islas de los Guanajos es especifico y comparable a islas de los Lucayos. Ambas agrupaciones de islas contienen en sus áreas geográficas sus propias denominaciones.

Juan Bautista Muñoz (1793: 11) añade lo que bien puede ser el concepto general de lo que hemos identificado como la falta de sensibilidad que ha conducido al completo olvido de la herencia o cultura nativa:

"Contentos generalmente con su miseria aquellos barbaros, poco se desvelaban por inquirir o preocuparse por las condiciones de otro. Así cada familia, tribu o nación pequeña estaba confinada en su territorio, sepultada en su ignorancia, y en una indolencia y pereza asombrosa. Cada una tenía su pobre lengua, sus costumbres y usos, sus vanos dioses y supersticiones".

Se levantaron las divisiones de familias, tribus y naciones pequeñas que existían en sus propias geografías independientes reconocidas por sus propias denominaciones. Para muchos estudiosos, el primitivismo y el barbarismo representaban al nativo de América, la civilización era imposible y la fulminación o casi extinción facilitabas sus desordenadas teorías. En este sentido la religión de europeos representaba lo civilizado y los vanos dioses y supersticiones eran inseparables del barbarismo, la idolatría y satanás. 


\title{
2. SUPERVIVENCIA NATIVA.
}

Examinemos la supervivencia nativa caribeña recopilando ideas generadas por autores reconocidos que en sus estudios proponen, en ocasiones, sobrepasan los limites científicos. En Fernando Ortiz (1940: 11) encontraremos en qué consistía el pensamiento cubano de la época:

\begin{abstract}
"Si estas Indias de América fueron Nuevo Mundo para los pueblos europeos, Europa fue Mundo Novísimo para los pueblos americanos. Fueron dos mundos que recíprocamente se descubrieron y entrechocaron. El impacto de las dos culturas fue terrible. Una de ellas pereció, como fulminada. Los indios se extinguieron. Se decía hace poco que aún quedaban algunos, aunque amulatados, por las sierras de Santiago y de Pinar del Río; pero nada científicamente puede asegurarse de si eran vástagos de la indiada cubana o de las numerosas cargazones de lucayos, guanajos, guajiros, jíbaros, macurijes, taironas, yucatecos, guachinangos y floridanos que fueron traídos a Cuba y que, juntos con los negros sometidos a la misma infelicidad, se huyeron a vivir libres por las cimas de los montes, fundando poblados y palenques, en escondida y abigarrada cimarronería".
\end{abstract}

En Morgan (1877) o en Brinton (1883) se identifican particularidades, en Ortiz un mortal conflicto. Ortiz levanta la extinción, fundamenta los guanajos y jibaros entre otros sin acreditar al pueblo mestizo su evolución biológica formando parte del cubanismo. Entresacamos: "Se decía hace poco que aún quedaban algunos, aunque amulatados, por las sierras de Santiago y de Pinar del Río”. El aún quedaban algunos es de importancia pues hablamos del 1940 en Cuba. Fernando Ortiz contribuye en su periodo histórico al concepto de las raices nativas en las comunidades cubanas. Fewkes (1907) y Harrington (1921) registraron la herencia biológica y la cultura material existentes en sus épocas, e identificaron rastros de supervivencia. Ortiz, en su conferencia, articula a los taínos como los habitantes encontrados por europeos en Cuba y adicionalmente identifica denominaciones culturales cubanas. Alejándonos de las estandarizaciones de Ortiz, señalamos que, aún quedaban algunos, aunque amulatados, y a su vez señalamos los floridanos que menciona, pues le da cierta credibilidad a lo señalado anteriormente en los relatos de Escalante, de viajes nativos entre Cuba y Florida, y a Johnson (1881) en su conmovedora historia de Wetamore Pocasset y unos ochocientos nativos desterrados al trópico. 
Fernando Ortiz busca el cubanismo entre blancos, negros e indios. En esta tesis buscamos el humanismo en la sensibilidad científica requerida para recoger en la supervivencia biológica del ADN ese cubanismo unificando esas denominaciones de Ortiz en la Cuba de hoy. Ortiz nos denomina esa valiosa herencia cubana aun cuando en su época la considerara inmaterial. Massimo Livi Bacci (2012: 32) plantea: "El grupo inmigratorio, si posee mas conocimiento y mejor tecnología, puede, por ejemplo, procurarse condiciones de vida más favorables en detrimento de la población autóctona. O bien puede ocurrir lo contrario". Livi Bacci utiliza el termino fitness, que es la combinación de supervivencia y natalidad. En sus estudios se recogen detalles, tales como la pobreza de la información cuantitativa de la que disponen los historiadores para hacer cálculos precisos. Otros detalles interesantes, por ejemplo, es el indicador fitness de los europeos en América. El 7,2 de franceses en Canadá, el 4,7 para los británicos en el resto de América del norte, el 3,1 para los españoles de Hispanoamérica y el 2 para los portugueses. "Digamos entre tanto que en estas disparidades influyen sin duda los errores a los diversos grados de aproximaciones de los datos básicos (además de la diferente intensidad de mestizaje, razón por la cual las diferencias se han tomado con gran cautela" (Livi Bacci, 2012: 36). Esa cautela es significante en Cuba, Puerto Rico y República Dominicana.

Livi Bacci (2006) y (2008) incluye e interpreta al taíno como un indio de la Hispaniola. Existe un problema al sumar los indios de la Hispaniola, la intensidad del mestizaje, la poca información histórica y los porcentajes de fitness de europeos en América, que la cautela puede no haber abarcado en el mestizaje especifico de Puerto Rico, Cuba y la República Dominicana de las primeras décadas. Lo común ha sido interpretar la historia en base a diversas épocas de extintos, fulminados o desconocidos.

Continuamos evaluando a Ortiz y su comentario de la cultura nativa y la europea: “(...) una de ellas pereció, como fulminada”. La pregunta es: ¿cómo es posible que ese mundo de diversidad nativa nunca existiera en el Caribe? Fernando Ortiz relaciona un mundo nativo cubano con los taínos, posiblemente basado en Bachiller y Morales, y su teoría nativa concluye en la fulminación aun cuando él mismo genera información que confirma algún nivel de supervivencia y herencia. Los estudios de ADN realizados por Marcheco-Teruel et al (2014) mostraron porcentajes de raza indígena en personas clasificadas de blancos al igual que en los negros. El amulatado de Ortiz bien representa las proporciones raciales de numerosos cubanos. 
Trataremos de entender lo sucedido en Cuba buscando en autores cubanos y los archivos que estos estudiaron para alcanzar un mejor entendimiento de lo escrito por Fernando Ortiz. Buscar en Cuba significa encontrar evidencia que prueba la supervivencia nativa no tan solo en Cuba, pero en el Caribe que estudiamos. Pablo J. Hernández González (1991: 2) cita dos referencias del siglo XVI: la primera, la visita eclesiástica de Juan del Castillo, obispo de Cuba (1569-1570). La segunda, el informe de la visita diocesana de Juan de las Cabezas Altamirano, obispo de Cuba (1608). Estas visitas contienen memorias sobre el estado poblacional de la isla. Debemos recordar que para 1569 y 1608 la persecución de nativos y su esclavitud estaban prohibidas. Y cita Hernández González: “(...) corresponde al Obispo Juan del Castillo, quien realizó un prolongado y penoso viaje a lo largo de la isla entre 1569 y 1570 . Contabilizando desde la sede catedralicia de Santiago de Cuba, el prelado registró 522 habitantes en toda la diócesis insular, de las cuales más de la mitad eran indios naturales, 297 individuos (56,8\% del total)". El recuento contabilizaba exclusivamente a los hombres, en cuyo caso las mujeres y niños fueron excluidos y por tanto el número de nativos sería más elevado. La segunda cita:

"A casi una década de iniciado el siglo XVII, en 1608, en el citado reporte del Obispo Cabezas Altamirano, de diez ciudades, villas y pueblos de Cuba visitadas y empadronados, apenas tres no muestran presencia, aunque sea reducida, de los naturales de ella. Toda la colonia, según el documento, sumaba 12.707 habitantes, de los cuales 1.027 eran considerados indios del país lo que daba una proporción del 8.08\% sobre el total, que quizás resulte menuda, pero que, frente al supuesto histórico de la extinción indígena en la Isla, no carece de interés".

Estos dos registros de nativos en Cuba pasadas las diez primeras décadas forman parte de una serie de evidencia representativa igualmente sucedió en la Hispaniola y Puerto Rico. Los obispos y sus misioneros contabilizaron nativos, lo cual es indicativo de un contacto entrevistador-entrevistado que en estos casos tienen valor. De la contabilización de nativos cubanos pasamos a un estudio de 1.019 muestras en 137 de los 168 municipios cubanos. Beatriz Marcheco-Teruel et al (2014: 3, 5):

"Con respecto a las contribuciones de los nativos americanos, también existe un patrón claro, con mayores contribuciones promedio en las provincias orientales, en particular Granma (15\%), Las Tunas (12\%) y Holguín (12\%) que en las provincias occidentales. . (...) El promedio de la ascendencia europea, africana y nativa americana en aquellos que se reportan como "blancos" fue de $86 \%, 6.7 \%$ y $7.8 \%$, en aquellos que se reportan como "mestizos" 63.8\%, 25.5\% y $10.7 \%$, y en esos autoinformes para ser "negro" $29 \%, 65.5 \%$, $5.5 \%$. " 
La pobre data histórica, los estudios de ADN y los datos demográficos de Livi Bacci que requerían cautela en base al mestizaje, en este estudio guardan una relación numérica a la supervivencia. ${ }^{83}$ Para entender en su totalidad las condiciones actuales comparamos resultados históricos verificables con las otras áreas geográficas estudiadas, alcanzando un consenso en el avance de las ciencias técnicas. La supervivencia nativa en Cuba se establece desde 1608 con ciertas aportaciones en Ortiz 1940. A este proceso lo hemos llamado en esta tesis la evolución biológica nativa caribeña.

\subsection{Familia y la mujer nativa}

Fernando Ortiz (1940) toca la superficie de la supervivencia nativa pero no la puede integrar a la sociedad cubana de su época pues la visualizó incorporada al mulato, no en el blanco desde la perspectiva del fulminado. La supervivencia puede vivir igualmente en el mulato como en el blanco, pero eso sería difícil de acatar dentro del racismo cuando ser blanco es debatible. La evolución biológica de los nativos caribeños son unas secuencias de genomas atribuibles a la herencia humana caribeña, convirtiéndose en una especie de medidor de fragmentos aun en una etapa de pleno desarrollo. Por tanto, es natural esperar que sigan surgiendo cambios en estos estudios de ADN cada vez más acertados en asuntos de variaciones biológicas. Entrados en el siglo XVI encontramos las raíces del mito de la extinción, mientras entrados en el siglo XX analizamos un nuevo marco histórico en el cual la evidencia biológica en secuencias y porcentajes encontradas en el ADN contemporáneo caribeño establecen una descendencia auténtica. En términos de historia, la evolución biológica caribeña se ha presentado según surge de la mujer y el carácter compartido de comunidades nativas; la biología añade a su vez un sistema verificable donde el aporte del género se mide en un resultado cuya

\footnotetext{
${ }^{83}$ Marcheco-Teruel, B., Parra, E.J., Fuentes-Smith, E., Salas, A., Buttenschøn, H.N., Demontis, D., Torres-Español, M., Marín-Padrón, L.C., Gómez-Cabezas, E.J., Álvarez-Iglesias, V. and Mosquera-Miguel, A. 2014. Cuba: exploring the history of admixture and the genetic basis of pigmentation using autosomal and uniparental markers. PLoS genetics, 10(7), p.e1004488. I Galanter JM, Fernández-Lopez JC, Gignoux CR, Barnholtz-Sloan J, Fernández-Rozadilla C, et al. 2012. Development of a panel of genome-wide ancestry informative markers to study admixture throughout the Americas. PLoS genetics, 10(7), p.e1004488. / Moreno-Estrada A, Gravel S, Zakharia F, McCauley JL, Byrnes JK, et al. 2013. Reconstructing the population genetic history of the Caribbean. PLoS Genet 9: e1003925
} 
secuencia es notable en la repetición fisionómica igualmente reconocible entre personas de una misma región.

Adelaida Segarra Gamazo (2005: 74) nos da una idea del aporte de género en la política y evolución del colonialismo: "Cada una de las mujeres indígenas que facilitaron la integración de los españoles o el refuerzo de las alianzas de poder fue en cierto modo una forma diferente de América". El concepto de integración desde una perspectiva de género y procreación lo han argumentado Lynne Guitar (2002) y Kathleen Deegan (2004: 598); cita como unos de los objetivos de su estudio las “(...) dinámicas sociales después del contacto y la conquista españolas, utilizando el género y la clase como elementos de estructuración primarias". Marcheco-Teruel et al (2014), por vía del ADN, añade que la mezcla del hombre europeo fue principalmente con mujeres nativas y africanas. Luis Joseph Peguero (1763: 377) escribió:

"Dichose ha en esta historia, Como vinieron los invictos españoles a descubrir la isla, conquistada y poblada, Como en diez años de su población aun no abian venido mugeres españolas a ella, y sucedió mezclarse en tanto inlisito, los españoles con las mujeres indias de los que produjeron una especie de gentes a los que llamaron mestisos, nitan blancos como los españoles, nitan colorados como los indios, solo un color gracieso como el color del oro".

La idea de que las mujeres facilitaron la integración de los españoles es verificable e identificable por vías históricas y genéticas. Un ejemplo de grandes abusos lo es Vasco Porcallo de Figueroa, padre de más de cien hijos e hijas. En este sentido, verificamos actividades de género según hemos sugerido anteriormente, en ocasiones forzadas, en ocasiones de naturaleza política $\mathrm{o}$, acorde con sus costumbres, promoviendo la natalidad mestiza. Se identifica, por tanto, lo que transcurría al correr de los años entre los nuevos mestizos, las conversiones religiosas, el bautismo y la separación social que en esa época se entendía normal. El simple observador no tenía herramientas para identificar la evolución biológica nativa caribeña, sin embargo, es un proceso científico innegable basado en sangre y herencia e historia.

La orientación familiar hispana y el espíritu de la mujer caribeña, típicamente datada entre los años 1492 y 1550, se compara con la de los hombres nativos de su propia comunidad tribal como defensores de su territorio. En esos comienzos, los acogidos en las uniones consanguíneas entre mujeres nativas y europeos dan un primer paso que pasaría desapercibido por más de quinientos años, hasta que la ciencia descubre esa composición biológica evolucionada de la sangre. Debe entenderse que los hijos de esas 
uniones de segunda y tercera generaciones pasarían desapercibidos entre europeos, y por tanto no figurarían en censos o padrones como nativos. En el caso de Mary Jemison esa pregunta queda contestada: es la madre blanca quien busca proteger su familia y hereda de la comunidad nativa Séneca tierras de esa nación por las leyes matriarcales de la tribu. La integración de una mujer blanca y dos jefes nativos es innegable cuando en sus propias palabras se constituye una descendencia heterogénea desde su propia perspectiva blanca protegiendo la nativa. El caso de Jemison es muy especial por ser una mujer blanca. Examinemos otra condición en España. Esteban Mira Caballos (2019: 958-959) señala un gran contraste de la supervivencia hacia 1558:

“(...) una india, llamada Beatriz, que con 14 años llegó a la Península en un navío negrero en el cual viajaban cuarenta indios para ser vendidos en la Península. Tras múltiples penalidades se estableció en Carmona como esclava primero de Hernán Pérez de Castroverde y luego del ya mencionado regidor de Carmona Juan Cansino. En esta localidad esta india «baja de cuerpo, delgada y con aspecto de india» procreó nada menos que a seis hijos y, transcurridos 27 años, cuando ya era una adulta, decidió pleitear contra su propietario. Cuando le preguntaron los motivos por los que había esperado tanto tiempo para pedir su libertad respondió «porque no sabía que lo podía reclamar hasta que por cierto mal tratamiento de palos que le dio el dicho Juan Cansino, siendo informada que el Rey Su Majestad mandaba libertar a los indios vino a reclamar». Igualmente declaró que la causa fundamental que le impulsó a pedir su libertad era la servidumbre en que había caído su hijo Simón el cual había sido herrado en la cara y vendido por el dicho Juan Cansino". ${ }^{84}$

El caso de Beatriz atiende el mal trato por su dueño y posible padre de algunos de sus hijos. Sus hijos permanecieron en España, igual que los hijos de muchas otras mujeres nativas. Algunos eran tratados como familia, otros no, mientras las mujeres jóvenes concubinas quizás tenían mejor suerte. A la altura de 1558 ser libre en España no rinde beneficio alguno para los nativos americanos. Sin embargo, un número de ellos prosperaron y se integraron a la sociedad española igual que lo habían hecho judíos y musulmanes conversos décadas antes.

Bartolomé de Las Casas (2009: 80) dio cuenta de la evolución del pensamiento nativo: "Comenzaron a entender los indios que aquellos hombres no debieron haber venido del cielo; y algunos escondían sus comidas, otros sus mujeres e hijos, otros húyanse a los montes por apartarse de gente de tan dura y terrible conversación". Los que

\footnotetext{
${ }^{84}$ Pleito por la libertad de la india Beatriz y de sus hijos, 1558. AGI, Justicia 908, N. 2. Los hijos se llamaban Catalina de 19 ó 20 años. Tomas de 16 años, Isabel de 14 ó 15 años, Juan de 10 ó 12 años, otra india que vivía en Sevilla, y finalmente, un indio llamado Simón que fue herrado fraudulentamente y vendido como esclavo en Sevilla.
} 
se huyeron a las montañas posiblemente sobrevivieron por décadas y se desconoce si algunas tribus contactadas al 1565 pudieran haber asimilado a algunos de esos exiliados, en lo poco que conocemos de tribus aisladas. La cita de Las Casas identifica tanto la familia, la mujer y las alternativas del vivir entre colonos y exploradores. Bartolomé de Las Casas y Fernando Ortiz coinciden en que nativos en Quisqueya y Cuba huían a los montes y algunos sobrevivieron bajo el mismo principio de fuga y escondite.

Los no contactados o aislados en áreas remotas mantuvieron el patrimonio tribal reteniendo las actividades de hombres y mujeres en los conjuntos de sus comunidades y estructuras sociales integrándose en el transcurso del tiempo a la nueva sociedad caribeña en evolución o evolucionada. Mientras algunos se esconden, otros son cautivos y las hembras disponibles a los españoles engendran las primeras generaciones de mestizos. Reexaminando documentos de ese período encontramos en las acciones de la mujer desde sus raíces, su poder y su sacrificio lo que conduce en el largo plazo a la supervivencia nativa caribeña ligado al resurgimiento nativo actual y al ADN. Por tanto, el evento descrito por Bartolomé de Las Casas aporta lo que resultaría una obvia opción, y debemos tomar en consideración el enorme territorio de La Española, difícil de ser controlado y subyugado por un número limitado de soldados, donde refugiarse en aislamiento resultaría natural.

Pedro Mártir de Anglería (1946: 118) señala otra actividad, en esta ocasión de los denominados Caribes: "Un grupo de soldados es atacado por una mujer caribeña, mataron a uno e hirieron a uno antes de ser capturados, hablan de la furia 'de estas personas y de las lanzas venenosas. Es notable que el grupo es comandado por una mujer. La mujer tuvo un hijo que fue capturado cuando resultó herido". Claramente, las mujeres caribes y araucas enfrentadas a la cara de un enemigo hostil lucharían hasta su muerte. La distinción entre el rol femenino o masculino en esa cita son claras: el líder era una mujer. Es considerable notar que la mujer podía claramente liderar guerreros hombres. En este sentido, la igualdad de género reflejada es esta cita señala el alcance, composición y estructura social nativa para protegerse de sus enemigos sin diferenciación de sexo. No hablamos exclusivamente de una mujer doblegada, existió una mujer guerrera de rango y una de descendencia y jerarquía política. En ese sentido, Anacaona, cacica de Xaragua, sobrina de Bohequio y esposa de Caonabo, comprendería un modelo político femenino de Haití-Quisqueya. Anacaona es una figura central en el entendimiento de la descendencia nativa y la política. Su nieta Mencía se casaría con Enriquillo en el futuro, y Anacaona termina ahorcada por su liderato y determinación. 
"Hay un ejemplo, muy citado, de los desesperados en Tlatelolcans que usaban mujeres y muchachos jóvenes en 1473 como un último esfuerzo para alejar a sus vecinos de Tenochcan. Las mujeres intentaron exponer sus genitales y estómagos y exprimir su aliento para producir leche, que arrojaron a sus enemigos" (Kellogg, 2005: 23).

Pienso que esto debe considerarse desde una perspectiva de interpretación. Por ejemplo, de Las Casas (2009: 88) dice lo siguiente: “(...) socávesele la leche de las tetas de las mujeres paridas, y así murieron en breve todas las criaturas. Y por estar los maridos apartados, que nunca veían a las mujeres, ceso entre ellos la generación". La leche fue sacada de las tetas de las mujeres, de esta manera los jóvenes murieron pronto. Sacar la leche a madres se logra al esclavizar mujeres sin alimentación, estas quedarían incapaces físicamente de producir leche para sus infantes. Los maridos fueron separados de las esposas que nunca volvieron a ver y así la generación entre entonces cesó. Las Casas (2009) trata a las aflicciones de mujeres como causa de muerte de los recién nacidos o infantes, o sea se refiere a un crimen cometido por españoles. Podemos decir que esto constituye un hecho de la práctica colonial. Las Casas, como religioso, se abstiene de escribir que esas mujeres se convierten en mujeres de colonos, soldados y exploradores. Kellogg (2005) utiliza la extracción de leche femenina y los genitales como una defensa militar anterior a la colonización.

Entre lo descrito por Kellogg y de Las Casas encontramos el argumento de los recién nacidos muriendo junto a hembras convertidas en víctimas. El caso es que las mujeres fueron vendidas, capturadas, violadas y esclavizadas por ser deseadas, lo convertido en una práctica común durante décadas, y según señalado con anterioridad una similar entre nativos en el trato a las mujeres plebeyas.

\subsection{Mujeres notorias y otros datos.}

Kellogg (2005: 23) escribe de una mujer indígena desconocida en compañía de Cortés montada a caballo. El acontecimiento histórico se refería a Marina, quien hablaba náhuatl y tradujo ese idioma en Chontal Maya para Jerónimo de Aguilar, convertido en traductor de Cortés. En Fray Gerónimo de Mendieta (1870: 175), al margen de la página, se lee lo siguiente: Misteriosa provisión de intérpretes a Cortés. Fray Mendieta no documenta lo que pudo saber de la vida de Marina o Malinche en sus páginas, dice ella era natural mexicana, que había sido encontrada en la costa del Yucatán y como había 
estado cautiva de Potonchan hablaba esa lengua y compartía con Jerónimo de Aguilar ese idioma, pues él había sido cautivo de Potonchan por ocho años. El discurso de fray Mendieta (1870: 176-177) es más intenso en la conversión cristiana que en la historia nativa: "En ninguna parte de los indios infieles entro que luego no derrocase sus ídolos y vedase el sacrificio de los hombres, levántese cruces y predicase la fe y creencia de un solo Dios verdadero y de su Unigénito Hijo Nuestro Señor Jesucristo. Cosa que no todos los victoriosos capitanes ni todos los príncipes (a cuyo poder viene las tales presas) suelen tomar tan á pecho”. Fray Gerónimo de Mendieta pasó por alto que Hernán Cortés era amante de Doña Marina en su descendencia azteca de lengua náhuatl. Olvidó a Cortés recibiendo mujeres que repartía entre sus hombres mientras estaba casado y emparentado con Diego Velázquez de Cuellar, a quien había traicionado. No obstante, fray Mendieta es el típico religioso que si bien leemos en sus escritos la profanidad de los indios bien merecidos tenían sus castigos. Mendieta dice excusar a Cortés y afirma: “(...) le fue casi forzado depositar y forzar los señores y naturales de estas partes para que sustentasen y sirvieran a los españoles, hasta que otra cosa su majestad el Emperador mandase".

Fray Mendieta favorece a Cortés y no entiende mal alguno. Debemos buscar otra visión que presente una perspectiva de las brutalidades semejante a lo aprendido en las islas. Bernal Díaz del Castillo concluyó su obra en 1568 y existían copias a mano, la primera copia impresa se produce en el 1632. Díaz del Castillo (2000: 13) comenta sobre el quinto y las reparticiones un indicador de lo requerido por los soldados refiriéndose a las campañas de Tepeaca y Tezcuco: “(...) que después que sacaban el quinto, era otro quinto para Cortés y otra parte para los capitanes; y en la noche y en la noche antes cuando las tenían juntas nos desparecieron las mejores indias”. Escribe también sobre las indias consideradas mercancía, y la manera en que ese trato se llevaba a cabo: “(...) y desde allí adelante muchos soldados que tomábamos algunas buenas indias, porque no nos la tomasen, como las pasadas, las escondíamos y no las llevábamos a herrar, y decíamos que habían huido". Mendieta y Díaz del Castillo relatan dos interpretaciones diferentes. Oro y mujeres era el cobro y se justificaría de cualquier manera. Díaz del Castillo (2000: 86) nos recuerda que en su estadía en una isla de Conzumel mando a buscar el calachioni, nombre utilizado para referirse a sus caciques y no se apareció ninguno, solo una india moza de buen parecer quien les dice que todos huyeron a los montes. La moza era de Jamaica y hablaba en su lengua yamaye relacionada con la de La Española, y contó que había llegado con su esposo y otros pescadores que habían sido arrastrados por la 
corriente, y que ella era la única sobreviviente. Como no llegó representante alguno de ese pueblo, los españoles embarcaron y trajeron consigo la india moza.

Queda claro que en las hazañas y campañas de México de los soldados de Cortés y sus capitanes, el interés por la cruz, según Mendieta, era prescindible frente al oro y las mujeres. Desde un comienzo los caciques entregaban sus mujeres como prendas de paz o pago de guerras y ese tributo era distribuido bajo la ley o bajo la práctica. En ese sentido, la posición de la mujer estaba muy comprometida y limitada a su cuerpo y su día a día, pues al ser herradas eran solo un producto comercial, lo peor de esperarse.

Marina se convierte en intérprete de Cortés acompañándolo a Honduras y a muchas batallas. Marina fue traductora, mujer y esclava de Cortés durante su estancia en Tabasco y luego, en Diego de Landa. Doña Marina Painala, conocida como la Malinche, se convirtió en esclava en Painala (Tabasco), entregada como tributo de guerra a los caciques ganadores, quienes a su vez la entregaron a los españoles. Doña Marina (15011529) se convirtió en consejera e influyente mujer nativa y amante de Hernán Cortés. Marina dio a luz al primer hijo de Cortés, llamado Martín. Ayudó a Cortés en la conquista del Imperio Azteca. Luego se convirtió en la esposa de Juan Jaramillo, con quien tuvo una hija, María. Doña Marina está representada en el relato náhuatl del Codex florentino por su audacia, mientras bien pudiese ser por su esclavitud. Dos maridos en un corto periodo de tiempo de los cuales sobreviven dos hijos, quedando ella grabada en la historia mientras desconocemos tanto vida como el sentimiento tras haber sido pasada al menos cuatro veces como un trofeo. Ese esquema, según Díaz del Castillo, era común, y de hecho análogo al caribeño y a tierra firme. Díaz del Castillo (2000: 155) cuenta que Marina era de padres señores, que su padre muere siendo ella una niña y su madre se casa con un mancebo cacique y hubieron un hijo, y por cuestiones de herencia después de sus muertes decidieron en una noche dar la niña a unos indios de Xicalango, para que no fuese vista, y echaron fama de que había muerto. Los indios de Xicalango se la dieron a los de Tabasco y estos la dieron a Cortez. Muere Marina a los veintiocho años algo verdaderamente sospechoso.

Thomas Cage (1677: 122) dice estando de viaje en México visitó un suburbio de la ciudad llamado Guadalupe: "En el año 1625. Visité este suburbio donde se juzgaba haber miles de indios. Pero la mayoría de estos han sido consumidos por el duro trabajo requerido por los españoles. Ahora solo quedan unos dos mil indios y mil que son mestizos, una mezcla de español con indio". Cage continua su relato hablando de la infidelidad entre estos y una de sus razones lo es la pobre circunstancias de los españoles. 
Narra las sediciones y rebeliones durante su visita, en la cual esa gente inferior junto a los nativos españoles, a los cuales llama Griolians, y otros indios y mulatos, desafiaban la autoridad (Cage, 1677: 142). Esta visita en 1625 valida lo sucedido en poco más de un siglo, siendo testigo de un amasijo extenso.

El códice de Selden (\#3135, a2) o códice Añute, es un relato de la genealogía de la dinastía de Jaltepec, del décimo al decimosexto siglo. Su significado en esta tesis es la interpretación nativa del origen del Ñuu Dzaui y Mexica en un estilo europeo con dibujos al estilo precolonial, que fue posiblemente completado alrededor del $1560 .{ }^{85} \mathrm{Su}$ elaboración circundando el 1560 y su significado nativo representa la dimensión política y teológica colonial, que para esa fecha permitió la elaboración de este y otros códices de la época en el amparo del arte recogiendo historia.

John Selden (1584-1654), jurista humanista e intelectual británico, hacia 1640 interpretaba la vida nativa. Los puntos de vista de Selden (asemejan a los de Grotius) tuvieron un gran impacto en el Gran Círculo Tew. El códice Selden, por así llamarle, es una sección parcial de uno más grande que componía parte de su colección. Cómo llegó a él es una buena pregunta. El códice muestra a la reina de seis monos personalmente tomando en cautiverio a los dos príncipes de la montaña de la luna y la montaña de los insectos que la habían insultado. Ella tenía sus corazones recortados. Los seis monos del apodo de Reyna cambiaron de Serpiente Quechquemitl a Quechquemitl de la Guerra. Entre diosas y princesas, las mujeres de las élites tenían poder sobre la vida tanto como los gobernantes masculinos desde las primeras dinastías. Ese poder se obtuvo a través de los matrimonios, que de hecho facilitó a los españoles ganar el poder y la fortuna por vía del matrimonio. Las mujeres de élite en las Américas eran un número sustancial y debían considerarse numerosas las casadas con varios esposos, en la mayoría de esas comunidades sus habitantes eran polígamas. Del caos desarrollado por el entendimiento original de la vida nativa surge que los oficiales españoles se casaran por el poder encontrado en el linaje real, manteniendo concubinas mientras que los soldados en general en sus contubernios consideraban a cualquier o cualquier número de ellas de pareja, formulándose el comienzo de la evolución biológica nativa caribeña que hemos examinado. En general, los códices post descubrimiento y contacto europeo enmarcan la

\footnotetext{
${ }^{85}$ Moreno, W. J. \& Higuera, S. M. eds. 1940. Códice de Yanhuitlán. Museo Nacional.
} 
política nativa en la expresión artística. Maarten Jansen y Gabina Aurora Pérez Jiménez (2009: 176) explican: ${ }^{86}$

"Aunque no sigue el camino de la negación completa y la resistencia, que caracteriza al Codex Añute (Selden), el Codex de Yanhuitlan contiene una clara perspectiva ideológica con muchas críticas subliminales de la condición colonial. Pero al mismo tiempo trata de construir puentes, en busca de una nueva coherencia social (convivencia) inspirada por la religión. En consecuencia, sienta las bases para una nueva memoria cultural".

Buscamos en los códices post descubrimiento la supervivencia nativa situada en esa perspectiva ideológica. Los resultados sociopolíticos y comunitarios de conflictos coloniales para la segunda mitad del siglo XV, bajo las leyes de protección desde 1542 , sumados a la orientación familiar de los criollos en evolución, dan inicio a los primeros ejemplos del perfeccionamiento de la supervivencia nativa caribeña que identifica una comunidad nativa evolucionada, sus clases privilegiadas y las plebeyas, mientras en el diario vivir todas encuentran consuelo en la familia.

Retornamos a La Española con Adelaida Segarra Gamazo (2005: 76), cuando señala un acontecimientos de protección de género: "En las instrucciones de 1501 a Ovando, gobernador de la isla Española, se detallan algunas cuestiones relativas a la protección de las mujeres antillanas, después del caos de los caciques blancos: que ningún español dispusiera de las mujeres e hijas de los indios, quienes lo hubieran hecho tendrían que restituir casándose si la india quisiera".

Entre las mujeres de la realeza y las nativas plebeyas existían grandes diferencias en cuanto a derechos y poder jerárquico; no obstante, la mujer plebeya era deseada por marinos y soldados de bajo rango. Los colonizadores señalados como caciques blancos lograban poder social al satisfacer su vanidad, sexo y controles en unas comunidades llenas de secretos. Un ejemplo lo encontramos en Gonzalo Guerrero, casado con la hija de Nachancan, rey de Chectemal, con la que tuvo al menos tres hijos. Gonzalo salió del Darién en 1511 en la expedición de Valdivia a Santo Domingo para rendir cuentas de la revuelta entre Diego de Nicuesa y Vasco Núñez de Balboa, y entregar 20.000 ducados del rey. La carabela se perdió en los bajos de víboras en Jamaica y anduvieron trece días a la deriva veinte hombres, de los cuales unos diez perecieron al mar:

\footnotetext{
${ }^{86}$ Jansen, M. and Jiménez, G.A.P. 2009. Mixtec Rulership in Early Colonial Times. The Codex of Yanhuitlan. Das kulturelle Gedächtnis Mesoamerikas im Kulturvergleich zum alten China: Rituale im Spiegel von Schrift und Mündlichkeit, pp.149-180.
} 
"Que esta pobre gente vino a mano de un mal cacique el cual sacrifico a Valdivia y a otros cuatro a sus ídolos, y después hiso banquetes de ellos a su gente, y dexo para engordar a Aguilar y Guerrero y otros cinco o seis, y quebrantaron la prisión y huieron por unos montes, y que aportaron a otro señor enemigo del primero, y mas piadoso, el cual sirvió de ellos como esclavos" (Diego de Landa [1566], 1864: 14).

El texto original de Diego de Landa se perdió y la versión que se examina es la que se publica posteriormente, en 1666. Landa recoge valiosa información sobre la escritura Maya e identifica costumbres del Yucatán como el bautismo y el canibalismo. Guerrero sobrevivió integrándose a la sociedad nativa y murió a los sesenta y seis años peleando en contra de los conquistadores en Honduras. Diego de Landa (1864: 144) nos identifica otra de las razones por la cual se entiende que tanto en la Española como en Cuba existía una conexión con el Yucatán más amplia de la que es generalmente aceptada. En este sentido, primero examinaremos el bautismo de Landa:

\begin{abstract}
"No se halla el bautismo en ninguna parte de las indias, sino en esta Yucatan, y aun con vocablo que quiere dezir nacer de nuevo o otra ves, que es lo mesmo que en la lengua latina renascor, porque en la lengua de Yucatan, Sihil quiere dezir nacer de nuevo, o otra vez, y no se usa sino en composición de verbos, y assi caput sihil quiere dezir nacer de nuevo".
\end{abstract}

Todas las mujeres servían un propósito donde el hombre europeo encontró madres, esposas y concubinas. En el perfeccionamiento crudo de esas primeras generaciones encontramos a las mujeres fundamentando la evolución biológica y la supervivencia. Ese pensamiento era más común de lo pensado y lo examinaremos en esta sección. Washington Irving (1829: 254) recoge la siguiente historia de Colón, tras celebrarse una misa en las costas de Jamaica, antes de partir a Cuba:

"Me dicen, dijo un viejo, que ha llegado últimamente a esta tierra con una fuerza poderosa, y ha sometido a muchos países; difundiendo gran temor entre la gente; pero, por lo tanto, no sea un vano glorioso. Sepa que, según nuestra creencia, el alma de los hombres tiene dos viajes que realizar, después de que se hayan apartado de su cuerpo; uno a un lugar triste, sucio y cubierto de oscuridad, preparado para aquellos que han sido injustos y crueles con sus semejantes. El otro lleno de deleite para quienes han promovido la paz en la tierra. Si eres mortal, y esperas morir, ten en cuenta de no hacer daño al hombre, y no hagas daño a los que no te han hecho ningún daño".

Estamos examinando el bautismo en el sentido de una vida nueva, el no hacer el mal, y promoviendo paz en la tierra. Es significante, pues, ese pensar del viejo que habló con Colón en plural, habla de los países de su gente, que Colón había sometido. Debemos recordar que entre los intérpretes que acompañaban a Colón se encontraba Diego el 
lucayo, y este debió dar noticia de esta gente bajada del cielo y a su vez de los lugares donde habían navegado y de sus tierras de origen. El viejo reconoce esos países del archipiélago sometidos como parte de la cultura de los naturales, quienes desde sus propios reinos conocían y convivían con otros reinos de sus entornos.

En el dialogo de mujeres, partos, bautismos y la vida tras la muerte, entre reinos y países de América, durante esas primeras décadas se hace acopio de conocimiento e incertidumbre. Eduard Seler (1902-03: 76) destaca en el Codex Vaticanus B a la mujer valerosa: "Para la mujer en partos de infantes era comparado a la captura de prisioneros de un guerrero". Y continúa narrando que tras un parto exitoso, la partera da un grito de guerra reconociendo que la paciente ha sido victoriosa y a capturado un niño. La mujer guerrera gana su lucha con la captura del recién nacido. El significado de esa batalla le da unas características muy especiales a lo ocurrido en América en general, pues es muy posible que las mujeres nativas, en las primeras décadas, vivían esas batallas al momento de dar parto por primera vez a un hijo suyo, cuyas características semejan a sus enemigos. El enemigo engendra en la mujer su victoria. Mientras la mujer asume una criatura de los invencibles, que ahora es su cautivo. Matemáticamente podemos interpretar ese cautivo de las mujeres nativas por el número de europeos que se entremezclaron con ellas y tuvieron niños o niñas. Cuántos nacieron de los primeros treinta y nueve españoles en 1493 dejados en la navidad, y cuántos nacieron de los más de los mil doscientos hombres llegados en 1493 al Caribe. La pregunta entonces es cuántas mujeres nativas pudieron capturar en vida e imagen a sus enemigos, y cuántos hombres estaban dispuestos a simplemente tener sexo y alejarse de todo contacto o incluso sacrificar tanto a la madre como al hijo. Deducir que en diez años nacieron sobre mil niños y que todos ellos engendraron sus propias criaturas en tres décadas tendríamos miles de hombres y mujeres que dejaron de tener las características netamente nativas, incorporándose a una nueva sociedad, bautizados y vestidos, de los que desconocemos sus aptitudes y destino final. Seler dice de las mujeres que parían que eran conocidas como mocinaquelzqui. Las mujeres que paren ganan su guerra y las mujeres que mueren han fallecido a manos de su enemigo, y por tanto la oración de ofrenda dice: O valiente hija mía que peleaste con escudo y espada como tu madre. Desde esa perspectiva, la mujer es recibida como víctima y en todo el alrededor se encuentra la Diosa de Tierra.

Hernán Colón (2000: 213) nos refiere en La Española la relación entre la mitología y la mujer: "Los cemis de piedra son de diversas hechuras, algunos hay que suponen sacados por médicos de cuerpos de los enfermos; de estos guardan aquellos que 
son mejores para el parto de mujeres preñadas". El concepto de parto y sus creencias en Hernán Colón asume una relación entre antepasados, enfermos, mitología y la vida tribal y expande sobre ese tema:

"El cemí Guabancex estaba en el país de un gran cacique, de los principales, que se llamaba Aumatex; este cemí era mujer y dicen hay otros dos en su compañía; el uno es pregonero, y el otro es recogedor y gobernador de la aguas. Cuando Guabancex se encoleriza, dicen que hace correr el viento y el agua, echa por tierra todas las casas y arranca todos los arboles; este cemís dicen que es mujer y esta hecho de piedra de aquel país; los otros dos cemíes que están en su compañía son dichos el uno Guataúba, y es pregonero y heraldo, que por orden de Guabanacex ordena que todos los otros cemíes de aquella provincia ayuden, a que haga viento y caiga lluvia. El otro se llamaba Coatrisquie, y este dicen que recoge el agua entre los valles y montañas, y después lo deja correr para que destruyan el país. Así lo tienen por cierto" (2000: 216).

En las fuerzas de la naturaleza, Guabancex destruye casas y arranca árboles, en este sentido espiritual es una mujer quien gobierna el país. Al echar casas y arboles a la tierra, su cólera se convierte en castigo removiendo lo construido y el material utilizado. El castigo no implica la muerte, pero sí nos muestra la importancia de las casas y los arboles, recogiéndose en esta manera el valor adjudicado a la vivienda y la naturaleza en la que se basa. Se unen el género y la mitología en una geografía muy abarcadora, en la cual países y etnias comparten ideologías dentro de sus diversidades.

En este sentido, examinamos asuntos de América y de España para llegar a identificar la ruta de la supervivencia dentro de los acontecimientos al paso de los años. La mujer nativa era una figura mitológica en su reino natural, creaba vida, castigaba y era reconocida. Mira Caballos (2019) considera en España trataban por todos los medios evitar pleitos y pagos a nativos, incluyendo, libertad, esclavitud, matrimonios, multas, tributos y cualquier violación de ley. Las mujeres nativas habían llegado a España y eran madres durante las primeras cinco décadas. Ese origen fue biológico, expandido, compartido y desconocido mayormente.

Neil Whitehead (1993: 287) nos señala el porqué de estos problemas; los europeos estaban entregados a vender al por mayor a caribes y taínos, pero ese tema lo hemos examinado en suficiencia: "Rara vez se reconoce la influencia práctica de los grupos nativos en el desarrollo de políticas coloniales, a pesar de la importancia de las alianzas nativas, como se mencionó anteriormente, para modelar activamente la ocupación inicial de las Américas". Estamos en un debate de historia donde el orden y la ley tiene dos caras: una americana y otra europea. La influencia practica y la emergente doctrina nativa para lidiar contra un nuevo y poderoso enemigo se ha discutido ampliamente. Ese dialogo 
requiere reafirmarse en torno a la mujer, el entorno construido y la mínima política particular de las naciones caribeñas. Los grupos nativos en las primeras colonias caribeñas dependieron de la mujer guerrera. En esa disyuntiva de biología y política durante el desarrollo social colonial de la reestructuración nativa, hay víctimas que sobreviven. Existía una cultura de género adaptable a esas condiciones de guerra. Fundamentalmente, el hombre nativo sucumbía en batalla y esclavitud, facilitando una dependencia de supervivencia nativa en la mujer guerrera, pues muy temprano entendieron que los abusos de los españoles nunca cesarían. Una cuestión fundamental en la geografía que estudiamos es cómo esa política nativa de adaptación se dispersa convirtiéndose finalmente en una supervivencia consanguínea. El matrimonio y amancebamiento existía entre tribus en sus propias costumbres precoloniales. Para el nuevo colono, las necesidades consistían en oro y poder. Sin embargo, esos dos planos se encontraron. La interpretación generalizada de la extinción y la negación de la evolución nativa en las islas por cuatro o cinco siglos supone razonar que los niños nunca nacieron. Pero en la historia de los siglos caribeños pasados, las caras de esos niños de mujeres guerreras fueron vistas, y muchos y muchas sobrevivieron.

Tenemos que examinar cuidadosamente la población original mestiza y sus cambios de matices. Resulta fácil proyectar la extinción del nativo caribeño y resulta tremendamente complicado negar los resultados de $\mathrm{ADN}$ sin tener una historia que explique esa trayectoria. Para entender esa narrativa etnohistórica es necesario separar los resultados científicos vigentes de una historia anuladora que dio por concluido ese tema hace siglos sin entender la política nativa de supervivencia y la influencia practica de grupos nativos. La estandarización terminológica se apoderó de la historia recogiendo por décadas hechos inexistentes, logros de la cristianización y la extinción sin considerar el pensamiento orgánico nativo y sus habilidades políticas. En esta tesis se examina lo vendido al por mayor según el pensamiento de Whitehead en el conjunto de lo fabricado simplemente por sus beneficios ajustado a un modelo institucional. En nuestro caso, tenemos cinco siglos de historia en los cuales la arqueología, etnohistoria y antropología han impuesto a su gusto a tendencias alejadas de la historia.

El cronista Antonio de Herreras y Tordesillas (1726: 28, cap. xiii L, I) nos presta una frase de importancia para nuestro argumento. El cronista escribe lo siguiente sobre la llegada de Colón a la que denomina isla de San Salvador (horas después de pisar nuevas tierras, Colón se apresura a bautizarlas con un nuevo nombre: "La gente natural acudió luego en grandísimo número". Herrera las llama gente natural. En esta tesis la gente 
natural, al igual que natural o naturales, tiene el significado de nativos. Continua Herrera usando indios o naturales en sus relatos, indistintamente.

Se examinó aquí el pensamiento nativo, las mujeres víctimas y las guerreras que a su vez representaron el futuro. La diversidad implica en este sentido lo fundamental de la convivencia y la familia. Cierto es que el abuso causó grandes estragos, muchos preferían la muerte, muchos fueron esclavizados, mientras algunos pasaron inadvertidos entre los blancos, otros en el mestizaje y otros en el amulatado. Los inadvertidos entre los blancos, un gran número de descendientes ocultos en las masas que históricamente sobreviven por mantenerse al margen racial caribeño, permiten la evolución biológica nativa y, por tanto, la supervivencia. En esta sección se distingue el amalgamiento genético selectivo como parte de la política nativa. En la selectividad española se comienza a diferenciar el resultado que en el largo plazo se convierten en el caribe en los troncos familiares de los jibaros, guajiros y campesinos, cuyos descendientes caminan las calles de Puerto Rico, Cuba y la República Dominicana.

\subsection{Fisionomía de la mujer indígena de América}

El jueves 11 de octubre de 1492 escribe Cristóbal Colón en su diario con relación a mancebos: “(...) muy bien hechos, de muy hermosos cuerpos, y muy buenas caras, los cabellos gruesos casi como cola de caballos y cortos. Los cabellos traen por encima de las cejas, salvo unos pocos detrás que traen largos, que jamás cortan". Continua Colón describiendo cómo se pintan de prieto, y que son del color de los canarios, ni negros, ni blancos, luego dice: “(...) se pintan de blanco y dellos de colorado, y de ellos de lo que hallan; y se pintan las caras y dellos todo el cuerpo, y de ellos solo los ojos y de ellos solo la nariz". Colón identifica colores y aplicaciones corporales, sin embargo, se desconoce si esas aplicaciones eran particulares a edades, grupos específicos o parentelas para identificarse entre ellos. Herreras (1726: 34, cap., xvi, L, I), refiriéndose a La Española, llamada bohío o babeque: “(...) gente mas blanca y de mejor parecer que le resto de las islas, y mas tratables ... y los hombres no eran tan grandes, fino membrudos y rehechos, fin baruas, y las ventanas de las narices muy abiertas, y las frentes llanas y anchas lo cual hazían cuando nacian por gentileza, por lo cual, y por traer las cabezas descubiertas, eran tan duros de cascos". 
A simple vista, entre Colón y Herreras reunimos menciones a pinturas y perfiles de colores, sin saber si estos eran simbólicos de casta. Las cabezas llanas y anchas tienen su significado de gentileza, y ese perfil si era común en otras partes de América. El sábado 13 de octubre, escribe Colón en su diario: “( ...) y todos de la frente y cabeza muy anchas, más que otra generación que hasta aquí halla visto; y los ojos muy hermosos y no pequeños". Irving (1829: 75) lo interpreta como sigue: "Estaban completamente desnudos $\mathrm{y}$ pintados con una variedad de colores y dispositivos, para tener un aspecto salvaje y fantástico. (...) su pelo no era crispo como las tribus de África recientemente descubiertas, era liso y grueso, parcialmente cortado sobre las orejas, con algunos cabellos traseros largos que llegaban hasta los hombros". Irving recrea el aspecto salvaje y fantástico, y sitúa lo referente al pelo con menciones a tribus africanas en su época. Colón estaba rodeado de gentes en una naturaleza en la que no encuentra significado a los colores ni a las deformaciones craneales. Colón solo reconoce estas cabezas anchas en La Española, y bien puede ser otro indicio de la influencia Maya en la isla, sobre la que existen numerosas teorías. Antonio de Herrera (1726: 40, cap. xix) relata que Colón preguntó a un mancebo por la existencia de minas, y este respondió: “ (...) una isla, hazia el leste, que, llamava, Guarionex, y otra Macorix, Mayonis, Fumay, Cibao, Coray, en las cuales auia infinito oro". Notamos al menos un nombre propio, el de Guarionex junto a otros de cacicazgos o provincias, resaltando las de Macorix y Mayonis, de las cuales hemos discutido con anterioridad si se hablaban más de una lengua, y se mantiene la posibilidad que estas fueran de influencia Maya. De ser esto correcto, se aclararía la procedencia de la práctica de las deformaciones craneales junto a otros asuntos como las jerarquías, costumbres y la mitología. Una nota adicional proviene de J.A. Cosculluelas (1946: 15), en la que señala que Colón se había impresionado por estas deformaciones craneales.

Al examinar la mujer nativa en su diario vivir empezamos por establecer un razonamiento de quiénes eran y el porqué se califica de tal manera. Primero analicemos lo que en B. Ashcroft et al (1998: 66) consideran la doble colonización: "El término se refiere a la observación de que las mujeres están sujetas tanto a la dominación colonial del imperio como a la dominación masculina del patriarcado. En este sentido, el imperio y el patriarcado actúan como análogos entre sí y ambos ejercen el control sobre los sujetos colonia- las femeninas, que son, así, doblemente colonizados por el poder imperial / patriarcal". Esta doble colonización se debe considerar cautelosamente a partir de Colón. Primero, la mujer nativa es dominada bajo una autoridad colonizadora, dentro o fuera de 
la ley, o se convirtió en una víctima sexual o esclava para satisfacer las necesidades de colonos en general. En esa práctica existe un nivel de selectividad, la vida o la muerte dentro o fuera de ese infortunio. Segundo, las mujeres de una casta superior se acogen a unas políticas inexploradas pues ellas y sus críos se convierten en parte de la nueva política colonial. En este sentido, profundizamos en tres mujeres nativas. Primero, la mujer de casta noble o principal; segundo, las mujeres de privilegios, y tercera, las plebeyas; en común, todas pueden caer víctimas del abuso sexual, la esclavitud o la muerte. No obstante, veremos que esta condición de doble colonización puede no haber sucedido nunca, pues el concepto sexual, matrimonial y social nativo tenía sus propias reglas. Bartolomé de Las Casas (2009: 80) narra el caso de un capitán que violó usando la fuerza a la mujer de un rey en La Española. Existe amplia evidencia de este tipo de comportamiento desde la perspectiva de violencia sexual. Igualmente, de abusos y falta de consideración. De este comportamiento dominante iniciado durante la primera década se puede razonar el comienzo del repoblamiento caribeño, originado por las nuevas condiciones exigidas a la mujer. En esas exigencias analizamos la vida cultural nativa enfrentada a necesidades y abusos de poder por los colonos. La mujer violentada decidía entre la vida y la muerte de sus hijos engendrados por colonos, quienes nunca se interesaron en los niños.

Examinemos y descifremos qué era el matrimonio nativo, o al menos cómo pudo ser entendido por cronistas, lingüistas y arqueólogos. D. G. Brinton (1871:15):

"Oviedo dice que en los matrimonios en Cuba era costumbre que la novia concediera sus favores a cada hombre presente de igual rango al de su marido antes de que llegara el turno de éste. Cuando todos lo habían disfrutado, corría a través de la multitud de sus invitados gritando manicato, manicato, elogiándose a sí misma, lo que significa que ella era fuerte, y valiente, e igual a mucho. Esto es evidentemente el Ar. Manikade, de mân, manin, y significa que estoy ilesa, soy invicta".

Se presenta en esta cita al manikade o manicato, según Oviedo una costumbre de Cuba, lo cual examinaremos más a fondo. Sin embargo, entendiendo las variadas costumbres matrimoniales nativas es fácil reconocer la facilidad con la que los colonos podían adueñarse de las mujeres. Pedro José Guiteras Font $(1865: 53,54)$ aporta su interpretación del manicato escribiendo: "I después de esto, salía la novia del aposento sacudiendo el brazo con la mano cerrada i alta i repitiendo manicato, manicato, que significaba, esforzada y de ánimo grande, como loándose des ser mujer valerosa i capaz 
de mucho". ${ }^{87}$ Guiteras se refiere a costumbres de los cibuneyes específicamente, y añade: "Las cibuneyes eran con los naturales continentes, i deshonestas con los castellanos".

Estas líneas son de interés pues forman parte no solo de las costumbres sexuales de las cibuneyes (sibuneyes) según sus prácticas matrimoniales, sino que reitera la palabra naturales en un contexto muy especial. Mientras examinamos lo liberal de las practicas matrimoniales cibuneyes encontramos tratos especiales a naturales junto a una supuesta deshonestidad en contra de los castellanos. Ese acto es en principio una decisión política de la mujer ante un poderoso enemigo que aparenta cierto nivel de credibilidad. Mientras esa práctica en el siglo XVI podía asombrar a muchos, en el siglo XXI bien puede no tener el mismo impacto. El tema del manicato es usado por otros autores. ${ }^{88}$ En este posible escenario nos encontramos con Juan Antonio Cosculluela Barrera (1952: 36), quien interpreta unas notas que en cierta manera identifican lo narrado por Brinton:

"La castidad entre las mujeres no era apreciada y carecía de valor y, por lo contrario, el taíno estimaba conveniente la experiencia sexual de la mujer con otros hombres antes del matrimonio. La prostitución hospitalaria estaba establecida, pero el incesto era desconocido. El hombre afeminado no era raro y hasta lo vestían de mujer para distinguirlo. La poligamia era corriente entre los nitaínos: y algunos caciques como Bohequio, llegaron a contar en su harén hasta 30 mujeres, de las cuales había una principal que debía ser enterrada viva a la muerte del cacique".

Cosculluelas reproduce la cita de Brinton y añade a ella la expresión prostitución hospitalaria, la homosexualidad nativa caribeña y la poligamia. Su gran problema es que en lugar de atribuir esas prácticas a los sibuneyes de Oviedo o al discurso de Herreras, o incluso al Arauco isleño de Brinton, Cosculluela afirma incorrectamente lo siguiente: "el taino estimaba conveniente la experiencia sexual de la mujer con otros hombres antes del matrimonio". Entre los cronistas y autores examinados no existía controversia hasta que Cosculluela substituye los sibuneyes por tainos, lo que constituye una inconsistencia en pleno siglo XX.

Esas afirmaciones del manicato las examinamos considerando la posible existencia de que tal comportamiento no fuera exclusivo de la Cuba prehispánica. Existe la posibilidad que esa práctica nativa fuera, a mayor o menor escala, común en el Caribe insular y no unas costumbres exclusivas de una etnia particular cubana, o bien según señala Brinton, simplemente un prejuicio de Oviedo destinada a denigrar a los nativos.

\footnotetext{
${ }^{87}$ Guiteras, P. J. 1865. cita a Oviedo, 1. xvii, cap. 8/ Guiteras (1865: 54) proviene de Herreras L. iii, cap. iv

${ }^{88}$ Entralgo Vallina, José Elías 1935. Esquema de sociografía indocubana. Molina, La Habana.
} 
Landa (1864: 318) señaló que los mayas tenían la palabra ma-in-ka-ti, que significaba no quiero, en el sentido de dar cuenta de las cosas de la gente. O puede entenderse en el sentido de batalla, pues existe un cierto nivel de poder y control derivado de la liberación. Esa liberación o actitud fue una de las bases por la cual incalculables abusos fueron tolerados y de alguna manera fomentaron eventos hacia un futuro incierto.

El abuso a la mujer nativa por los colonos es innegable, la formación de familias estables o inestables y las biologías mestizas de las primeras décadas de la colonización igualmente son innegables, pero su estudio ha sido descuidado, histórica y científicamente. De estas primeras relaciones proviene la raíz histórica y biológica de la sobrevivencia nativa caribeña. En este sentido, si esas prácticas de manicato eran comunes en el Caribe, y se añade las prácticas de violar, mercadear o regalar y casar mujeres por los conquistadores, esto contribuye a interpretar el concepto de la evolución biológica dentro de la conformidad nativa. En adición, esa práctica fuera de la conformidad nativa significa la evolución biológica nativa caribeña integrada a todas las razas que llegaron a América desde 1492. Lourdes Domínguez (1995: 9) expresa lo conocido convencionalmente en Cuba, en relación con la supervivencia nativa:

“(...) este hecho no significó de inmediato la total desaparición física de los indocubanos como se ha divulgado erróneamente a causa de un desenfoque de la problemática real, presente en un buen número de textos históricos. Los documentos de los siglos XVI, XVII y XVIII recogen noticias que prueban la supervivencia de aborígenes en Cuba en ese período y, aunque de manera cada vez más esporádica, también en décadas posteriores".

Alexander von Humboldt (1827: 126), el explorador y científico narra: "En las colonias españolas del continente se hallan los descendientes de los indios que desaparecían entre los mestizos y zambos mezclas de indios con los blancos, y negros; esta idea consoladora no se presenta en el archipiélago de las Antillas". Humboldt, convencido en 1827 de que los indígenas habían desaparecido de Cuba, nos presenta un cuadro en el que a partir del siglo XVI el estado de la sociedad cubana se encontraba en tal estado de decadencia que los nuevos colonos no se mezclaban con los indígenas. Igualmente nos dice que en Guanabacoa cuarenta años antes hubo algún tipo de renovación. Esto significa que, aunque Humboldt no lo cree posible, si hubo algunos habitantes cubanos que hacían constar sus identidades nativas. Humboldt (1827: 127) cita a fray Luis Bertrán, quien estimó la población nativa en doscientos mil, y entre estos “( ...) que la raza indígena estaba muy distante de extinguirse entre los años 1555 y 1569”. 
Humboldt se enfrenta a un problema histórico repleto de contradicciones, y dice: “(...) tal es la confusión entre los historiadores de aquellos tiempos". Naturalmente, reconocer a simple vista si corre o no sangre nativa en una población exige un grado de especialización apenas formalizada antes de los estudios de ADN. Juan Bautista Muñoz (1793: 19) dice:

\footnotetext{
"Ni son tan pequeñas otras compensaciones que recibió el nuevo mundo: la multiciplidad en el de la generosa casta europea, la indecible cantidad de africanos que se han transferido, la multitud de razas mixtas tan propagadas por aquellas partes. Estas generaciones, sino en el número, en la calidad suplen abundantemente la falta de puros americanos, ya raros o ningunos en ciertas islas".
}

Muñoz interpreta como un resultado favorable la calidad de las razas mixtas. La supervivencia nativa es rara para Muñoz, cosa menos posible para Humboldt, y muy probable para Domínguez en el siglo XX.

En los capítulos anteriores habíamos señalados casos semejantes a estos de Cuba en las islas estudiadas. Por tanto, lo apreciado a simple vista en siglos anteriores desde finales del siglo XX puede validarse bajo el microscopio. En adición a documentos históricos, y resultados de $\mathrm{ADN}$ al establecer las posibilidades de la supervivencia, igualmente ampliamos el análisis al añadir el entorno construido, el lenguaje, la agricultura y las costumbres nativas.

Primero, analicemos el pensamiento de autores prominentes cubanos. Manuel Sanguily (1890: 19), en su estudio de José de la Luz y Caballero, a quien se refiere como el maestro de los jóvenes, afirma: "La vida entera de José de la Luz y Caballero de como cada hombre es un compuesto, algo complejo y resultante de causas varias, y diversas, un producto de la raza y el complicado movimiento del pasado, y de las circunstancias peculiares que lo envuelven y lo afectan, desde que surge la existencia". Notamos que un producto de la raza y el complicado movimiento del pasado corresponde a lo desconocido en el Caribe, la política nativa recogida en la dinámica hereditaria. José de la Luz y Caballero era un estudioso ecléctico y filosofo conservador que escribió sobre el pensar y sentir de su gente. Los diálogos de José de la Luz y Caballero se acogen a Dios y su naturaleza. José Ignacio Rodríguez (1874: 284, n6), en quien se basa Sanguilly, distingue en la vida de Luz de Caballero el momento en que a la filosofía se pide explicar la triple pregunta de: ¿Quién eres? ¿de dónde vienes? y ¿a dónde vas?. En el entierro de Luz, el poeta José Fornaris publicó en El Progreso de Guanabacoa el 29 de junio de 1862 un poema a Luz de Caballero (Rodríguez, 1874: 315): 
Jamas mi lira altiva en tus palacios

Sus ecos dilató. Ni pude nunca

Soñar siquiera que mi voz un día

Llegase a ti. Poeta infortunado,

Canté solo la raza siboneya,

Tan pobre como yo.

El poema de Fornaris funde el arte, la palabra y una filosofía de la pobreza en la cultura cubana y la diplomacia de la época, cuando considerándose un "poeta infortunado", y "la raza siboneya, tan pobre como yo", dedica a la patria de Luz de Caballero sus palabras; palabras, que, a su vez, contestan las tres preguntas de origen. En suma, era reconocible en el siglo XVIII que en el archipiélago de las Antillas sí había sobrevivido algo de los nativos caribeños. Una supervivencia de vida e ilusiones ancestrales igual a las topadas en otras colonias del continente.

Rodríguez afirmó que la filosofía de Luz era cristiana y práctica. Rodríguez (1874: 199) describe también el partido español, sin entrar en un debate político, y en sus palabras evita agregar a este retrato ni una palabra con relación a méritos o deméritos, para señalar lo que representaba el partido opuesto, “(...) indistintamente denominado criollo o cubano, y á que pertenecen la mayoría numérica, la propiedad territorial, las capacidades, los ancianos, las mugeres, los niños, las familias para decirlo de una vez". Al incluir a las familias para decirlo de una vez, se da a entender quiénes forman la oposición; no es un grupo o partido fraccionado o de élite, es el pueblo en todos sus elementos y diversificación que comprenden un país. En este sentido, los factores de la vida y filosofía de Luz de Caballero se acoplan a la diversificación de la población cubana donde existía una humanidad y un patriotismo unificador. Sanguily (1890) da cuenta del testamento de Luz y de sus posesiones: donaba una colección de unos 4.500 a 5.000 volúmenes a la biblioteca pública establecida en la Real Sociedad Económica de la Habana. Pero concedía al Colegio del Salvador un estante de libros que estos escogieran. Para el 1865, tres años después de la muerte de Luz, solo restaban unos dos mil libros, unidos a algunos de Juan Clemente Zenea. El Colegio del Salvador cerró sus puertas entre 1869 o 1870 y el paradero de sus reclamos quedó desconocido. Vemos en este diario vivir el sentir de la vida cubana en la Habana en el siglo XIX en el desempeño del desarrollo intelectual. En la cláusula n ${ }^{\circ} 16$ de su testamento, y para cumplir con ese encargo, D. José Bruzon (hijo) y D. Jesús Benigno Gálvez solicitaron a los señores D. José María Zayas y a D. Antonio Bachiller y Morales el cuidado de los documentos personales de Luz de 
Caballero, sin embargo, estos ilustres cubanos fallecieron sin cumplir los votos del testador. No obstante, toda historia debe tener una intención y está contiene varias: José María Zayas era el padre del joven Alfredo Zayas y Alfonso, quien desde temprano escribió artículos basados en documentos inéditos de Luz de Caballero. Los señores Bruzon y Gálvez sobrevivieron para leer esos artículos de Alfredo Zayas y Alfonso. Como bien hemos señalado anteriormente, en esta tesis, Zayas y Alfonso no solo fue un jurista e ilustres diplomático y cuarto presidente de Cuba, fue el hombre que desafíó a Mark Harrington al no aceptar el término taino, el mismo Harrington quedo perplejo en 1921.

El trasfondo de la sociedad cubana era conservador y religioso en su filosofía desde la perspectiva que José Manuel Mestre, Félix Varela y José Zacarías Gonzales del Valle trasfieren al publicar su libro, a la memoria del más sabio, el más virtuoso, y el más bueno entre los cubanos, José de la Luz y Caballero. ${ }^{89}$ Mestre (1862: 6) resume ese sentir:

"Cada idea tiene su genealogía: su oriente en que aparece con luz indecisa y poco perceptible; su zenit en que alumbra y vivifica toda la tierra. Cada época encierra una síntesis de todas las que le han precedido: Despojad al hombre de su pasado, y lo anulareis completamente; como lograrías secar el rio más caudaloso, si pudieras separar de él las gotas de agua que le enviaron sus manantiales".

Encontrar las gotas que vienen de manantiales es una metáfora a la que le seguimos sus huellas en lugares inesperados. Se examinó el trasfondo sociopolítico, intelectual e histórico en el cual Alfredo Zayas y Alfonso desarrolla su comprensión de la cultura cubana.

En esta intersección histórica de la cultura nativa cubana Antonio Bachiller y Morales y Mark Harrington comparten una ideología y una teoría de un nuevo y desconocido nativo caribeño. Es Alfredo Zayas y Alfonso quien se opone a esa interpretación de C.S. Rafinesque que desde Norteamérica y Europa sustituía a la raza siboneya del poeta José Fornaris. Si Fornaris asumía ser parte de la raza y la economía siboney en su publicación de 1862, Alfredo Zayas y Alfonso entendía y razonó a esa raza nativa cubana y su mensaje, netamente típico en el concepto criollo y cubano de Cuba. Zayas y Alfonso conoció de los taínos de Antonio Bachiller y Morales antes de conocer sus diferencias con Harrington debido a sus relaciones con el circulo académico y social de su padre. Esos hombres entendían los límites de las culturas nativas caribeñas.

\footnotetext{
${ }^{89}$ Mestre, J.M., Varela, F. \& Valle, J.Z.G. del 1862. De la filosofía en La Habana. La Antilla.
} 


\subsection{Variaciones a matrimonios nativos y sus abusos.}

Examinemos nuevamente la vida y aventura de Vasco Porcallo de Figueroa. Nace en Cáceres hacia 1494 y muere en Puerto Príncipe, Cuba en 1550. Fue un explorador, para muchos un hombre sin escrúpulos y para otros una noble figura. Encontramos en este hombre el prototipo peninsular adaptado al ambiente caribeño en toda su furia, abusos, éxitos, fortuna y familia. En una declaración jurídica oficial fechada el 28 de febrero de 1522 ante los oidores Marcelo de Villalobos y Juan Ortiz de Matienzo, consta que Vasco de Porcallo, natural de Cáceres, de 28 años y vecino de Villa de la Trinidad de Cuba, se escuchó:

\footnotetext{
"Preguntando si corto los compañones y otros miembros de ciertos indios dijo, que viendo el abuso de los indios en comer tierra, tan dañoso que en las provincias de Comaguey y Guamohaya se habían muerto dello más de las $2 / 3$ partes de los indios, i seguían matándose de intento comiendo tierra, y otros guaymaros; porque con ningún medio podía cortar con tan grave daño, hizo castigo con que lo atajo en gran parte" (En Buckingham Smith,1857: 46).
}

La historia continúa: Porcallo Figueroa somete a los indios moribundos a comerse sus miembros y luego los quema; a otros les quemó la boca sin que por ello muriesen. La barbarie de estos actos no parece ser digna de una figura de excelencia. Esas acciones no parecen concordar con lo examinado por Mestre (1862) dentro del pensamiento filosófico cubano. Sin embargo, Porcallo de Figueroa personifica la evolución biológica nativa, la política nativa y la importancia de la mujer natural cubana. En el Diccionario Bibliográfico de la Real Academia consta que Porcallo de Figueroa: "Estuvo casado con la hija de un importante cacique, la bella Tinima. Fue famoso por las numerosas concubinas indias que tuvo y el innumerable número de violaciones que cometió. Tuvo más de un centenar de hijos, algunos de los cuales se suicidaron junto a sus madres".

Estas dos citas de Porcallo de Figueroa son tan impactantes que requirieren un temple armonizador al analizar sus implicaciones. En el testimonio juramentado de Porcallo de Figueroa encontramos su declaración sobre y otros guaymaros, refiriéndose a nativos cubanos, por tanto, guaymaros, consiste en una adscripción posiblemente aplicada entre los indios de Guayma. Porcallo de Figueroa era conocedor de nativos y costumbres, y en sus inexorables prácticas logra establecer un sistema de orden y control que pasa es acogido en la política colonial. En la dualidad de sus graves ofensas 
encontramos, tramas, torturas y asesinatos enmarcados en una cultura de mestizaje y amoríos inseparables de la vida colonial según la conocemos. Podemos preguntarnos qué lógica acreditaría esa mente colonial que eventualmente se convierte en padre y abuelo de las familias que componen sus víctimas. En las numerosas concubinas nativas durante su vida procreó entre cien y cientos de hijos e hijas, y casó a un significante número de ellos y ellas con españoles y otros mestizos, por tanto, entre los descendientes de Vasco Porcallo de Figueroa al día de hoy se recogen gotas de sangre nativa. De examinarse rápidamente las páginas de historia y heráldica encontramos huellas de parientes y descendientes de Porcallo. Cuesta pensar si quisieran sus descendientes conocen el trato y nombre de sus primeras madres y abuelas nativas. “En un 'Libro Genealógico' escrito en Bayamo el año de 1775 por el Alferes D. Pedro del Prado y Pardo se asegura que las familias mas distinguidas de Puerto Príncipe descienden de Vasco Porcayo" (2014: 1). En el año 1775 queda claro que existía una supervivencia nativa en la estructura social de Bayamo entre familias distinguidas. Por vía de Porcallo de Figueroa se logra establecer la supervivencia nativa en Puerto Príncipe. La pregunta inmediata es: ¿Porcallo de Figueroa es el único colono que logra tal descendencia en Cuba y el Caribe, o existieron muchas de estas familias? Podemos razonar que un significante número de descendientes de origen nativo provienen de estos linajes, hemos presentado evidencia suficiente de ese tipo de supervivencia. En adición, los resultados de hoy día encontrados en el ADN caribeño según examinados en esta tesis tienen sus raíces biológicas en estas familias. El orden genético selectivo, junto a las características sociopolíticas analizadas, implican que desde muy temprano un ordenamiento político, sociológico y filosófico. En su testamento, Porcallo menciona un sin número de hijos y entre estos a una hija de especial interés casada con Juan de Argote: “(...) y otra nombrada doña María Porcayo, casada con Juan de Argote, Indio natural de esta Isla, criado por Porcayo, y se supone fuese hijo de algún Cacique" (Smith 1857).

Juan de Argote era un nativo natural de la nobleza pre-columbina que simboliza la política de supervivencia. Porcallo de Figueroa es una figura controversial, entre la violencia, y la familia parece guardar una naturalidad ilógica, a su vez esa práctica en las páginas de la etnohistoria nativa cubana y caribeña era común. De este ensamble antropológico surgen verdades históricas en rumbos discordantes como lo sería la extinción vis a vis la supervivencia nativa. Porcallo de Figueroa contesta ¿Quiénes son? Pues son sus propios hijos, ¿De dónde vienen? Vienen de mujeres nativas, colonos y esclavos, ¿A dónde van? A formar familias criollas, cristianas y otras en comunidades 
caribeñas. Resulta insólito que Porcallo de Figueroa engendrará generaciones nativas convirtiéndose en parte de la evolución biológica caribeña y la supervivencia nativa cubana, pero así es.

Julián de Miranda y Argüelles era un asturiano que llegó a Cuba con el gobernador y adelantado Pedro Menéndez de Avilés, fue alcalde ordinario de Puerto Príncipe entre 1589 y 1593, y se casó con Juana Manuel de Figueroa y Argote hija del capitán Juan de Argote y María de Figueroa (Zerquera y Fernández de Lara, 2015: 6). El capitán Juan de Argote es el cacique natural amigo de Porcallo de Figueroa y su hija María de Figueroa es la misma llamada María de Porcayo, una de las hijas de Porcallo de Figueroa y una mujer nativa. Juana Manuel Figueroa y Argote era biológicamente tres cuartas partes nativa. Julián de Miranda y Arguelles y su legítima esposa Juana Manuel de Figueroa y Argote tuvieron cinco hijos. Esa descendencia de origen estaba establecida en el siglo XVII, y a esa se unen otros cientos de casos similares en Cuba.

Del linaje de Porcallo de Figueroa se recogen gotas de sangre del ADN nativo, ligados a otros blancos, mestizos, amulatados o negros todos cubanos. Volviendo a la historia actuante, los datos de heráldica se verifican en el trabajo de Juan Torres Lasqueti (1888), que a su vez facilita información histórica en relación con los autores citados en esta sección. ${ }^{90}$

Jacobo de la Pezuela, refiriéndose al nombramiento de Sancho de Alquizar el 7 de setiembre de 1616 hace referencia a Bayamo. Llama la atención su modo de expresarse: "Los pocos descendientes que quedaban de la raza indígena, inútiles para la dura tarea de los ingenios, y aun para las labranzas ordinarias, o se aplicaban al servicio doméstico, o seguían reunidos en Guanabacoa, pobres, perezosamente, y sin industrias" (Pezuela, 1868: 17). La obra de Pezuela trata de política y batallas con ingleses, holandeses, franceses, bucaneros, corsos, piratas, mientras que curiosamente recogió noticias de la supervivencia indígena en 1616 en el área de Guanabacoa. Pezuela singulariza una provincia geográfica, una sola comunidad y no a Cuba en su totalidad. Esa comarca específica es importante por varias razones: en 1862 fue en Guanabacoa donde el poeta Fornaris mantiene el ser de la raza siboneya. Los descendientes de Porcallo de Figueroa citados en 1776 y esos nativos de Guanabacoa son dos comunidades distanciadas entre sí que recogen entre ellas la supervivencia nativa cubana. Esas dos

\footnotetext{
${ }^{90}$ Torres Lasqueti, J. 1888. Colección de datos históricos-geográficos y estadísticos de Puerto del Príncipe y su jurisdicción. El Retiro.
} 
comunidades independientes en Cuba representan un segmento de la evolución biológica nativa en la descendencia de cubanos y la supervivencia de origen. Los llamados naturales precolombinos sobrevivieron por siglos y no solo en la lira de Fornaris, sino en el corazón de la raza sibuneya que late en 1862. La relación matemática de esas dos comunidades guarda una relación mucho más amplia en Cuba de la cual puede estimarse una descendencia biológica y social en los porcentajes de ADN.

Pezuela se desplaza en su narrativa al 22 de abril de 1622, cuando tras un fuego en la capital, Venegas recoge de Guanabacoa y en otras comunidades cercanas más de quinientos indígenas traídos a viviendas de la capital. De estas sumas de indígenas llevados a La Habana se deduce que quedaron otros en Guanabacoa y sus alrededores; en adición, en la Habana, a donde eran llevados, ya vivían otros indígenas cuyos números se desconocen.

Hemos señalado lo consistente de buscar la palabra singular histórica para examinar el discurso antropológico. Por lo tanto, discutiremos ese discurso desde la perspectiva de la palabra singular y su alcance. En Cuba, según José María de Andueza (1841: 153), Colón recorrió desde la ensenada de Carenas hasta la punta de Maizi, y continúa narrando sobre los exploradores: "Sus enviados volvieron sin haberse internado mucho por prudencia, acompañados según Arrate, por tres naturales, aunque el manuscrito a que ya me he referido asegura que por dos indios y asegura bien dispuestos". José María de Andueza se centra en el hecho de que fueron dos los naturales, y según Arrate eran tres. Independientemente si eran dos o tres, lo importante en esta tesis es que se les consideraban naturales y cuál puede ser su relevancia. Examinemos el significado de naturales y encontramos que, según Andueza, son los nativos cubanos o los oriundos de una nación. En Pezuela (1868: 41-42) examinamos la aplicación del término naturales aplicado en un asunto relacionado al prelado Henríquez de Armendáriz quien:

“(...) destinando en el tres becas para los naturales de su antigua misión, (...) por setiembre de 1627 remplazo a Amendariz D. Leonel Cervantes obispo anterior de Santa Marta. Antes que este estuvo destinado para Cuba el agustino D. Gregorio de Alarcón, que salió de Madrid a embarcarse a pie y descalzo, pero que en lugar de mitra, ni tumba hallo siquiera, porque murió en la navegación al avistar a las Antillas, y fue arrojado al mar su cuerpo".

La historia tiene cierta ironía, que por cierto es muy de América. Nos compete que Pezuela (1868) y Andueza (1841) utilizan naturales al referirse a nativos. La integración social, eficiente o no, tiene valor histórico, pues representa una actividad real 
documentada. Juan Torres Lasqueti (1888: 57) refiere una encomienda que esta testimoniada en Santiago de Cuba el 2 de mayo de 1532 por el escribano Esteban Roca, y continúa narrando una conversación entre el licenciado Vadillo y la emperatriz, en la cual se contabilizaban en la isla entre 4.500 y 5.000 indios naturales. Smith (1857: 202208) presenta una carta de Cuba narrando la historia de una invasión corsaria de la fortaleza del Morro por el capitán francés Jackes de Gores y unos doscientos hombres de guerra el miércoles 10 de julio de 1855. El alcalde Juan de Lobera solicitó ayuda al Gobernador y este acudió a escondidas el jueves con diez españoles y cuarenta indios, y a media legua de la fortaleza se enteró que los franceses habían atacado y el alcalde había entregado la fortaleza. Se reunió una fuerza mayor de doscientos veinte negros y ochenta indios cuyos gritos de guerra alertaron a los franceses siendo el ataque revertido. El 28 de julio Gores mandó poner fuego a todo el pueblo. Dio sobre la estancia de Coximar y Guanabacoa y quemó parte de ellas, pues no le pagaban rescate. El 4 de agosto dejó ahorcados a los negros varones frente a la puerta de Juan de Rojas y nunca se supo de las negras mujeres o de un español. Claramente la defensa de la ciudad desde 1555 solicitaba ayuda de los indios, e incluso usaban de negros once décadas antes de la llegada de Morgan. Lasqueti (1888: n8), citando a Pezuela, describe algunas de las acciones del alcalde de la Villa durante ese conflicto con Morgan: “(...) y logro reunir unos setecientos hombres de todas condiciones y color, sin otros cien montados en jacas de la tierra”.

En estas referencias encontramos indios naturales a quienes acude la autoridad local en busca de asistencia militar en 1668. Lasqueti escribe sobre los naturales y Pezuela describe quienes eran: de todas condición y color. Aquí encontramos que los naturales en 1668 habían sobrevivido desde 1492 y se encontraban inmersos en la sociedad cubana, de tal forma que en casos extremos se les solicitaba asistencia incluso en el campo de batalla. Por tanto, entre Andueza (1841), Pezuela (1868) y Lasqueti (1888) los naturales aparenta ser una usanza a nativos cubanos que habían sobrevivido hasta el 1668. A estos naturales se les reconoció por haber actuado exitosamente en campañas militares y frecuentar estudios en las antiguas misiones. La importancia de estas referencias estriba en la evidente aceptación de los naturales en el diario vivir de la comunidad de Puerto Príncipe y otras comunidades cercanas. El discurso aparente de esas aportaciones de los nativos a la comunidad y a la autoridad implican una coexistencia perfeccionada entre nativos, ciudadanos y colonos. ¿Por qué razón arriesgarían los nativos sus vidas para proteger esa misma gente que les sometían? O habían alcanzado en esa comunidad de Puerto Príncipe una integración más abarcadora para el 1668. En 
esta sección encontramos a Andueza, Smith, Pezuela, Lasqueti (1888), la memoria de José de la Luz y Caballero y la lira de José Fornalis fortaleciendo el discurso de los naturales y su trayectoria a la supervivencia examinada en otras secciones.

Los naturales es un término usado generalmente por cronistas e historiadores en referencia a nativos o indios en América en general. Antonio de Herreras y Tordesillas (1726: 26): "El Almirante fe leuanta, y llamo San Salvador aquella isla, que los naturales dezian Guanahani de las islas”. Continuó Colón formalizando su toma de posesión en nombre de los Reyes Católicos ante el escribano Rodrigo Escobedo de la Real Armada: "(...) eftando mirando géte infinita de la natural". Encontramos que ambas palabras naturales y natural se refieren a los nativos desde los primeros encuentros entre lucayos y castellanos. Juan Bautista de Muñoz (1793: 265, 266) narra cómo se entera Colón, en el Bonao, de una sublevación por parte de Guarionex:

"Y antes que los naturales pudieran efectuar su designio, resolvió prender á todos los señores del país en una misma noche, destinando para cada uno su capitán y cuadrilla armada. El se reservo a Guarionex. Catorce caciques fueron traídos a la Concepcion en la noche prescrita. Los dos que resultaron principales en la conjuracion pagaron con sus cabezas".

El remanente de los caciques arrestados por Colón fue liberado después de ser humillados. En definitiva, Colón en un corto plazo activa pequeñas cuadrillas y ejecuta caciques que vivían en sus propios territorios. Colón asumía las facultades de la ley, actuaba de juez supremo en toda autoridad con recursos y consecuencias inmediatas que incluyeron muerte y tortura. La vida nativa había cambiado y las lecturas históricas presentan la inhabilidad nativa para oponerse ante tal enemigo. Se suman Antonio de Herreras y Juan Bautista Muñoz al resto de autores presentados en esta sección al utilizar el término de naturales al referirse a los nativos. Añade Gerónimo de Mendieta (1870: 49): "Verdad es que en algunas partes de las Indias los naturales han muerto y aun comido religiosos, en especial de la orden de S. Francisco porque son los que mas han andado y andan por los confines de los indios de guerra”. En todos estos casos presentados los historiadores se refieren a los nativos de naturales, sean o no indios de guerra. Este tema se ha examinado ampliamente en una temática de sensibilidad y perspectiva nativa, acumulando en un conjunto de siglos las interpretaciones de cronistas, historiadores europeos, historiadores caribeños, de América en general y académicos multidisciplinarios. 


\section{MUJERES NATIVAS}

En el transcurso de las actividades de las mujeres y sus complicadas decisiones en el largo plazo se ha desarrollado el génesis de la sociedad caribeña. Entre la esclavitud, abusos y conveniencias, la mujer nativa forjó en su martirio la vida de una familia evolucionada.

De Miguel de Pasamonte se recoge: "Tiene en su casa ocho o diez mozas de mancebas públicas, y de celoso no permite que duerma ombre en su casa, aun que tiene en ella todo el oro del rey" (Smith, 1857: 40). Pasamonte era un judeoconverso y tesorero de La Eapañola, favorecido por Lope de Conchillo y Quintana, un judío converso, secretario y miembro del Real Consejo de Fernando el Católico.

En los entornos de la vida nativa, al entregar la mujer joven, vida y alma en el matrimonio, se acogían en su cultura a un pensamiento ancestral. Siendo esa práctica muy diferente a una experiencia sexual, donde su cuerpo es utilizado irreverentemente por hombres despiadados o, aun peor, que sus cuerpos se convertían en propiedad privada. Este discurso antropológico los desarrolla una sociedad hispana en América en la que se identifican raíces comunes en las actividades de colonos y exploradores.

Fulvia fue la mujer nativa más bella de Vasco Núñez de Balboa (1475-1519). Decimos la más bella pues señalaremos que no fue su única mujer, pero si su verdadera compañera en el concepto nativo. Junto a ella, y por su ayuda, afrontó políticas, conquistas y batallas. La historia de Fulvia no es conocida a fondo, pero sí tuvo grandes consecuencias. Los elementos humanos que examinaremos reflejan una cierta hermandad o una uniformidad antigua, por no decir primitiva. Hubert Howe Bancroft (1882: xi) señala que solo hay una manera de contar la historia y consiste en decir la verdad, simple y concisamente. Bancroft recuerda al lector que la historia interpretada se basa en las fuentes más confiables. Y en las páginas de su obra encontramos a Núñez de Balboa despidiéndose del cacique de la región de Coiba, llamado Careta. Había escuchado que era un cacique rico en oro y había decidido conocerle, y en su primer encuentro le pidió maíz, a lo cual dijo Careta que no había sembrado ese año por conflictos con Ponca, un cacique vecino. Narra Bancroft (1882: 346):

“(...) pero a media noche retornaron, atacaron la villa por tres lados y mataron habitantes, quemaron casas y cargaron sus brigantinas con riquezas, y se llevaron a Careta y su familia prisioneros a la Antigua. ‘¿Porque me ha hecho esto?' Pregunta Careta. ‘¿Cómo 
le eh hecho un mal?' Coja mi oro y restáureme a mi país. Y como promesa de mi buena fe, coja a mi hija quien permanecerá de rehén en sus manos. Acéptela y deje que seamos amigos".

En este trágico escenario de muerte y conquista encontramos que se realiza un pacto que encierra oro, amistad y familia. Una mujer es entregada en una transacción económica. La oferta fue aceptada por Balboa, y ese es el comienzo de nuestra historia. Fulvia es hija de Careta y se entrega a un desconocido siguiendo instrucciones de su padre, según sus propias costumbres. Bancroft se refiere a Fulvia como la doncella oscura, quizás nunca conoció su nombre, o no quiso escribirlo, pero citó a Oviedo, Las Casas, Herrera y a otros historiadores de los que pudo rescatar el nombre de haberlo querido. Fulvia es conocida por otros nombres: Caretita, Anayansi y Balcainés. Sebastián Lorente (1861: 11) lo interpreta de la siguiente manera: "Fulvia, que estaba unida al gallardo caudillo por una pasión reciproca, fue informada de la conjuración por un hermano suyo y pensando más su corazón el amor que los sentimientos de familia y patria, descubrió el secreto a tiempo para que los caciques pudiesen ser sorprendidos y muertos".

Hubert Howe Bancroft interpreta un pacto económico y político para salvar vida y poder. Sebastián Lorente lo interpreta como una pasión reciproca; desconocemos con exactitud si esa pasión existió, ahora sí que existió una relación de unos siete años. En ese periodo, el cacique Careta, Fulvia y su familia ayudan a Núñez de Balboa en sus hazañas y logros. Fulvia informó a Balboa de asuntos nativos regionales y levantamientos; si fue o no interprete lo desconocemos, pero si fue su informadora. Es innecesario interpretar el amor o la familia en la vida privada de Núñez de Balboa y Fulvia los hechos de sus acciones hablan por si solos.

En general, las mujeres desempeñaron papeles importantes cuando los españoles buscan colocarse en el poder, casándose o simplemente viviendo con mujeres nativas, ya sean traductoras, herederas de riquezas y regiones de nobles familias o simplemente concubinas plebeyas. Pedro Arias Dávila, llamado Pedrarias, fue nombrado gobernador y capitán general de la Castilla del Oro, Colonia del Darién, en julio de 1513. D. Pedro Arias Dávila llegó con una fuerza de unos dos mil hombres armados, jueces, escribanos, frailes, en compañía de su esposa Isabel de Bobadilla, hija de Francisco de Bobadilla, gobernador de La Española en 1499. Pedrarias nunca confió en Vasco Núñez de Balboa y se esforzó por convencer a las autoridades de la traición de Balboa. Esa traición se refiere a la muerte de Diego de Nicuesa y de sesenta hombres en una confrontación y a la prisión del bachiller Enciso. En esta historia de traición, la venganza prevalece: Pedrarias 
arregló casar a su hija mayor, María Arias de Peñalosa, con Balboa para asumir el control por linaje de los lazos familiares. El matrimonio de María Arias y Balboa, pactado, legal, nunca fue consumado. María Arias se casó por segunda vez con Rodrigo de Contreras. Bancroft (1888: 466) cita a Andagoya en la Relación de Navarrete, a Las Casas y Gómara. A ojos de Pedrarias, Garabito, un antiguo amigo de Balboa a quien este reprendió fuertemente por haber llevado a cabo un avance indigno contra Fulvia, proporcionó la carta que necesitaba Pedrarias para vengar la humillación sufrida por su hija María Arias. Balboa fue condenado por traición y decapitado en 1519 junto a algunos de sus oficiales, Andrés de Valderrábanos, Luis Botello, Fernando Muñoz y Fernando de Arguello; su cabeza fue hincada en una estaca y exhibida en la plaza de mercado.

Dentro del número prominente de caciques y de clases nativas, las mujeres de alto rango o de nobleza abundaban y eran cada vez más deseadas por los exploradores, que comprendían el poder económico de ese matrimonio nativo. Estos matrimonios con hijas de caciques eran comunes, convirtiéndose en una práctica, logrando mano de obra obligada para desenterrar el oro sin comprometer su autoridad. De ninguna manera debe entenderse que la unión real basada en amor era imposible, sólo necesitamos recordar a Gonzalo Guerrero o a Núñez de Balboa sin cruzar limites interpretativos.

Refiriéndose a Vasco Núñez de Balboa, Bernal Díaz del Castillo (2000: 63, 64) sostiene:

“(...) hombre rico, con quien Pedro Arias de Ávila casó en aquel tiempo una su hija doncella con el mismo Balboa. (...) y después que la hubo desposado, según pareció, y sobre sospechas que tubo que el yerno se le quería alzar con copia de soldados por la mar del Sur, por sentencia le mando a degollar. Y después que vimos lo dicho tengo y otras revueltas entre capitanes y soldados (...) acordamos ciertos hidalgos y soldados (...) de demandarnos licencia para nos ir a la isla de Cuba".

En esta sección hemos recogido el sentir humano de los matrimonios nativos y su diferenciación ante la convención de los matrimonios europeos. En este sentido, encontramos las tramas de poder, las realidades de la natividad, el mestizaje y el significado de familia desde una política de clase. La hija princesa de una familia rica y poderosa se convertía en una ruta hacia el poder y las riquezas que muchos exploradores no podían conseguir de ningún otro modo. Las diferentes clases sociales se ajustaban a las condiciones locales y buscaban sacar adelante sus descendientes.

Moctezuma II tenía sinnúmero de esposas y más de cien descendientes con cincuenta mujeres y concubinas. De las más de veinte hijas, “Tecuichpo Ixcaxochitzin”, 
bautizada Isabel de Moctezuma, fue la mejor conocida, se casó cinco veces. Primero, se casó con su tío Cuitláhuac y luego con Cuauhtémoc. Después de que Cuauhtémoc muriera se casó otras tres veces por orden de Hernán Cortés con tres españoles. Fue madre de seis hijos legítimos. Tuvo además una hija llamada Leonor Cortés Moctezuma, hija no reconocida de Hernán Cortés. Isabel de Moctezuma murió en 1551. La Corona española otorgó a sus descendientes el titulo real de condes de Miravalle, convirtiéndose esa línea de descendientes de una casa real en los duques de Atrisco. Peter Boyd-Bowman (1976: 56) explica: “en Cáceres, Francisco de Godoy, quien regresó del Perú en la década de 1540, construyó su casa en la cercanía de la iglesia de Santiago en una parroquia mayormente obrera y artesana, y don Juan Cano Moctezuma, hijo del emigrante Juan Cano y Doña Isabel Moctezuma (hija del último emperador mexicano), construyó el 'Palacio de Moctezuma' dentro de los muros de la ciudad vieja".

En adición al tema de los naturales de América en España llegados en calidad de criados, concubinas o esclavos, existía una realeza indígena entre hidalgos españoles con grandes riquezas. Un punto de interés es que desde los 1530 los destinos de los españoles eran México y Perú, mientras el Caribe estaba empobrecido. Las riquezas se habían esfumado y solo restaba examinar las consecuencias, tanta fue la confusión que para enterrar tan cruel recuerdo se le llama extinción, fulminación y genocidio. Y todo esto mientras en los montes y montañas aun vivían entre palmeras los sobrevivientes de las primeras cinco décadas. Añade Boyd-Bowman (1973: 279): "En los primeros años de conquista y asentamiento, la presencia española seguía siendo esquelética y experimental; el aumento de la emigración después de las conquistas de las áreas continentales en las décadas de 1520 y 1530 significó que habría una mayor concentración de personas de un lugar en el Nuevo Mundo".

La gran expansión al continente y sus riquezas significó un alejamiento de las islas caribeñas. El bajo número de colonos, las leyes protectoras de 1542 y las familias ya establecidas dieron lugar a una nueva trayectoria en la cual nace la supervivencia nativa caribeña cuya herencia subsiste hasta nuestros días. 
Tabla 4 Emigrantes a La Española entre 1493-1600

\begin{tabular}{|c|r|c|}
\hline Fechas & Hombres & Mujeres \\
\hline $1493-1519$ & 5,481 & 308 \\
\hline $1520-1539$ & 13,262 & 845 \\
\hline $1540-1559$ & 9,044 & 1,408 \\
\hline $1560-1579$ & 17,586 & 5,013 \\
\hline $1580-1600$ & 9,508 & 2,472 \\
\hline
\end{tabular}

Fuente: Peter Boyd-Bowman (1973)

Frank Moya Pons (1992: 231) considera que la población nativa de La Española en 1492 era de 400.000, y de haber una mejora en la metodología del cálculo pudiera ser mayor. Destaca Moya Pons algunos detalles de interés, por ejemplo, que la mortalidad al 1508 había sido de un tercio de millón, o sea, en 1508 sobrevivieron unos 60.000 nativos. Añade que entre 1508 y 1513 por orden del rey Fernando se transportaron a La Española por cazadores de indios y se esclavizaron 40.000 nativos. El total hubiese alcanzado 100.000 para el 1513, con una alta mortalidad. Ese traslado en cinco años representaría mover 200 esclavos semanalmente en galeones ubicados en él Caribe. Esa movilización incluiría la captura, encadenamiento, alimentación y navegación de ida y vuelta de hombres y mujeres. Sabemos que los números de emigrantes registrados en la tabla 4 , hombres y mujeres europeos, era menor de 5.800. Livi Bacci (2012) establece ciertos patrones de mortalidad, incluyendo la inestabilidad de datos específicos y epidemias que arrojarían hasta un 60\% de supervivencia entre una generación y otra. Moya Pons (1977: 10) estableció la población nativa de 1494 en 377,559 basándose en el censo de 1514 para establecer el repartimiento. Para 1514 establece la población en 25.303 basándose en la documentación y la letalidad de las actividades. Moya Pons establece diferencias entre sus estudios de 1977 y 1992, donde el factor fitness no esta considerado, como es identificado por Livi Bacci en la población nativa de las primeras décadas, y está incuestionablemente ligado al mestizaje. Livi Bracci $(2012$ : 33, 34) considera que en sistemas consolidados y socialmente homogéneos el registro de la población, especialmente el centralizado y autorizado, puede dar información más clara y precisa: "para iluminar algunos aspectos que de otra forma son inaccesibles". Por ejemplo, los aspectos de nacimientos híbridos y sus datos en el largo plazo desde 1492 en relación con 
matrimonios, bautizos, padrones y otros registros solo indican en sus relaciones al ADN actual un patrón de supervivencia.

"A diferencia de Santo Domingo, sede de la Real Audiencia, un centro comercial floreciente y, junto a México, el destino favorito de los numerosos colonos pacíficos: médicos, abogados, artesanos, mujeres no exactamente aventureras, que también emigraron a las Indias. Puerto Rico y Cuba rara vez son mencionados como destinos. Por el contrario, con las conquistas de México y Perú estas islas comenzaron a despoblar alarmantemente" (Boyd-Bowman,1976: 26).

El género, la demografía, los patrones ordenados y sus intersecciones históricas durante las primeras décadas de contactos se destacan y favorecen la evolución biológica y la supervivencia nativa caribeña en el largo plazo. Es de notar que la evidencia y trayectoria de supervivencia nativa, en su complejidad, une la ideología, costumbres, el entorno, la agricultura y la construcción común en un proceso sostenible de actividades que en cierto grado viabilizaría dicha supervivencia. El ambiente construido se añade a este tema de género por guardar una relación directa que en el largo plazo avanzó la supervivencia material y la biológica. La tabla 4 representa emigrantes a La Española dividida por sexos, lo que Boyd-Bowman llama la esquelética presencia y el periodo de experimentación. El autor del primer libro de historia de autor dominicano, Luis Joseph Peguero (1763, II: 12) dice sobre la isla: “(...) la deseada por los europeos; la poblada de un millón seiscientos indios; la codicia de las naciones extranjeras; y sobre todo la primera en la que se predicó el santo evangelio; y se selebró en 5to sacrificio de la missa". Peguero incluye nombres nativos de ríos y propios mapas de ciudades e islas adyacente. Continúa narrando (1763, II: 70): “(...) la comarca de San German donde los indios, sus naturales tuvieron sus mayores abiraciones, por que como estas fueron caribes, que quiere decir comedores de carne humana, y a quienes temían los de la española, por que a ellos tomaban para su pasto, y no pocos españoles pasaron por sus banquetes". Peguero (1763, II: 208) informa también que tras la guerra y muerte de Cotubanama y Cayacoa en Saona, Higüey se salvó: “(...) fundo Juan de Esquibel y otra en la provincia de Acajagua que llamo Sta Cruz; cuyo cacique se llamo Seybo. En la primera se contaron 17 mil indios tributarios; y en la segunda 11 mil de lo mismo, y a fines de este año 1504”.

Richard Ligon Gent (1657), en su historia de Barbados, mencionó en una de sus páginas a Yarico. Issac Story (1750), un siglo más tarde, escribe un relato personalizado del viaje a las Antillas de Thomas Inkle, de Londres, el 16 de junio de 1647. Llegado a las playas de Barbados, Inkle se separa de su grupo justo antes de ser atacados y muertos 
por nativos, que por su localización debieron ser caribes. En la confusión, Inkle corre hacia el bosque y sufre un accidente en una pierna. Yarico, una india, lo encuentra y lo esconde en una cueva en la montaña por un tiempo indeterminado. Yarico le atiende y se surge un romance apasionado entre ambos. Al pasar el tiempo, aparece un barco en la bahía y durante la noche ambos se acercan al capitán; justo esa noche llega otra embarcación. Inkle, rodeado de sus compatriotas, pensó en el tiempo perdido y decidió vender a Yarico como esclava a un mercader. Yarico, sorprendida de esa traición, informa a Inkle que está embarazada y le pide que la libere. Inkle, intuitivamente, pacta un precio más elevado con el mercader. La historia refleja una actitud inhumana que a la altura de 1647 imperaba en las islas del Caribes.

\section{EL ENTORNO DE LO CONSTRUIDO, AGRICULTURA Y SOBREVIVENCIA.}

Las Antillas Mayores compartieron flora exótica, fauna, vida silvestre y un profundo canope de selva sobre un inmenso campo de montañas cruzadas por ríos claros, y un libre acceso a la espléndida vida marina del Mar Caribe que añadió dimensiones particulares y diversidad en cada isla. Francisco Moscoso (2011: 3) explica: “ (...) a pesar de que la tierra era propiedad común de los yucayeques, o comunidades agroaldeanas, el nivel tecnológico-económico de agricultura excedentaria, especialmente, creó las condiciones materiales que permitieron la separación de productores y no-productores. En el tema de la agricultura nativa caribeña, coinciden Moscoso y Deagan: "Para estimular el negocio colonial, en lo que constituye uno de los procesos de expropiación de los cacicazgos, Ponce de León subastó conucos (tierras de agricultura) y cantidades de montones (refiriéndose a la técnica de cultivo)" (Moscoso, 2011: 7). Por su parte, Deagan (2004: 601) dice:

"Cultivar y recolectar raíces de mandioca aparentemente no eran actividades específicas de género; sin embargo, se supone que el desmonte de los campos y la preparación de conucos, los montículos elevados en los que se sembró la yuca, fueron hechos por hombres. La transición de la agricultura de cortar y quemar al cultivo de conuco en muchas poblaciones caribeñas después de aproximadamente 700 a 800 A.D sirvió no solo para aumentar en gran medida el rendimiento de la mandioca, sino también para disminuir la cantidad total de mano de obra requerida para cultivarla".

Se identifica el valor de la agricultura originaria caribeña durante los cambios alimentarios de las nuevas comunidades coloniales en base a las practicas nativas de 
cultivos. Una vez comenzada la explotación de los recursos naturales por colonos, y puesta en práctica la encomienda, resultaba eficiente mantener el sistema de cultivo desarrollado por siglos acogidos al clima y las condiciones geográficas. Francisco Moscoso (2011: 8) contabilizó las cantidades de montones de tierras subastadas en el 1510 en Puerto Rico, cuyo total asciende a 31.956 montones en ocho lotes. Esos montones corresponden a áreas cultivadas en producción. La expropiación de esos terrenos y los números de habitantes que subsistían de esos cultivos son desconocidos, pero no carecen de interés. En las comunidades nativas, los conucos y las aldeas se integraban entre sí aportando las bases de la supervivencia. Por tanto, la idea de la continuidad de la alimentación tradicional, los sistemas agrícolas y las viviendas sostenibles son inseparables al tema de la supervivencia. Esa conexión natural de tierras y mar durante siglos elaboró una compleja condición social, un estilo de vida inmerso en el mito, la sostenibilidad y la magia de las tradiciones naturales profundamente arraigadas en la estructura familiar y sus ancestros. Esas estructuras en sus conformidades habían encontrado un balance que proporcionaba sociedades organizadas. Lourdes S Domínguez (1986: 3) lo explica:

"El patrón habitacional de El Yayal es parecido al utilizado por los aborígenes agroalfareros de Cuba; esto se ha podido determinar recientemente por investigaciones hechas en el lugar [12: 187-250]. También se precisó que su verdadera razón de ser fue la concentración indígena organizada por los españoles dentro de la hacienda de Francisco García Holguín, y que posiblemente traían a los indios de las densamente pobladas áreas de Banes, cuyo acceso era difícil a los españoles sin que recibiesen la hostilidad de sus moradores autóctonos

El capitán extremeño Francisco García de Holguín "fué quien, en 1523, hechó los cimientos de lo que había de llegar a construir la población de San Isidoro de Holguín. La primitiva población de Holguín (...) - anduvo poco menos que ambulante en los días de su formación" (Santovenia, 1946: 69, 70).

La estructura interna de la vida cotidiana era orgánica y mística, a veces metafísica desde sus creencias religiosas, la medicina, la cosmología, el patrimonio cultural y la arquitectura del entorno construido, combinando los materiales disponibles en sus técnicas y habilidades dentro del ambiente. Los naturales vivían en el ambiente y no sobre él. La vinculación social de la artesanía, el pensamiento arquitectónico primitivo, las actividades y el entorno natural proporcionaron un rendimiento colectivo mejorado en los peores momentos. La supervivencia de la familia y los caminos ancestrales pasaron de 
generación en generación a lo largo de siglos, uniéndose los mecanismos de sostenibilidad y desempeño técnico a medida que pasaba el tiempo. Roberto Cassá (1974: 89) señala cómo la vivienda se acopla a la familia: “(...) fueron de carácter comunal, no sirvieron como morada de una familia natural, sino de un linaje o familia extendida que agrupaba varias familias naturales. De ahí proviene que su tamaño fuera considerable”. En este sentido, lo heredado de generación en generación es la tecnología, el logro experimentado en el clima en el conjunto de la poca durabilidad del material perecedero en el corto plazo.

La calidad del refugio y las estructuras encontradas durante el descubrimiento se vieron afectadas por las duras condiciones implantadas por los recién llegados. Esa subyugación y los crímenes contra la forma de vida nativa alteraron las capacidades mecánicas y las cualidades de diseño como se observa en la actualidad en las viviendas de origen. Los cambios lentos y sus mejoras técnicas ocurrieron durante el transcurso de generaciones, mientras el diseño y el uso del espacio alcanzaron y mantuvieron un equilibrio pre contacto eficiente y mejorado. Las Antillas Mayores y Menores, la Península de Yucatán, el Darién, Mesoamérica, las islas Lucayas (Bahamas) y Tierra Firme, compartieron denominadores comunes en materiales y diseño de viviendas naturales, ordenando palmeras, frondas, vides, palos, hojas y ramas. En el Caribe estos materiales orgánicos incluían uso limitado de piedras, utilizadas en su mayoría en la construcción de plazas para reuniones, juegos, macetas, morteros, cemíes y áreas ceremoniales decoradas con petroglifos. Decoraciones de piedras, madera, arcilla y diseños de materiales que surgieron de los alrededores y vida natural los habían en abundancia.

El comportamiento tribal y cultural era tradicional, diverso en costumbres, lengua y portabilidad. Sus hábitos culturales y el clima fueron recogidos en el diseño. El entorno construido presentaba la utilización práctica del ambiente integrada de manera sostenible a la vida nativa. Ese primer contacto se fundió con la conformidad nativa, el cambio biológico que surgió se convirtió en un proceso evolutivo desconocido y mal interpretado por siglos. Domínguez (1986: 4) habla de simbiosis de españoles y nativos en esta forma:

"Ejemplo de ello tenemos, como herramienta de trabajo, un hacha petaloide de hierro martillado; vasijas de barro cocido, con formas españolas, pero confeccionadas con material y técnica aborigen; adornos colgantes, realizados en mayólica española policromada del siglo XVI; cuentas de barro que imitan las de cristal; cerámicas o vasijas indígenas con forma europea; y otros objetos". 
Examinamos la técnica y el desarrollo mecánico de la vivienda nativa integrado al medio ambiente y a las necesidades de los sistemas sociales y culturales. El material implica la disponibilidad, durabilidad, practicidad en su integración al diario vivir y las costumbres. Las hojas de palmas, las maderas de palmas, las ramas y los troncos de árboles tenían un propósito interactivo, entre necesidad, usos y tradiciones. La selectividad del territorio tribal se estructuraba en acorde a la cantidad de habitantes, las viviendas requerían, agua, bosques y terrenos cultivables. Un cacicazgo requería la materia prima accesible para el cobijado, la agricultura, juegos, actividades de la comunidad y su crecimiento. Estos conceptos los discuten Cassá (1974), Domínguez (1986), Deagan (2004) y Moscoso (2011).

Basado en la topografía se producen divisiones entre diseños y estructuras; a) la ubicación implica diseño especifico b) carreteras, edificios comunes (capillas), c) casas familiares, d) casas de caciques y realeza, e) transporte marino f) otras facilidades.

Revisamos los censos utilizados por Ángel Rosenblat (1945) en función de examinar una data que permita interpretar hasta que niveles llegaron las necesidades de viviendas en cada una de las islas. El tamaño y habitantes de las estructuras se acondicionaban a las costumbres tribales y a la tecnología común de una tribu. Una vivienda de cientos de personas tiene requisitos estructurales diferentes a los de una vivienda de veinte personas. Los censos durante los primeros contactos, según Rosenblat, aparentan ser los más razonables entre los examinados. Definitivamente, los datos caribeños no son representativas de millones de habitantes.

Tabla 5. Población según Ángel Rosenblat (1945: 61)

II México, América Central y las Antillas

\begin{tabular}{|l|c|}
\hline México & 4.500 .000 \\
\hline Haití y Santo Domingo (La Española) & 100.000 \\
\hline Cuba & 80.000 \\
\hline Puerto Rico & 50.000 \\
\hline Jamaica & 40.000 \\
\hline Antillas Menores y Bahamas & 30.000 \\
\hline
\end{tabular}


Según la tabla 4, de Boyd-Bowman, en La Española habían emigrado 5.481 personas entre (1492-1519) y otros 13.262 entre (1520-1539), mayoritariamente hombres. Afirma Rosenblat (1945: 66):

"El dinamismo demográfico de la Española estaba ya roto. Hay repartimientos de 40 y 50 indios en que consta expresamente que no hay ni un solo niño; sobre un total de 22.336 hombres y mujeres de servicio, no había con seguridad más de 5.000 niños, a juzgar por los datos parciales (hemos contado 1515, pero no siempre consta el número). Hay aún otro factor de desequilibrio: había más hombres que mujeres, contra lo que se podía esperar después de un período de guerra (en la Concepción, por ejemplo, contamos 1.072 hombres por 880 mujeres). Consta que 60 encomenderos estaban casados con cacicas. $¿ Y$ el resto de los varios miles de españoles que poblaban la isla? Se sabe que muchos de ellos vivían con mujeres indígenas, y de la época de Roldan y de Bobadilla hay testimonios de que muchos hasta tenían un harén de indias. La escasez de niños está relacionada indudablemente con la escasez de mujeres, y los cronistas dicen que el indio ponía además trabas a la procreación. Es indudable que en 1514 la población indígena de la Española —unas 30.000 almas - estaba a un paso de la extinción".

Gonzalo Fernández de Oviedo y Valdés (1851-1855: 26) aclara la razón por la cual en esas primeras décadas, y durante el transcurso de siglos, ha sido tan fácil interferir, sacrificar y enterrar lo sucedido en América:

"I grande fué el mérito que adquirió nuestra nación en ser por españoles buscadas estas provincias, e tantos reyes de gentes perdidas e idolatras, por industria y en compañía, y debaxo de la guia del primer Almirante, don Cristóbal Colom, reedificando e tornando a cultivar en estas tierras tan apartadas de Europa la sagrada pasión e mandamientos de dios y su iglesia católica; donde tantos millones de animas gozaba, o mejor diciendo, tragaba el infierno; y donde tantas idolatrías y diabólicos sacrificios y ritos que en referencia a Satanás se facian muchos siglos avia, cessassen; i donde tantos nefandos crímenes y pecados se exercitaban, se olvidassen.

Esas palabras de Oviedo, reproducidas por otros historiadores durante siglos, impusieron una visión teológica de nefastos criminales amparados en una religión que fulminó el alma de una gente por considerarles idolatras. Esa teoría bíblica interpretó que ser nativo estaba íntimamente relacionado a Satanás desde el siglo XV. Sin embargo, en contradicción a los originales extintos, los resultados del ADN nativo se encuentran entre los cristianos o sus descendientes.

Las características de los pueblos narrados por Cristóbal Colón junto al conjunto de artefactos, herramientas y embarcaciones de grandes proporciones y decoraciones avanzadas representan un estado mayor de civilización. En ese contexto encontramos tribus viviendo en cuevas junto a otros viviendo en pueblos organizados en una misma isla. En el oriente de Cuba anduvo Cristóbal Colón recorriendo la costa identificado 
siembras en tierras fertilísimas y narra el cuatro de noviembre: "y otras mil maneras de frutas que no es posible escribir, pero todo debe ser cosa provechosa". Envió Colón el 5 de noviembre a tierra adentro a dos hombres, Rodríguez Sancho y a Maestre Diego:

“(...) regresaron y; le dijeron como habían andado doce leguas hasta una población de cincuenta casas que habría mil vecinos porque viven muchos en una casa. Estas casas son de maneras de alfaneques grandísimos. Dijeron que los habían recibidos con gran solemnidad, según su costumbre y todos, así hombres como mujeres, los venían a ver; y aposentarlos en las mejores casas".

Alfaneques son tiendas, el nombre desciende del árabe y en su forma beréber es una muralla de lino, parece por su tamaño y relación a una casa existía ese contexto en el siglo XV. De Cuba partieron a Bohío o Haití, luego llamada La Española, pues vieron que tenían oro y perlas y oyeron:

“(...) y respondieron ciertos viejos que en un lugar que llamaban Bohio había infinito, y que lo traían al cuello y a los brazos y a las piernas, y también perlas”. Entiendo más, que decían que habían naos grandes y mercaderías y todo esto era al Sueste. Y entiendo también que lejos de allí habían hombres de un ojo, y otros con hocicos de perro que comían hombres, y que en tomando uno lo degollaban y le bebían la sangre y les cortaban la natura".

Las cincuenta casas de mil vecinos siendo estas grandes es muy posible que fuesen habitadas múltiples familias. Se desconoce la composición de parentelas habitando cada una de esas estructuras lo que hubiese facilitado otros datos de interés. Sin embargo, cincuenta casas es especifico y fue posible que cada una se conociera en su propia denominación en adición al término aplicado al pueblo. Ya encontrado en La Española, Colón, en su empeño de rastrear el oro que venía siguiendo desde Cuba, relata el jueves 13 de diciembre que envió a nueve hombres bien aderezados de armas y aptos para semejante negocio, con los cuales fue un indio de los que traía y narra así:

"La población era de mil casas y de más de tres mil indios. (...) Decían todas esas tierras estaban labradas y que por medio de aquel valle pasaba un rio muy ancho y grande que podía regar todas las tierras. Estaban todos los arboles verdes y llenos de frutas, y las hierbas todas floridas y muy altas; los caminos muy anchos y muy buenos; los aires eran como en abril en Castilla; cantaba el ruiseñor y otros pajaritos como en el dicho mes en España; que dicen que era la mayor dulzura del mundo; las noches cantaban algunos pajaritos suavemente; los grillos y ranas se oían mucho; los pescados, como en España”.

Por las observaciones de cultivos y naturaleza en sus entornos naturales de labranza y economía de producción, se establecen principios integrados de 
autosuficiencia que se habían desarrollado tecnológicamente por siglos. Peguero (1763: 236) nos recuerda que la comunicación nativa entre La Española y Cuba era continua. Afirma que los espías del valiente Hatuey actuaban entre las dos islas para mantenerle al tanto de los españoles.

Al escuchar oro y perlas, Colón cambia de inmediato el rumbo, dirigiéndose a la fuente principal. Navegaron por un mes en busca de esas riquezas, entre noviembre 6 y diciembre 13. El día 14 de diciembre narra Colón: "Esta isla de la Tortuga es tierra muy alta, pero no montañosa, y es muy hermosa y muy poblada de gente como La Española, y la tierra así toda labrada, que parecía ver la campiña de Córdoba”. La narración de Colón proporciona datos de las grandes siembras y en varias ocasiones las refiere a las de Córdoba. Es natural pensar que entre el oriente de Cuba la isla Tortuga y el área noroeste de La Española los cultivos y pueblos que documentaron totalizarían números más altos de haber hecho esa relación, entre islas y pueblos. Los dos pueblos de cincuenta y mil casas se identifican en tan solo dos escasas líneas. En ese conjunto de lo nuevo y maravilloso pasó desapercibida la vida y naturaleza. Narra Colón ese día 16 de diciembre:

"Y crean que esta isla y todas las otras son así suyas como Castilla, que aquí no falta salvo asiento y mandarles hacer lo que quisieren, por que yo con esta gente que traigo, correrían todas estas islas sin afrenta, que ya he visto solo tres de estos marineros descender en tierra y haber multitud de estos indios y todos huir, sin que les quisieren hacer daño. Ellos no tienen armas, y son todos desnudos y de ningún ingenio en las armas y muy cobardes, que mil no aguardaran tres, y así son buenos para el mandar, y les hacer trabajar y sembrar, y hacer todo lo que fuese menester, y que hagan villas y se enseñen a andar vestidos y a nuestras costumbres".

En las primeras semanas de contacto el pensamiento era claro, la subyugación de las masas y la explotación de los bienes era de máximo interés. Las confrontaciones de las primeras dos décadas entre Montecinos, Las Casas, Sepúlveda, Oviedo y otros removerían todo derecho a los naturales.

Examinemos la navegación de unas cien leguas realizadas por Colón. El almirante describe patrones en tres islas de pueblos autosuficientes en las cuales tuvo poco interés en identificar quienes eran. El 16 de diciembre narra Colón:

"A la media noche, con el ventezuelo de tierra, dio las velas por salir de aquel golfo, y vieron del borde de la isla Española yendo a la bolina, porque luego a hora de tercia ventó leste, a media noche allá una canoa con un indio solo en ella, de que se maravillaba el almirante como se podía tener sobre el agua siendo el tiempo grande. Hízolo meter en la nao a el y a su canoa, y halagado, diole cuentas de vidrio, cascabeles, y sortijas de latón". 
En alta mar, un hombre solo maravilla al almirante, pensemos en los viajes logrados por más de cincuenta remeros en una embarcación. El hombre viajaba al viento y solo por los nudos de la corriente podía avanzar entre dos a cuatro nudos. Un marino hábil, conocedor de mareas en una pequeña embarcación podía recoger distancias inesperadas. Washington Irving (1829: 150) se hace eco de la experiencia de Colón en Jamaica:

"Se encontró con nativos mas ingeniosos y mas de guerra que los que esos de Cuba y Hayti. Sus canoas estaban construidas con mas arte, y ornamentadas de proa y popa con tallados y pinturas. Muchas eran de un gran tamaño, pero hechas de un solo madero ahuecado, comúnmente de alguna especie de caoba. Colón midió uno que probó ser de noventa y seis pies de largo y ocho de ancho; estaba ahuecado de uno de esos arboles que se levantan como verdísimas torres en medios de esos bosques del trópico".

Si entendemos la facilidad de viajes entre las islas y las fuerzas recogidas por los caciques podemos preguntarnos cómo acordaban entre tribus sus lindales y cuáles eran las políticas internas de negociar territorios. Colón expuso idea alguna de cómo proteger la vida o libertad de esa gente a quien pretende conquistar. A su regreso del tercer viaje a España lo conocido de América causaba disgusto; a tal extremo llego ese descontento que Colón se ve obligado a incorporar a su tripulación por un plazo limitado de años a criminales, excluyendo los de crímenes atroces (Irving, 1829). Estos nuevos tripulantes y sus acompañantes sedientos de fortuna viajaron a América y protegidos por el Estado cometerían grandes injusticias.

A lo largo de la tesis se ha ordenado la naturaleza, sus paisajes y geografía que en su conjunto y evolución albergó tribus y naciones de naturales que supieron integrarse en esa vida, convirtiéndose en un elemento inseparable. Examinamos algunos estudios de Fitch y Branch (1960), Dunphy et al (2000), Muñiz y Borhidi (1982), Pintaud et al (-), ${ }^{91}$ Rick et al (2013), Chaves et al (2011), ${ }^{92}$ evidenciando los sistemas de reforestación,

${ }^{91}$ Fitch, J.M. \& Branch, D.P. 1960. Primitive architecture and climate. Scientific American, 203(6), pp.134-144.Dunphy, B.K., Murphy, P.G. \& Lugo, A.E. 2000. The tendency for trees to be multiple-stemmed in tropical and subtropical dry forests: studies of Guanica forest, Puerto Rico. Tropical Ecology, 41(2), pp.161-168. / Muñiz, O. \& Borhidi, A. 1982. Catálogo de las palmas de Cuba. Acta Bot. Acad. Sci. Hung, 28, pp.309-345. / Pintaud, J.C., Montúfar, R., Sanín, M.J. and Anthelme, F. 2015. Patrones genéticos y ecológicos, naturales y antropogénicos, en las palmas del noroeste de América del Sur.

${ }_{92}$ Rick, T.C., Kirch, P.V., Erlandson, J.M. \& Fitzpatrick, S.M. 2013. Archeology, deep history, and the human transformation of island ecosystems. Anthropocene, 4, pp.33-45. / Chaves, J.A., J. T. Weir \& T. B. Smith. 2011. Diversificacion in Adelomyia hummingbirds follows Andean uplift. Molecular Ecology 20: 4564-4576. 
germinación y duración de estructuras primitivas en varias áreas geográficas junto a generalidades de ecosistemas de América.

Al organizar descripciones de la vivienda caribeña de origen se pueden comparar narraciones con dibujos tempranos y fotografías de hace solo un siglo a otras recientes, evidenciando el resultado de la tradición técnica y la evolución de las necesidades. Según Fitch y Branch (1960), en la escala de climas, los bosque selváticos lluviosos y sus materiales orgánicos son las regiones de durabilidad limitada en la fabricación de refugios. Las palmas, hojas, bejucos, cuerdas y paja tienen límites temporales. Lo que sí es cierto es que la regeneración de los materiales básicos es muy rápida y la técnica aprendida entre generaciones genera una continua producción. O sea, un ciclo natural de materiales repone eficientemente lo necesario entre generaciones para la fabricación de viviendas. Los tallos de reproducción de palmas crecen sobre el terreno de manera natural y su propagación supera a la de otras especies. Los naturales se establecían y vivían en entornos que facilitaban la sostenibilidad, supervivencia y el desarrollo de sus comunidades. A partir de las primeras décadas entre la esclavitud y el alejamiento de sus entornos, algunos huyen a crear nuevos entornos en lugares donde los colonos no tenían interés o acceso, Hatuey y Enriquillo representan dos casos.

La artesanía era de alta calidad según notado en el dibujo 1, donde existen enlaces y simetrías estructurales. El avance de la ingeniería y arquitectura nativa representada en los dibujos de Oviedo es significante por varios factores: (1) La técnica y materiales utilizados en esas estructuras eran accesibles, sostenibles y duraderos. (2) La construcción no requería equipos especializados, requería práctica y destreza. (3) Los integrantes artesanos y técnicos en comunidades geográficamente alejadas compartían especialidades y trabajos en común dentro de las diferencias tribales. (4) Las viviendas de madera podían durar entre veinte y cuarenta años. Hoy en día es sobre todo una versión simplista de la gran obra de los primeros días, pero el camino a la reorganización y el crecimiento a la calidad tradicional es clara y reproducible. En primer lugar, apuntamos a las especies de árboles, hierbas y plantas endémicas de la región fácilmente disponibles, junto al material confiable y sostenible. Uno de los problemas en la República Dominicana es la legislación que prohíbe el uso de materiales naturales por el interés de proteger sus bosques y naturaleza. Ese problema tiene alternativas y lo consultaremos en las conclusiones.

La variedad de palmas presenta una fuente de materia prima añadida a maderas selectivas y vides (bejucos) utilizadas para mantener la estructura y los materiales en su lugar. De estos materiales y el algodón se producían sogas, cabuyas, curricanes, hilos y 
otras fibras para la construcción, navegación, pesca y la fabricación de telas, mantas, hamacas y mayas.

Peguero (1763: 360, v. I) lista las palmas en esta forma: Palma corozo, se comían el tronco, palma catay, usada en la fabricación de flechas, palma manaza, muy hermosa, palma cacheo, usada pare endulzar el cacao, palma de coco, encontrada por Ponce de León entre los caribes de Puerto Rico y la trajo a esta isla, Palma de dátil, traída por Diego Colón, palma de coyos, se hayo en Cuba.

Entre las palmas más reconocidas en nuestra área de estudio utilizadas en la construcción de viviendas encontramos, sin limitarnos en el hecho que existen otras variedades de estas: (1) Acrocomia (2) Bactris (3) Caliptronoma (4) Coccotrinax (5) Copernicia (6) Gausia (7) Hemitrinax (8) Rivularis (9) Roystonea (10) Sabal (11) Trinax. En los apéndices se muestras fotográficas y dibujos de algunas de estas palmas documentadas por cronistas y fotografías recientes.

La vivienda fue inseparable del desarrollo tradicional caribeño y notamos que aun considerando la diversidad y particulares tribales el material básico, era uno común y compartido entre los naturales isleños. Peguero (1763, I: 360) identifica una palma de coco encontrada entre los caribes de Puerto Rico. 


\section{CONCLUSIONES}

A lo largo de esta tesis se analizaron datos históricos, crónicas y publicaciones contemporáneas desde los primeros contactos entre europeos y caribeños. Encontramos que un sinnúmero de teorías desde el siglo XIX se apartaban de lo histórico documentado, o más bien de la intención de los autores clásicos, formulándose durante décadas interpretaciones anacrónicas que exponían una nueva historia del nativo caribeño. Esa nueva configuración a partir del siglo XIX representaba unas nuevas oportunidades investigativas desarrolladas sobre una base terminológica dudosa, basada en el término taíno y una estandarización académica. A esa imposición terminológica la designamos como una fabricación científica y no una denominación natural rescatada atribuible al nativo caribeño. Se examinaron espacios investigativos ocupados por controversias de lo supuesto, lo asumido y no de lo sucedido.

Los textos antiguos o clásicos, a partir de 1492 recogieron información fundamental de los nativos, cuyas costumbres e integración al medio ambiente reflejaban su forma de vivir y relacionarse en colectividades diferenciadas las unas de las otras, en áreas geográficas cercanas o distanciadas. Esas diferenciaciones o particularidades no fueron únicas de los nativos caribeños sino compartidas por tribus y naciones de otras regiones de América. Sin embargo, al identificar al nativo caribeño en las diversas geografías caribeñas, las particularidades reconocidas en el continente americano dan lugar a interpretaciones ajenas de la pluralidad tribal. Algunos autores lo atribuyen a las narraciones de los invasores españoles que se ocuparon de la supuesta exterminación del nativo caribeño. En definitiva, los errores y una falta de sensibilidad hacia las culturas nativas originalmente documentadas abrieron las puertas a teorías alejadas de la vida de los nativos originarios.

¿Quiénes eran? o ¿quiénes somos? Son preguntas que tienen repuesta en las palabras empleadas por los nativos para autodenominarse. Una de las razones del problema interpretativo es que grupos aislados de nativos habitando islas vecinas no necesariamente pertenecían a una parentela o etnia compartida. A lo largo de la tesis se presentaron casos en los que nativos diferenciados en tradiciones y lenguajes habitaban incluso en una misma isla. El principio general consiste en la convivencia que existió o pudo existir entre parentelas clanes o tribus diferenciadas en algunos territorios. El caso de tierras compartidas por múltiples etnias era más común de lo aceptado y afecta en el 
largo plazo la etnicidad actual de las comunidades caribeñas. El nativo caribeño, desde los primeros contactos, fue marginado, terminando en la esclavitud, mientras sus nombres tribales y nacionales fueron reducidos al concepto académico más moldeable o de menos fricción, frente a la complejidad de términos que en sus épocas eran comunes.

Las denominaciones nativas de origen del Caribe evolucionaron académicamente a partir de la segunda mitad del siglo XIX, a partir de Constantino Samuel Rafinesque. En el siglo XXI, numerosos científicos aún desconocen la ausencia de historicidad del taíno. La diversidad nativa que existió durante el "descubrimiento" no se puede singularizar. A partir de los errores terminológicos, de la falta de sensibilidad investigativa alejadas de la diversidad y de la aceptación por movimientos culturales nativistas de esa terminología, se identifica una crisis cultural. Como consecuencias, en la actualidad, los nativistas han de gestionar los conflictos de esa crisis cultural mientras los investigadores se alejan desde comienzos del siglo XX de la comprensión de tal diversidad y contribuyen a la comercialización taína. Numerosos estudiosos que por décadas contribuyeron a la trágica visión de la estandarización taína, en la cual lo imaginario es convertido en una cultura predominante, consideran que su apoyo a esa fabricación terminológica es un detalle insignificante.

Desde el siglo XIX la difusión de lo imaginario se convirtió en la historia de los términos y la terminología adjudicada a los nativos caribeños. Entre esas páginas se analizaron las sustituciones e imposiciones "científicas" que por décadas organizó al ancestro caribeño. En el análisis de la inexistencia de una raza, lengua o nación taína ha quedado expuesto, diferenciando lo real de lo ficticio que constituye la historia nativa caribeña. A su vez, se contrasta lo que fueron términos de origen con términos “científicos", donde se descubre el alcance de las investigaciones. La actividad académica que persista en validar ese término o terminología según avanza el siglo XXI se alejará de la herencia, cultura e historia de las naciones naturales caribeñas. Lo desafortunado consiste en que algunos científicos niegan su responsabilidad y sus estudiantes seguirán añadiendo páginas a esa ficción. En esta tesis se identifica ese vivir como vivir en una simbología o fenomenología cultural fabricada. Podemos preguntaron qué persona o comunidad seleccionaría un nombre imaginario para representar a sus ancestros, familia y cultura, uno que a su vez impuesto por una sociedad científica alejada de la vida natural de las sociedades tribales. En este sentido, especialistas con décadas de experiencia han influenciado a jóvenes estudiantes con una historia que no representa ancestro alguno. 
Esos valores establecidos, impuestos, contribuyen a una crisis cultural que requiere una corrección.

La terminología como nomenclatura estructurada y mecánica atiende las necesidades de los avances científicos o tecnológicos. La identificación de procesos y productos emblemáticos son un requisito exclusivo para la comercialización de productos, tecnologías y materiales. La efectividad de las denominaciones relacionadas con factores humanos extraídos de contenidos históricos requiere interpretaciones fiables, sin daños colaterales o desventajas para comunidades de las que se trata. Esa efectividad de intereses históricos y humanos deben realizarse considerando realidades fundamentales. En base a esas dinámicas de efectividad y mercado, actuantes en temas concernientes a las humanidades, es donde la estandarización terminológica taína avanzó por intereses; en ese sentido, encontramos lo que definimos como la trilogía económica tainista. Esta práctica se basó en transmitir una estandarización fabricada académicamente que es difundida por vías gubernamentales, institucionales, públicas o privadas favoreciendo económicamente a grupos especializados. La perfección de esa práctica a lo largo de más de un siglo despertó el interés de investigadores especializados cada vez más reconocidos académica y económicamente, mientras comunidades nativistas caribeñas se encuentran en una crisis cultural por asumir lo imaginario.

El término taíno emerge a la par con necesidades comerciales de principios del siglo XX de académicos ampliando un nuevo campo teórico acoplado a una base histórica, favorecidos por instituciones e intereses especializados que no consideraron posibles consecuencias. Esos primeros científicos difusores organizaron una nomenclatura terminológica que consideraron científica y que favoreciera la clasificación de objetos, monumentos, etnias y aspectos comunitarios caribeños, basándose en una raza predominante por conveniencia y comercio de sus supuestos atributos unificados. Cientos de estudios favorecieron esa imposición estratégica por su efectividad y fácil comercialización.

Los naturales pre-colombinos de todas estas tierras caribeñas nunca conocieron de los taínos. Estos nacieron en 1836, fueron bautizados en 1898 y recibieron su primera comunión en 1907. La religiosidad de la época junto a las ediciones fantásticas en su conjunto lideró nuevas brechas a la imaginación de lo incongruente. Una imposición ajena a la intención original de Rafinesque es utilizada para referirse a los antepasados de nativos caribeños ubicados en islas geográficamente distanciadas. Debemos comenzar por entender que las reglas aplicables a estudios humanos y comunitarios son distintas a 
esas parametrizables a industrias y tecnologías. Sustituir el nombre a un producto o un objeto en un mercado competitivo financiero no es comparable a crear una etnia para la sustitución de ancestros de naciones diversificadas.

A lo largo de esta tesis, el periodo de tiempo transcurrido desde 1836 se dividió en tres fases que identifican la estandarización terminológica taína. Esos espacios son los siguientes: la fase de incubación (1836-1900), la segunda fase de expansión (1901-1955) y la tercera fase de consolidación (1956- hoy en día). A lo largo de la tesis las diferentes fases recogen información sobre los autores principales de cada época y sus aportaciones a partir de la obra de Rafinesque, directa o indirectamente.

Se ha creado un vacío al producir interpretaciones históricas creativas sobre una base científica fabricada. El término taino ha triunfado en su campaña académica, operacional y financiera, y su diseminación ha convertido a Constantine Sammuel Rafinesque en un héroe. Un héroe desconocido de muchas naciones debido a la labor de los escritores difusores desde la segunda fase de la estandarización tainista, que omiten citarlo.

La documentación analizada condujo a estudios recientes que incluían el ADN del nativo caribeño, siendo esta una vía biológica en la cual se refleja la supervivencia nativa caribeña de origen. Se presentó evidencia de un ADN nativo en los habitantes del Caribe que caminan por las calles de Puerto Rico, Cuba y la República Dominicana en el siglo XXI. Ante estos hechos biológicos tenemos que reconsiderar el origen e historia nativa desde una perspectiva que suponga la reconstrucción histórica de la supervivencia negada por siglos. El minucioso análisis cronológico del sacrificio de la mujer nativa presentado en esta tesis proporciona una guía de la supervivencia nativa caribeña. $\mathrm{Y}$, a su vez interpreta el significado de la utilización de denominaciones históricas acogidas en una conformidad de origen en base a la diversidad.

Se examinó el género, el ambiente construido y la naturaleza por ser valores originales que generan una continuidad socializadora, a su vez ligadas a la supervivencia biológica nativa. Las destrezas técnicas, la cultura material y las costumbres de los naturales aportaron una trayectoria lógica y fiable por haberse establecido por ellos mismos. Esas destrezas y las circunstancias surgidas desde los primeros contactos tomaron un curso humano directamente ligado al entorno natural, la geografía, el autoabastecimiento y las construcciones nativas, mientras la supervivencia coincide con el ADN encontrado hoy día. Ese rastro se ha evidenciado desde los conceptos de salvajes e idolatras hasta lo más básico de las corrupciones idiomáticas y el genocidio. 
Analizamos la práctica terminológica científica y encontramos que desde su punto de partida en el siglo XIX se consideró incongruente y había sido resistido por décadas. En este sentido, el pasado legó raíces, semillas y un sendero un tanto oculto del cual nació vida nueva. Esa vida ha encontrado en la diversidad de las pisadas de hombres, mujeres y niños antes de la llegada de los europeos una historia fiable y una continuidad biológica que, aunque frágil, es real. Esa vida, esas pisadas y esos legados fueron escasamente recogidos en las páginas de la historia desde el siglo XV y sirven para establecer una narrativa. La nueva historia de la terminología taína ha pasado a ser fícción por sus deficiencias científicas al pretender una estandarización cultural de la pluralidad del nativo caribeño.

Las generaciones anteriores al descubrimiento nacían en un ambiente experimentado, establecido, donde las costumbres y el vivir día a día eran definidos y claros. Los naturales eran experimentados navegantes y mercaderes entre sus islas habiendo establecido rutas que facilitarían a Colón el desplazarse rápidamente en su busca de oro y riquezas asistido por los propios naturales.

Los naturales habían establecido sus riquezas en la sostenibilidad de sus tierras, sus pueblos, ciudades y estructuras conformadas en sus cacicazgos. Los cacicazgos se constituían en naciones ocupando un numero de pueblos y tribus bajo una denominación general a su vez acompañado por propias definiciones y nombres particularizados. La diversidad cultural les proporcionaba distintivos específicos mientras su conformidad biológica los integraba al medio ambiente actuando como un denominador común. Y se decían entre ellos, yo soy ciguayo y tu siboney o macorix dentro de un entorno heredado de sus ancestros, viviendo dentro de una evolución continua su patrimonio cultural y etnias diferenciadas en sus costumbres y creencias mitológicas. Desde esa perspectiva, los mercaderes encontraban sus riquezas en sus mejores casas, en el contenido de estas, en la composición estructural de sus pueblos, sus técnicas, el diario vivir y la hegemonía del clan. La perspectiva nativa de riqueza y el significado de valores en el Caribe desde los primeros contactos con europeos fue de asombro, de hecho, le permitió una ventaja comercial a los castellanos. Los castellanos documentaron e identificaron la naturaleza y la sostenibilidad del entorno por los naturales en el que cada habitante, tribu o nación, encontrando que estos no mostraban apegos por riquezas y valores a perlas, joyas, oro o plata. Los castellanos quedaron favorecidos por el desapego de los naturales caribeños a las riquezas buscadas, sirviendo ese desapego de beneficio a los colonizadores, pues para ellos el avance de la conquista dependía de riquezas como el oro, plata, perlas y esos 
valores. El apego de los nativos caribeños a su medio ambiente y la busca de riquezas de los conquistadores constituiría la diferencia entre colonos y nativos. Los castellanos, por costumbre, vivían en estructuras de piedra y las de los naturales les parecían maravillosas y a su vez adversas a su cultura. Con el tiempo construirían en piedra o ladrillos y lograrían bellas ciudades en sus colonias sin alejarse de sus costumbres europeas. No obstante, los naturales dependerían del entorno heredado y su sostenibilidad por siglos mientras cursaban entre libertad, esclavitud y pobreza. Durante la colonización de América el proceso de la evolución biológica del nativo caribeño y sus consecuencias en el largo plazo eran desconocidos. Tanto los nativos como sus primogénitos híbridos vivirían en su mayoría aislados del desarrollo colonial, encontrándose en el siglo XXI un habitante de origen sin un rastro reconocido en su evolución biológica. Nuestro concepto de la evolución biológica nativa caribeña y la supervivencia evolucionada del natural caribeño pre-contacto europeo hoy día es considerada inexistente por muchos investigadores que prefieren la estandarización y su vínculo a la extinción. Estas características se reflejan en algunas comunidades nativistas que viven en unas estructuras clásicas de origen técnicamente desarrolladas en base a la terminología científica taína, e integradas a programas educacionales y políticas culturales tratando el tema de supervivencia ligeramente, y la herencia cultural y material en base a lo taíno. La población nativa original y su diversidad, ubicados en sus propios entornos geográficos caribeño seleccionados, entre extensas montañas, valles y ríos e islas aisladas se presta a muchas condiciones de supervivencia según planteado en esta tesis. Entre la diversidad y la coexistencia nativa de origen existió en el Caribe una armonía dentro de un propio balance entre política, mitología, matrimonios y mercados. No se ha considerado la posibilidad de que los naturales implementaran doctrinas tribales para coexistir entre el enemigo, que a su vez procreaba entre las mujeres nativas de otras tribus. Esa discusión se planteó en esta tesis en base a la normalidad de costumbres e intercambios tribales donde no existía una diferenciación fisionómica. Eventualmente esa ruta tradicional da paso a la evolución nativa caribeña dentro de lo comúnmente denominado como el mestizaje, inadvertidamente culminando siglos más tarde en lo multirracial. Originalmente esa ruta encontró gran oposición en las colonias que estudiamos donde una de esas resistencias era de origen religioso. El bautismo, sin embargo, no era una vía por la cual un indio o bárbaro dejaba de ser un idólatra o una bestia sin alma como algunos pensaban. La integración de indio y colono supuso desde los primeros contactos un proceso de aculturación complejo y de larga duración. Entre la evolución nativa caribeña, 
la familia criolla, la fe cristiana y la aculturación de padres y madres en algunas familias se creó una vía que en la eventualidad cobraría nueva vida en el Caribe y América. Esa nueva vida tiene raíces desde el primer contacto entre nativos y europeos, fácil de negar en las páginas de la historia y difícil de proteger o identificar por el prevalente concepto del exterminio nativo caribeño. Esa discusión se aclara en base a los resultados de estudios de ADN de las últimas dos décadas. Al considerar los resultados de estudios de ADN, la evolución nativa caribeña y la documentación histórica presentada en esta tesis encontramos unas raíces meritorias para el reconocimiento de la supervivencia nativa entre la diversidad tribal caribeña de origen y la evolución multirracial.

Las ordenaciones científicas de tendencias étnicas caracterizan orígenes, condiciones y circunstancias actuales que resultan imprescindibles al tratar de rescatar particularidades regionales independientes desde la toponimia, en conexión con los complejos exónimos y etnónimo tribales, junto a las divergencias contemporáneas y sus consecuencias socio-colectivas prehispánicas isleñas.

De entre los prejuicios encontrados surgen deficiencias terminológicas que crean problemas a la historia de origen. Los conflictos raciales, la esclavitud y las políticas originales adversas a los naturales durante las primeras décadas del descubrimiento no se han ordenado desde una neutralidad y perspectiva sensible al entendimiento de las vidas nativas. Los exploradores soñadores durante el descubrimiento, junto a los apasionados nativos de América cambiaron el mundo. Por esa potente razón debería la historia definir un patrimonio cultural particularizado y no colectivo, reconstruyendo los nombres tribales originales utilizados por la propia gente en sus momentos históricos. De esa forma encontraremos formas de subsanar los daños culturales a comunidades.

Examinamos los valores técnicos y diseños de viviendas, la arquitectura, ingeniería y tecnología, encontrando su aportación al medio ambiente y a la autosuficiencia, pues de no haber tenido aplicaciones perfeccionadas no hubiese miles de familias evolucionadas al hoy día dependiendo de esas técnicas y esa agricultura originaria. Por décadas, nativos y colonos de bajos recursos en el ámbito familiar se adaptaron a las costumbres y economías nativas para su supervivencia. Mientras la realeza nativa alcanzaba tratos privilegiados con las autoridades y en sus matrimonios y acuerdos con altos funcionarios o conquistadores, la muchedumbre convivía y evolucionaba hacia el futuro adaptándose a cambios políticos, sobreviviendo en costumbres y tradiciones para lograr su autoabastecimiento. 
En el Caribe la tecnología nativa no alcanza niveles avanzados de diseño en arquitectura e ingeniería desde la perspectiva europea por varias razones. Una de esas razones era que los materiales utilizados en la construcción de cada villa o pueblo eran perecederos; otra era la estructuración basada en las prácticas agrícolas y costumbres para su abastecimiento de pueblos acogidos a la política de cacicazgos. La densidad poblacional y los requisitos comunales de pueblos o villas estaban sujetos a la disponibilidad del recurso material en su entorno natural y su ubicación. La diversidad poblacional de pueblos en un territorio surge de ese principio de pertenencia a su tierra dentro de sus colindancias.

Esa integración de diseño, medio ambiente y convivencia se vio afectada desde las primeras décadas de contacto por incidir en el producto agrícola, el orden político y las tradiciones. Concentrándonos en la vivienda, encontramos que su construcción de madera comúnmente disponible era práctica, económica, abundante y a su vez perecedera y eficiente. Por tanto, tras cinco siglos esa tecnología nativa de residencia y autoabastecimiento ha logrado una continuidad, pues se encuentran ejemplos en algunos parajes de las islas estudiadas.

Como se ha señalado, la periodización y geografía marcan espacios definitivos al interpretar resultados de ADN, la supervivencia biológica y la evaluación de teorías que han apoyado estados culturales dudosos, como la estandarización terminológica taínaa plicada a la diversidad de vida nativa caribeña. La evidencia presentada no deja duda de que la estandarización del nativo caribeño está fuera de lugar, y que sus efectos secundarios son perturbadores. La supervivencia biológica del nativo caribeño existe y es una realidad defendible y justificable.

El taíno como denominación nunca debió existir en forma alguna. En el futuro los científicos especializados deben proceder a identificar a los nativos caribeños por sus propias denominaciones o basados en sus areas geográficas. Nombres como indígenas, indios y aborígenes para identificar a las culturas caribeñas de antaño son igualmente inútiles y solo nos vinculan a siglos de insensibilidad vividos en el Caribe. 


\section{BIBLIOGRAFÍA}

Abbad y Lasierra, F. Iñigo. 1866. Historia, geografia civil y natural de la Isla de Puerto Rico José Julián de Acosta y Calbo., Puerto Rico.

Abreu Cardet, José. ed., 2013. Historia de Cuba. Impreso en República Dominicana

Acosta, Joseph de 1894. Historia Natural y Moral de las Indias. Casa de Juan León. Sevilla

Acosta, José de 1987. De Procuranda Indorum Salute, educación y evangelización. Consejo Superior de Investigaciones Madrid

Acosta, Joseph de. 1985. Historia Natural y Moral de las Indias. E. O'gorman, editor, 2da edición. Madrid.

Acosta, J. 1880. The Natural and Moral History of the Indies E. Grimston, C, R Markham, translated., London: Hakluyt Society

Alencar, F. L., y Ruiz-González, R. 2010. ¿Puede el cristianismo inspirar una cultura global? Una aproximación hacia la lusitanidad. Univ Forum Scientific CommitteUniversidad de Navarra, pp.39-45.

Alegría, R. E. 1971. Descubrimiento, conquista y colonización de Puerto Rico, 14931599., Puerto Rico: Instituto de Cultura Puertorriqueño.

Alegría, R. E. 1978. Apuntes en torno a la mitología de los indios taínos de las Antillas Mayores y sus orígenes suramericanos. Centro de Estudios Avanzados de Puerto Rico y el Caribe, Museo del Hombre Dominicano.

Alegría, R. 1981. Las Primeras Noticias Sobre Los Indios Caribes I. G. Manuel Pareja., Barcelona: Editorial de la Universidad de Puerto Rico.

Alegría, R. \& Castro Arroyo, M. Modelos A., 1989. San Juan de Puerto Rico Ediciones de Cultura Hispánicas., España.

Alegría, R. \& Nicholson, N.B., 1955. The Archaic Tradition in Puerto Rico American Antiquities., USA.

Alles, D. L. 1995. The Third Culture: Exploring the Relationship between Biology and Philosophy. Western Washington University, p.21.

Alonso, Manuel A. 1849. El Gibaro., Juan Oliveres Barcelona.

Amadeo, J. 2008. 'Cristobal Colón y los inicios de la justicia en la isla Española. Nombramiento y actuación de los primeros alcaldes mayores.', Casa de Colon, (XIII Coloquio de Historia Canario-Americana), pp. 676-700.

Antequera Luengo, JJ. 1992. La Cartuja de Sevilla. Amaya, Mostoles, Madrid

Antolini, Paola. 1992. The Role of Women. Commission Of The European Communities \#37

Arango, R. \& Sánchez, E. 1997. Los pueblos indígenas de Colombia 1997: desarrollo y territorio Autor: Raúl Arango; Enrique Sánchez TM Editores., Columbia: Publicación gubernamental nacional. 
Arens, W. 1979. The man-eating myth Anthropology and anthropography Oxford University Press., UK: Galaxy books.

Ares Queija, B. 2006. Relaciones sexuales y afectivas en tiempos de conquista. La Española (1492-1516). Historia y Leyenda, pp.237-256.

Armillas Vicente, J. A. 2013. Pedro Mártir de Anglería, contino real y cronista de Castilla. La invención de las nuevas Indias. Jerónimo zurita, 88(Universidad de Zaragoza), pp.211-219.

Arnainz-Villena, A. 2011 Aboriginal DNA Genes Remains in the Cuban Population. Segunda convención de antropología la Habana

Arrom, J. J. 1967. 'El mundo mítico de los taínos: Notas sobre el Ser Supremo.', Thesaurus, 1(3), pp. 378-393.

Aruca Alonso, L. 2012. Habrá un cambio de paradigmas en torno a la historia antigua de Cuba y su Cultura. Cuba Arqueológica, Año V, num, I, p.4.

Ashcroft, B., Griffiths, G. \& Tiffin, H., 1998. Key concepts in post-colonial studies., USA: Psychology Press.

Augusta, F. J. de 1916. Diccionario Araucano/Español y Español/Araucano, Santiago de Chile: Imprenta universitaria.

Augusta, F. J. de 1903. Gramática Araucana. Valdivia, Imprenta Central J. Lampert.

Bachiller y Morales, A. 1883 Cuba primitiva. Origen, lenguas, tradiciones e historia de los indios de las Antillas Mayores y Lacayas. 2da ed. Cuba: Liberia de Miguel de Villa.

Badillo, J. S. 2007. Guadalupe: ¿Caribe o taína? La isla de Guadalupe y su cuestionable identidad caribe en la época pre-colombina: Una revisión etnohistórica y arqueológica preliminar. Caribbean Studies, pp.37-85.

Badillo, J. S. 2011. El Dorado borincano. La economía de la conquista 1510-1550 Ediciones Puerto. J. Carbaja, ed., Puerto Rico.

Badillo, J. S. 1978. Los caribes realidad o fabula, Puerto Rico: Editorial Antillana.

Bal, F. 2011. Ottoman-Spanish Economic Relations in the Sixteenth Century: Rivalry in the Mediterranean. Journal of Business and Social Science (Special Issue), 2(21), pp.296-306.

Bajetta, C. M. 2006 'The Authority of Editing: Thoughts on the Function (s) of Textual Criticism.', Textus, 19, p. 305 - 322.

Ballesteros Caibrois, M. 1978. Las Culturas Olvidadas. Historia, VI (16), p.5.

Bancroft, H. H. 1882. The works of Hubert Howe Bancroft. San Francisco, A.L. Bancroft \& Co.

Bello, A. 1848. Modo de escribir la historia. El Araucano, 28.

Benzoni, Girolomo. Edición 1989 Historia del Nuevo Mundo. Alianza, Madrid,

Bergman, J. 2001. Evolutionary Naturalism: An Ancient Idea. Originally published in Journal of Creation, 15(2), pp.77-80.

Bernáldez, A. 1870. Historia de los Reyes Católicos, D. Fernando y Doña Isabel Imprenta que fue de D. José María Geofrin. España. 
Berry, J. W. 2005. Acculturation: Living successfully in two cultures. International journal of intercultural relations, 29(6), pp.697-712.

Bidney, D., 1946. The concept of cultural crisis. American Anthropologist, 48(4), pp.534552.

Blavatsky, H. P., 1895. The Secret Doctrine: The Synthesis of Science, Religion and Philosophy William Q Judge., USA: Theosophical Publishing Society.

Blavatsky, H. P. 1879. Qué es la Teosofía. Theosophist, (october).

Brau, S. 1894. Historia de Puerto Rico. Imprenta de Francisco Vives Mora. Valencia: D. Appleton.

Brau, S. 1917. Historia de Puerto Rico. New York: D. Appleton.

Brinton, Daniel Garrison, 1871. The Arawack Language of Guiana in Its Linguistic and Ethnological Relations. American Philosophical Society Transaction 14:427-44.,

Brito, L. 2006. Señores del Caribe, indígenas, conquistadores, piratas y corsarios en el mar colonial., Habana: Editorial de Ciencias Sociales.

Boas, F. 1920. The classification of American languages. American Anthropologist, 22(4), pp.367-376.

Boas, F. et al. 1915. Anthropology in Nort America. G E Stechert \& Co.

Boetsch, G. A. 2004. Metaphor of Primitivism: Cannibals and Cannibalism in French Anthropological Thought of the 19th Century. Centre National de la Recherche Scientifique, France

Botello, O. 1990. Toponimia Indígena de Aragua., Venezuela: Publicaciones del Consejo del Municipio de Girardot Oficina del Cronista de la Ciudad.

de Booy, T. 1915. 'Pottery from certain caves in eastern Santo Domingo, West Indies', American Anthropologist, 17(1), pp. 69-97.

Boyd-Bowman, P., 1973. Patterns of Spanish Emigration to the New World (1493-1580). Special Studies No. 34.

Boyd-Bowman, P. 1976. 'Patterns of Spanish emigration to the Indies until 1600', The Hispanic American Historical Review, 56(4), pp. 580-604.

Burigny, M. de 1754. The life of the truly eminent and learned Hugo Grotius, London: A Millar.

Cabeza de Vaca, A.N. 1982. Naufragios Ediciones Orbis y Editorial Origen., España: Ediciones Orbis.

Cabeza de Vaca, A. N. 1749. Naufragios Gutenberg Project 2004 (idioma original y errores)

Cairo, A. y Gutiérrez, A. eds. 2011. El Padre las Casas y los Cubanos Royma Cañas. Cuba: Instituto Cubano del Libro.

Cano, R. et al., 2014. Paleomicrobiology: reveling Fecal microbiomes of Ancient Indegenous Cultures. Journal Plos, p.14.

Castellanos, J. de 1962. Elegías de varones ilustres de Indias. Edime. I. J. Pardo, ed., Venezuela: Academia Nacional de la Historia. 
Cassá, R. 2000. El campesinado dominicano. Historia Social y Económica de la Republica Dominicana, Santo Domingo

Cassá, R. et al. 2013. Historia General del Pueblo Dominicano 2da ed., Italia: Academia Dominicana de la Historia.

Catelli, 1. 2008 'El caribe precolombino. Fray Ramón Pané y el universo taíno’, Catálogo de la Exposición, (organizada por el Museu Barbier-Mueller dArt Precolombí, con la.).

Cervera Obregon, M. 2006. The macuahuitl: an innovative weapon of the Late PostClassic in Mesoamerica. Arms Gf Armour, 3(2).

Chartier, R. 1994. "Cultura Popular" retorno a un concepto Histórico. Manuscrits, 12, pp.43-61.

Charlevoix, P.F.X., de 1744. Histoire et description générale de la Nouvelle France (Vol. 1). Cambridge, Mass.: General Microfilm Company.

Chez Checo, J. 1979. El sistema de encomiendas en Santo Domingo durante el siglo XVI. Academia Dominicana de la Historia, pp.59-86.

Cifre de Lubriel, E. 1964. Catálogo de extranjeros residentes en PR en el siglo XIX. Puerto Rico: Instituto de Cultura Puertorriqueña.

Colón, C. 1936. Diario de A bordo Cristóbal Colón Editorial E. Gómez., Ediciones Pastor.

Colón, C. 1991. Diario de a bordo Luis Arranz. Madrid: Cambio.

Colón, H., 1946. Los cuatro viajes del almirante y su testamento cuarta edición. Anzoategui Ignacio, ed., Madrid: Repasa Calpe.

Colón, H. 1947. Vida del Almirante don Cristóbal Edición, prólogo y notas de Ramón Iglesia. México and Buenos Aires. R. Iglesias, ed.,

Colón, H. 1947. Vida del Almirante Don Cristóbal Colón H. Iglesias, ed., Fondo de Cultura Económica.

Colón, F. 1892. Historia del Almirante Don Cristóbal Colón Libros Raros. Madrid.

Colón, F. La vida del Almirante Cristóbal Colón. Colección de libros raros. Madrid: Imp.Tomas Minuesa.

Colón, F. 1749. Historia de D. Fernando Colon. traducción Alonso de Ulloa., España.

Coll y Tosté, Cayetano. 1907. Prehistoria de Puerto Rico. Puerto Rico

Coll y Tosté, Cayetano. 1897. Prehistoria de Puerto Rico. Puerto Rico

Coll y Tosté, C. 1972. Historia de la Esclavitud en Puerto Rico, Sociedad de Autores Puertorriqueños., Puerto Rico

Coll y Tosté, Cayetano. 1986. La formación del Pueblo Puertorriqueño. Inst. de Cultura Puertorriqueña. Editora Corripio. Santo Domingo

Coll y Tosté, C. 1926. Tradiciones y Leyendas Puertorriqueñas, Madrid: Editorial Maucci.

Coll, J. 1891. Colón y la Rábida: con un estudio acerca de los Franciscanos en el Nuevo mundo. Librería Católica de Gregorio del Amo., España.

Columbus, C. 1893. Christopher Columbus; His own book of privileges B. F. Stevens, ed., London: B F Stevens. 
Columbus, C. 1893. The journal of Christopher Columbus (during his first voyage, 149293) and documents relating the voyages of John Cabot and Gaspar Corte Real (No. 86). Hakluyt society.

Columbus, C. 1870. Select Letters of Christopher Columbus: With Other Original Documents, Relating to His Four Voyages to the New Word (43 vol). 2nd edn. Translated by R. H. Major. UK: Hakluyt Society.

Columbus, C. y de las Casas, B. (1827) Personal narrative of the first voyage of Columbus to America: From a manuscript recently discovered in Spain. Translated by S. Kettell. USA: Wait, Greene and Co.

Conde Sturla, P. 1978. Notas Sobre el Enriquillo., República Dominicana: Ediciones de Taller.

Cook, N. D. 2003. ¿Una Primera Epidemia Americana de Viruela en 1493? Revista de Indias, LXIII, núm., 227, pp. 49-64.

Córdoba, P. T. de 1831. Memorias Geográficas, Históricas, Económicas y Estadísticas de La Isla de Puerto Rico. Madrid: Oficina del Gobierno, a cargo de Valeriano de Santillán.

Cosculluela, J. A. 1946. Prehistoric cultures of Cuba. American antiquity, 12(1), pp. 1018.

Cosculluela, J.A., 1947. Sincronismo de las culturas indo-antillanas. Grupo Guamá.

Cosculluela Barrera, J. A. 1952. 'Cuba Precolombina, Descubrimiento, Exploración y Conquista', in La Historia de la Nación Cubana. La Habana: Cultural SA.

Courtz, H. 2008. Carib grammar and dictionary. Magoria Books.

Cozby, P. C. 2002. Methods in Behavioral Research., USA: McGraw-Hill.

Cuneo Vidal, R. 1903. Cristóbal Colon-Genovés-., Barcelona: Editorial Mauccci.

Curet, L. A. 2015. Indigenous revival, indigeneity, and the jíbaro in borikén. " CENTRO: Journal of the Center for Puerto Rican Studies 27.1 (2015): 206-248.

Curet, L. A. 2014. The Taíno: Phenomena, concepts, and terms. Ethnohistory 61.3 (2014): 467-495

Cuartero y Huerta, B. 1950. Los Colón en la Cartuja. Real Academia Sevillana de las Buenas letras, pp.67-152.

Curtis, K. J. y Scarano, F. 2011. Latin American Research Review, 46(2), pp.200-213.

Davies, W. W. 1905. The Hammurabi and Moses., US: Jennings and Graham.

Deagan, K. 2004. Reconsidering Taino social dynamics after Spanish conquest: gender and class in culture contact studies. American Antiquity, 69(4), pp.597-626.

Descartes, R., 1912. Discourse on Method, New York: J. M. Dent \& Sons Ltd.

Diaz de Castillo, B. 1844. Memoirs, of the Conquistador Bernal Diaz del Castillo written by himself containing a true and full account of the discovery and conquest of Mexico and New Spain, Canada: London: J. Hatchard.

Dick, K. C. 1977. Aboriginal and early Spanish names of some Caribbean, circumCaribbean islands and cays. Archaeological Society, 4, pp. 17-41. 
Domínguez, L. 1984. Arqueología Colonial: dos estudios. Editorial de ciencias Sociales. La Habana.

Domínguez, L.S., 1986. Fuentes arqueológicas en el estudio de la esclavitud en Cuba. La esclavitud en Cuba, pp.267-279.

Dominguez, L. S. y Rives, A. 1995. Aproximación al estudio del contacto entre aborígenes y europeos en Cuba. AULA Revista de Humanidades y Ciencias Sociales.

Edwards, J. 1988. Raza y religión en la España de los siglos XV y XVI: una revisión de los estatutos de limpieza de sangre. Universidad de Alicante, p.19.

Elliot, J. H. 1989. Spain and its World, 1500-1700: Selected Essays, New Haven Conn., USA: Yale University Press.

Elliot, J. H. 1992. The old world and the new: 1492-1650., UK: Cambridge University Press.

Elliot, J. H. 2007. Empires of the Atlantic world: Britain and Spain in America, 14921830, USA: Yale University Press.

Estevez, J. B. 2013. Origins of the word Taino., p.11.

Fabre, A. 2005. Diccionario etnolingüístico y guía bibliográfica de los pueblos indígenas suramericanos. Arawaks.

Febvre, L. 1971. Combates por la historia. Traductores, Buey, F.F. and Argullol, E. Barcelona: Ariel.

Fernández de Navarrete, M. 1946. Primer viaje de colón, Los indígenas, España: Calpe.

Fernández de Navarrete, M. 1941. Viajes de Américo Vespucio, España: Espasa Calpe.

Fernández de Navarrete, M. 1923. Viajes de Américo Vespucio, Madrid, España: Calpe.

Fernández de Navarrete, M. 1851. Biblioteca marítima española, Obra póstuma, España: Editorial: Vda. de Calero, Madrid.

Fernández de Oviedo y Valdés, G., 1851. Historia General de la Indias, Madrid, España: Casa de la Real Academia de la Historia.

Fewkes, J.W. 1907. The Aborigines of Porto Rico and Neighboring Islands, US: US Gov. Print. Off.

Fewkes, J. W. 1903-4. The Aborigines of Porto Rico and Neighboring Islands, US: US Gov. Print. Off.

Fewkes, J. W. 1914. Relations of aboriginal culture and environment in the Lesser Antilles. D. Taylor.

Figueredo, A. E. 2009. Las Culturas Marginales de las Antillas Mayores Durante los Tiempos Históricos Tempranos. Cuba Areological.

Franch, J. A. 1978. Valoración Global de las Culturas Precolombinas. Historia, (Extra VI), pp.139-146.

Franco, S. 2014. The integration of the Dominican Cultural Diaspora and to rebuild trust in the relations with Haiti. Institute of Cultural Diplomacy, p.19.

Franqui-Rivera, H. 2013. National Mythologies: US Citizenship for the People of Puerto Rico and Military Service Mitología nacional: Ciudadanía norteamericana para la 
gente de Puerto Rico y Servicio Militar. Studies. Memorias: Revista Digital de Historia y Arqueología desde el Caribe, (Universidad del Norte Columbia).

Foucault, M. 1978. Nietzsche, genealogy, history.

Fuson, R. H. 1987. The log of Christopher Columbus. Maine: International Marine Publishing.

Galván, M. de J. 1882. Enriquillo; Leyenda Historia Dominicana (1503-1533), Haití: García Hermanos.

Galván, M. de J. 2008. Textos reunidos 3, Artículos y Controversias Históricas A. Blanco Díaz, ed., República Dominicana: Archivo General de la Nación.

Garner, J. L. 1912. Caesar Borgia: A Study of the Renaissance. McBride, Nast.

Gamazo, A. S. 2009. Digo Álvarez Chanca Primer espía de América. Universidad de Burgos, pp. 20-40.

Gamazo, A. S. 2005. 'Juan de Fonseca y el memorial de 1503: la creación de la Casa de la Contratación.', Universidad de Valladolid, pp. 11-139.

Gambín García, M. 2014. 'Los Procesos Judiciales de Liberación de Esclavos Palmeses y Guanches en Sevilla (1496-1512). Nuevos Daros para su Estudio. Coloquio de Historia Canario Americana, XXI-017., (XX-017) http://coloquioscanariasmerica.casadecolon.com/index.php/aea/article/view

García Bido, R. 2010. Voces d bohío Vocabulario de la cultura Taina. Archivo General de la Nación.

García Gallo, A. 1976. Los sistemas de colonización de Canarias y América en los siglos XV y XVI. Coloquios de Historia Canario Americana., 1(1), pp.424-442.

García Molina, J. A., Garrido Mazorra, M. y Fariñas Gutiérrez, D., 2007. Huellas vivas del Indo-cubano. Historia., Editorial de Ciencias Sociales.

Garroutte, E. M. 2001. The racial formation of American Indians: Negotiating legitimate identities within tribal and federal law. The American Indian Quarterly, 25(2), pp. 224-239.

Geertz, C. 1987. Descripción densa: hacia una teoría interpretativa de la cultura. La interpretación de las culturas, pp.19-40.

Geetrz, C. 1994. Desde el punto de vista del nativo: sobre la naturaleza del conocimiento antropológico. Ensayos sobre la interpretación de las culturas, pp.73-90

Ghisalberti, M. 1952. El oro y la cruz, Montevideo y Caracas: Editorial José Janes Americana.

Giménez Fernández, M. 1966. Breve biografía Fray Bartolomé de las Casas Facultad de filosofía y letras, primera edición., Sevilla.

Gould, G. M. y Pyle, W. L. 1996. Nomalies and Curiosities Medicine, USA: Gutenberg, Benedictine University.

Gould, A. B. 1984. Nueva lista documentada de los tripulantes de Colón en 1492 (Vol. 6). Real Academia de la Historia.

Ginorio, J. G., Colon, E. M. y dal Verde, S. 1971. El descubrimiento de Puerto Rico. Editorial Coquí. 
Gómez Tabanera, J. M. 1978. Las civilizaciones marginales. Historia, VI (16), pp.134145.

González, S., Huddard, D. y Bennett, M., 2006. Valsequillo Pleistocene Archaeology and Dating: Ongoing Controversy in Central Mexico. World Archaeology, 38(4), pp.611627.

González Herrera., U. M. 2010. Mark R. Harrington y el problema de las fuentes primarias en los estudios de reconstrucción etnohistórica en Cuba. Cuba Arqueológica, Año III, num, 1, pp.5-13.

Gordon, T. F. 1831. History of the Spanish dicoveries. Containing the History of the Spanish Discoveries Prior to 1520. (Vol. 1). Carey \& Lea.

Gould Quincy, A. B. 1927. VI Nueva lista documentada de los tripulantes de Colón en 1492.

Granberry, J. 2012. Lenguas Indígenas del Caribe. Cuba Arqueológica. Revista digital de Arqueología de Cuba y el Caribe, Año 5, №. 1 (enero-junio), págs. 5-11, p.6.

Green, K. y Moore, T. 2010. Archeology: an introduction, UK: Routledge.

Guanche, J. y Corral, C. 2015. Diccionario Etnográfico, Los pueblos del Caribe Insular $y$ de Mexica-Centroamérica, Cuba: Editorial Ciencias Sociales, La Habana.

Guitar, L. 1997. No more negotiation: slavery and the destabilization of colonial Hispaniola's encomienda system. In Guyane: Association of Caribbean Historians. Conference, p. 25.

Guiteras, P. J. 1865. Historia de la isla de Cuba: con notas e ilustraciones (Vol. 1). J. R. Lockwood.

Guanche Pérez, J. 1993. Aspectos etnodemográficos de la nación cubana: problemas y fuentes de estudio. Cuba: Cabildo Insular de Fuerteventura, pp. 199-221.

Gutiérrez, E. M. 2012. Jerez de la Frontera a la luz de la Información o probanza de1505. Norba. Revista de historia, 25, pp. 227-246.

Hall, Catherine. 2018. What is a West Indian. UK: Manchester University Press, In West Indian Intellectuals in Britain, p. 48.

Hall, S. 1990. Cultural identity and diaspora. In Cultural identity and diaspora. UK, p. 17.

Hall, S. 1996a Critical Dialogues in Cultural Studies. Edited by D. Morley and K.-H. Chen. London-New York: Routledge

Hall, S. 1996b. New ethnicities. Critical dialogues in cultural studies, pp. 441-449.

Harrington, M. R. 1921. Cuba Before Columbus. New York Museum of the American Indian. Ed. F. W. Hodges. NY: Heye Foundation.

Harris, W., Griffith, G. y Tiffin, H. 1995. History, Fable and Myth in the Caribbean and Guiana. (1970) B. Ashcroft, ed. The Post-Colonial Studies Reader., pp.378-382.

Harris, W. 1970. History, fable and myth in the Caribbean and Guianas. Caribbean Quarterly, 16(2), pp.1-32.

Harrison, F. V. 1998. Introduction: Expanding the discourse on" race. American Anthropologist, (100.3), pp. 609-631.

Hartley, M. 1920. Red Man Ceremonials: An American Plea for American Esthetics. 
Hebreo, L. 2009. La traducción del indio de los tres Diálogos de Amor, España: casa de Pedro Madrigal 1590.

Heidegger, M. y Kahnemann, H. 1958. ¿Qué significa pensar? (pp. 32-33). Buenos Aires: Nova.

Hernández González, Pablo J. 1992. El componente aborigen en la población cubana a través de dos padrones eclesiásticos $(156970 ; 1608)$. Cuadernos de I.N.I.C.E. Universidad de Salamanca, 49, pp.48-52.

Hernández González, Pablo J. 2006. 'De los Pueblos de Indios en Cuba. Segunda mitad del siglo XVI.', Cuba Arqueológica (Estudios Culturales, Madrid), p. 6.

Herreras, A. 1625. Descripción [de] las Indias Occidentales. Ed 1730th, España.

Herreras y Tordesillas, A. D., 1726. Historia General De Los Hechos De Los Castellanos En Las Islas I tierra Firme Del Mar Océano (Vol. 1). En la Inprenta real.

Hill, R. 1900. The Official Spelling of Porto Rico New Series. American Association for the Advancement of Science, 11(279), pp.712-713. Available at: http://www.jstor.org/stable/1625713

Hobsbawm, E.J., 1971. From social history to the history of society. Daedalus, pp.20-45.

Hofman, C. L. y Hoogland, M. L. P. 1999. Expansion of the Taíno cacicazgos towards the Lesser Antilles. Journal de la Société des Américanistes 85:93-113. doi: 10.3406/jsa.1999.1731.

Hofman, C.L., Ulloa Hung, J., Herrera Malatesta, E., Jean, J.S., Hoogland, M.L.P., 2018. Indigenous Caribbean Perspectives. Archaeologies and Legacies of the First Colonized Region in the New World. Antiquity

Hogg, G. 1958. Cannibalism and Human Sacrifice., Robert Hale Limited

Honigmann, J. J. 1954. Culture and Personlity. New York: Harper \& Brothers Publishers.

Hoogland, M. and Hofman, C. 1993. Kelbey's Ridge 2, A 14th Century Taino Settlement on Saba, Netherlands Antilles. Analecta, (26), pp. 163-180.

Hostos, A. de 1923. Anthropomorphic carvings from the Greater Antilles. American Anthropologist, 25(4), p. 525.558.

Hostos, Adolfo. de 1923. Three-Pointed Zemi or Idols from the West Indies: an interview.. American Anthropologist, 25(1), pp.56-71.

Hough, W. 1932. Biographical Memoir Of Jesse Walter Fewkes. National Academy Of Sciences Of The United States Of America Biographical Memoirs, Xv (ninth memoir), pp.261-283.

Hulme, Peter. 1993. Making Sense of the Native Caribbean. New West Indian Guidel Nieuwe West-Indische Gids 67 (1993), no: 3/4, Leiden, 189-220

Hulme, P. 1993. Elegy for a Dying Race: The Caribs and Their Visitors. Department of Spanish and Portuguese, University of Maryland at College Park.

Humblodt, A. de, 1942. Viaje a las Regiones Equinocciales del Nuevo Continente, Biblioteca Venezolana de Cultura.

Humbolt, A., Bonpland, A. y Williams, H.M. 1818. Narrative of Travels to the Equinoctial Regions of the New Continent, During the Years 1799-1804., Longman, Hurst, Rees, Orme, Brown, Paternoster row. 
Iglesias, R. 1969. Columbus, Cortes, and other Essays University of California Press., USA.

Irving, W. 1854. Vida y viajes de Cristóbal Colón,

Jahn, A. 1973. Los Aborígenes del Occidente de Venezuela, su historia, etnografía y afinidades lingüísticas. Monte Avila Editores.

Jesús Galván, M. de 1882. Enriquillo, leyenda histórica dominicana, (1503-1533). García hermanos.

Jiménez-Santander, J. y Jiménez-Ortega, L. 2008. Propuesta de periodización para la historia aborigen del Caribe. Ciencia en su PC, №2, abril-junio, 2008, p. 12-23., p.11.

Jiménez, V.M. 2005. El primer asentamiento castellano en América: el fuerte de Navidad. Actas del Congreso Internacional de Historia de América, (En Estudios sobre América, siglos XVI-XX), pp.463-482.

Johnson, E. 1881. Legends, traditions and laws, of the Iroquois, or Six Nations, and history of the Tuscarora Indians. Union Printing and Publishing Company.

Jung, C. G. 1936. The Concept of the Collective Unconscious. p.6.

Katz, W. L. 2002. Black Indians a hidden heritage. Ethrac Publication.

Keegan, W.F. 1996. West Indian Archaeology. 2. After Columbus. Journal of Archaeological Research 4.4, pp.265-294

Keegan, W.F. 2007. A Biographical Memoir. Benjamin Irving Rouse $1913-2006$. National Academy of Sciences, p.27.

Kellogg, S. 2005. Weaving the Past: A History of Latin America's Indigenous Women from the Prehispanic Period to the Present American Historical Association., Oxford University Press.

Kennedy, J. 1854. Probable Origin of the American Indians: With Particular Reference to that of the Caribs. Paper Read Before the Ethnological Society the 15th March 1854. E Lumley.

Kirkpatrick, F. A. 1940. Los Conquistadores Españoles Colección Austral., Madrid: Espasa Calpe.

Klein, C. F. 2001. Gender in Pre-Hispanic America. Dumbarton Oaks, Washinton DC.

Knowlton, E. 1944. The Arhuaco Indians, Twenty Years after. American Anthropologist, 46(2), pp. 263-266

Kothari, C. R., 2004. Research methodology: Methods and techniques. New Age International.

Kottak, C.P., 1994. Antropología cultural. McGRAW-Hill, 357.

Krieger, H. 1930. The Aborigines of the Ancient Island of Hispaniola, Washington DC: United States Printing Office.

Krieger, H. 1929. Archaeological and Historical Investigations in Samaná Dominican Republic United States National Museum., Government Printing Office.

Korotkikh, N., 2018. Filosofía de la historia de América: los cronistas de Indias en el pensamiento español. 
Kuhn, T. S. 1970. The Structure of Scientific Revolution Encyclopedia of United Science., Chicago, USA: University of Chicago Press.

Ladson-Billings, G. 2013 'Critical race theory-What it is not! In Handbook of critical race theory in education', in. Routledge, pp. 33-47.

la Guardia Martínez, J. ed., 2014. El Caribe, sus islas y el difícil camino de independencia, identidad e integración. Instituto Cubano del Libro., Cuba: Ruth.

Lalueza-Fox, C. et al., 2001. MtDNA from extinct Tainos and the peopling of the Caribbean. Annals of human genetics. 2001 Mar 1;65(2):137-51.

Landa, D. de 1975. The Maya: Diego de Landa's Account of the Affairs of Yucatan A. R. Pagden, ed. J. P. O'Hara.

Las Casas, B. de 2001. Brevísima relación de la destrucción de las Indias Clásicos Universitarios. J. A. Mestas, ed., España: Edición Mestas.

Las Casas, B. de 2009. Brevísima relación de la destrucción de las Indias 16th ed. A. Saint-Lu, ed., Madrid: Ediciones Catedra.

Las Casas, B. de 1875. Historia de la Indias Márquez de la Fuensanta del Valle y D. José Sancho Rayón., Madrid.

Las Casas, B. de 1992. In Defense of the Indians, USA: Northern Illinois University

Lazarsfeld, P.F. y Rosenberg, M. 1955. The language of social research: a reader in the methodology of social research. Glencoe, IL: Free Press.

Leerssen, J. 2007. Imagology: History and method. Imagology: The cultural construction and literary representation of national characters, pp.17-32.

Lethaby, W. R. 1892. Architecture, Mysticism and Myth Dover Publication 2004., Percival \& Co., London.

L'Etang, T. 2000. Du nom indigène des îles de l'archipel des Antilles. , p.37.

Levy-Bruhl, L. 1926. How Natives Think, Martino Fine Books (23 Feb. 2015).

Levy-Bruhl, L. 1923. Primitive Mentality George Allen \& Unwin Brothers Limited, The Macmillan Company., George Allen \& Unwin Brothers Limited, The Macmillan Company.

Levy-Strauss, C. 1970. El oso y el barbero The Journal of the Royal Anthropological., Barcelona, España: Anagrama.

Lewis, Gordon. 1969. Puerto Rico, Libertad y Poder en el Caribe. Editoriales Edil, Barcelona

Livi-Bacci, Massimo. 2003. Return to Hispaniola: Reassessing a Demographic Catastrophe. Hispanic American Historical Review 83 (1): 3-51.

López-Baralt, M. 1988. Icono y conquista: Guamán Poma de Ayala., Hiperion.

López de Gómara, F. 2000. Guerras de mar" del emperador Carlos V. M. A. Bunes Ibarra \& N. Edith, eds.

Loren-Katz, W. 1986. Black Indians a hidden heritage. Etharc.

Lorente, S., 1861. Historia de la conquista del Perú. Se vende en la librería de Masías.

Loven, S. 1935. Origins of the Tainan culture, West Indies, Germany: Göteborg: Elanders boktryckeri aktiebolag. 
Lugo, A. 1950. Los Restos de Colón, República Dominicana: Librería Dominicana.

Major, R. H. ed. ([1847],1870). Select Letters from Columbus with other original documents relating to his Four Voyages to the New World. 2nd edition. Translated by R. H. Major. London: Hakluyt Society.

Malaret, A. 1917. Diccionario de Provincialismos de Puerto Rico, San Juan PR: Cantero Fernández Co.

Manzano Manzano, J. 1941. 'Sentido misional de la empresa de las Indias', Revista de estudios políticos, 1, p. pág. 103-120.

Manzano Manzano, J. 1942. ¿Por qué se incorporaron las Indias a la Corona de Castilla? Revista de estudios políticos, (5), pp. 95-124.

Marcheco-Teruel, B., Parra, E.J., Fuentes-Smith, E., Salas, A., Buttenschøn, H.N., Demontis, D., Torres-Español, M., Marín-Padrón, L.C., Gómez-Cabezas, E.J., Álvarez-Iglesias, V. and Mosquera-Miguel, A., 2014. Cuba: exploring the history of admixture and the genetic basis of pigmentation using autosomal and uniparental markers. PLoS genetics, 10(7), p.e1004488.

Marte, R. 1988. Cuba y la República Dominicana: transición económica en el Caribe del siglo XIX, Santo Domingo: CENAPEC: Universidad APEC.

Martínez Almanzar, J.F. 1882. Manual de Historia Critica Dominicana (1492-1865) Republica Dominicana, Republica Dominicana: Centro de Adiestramiento e Investigación Social.

Martinez Cruzado, J. C. 2005. The use of Mitochondrial DNA to Discover Pre-Colonial Migration to the Caribbean: Results for Puerto Rico and the Expectations to the Dominican Republic L. Guitar, ed. Journal of the Caribbean Amerindian History and Anthropology, (Special Issue).

Martínez Martínez, J. G. 1996. 'Las Islas Canarias y su relación con el descubrimiento y poblamiento de indias a través del "cedulario indiano" de Diego de Encinas', Anuario de la Facultad de Derecho, 14-15, pp. 427-442.

Martinon Torres, M. et al., 2012. Metallic encounters in Cuba: The technology, exchange and meaning of metals before and after Columbus. Journal of Anthropological Archaeology, 31(4), pp.439-454.

Marigó, G.A. 1992. Un language que no cesa. Scriptura, (8), pp. 9-15.

Marsden, H. 1920. Red Man Ceremonials: An American Plea for American Esthetics.

Martyr D'Anglería, P. 1912. The eight decades of Peter Martyr D'Angleria. Francis Augustus MacNutt., New York, London

Mártir Anglería, P.M. 1892. Fuentes históricas sobre Colón y América: Tomo III., Madrid: Imprenta de la S.E. de San Francisco de Sales

Mártir de Anglería, Pedro. 1946. MCMLXIV. Décadas del Nuevo Mundo. Biblioteca José Porrúa Estrada. México

Mártir de Angleria, P. 1989. Decadas del Nuevo Mundo vol. I y II, Ed. E O’Gorman.

Mártir de Anglería, P. 1944. Décadas del Nuevo Mundo. Buenos Aires: Editorial Bajel.

Medeiros, O. 1945. Antología de Andrés de Bernáldez Gráficas Uguina., Madrid. 
Mendisco, F. et al., 2015. Where are the Caribs? Ancient DNA from ceramic period human remains in the Lesser Antilles. Phil. Trans. R. Soc. B, 370(1660), p.20130388. Phil. Trans. R. Soc. B, 370(1660), p.20130388.

Mendizabal, I. et al., 2008. Genetic origin, admixture, and asymmetry in maternal and paternal human lineages in Cuba. BMC evolutionary biology, 8(1), p.213.

Mendieta, G. de 1870. Historia eclesiástica indiana. Antigua librería.

Mestre, J. M., Varela, F. y González del Valle, J. Z. 1862. De la filosofía en La Habana. La Antilla,

Mestre, A. 1917. La vida de la "Sociedad Poey" de 1917 a 1918. Memorias de la Sociedad Cubana de Historia Natural "Felipe Poey,. Cuba: Siglo XX, de la Sociedad Editora Cuba Contemporánea.

Mintz, S. 2010. Food Enigmas, Colonial and Postcolonial. Gastronomica Winter, by the Regents of the University of California., 10(1), pp.149-154.

Mira Caballos, E. 2001. Caciques guatiaos en los inicios de la colonización: el caso del indio Diego Colón. Iberoamericana, pp. 7-16.

Mira Caballos, E. 2000. Las Antillas Mayores, 1492-1550: ensayos y documentos. Vervuet - Iberoamericana.

Mira Caballos E. 1999. La educación de indios y mestizos antillanos en la primera mitad del siglo XVI. Revista complutense de historia de América, 25, pp.51-66.

Mira Caballos, E. 2003. Indios nobles y caciques en la Corte real española, siglo XVI. Temas Americanistas, 16, 1-15.

Mira Caballos, E. 1995 Los prohibidos en la emigración a América (1492-1550). Estudios de historia social y económica de América. 12, pp. 37-54.

Mixer, K. 1926. Porto Rico History and Conditions Ediciones Puerto 2nd, ed. J. Carvajal, ed., reprinted in Columbia 2005: National Endowments for Humanities, Fundación Puertorriqueña de las Humanidades, Academia Puertorriqueña de la Historia y La Oficina del Historiador de Puerto Rico.

Morales Cabrera, P. 1932. Puerto Rico Indígena y Protohistoria de Puerto Rico Imprenta Venezuela Puerto Rico., Puerto Rico.

Morales Otero, P. 1945. Nuestros problemas., Puerto Rico: Biblioteca de autores puertorriqueños.

Moreno-Estrada, A., Gravel, S., Zakharia, F., McCauley, J.L., Byrnes, J.K., Gignoux, C.R., Ortiz-Tello, P.A., Martínez, R.J., Hedges, D.J., Morris, R.W. and Eng, C., 2013. Reconstructing the population genetic history of the Caribbean. PLoS genetics, 9(11), p.e1003925.

Morgan, L.H. 1877. Ancient society; or, researches in the lines of human progress from savagery, through barbarism to civilization. H. Holt.

Montaner, C. A. 2001. Las Raíces Torcidas de América Latina, Madrid.

Moya Pons, F., 1992. El choque del descubrimiento. Ciencia y sociedad.

Mukhopadhyay, C. C. y Moses, Y. T. 1997. Reestablishing" race" in anthropological discourse. American Anthropologist, (99(3)), pp. 517-533.

Muñoz, Juan Bautista, 1793. Historia del Nuevo-mundo (Vol. 1). Por la viuda de Ibarra. 
Oberg, K. 1955. Types of social structure among the lowland tribes of South and Central America. American anthropologist, 57(3), pp.472-487.

Ober, Frederick Albion. 1899. Puerto Rico and its resources. Originally printed by D. Appleton., Puerto Rico: Fundación Puertorriqueña de las Humanidades.; Academia Puertorriqueña de la Historia.

Olaechea, L. y Bautista, J. 1969. 'Experiencias cristianas con el indio antillano', Anuario de Estudios Americanos, XXVI, pp. 65-114.

Olaechea, L. y Bautista, J. 1998. 'De cómo, dónde y cuándo fueron bautizados los primeros indios', Hispania Sacra, 50, pp. 611-636.

Oliver, J. R. 1999. Caciques and Cemi Idols: The Web Spun by Taino Rulers Between Hispaniola and Puerto Rico, USA: University of Alabama Press

Oliver, J. R. 2008. 'El universo material y espiritual de los taínos. El Caribe precolombino: Fray Ramón Pané y el universo taino.' Edited by J. R. Oliver, C. McEwan, and A. Casas, pp. 137-201.

Olsen, Julius E, y Bourne, Edward Gaylord. 1906. The Northmen, Columbus, and Cabot, 985-1503 US: Charles Scribner sons.

Ostapkowicza, J. et al., 2012. Chronologies in wood and resin: AMS 14C dating of preHispanic Caribbean wood sculpture. Journal of Archaeological Science, 39(7), pp. 2238-2251.

Ortiz, F. 1923. Un catauro de cubanismos apuntes lexicográficos Extracto Revista Bimestre Cubana., Habana Cuba

Ortiz, F. 1940. Del fenómeno social de la transculturación y de su importancia en Cuba. Revista Bimestre Cubana, 46, pp.273-278.

Ortiz, F. 1940. Los factores humanos de la cubanidad (pp. 187-207). Impreso por Molina y Cia.

Oviedo y Valdés, G.F. 1555. Historia General de las Indias Imprenta de la Real Academia de la Historia., España: La Real Academia de la Historia ed., 1851.

Pacheco-Valera, I. 2012. El imaginario identitario cubano en los primeros veinte años de la República (1902-1922). Cuadernos de Letras de UFF, 22(45), pp. 93-114.

Pagan, B. 1961. Procerato puertorriqueño del siglo XIX, San Juan: Editorial Campos.

Pane, F.R. 1999. An Account of the Antiquities of the Indians: New Edition, with an Introductory Study, Notes, and Appendices by José Juan Arrom., Duke University Press.

Pané, R. 1988. Relación acerca de las antigüedades de los indios: el primer tratado escrito en América. 3ra ed. Editado por J. J. Arrom. Siglo XXI.

Peck, Douglas T. 2008. Prehistoric Seafaring Exploration by the Taino and Carib Indians in the Antilles and the Maya from Northern Yucatan. YUMPU, p.25.

Perea, J. A. y Perea, S. 1941. Glosario Etimológico Taino Español., Mayagüez Printing.

Perea, S., 1972. Historia de Puerto Rico, 1537-1700, Universidad Católica de Puerto Rico.

Pereyra, C. 1929. Las Huellas de los Conquistadores., Madrid: M Aguilar. 
Pérez Bustamante, C. 1951. Libro de los privilegios del Almirante Cristóbal Colón, Madrid: Real Academia de Historia.

Peschel, O. 1876. The races of man, and their geographical distribution. UK: HS King \& Company.

Pezuela, J. de la 1866. Diccionario geográfico, estadístico, histórico de la isla de Cuba Joaquín Bernat., Madrid, España.

Pezuela, J. de la 1868. Historia de la isla de Cuba (Vol. 2). C. Bailly-Baillière.

Pichardo, E. 1836. Diccionario provincial de voces cubanas Imprenta de la Real Marina., Cuba.

Pichardo, E. 1875. Diccionario provincial de voces cubanas 4ta ed., Cuba.

Poey, F. 1851. Memorias sobre la historia natural de la isla de Cuba: acompañadas de sumarios latinos y extractos en frances (Vol. 1). Barcina.

Poole, R. 2011. The tainos a new revelation, they are not extinct. Smithonian, (October), p.10. USA

Preservation of American Antiquities 1906. 59th Congress, House of Representatives. 1st Session No. 2224. Washington: US Congress, p. 8.

Premdas, R. P. 1996. Ethnicity and Identity in the Caribbean: Decentering a Myth. The Hellen Kellog Institute for International Studies, (Working Paper \#234), p.47.

Purdyno, J. L. People, Place and Politics: D'Arcy McNickle's 2016. (Re)Valuing of Native American Principles. European Journal of American Studies, Vol 11, Summer.

Quijano, A. 1995. Raza, etnia y nación en Mariátegui: cuestiones abiertas. Estudios latinoamericanos, 2.3, p. 16.

Rafinesque, C. S. 1836. The American Nations or, outlines of their General History, Ancient and Modern Annals., Philadelphia: C. S. Rafinesque.

Rafinesque, C. S. 1836. A Life of Travels and Researches in North America and South Europe: or Outlines or Life, Travels and Researches or C.S. Rafinesque., Philadelphia: C S Rafinesque.

Ramos, R. R. 2008. From the Guanahatabey to the Archaic of Puerto Rico: The nonevident evidence. American Society of Ethnohistory, (55), pp. 393-415.

Rainy, F. 1940. Scientific survey of Porto Rico and the Virgin Islands, New York Academy of Sciences.

Rangel, F. 2011. Últimos Vestigios de la Vivienda Indígena en Lagunillas Municipio Sucre - Merida - Venezuela. Museo Arqueológico -Universidad de Los Andes Venezuela Mérida.

Redfield, Robert, Ralph Linton, y Herskovits Melville J. 1936. 'Memorandum for the Study of Acculturation', American Anthropologist, p. 149-52

Regnault, E., Historia de las Antillas Traducida por Sociedad Literaria., España: Imprenta del Fomento.

Reichel-Dolmatoff, G., 1977. El misionero ante las culturas indígenas. Estudios antropológicos de Gerardo y Alicia Reichel-Dolmatoff, pp.421-432.

Reichel-Dolmatoff, G., 1960. Contribuciones al conocimiento de las tribus de la región de Perija. Revista Colombiana de Antropología, 9, pp.199-159. 
Reinoso, M. \& Von Der Walde, L. eds., 2008. Dossier Virreinatos Año 3., México: Dostiempos.

Rey, E. y Tabio, E. E. 1979. Prehistoria de Cuba., Habana: Editorial de Ciencias Sociales.

Riega, C. G. de la 1897. La Gallega: nave capitana de Colón en el primer viaje de descubrimientos. la Vda. de JA Antúnez.

Rivas Moreno, J. 2014. La ley de matrimonios mixtos que cambió la colonización de América. Editorial el Mundo España.

Rockfort, C. 1681. Histoire Naturelle et Morale des Antilles-Rotterdam. Rotterdam, R. Leers, p.583.

Rodríguez Álvarez, A. 2008. Mitología Taina o Eyeri Ramón Pané y la Relación sobre Antigüedades de los Indios: El primer tratado etnográfico hecho en América Edición revisada y aumentada., Puerto Rico: Editorial Nuevo Mundo.

Rodríguez Hernández, N. E. 2014. 'Cartografía de la frontera bárbara": las representaciones del Darién a propósito del conflicto entre el Virreinato de Nueva Granada y los Cunas*', Anuario de Historia Regional y de las Fronteras, 19(1).

Rodriguez Ramos, R. 2010. What is the Caribbean? An Archaeological Perspective. C. Hofman \& A. J. Bright, eds. Journal of Caribbean Archaeology., 3(Extra).

Rodriguez Ramos, R. 2010. Rethinking Puerto Rican History., USA: University of Alabama Press.

Rodriguez Ramos, R. Babilonia, E. and Curet, A. L. 2008. 'The Pre-Arawak Pottery horizon in the Antilles', Latin American antiquity, Vol. 19(No. 1), pp. 43-63

Rosenwein, B.H., 2002. Worrying about emotions in history. The American historical review, 107(3), pp.821-845.

Ross, A. H. 2004. Cranial Evidence of Pre-Contact Multiple Population Expansions in the Caribbean. Caribbean Journal of Science, 40(3), pp.291-298.

Rouse, I. 1939. Prehistory in Haiti; a study in method, Yale University Press USA.

Rouse, I. 1952. Scientific Survey of Porto Rico and the Virgin Islands, New York Academy of Sciences.

Rouse, I. 1953. The circum-Caribbean theory, an archeological test. American Anthropologist, 55(2), pp. 188-200.

Rouse, I. 1992. The Tainos Rise and Decline of the People who Greeted Columbus, Yale University Press.

Russell Bernard, H. 1999. Research Methods in Anthropology, qualitative and quantitative methods, USA: Sage Publications.

Ruhstaller, S. 1992. Bartolomé de las Casas y su copia del'Diario de a Bordo'de Colón. Tipologia de las Apostillas. Cauce, (14-15), pp.615-637.

Sahagún, B. Historia general de las cosas de Nueva España 2 A. Lopez \& J. Garcia., Madrid España: Alianza Editorial.

Salas, J. C. 1908. Etnología é historia de Tierra-Firme (Venezuela y Colombia) Editorial America. 
Salazar, Francisco Cervantes. De 1875. México en 1554: Tres diálogos latinos que Francisco Cervántes Salazar escribió é imprimió en México en dicho año. Andrade y Morales.

Santa Teresa, S. de 1956. Historia Documentada de la Iglesia en el Darien y Uraba. Desde el descubrimiento hasta nuestros días. Editorial Kelly.

Salva, M. Sainz de Baranda, P. 1849. Colección de Documentos inéditos para la Historia de España Academia de la Historia Examen Histórico-Crítico de los Viajes y Descubrimientos Apógrafos (1848) M. Fernández de Navarrete \& E. Fernández de Navarrete. España, España: Academia de la Historia.

San Miguel, P. L. 2014. Los campesinos del Caribe: Una perspectiva dominicana1. Memorias, 2, p.25.

Sanchis y Sivera, J. 1924. El cardenal Rodrigo de Borja en Valencia. Boletin de la Real Academia de la Historia, pp. 120-164.

Sánchez Lustrino, G. 1942. Caminos cristianos de América. Río de Janeiro.

Sauer, C. O. 1952. Agricultural origins and dispersals. New York: American Geographical Society (2).

Sauer, C .O. 1966. The early Spanish main. University of California Press.

Schroeder, H., Sikora, M., Gopalakrishnan, S., Cassidy, L.M., Delser, P.M., Velasco, M.S., Schraiber, J.G., Rasmussen, S., Homburger, J.R., Ávila-Arcos, M.C. and Allentoft, M.E., 2018. Origins and genetic legacies of the Caribbean Taino. Proceedings of the National Academy of Sciences, 115(10), pp.2341-2346.

Segal, R. A. 2007. Jung and Levy-Bruhl. Journal of Analytical Psychology, 2007, 52, 635-658, Aberdeen, Scotland, p.25.

Segarra Gamazo, A. 1995. El protagonismo de Juan Rodríguez de Fonseca, gestor indiano, en la diplomacia y política castellana desde su sede episcopal de Burgos.

Boletín de la Institución Fernán González, pp. 273-317.

Segarra Gamazo, A. 2009. Diego Álvarez Chanca, Primer Espía de América. Revista de estudios colombinos, (5), pp. 19-40.

Serna, M. 2000. Crónicas de Indias edición de Mercedes Serna. Catedra.

Siegel, P. E. 2010. Continuity and change in the evolution of religion and political organization on pre-Columbian Puerto Rico. Journal of Anthropological Archaeology, 29(3), pp.302-326.

Siegel, P. E. 1999. Contested places and places of contest: the evolution of social power and ceremonial space in prehistoric Puerto Rico. Latin American Antiquity, 10(3), pp. 209-238.

Sidrys, R. 1976. Mayan Obsidian Trade. American Antiquity, 1(4), pp.449-464.

Sloan Toraño, R. 2017. Labradores y Desbandados 1898. 2nd ed. US.

Sloan-Toraño, R. 2019. Caribbean History and Heritage Crisis Resulting from Generic Standardization and Substitution of the Native Borinqueños, Boriquans or Boricuas of Puerto Rico Subsequent to Suspicious Taino Research, p. 15. doi: http://doi.org/10.5281/zenodo. 257 
Sloan Toraño, R. 2018. Terms and Terminology Conflicts of Social Quandaries Engendered by the Taino Native Fixation a Cultural Crisis Analytical Study in Caribbean Contemporary History. Novelty Journal, pp. 243-256.

Slocum, K. y Thomas, D., 2003. Rethinking global and areas studies; Insight from, Caribbianist anthropologist. Insight from, Caribbianist anthropologist. American Anthropology. 105(3), pp.553-565.

Smith, L. T. 2013. Decolonizing methodologies: Research and indigenous peoples. Zed Books limited.

Smith, V. 2013. Using Sociology and Anthropology to Explain the Perpetual Underdevelopment of Africa and the Caribbean. Trinidad \& Tobago Société des américanistes de Paris, 1921. Journal de la Société des américanistes de Paris, France:International Journal of Developing Societies, 2(1).

Smith, Buckingham. 1857. Colección de varios documentos para la historia de la Florida y tierras adyacentes. London, Truber.

Smithsonian Institution. Bureau of American Ethnology, 1962. List of publications of the Bureau of American Ethnology: with index to authors and titles, USA: Smithsonian Institution. Bureau of American Ethnology.

Stahl, A. 1889. Los Indios Borinqueños Imprenta y Librería de Acosta., Puerto Rico.

Stewart, J. H. 1963. Handbook of South American Indian. University of MichiganDearborn., USA: Bureau of American Ethnology.

Swanson, A.V.M., Hoogland, M.L.P. y Hofman, C.L. 2010. Trayectorias de habitación: las viviendas indígenas en el yucayeque (La comunidad) de El Cabo. Higüey, República Dominicana, 800 a 1504 d.C. Holland: University of Leiden.

Sweeney, J. L. 2007. Caribs, Maroons, Jacobins, Brigands, and Sugar Barons: The Last Stand of the Black Caribs on St. Vincent. The African Diaspora Archaeology Network, p.38

Szaszdi Leon-Borja, I. 1991. Los pactos de hermandad entre los indios tainos y los españoles. IX Congreso del Instituto Internacional de Historia del Derecho Indiano, pp. 405-438.

Szászdi León-Borja, I. 1991. Guatiao, los primeros tratados de Indias. Universidad de Valladolid, pp. 405-438.

Tanselle, G. Thomas. 1978. The editing of historical documents. Studies in Bibliography, 31, pp.1-56.

Tapia y Rivera, A. 1862. La Palma del Cacique, Habana: Imprenta del Tiempo.

Taylor, D., 1938. The Caribs of Dominica. Smithsonian Institution Bureau Of American Ethnology, (Bullerin 119).

Tejera, E. 1977. Indigenismos, Republica Dominicana: Editora Santo Domingo.

Tejera, E. 1951. Palabras indíjenas de la isla de Santo Domingo, República Dominicana: Editora del Caribe

Tejera Penson, E. 1878. Los Restos de Colon en Santo Domingo, Garcia Hermanos.

Tío, Aurelio. 1966. Diego Álvarez Chanca, printed in Barcelona, Spain: Publicaciones de la Asociación Médica de Puerto Rico. 
Thibault de Chanvalon, J.B. 1979. Voyage a la Martinique. Instituto de cultura puertorriqueña, 82 , pp.40-48.

Tiesler Blos, V. 2003. Cranial Surgery in Ancient Mesoamerica. Mesoweb.

Torres Lasqueti, J. 1888. Colección de datos históricos-geográficos y estadísticos de Puerto del Príncipe y su jurisdicción. El Retiro.

Torres Etayo, D. 2008. En busca del Taíno, historia de una pelea cubana contra el normativismo. Arqueología de Cuba y el Caribe, 1(1), pp.6-17.

Torre Revello, J. 1957. Pedro Mártir de Anglería y su obra de Orbe Novo. Thesaurus., XII $(1,2,3)$.

Trollope, Anthony. 1859. The West Indies and the Spanish Main. Chapman and Hall.

Ubeda y Delgado, M. 1878. Isla de Puerto Rico: estudio histórico, geográfico y estadístico de la misma. PR: Academia Puertorriqueńa de la Historia.

Ulloa, L. 1951. Manual de Historia de la Espanola., I. G, Seix y Barral Hnos.

Uribe, C. A. 1987. Los kogi: de la Sierra Nevada de Santa Marta. Boletín Museo del Oro, (19), pp.125-129.

Valdeblánquez, D. 1979. La Colombia indígena: ¿De dónde vienen los arhuacos? Boletín Cultural y Bibliográfico, 16(07-08), pp. 138-143.

Vaioleti, Timote M. 2006. Talanoa research methodology: A developing position on Pacific research. Waikato Journal of Education, 12(1), p. 34.

Vasconcelos, J. 1925 La Raza Cósmica, Misión de la raza iberoamericana. Madrid: Agencia Mundial de Librería.

Varela Marcos, J. 2009. Juan Rodríguez de Fonseca sucesor de Cristóbal Colón. Revista de estudios colombinos, (5).

Vázquez Calzada, J. L. 1964. El Crecimiento Poblacional de Puerto Rico 1493 al Presente. Thesis. USA: University of Chicago.

Veloz Maggiolo, M. 1979. Notas históricas sobre la Arqueología en las Antillas Universidad Autónoma de Santo Domingo., Revista española de antropología americana.

Vespucio, Américo 1503. El Nuevo Mundo Biblioteca Municipal de Ferrara. (Cf. Relazione delle scoperte fatte da C. Colombo, da A. Vespucci e da altri, dal 1492 al 1506; Bolonia, 1895; pp. 152-154

Versteeg, A. H. 1998. The history of archaeological research in Suriname. In: Th.E. Wong, D.R. de Vletter, L. Krook, J.I.S. Zonneveld y A.J. van Loon (eds): The history of earth sciences in Suriname - Kon. Ned. Academie Wetenschappen y Nederlands Instituut voor Toegepaste Geowetenschappen TNO, 203-234.

Versteeg, A. H. \& F. C. Bubberman, 1992. Suriname before Columbus. Mededelingen Stichting Surinaams Museum 49A, Paramaribo, Suriname. pp. 3-65; updated Internet version 1998).

Vigil, C. M. 1892. Noticias biográfico-genealógicas de Pedro Menéndez de Avilés, primer adelantado y conquistador de la Florida, continuadas con las de otros asturianos que figuraron en el descubrimiento y colonización de las Américas. Aviles: L Union. 
Viveros de Castro, E. 1998. Cosmological Deixis and Ameridian Perspective. The Journal of the Royal Anthropological Institute, Vol. 4, No. 3 (Sep. 1998), pp. 469- 488, p.488.

Von Humboldt, Alexander 1826. en Colombia Extractos de sus Diarios. Obra suministrada por la Biblioteca Luis Ángel Arango, Colombia.

Von Humboldt, A., 1827. Ensayo político sobre la isla de Cuba... Jules Renouard.

Von Sievers, Jegor. 1861. CUBA: Die Perle der Antillen. Leipzig: Fliescher.

Von Martius, K. F. P. 1867. Etnographie un Sprachenkunde Amerika's zumal Brasiliens. Leipsig: Friedrich Fleicher.

Wade, Peter. 2003. Repensando el mestizaje. Revista Colombiana de Antropología, vol. 39 , pp. 23.

Wade, P. 2017. Degrees of mixture, degrees of freedom: Genomics, multiculturalism, and race in Latin America. Duke University Press.

Walcott, D. 1974. The Caribbean: culture or mimicry? Journal of Interamerican Studies and World Affairs, 16-1, pp. 3-13

Washington, C. J. 2006-2008. Women and Resistance in the African Diaspora, with special focus on the Caribbean, Africa and USA. Portland State University McNair Research Journal, 2(1ss), pp.1-26.

Washington, I. 1882. The life and voyages of Christopher Columbus. New York: Pollard \& Moss.

Whitehead, N. L. 1984. Carib Cannibalism. The Historical Evidence. Journal de la Societe des Americanistes, 70(70), pp.69-87.

Whitehead Neil L. 1993. Ethnic Transformation and Historical Discontinuity in Native Amazonia and Guayana, 1500-1900. In: L'Homme, tome 33 n¹26-128. La remontée de l'Amazone. pp. 285-305;

Whitehead, N. L. 2002. Arawak linguistic and cultural identity through time: Contact, colonialism, and creolization. In pp. 51-73.

Wilson, S. M. 2007. The Archaeology of the Caribbean., UK: Cambridge World Archaeology, University Press.

Wilson, S. M. 1999. Hispaniola Caribbean chiefdoms in the age of Columbus, USA: University of Alabama Press.

Wilson, S. M. y Rogers, J. D. 1993. Ethnohistory and Archaeology, Springer Science.

Zayas y Alfonso, A. 1914. Lexicografía Antillana Imprenta siglo XX de Aurelio Miranda. Cuba. 
APÉNDICE DOCUMENTAL 
Entorno construido, álbum fotográfico, dibujos y grabados.

Dibujos \#1 y \#2

Notemos que en ambos dibujos se presentan las palmas y sus variados usos.

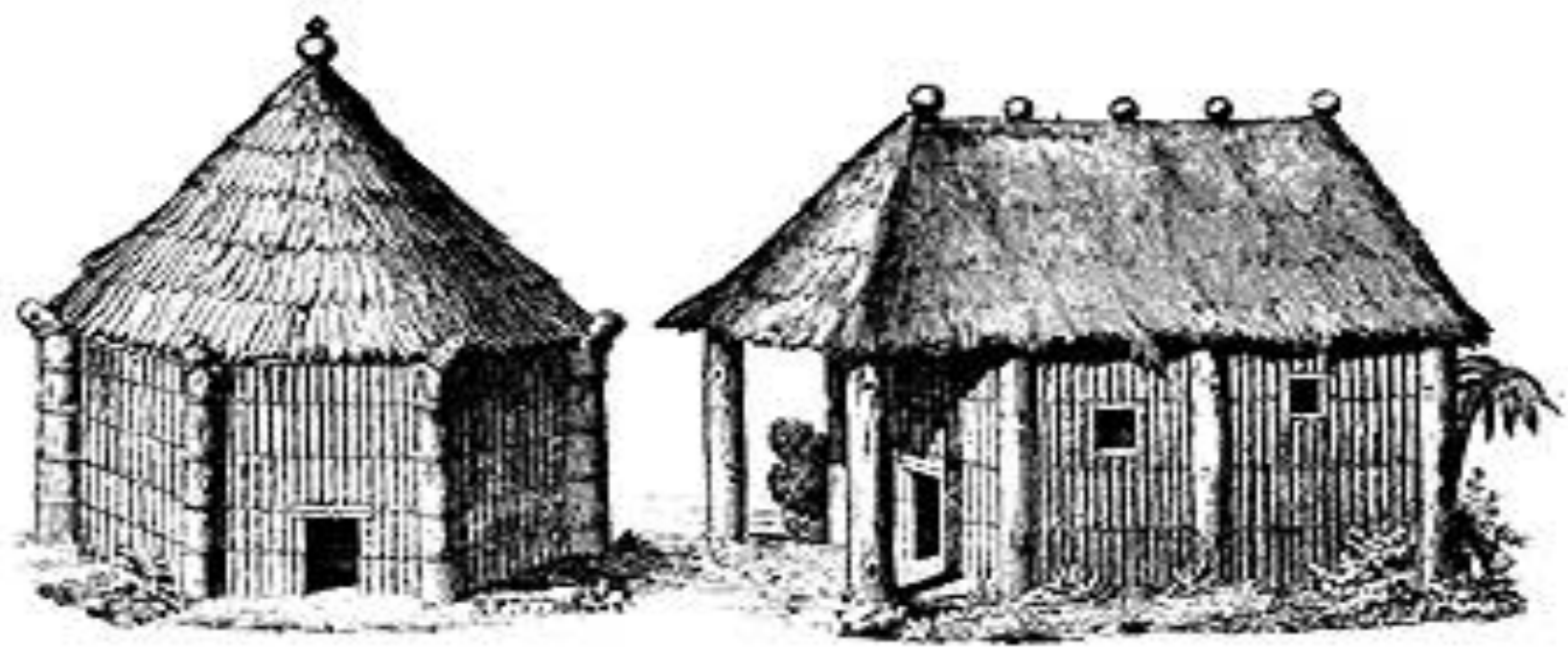

Gonzalo Fernández de Oviedo y Valdés, Cronista de las Indias, gobernador y explorador.

Obra: Historia General y Natural de las Indias [1535], 50 libros en tres partes, Indias, México y Perú.

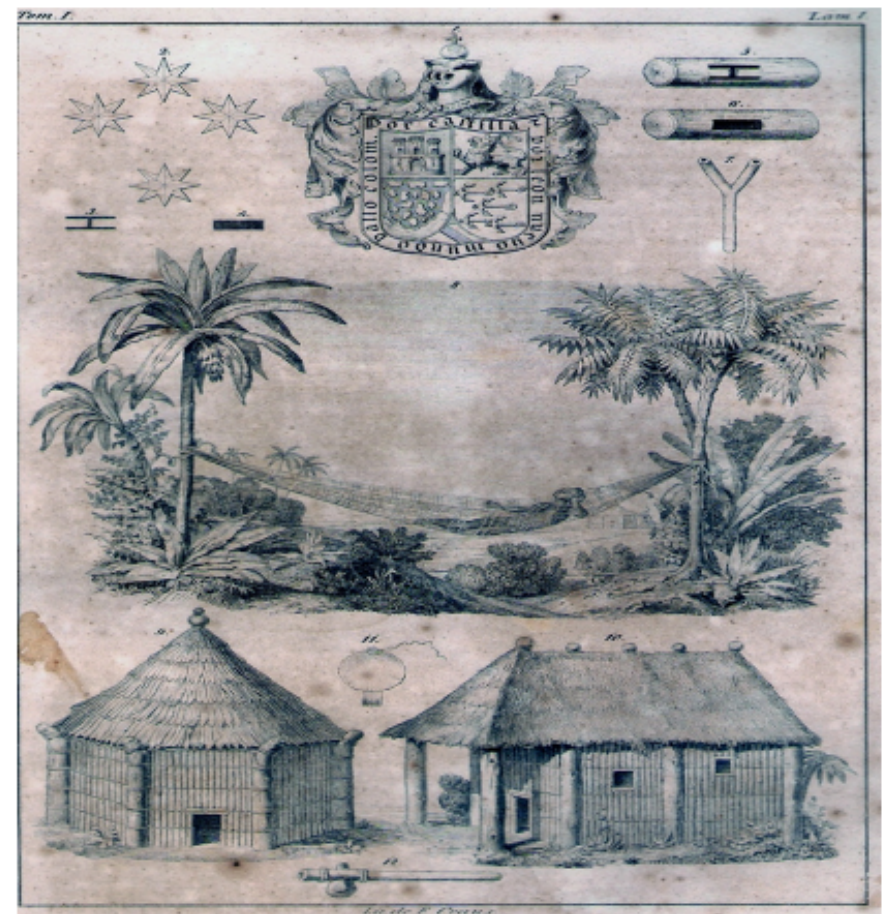

Dibujos originales publicados en la obra de Gonzalo Fernández de Oviedo y Valdés.

Las fotografías a continuación representan la transición de la vivienda nativa en los siglos XIX y XX junto a lo encontrado en el XXI. Se presenta la uniformidad entre ellas en la selección de los materiales de construcción y la cercanía a estos. La semejanza entre las fotos es indicativo de la evolución material y racial al pasar de los siglos. La identificación es minima pues las fotos y los gravados hablan por si solos y algunas contienen sus propios textos mientras los temas han sido tratados a lo largo de la tesis. 
Los gravados son indicativos de materiales y actividades nativas encontradas originalmente Fotos \#1 de Jesse Walter Fewkes publicadas en 1907. Varias estructuras en Puerto Rico construidas con materiales de origen y tecnología nativa hace un siglo. La practica y tecnología de origen es básicamente desconocida hoy día.
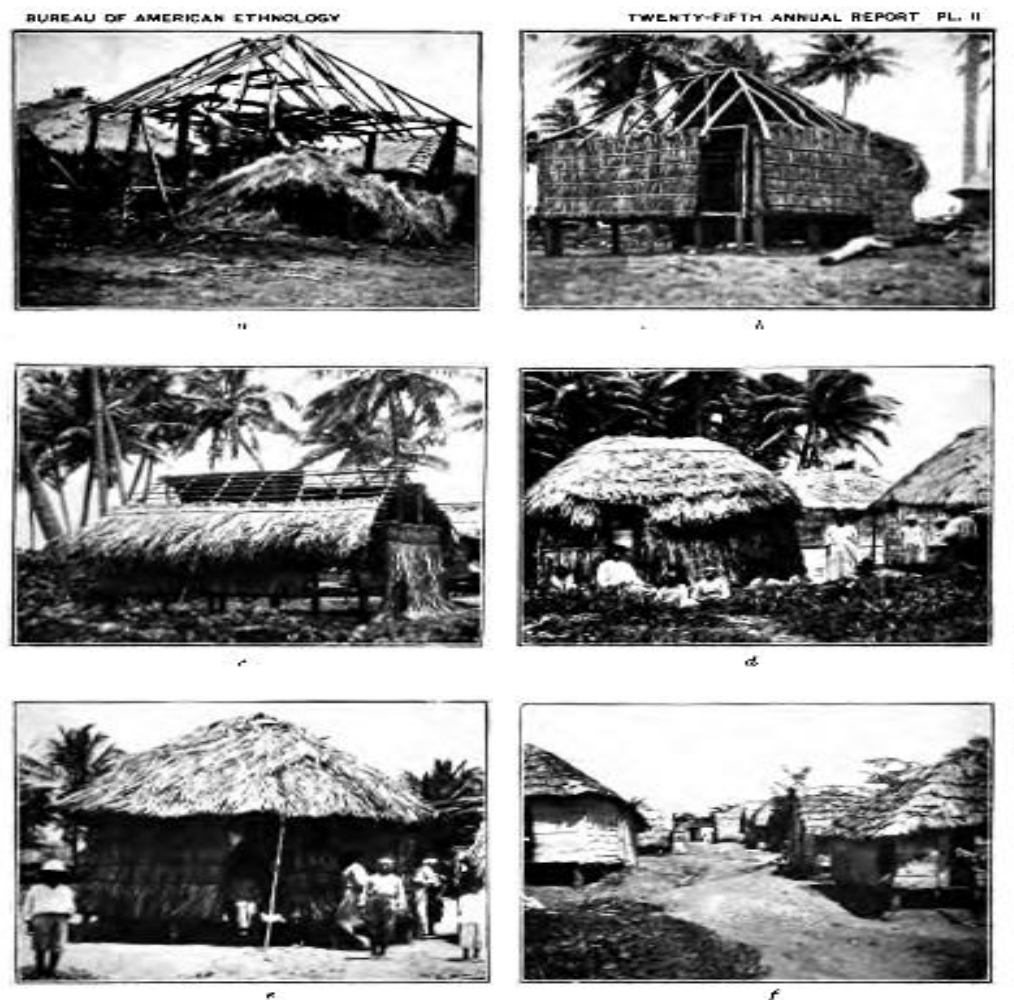

Hauses in process of const nuction,

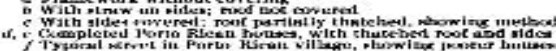

Foto \#2, Puerto Rico 1920, casita y bohío de pencas.

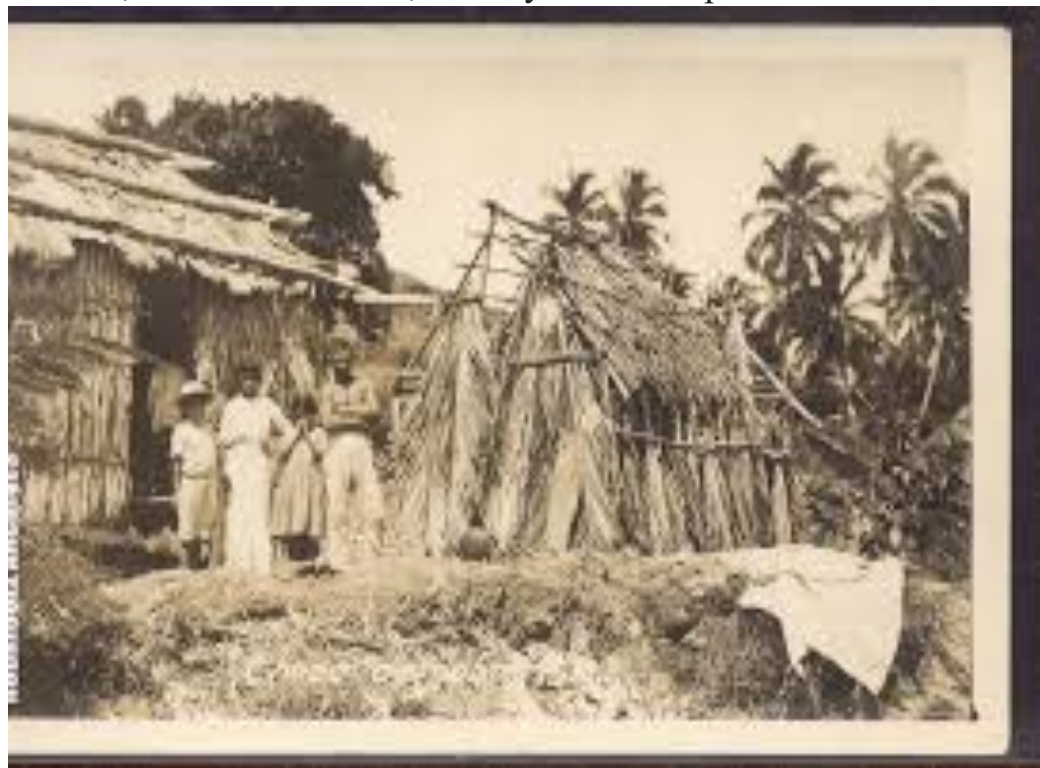

Puerto Rico 1898-Archivo Fotográfico de la Biblioteca José M. Lázaro de la Universidad de Puerto Rico. Se notan algunas palmas en la distancia posiblemente usadas para la construcción 
esta cercanía a materiales y los diseños estructurales típicos los encontramos entre islas y naciones.

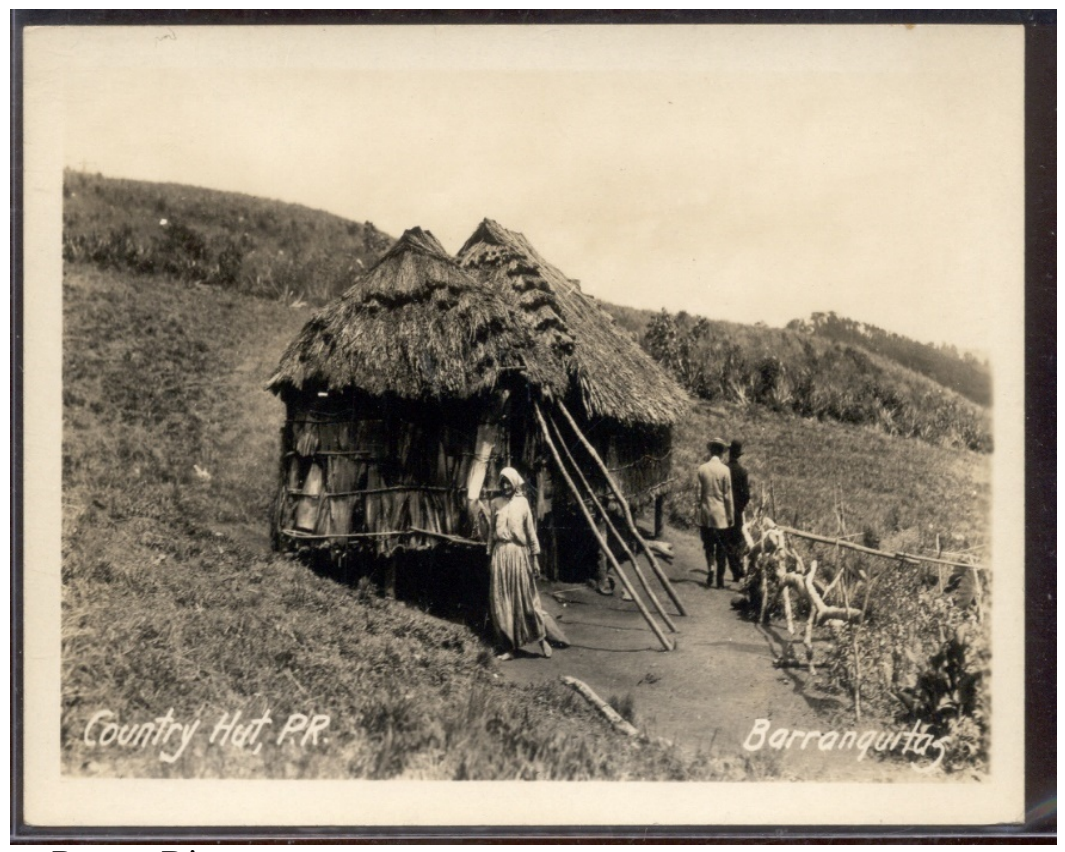

Foto \#3 casa de paja.

en Puerto Rico

Foto \#4 una villa típica

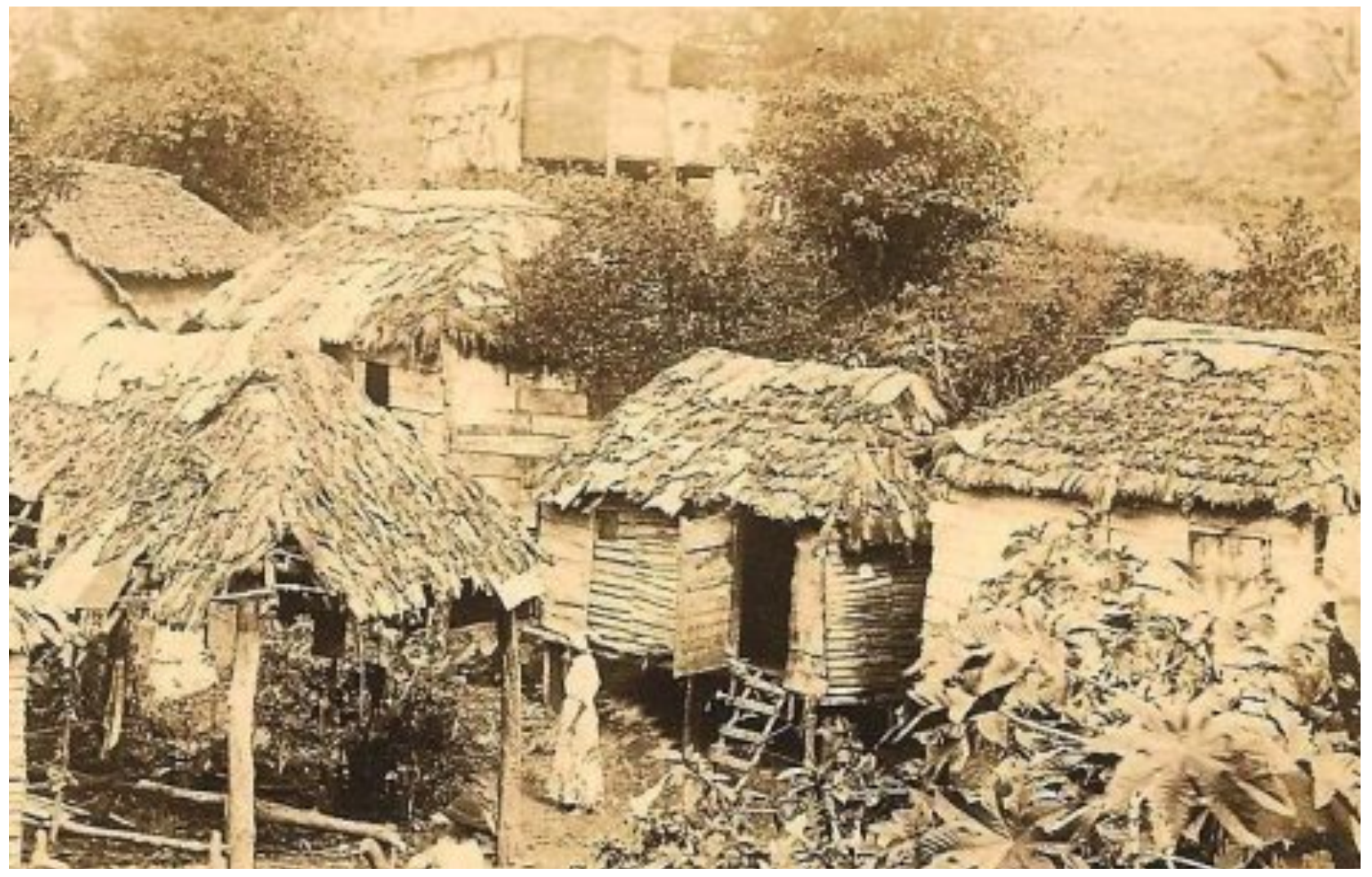


Foto \#5, Grupo de parentela, sudamerica, 1900

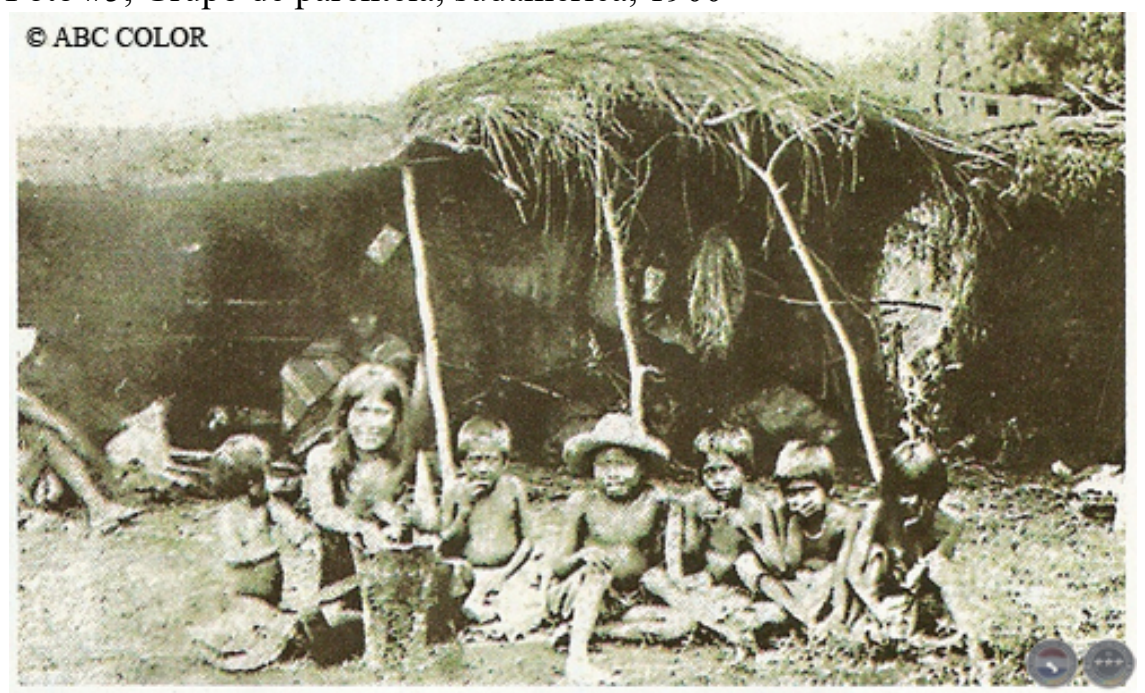

Familia indígena toba preparando el almuerzo delante de su choza. La escena no habría diferido en demasía de los hábitos que los nativos tenían antes de la llegada de los españoles.

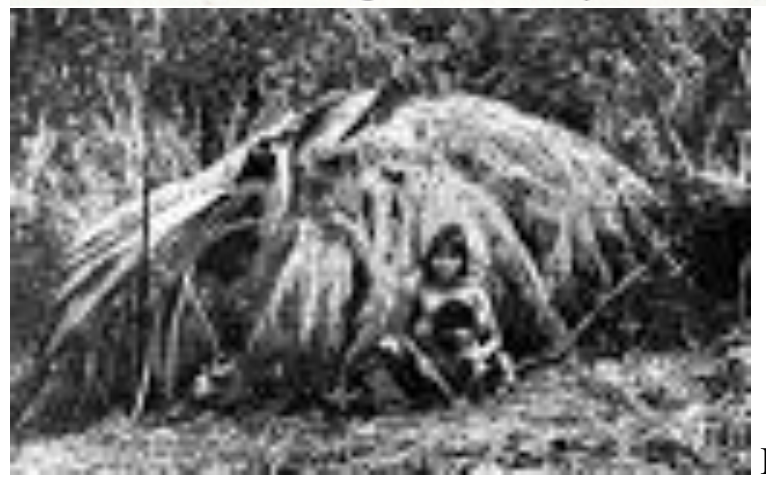

Foto \#5a viviendo entre pencas y paja.

Foto \#6, Cuba 1890-1900, palmeras en los alrededores de donde proviene el material de construcción.

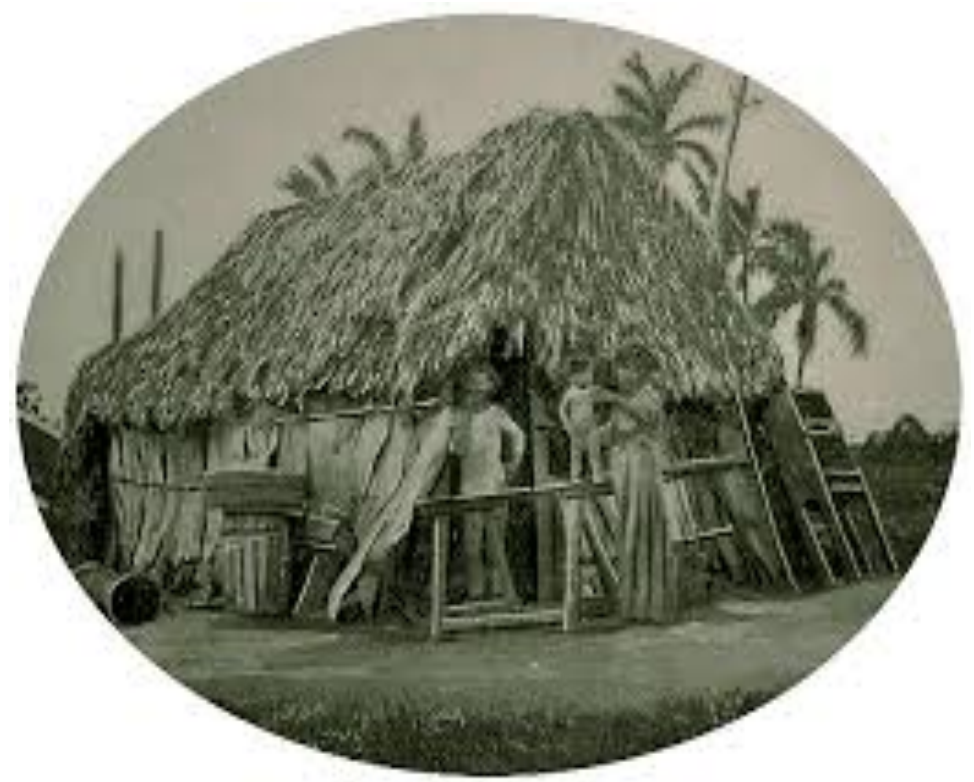



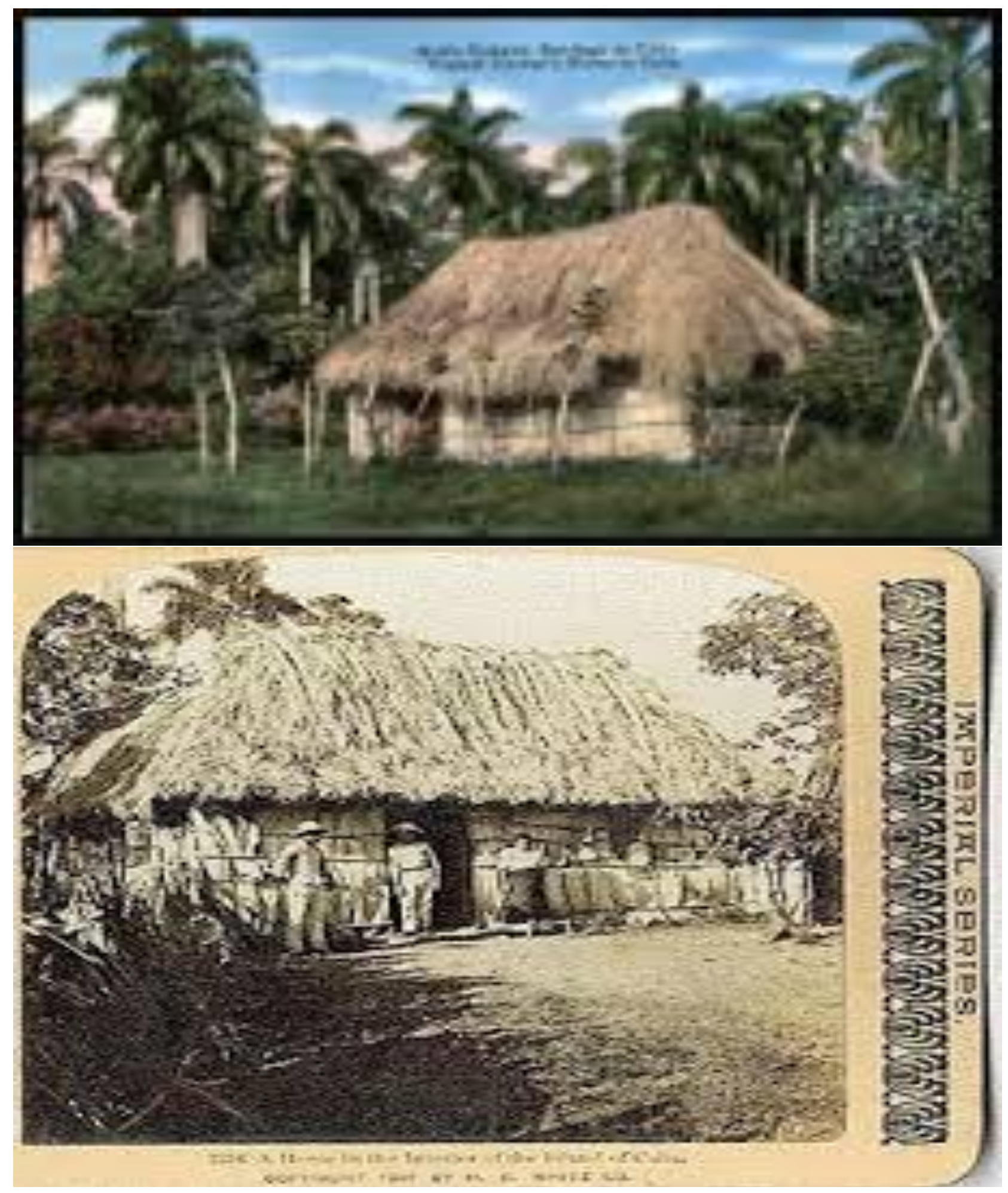
Foto \#7, \#8 Cuba..

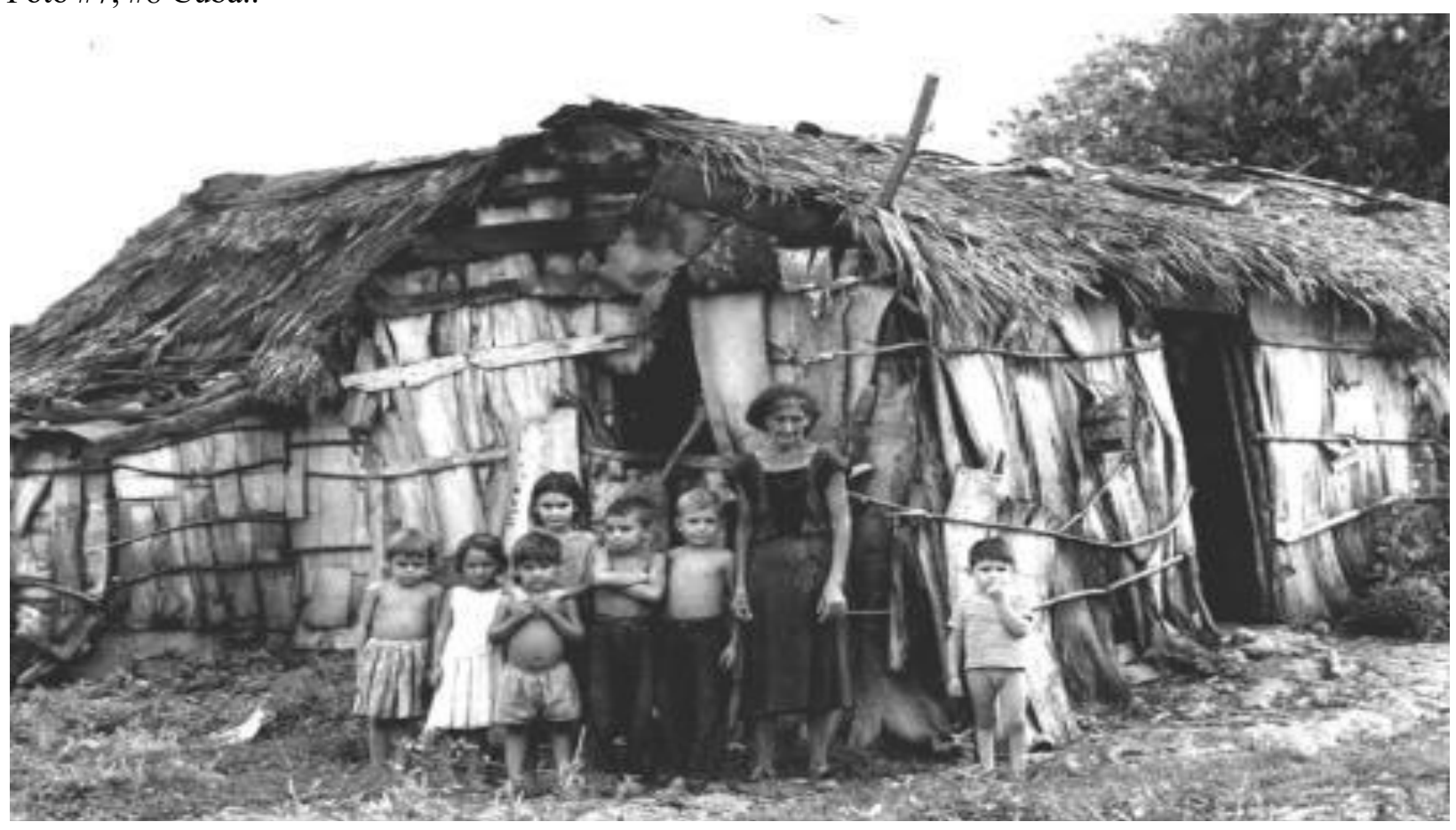

Fotos \#9 familia híbrida viviendo en una construcción típica en la pobreza, \#10 una construcción de campanas en tierra firme, encontradas en el Caribe originariamente. Note en la foto \#11 la baja altura de la entrada los postes, listones y una segunda hilera de contención. El puntal y la segunda circunferencia distribuyen el peso la primera circunferencia exterior sostiene las paredes.

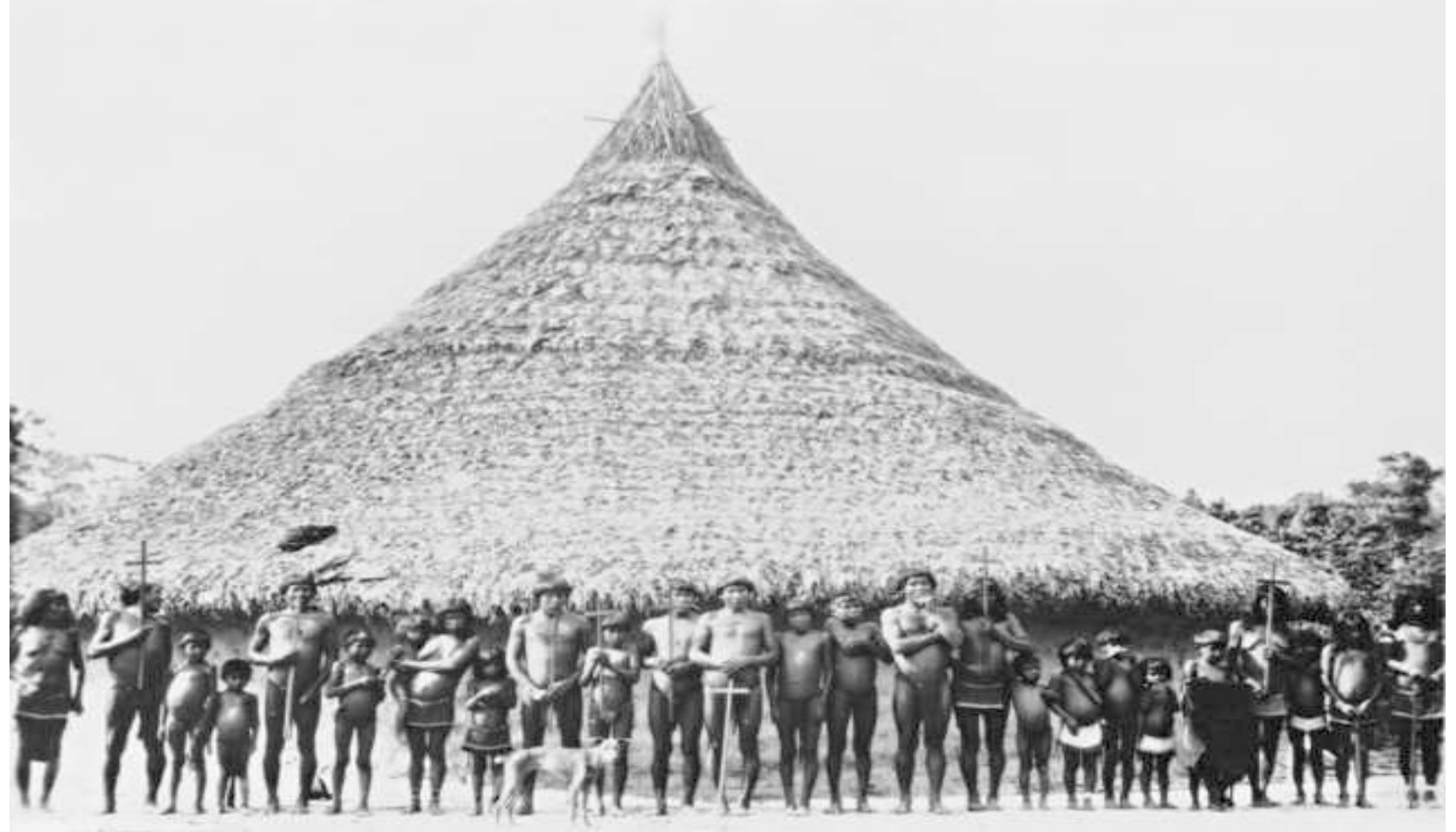




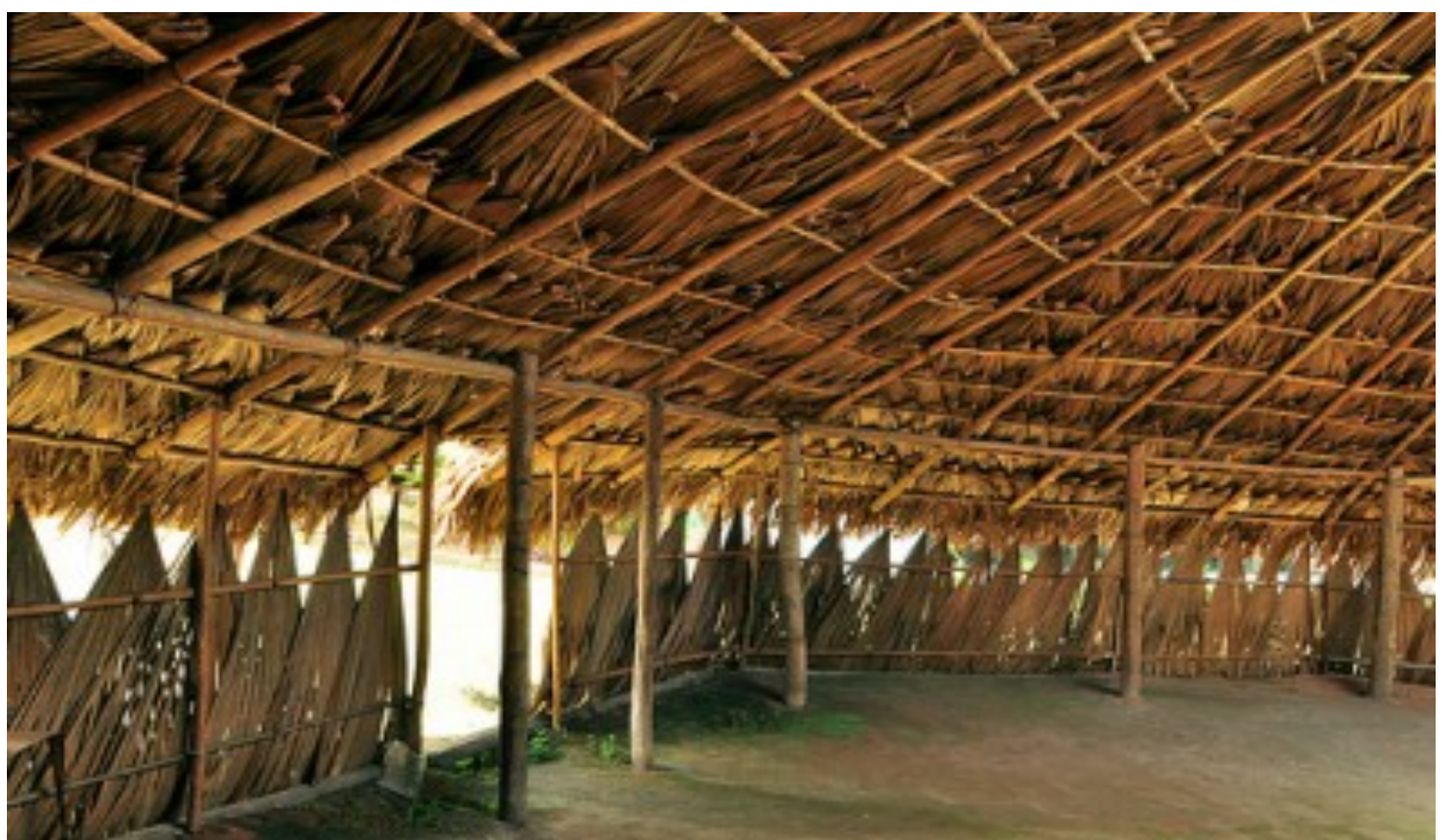

Foto \#11 en el Surinam, estructura mayormente de varas cubiertas con ramas. La forma de campana ha sido identificadas en el Caribe originalmente.

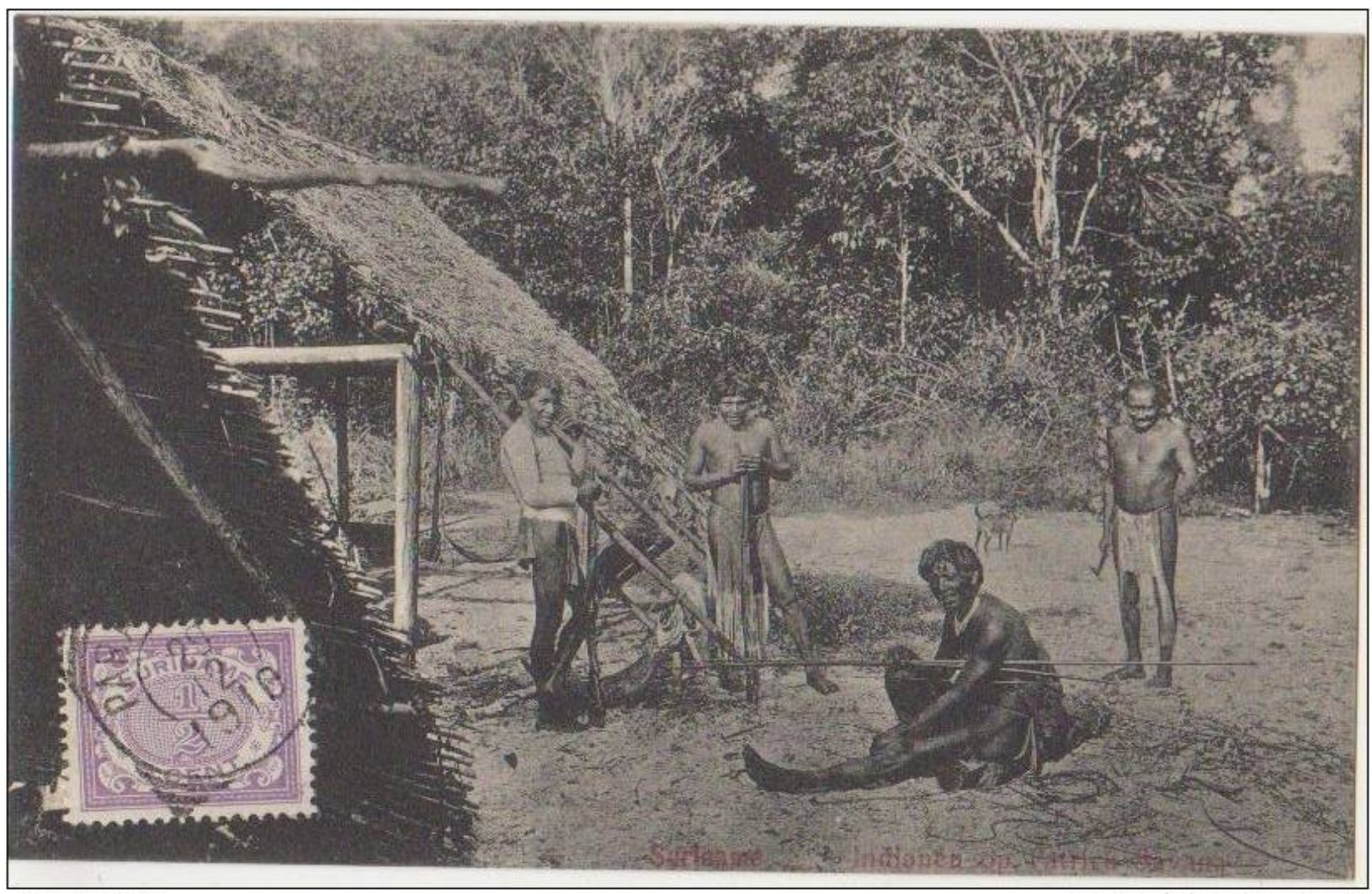

Www, delcampe, net

Foto \#12 una muy rustica vivienda posiblemente provisional durante labores de campo. 
Foto \# 13 Puerto Rico (1898-1910) entre palmeras, construcción de ramas sobre varas y pequeños postes. Foto \#14 diseño de lados bajos y dos aguas típica junto a las palmeras de materiales.
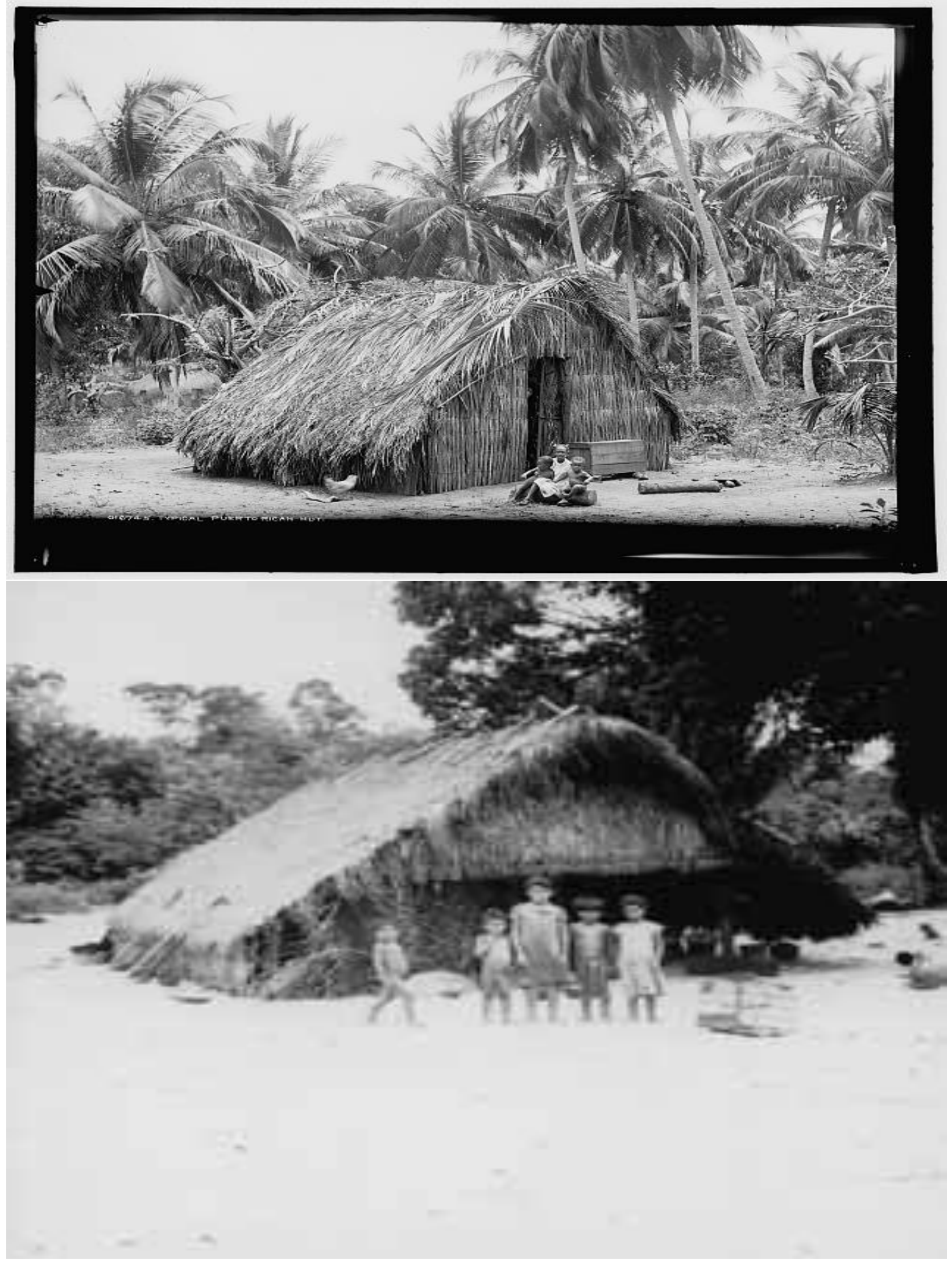

Dibujo \#3 Palma de Yagua. 


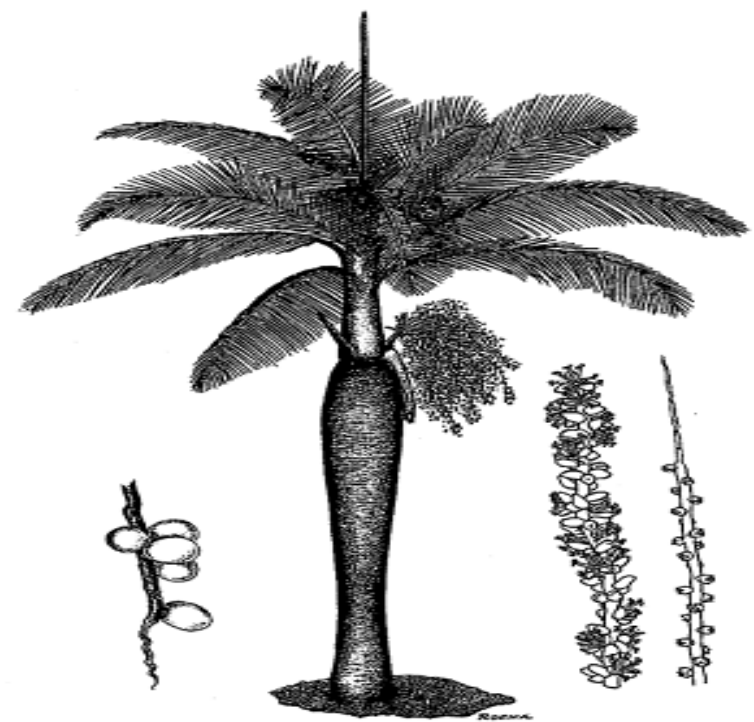

Sropertane

45

Foto \# 15 palmas variadas altas y bajas.

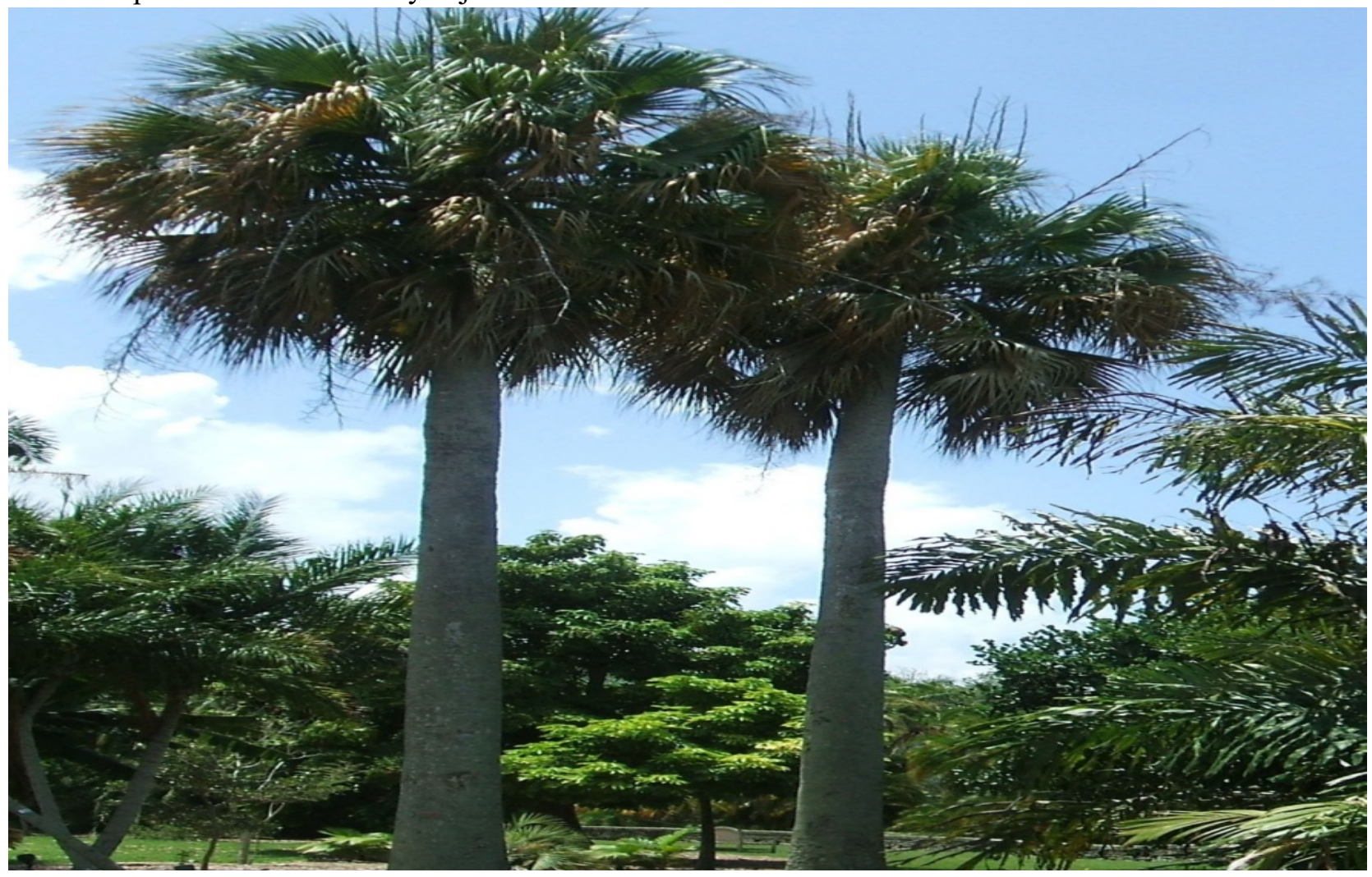


Foto \#16 distribución y venta de jaguas en Puerto Rico (1910)

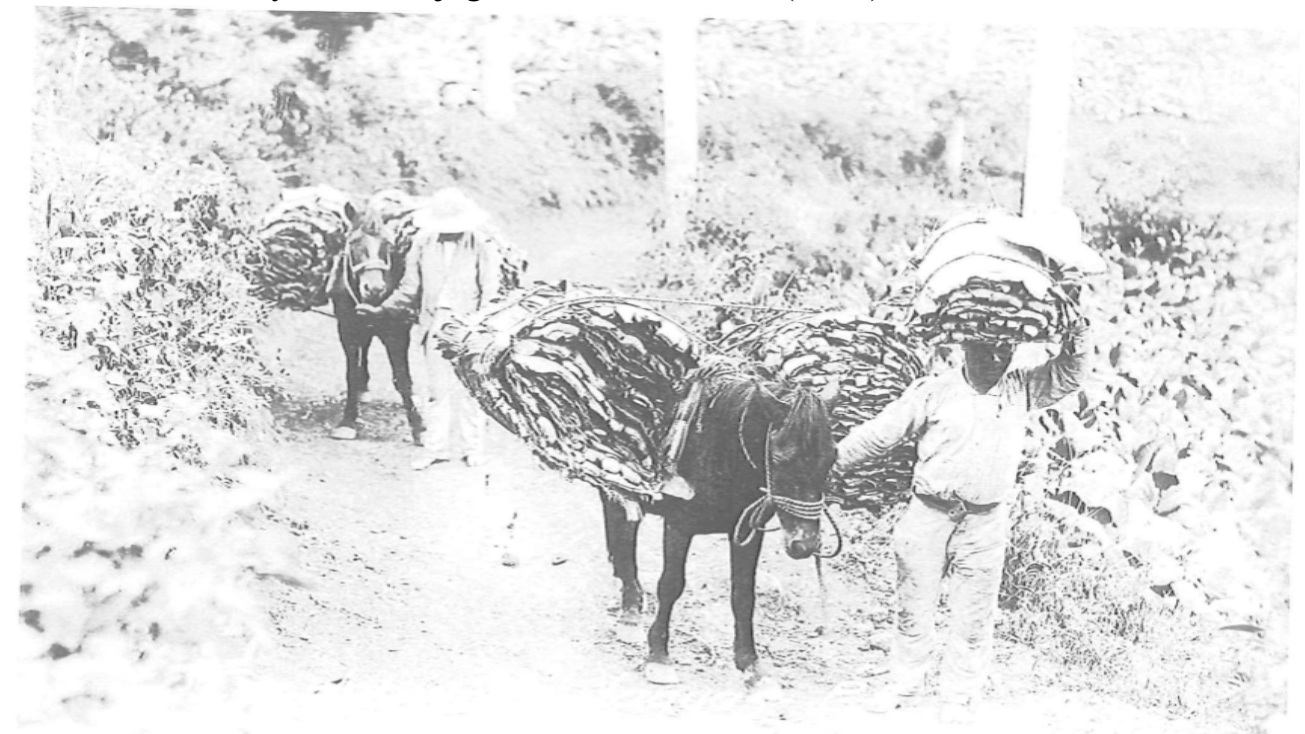

Vendedores de yaguas, 1910.

Foto \#17 secador de jaguas República Domincana (R).

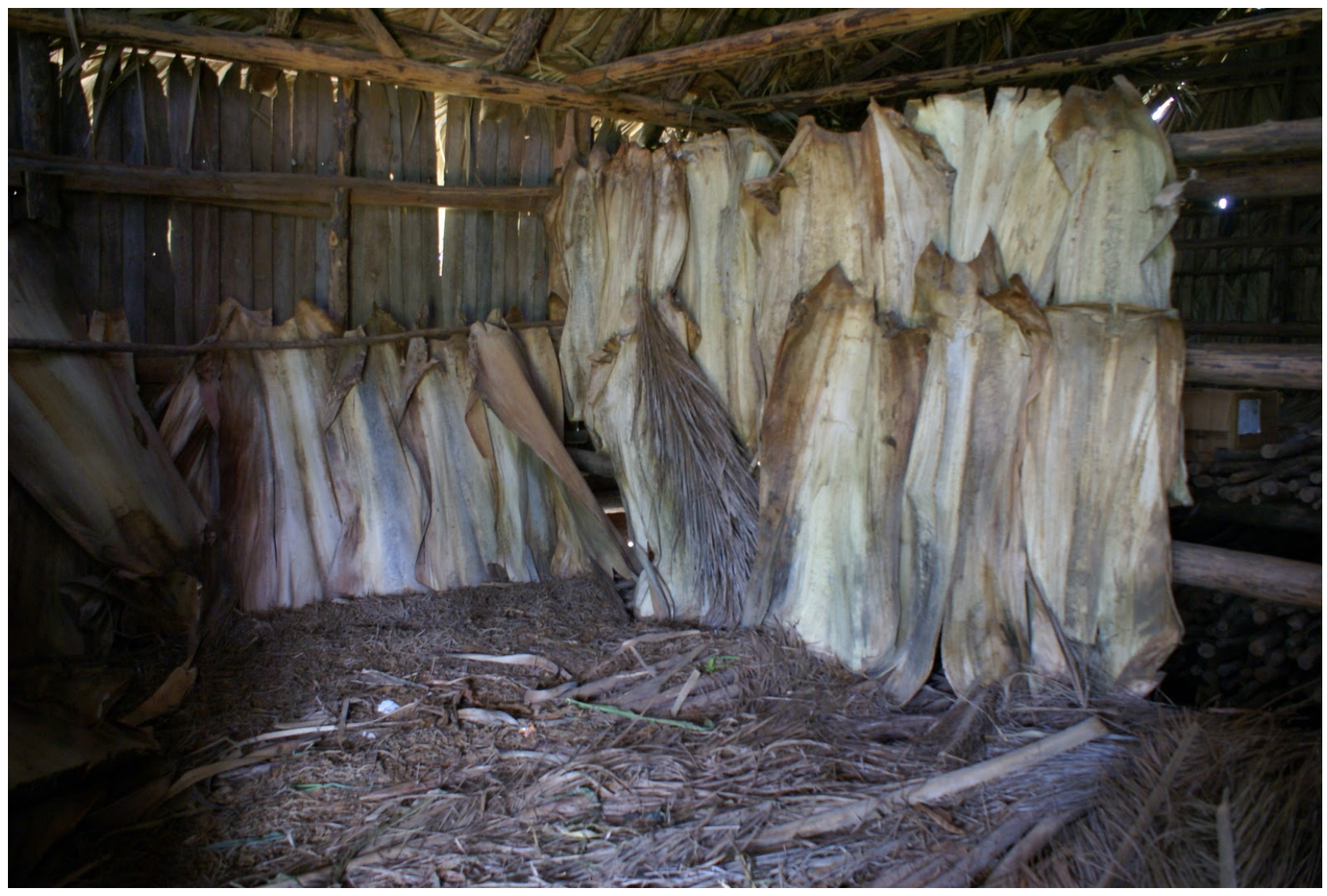

Foto\# 18 anudaje rustico de jaguas con fibras a paredes y techo 2014 en RD. (R. Sloan). 


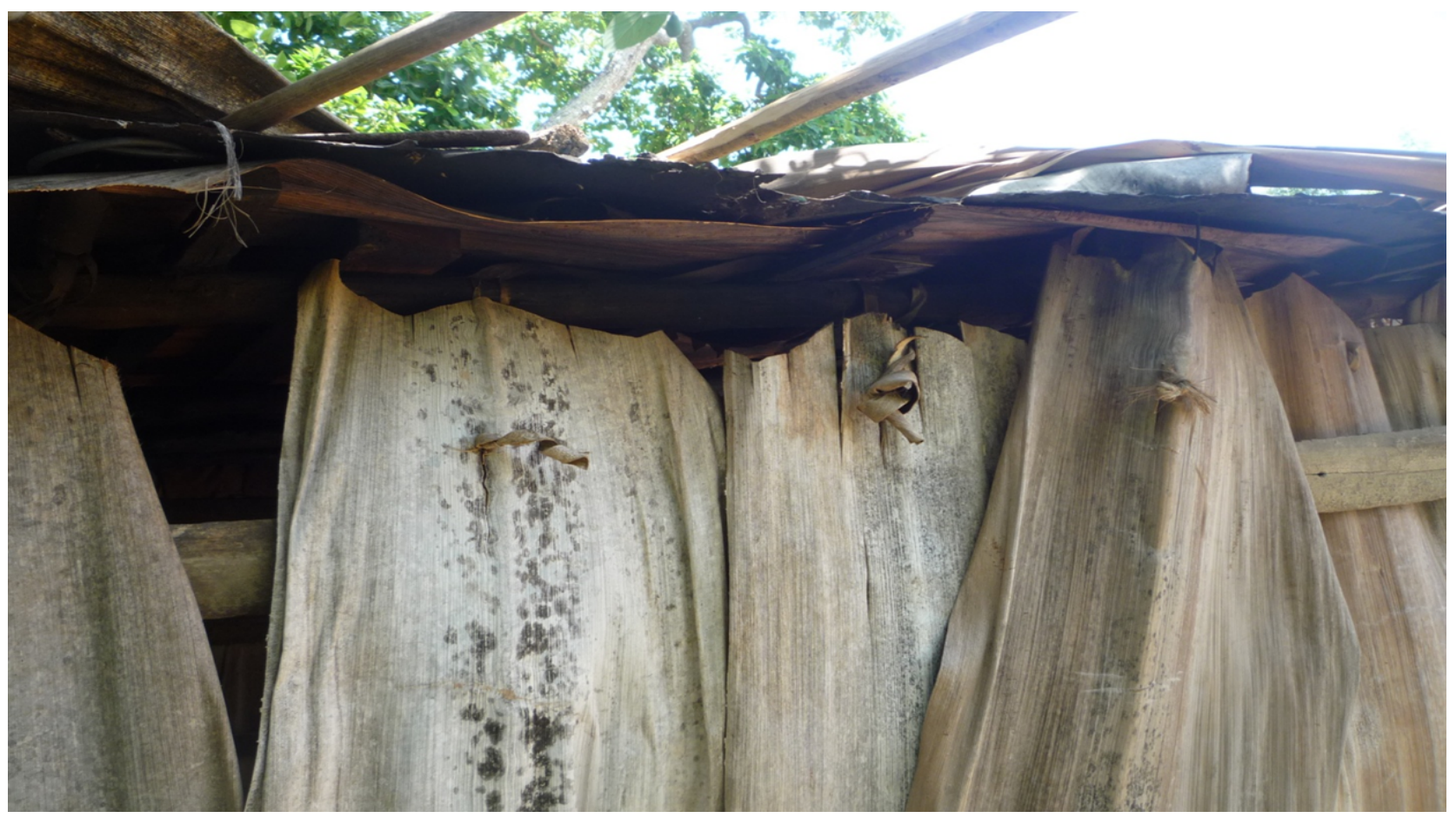

Foto\#19 plafón tipico actual de la casa de campo junto a la técnica de anudar RD.

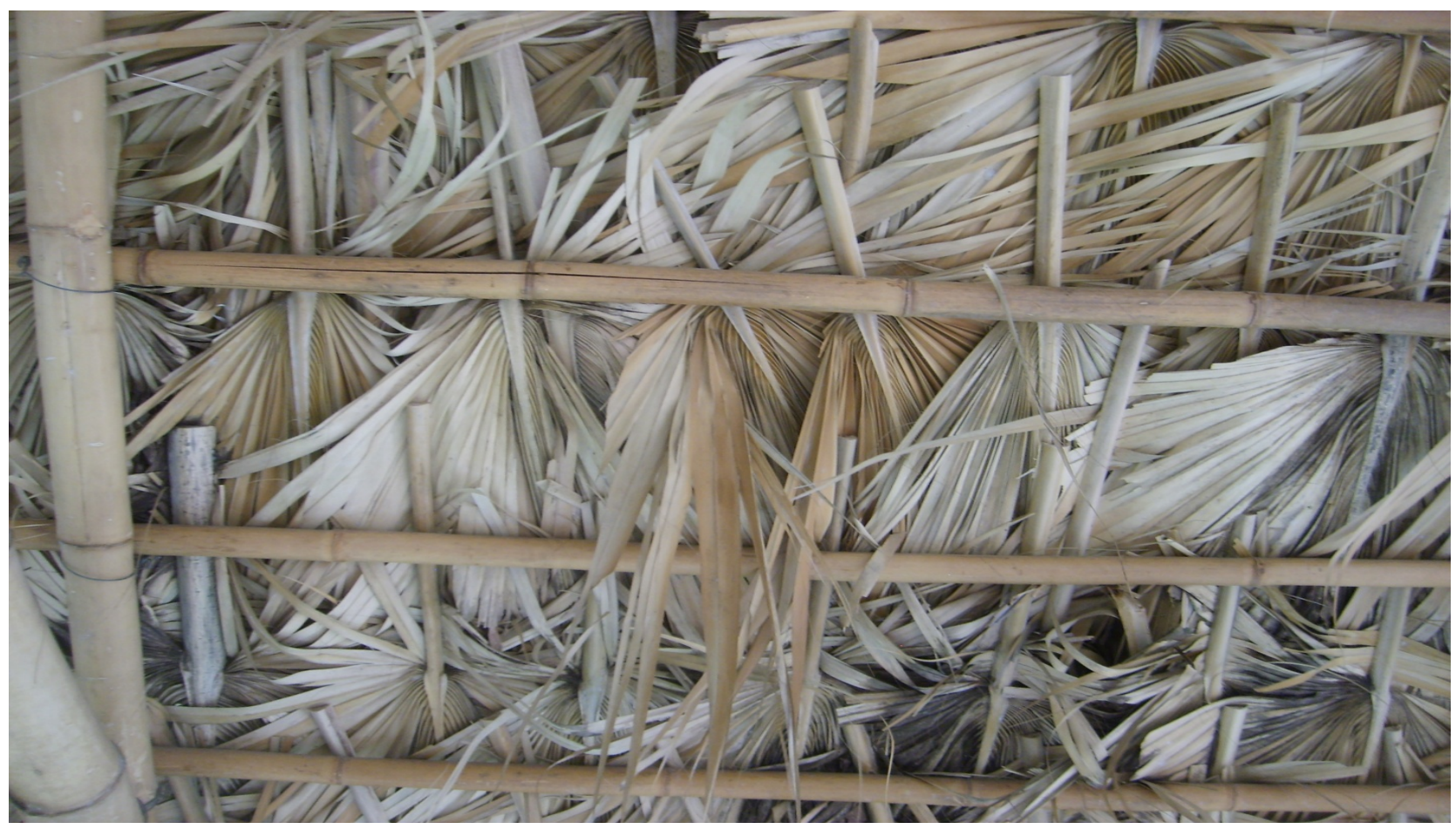

Foto \#20 vigas y estructura de plafón y techo exterior. 

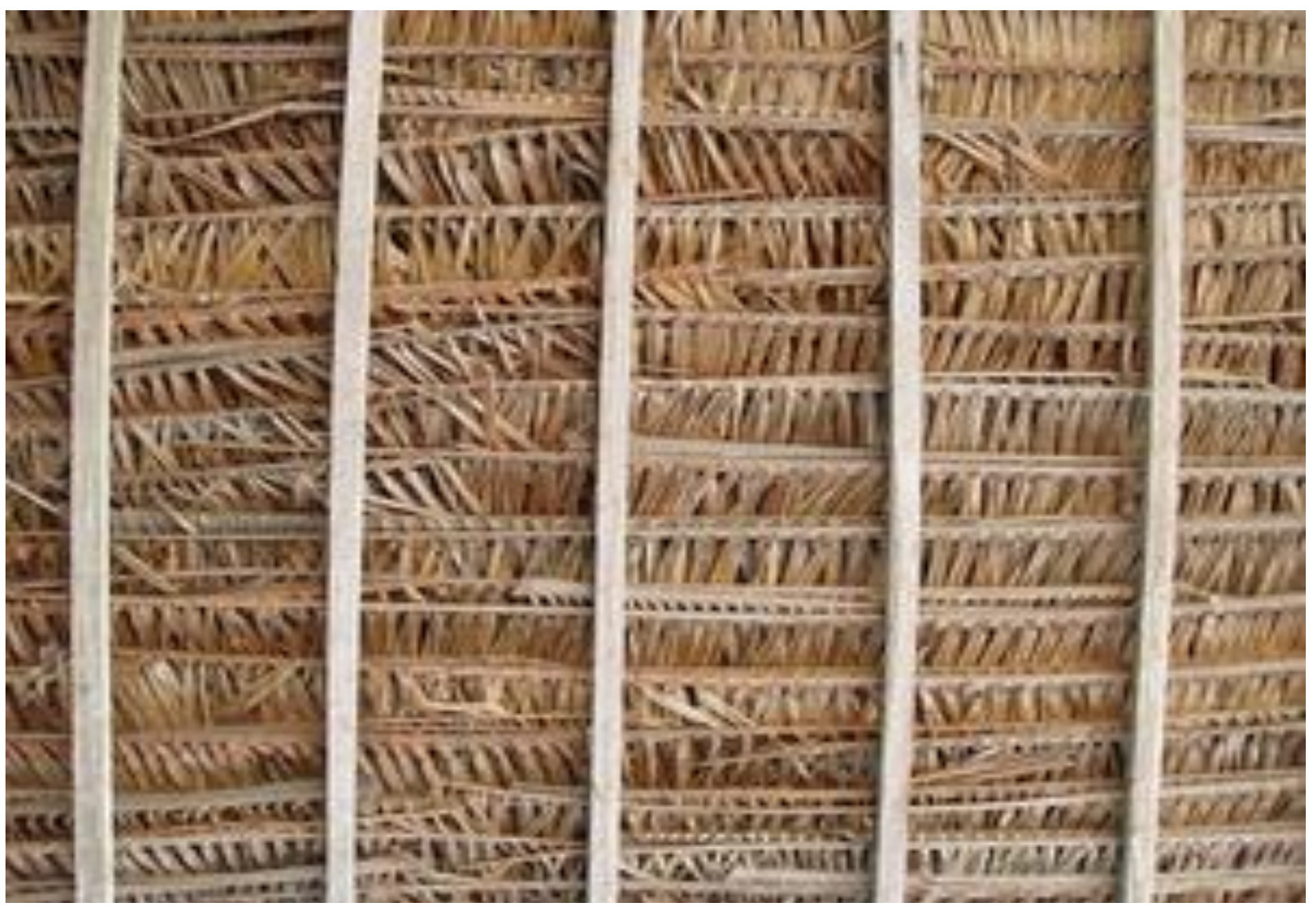

Foto \# 21 foto 2014 de una cocina en la RD. (R. Sloan).

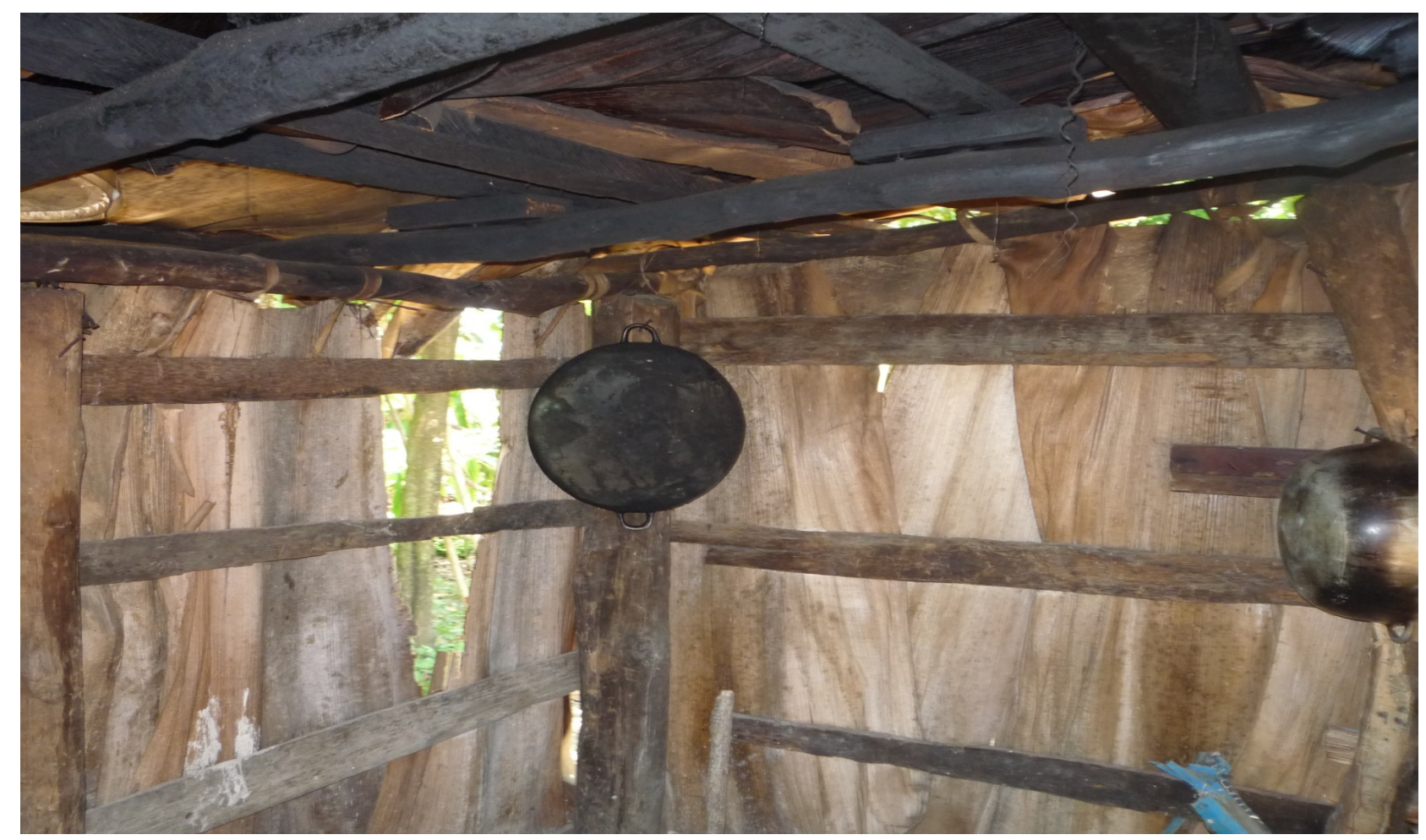

Fotos \#22 en 2014 de cocina y fogón de varas y jagua y casa pobre de campo construida con tablas locales en RD. (R. Sloan). 


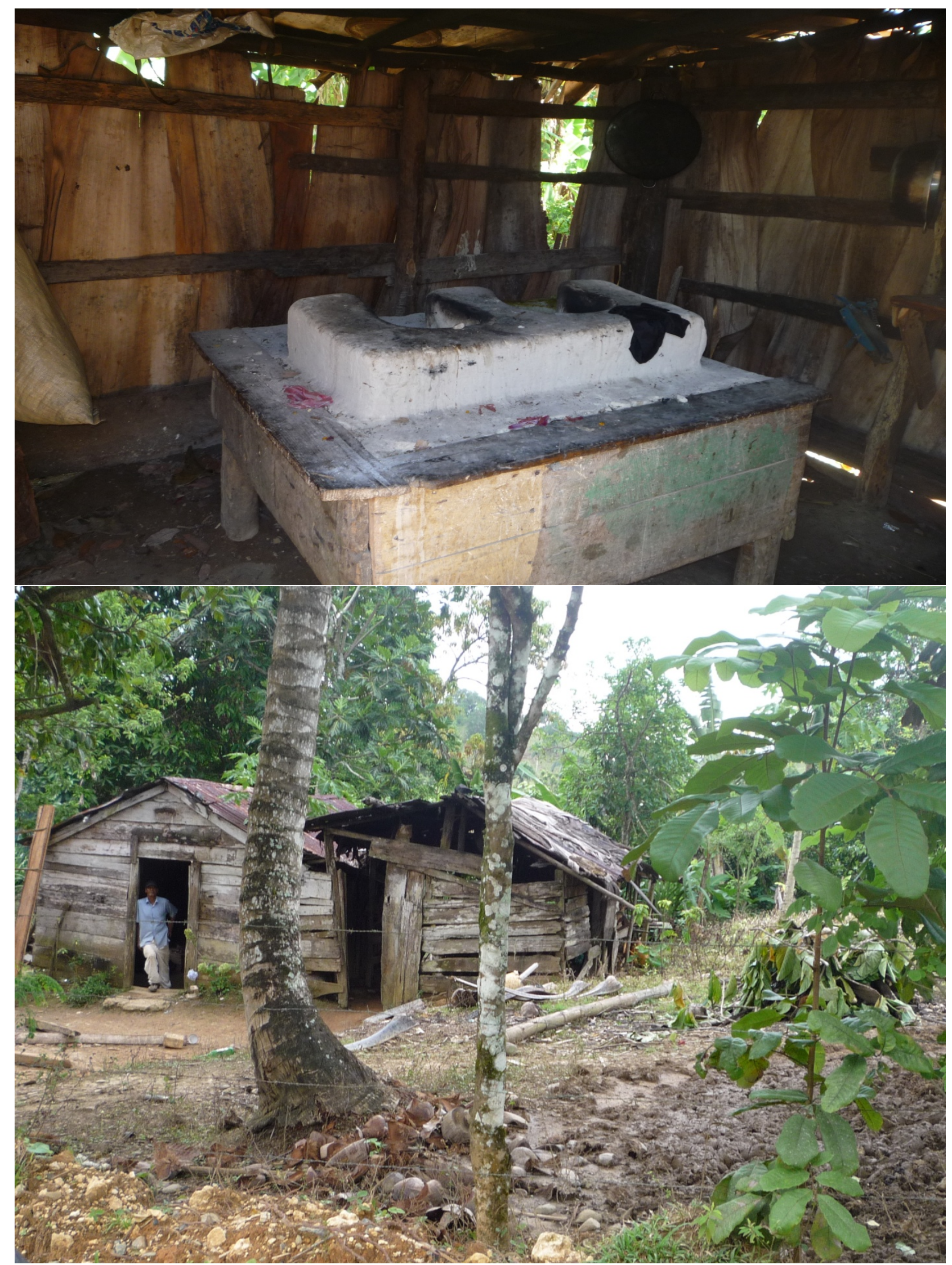

Foto \#23, casa de campo 2014 (1-2)construida con tablas y hojas de palma RD, (R. Sloan). 


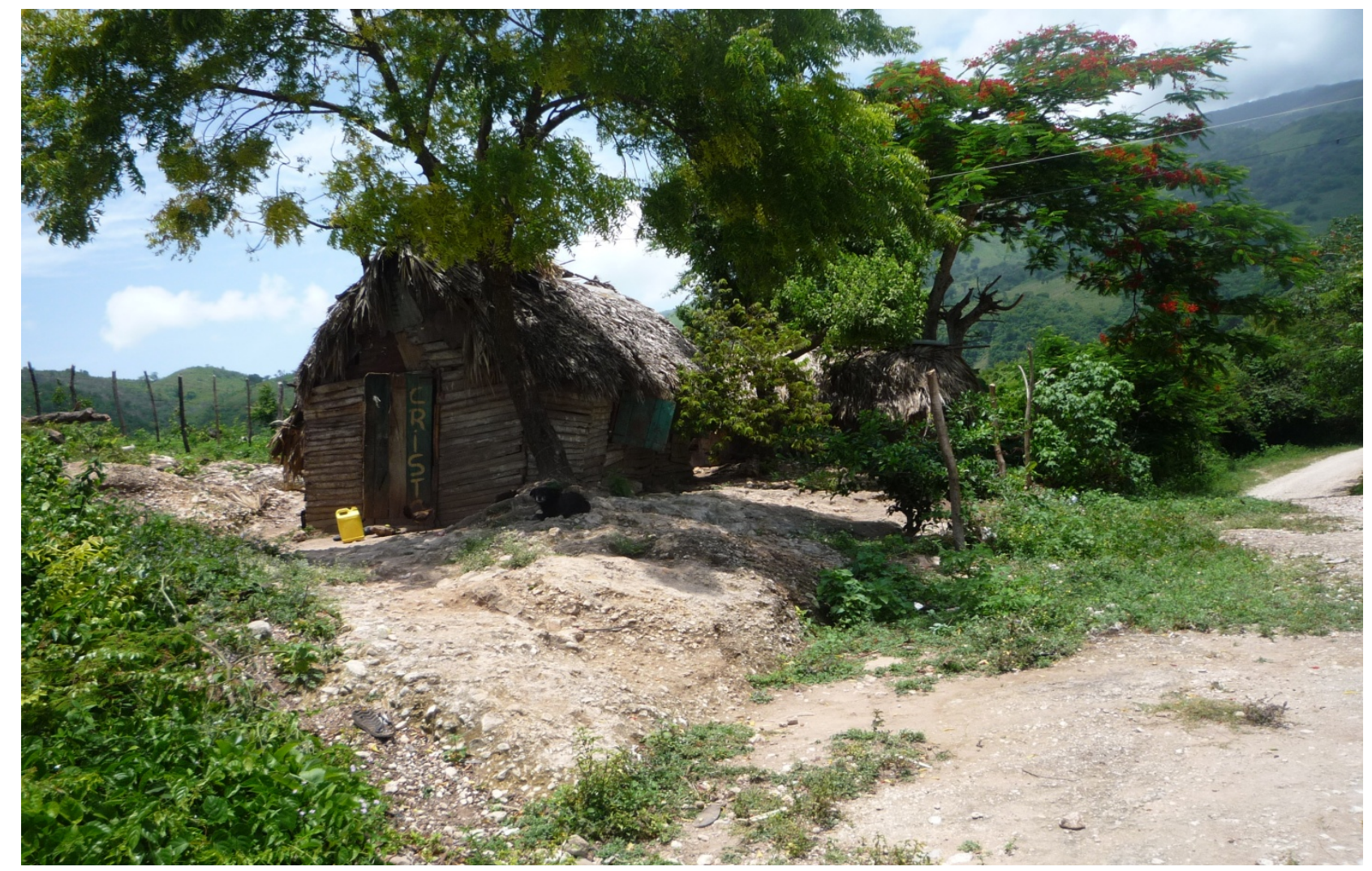

Foto \#24 casita República Dominicana (R. Sloan).

Foto \#25 venta de yaguas secas 2014 en la República Dominicana (R. Sloan).

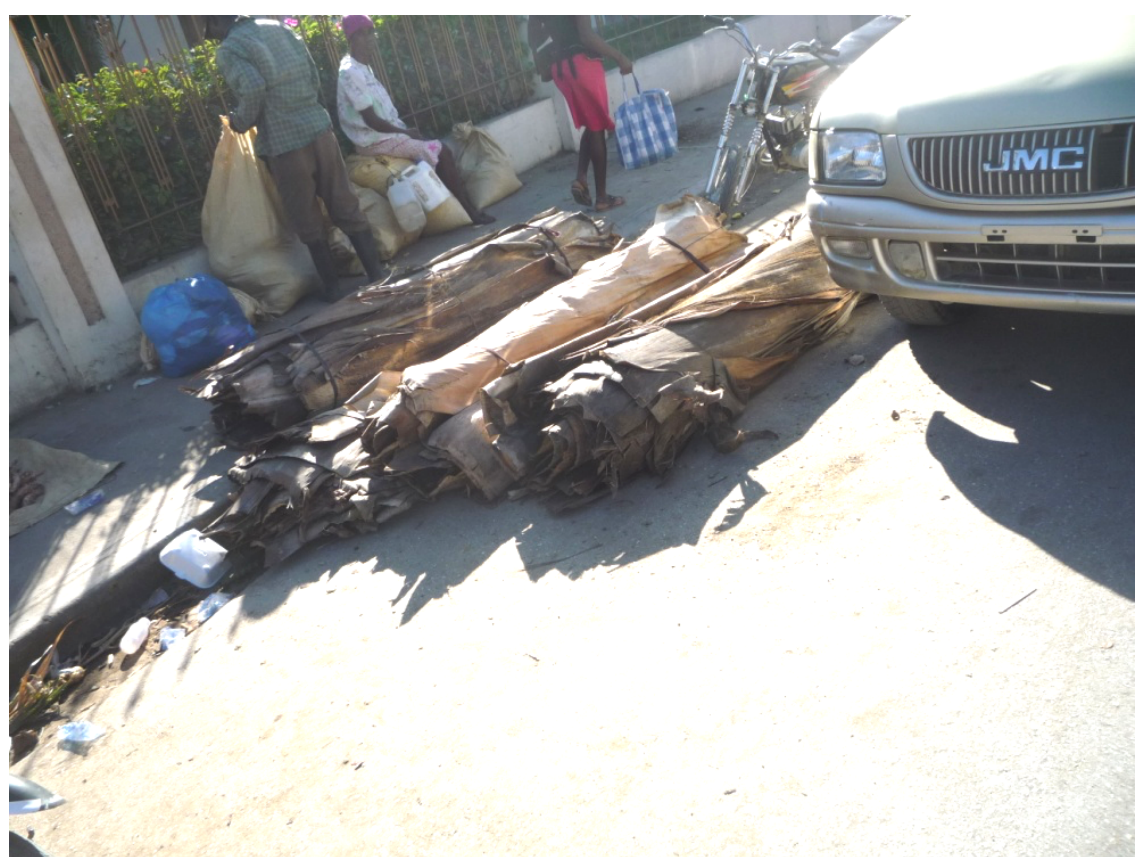


Foto \#26 tablas de palma cercanías de Rio San Juan, RD.

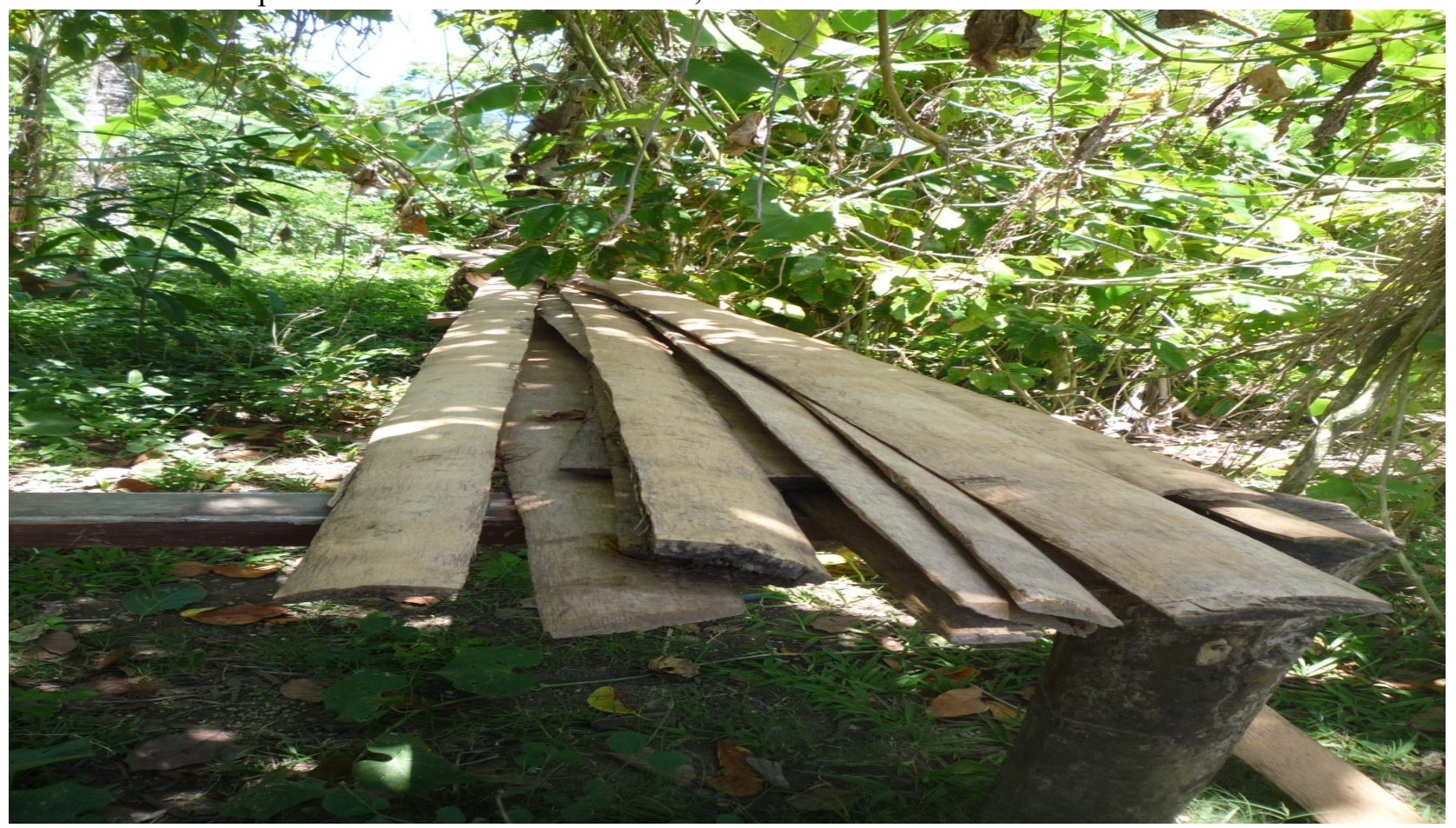

Fotos \#27 y \#28 del 2014, parte de la cuenca hidrográfica del Artibonito a nivel de Pedro

Santana, el río más largo de la isla. Ruta y cruce comercial de uso común entre RD y Haití.

Varias piraguas de un solo madero semejantes a las nativas de origen. (R Sloan)

La esposa y hermana del autor estan nadando en el río.

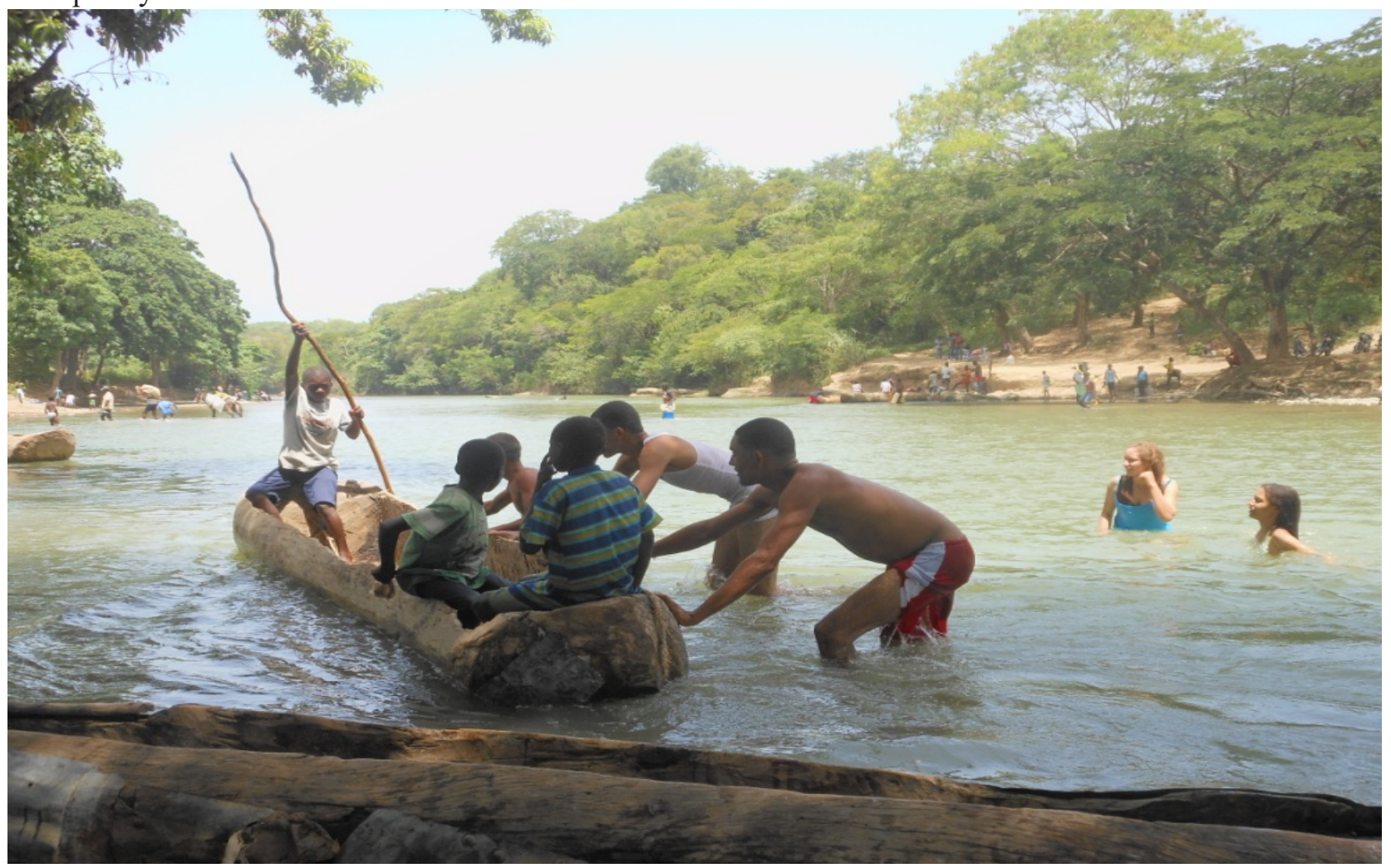




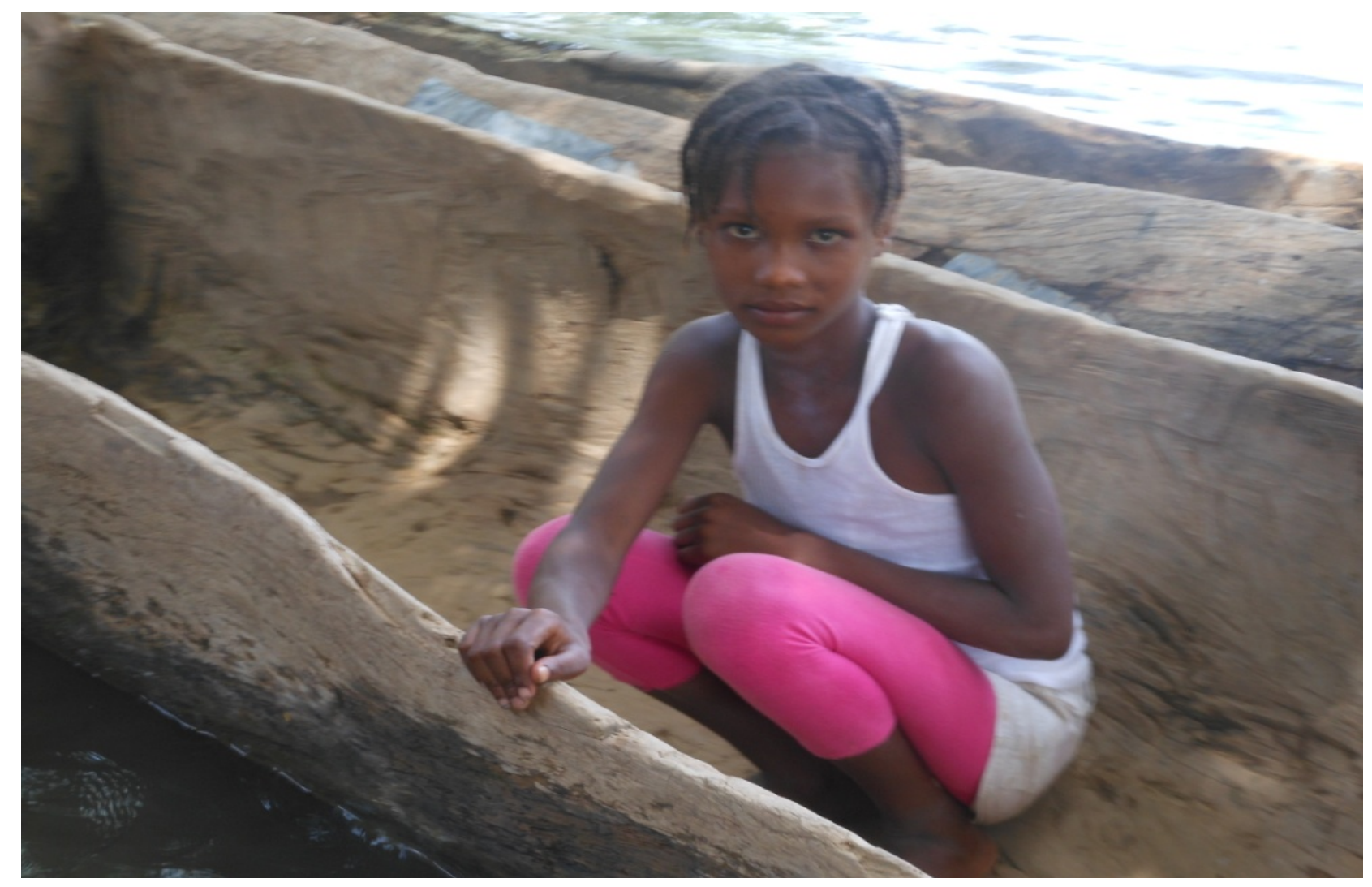

Foto \#28

Foto \#29 la orilla haitiana y el transporte para la mercancía que cruza el Artibonito, (R. Sloan).

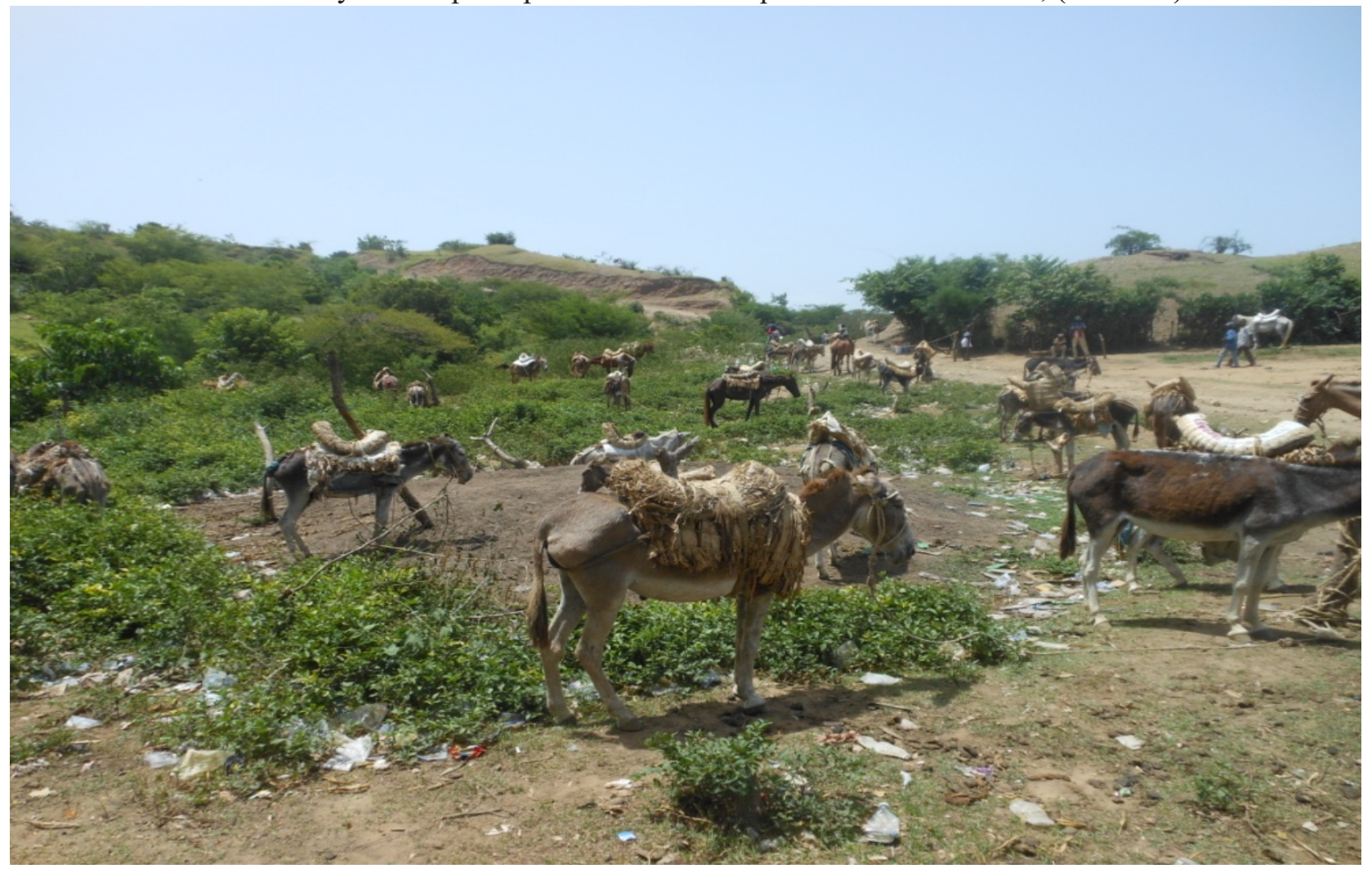


Grabados: América de Theodor de Bry edición alemana de 1617, disponible en Internet Archive.

Los grabados contienen su propio texto uno que no se analiza. En este sentido el significado es lo representado por un grabado de la época. En esos grabados encontramos la construcción de canoas y piraguas como las encontradas y documentadas en la RD y Haiti en el Artibonito fotod 27 y 28 en el 2014. No entramos en una evaluación científica sobre el mérito o significado histórico o científico del trabajo de Theodor de Bry. 


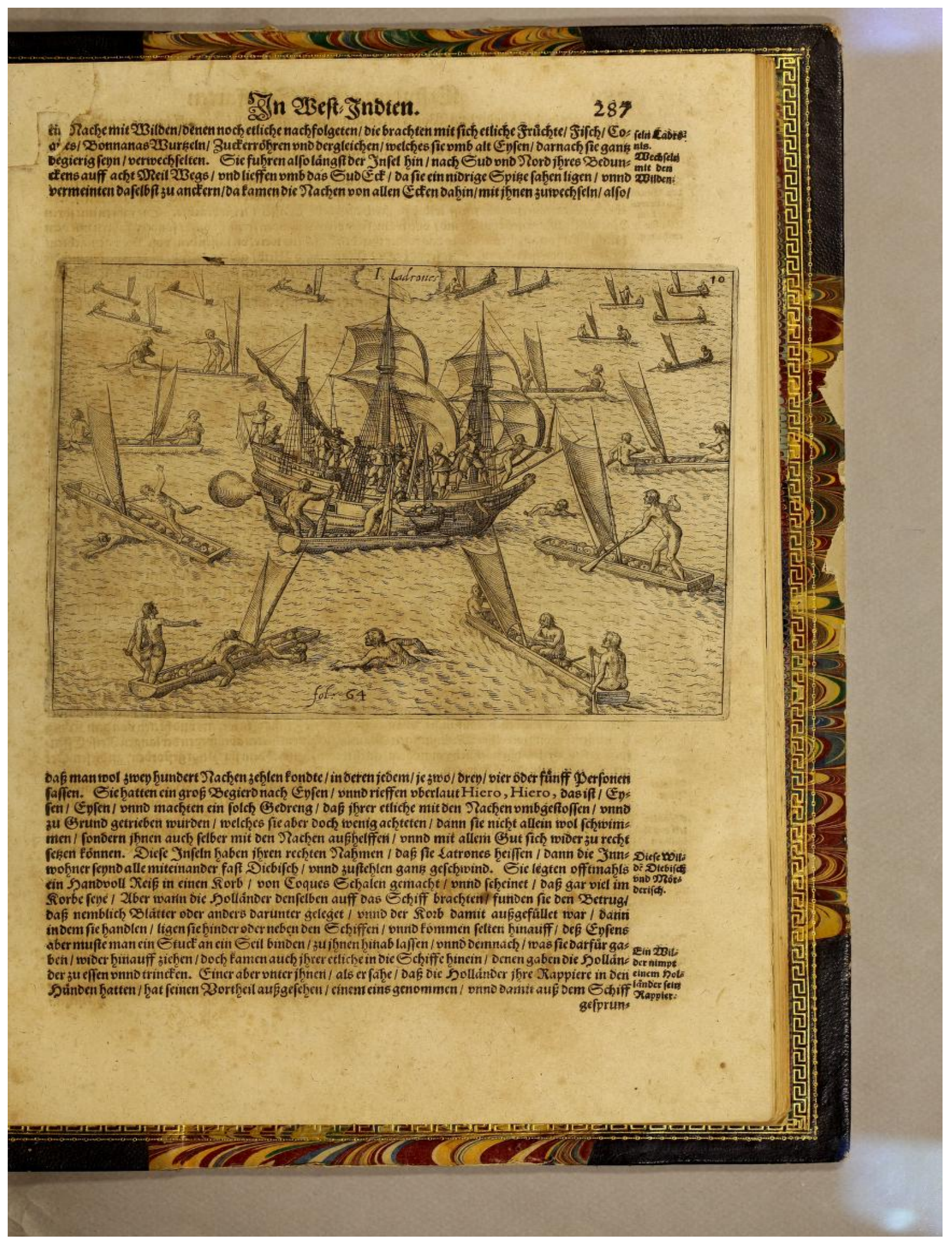




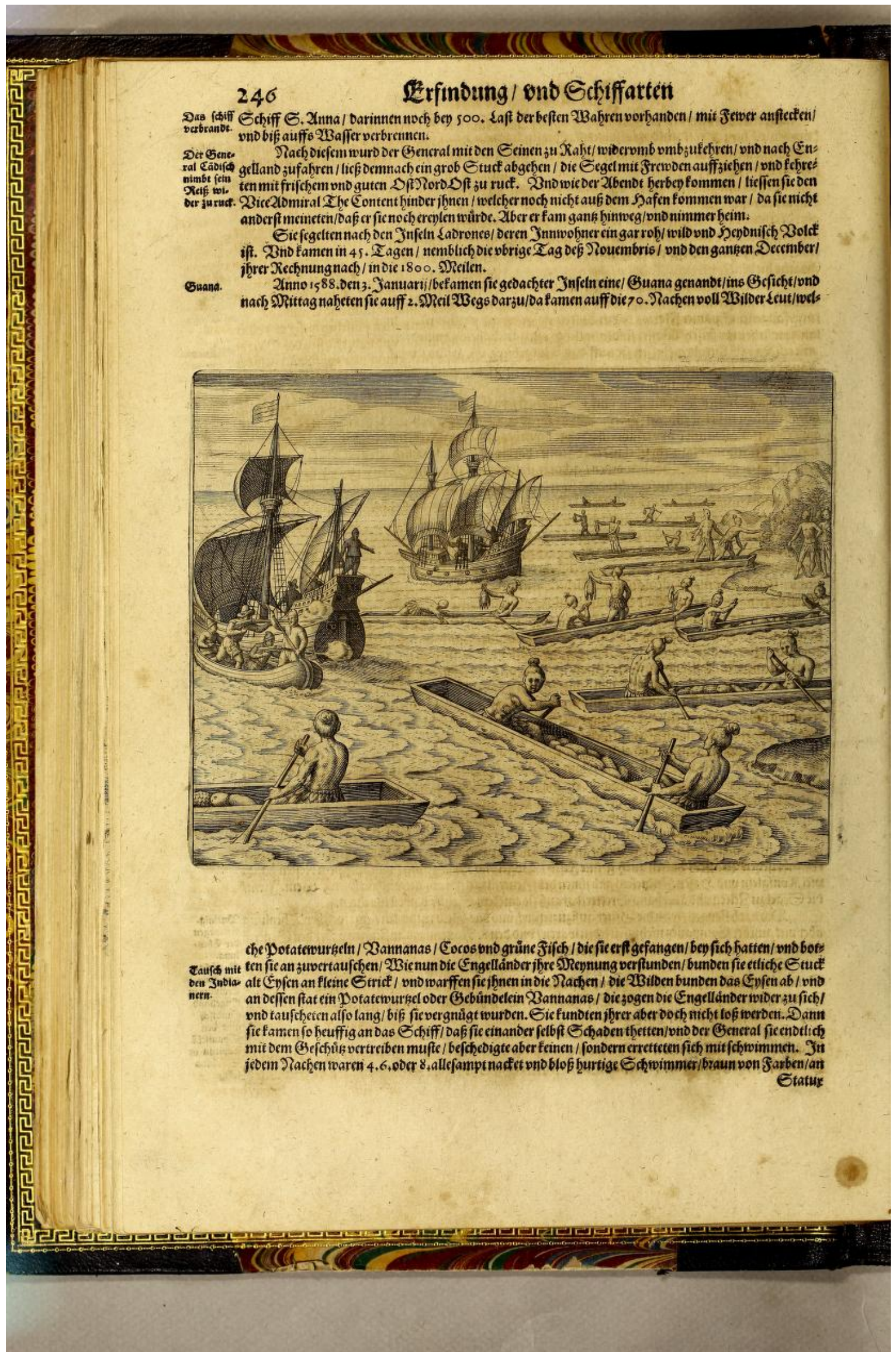




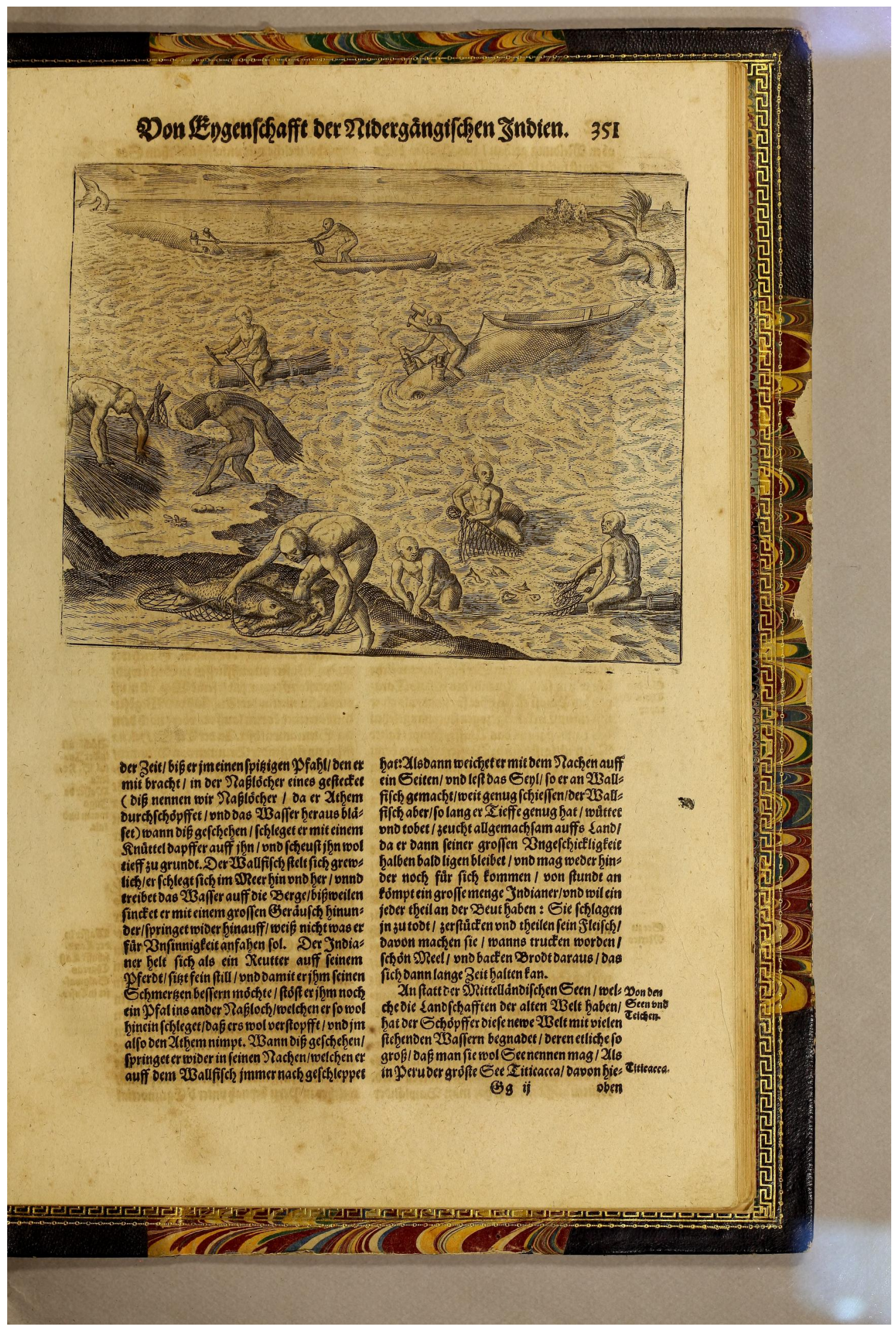




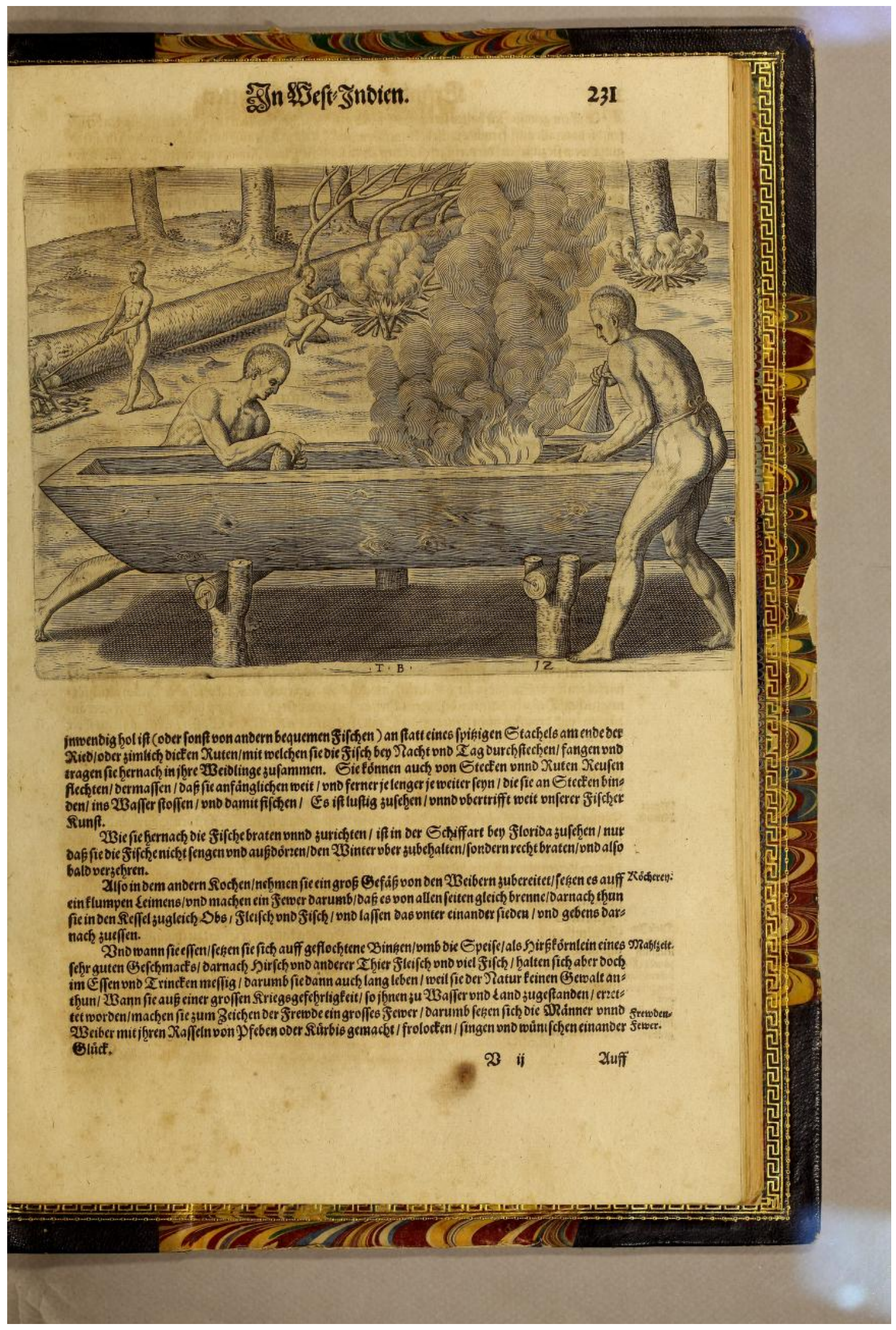




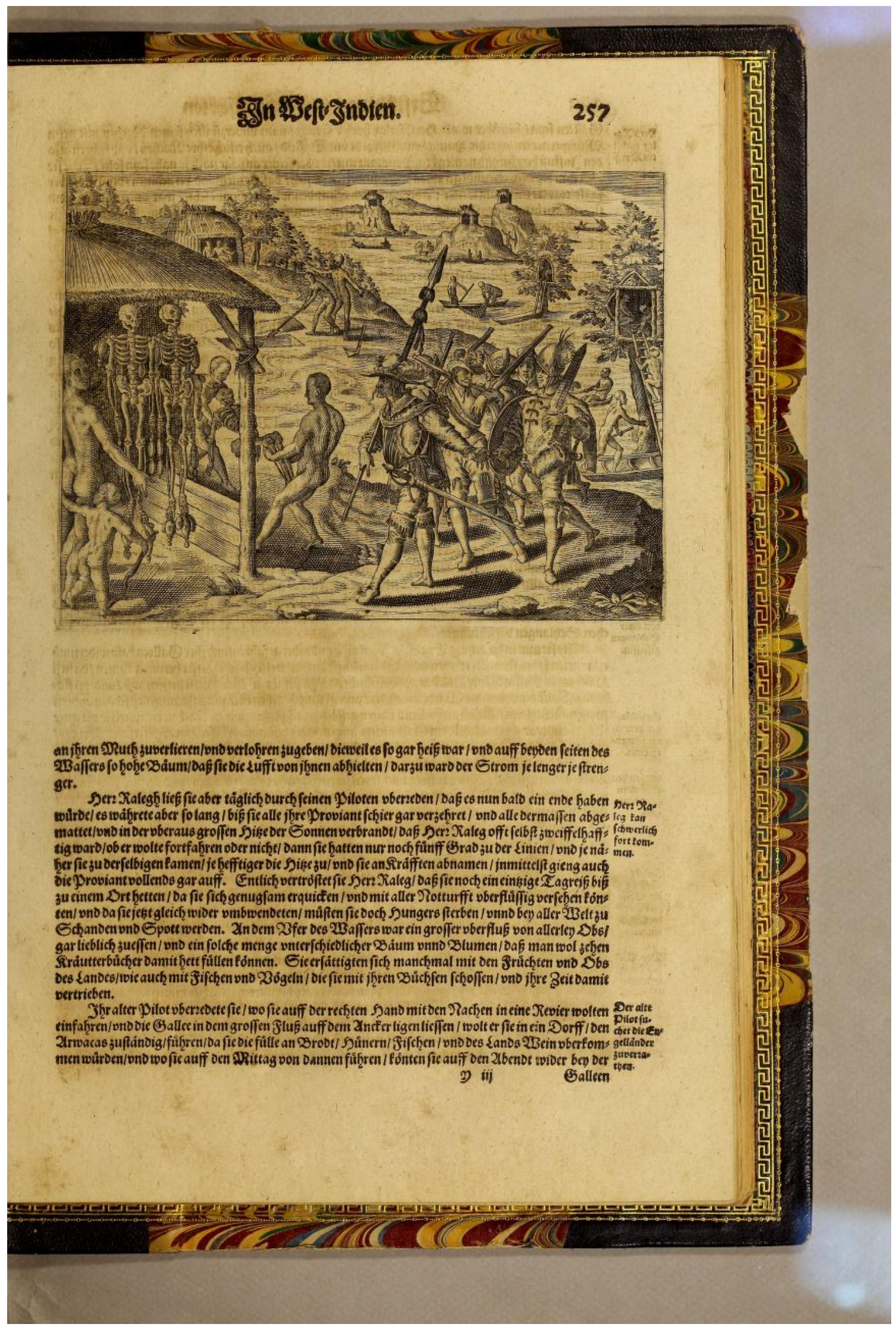


Dibujo \#4 Velero, piraguas nativas junto a la imaginación europea.

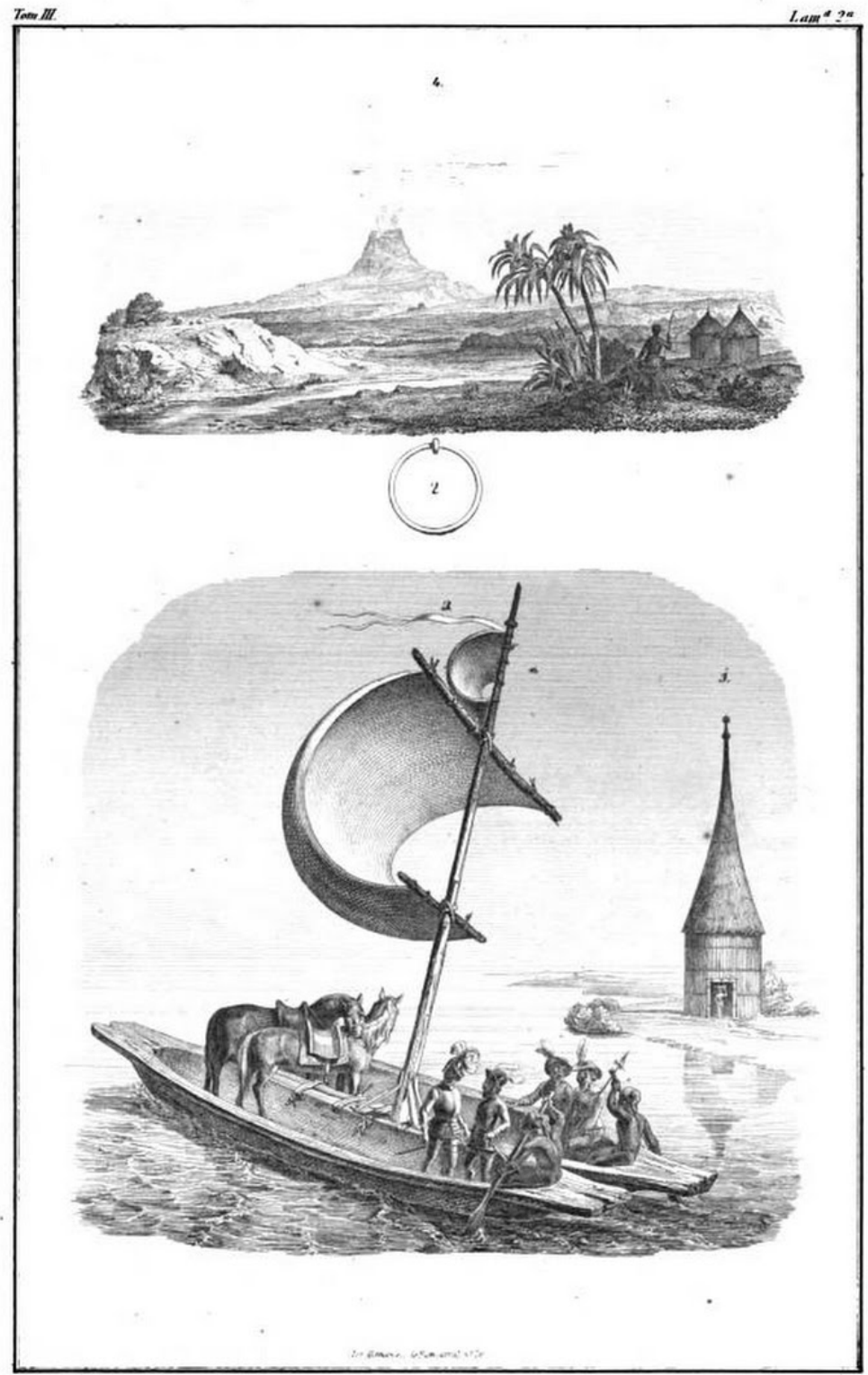


Páginas de la memoria original de: Hernando Escalante de Fontaneda. Memoria de las cosas y costa y indios de la Florida, que ninguno de cuantos la han costeado, no lo han sabido declarar, 1575. Disponible en los; Archivos Estatales, http://pares.mecd.gob.es.

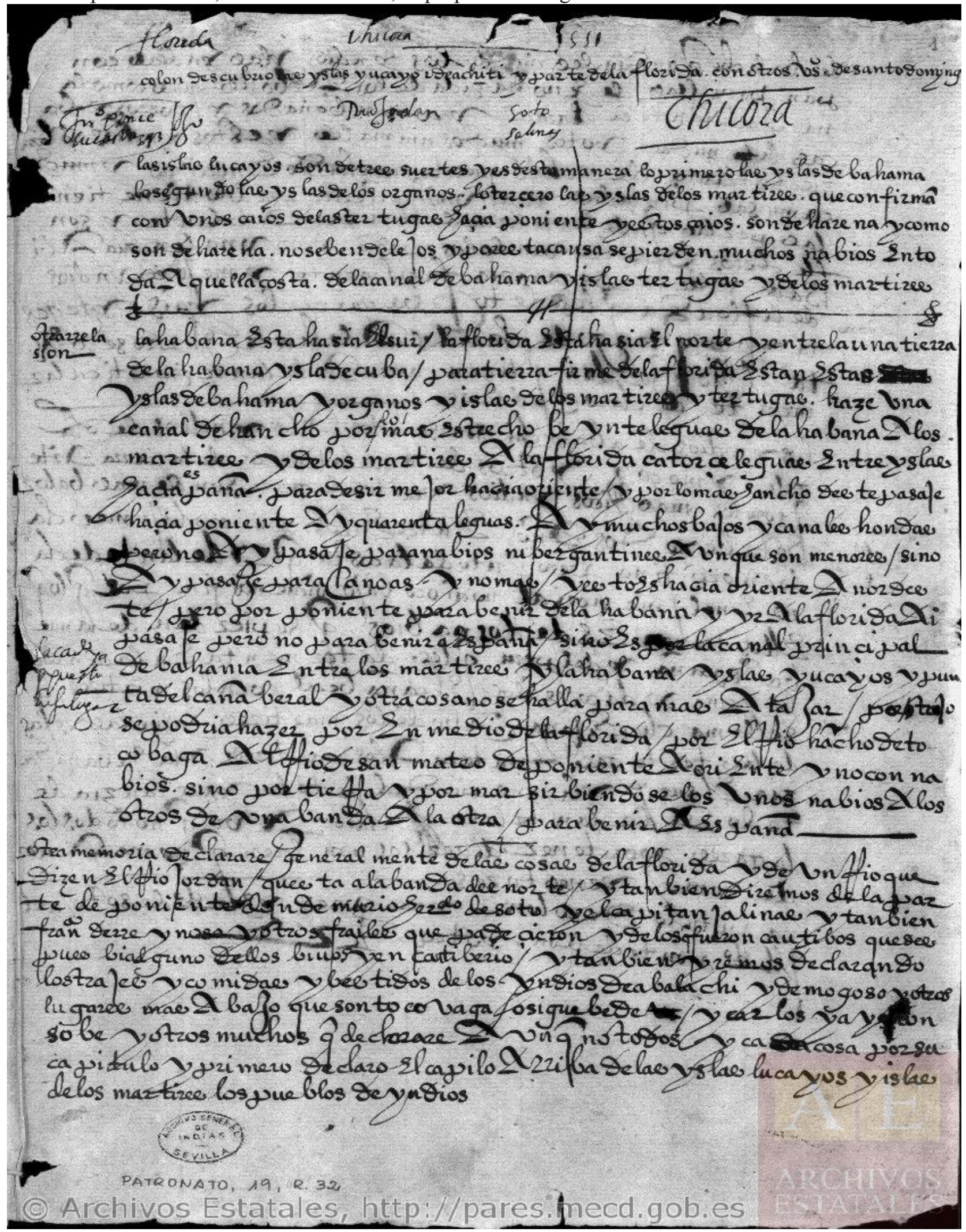




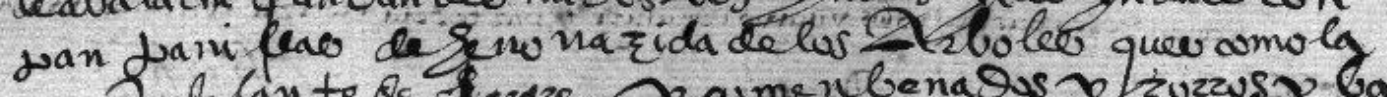

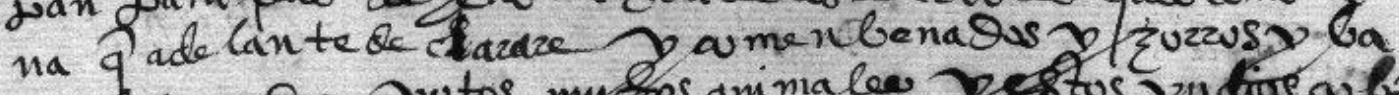

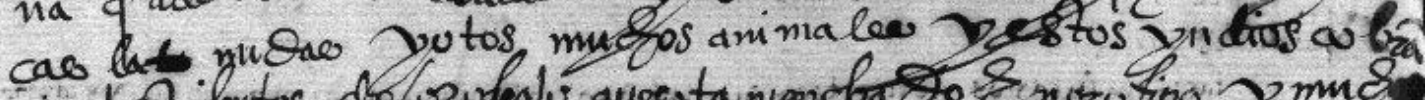

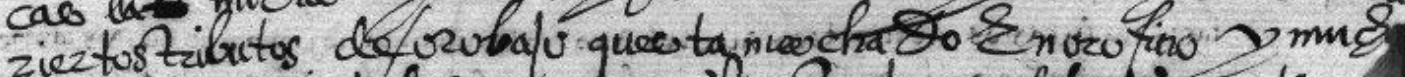

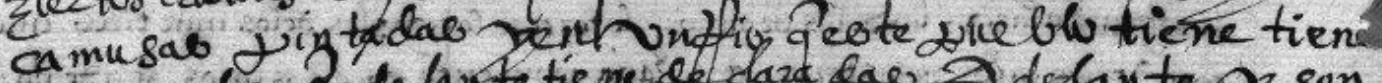

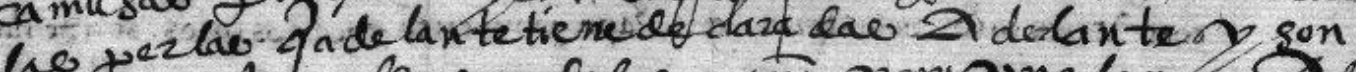

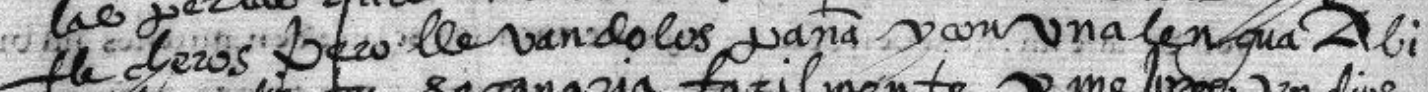

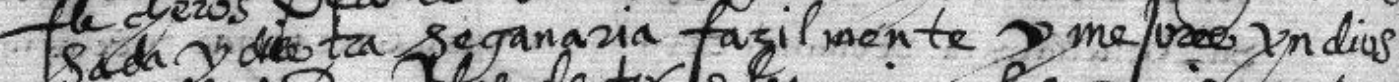

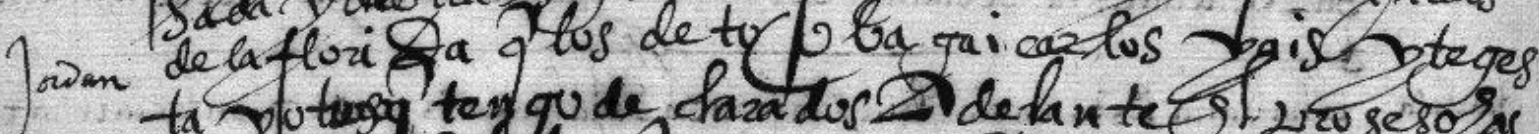

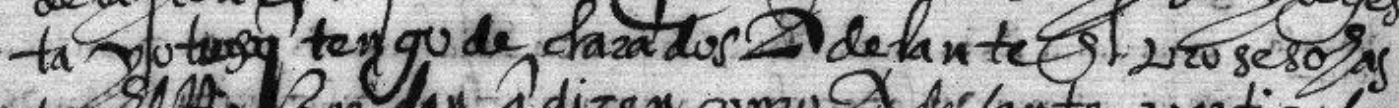

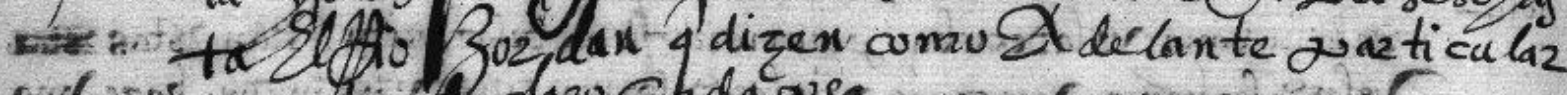

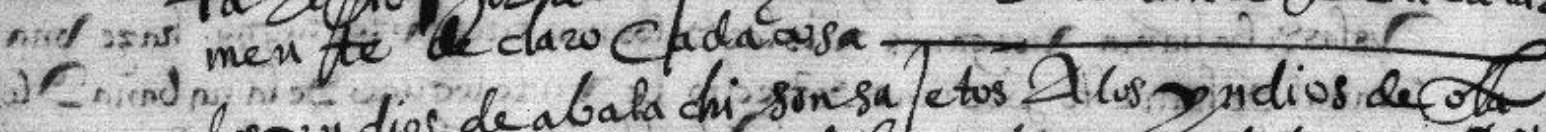

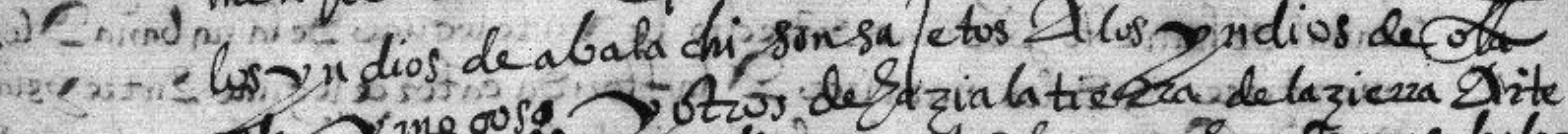

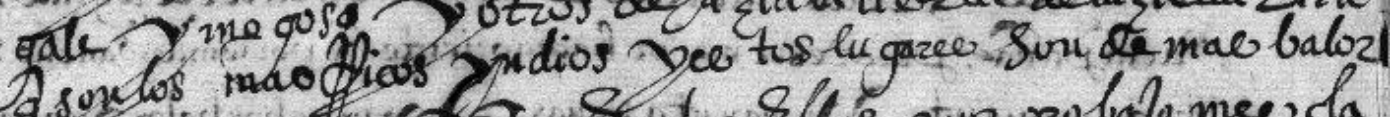

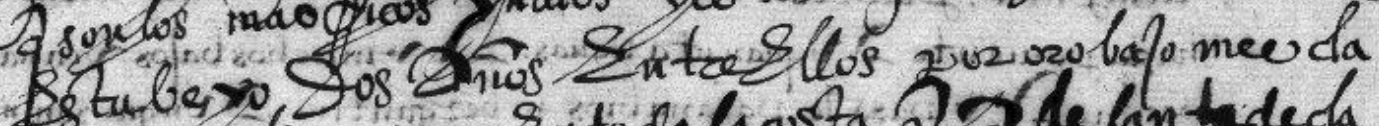

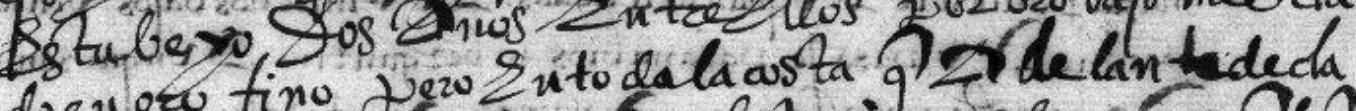

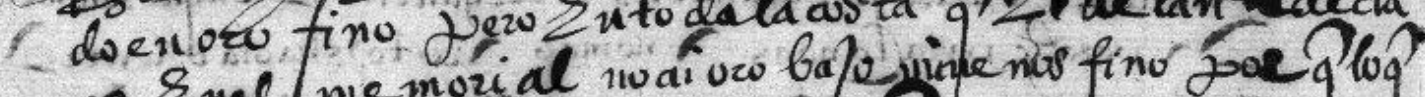

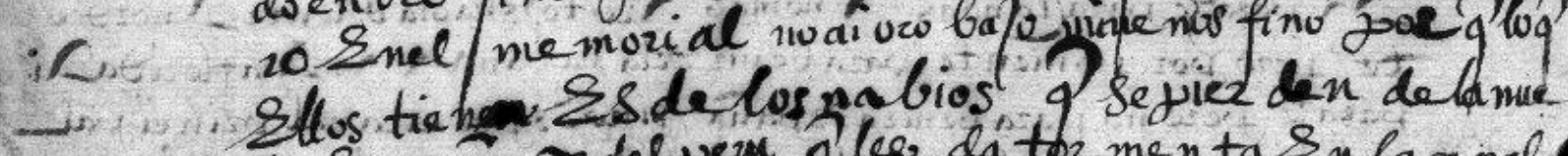

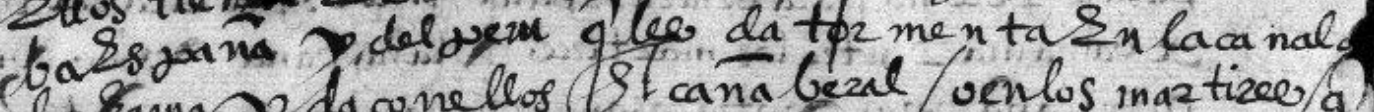

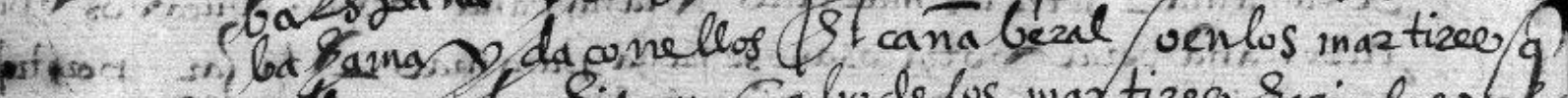

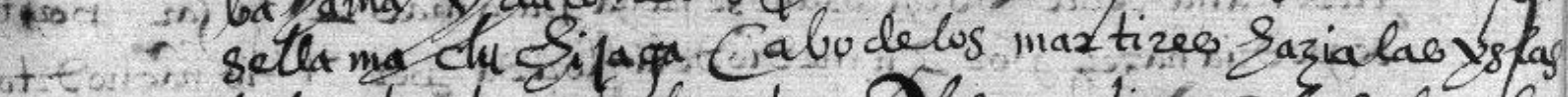

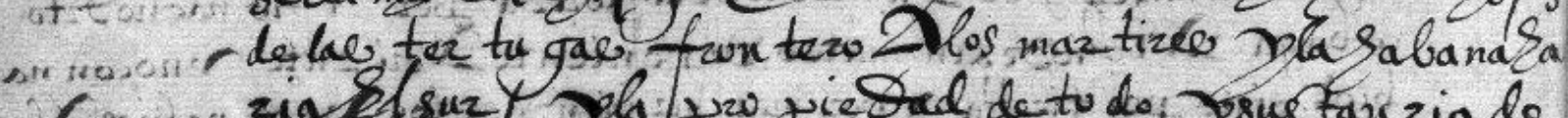

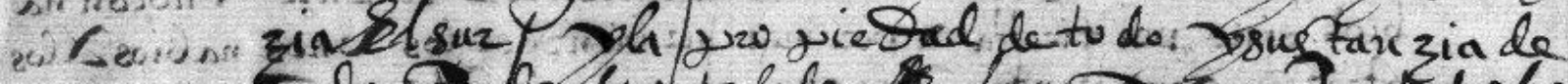

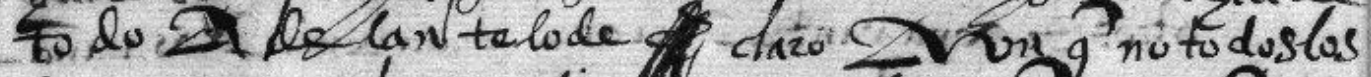

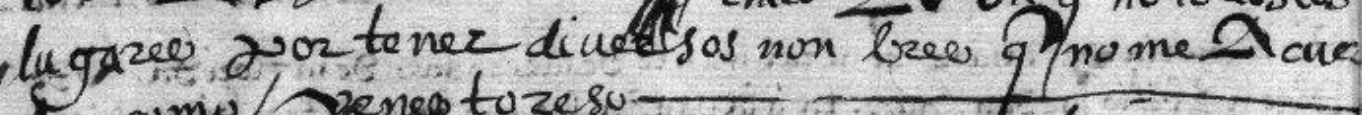

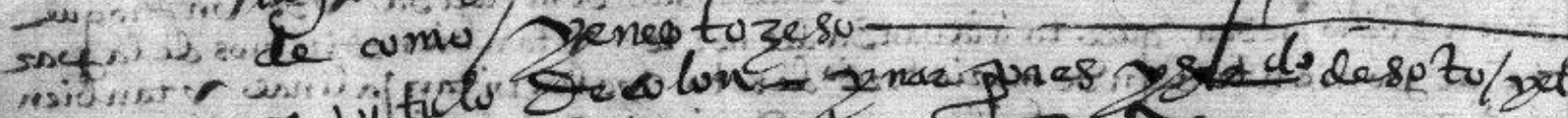

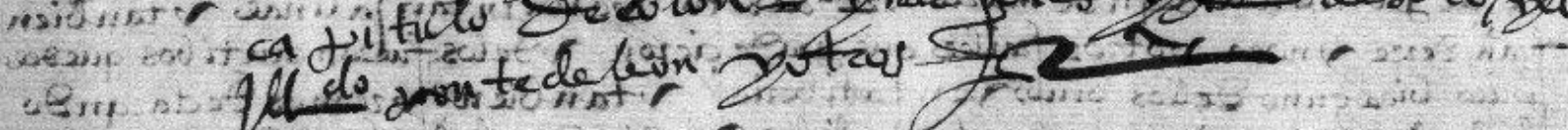

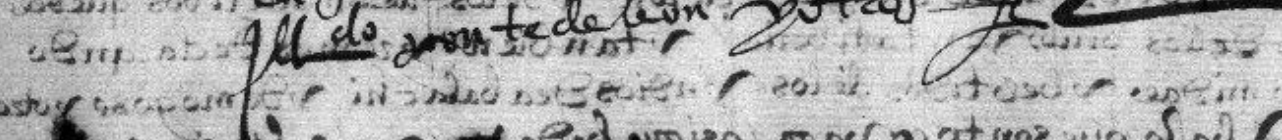

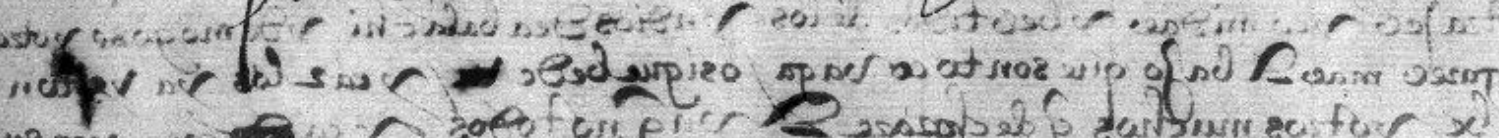

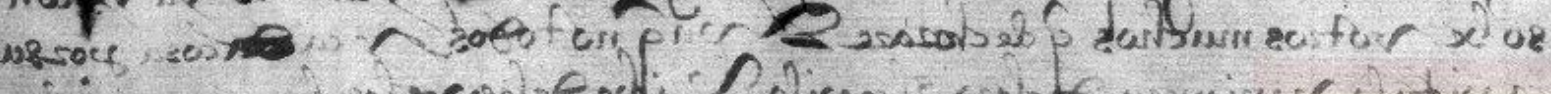

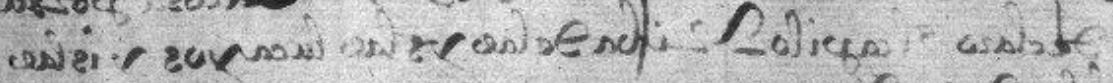

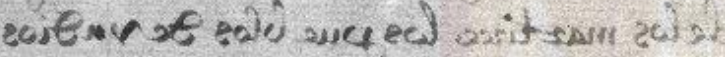


enlaticcal

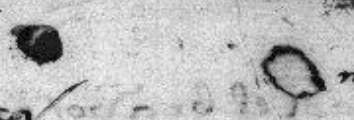

(3) Qesbala cbi

Elprimercasique questamas sezca Semigico Ssplagh

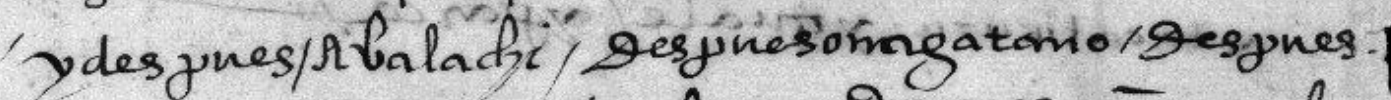
1 mogosal gesyues tocolagay Desynes comiogacala gesjunes/jebe/ $\rightarrow$ Des jues/esquega/ y resjunes/osig beqe, y Qespues/giyaya, ygespues/tanjacaste etilaticien occarlos

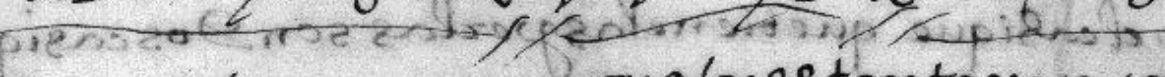

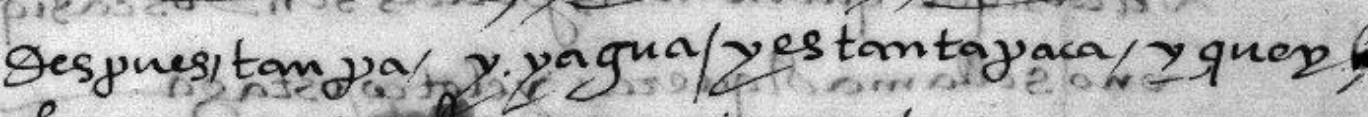
cha/ ypuestocabaga/y sinajas/ytomo/ycaynica

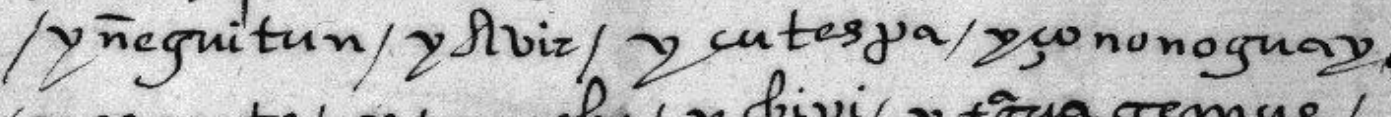
yesquete) ytuncobe/ ydizi/ ytg̈ragemue/ ynamuguva/ycaragara/y gen benqueja/ yogncataga/y yanar/yegcuru/zmetamajo,

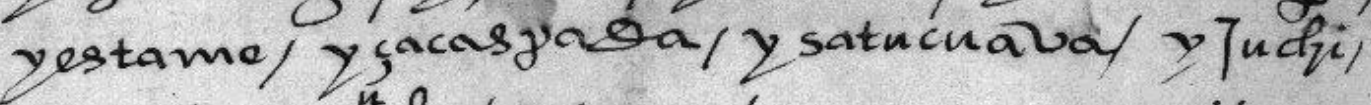
ysocol y vele/ ytero/ynusga yecasitual ycotebo/z coyovish/y teque majoy putan/ gurtervina / gestos sen los que gujetan flca

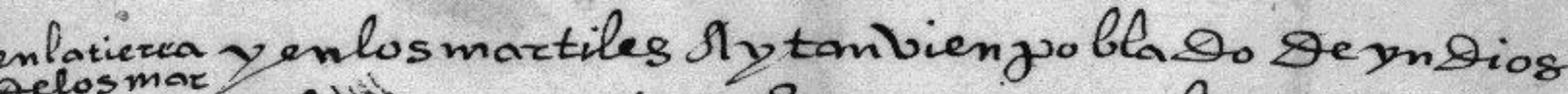
telesmar yeljtimercasique $\$$ sguarungube/gesjuescu yaga/sesjunestatestay

gespueg mas 81 gelomte esta tegesta/ptaunacio/ y Janaz/ycabista/pecustegiyo yzeagayasi muichos yn gias 9 moles seelnonlize

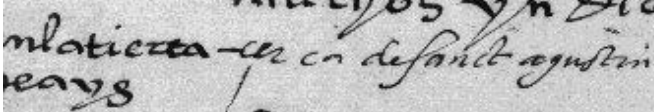

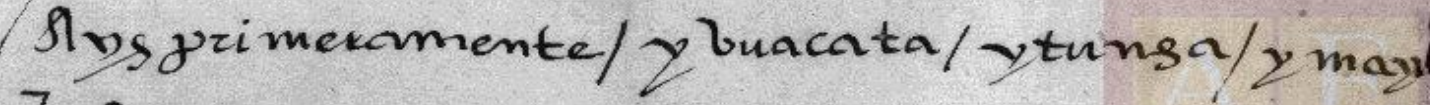

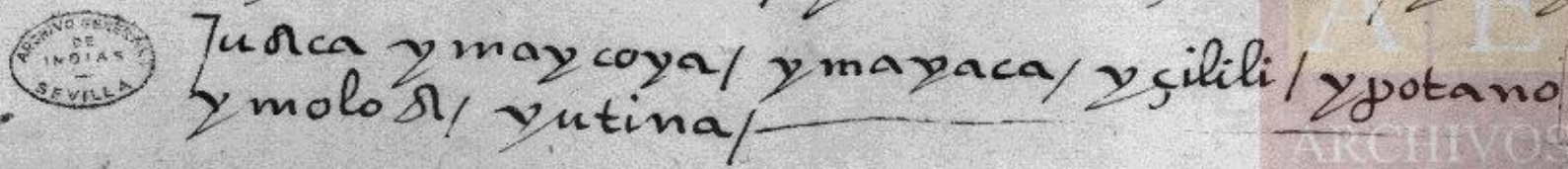
\%

Árchivos Estatales, http://pares.mecd.gob.es 


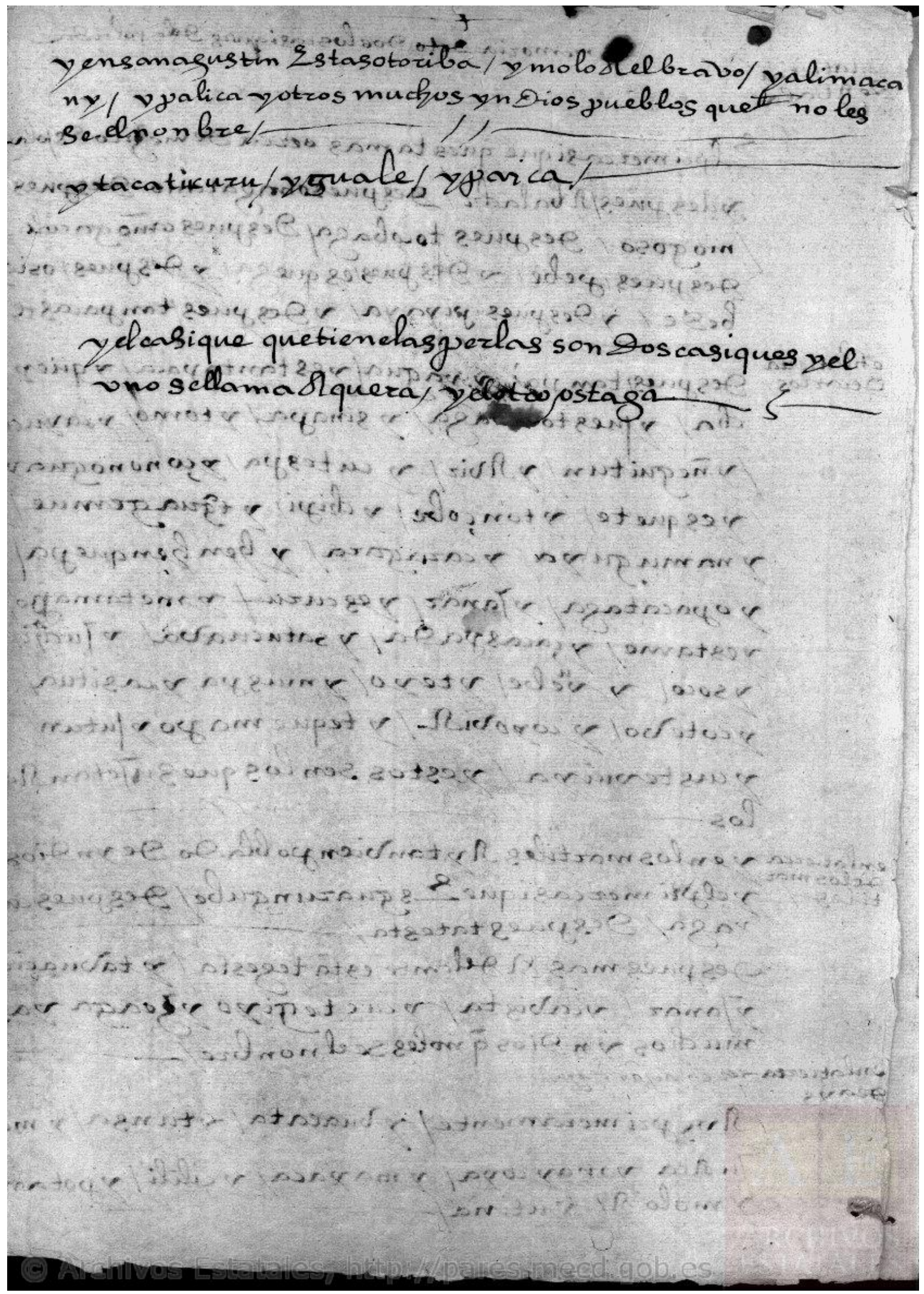




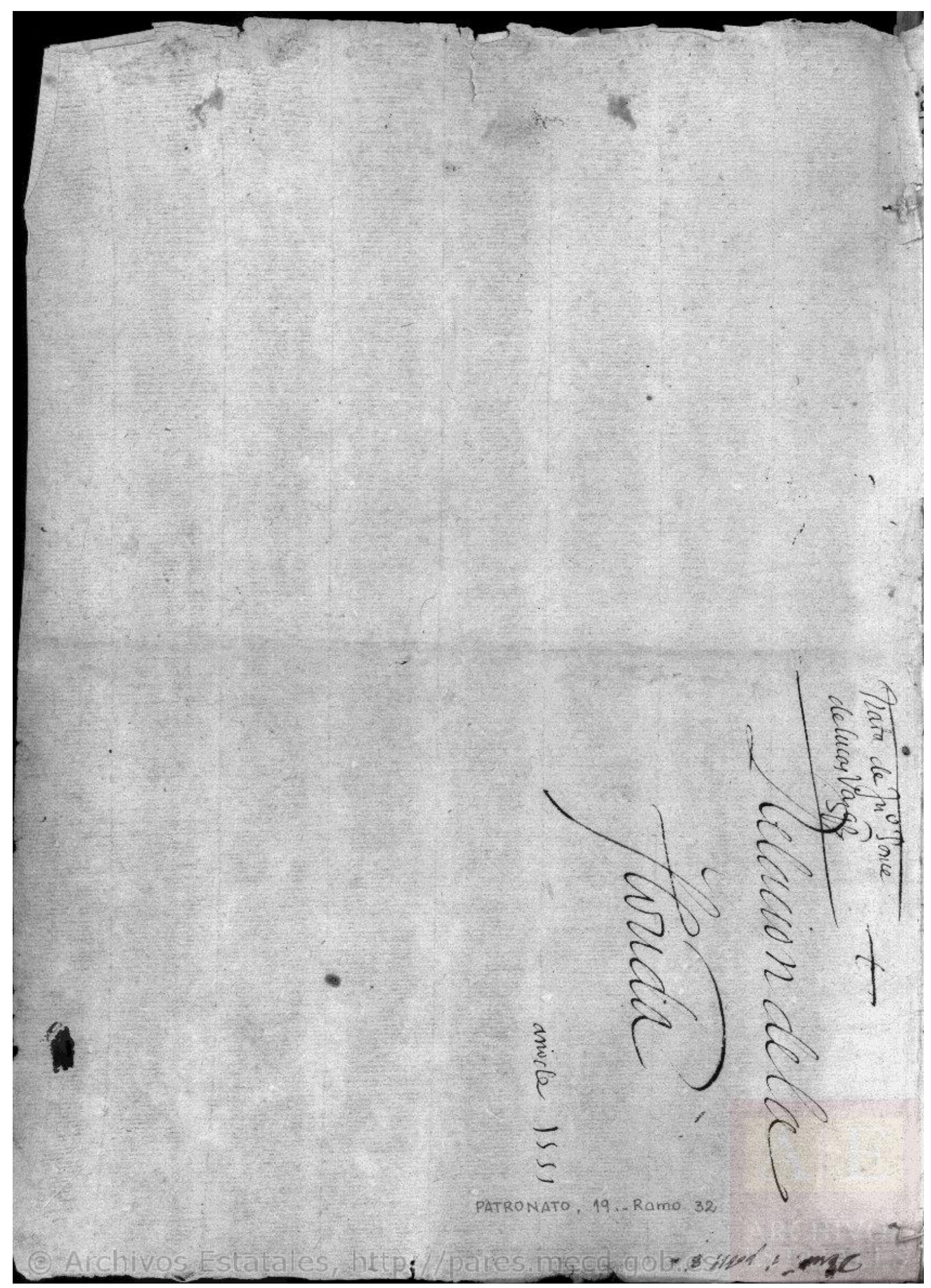




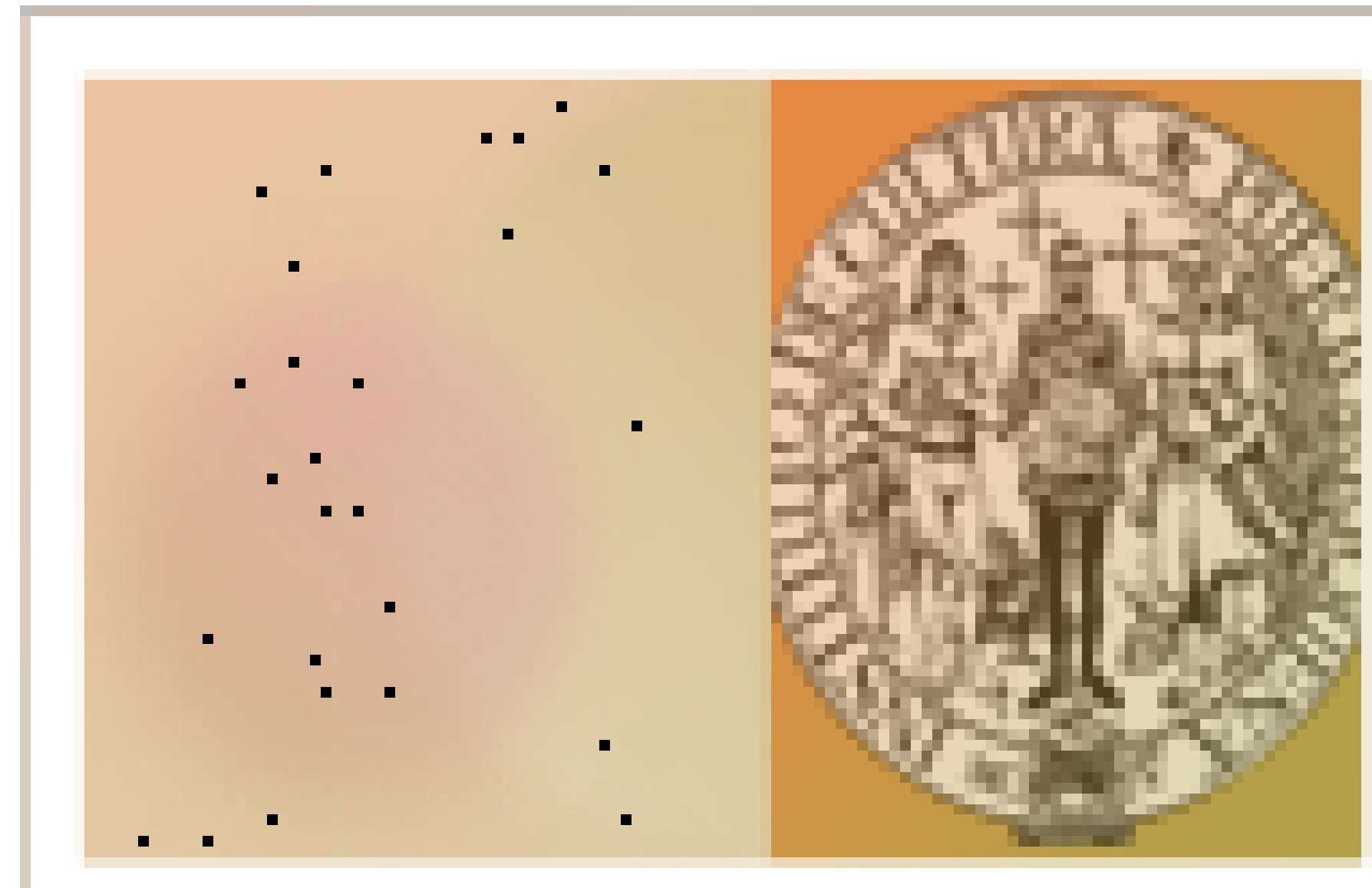

